\author{
UNIVERSIDADE DE SÃO PAULO \\ FACULDADE DE FILOSOFIA, LETRAS E CIÊNCIAS HUMANAS \\ DEPARTAMENTO DE LETRAS MODERNAS \\ PROGRAMA DE PÓS-GRADUAÇÃO EM ESTUDOS LINGUÍSTICOS, LITERÁRIOS E \\ TRADUTOLÓGICOS EM FRANCÊS
}

EMILY CAROLINE DA SILVA

\title{
O vivido, o revivido e os possíveis do desenvolvimento em diálogo: um estudo sobre o trabalho do professor de FLE com os conteúdos culturais
}

\author{
Versão Corrigida
}

São Paulo 
EMILY CAROLINE DA SILVA

\section{$O$ vivido, o revivido e os possíveis do desenvolvimento em diálogo: um estudo sobre o trabalho do professor de FLE com os conteúdos culturais}

Dissertação apresentada ao Programa de PósGraduação em Estudos Linguísticos, Literários e Tradutológicos em Francês do Departamento de Letras Modernas da Faculdade de Filosofia, Letras e Ciências Humanas da Universidade de São Paulo, para obtenção do título de Mestre em Letras, Língua e Literatura Francesa.

Área de concentração: Línguas Estrangeiras Modernas; Estudos Linguísticos em Francês

Orientadora: Profa. Dra. Eliane Gouvêa Lousada

Versão Corrigida

São Paulo 
Autorizo a reprodução e a divulgação total ou parcial deste trabalho, por qualquer meio convencional ou eletrônico, para fins acadêmicos ou científicos, desde que citada a fonte.

\section{Ficha Catalográfica}


Nome: SILVA, Emily Caroline.

Título: O vivido, o revivido e os possíveis do desenvolvimento em diálogo: um estudo sobre o trabalho do professor de FLE com os conteúdos culturais

Dissertação apresentada ao Programa de PósGraduação em Estudos Linguísticos, Literários e Tradutológicos em Francês do Departamento de Letras Modernas da Faculdade de Filosofia, Letras e Ciências Humanas da Universidade de São Paulo, para obtenção do título de Mestre em Letras, Língua e Literatura Francesa.

Aprovado em:

\section{Banca Examinadora}

Profa. Dra. Eliane Gouvêa Lousada

Julgamento:

Profa. Dra. Ana Maria Mattos Guimarães

Julgamento:

Profa. Dra. Luzia Bueno

Julgamento:

Profa. Dra. Ermelinda Barricelli (suplente)

Julgamento:

Prof. Dr. Patrick Chardenet (suplente)

Julgamento:
Instituição: Universidade de São Paulo (USP)

Assinatura:

Instituição: Universidade Vale dos Sinos (UNISINOS)

Assinatura:

Instituição: Universidade São Francisco (USF)

Assinatura:

Instituição: Faculdade Método de São Paulo (FAMESP)

Assinatura:

Instituição: Université Franche-Comté

Assinatura:

Profa. Dra. Heloisa Albuquerque Costa (suplente) Instituição: Universidade de São Paulo (USP) 
Dedico este trabalho a minha familia, presente de Deus.

A meus pais, Marli e Emiliano, pelo amor incondicional com que me criaram, pela educação e valores que me ensinaram, por serem meu norte, meus mestres, meu tudo.

A meus irmãos, Fernanda e Flávio, pelo apoio, companhia e paciência desde sempre.

A minhas avós, Clélia e Dejanira, por tanta paixão, carinho e cuidado.

Porque nenhuma vitória na vida se equipara a uma vitória no lar. 


\section{AGRADECIMENTOS}

À Deus, em primeiro lugar, porque Dele, por Ele e para Ele são todas as coisas. Por seu amor e cuidado a cada dia, por me abençoar com o amparo de cada uma das pessoas abaixo.

A minha orientadora, Eliane Gouvêa Lousada, por seu empenho em me orientar, por sua dedicação em construir essa pesquisa juntamente comigo, por seu incentivo nos momentos de dificuldade ou desânimo e por corrigir pacientemente cada um dos capítulos desta dissertação. Seu exemplo de pesquisadora comprometida e professora seriamente dedicada foi essencial para meu desenvolvimento acadêmico, profissional e pessoal.

Às professores Ana Maria Guimarães e Luzia Bueno por aceitarem o convite para a banca e pelas contribuições durante a qualificação. À querida professora Cristina Casadei Pietraróia, pela leitura atenciosa e participação no exame de qualificação.

Aos demais professores que contribuíram para fundamentar, delinear e aprofundar esta pesquisa e os quais tive o prazer de conhecer: Patrick Chardenet, Daniel Faïta, René Amigues, Christine Felix, Laurence Espinassy, Jean-Claude Mouton, Katia Kostulski, Janette Friedrich, Yves Clot, Rozania Moraes e Ermelinda Barricelli, além dos professores da área de Francês.

A Suélen Rocha e Danilo Andrade, colegas de profissão, amigos e protagonistas deste trabalho, meus sinceros agradecimentos. Se algum conhecimento produzimos sobre o métier de professor de línguas estrangeiras, é porque vocês lhe dão alma.

Aos colegas professores-monitores dos Cursos Extracurriculares de Francês, pelo interesse nas pesquisas que investigam o trabalho educacional e participação nas formações pela

própria análise do trabalho. É com carinho que guardo as lembranças de cada um de vocês.

Ao grupo de pesquisa ALTER-AGE, por ter a certeza de que cada encontro mensal do grupo, congressos e discussões no café foram absolutamente preciosos para meu aprendizado. Um obrigado especial a Simone Dantas-Longhi e Flávia Fazion, apaixonadas como eu pelo estudo do nosso métier; a Suélen Rocha, Luiza Guimarães Santos, Priscila Melão, Renata Añez, estudiosas do desenvolvimento dos alunos; aos colegas Marcos da Costa Menezes, Mariana Barioni, Thiago Santos, Ana Paula Silva Dias, Jéssica Lima, Jaci Brasil, Lygia Rachel Torelli, 
Lucia Claro, Renata Correa da Rocha e Juliana Zani e todos os outros participantes, pelos aprendizados compartilhados e co-construídos.

Aos meus pais, Marli e Emiliano, por serem minha fortaleza, meu refúgio, meu ninho. Obrigada por todo amor e cuidado. À toda minha família, Fernanda, Flávio, Clélia, Dejanira, tios, primos, sobrinhos e familiares, por todo apoio a minha escolha pela vida acadêmica e por todo incentivo durante a realização deste trabalho. Se consegui conclui-lo, certamente é porque vocês fizeram parte dele.

À minha irmã Fernanda, em especial, por me inspirar alegria, coragem e fé. Não sei se eu seria metade do que sou se não a tivesse ao meu lado. Obrigada pelo amor incondicional, por cada momento compartilhado e também pelas noites em claro.

Ao meu namorado, Ícaro, companheiro doce e amoroso, por toda a paciência e incentivo ao longo desses três anos. Obrigada por dividir comigo sua generosidade, curiosidade e paixão pela ciência, por me ensinar a ser melhor a cada dia.

A todos meus amigos que me apoiaram (mesmo de longe) durante esta empreitada e que se alegram pela conclusão dessa conquista. A minha família da fé, obrigada por todas as orações e mensagens de carinho, vocês são e serão sempre essenciais em minha vida.

À Kelcy, por partilhar comigo as ansiedades, aflições e dramas do final desse percurso, mas também a celebração e a vitória da entrega e da defesa.

Aos colegas Talita, Douglas e Jackeline, aos profs. Krieger e Segurado da FMUSP por todo apoio e incentivo, por acreditarem na importância da formação.

Finalmente, à Universidade de São Paulo, pela formação universitária, pela pós-graduação e por ter viabilizado minha participação em congressos essenciais para o desenvolvimento desta pesquisa. À CAPES, por um ano de bolsa, que me permitiu dedicar-me integralmente à pesquisa no período. 
Procuro semear otimismo e plantar sementes de paz e justiça. Digo o que penso, com esperança. Penso no que faço, com fé. Faço o que devo fazer, com amor. Eu me esforço para ser cada dia melhor, pois bondade também se aprende.

Cora Coralina 


\section{RESUMO}

SILVA, Emily Caroline. O vivido, o revivido e os possíveis do desenvolvimento em diálogo: um estudo sobre o trabalho do professor de FLE com os conteúdos culturais. 2015. 313 fls. Dissertação (Mestrado). Faculdade de Filosofia, Letras e Ciências Humanas da Universidade de São Paulo. São Paulo, 2015.

Esta dissertação tem por objetivo estudar a maneira como os professores de francês língua estrangeira (FLE) trabalham os conteúdos culturais em suas aulas através de uma análise de textos orais de entrevistas sobre o trabalho. De maneira mais específica, propomo-nos a identificar as "representações construídas nos e pelos textos" (BRONCKART, 2006) dos professores sobre a pertinência ou a necessidade que eles têm (ou não) de abordar os conteúdos culturais em aulas de língua estrangeira. Escolhemos investigar o trabalho de ensino dos conteúdos culturais, porque, apesar de ser um tema amplamente explorado pelas teorias em Didática das Línguas e Culturas, trata-se de um objeto complexo do ponto de vista de sua implementação nas aulas de línguas (BYRAM, 2011), sendo por esta razão um dos dilemas do trabalho do professor de FLE. Para compreender essa questão a partir da ótica dos próprios professores, realizamos nosso estudo em um contexto de um curso livre de francês em extensão universitária. Fizemos uso de um método de intervenção formativa, a autoconfrontação (CLOT, FAÏTA, 2000), em que convidamos dois professores a assistirem e comentarem vídeos de suas aulas, possibilitando assim que eles verbalizassem sobre sua experiência vivida. $\mathrm{O}$ quadro teórico maior deste estudo se baseia em algumas das teses Vygotski (1934/1997; 1925,1930/2004), desenvolvidas e ampliadas no Interacionismo Sociodiscursivo (BRONCKART, 2006; BULEA, 2010) no diz respeito à questão do agir e da linguagem. Considerando o ensino como trabalho, inspiramo-nos em pesquisas brasileiras oriundas dessa perspectiva (MACHADO, 2004; LOUSADA, 2006; BUENO, 2007; GUIMARÃES et al, 2007; MACHADO et al, 2011; DANTASLONGHI, 2013), contando também com aportes teóricos também da Clínica da Atividade (CLOT, 1999, 2001, 2008), da Ergonomia da Atividade (FAÏTA, 1997; 2011; AMIGUES, 2002, 2004; SAUJAT, 2004). O corpus desta pesquisa consiste em um recorte da transcrição da entrevista em autoconfrontação cruzada e um recorte de um documento prescritivo do agir dos professores, ambos referentes ao trabalho com os conteúdos cutlurais. As análises se basearam no modelo de análise de textos do Interacionismo Sociodiscursivo (BRONCKART, 1999, 2006) acrescido de outras categorias (BULEA, 2010; MAINGUENEAU, 2001; AUTHIER-REVUZ, 2001; LOUSADA, DANTAS-LONGHI, 2014; ROCHA et al, 2002; BRONCKART, MACHADO, 2004). Os resultados mostraram que, diante de prescrições difusas e imprecisas sobre o trabalho prático com os conteúdos culturais em sala de aula, os professores se valeram muito mais de suas experiências para definir esse trabalho, representando-o como algo multifatorial, no qual entram em jogo a ação dos alunos, dos professores, o objeto de ensino e os instrumentos. Os professores representaram os conteúdos culturais como pertinentes, como algo ligado à reflexão; entretanto, em sua prática, outros fatores interferiram e influenciaram seu trabalho, como a prescrição de se trabalhar a gramática ou a relação do conteúdo gramatical com o conteúdo cultural. Dentre as contribuições, destacamos que a pesquisa corrobora a ideia da autoconfrontação enquanto método propiciador do desenvolvimento, uma vez que foi possível identificar, através dos indícios de tomada de consciência, que o vivido nas aulas e revivido nas entrevistas pode devolver aos professores seu poder de agir, abrindo caminhos para os possíveis do desenvolvimento.

Palavras-chave: conteúdos culturais; trabalho do professor; ensino de língua estrangeira; desenvolvimento. 


\begin{abstract}
SILVA, Emily Caroline. Dialogue between Lived Experience, Revived Experience and Possibilities of Development: a Study on How French as a Foreign Language Teachers Work Cultural Subjects. 2015. 313p. Thesis (Master). Faculdade de Filosofia, Letras e Ciências Humanas da Universidade de São Paulo. São Paulo, 2015.
\end{abstract}

This paper aims to study how French as a foreign language teachers work cultural subjects in their classes, through an analysis of oral interview texts on their work. More specifically, we propose to identify the "representations built in and by the teachers texts" (BRONCKART, 2006) about the relevance or need they have (or not) to address the cultural subjects in foreign language classes. We decided to investigate this matter because, despite of its large exploration from a theoretical point of view in the Language and Cultures Pedagogies, it is a complex object from the point of view of its implementation in second language classes (BYRAM, 2011), and for this reason it is one of second language teacher's dilemmas. To understand this question from a teacher's perspective, the research context was a French as a foreign language extension course in a university. Using an intervention method, the self-confrontation (CLOT, FAÏTA, 2000), we invited two teachers to watch and comment on videos of their classes, enabling them to verbalize about their lived experience. The larger theoretical framework of this study is based on some of Vygotsky's thesis (1934/1997; 1925,1930/2004), developed and expanded in Socio-Discursive Interactionism (BRONCKART, 2006; BULEA, 2010) on the topic of action and language. We are also based on theoretical contributions from Activity-Clinic (CLOT, 1999, 2001, 2008), Ergonomics of Activity (FAÏTA, 1997; 2011; AMIGUES, 2002, 2004; SAUJAT, 2004) and Brazilian investigations considering teaching from a work perspective (MACHADO, 2004; LOUSADA, 2006; BUENO, 2007; GUIMARÃES et al, 2007; MACHADO et al, 2011; DANTAS-LONGHI, 2013). The research corpus consists is in an extract of the crossed self-confrontation transcript and in an extract of a document that prescribes teachers' work, both excerpts regarding cultural subjects teaching. The analysis proceeded according to Socio-Discursive Interactionism texts analysis model (BRONCKART, 1999, 2006) added by other categories (BULEA, 2010; MAINGUENEAU, 2001; AUTHIER-REVUZ, 2001; LOUSADA, DANTAS-LONGHI, 2014; ROCHA et al, 2002; BRONCKART, MACHADO, 2004). The results indicate that, facing a diffuse and inaccurate practical orientation on how to work cultural subjects in class, teachers have used their experiences to define their work, representing it as multifactorial, where the students and teachers actions, the teaching object and the instruments interact. They represented the cultural subjects as relevant and related to reflexion; however, in practice, other factors interfered and influenced the work, as grammar prescriptions or the relation between some grammatical contents and cultural subjects. Among the contributions, this research underline the idea of self-confrontation as a development trigger method, since it was possible to identify through indices of awareness that lived experiences in class revived in the interviews may restitute the power to act, opening ways for possibilities of development.

Keywords: cultural subjects; teaching work; foreign language teaching; development. 


\section{RÉSUMÉ}

SILVA, Emily Caroline. Le vécu, le revécu et les possibles du développement en dialogue: une étude sur le travail enseignant de FLE avec les contenus culturels. 2015.313p. Mémoire (Master). Faculdade de Filosofia, Letras e Ciências Humanas da Universidade de São Paulo. São Paulo, 2015.

Ce mémoire vise à étudier la manière dont les professeurs de français langue étrangère (FLE) travaillent les contenus culturels dans leurs cours à travers une analyse de textes oraux d'entretiens sur le travail. De manière plus spécifique, nous nous proposons d'identifier les « représentations construites dans et par les textes »(BRONCKART, 2006) des enseignants sur la pertinence ou la nécessité qu'ils ont (ou non) d'aborder les contenus culturels dans leurs classes de langue étrangère. Nous avons choisi d'examiner le travail enseignant avec les contenus culturels, car, bien qu'il soit un objet largement exploité du point de vue de la Didactique des Langues et Cultures, il s'agit d'un thème complexe du point de vue de sa mise en œuvre en classe (BYRAM, 2011) et il est, pour cette raison, un des dilemmes du travail enseignant. Dans le but de comprendre cette question à partir de l'optique des enseignants eux-mêmes, nous avons réalisé notre étude dans un contexte d'un cours libre de français en extension universitaire. Nous avons fait recours à une méthode d'intervention formative, l'autoconfrontation (CLOT, FAÏTA, 2000), où nous avons invité deux professeurs à regarder et à commenter leurs filmages de cours, en produisant ainsi des verbalisations sur leur expérience vécue. Le cadre théorique majeur de cette recherche se fonde sur quelques-unes des thèses de Vygotski (1934/1997; 1925,1930/2004), développées et élargies dans l'Interactionnisme Socio-discursif (BRONCKART, 2006; BULEA, 2010) en ce qui concerne l'agir et le langage. En considérant l'enseignement comme travail, nous sommes inspirés des recherches brésiliennes venues de cette perspective (MACHADO, 2004; LOUSADA, 2006; BUENO, 2007; GUIMARÃES et al, 2007; MACHADO et al, 2011; DANTAS-LONGHI, 2013), en faisant recours également aux apports de la Clinique de l'Activité (CLOT, 1999, 2001, 2008) et de l'Ergonomie de l'Activité (FAÏTA, 1997; 2011; AMIGUES, 2002, 2004; SAUJAT, 2004). Le corpus de cette recherche consiste en un extrait de la transcription de l'entretien en autoconfrontation croisée et en un extrait du document prescriptif de l'agir enseignant, tout les deux concernant le travail avec les contenus culturels. Les analyses ont été réalisées selon le modèle d'analyse de texte de l'Interacionnisme Socio-discursif (BRONCKART, 1999, 2006) à côté d'autres catégories (BULEA, 2010; MAINGUENEAU, 2001; AUTHIER-REVUZ, 2001; LOUSADA, DANTAS-LONGHI, 2014; ROCHA et al, 2002; BRONCKART, MACHADO, 2004). Les résultats ont montré que, face à des prescriptions floues et imprécises sur le travail pratique avec les contenus culturels en classe, les enseignants ont fait recours à leur expérience pour définir ce travail, le représentant comme multifactoriel, où l'action des apprenants, des enseignants, l'objet d'enseignement et les instruments dialoguent. Ils ont représenté les contenus culturels comme pertinents et liés à la réflexion, pourtant, dans leur pratique, d'autres facteurs sont intervenus et ont influencé le travail, comme la prescription de l'enseignement de la grammaire ou la relation du contenu grammatical avec le contenu culturel. Parmi quelques contributions, la recherche étaie l'idée de l'autoconfrontation comme méthode qui déclenche le développement, puisqu'il a été possible d'identifier, par des indices de prise de conscience, que le vécu des cours, qui est révecu dans les entretiens, peut rendre aux enseignants leur pouvoir d'agir et ouvrir des voies aux possibles du développement.

Mots-clés: contenus culturels ; travail enseignant ; enseignement de langues étrangères ; développement. 


\section{SUMÁRIO}

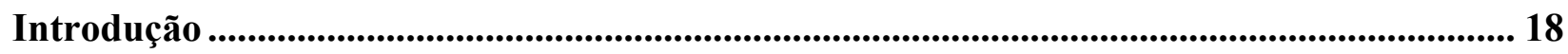

I. Histórico da Pesquisa: das motivações iniciais ao projeto final .......................................... 19

II. Os Conteúdos Culturais na Didática das Línguas............................................................. 21

III. Estado da Arte das pesquisas sobre formação de professores no Brasil ........................... 24

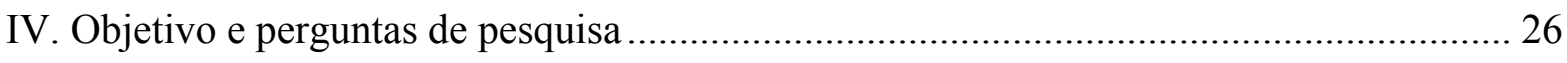

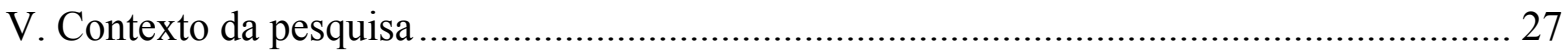

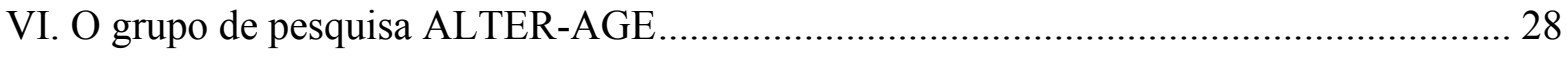

VII. Organização da Dissertação ……………………………………………………......... 30

Capítulo 1 - Fundamentação Teórica ................................................................................... 31

1.1. Interacionismo Social ............................................................................................................. 33

1.1.1. Pensamento e linguagem no desenvolvimento humano …………………….... 36

1.1.2. A questão da consciência e dos métodos indiretos .............................................. 38

1.1.3. Instrumento, atividade mediadora e atividade mediada .................................... 39

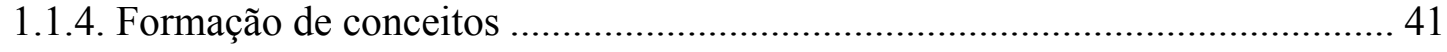

1.2. Interacionismo Sociodiscursivo ........................................................................................ 44

1.2.1. Conceitos de base do Interacionismo Sociodiscursivo ....................................... 45

1.2.2. A problemática do agir ................................................................................. 49

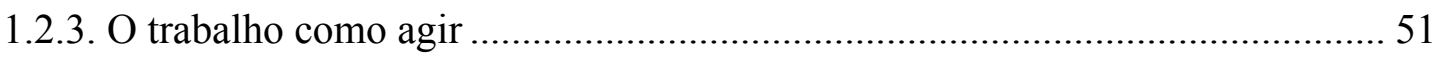

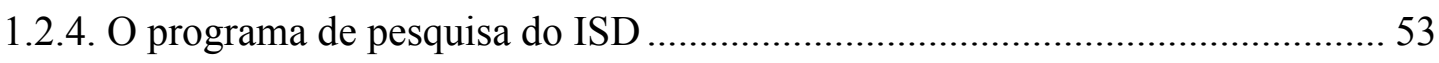

1.3. A abordagem do ISD para análise de textos .................................................................... 55

1.3.1. O modelo geral de análise de textos do ISD .................................................. 55

1.3.2. As teorias de cunho enunciativo: vozes e modalizações ..................................... 59

1.3.3. Voz da fala egocêntrica e voz fala egocêntrica reconstituída.............................. 61

1.3.4. A análise de textos em situação de trabalho ....................................................... 64

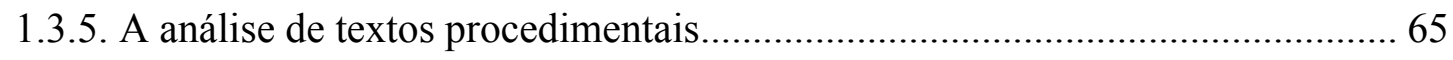

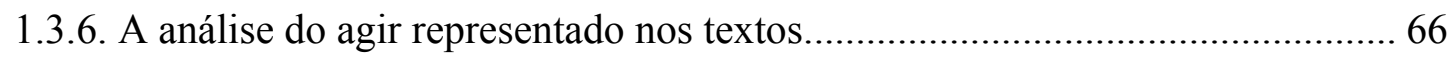

1.4. Aportes das ciências do trabalho........................................................................................ 79

1.4.1. O trabalho em perspectiva ........................................................................... 79 


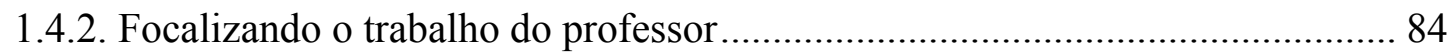

1.4.3. Métodos de intervenção e análise da situação de trabalho ................................. 89

1.5. Reflexões sobre os conteúdos culturais no ensino de línguas ...................................... 94

1.5.1. A noção de "cultura” na Didática das Línguas e Culturas.................................... 95

1.5.2. A problemática da noção de "competência"................................................... 104

1.5.3. Desenvolvimento como transformação pela apropriação das obras da cultura 107

1.5.4. O trabalho de ensino com os conteúdos culturais na perspectiva do ISD ...... 110

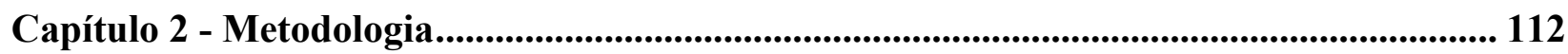

2.1. Orientação metodológica: os instrumentos de pesquisa .............................................. 113

2.2. Contexto da pesquisa.......................................................................................................... 115

2.2.1. Os Cursos Extracurriculares de Francês ........................................................... 115

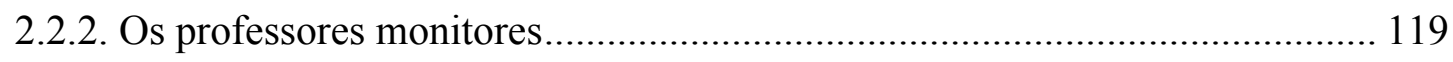

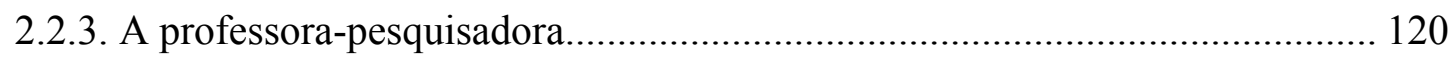

2.3. Coleta e produção de dados .................................................................................................. 121

2.3.1. Coleta dos documentos prescritivos e análise …………………………….... 121

2.3.2. Produção de dados: etapas de realização da autoconfrontação ……………..... 122

2.4. Procedimentos de seleção dos dados .................................................................................. 130

2.5. Procedimentos de análise dos dados ............................................................................... 132

2.6. Credibilidade e aspectos éticos .............................................................................................. 135

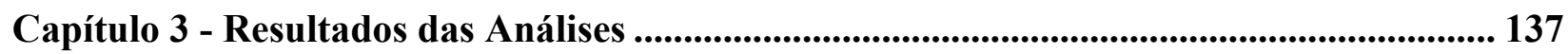

3.1. Quadro Comum Europeu de Referência para as Línguas ........................................... 140

3.1.1. Contexto de produção …………………………………………………..... 140

3.1.2. Infraestrutura geral: conteúdos temáticos e tipos de discurso ......................... 144

3.1.3. Mecanismos de textualização: coesão nominal e coesão verbal ...................... 154

3.1.4. Mecanismos enunciativos: vozes e modalizações ............................................ 159

3.1.5. Síntese intermediária dos resultados das análises do CECRL ........................ 162

3.2. Análise da entrevistas em ACC ......................................................................................... 166

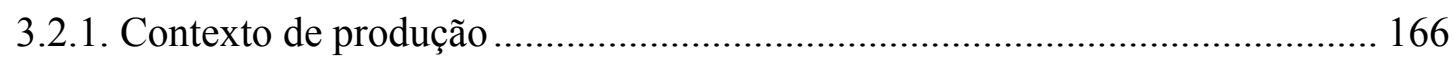




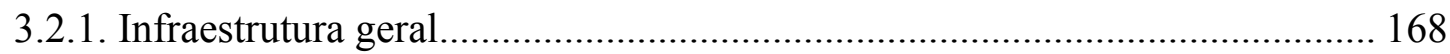

3.2.2. Apresentação dos resultados das análises por excerto da entrevista ............... 170

Excerto 1: Quando damos voz aos alunos......................................................... 171

Excerto 2: Quando trabalhamos o livro didático................................................. 176

Excerto 3: Quando os alunos nos contam histórias............................................. 180

Excerto 4: Quando temos a "voz da razão"....................................................... 184

Excerto 5: Quando confrontamos nossas práticas............................................... 192

Excerto 6: Quando sugerimos atividades......................................................... 196

Excerto 7: Quando trazemos nossos textos e criamos nossas atividades........... 200

Excerto 8: Quando nos encontramos entre a forma e o sentido........................... 205

3.2.3. Síntese intermediária dos resultados das análises da entrevista em ACC ...... 212

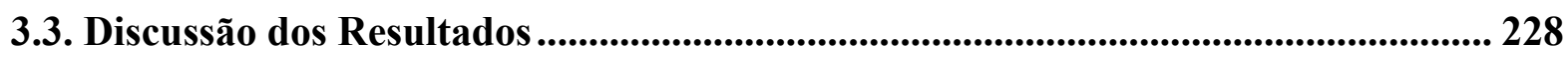

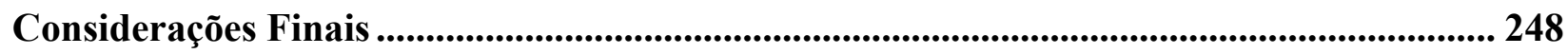

Referências Bibliográficas ..................................................................................................................... 258

Apêndice - Transcrição completa da Autoconfrontação Cruzada ................................................. 267

Anexo A - Texto "Nove brasileiros que vivem em SP listam suas impressões sobre a cidade" 296

Anexo B - Material didático referente à aula de Danilo (Alter Ego A1, 2006) ........................... 302

Anexo C - Material didático referente à aula de Suélen (Alter Ego A2, 2006) ……………….... 307

Anexo D - Termo de consentimento de participação na pesquisa ................................................. 312

Anexo E - Normas de transcrição do projeto NURC/SP ............................................................ 313 


\section{LISTA DE TABELAS}

Tabela 1: Resultados da pesquisa no Banco de Teses da CAPES em abril de 2012 ….............................................2 24

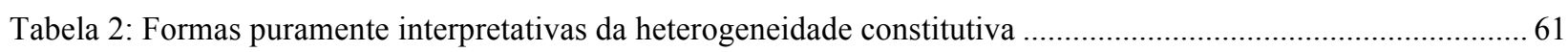

Tabela 3: Síntese das características figuras de ação (DANTAS-LONGHI, 2013, p.62) ………………………….... 71

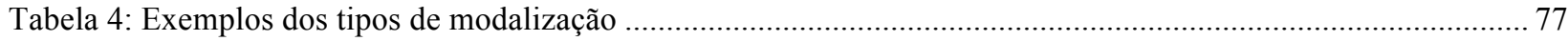

Tabela 5: Didática, Pedagogia e Ergonomia (DEVOLVÉ e POUDOU-ZERBATO, 1998, p.129) ............................ 86

Tabela 6: Evolução histórica das configurações didáticas (PUREN, 2010) ……………........................................... 101

Tabela 7: Níveis dos Cursos Extracurriculares de Francês .................................................................................. 116

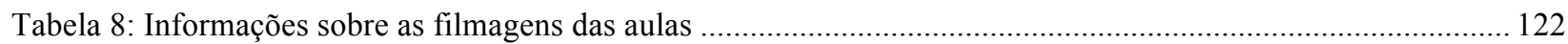

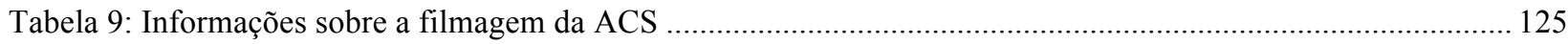

Tabela 10: Quadro síntese - data e duração das filmagens realizadas ......................................................................... 129

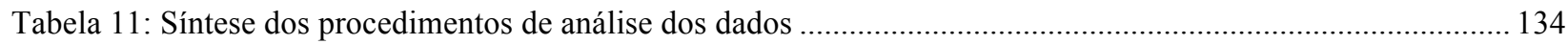

Tabela 12: Quadro geral do contexto de produção dos dados .................................................................................. 138

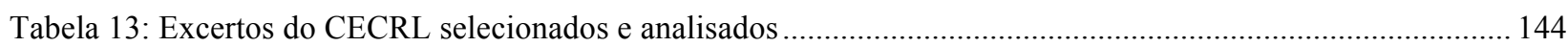

Tabela 14: Série coesiva nominal dos protagonistas do agir do CECRL …………............................................... 154

Tabela 15: Série coesiva nominal da cultura no CECRL ...................................................................................... 154

Tabela 16: Série coesiva nominal dos termos associados a social e individual no CECRL ….................................... 155

Tabela 17: Série coesiva nominal de língua e linguagem no CECRL ................................................................ 155

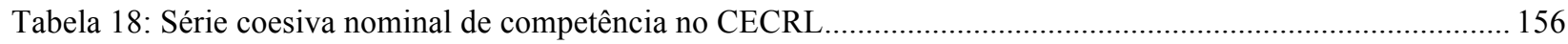

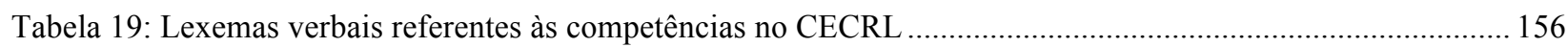

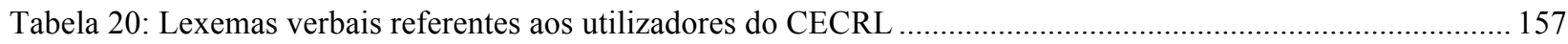

Tabela 21: Lexemas verbais referentes à ação de ensino / dos professores no CECRL .............................................. 157

Tabela 22: Lexemas verbais referentes à ação dos aprendizes no CECRL ………………………............................ 157

Tabela 23: Expressões contendo o termo "intercultural" no CECRL …………..................................................... 158

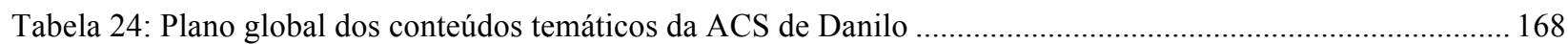

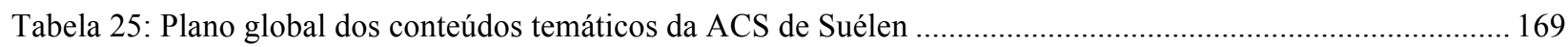

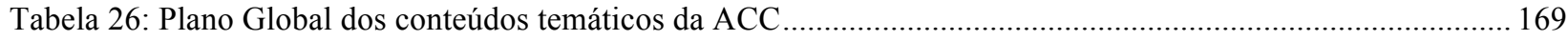

Tabela 27: Conteúdos temáticos relacionados ao tratamento dos conteúdos culturais............................................... 170

Tabela 28: Ações relacionadas aos conteúdos culturais no excerto 4 da ACC ......................................................... 188

Tabela 29: Ações realizadas, ações possíveis e resultados prováveis no excerto 5 da ACC ........................................ 194

Tabela 30: Ações ligadas aos conteúdos culturais no excerto 8 da ACC ………...................................................... 207

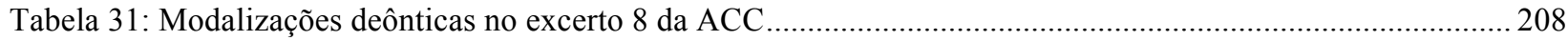

Tabela 32: Conteúdos temáticos relacionados ao tratamento dos conteúdos culturais............................................. 212

Tabela 33: Os campos lexicais identificados a partir das séries coesivas nominais da ACC ….................................2215

Tabela 34: Lexemas verbais associados aos conteúdos culturais ACC ……………………………….................. 217

Tabela 35: Conflito de Danilo relacionado ao tratamento dos conteúdos culturais...................................................220

Tabela 36: Modalizações lógicas de possibilidade e pragmáticas com relação aos conteúdos culturais ................... 222

Tabela 37: Referentes da figura de ação experiência de Danilo .......................................................................... 225

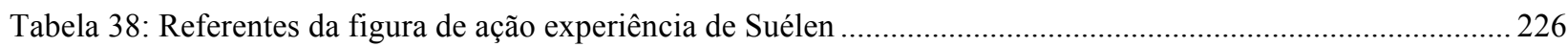




\section{LISTA DE FIGURAS}

Figura1: Gráfico de recorrência de temas no Banco de Teses da CAPES ................................................................... 25

Figura 2: Articulação entre as pesquisas do Grupo ALTER-AGE (LOUSADA, 2012) ............................................. 29

Figura 3: Esquema vygotskiano do desenvolvimento do pensamento (DANTAS-LONGHI, 2013) .......................... 37

Figura 4: Função do instrumento psicológico (FRIEDRICH,2012, p.56) ............................................................. 40

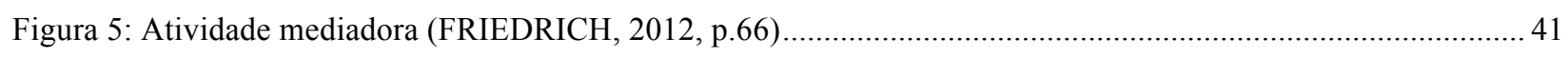

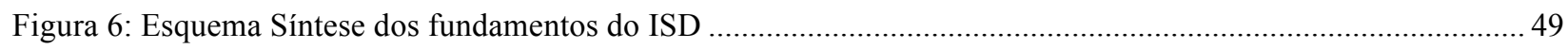

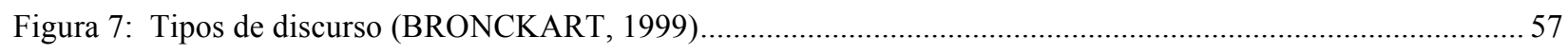

Figura 8: Modelo de planificação dos textos empíricos (FEITOZA, 2012) ................................................................59

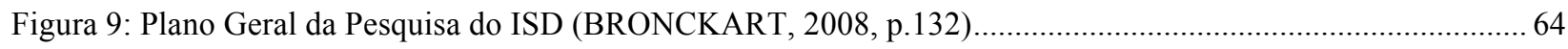

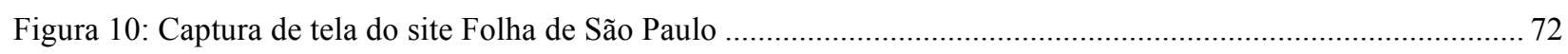

Figura 11: Relação entre saber, aluno e professor (DEVOLVÉ e POUDOU-ZERBATO, 1998, p.130).................... 87

Figura 12: Esquema do trabalho do professor (MACHADO, 2007) ………..............................................................92

Figura 13: Gráfico do número de turmas por semestre: de 2009 a 2013 ............................................................... 117

Figura 14: Gráfico do número de alunos por semestre 2009 a 2013 ............................................................... 117

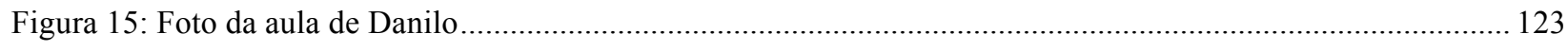

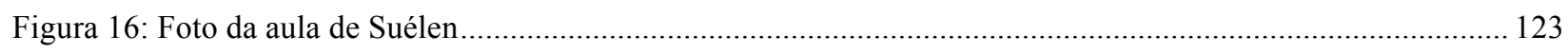

Figura 17: Entrevista em autoconfrontação simples com Danilo ....................................................................... 124

Figura 18: Entrevista em autoconfrontação simples com Suélen ........................................................................ 124

Figura 19: Entrevista em autoconfrontação cruzada com Danilo e Suélen ............................................................ 126

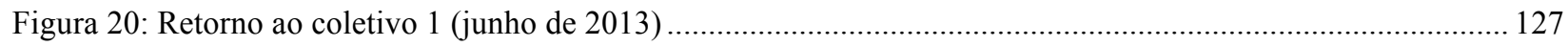

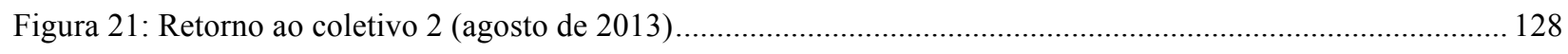

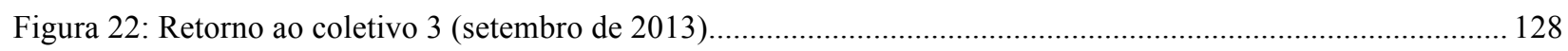

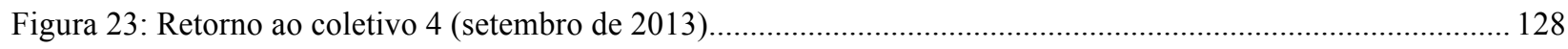

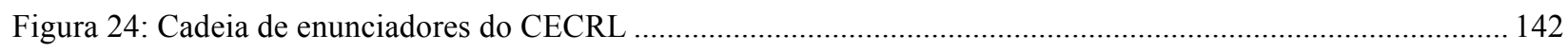

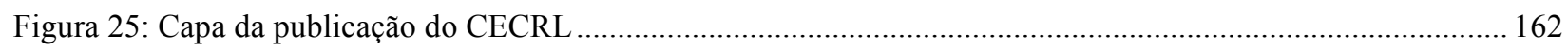

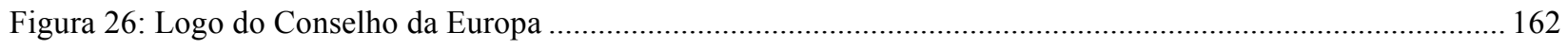

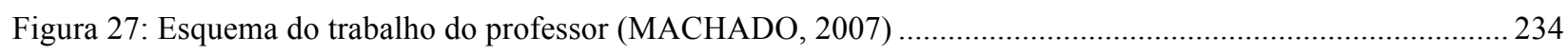

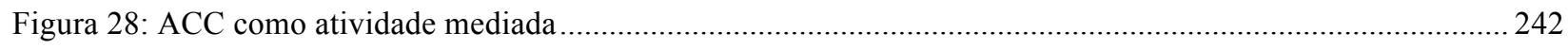

Figura 29: Dinâmica das figuras de ação de Suélen na ACC ……..................................................................... 245

Figura 30: Dinâmica das figuras de ação de Danilo na ACC ............................................................................. 246 


\section{LISTAS DE SIGLAS}

\begin{tabular}{|c|c|}
\hline $\mathrm{ACC}$ & Autoconfrontação cruzada \\
\hline ACS & Autoconfrontação simples \\
\hline ALTER & Análise da Linguagem, trabalho educacional e suas relações \\
\hline ALTER-AGE & $\begin{array}{l}\text { Análise da Linguagem, trabalho educacional e suas relações - aprendizagem, gêneros } \\
\text { textuais e ensino }\end{array}$ \\
\hline CAPES & Coordenação de Aperfeiçoamento Pessoal de Nível Superior \\
\hline CECRL & $\begin{array}{l}\text { Cadre Européen Commun de Référence pour les Langues (Quadro Comum Europeu de } \\
\text { Referência para as Línguas) }\end{array}$ \\
\hline DLC & Didática das Línguas e Culturas \\
\hline ERGAPE & Ergonomie de l'Activité des Professionnels de l'Éducation \\
\hline FLE & Francês como Língua Estrangeira (Français Langue Étrangère) \\
\hline GRAFE & $\begin{array}{l}\text { Groupe de Recherche des Langues et Formation des Enseignants: analyse du français } \\
\text { enseigné }\end{array}$ \\
\hline ISD & Interacionismo Sociodiscursivo \\
\hline LAF & Langage, action et formation \\
\hline $\mathbf{L E}$ & Línguas estrangeiras \\
\hline NURC/SP & Projeto da Norma Urbana Oral Culta - São Paulo \\
\hline $\mathbf{U E}$ & União Europeia \\
\hline ZPD & Zona de Desenvolvimento Potencial \\
\hline
\end{tabular}




\section{Introdução}

Para mim, pensar é viver e sentir não é mais que o alimento de pensar.

Bernardo Soares (Fernando Pessoa) Livro do Desassossego

There is nothing like returning to a place that remains unchanged to find the ways in which you yourself have altered.

Nelson Mandela

Long Walk to Freedom 
Um trabalho de pesquisa muito revela sobre as trajetórias do pesquisador, de suas ideias, de seus diálogos e de suas inquietações, levando-o a buscar, através do trabalho científico, conhecimentos para ajudá-lo a compreender as diversas dimensões dos fenômenos com os quais ele se depara e que o desafiam. É nesse sentido que este trabalho nasceu, tomou forma e se concretizou nesta dissertação, a partir de dois eixos de experiências que apresento a seguir.

\section{Histórico da Pesquisa: das motivações iniciais ao projeto final}

A investigação sobre o trabalho do professor de língua estrangeira e sobre os conteúdos culturais no ensino de línguas liga-se à minha trajetória pessoal, profissional e acadêmica ${ }^{1}$. Durante minha formação universitária em Letras - Português e Francês, tive a oportunidade de ser selecionada a participar do Programa de Assistentes de Língua Portuguesa, promovido pela Embaixada Geral da França no Brasil para lecionar como professora-assistente em lycées e collèges de Bourges, na França, durante um ano letivo. A experiência de ter vivido em um país francófono e de ter exercido minha profissão nesse contexto me proporcionaram um olhar mais acurado e curioso sobre as culturas daquele país. Ao mesmo tempo, esse olhar me fez considerar de outra forma minhas próprias raízes, instigando-me a buscar compreender mais sobre esse fenômeno do encontro com o outro, da alteridade, de conhecer outras culturas, sendo esse o primeiro eixo de motivação da pesquisa. Posteriormente, durante o segundo semestre do mestrado, pude vivenciar mais uma experiência no exterior, dessa vez como professora-assistente de línguas francesa e portuguesa na Universidade de Guelph, no Canadá, onde pude confirmar não só meu grande interesse pelas questões culturais ligadas ao ensino de línguas, mas também que muitas questões desse campo de ensino-aprendizagem extrapolavam os conhecimentos linguísticos.

O segundo eixo de inquietações que motivou o desenvolvimento desta pesquisa diz respeito à minha experiência profissional, ao trabalho de ensinar, pois, tendo iniciado minha experiência profissional no contexto dos Cursos Extracurriculares de Francês ${ }^{2}$ da Faculdade de Filosofia, Letras e Ciências Humanas, pude contar com uma formação profissional inicial

\footnotetext{
${ }^{1}$ Empregaremos a primeira pessoa do singular quando nos referirmos à pessoa individual da pesquisadora e a primeira pessoa do plural quando se referir à pesquisa, representando a pluralidade de vozes com quem dialoguei para realizá-la: orientadora, grupo de pesquisa, sujeitos participantes da pesquisa, colegas etc..

${ }^{2}$ No capítulo de Metodologia apresentaremos esse contexto com mais detalhes.
} 
consistente, aliando teoria e prática de ensino, acompanhamento do processo de aprendizagem da profissão pela coordenação e compartilhamento do aprendizado com os outros professores. Após três semestres de prática de ensino nesse contexto e depois da experiência na França, tive a ocasião de acompanhar professores iniciantes nos Cursos Extracurriculares enquanto sua tutora, o que me motivou a buscar compreender a complexidade do trabalho de ensino que o torna, paradoxalmente, tão difícil de ser "ensinado". Tais experiências foram extremamente positivas e relevantes, pois tive um aprendizado concreto, partindo da prática e dos problemas emergidos da sala de aula, passando por uma reflexão ao mesmo tempo teórica e prática junto ao grupo de professores, resultando em possibilidades de solução para os conflitos do complexo trabalho educacional, que foram concretizadas quando me tornei tutora de outros professores iniciantes.

Cronologicamente, ambos os centros de interesse se mantiveram paralelos e alternados: primeiro como professora de francês no Brasil, em seguida como professora de português na França; em um terceiro momento, tive a experiência como tutora no Brasil e, finalmente, a experiência como professora das duas línguas no Canadá, o que contribuiu para reforçar esse diálogo entre as problemáticas que me intrigaram.

Com efeito, o fato de ter vivenciado a profissão de professor de língua estrangeira e seus conflitos em diferentes contextos me proporcionou um olhar bastante atento sobre a inserção e o trabalho com conteúdos culturais ${ }^{3}$ no ensino, assim como sobre conflitos e dificuldades da profissão. Um dos conflitos recorrentes entre os professores dos Cursos Extracurriculares de Francês ${ }^{4}$, que também me inquietava enquanto professora, era justamente a dificuldade em se trabalhar os conteúdos culturais nas aulas de língua, seja ela devido a uma questão de prioridade em relação aos conteúdos linguísticos, por falta de tempo, por não se sentir à vontade para falar da cultura do outro, por falta de formação ou por falta de estratégia em classe etc. Observando que minhas preocupações encontravam eco nos colegas enquanto uma problemática comum do nosso trabalho e que seria possível transformá-las em objeto de reflexão e análise para nossa formação, escolhemos essa temática para a realização da pesquisa.

\footnotetext{
${ }^{3}$ Nesta dissertação, empregaremos "conteúdos culturais" para designar o objeto de ensino e de trabalho dos professores de FLE. Nós problematizaremos a noção de cultura e definiremos melhor esse termo no capítulo de Fundamentação Teórica.

${ }^{4}$ No Contexto dos Cursos Extracurriculares de Francês esses conflitos acerca dos conteúdos culturais eram reiteradamente discutidos e tratados em várias situações, desde conversas informais na sala dos professores, de tema de reuniões pedagógicas e até como tema da Jornada semestral de Formação.
} 
Essa dificuldade parece ter se produzido, pois, por um lado, os professores se sentiam obrigados a trabalhar os conteúdos programados ou indicados nos documentos que orientam o seu trabalho, como o Quadro Comum Europeu para o Ensino das Línguas (CONSELHO DA EUROPA, 2001) e que se traduzem no livro didático; por outro lado, não sabiam exatamente o que ensinar e como fazê-lo, afinal somente as orientações desse Quadro e do livro não davam conta desse objeto.

\section{Os Conteúdos Culturais na Didática das Línguas}

Os conteúdos culturais têm sido um aspecto polêmico e polissêmico na didática das línguas e têm suscitado vários escritos que, no entanto, acabam por não conseguindo defini-los e

delimitá-los. É por essa razão que alguns autores os qualificam como difusos, fluidos, sem contornos definidos (BYRAM, 1992). Eles aparecem nos documentos de orientação para os professores, como o Quadro Comum Europeu de Referência para as Línguas (doravante CECRL ou Quadro), aparecem também no próprio nome da disciplina "Didática das Línguas e Culturas", mas sem que se ensine ao professor como tratá-los, concretamente, em uma aula.

Segundo Byram (1992, p.109), essa fluidez decorre, em parte, do grande número pulverizado de publicações que carecem de uma corrente precisa para o estudo da cultura. Decorre também dos estudos teóricos, que buscaram explorar e delinear os conceitos de cultura, tratando de objetivos sem tocar nas acepções práticas de seu ensino, dificultando o trabalho e a compreensão por parte dos professores que tiveram acesso a um conjunto menor de disciplinas de sociologia, antropologia, dentre outras, que os teóricos. Somam-se a isso as poucas pesquisas empíricas efetuadas em pequena escala que advém da prática individual sem considerações teóricas, interessando-se mais pelo resultado que pelo processo de ensino-aprendizagem.

Outra das evidências dessa fluidez é a multiplicidade de termos, apontada por Byram (2011, p.253) como elemento gerador de debate em si mesmo:

Expressões como competência intercultural, savoir-faire interculturais, tomada de consciência intercultural ou competência comunicativa intercultural são frequentemente empregadas nos textos que desenham as finalidades para o ensino de línguas estrangeiras. Essa tendência é relativamente recente e ela pode ser datada do início do século. (...) $\mathrm{O}$ sentido a ser dado à competência intercultural e às noções vizinhas é objeto de debate em si mesmo; os modelos que se referem a isso são bastante numerosos 
(Hu, 2000; Rathje, 2006; Humphrey, 2007; Risager, 2007, Deardoff, 2009) e eles influenciam certamente a formulação das problemáticas de pesquisa. Nos documentos de política educativa, essas expressões servem mais para nomear as finalidades educativas que para definir ou descrever práticas pedagógicas atuais, enunciando mais "o que deveria ser feito" do que "o que se faz". Em todos os lugares onde a inovação em educação procede dessa maneira, a pesquisa tem um papel específico a atuar. (BYRAM, 2011, p.253, tradução e grifo nossos) ${ }^{5}$

Em nossa pesquisa, vivenciamos as consequências dessa amplitude e variação de termos, fluidos e muitas vezes intercambiáveis entre si. Depois de inúmeras discussões e reformulações, o projeto, que se delineou inicialmente em torno da palavra "intercultural", se definiu em torno da noção de "conteúdos culturais". A fluidez do conceito, que nos desmotivou no início, por uma ausência de uma definição precisa e pela diversidade de autores que o empregam para as mais diferentes acepções, acabou se tornando um objetivo em si, ao longo das leituras, discussões com o grupo de pesquisa, orientadora e com outros professores e participantes dos congressos de que participei, pois passamos a almejar justamente tratar um tema que, por sua falta de precisão, torna-se uma dificuldade para os professores de língua estrangeira.

A diversidade e fluidez encontradas no âmbito da conceituação dos conteúdos culturais ecoaram sobre as metodologias de ensino de línguas estrangeiras. A Didáticas da Línguas foi definindo, de maneira diferente, ao longo do últimos séculos, as formas de ensinar e aprender os conteúdos culturais nas aulas de língua estrangeiras (PUREN, 2010). Dessa forma, o trabalho, assim como a formação de professores, foi tornando-se cada vez mais complexa.

Soma-se a essa dificuldade, o fato de que as formações de professores, em geral, ainda se apresentam de forma tradicional e descendente, enquanto conjunto de prescrições para o trabalho do professor, ensinando-os conceitos da didática e da linguística independentemente do contexto ou do grupo de alunos, ao invés de partir no sentido oposto, de maneira ascendente, dos conflitos

\footnotetext{
${ }^{5}$ Citação no original: "Expressions comme compétence interculturelle, savoirs-faire interculturels, prise de conscience interculturelle ou compétence communicative interculturelle sont fréquemment employées dans les textes qui dessinent des finalités pour l'enseignement des langues étrangères. Cette tendance est relativement recente et ele peut être datée du début du siècle. (...) Le sens à donner à la compétence interculturelle et à des notions voisines est objet de débat en lui-même; les modele s'y rapportant sont fort nombreux et ils influencent certainement la formulation des problématiques de recherche. Dans les documents de politique éducative, ces expressions servente plutôt à nommer des finalités éducatives qu'à definir ou à décrire des pratiques pédagogiques actuelles, énonçant plutôt "ce qu'il faudrait faire" que "ce qui se fait". Partout où l'inovation en éducation procede de la sorte, la recherche a un rôle spécifique à jouer." (BYRAM, 2011, p.253, tradução e grifo nossos)
} 
e problemáticas encontrados nas práticas de ensino e levando-os para a reflexão ${ }^{6}$. Saujat (2004), ao fazer um histórico sobre os diferentes paradigmas de formação de professores ao longo do século XX, aponta para o fato de que, apesar de cada uma delas se justificar e trazer certos aportes e contribuições, nenhuma delas prepara realmente o professor para o trabalho de ensinar. Isso pode ser facilmente constatado se tomarmos como exemplo a insuficiência da formação inicial e as dificuldades que enfrentam os jovens professores ao começar sua atividade profissional (DEVOLVÉ, POUDOU-ZERBATO, 1998; SAUJAT, 2002; AMIGUES, 2002; MACHADO, 2004; LOUSADA, 2006). Essa problemática é de extrema relevância para nossa pesquisa, já que, em nosso contexto, recebemos inúmeros jovens professores de francês que procuram justamente os Cursos Extracurriculares de Francês, pois almejam iniciar sua atividade profissional em um ambiente em que possam exercitar-se e aprender, a partir da prática, o trabalho de ensinar.

Sendo assim, os aspectos levantados até aqui nos levam a crer que há uma compreensão ainda parcial e limitada tanto do trabalho do professor de língua estrangeira, das habilidades que ele deve ter e mobilizar para realizar seu trabalho, quanto dos objetos de ensino e de seus componentes para levar o aluno não só ao domínio gramatical e estrutural da língua, mas à capacidade de ação e interação através dela, levando em conta os aspectos culturais importantes de sua época e de seu contexto.

É, portanto, na confluência dessas duas problemáticas, por um lado, o agir por meio da linguagem, que envolve os conteúdos culturais, por outro lado, da aprendizagem do trabalho de ensinar, que se delineia nosso objeto de estudo: o trabalho do professor com os conteúdos culturais. Nossa pesquisa busca, então, retomar essa discussão teórica existente na didática de línguas em torno de orientações para o ensino da língua-cultura e compreendê-la para além dessas noções dadas a priori, porém, não do ponto de vista da aprendizagem, mas, sim, do trabalho do professor de língua estrangeira.

\footnotetext{
${ }^{6}$ Em um breve levantamento das ementas das disciplinas de Metodologia do Ensino de Francês I e II do Curso de Licenciatura em Francês da USP, observamos que os programas dessas duas disciplinas não incluem explicitamente como se tratar os conteúdos culturais ou a interculturalidade (o que não impede, no entanto, que eventualmente esses temas sejam tratados pelos professores em suas aulas). Apontamos apenas que, enquanto orientação geral, o ensinar a se trabalhar com conteúdos culturais não está previsto.
} 


\section{Estado da Arte das pesquisas sobre formação de professores no Brasil}

Para situar nossa pesquisa no quadro dos estudos realizados no Brasil sobre esse tema, realizamos uma busca no banco de teses virtual da $\mathrm{CAPES}^{7}$ com relação ao que já foi estudado e publicado na comunidade científica acerca dele. Para efetuar consultas, os campos de pesquisa disponíveis são quatro: autor, assunto, instituição, nível/ano base, podendo ser consultados individualmente (podemos pesquisar, por exemplo, o assunto "formação de professores") ou ser articulados entre si (por exemplo, podemos buscar uma tese consultando o nome do autor SILVA, a instituição USP e o assunto formação de professores, ao mesmo tempo). Nos campos autor, assunto e instituição, há a possibilidade de se buscar todas as palavras da expressão digitada, qualquer uma das palavras ou a expressão exata.

Em pesquisa realizada em abril de 2012 sobre as temáticas da pesquisa, verificamos as expressões "formação de professores", "formação de professores de línguas estrangeiras", "formação de professores de línguas estrangeiras e intercultural". Pensando em pesquisas que pudessem levar em conta o trabalho de ensino além do campo da Didática, buscamos também o termo ergonomia: em "ergonomia do trabalho do professor", "ergonomia do trabalho do professor de língua estrangeira", efetuando cada busca nas duas modalidades, todas as palavras da expressão e expressão exata (conferir Tabela 2).

\begin{tabular}{|l|c|c|}
\hline Expressão pesquisada & $\begin{array}{l}\text { Resultados para } \\
\text { todas as palavras }\end{array}$ & $\begin{array}{l}\text { Resultados para } \\
\text { expressão exata }\end{array}$ \\
\hline formação de professores & 14339 & 5715 \\
\hline formação de professores de línguas estrangeiras & 385 & 40 \\
\hline $\begin{array}{l}\text { formação de professores de línguas estrangeiras e } \\
\text { intercultural }\end{array}$ & 13 & 0 \\
\hline ergonomia do trabalho do professor & 93 & 1 \\
\hline $\begin{array}{l}\text { ergonomia do trabalho do professor de línguas } \\
\text { estrangeiras }\end{array}$ & 3 & 0 \\
\hline
\end{tabular}

Tabela 1: Resultados da pesquisa no Banco de Teses da CAPES em abril de 2012

\footnotetext{
${ }^{7}$ CAPES: Coordenação de Aperfeiçoamento Pessoal de Nível Superior. O banco de teses e dissertações virtual pode ser consultado no endereço: http://capesdw.capes.gov.br/capesdw/

${ }^{8} \mathrm{Na}$ formulação inicial do projeto de pesquisa, pensávamos em investigar o intercultural no ensino de LE, por isso a busca pelo estado da arte foi realizada com esse termo. Entretanto, como já mencionamos em nota anterior, optamos por empregar o "conteúdo culturais", por razões que serão detalhadas na Fundamentação Teórica.
} 
Os resultados nos mostraram que 14339 teses e dissertações continham todas as palavras da expressão "formação de professores" sendo que 5715 trabalhos correspondiam à expressão exata. Afunilando para as línguas estrangeiras, vimos que 385 continham as palavras "formação de professores de língua estrangeira", sendo 40 correspondentes à mesma expressão exata. Acrescentando o termo "intercultural", vimos que apenas 13 continham todas as palavras “formação de professores de língua estrangeira e intercultural”, sendo cinco delas sobre a língua inglesa, três sobre a língua portuguesa, duas sobre a língua francesa, uma sobre a língua espanhola e duas sobre as línguas estrangeiras em geral, e nenhuma correspondia à expressão exata. Observamos ainda, com relação à linha teórica de pesquisa, que 93 teses e dissertações atendiam a todas as palavras da expressão "ergonomia do trabalho do professor" e apenas um trabalho correspondia à expressão exata (conferir Figura 1).

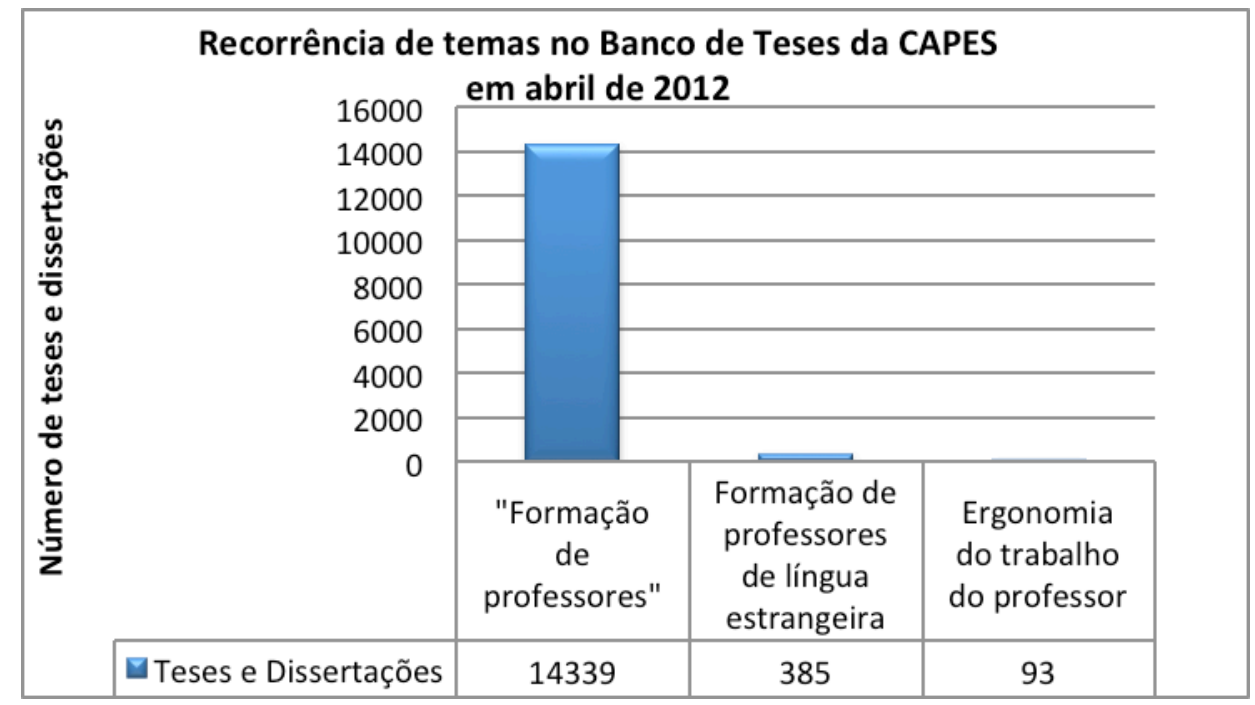

Figura1: Gráfico de recorrência de temas no Banco de Teses da CAPES

Concluímos que, apesar de constatarmos muitas produções científicas referentes à formação de professores, uma minoria muito pouco representativa a articula com as línguas estrangeiras e o intercultural, como podemos visualizar na Figura 1, não sendo diferente o resultado da articulação com a ergonomia da atividade do professor de língua estrangeira. Vale lembrar que ainda não há nenhuma tese articulando as quatro expressões pesquisadas: "formação de professores", "formação de professores de línguas estrangeiras", "intercultural" e "ergonomia

\footnotetext{
${ }^{9}$ A ergonomia do trabalho será definida na seção de Fundamentação Teórica.
} 
do trabalho do professor", o que evidencia a pertinência acadêmica em se realizar uma pesquisa para suprir tal ausência.

Dessa forma, o presente estudo responde não somente a uma carência de estudos brasileiros na área, mas também à demanda por pesquisas empíricas sobre práticas docentes, como já apontamos (BYRAM, 2011), mostrando-se assim relevante cientificamente ${ }^{10}$.

\section{Objetivo e perguntas de pesquisa}

Levando em conta nossas motivações, a problemática existente e o estado da arte sobre o tema, esta pesquisa objetiva estudar a maneira como os professores de FLE trabalham os conteúdos culturais em suas aulas através de uma análise de textos orais de entrevistas produzidas em situação de trabalho de ensino. De maneira mais específica, propomo-nos a identificar as "representações construídas nos e pelos textos" (BRONCKART, 2006) dos professores sobre a pertinência ou a necessidade que eles têm (ou não) de abordar os conteúdos culturais em aulas de FLE.

Embasada nos escritos de Vygotski ${ }^{11}$ (1934/997) sobre aprendizagem, desenvolvimento e linguagem e também nos autores que retomaram os estudos vygotskianos nas áreas da linguagem e desenvolvimento humano (BRONCKART, 1999, 2006, 2008), da filosofia (FRIEDRICH, 2010, 2012) e do trabalho (CLOT, 2001, 2008, 2011; FAÏTA, 1997, 2011; AMIGUES, 2002, 2004; SAUJAT, 2002, 2004, 2011), nossa pesquisa busca compreender o trabalho dos professores com respeito aos conteúdos culturais não somente do ponto de vista das orientações do que deve ser feito, mas a partir da ótica do sujeito em meio aos seus pares, realizando seu trabalho.

Interessa-nos primeiramente saber quais são as orientações previstas para o trabalho com os conteúdos culturais e como os professores entendem essas orientações, se elas lhes parecem

\footnotetext{
${ }^{10}$ Soma-se a essa justificativa, o comentário do Prof. Dr. Patrick Chardenet após uma apresentação da pesquisa, evidenciando a pertinência de pesquisas concretas sur le terrain de trabalho. Transcrição do comentário do prof. Chardenet em 28 de junho de 2013, gravado em áudio: "Se você conseguir fazer esse trabalho seria um passo muito importante: pegar o que determina a interculturalidade, que a União Europeia colocou no CECRL sem dizer o que isso quer dizer concretamente, porque os parâmetros não o dizem concretamente e ninguém sabe como fazer, como ensinar, como aprender e como avaliar. Isso é muito interessante, falar com os professores sobre isso, porque talvez através do agir do professor a realidade vai poder mostrar algumas coisas concretas, mas é um tema muito difícil."

${ }^{11}$ Adotaremos a grafia francesa do nome do autor russo: Vygotski, pois algumas das obras a que tivemos acesso empregaram esse modo de escrita. Em português muitos autores utilizam dois "i”": Vigotski.
} 
relevantes ou pertinentes. Em seguida, nos indagamos sobre como os professores representam e interpretam sua própria abordagem dos conteúdos culturais e se há diferenças entre elas. Finalmente, nosso intuito é, a partir das representações apontadas pelos sujeitos, levantar elementos para uma melhor compreensão do trabalho do professor de FLE com os conteúdos culturais.

Nossas perguntas de pesquisa retomam, então, essas preocupações:

(i) Quais são as orientações nos documentos oficiais acerca da cultura e do tratamento dos conteúdos culturais?

(ii) Quais são as representações construídas nos e pelos textos dos professores sobre a relevância ou a pertinência de se trabalhar conteúdos culturais?

(iii) Quais são as representações construídas nos e pelos textos dos professores sobre seu trabalho com conteúdos culturais? Há diferenças nas maneiras que os professores encontram para trabalhar os conteúdos culturais?

(iv) A partir de uma comparação/contraposição entre o trabalho prescrito, o trabalho realizado e o real da atividade de trabalho, como podemos apontar elementos para uma melhor compreensão sobre o trabalho do professor com conteúdos culturais?

(v) A partir de uma comparação/contraposição entre o trabalho prescrito, o trabalho realizado e o real da atividade de trabalho, como a análise da situação de trabalho pode ser considerada como potencialmente geradora de desenvolvimento? Que elementos podem ajudar a identificar e interpretar esse potencial?

\section{Contexto da pesquisa}

Como dissemos, nossa pesquisa nasceu de inquietações que surgiram enquanto professora e tutora em um curso de francês. Portanto, optamos por realizar nossa pesquisa nesse contexto, um curso de extensão universitária de Francês Língua Estrangeira em São Paulo: os Cursos Extracurriculares de Francês ${ }^{12}$. Do grupo de professores que integravam esses cursos, dois participantes se voluntariaram para terem suas aulas registradas e realizarem entrevistas.

\footnotetext{
${ }^{12} \mathrm{O}$ contexto da pesquisa, assim como os métodos de produção e seleção de dados serão mais bem detalhado no capítulo de Metodologia.
} 
Posteriormente, todo o coletivo de professores participou de duas reuniões para assistirem e discutirem trechos das aulas e das entrevistas, escolhidos e compartilhados pelos voluntários.

Dessa forma, os dados foram coletados na seguinte sequência:

- Documento interno de orientação aos novos professores dos cursos de francês;

- Livros didáticos de FLE empregados no curso (dois livros da mesma coleção);

- Quadro Comum Europeu de Referência para as Línguas;

- Registro em vídeo de uma aula de cada professor voluntário;

- Registro em vídeo de uma entrevista individual com cada professsor;

- Registro em vídeo de uma entrevista com os dois professores;

- Registro em vídeo de quatro reuniões com o grupo de professores dos cursos de francês, discutindo as aulas e entrevistas gravadas.

Do conjunto de dados disponíveis, os destacados em negrito constituíram o corpus de análise neste trabalho. Os demais documentos e registros apontaram elementos que nos permitiram melhor compreender e interpretar os dados.

\section{O grupo de pesquisa ALTER-AGE}

Antes de finalizar esta Introdução, parece-nos relevante mencionar minha participação no grupo de pesquisa ALTER-AGE ${ }^{13}$, já que ele teve papel preponderante no delineamento do estudo, tanto no que diz respeito aos objetivos, quanto à metodologia empregada e aos pressupostos teóricos adotados. O grupo ALTER-AGE, ao qual pertenço, articula-se em três grandes polos em torno do trabalho de ensinar: o polo do aluno, que se concentra na aprendizagem; polo dos artefatos e instrumentos, que estuda os instrumentos mediadores da relação de ensino-aprendizagem, como, por exemplo, os gêneros textuais; e o polo do professor, que se preocupa com a atividade de ensino, formação e desenvolvimento dos professores. Nossa pesquisa insere-se, justamente, no polo trabalho do professor, representado na figura abaixo.

\footnotetext{
${ }^{13}$ Análise da Linguagem, trabalho educacional e suas relações - aprendizagem, gêneros textuais e ensino.
} 


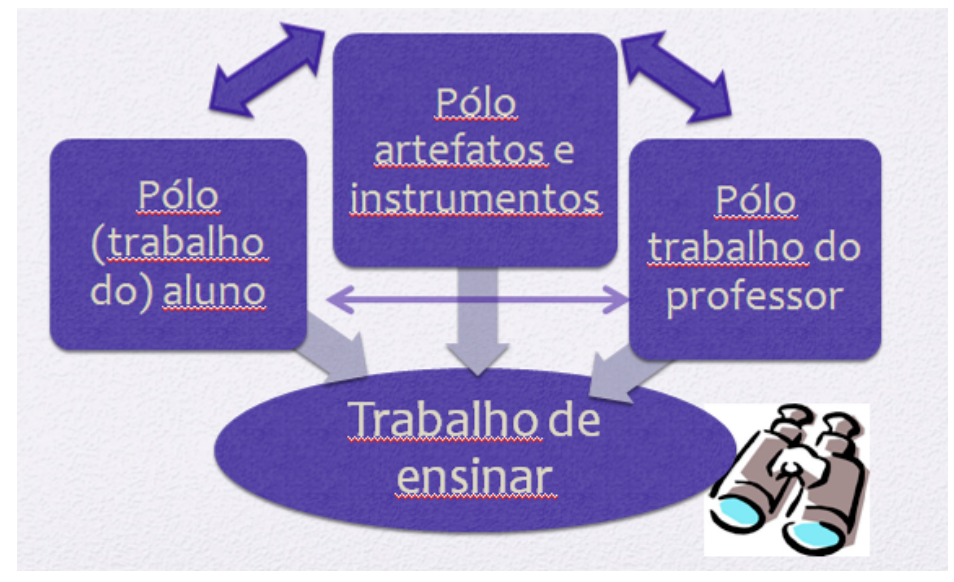

Figura 2: Articulação entre as pesquisas do Grupo ALTER-AGE (LOUSADA, 2012) ${ }^{14}$

No plano teórico, em consonância com as pesquisas do grupo ALTER-AGE-CNPq, adotamos uma abordagem interdisciplinar, envolvendo a Didática das Línguas e Culturas, o Interacionismo sociodiscursivo e duas das ciências do trabalho: a Ergonomia da Atividade e a Clínica da Atividade. Nosso estudo dialoga, assim, com a pesquisa de Simone Dantas-Longhi (2013), que realizou uma investigação acerca do trabalho dos professores de francês com os jogos na sala de aula, elemento esse também não delineado a fundo pela didática, mas com os quais os professores se defrontam todos os dias. Da mesma forma que Dantas-Longhi (2013), me proponho a ver a abordagem dos conteúdos culturais do ponto de vista dos professores de língua que têm de incluí-los em sua prática sem saber exatamente como.

No plano metodológico, adotamos o método da autoconfrontação (CLOT, FAITA, 2000), oriundo das ciências do trabalho, como meio de proporcionar verbalizações sobre o trabalho, possibilitando ao sujeito de reviver a experiência vivida. No grupo ALTER-AGE, empregamos ainda também outros métodos (conferir LOUSADA, SILVA, MENEZES, 2014), como, por exemplo, a instrução ao sósia.

\footnotetext{
${ }^{14}$ Esquema criado e apresentado por Lousada (2012) no Colóquio sobre o Trabalho Docente, realizado na Faculdade de Educação da USP em junho de 2012.
} 


\section{Organização da Dissertação}

O texto desta dissertação está organizado em cinco capítulos, além desta Introdução.

No Capítulo 1 - Fundamentação Teórica, descreveremos em cinco seções os pressupostos teóricos que fundamentam este estudo, a saber, o Interacionismo Social; o Interacionismo Sociodiscursivo; a abordagem do ISD para análise de textos; os Aportes das ciências do trabalho, a Clínica da Atividade e a Ergonomia da Atividade; finalizando com uma reflexão sobre os conteúdos culturais na Didática das Línguas e Culturas.

O Capitulo 2 - Metodologia abordará o contexto em que foi realizada a pesquisa, seus participantes, os procedimentos de produção, coleta e seleção dos dados, bem como ponderações sobre a credibilidade e os aspectos éticos de nosso estudo.

O Capítulo 3 - Resultados das Análises expõe, em três seções, os resultados encontrados a partir de nossas categorias de análise, a primeira sobre o documento prescritivo do agir dos professores, a segunda sobre a entrevista com os professores, terminando com a terceira seção em que propomos a discussão e interpretação desses resultados à luz de nosso quadro teórico, retomando nossas perguntas de pesquisa.

Finalmente, nas Considerações Finais, retomaremos o percurso da pesquisa, fazendo um balanço dos resultados obtidos, apontando as limitações e as contribuições do presente estudo. 


\section{Capítulo 1 - Fundamentação Teórica}

Por que é somente a partir de pessoas concretas, de carne $e$ osso, que a linguagem é falada. E a grande questão que é colocada à educação é a possibilidade que se lhe abra de invadir uma realidade dada com novos objetos de linguagem, capazes de fazer explodir a ação criativa.

Rubem Alves Conversas com quem gosta de ensinar 
Apresentaremos, neste capítulo, os autores e teorias que fundamentam nosso estudo, sua metodologia, análises, bem como a discussão dos resultados.

$\mathrm{Na}$ seção 1.1 - Interacionismo Social, situaremos nossa pesquisa dentro das ciências humanas, mencionando o grande quadro teórico em que nos inserimos, baseado nas obras de Vygotski (1997; 2004), dentre outros. Destacaremos alguns conceitos desse autor e de teóricos que avançaram na discussão dos estudos vygotskianos.

Na seção 1.2 - Interacionismo Sociodiscursivo, faremos uma exposição dos pressupostos e fundamentos que embasam esse quadro-teórico metodológico, a problemática do agir, o trabalho como agir, expondo também seu programa de pesquisa.

Na seção 1.3 - A abordagem do ISD para análise de textos, apresentaremos o modelo utilizado para análise dos dados e as categorias empregadas: estudaremos o modelo geral de análise de textos, algumas teorias da enunciação, elementos para a análise de textos procedimentais, categorias para análise do agir e das vozes.

Na seção 1.4 - Aportes das ciências do trabalho, desenvolveremos as relações entre ensino e trabalho, destacando conceitos que para compreender o métier de professor e metodologias de investigação desse trabalho.

Na seção 1.5, intitulada Reflexões sobre os conteúdos culturais no ensino de línguas, apresentaremos primeiramente algumas das noções que subjazem aos conteúdos culturais segundo a Didática da Línguas e Culturas; em seguida, proporemos a discussão da noção de competência, que aparece no documento de orientação para os professores; abordaremos a perspectiva vygotskiana de desenvolvimento; e finalizaremos com uma síntese do que expusemos, apresentando a perspectiva que adotamos neste trabalho. 


\title{
1.1. Interacionismo Social
}

Gostaríamos de começar esta seção situando nossa pesquisa dentro das ciências humanas, partindo de um quadro teórico bastante particular: o interacionismo social. Particular, pois não se trata simplesmente de uma base teórica, mas de um posicionamento diante das correntes existentes. Para tanto, trazemos uma definição de Bronckart (2005) sobre o Interacionismo Social, seguida de uma síntese dos quatro princípios de base aos quais tal posicionamento se articula.

\begin{abstract}
Aquilo que qualificamos hoje, retrospectivamente, como interacionismo social original não é um movimento formalmente constituído, mas uma orientação epistemológica geral à qual aderem de fato diversos pensadores das ciências humanas/ sociais: centralmente, Bühler (1927), Dewey (1925), Mead (1934), Politzer (1928) e, é claro, Vygotski (1927/1999); mais perifericamente ou parcialmente, Durkheim (1898), Saussure (1916), Wallon (1938) dentre outros. (BRONCKART, 2005, p.149, tradução nossa, grifo do autor). ${ }^{15}$
\end{abstract}

Bronckart (2005, p.150) esclarece que esses autores fizeram em sua época um diagnóstico da crise em psicologia, o qual representava, na verdade, um diagnóstico da crise das ciências humanas. Eles questionavam a fragmentação das disciplinas (antropologia, psicologia, sociologia, linguística etc.) e propunham uma reunificação das ciências do humano, entendendo que, para compreender o funcionamento e o desenvolvimento desse humano, era preciso levar em conta todas as suas dimensões e a interação que havia entre elas e fazer, assim, uma só ciência do humano. Esse modo de estudar o homem permitiria, assim, entender o processo dinâmico ou genealógico que caracteriza a antropogênese como ontogênese.

Para realizar esse projeto de ciência unificada, Bronckart (2005) aponta que seria preciso aliar-se ao slogan de Vygotski: "filosofia e prática". Prática significaria partir dos problemas concretos da vida humana, propondo formas de intervenção que visem à transformação da

\footnotetext{
${ }^{15}$ BÜHLER, K. Die Krise des Psychologie.Jena, Fischer, 1927

DEWEY, J. Experience and Nature, New York, 1925.

MEAD, G. H. Mind, self and society from the standpoint of a social behaviorist.Chicago, University of Chicago Press, 1934.

POLITZER, G. Critique des fondements de la psychologie, Paris, Rieder, 1928.

VYGOTSKI, L. S. La signification historique de la crise en psychologie. Paris, Delachaux et Niestlé, 1999 (escrito DURKHEIM, E. Représentations individuelles et representations collectives. Revue de métaphysique et de morale: 6, 1898, p. 273-302.

SAUSSURE, F. de. Écrits de linguistique générale. Paris, Gallimard, 2002.

WALLON, H. La vie mentale. Paris, Editions socials, 1938.

em 1927).
} 
realidade. Filosofia significaria que o trabalho de intervenção deveria ser sustentado por um trabalho propriamente científico, orientado por uma reflexão epistemológica, que se retroalimente através do questionamento dos modelos ou dos dados disponíveis, assim como da concepção filosófica que os sustentam.

A concepção filosófica que sustenta essa corrente poderia ser formulada, segundo Bronckart (2005), através da seguinte frase "a ciência do humano é uma ciência natural". Rejeitando o dualismo cartesiano (espírito vs. matéria), essa corrente postula que tudo que integra o universo e tudo que forma um ser humano é apenas e tão somente matéria, aderindo assim ao princípio do monismo materialista de Spinoza $(1954)^{16}$. Outro princípio que decorre deste é o do paralelismo fisio-psicológico, segundo o qual as matérias têm uma dimensão dinâmica ou psíquica que permite sua reorganização e transformação nos processos e nas interações com o ambiente.

Nessa perspectiva, o humano não é subestimado, ao contrário, suas características específicas, que os distinguem dos outros seres vivos, não podem desconsideradas, pontua Bronckart (2005). Segundo ele, a primeira dessas características é a organização das condutas em atividades coletivas diversificadas e complexas, constituindo quadros organizadores $e$ mediadores através dos quais os indivíduos entram em contato com o meio ambiente. A segunda é a emergência da linguagem verbal como instrumento para coordenação e gestão dessas atividades, constituído de signos, entidades sonoras que têm a potencialidade de remeter a representações do mundo e que tornam observável parte do processo psíquico e dinâmico subjacente. Esses signos se organizam em textos ou discursos que são, por sua vez, instrumentos de elaboração da sócio-história humana, que se diversifica sob o efeito da diversidade das línguas e das atividades que comentam, dando origem às múltiplas formações sociais e culturais. Em terceiro lugar, há a emergência do pensamento consciente no individuo, processo que deu origem à pessoa humana propriamente dita. Em quarto lugar, tem-se um sistema de interface entre esses dois sistemas (a sócio-história de um lado e os indivíduos de outro), constituído de um conjunto de modalidades de educação e de formação, visando transmitir às pessoas os conhecimentos da sócio-história (dimensão de reprodução ou de instrução) e a lhes permitir ter um papel ativo e criativo no devir dessa mesma sócio-história (dimensão da educação).

${ }^{16}$ SPINOZA, B. L’Éthique. In: Spinoza, Euvres complètes. Paris, Gallimard/ La Pléiade, 1954 p. 301-596. [edição original:1677). 
Bronckart (2005, p.151) ressalta que tais características não são, no entanto, relacionadas e hierarquizadas da mesma forma: para Piaget $(1946)^{17}$, por exemplo, é a transformação do pensamento que gera as atividades coletivas, a linguagem e a sócio-história; para Leontiev $(1976)^{18}$, as atividades coletivas seriam condição necessária para se gerar pensamento e linguagem; já Vygotski (1934/1997) concede o papel principal à emergência dos signos no comentário da atividade, signos cuja interiorização seria a condição da delimitação das unidades de pensamento e, portanto, da operação cognitiva e da consciência. $\mathrm{O}$ interacionismo social retém essas duas últimas vertentes, aprofundando-se na hipótese vygotskiana.

O interacionismo social propõe uma abordagem da ontogênese humana que apresenta duas grandes diferenças com relação às teorias dominantes do desenvolvimento (BRONCKART, 2005). A primeira é a inversão da ordem dos fenômenos, pois não se trata mais de partir das potencialidades cognitivas do sujeito e de observar o que elas permitem no nível da linguagem, da afetividade e das interações, mas, ao contrário, adotar uma abordagem descendente que examine:

a) o conteúdo dos pré-construídos vindos da história social de um grupo, isso é, as características organizacionais funcionais: os tipos de atividades em acontecem; as formações sociais que organizam a vida coletiva, com os valores, normas que essas formações constroem; a(s) língua(s) natural(is) em uso e os gêneros de textos que circulam;

b) as propriedades dos sistemas educativos-formativos, institucionalizados (escolarizados) ou não, que organizam os processos de transmissão desses pré-construídos aos "novos" humanos;

c) os mecanismos de apropriação e de interiorização pelos quais, no quadro desses sistemas formativos, os indivíduos constroem, por um lado, seus conhecimentos do mundo (dimensão epistêmica), por outro lado, seu estatuto de ator ou de pessoa (dimensão praxeológica, modalidades de participação nas atividades coletivas).

A segunda diferença consiste em considerar que essas mesmas interações formativas constroem, em um mesmo processo, a pessoa individual e os fatos sociais, o que implica uma

\footnotetext{
${ }^{17}$ PIAGET, J. Le développement de la notion de temps chez l'enfant. Paris, Delachaux et Niestlé, 1946.

${ }^{18}$ LEONTIEV, A.N. Le développement du psychisme. Paris, Éditions sociales, 1976.
} 
abordagem de análise de caráter ascendente que investigue as condições pelas quais as transformações sofridas pelos pré-construídos engendram cristalizações sociais e a reorganização das estruturas e fatos sociais.

É em Vygotski e na continuação de seus estudos por outros autores que encontramos alguns conceitos-chave para compreender e discutir o desenvolvimento humano, conceitos que empregaremos para levantar indícios de potencial desenvolvimento dos professores com relação a seu trabalho em nossos dados. $\mathrm{Na}$ sequência, abordaremos algumas de suas questões fundamentais: a relação entre pensamento e linguagem (VYGOTSKI, 1934/1997; BRONCKART, 2006, 2008); a questão da consciência e dos métodos indiretos (VYGOTSKI, 1925/2004, 1927/2004); instrumento e atividade mediadora (VYGOTSKI, 1930b/2004; FRIEDRICH, 2012); os conceitos cotidianos e científicos (VYGOTSKI, 1934/1997; FRIEDRICH, 2012).

\subsubsection{Pensamento e linguagem no desenvolvimento humano}

Para Vygotski (1934/1997), pensamento e linguagem teriam raízes genéticas distintas. Haveria na criança um estágio pré-verbal da inteligência e um estágio pré-intelectual da linguagem. Através da construção de capacidades de representação dos objetos e das ações, as crianças passariam a dominar agrupamentos e deslocamentos no plano mental. Por meio de interações mediadas pela linguagem e pelos instrumentos semióticos com os parceiros sociais, seriam levadas à construção de capacidades de comunicação: co-ações e proto-linguagem. Quando essas duas raízes se fundem, as entidades sonoras tornam-se signos e, uma vez unidos, pensamento e linguagem não se separam mais.

O signo, entidade sonora ligada a uma ideia ou representação, possui uma dupla face. A experiência com o mundo físico é reinvestida e reorganizada pelos signos da língua natural. Nesse sentido, é possível afirmar que a linguagem passa a assumir duas funções: uma função social de comunicação e interação com o ambiente e uma função individual de planejamento e controle das próprias ações.

Essa função individual foi estudada por Vygotski (1934/1997) quando ele identificou a chamada linguagem egocêntrica reguladora, ao observar crianças da faixa dos três a cinco anos realizando atividades e dirigindo falas a si mesmas como organizadoras do pensamento e da 
atividade. À medida que as crianças crescem, essa linguagem egocêntrica perde o essencial, restando um léxico pouco conectado, até que cessa de ser oralizada, transformando-se em linguagem interiorizada (ou interior) ${ }^{19}$ no adulto.

A linguagem interiorizada torna-se o organizador fundamental do funcionamento psicológico, sendo assim, a origem da consciência. $\mathrm{O}$ funcionamento consciente é, então, o produto da interiorização das unidades e das estruturas da língua e do ambiente social, sendo, portanto, essencialmente semiótico e social. Essa formação pode ser sintetizada no esquema abaixo:

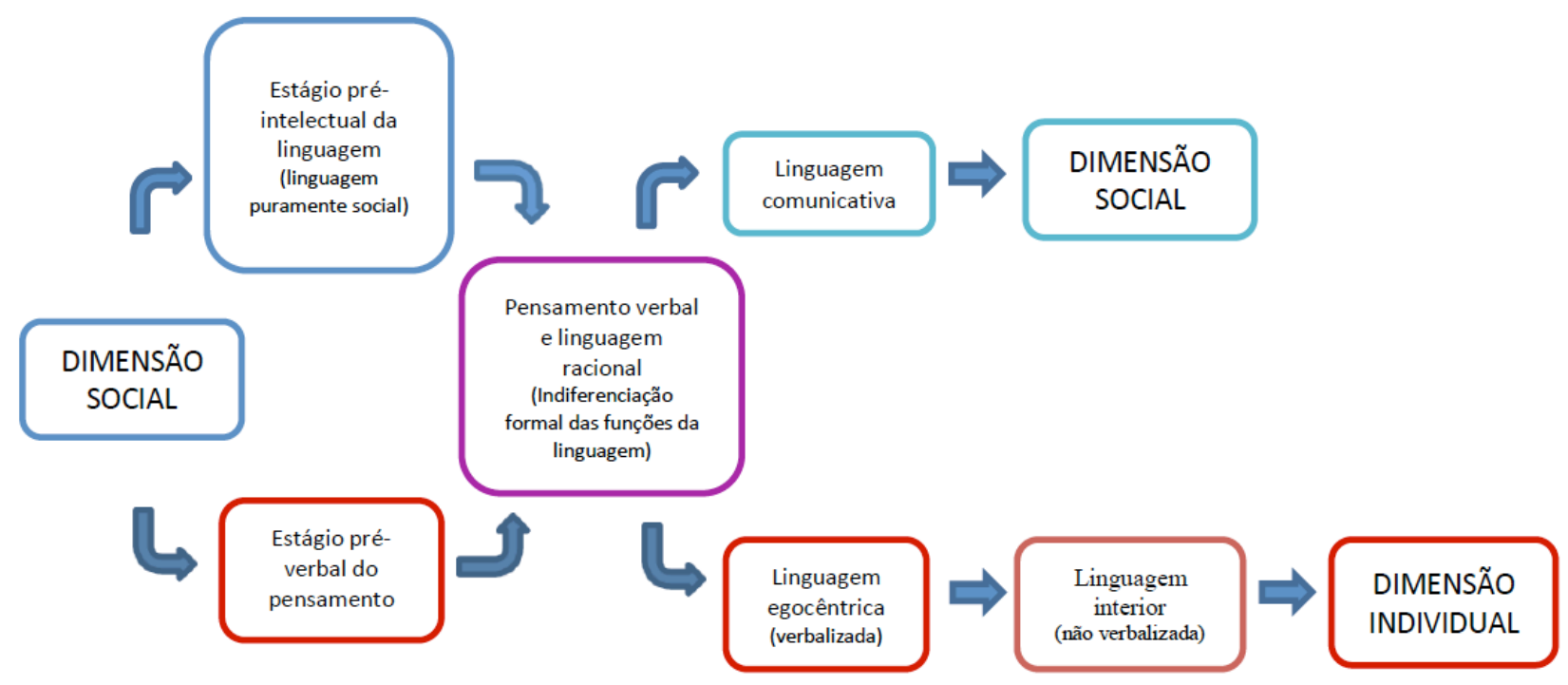

Figura 3: Esquema vygotskiano do desenvolvimento do pensamento (DANTAS-LONGHI, 2013)

Para Vygotski (1934/1997), é na interiorização da linguagem que se dá a revolução da espécie humana: o que era desenvolvimento natural torna-se desenvolvimento sócio-histórico ${ }^{20}$. As significações historicamente elaboradas por um grupo social são cristalizadas na língua natural e passam a organizar o funcionamento psicológico do indivíduo. Nesse sentido, Vygotski (1934/1997) postula que o desenvolvimento se dá em duas fases, primeiramente em um nível interpsicológico, social, e depois em um nível intrapsicológico, individual.

Bronckart (2006b) encontra alguns pontos a serem mais explorados na descrição desse modelo de Vygotski (1934/1997). Para ele, a orientação geral do desenvolvimento que é proposta (o papel das significações sociossemióticas na construção do pensamento) continua aceitável,

\footnotetext{
${ }^{19}$ Linguagem interior, linguagem interiorizada e fala interior serão empregados como sinônimos neste trabalho.

${ }^{20}$ Desenvolveremos também a questão do desenvolvimento nas seções 1.2 e 1.4 e 1.5 .
} 
porém a análise efetiva dos processos por meio dos quais essa apropriação se opera implica que sejam mais bem delimitadas duas unidades de análise: ação e estruturas práticas de linguagem. É justamente na articulação, investigação e aprofundamento dessas duas unidades de análise que surge a perspectiva do Interacionismo Sociodiscursivo, que abordaremos posteriormente na seção 2 deste capítulo.

\subsubsection{A questão da consciência e dos métodos indiretos}

A partir da relação entre pensamento e linguagem, Vygotski (1925/2004, p.71) define a consciência como "a vivência das vivências" (ou a experiência vivida da experiência vivida), pois nela se desdobra ou se duplica o que ocorre no nível das sensações.

Vygostki (1925/2004, p.74) traz um exemplo para ilustrar esse desdobramento. Ao presenciar o movimento do braço de alguém, sabemos que ele é perceptível ao olhar, tanto para a pessoa que movimenta, quanto para quem o observa. Contudo, a consciência desse movimento, as excitações que surgem dele e provocam reações secundárias, existem apenas para aquele sujeito, no nível de sua consciência.

Para ele, consciência ou conscientização seria "um sistema de mecanismos transmissores de uns reflexos para outros que funciona perfeitamente em todo momento consciente", dessa forma, tomar consciência ou "dar-se conta de algo significa justamente transformar certos reflexos em outros" (VYGOTSKI 1925/2004, p.71). Poderíamos, então, afirmar que, segundo Vygotski (1925/2004), nem toda tomada de consciência leva a uma mudança de comportamento, mas uma mudança de comportamento só será possível se o indivíduo se der conta e recolocar esse comportamento no nível da consciência.

Esses reflexos que se desdobram na consciência, apesar internos e inicialmente inerentes somente ao sujeito, podem ser acessíveis. Nesse sentido, Vygotski afirma (1925/2004, p.74):

Os reflexos não manifestos (a fala silenciosa), os reflexos internos, inaccessíveis à percepção direta do observador, podem ser descobertos, muitas vezes, indiretamente ou de forma mediatizada, através de reflexos acessíveis à observação, dos quais, por sua vez, são excitantes.

Disso decorrem implicações científicas para o campo da psicologia. Ao analisar o significado histórico da crise da psicologia (VYGOTSKI, [1927]/2004), o autor russo conclui que a observação dos fenômenos na psicologia deve se valer de métodos indiretos, empregando 
instrumentos que permitam ir além das observações diretamente acessíveis. A psicologia, para ele, deveria se inspirar em instrumentos como o termômetro:

A termometria constitui um modelo puro do método indireto: porque, diferente do que acontece com o microscópio, não estudamos aquilo que vimos - a elevação do mercúrio, a dilatação do álcool -, mas o calor e suas mudanças, indicados por suas marcas, por sua influencia na dilatação do corpo. (...) Por conseguinte, interpretar significa reconstruir o fenômeno segundo suas marcas e influências, baseando-se em regularidades estabelecidas anteriormente. (VYGOTSKI, 1927/2004, p.281).

Nesse sentido, Vygotski (1927/2004) propõe que se elaborem instrumentos a serem empregados em métodos indiretos capazes de reconstruir os fenômenos imperceptíveis ao olhar ou aos sentidos humanos. Nesse sentido, Vygotski (1934/1997, p. 335, 378) postula que os métodos indiretos, assim como os instrumentos, permitem que a atividade entre em uma zona de desenvolvimento potencial, que pode ser definida como a distância entre aquilo que o sujeito só consegue fazer com a ajuda de outra pessoa, em colaboração, e aquilo que é capaz de fazer sozinho. Retomaremos essa ideia ao apresentar a Metodologia desta pesquisa.

\subsubsection{Instrumento, atividade mediadora e atividade mediada}

Além de considerar os instrumentos no âmbito da investigação em psicologia, em "O método instrumental em psicologia", Vygotski (1930b/2004) elabora a questão do instrumento como dispositivo artificial para o domínio dos próprios processos psíquicos. Segundo ele, todas as funções psíquicas superiores como, por exemplo, a atenção voluntária ou a memória lógica, nascem com ajuda de instrumentos psicológicos e constituem, consequentemente, fenômenos psíquicos mediados (FRIEDRICH, 2012, p.56).

Essa tese é ilustrada pela comparação entre o exemplo da memória natural e o da memória artificial. A memória natural seria quando há um estímulo para guardar certa informação e a efetiva memorização da informação. Já a memória artificial ou voluntária, classificada por Vygotski (1931/2004) como uma das funções psíquicas superiores, se dá quando um instrumento

é inserido entre o estímulo ou a tarefa de memorizar e a efetiva memorização. Por exemplo, se para lembrar-se de trancar a casa antes de sair, o sujeito pendura a chave na maçaneta da porta, a chave será um instrumento usado voluntariamente para agir sobre a memória. A diferença entre uma e outra é que, por meio do instrumento, o processo que seria natural, torna-se artificial, 
sendo portanto passível de controle e domínio do homem (VYGOTSKI, 1930b/2004, p.94; FRIEDRICH, 2012, p.56).

A diferença entre os instrumentos materiais, usados para realizar um trabalho, como o martelo, por exemplo, e os instrumentos psicológicos, é que os primeiros são concebidos em função de seu objetivo e têm uma forma precisa e adaptada à tarefa. Ambos funcionam como intermediários e são intercalados entre a atividade humana e seu objeto. Porém, o instrumento psicológico não atua sobre o mundo físico, mas sobre o mundo psíquico do sujeito, como meio de autorregulação e autocontrole, assim, "qualquer objeto pode tornar-se um meio mnemotécnico, desde que permita que o sujeito se lembre melhor de alguma coisa" (FRIEDRICH, 2012, p. 57). Esse processo é ilustrado pelo quadro a seguir:

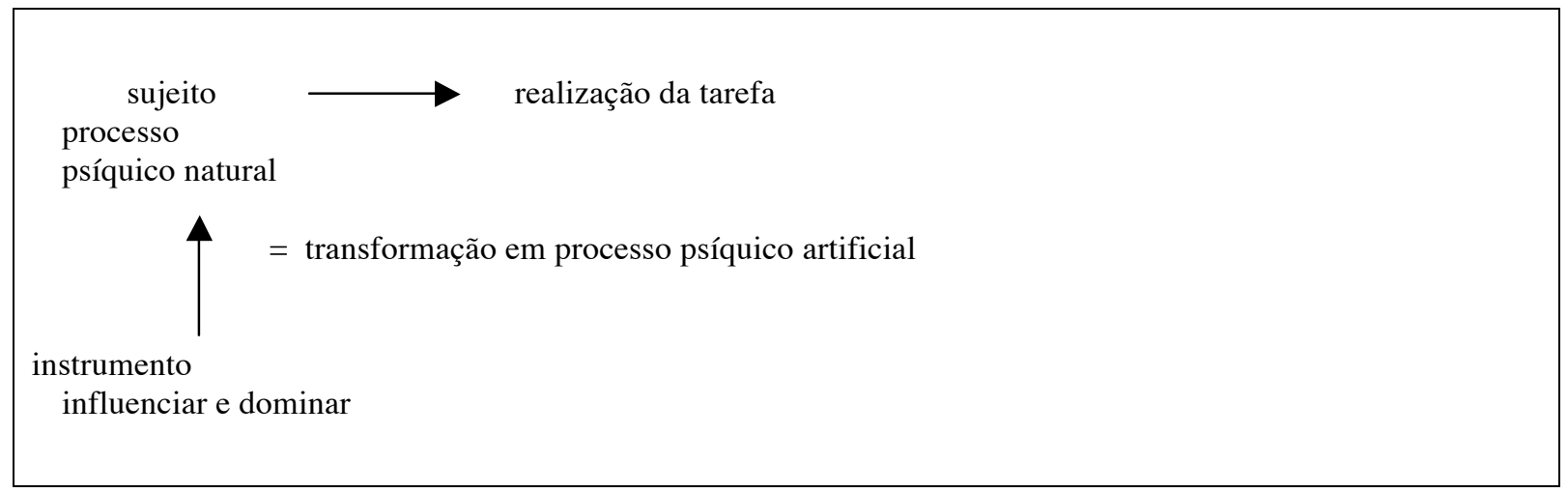

Figura 4: Função do instrumento psicológico (FRIEDRICH,2012, p.56)

Para explicar como esses instrumentos podem mediar os processos psíquicos, Vygotski (1930b/2004, p.93) ainda dá exemplos de instrumentos psicológicos e de seus sistemas complexos, enumerando-os: "a linguagem, os diversos sistemas de contagem e de cálculo, os meios mnemotécnicos, os sistemas algébricos, as obras de arte, a escritura, os esquemas, os diagramas, as cartas, os mapas, todos os signos possíveis etc.”.

Com efeito, não é o conceito de signo que permite identificar um instrumento psicológico, mas três outras características que os signos podem igualmente possuir: a) o instrumento é uma adaptação artificial; b) tem uma natureza não orgânica, em outras palavras, social; e c) é destinada ao controle dos próprios comportamentos psíquicos e dos outros (FRIEDRICH, 2012, p.58).

Para uma melhor compreensão do que é um instrumento psicológico para Vygotski, Friedrich (2012, p.63) menciona a distinção de atividade mediada (ou mediatizada, médiatisée) e 
mediadora (ou mediatizante, médiatisante), afirmando que tanto os instrumentos de trabalho quanto os instrumentos psicológicos estão subordinados à atividade mediadora. Segundo a autora, Vygotski $\left(1930 / 1985\right.$, p.39) ${ }^{21}$ retoma a ideia da astúcia da razão de $\operatorname{Heigel}^{22}$ e de $\operatorname{Marx}^{23}$, mostrando que o homem usa das propriedades dos objetos para fazê-los agir sobre outros objetos, de acordo com seus objetivos, como, por exemplo, posicionar uma goteira de maneira de que as gotas que caiam façam um buraco sobre uma pedra. Quando o sujeito age, ele mesmo, sobre a natureza com um instrumento (um machado, uma furadeira), temos uma atividade mediada. Contudo, quando o sujeito não age fisicamente sobre a natureza, mas deixa a natureza agir sobre a própria natureza, produzindo o que foi projetado pelo sujeito (como ilustra o quadro abaixo), temos uma atividade mediadora.

$$
\text { Objeto } \longrightarrow \text { Objeto }
$$

Sujeito

Figura 5: Atividade mediadora (FRIEDRICH, 2012, p.66)

\subsubsection{Formação de conceitos}

A ideia de mediação é também retomada em outra tese de Vygotski (1934/1997, p.211214): a formação de conceitos. Para o autor russo, o conceito é formado quando traços distintivos de um grupo de objetos foram abstraídos e submetidos a uma nova síntese, tornando-se esta a forma fundamental do pensamento. O método de abstração se apoia justamente na ideia de que o conceito é sempre uma representação do espírito que reúne múltiplos objetos pela abstração de um traço comum (FRIEDRICH, 2012, p.95).

\footnotetext{
${ }^{21}$ VYGOTSKI, L.S. La méthode instrumentale en psychologie. In: BRONCKART, J.P.; SCHNEUWLY, B. (org) Vygotsky aujourd'hui. Paris: Lausanne: DelachauxetNiestlé, p.39-47.

${ }^{22}$ HEGEL, G.W.F. Encyclopédie des sciences philosophiques. In: La science de la logique. Paris: Vrin, [1830]/1970.

${ }^{23}$ MARX, K. Le capital. Critique de l'économiepolitique. Vol 1: Le développement de la production capitaliste. Paris: Éditions sociales, [1867]/1959.
} 
Vygotski (1934/1997, p.271-410) considera como conceito quotidiano, aqueles adquiridos nas interações corriqueiras e o conceito científico, aquele desenvolvido no quadro escolar a partir de generalizações complexas. Assim, os conceitos científicos sempre se apoiam nos conceitos cotidianos, não podendo existir sem eles. Além disso, um conceito científico existe sempre no interior de um sistema de conceitos, sendo uma generalização de segunda ordem, já que a referência ao mundo que ele opera não é direta nem imediata.

Vygotski (1934/1997, p.207) destaca que é a mediação da palavra que torna essa operação mental possível:

O conceito é impossível sem as palavras, o pensamento conceitual é impossível sem o pensamento verbal; o elemento novo, o elemento central de todo o processo, que somos instituídos a considerar como causa produtiva da maturação dos conceitos é o emprego especifico da palavra, a utilização funcional do signo como meio de formação de conceitos. (VYGOTSKI, 1934/1997, p.207)

Em outras palavras, utilizar um conceito não significa simplesmente generalizar, conseguir reunir coisas do mundo, mas sim poder pensar o mundo e a criar relações, não factuais, diretas ou naturais, entre as coisas do mundo (FRIEDRICH, 2012). Segundo o autor:

Isso [utilizar um conceito] equivale à possibilidade de desenvolver o pensamento e, em última instância, uma concepção do mundo. (VYGOTSKI, [1930b]/2004, p.121)

Para Vygotski (1934/1997, p.267-268) a formação de conceitos aparece em operações intelectuais onde a palavra dirige as outras funções (direcionar a atenção voluntária, abstrair, diferenciar traços, sintetizar e simbolizar), para efetuar a resolução de um problema que se coloca.

Todos os elementos que apresentamos anteriormente fundamentam a hipótese de Vygotski (1934/2004) sobre o desenvolvimento, que é, em síntese, sócio-histórico, construído nas interações, ligado à experiência, à consciência, mediado por instrumentos (linguagem, conceitos e instrumentos) e está em constante transformação. ${ }^{24}$

Antes de passar à próxima seção, destacamos que os conceitos introduzidos serão importantes para este trabalho, pois fundamentam nosso quadro teórico, sendo, por esta razão, retomados em outros momentos deste capítulo. Além disso, eles serão essenciais para compreender e justificar nossa opção metodológica (método indireto), para integrar as categorias

\footnotetext{
${ }^{24}$ Retomaremos a perspectiva vygotskiana de desenvolvimento na seção 1.5 deste capítulo.
} 
de análise (fala interior e fala egocêntrica, tomada de consciência), bem como fornecer elementos para a interpretação dos resultados das análises (instrumento, atividade mediadora, conceito cotidiano e cientifico). 


\subsection{Interacionismo Sociodiscursivo}

De acordo com Bronckart (2006), o Interacionismo sociodiscursivo (doravante ISD) é ao mesmo tempo uma variante e um prolongamento do Interacionismo Social.

Bronckart $(1999,2006,2008)$ situa o ISD como uma reação à concepção positivista dominante nas ciências humanas, na qual se afirma a existência de um mundo empírico e de sujeitos dotados de capacidades cognitivas de representação desse mundo. Nessa concepção, considera-se que, primeiro, faz-se uma representação mental desse mundo e posteriormente a linguagem a descreve. No plano metodológico, isso implica que se estudem primeiramente as capacidades cognitivas, independentemente de qualquer contextualização histórica, e num segundo momento o modo como as línguas recodificam tais representações.

Baseado nos estudos vygotskianos, o ISD parte do pressuposto contrário, tanto as formas iniciais de conhecimento quanto as de linguagem nascem de atividades coletivas e sociais e depois passam por um processo de interiorização. A transformação da inteligência prática em um pensamento consciente "é consecutiva à apropriação do valor arbitrário ativo e discreto dos signos veiculados pelos textos do meio social" (BRONCKART, 1999, p.106), organizados primeiro numa lógica natural, acional e discursiva, dependente do contexto e depois permitindo abstração e descontextualização. Como vimos, segundo Vygotski (1934/1997), na ontogênese humana as atividades verbais do meio social teriam sido a origem do pensamento consciente, dependentes do contexto de ação e progressivamente se separando dele. Na filogênese humana, faz-se a hipótese de que a linguagem tenha surgido como uma necessidade de organização das atividades coletivas, portanto, de maneira análoga, do social para o individual.

Dessa forma, o ISD se propõe a realizar uma parte do projeto do interacionismo social, se concentrando primeiramente sobre a ontogênese humana a partir da abordagem descendente, deixando as outras questões às outras formas de interacionismo e às correntes da sociologia reconstrutiva. Mais especificamente, com o objetivo de abordar o desenvolvimento dos indivíduos sob os ângulos epistêmico (filosófico) e praxeológico (prático), o ISD visa demonstrar o papel fundador da linguagem e do funcionamento discursivo no desenvolvimento humano (BRONCKART, 2006), assumindo uma posição relativamente logocêntrica. 


\subsubsection{Conceitos de base do Interacionismo Sociodiscursivo}

Para demonstrar esse papel fundador da linguagem, o ISD se fundamenta em bases filosóficas, psicológicas e linguísticas representadas notadamente por Spinoza, Vygotski, que já citamos, além de $\operatorname{Marx}^{25}$, Saussure ${ }^{26}$, Habermas ${ }^{27}$, Volochinov $^{28}$, Durkheim $^{29}$ e Ricoeur ${ }^{30}$. Salientaremos a seguir alguns dos conceitos de base do ISD que permitirão uma melhor compreensão de nossa pesquisa.

É inspirado na teoria do agir comunicativo de Habermas (1987) que Bronckart (2008) desenvolve a concepção de linguagem do ISD. O princípio da teoria de Habermas (1987) é o de que qualquer atividade se desenvolve levando-se em consideração determinadas representações coletivas que se encontram em três sistemas chamados de mundos ("formais" ou “representados"): mundo físico, sobre o universo material tal como conhecido pela sócio-história humana; mundo social, conhecimentos coletivos sobre regras, convenções, condições de organização e cooperação entre membros de uma sociedade; e mundo subjetivo, constituído de produtos dos processos dialéticos entre o social e o indivíduo. Assim, qualquer agir humano exibe pretensões à validade em cada um desses mundos.

Imaginemos um exemplo concreto, para ilustrar: um aluno está atrasado para aula e hesita se deve entrar na sala atrasado ou se perderá a aula. Primeiro, ele sabe que é fisicamente possível entrar na aula e também socialmente possível, mesmo que isso implique em consequências. Essa dimensão ligada ao mundo objetivo é chamada de agir teleológico. Considerando que, em sua cultura, entrar atrasado seja muito desrespeitoso, caso ele decidisse ficar fora da aula, poderíamos classificar seu agir como regulado por normas (validado pelo mundo social). Caso ele se interesse muito pela aula e não queira se ausentar, ignoraria as regras sociais em detrimento de sua grande motivação pessoal, nesse caso poderíamos classificar seu agir como dramatúrgico (validado pelo mundo subjetivo).

\footnotetext{
${ }^{25}$ MARX, K. Thèses sur Feuerbach. In: MARX, K; ENGELS, F. Études philosophiques. Paris, Editionssociales, 1951, p.61-64 (manuscrito redigido em 1845).

${ }^{26}$ SAUSSURE, F. de. Ecrits de linguistique générale. Paris, Gallimard, 2002.

${ }^{27}$ HABERMAS, J. Théorie de l'agir communicationnel. Paris: Fayard, 1987.

${ }^{28}$ VOLOCHINOV, V.N. Marxisme et philosophie du langage. Paris, Minuit, 1977.

${ }^{29}$ DURKHEIM, E. Représentations individuelles et representations collectives. Revue de métaphysique et de morale: 6, 1898, p. 273-302.

${ }^{30}$ RICOEUR, P. Du texte à l'action; essais d'herméneutique II. Paris, Seuil, 1986.
} 
Dessa forma, podemos observar que um agir pode se mostrar eficaz com relação a um mundo e ineficaz com relação a outro. Portanto, a grande contribuição dessa teoria é a de mostrar que "a realização de um agir necessariamente se efetua considerando-se diferentes sistemas de determinações, que podem estar em conflito e não em uma trajetória retilínea determinada pelas propriedades que caracterizam a responsabilidade do agente" (BRONCKART, 2008, p.23).

É também em "Marxismo e Filosofia da linguagem”, de Volochinov", que Bronckart (2008) encontra seus pressupostos para definir a linguagem. Volochinov (1929/2006, p.47) defende que a consciência é um fato sócio-ideológico e, enquanto tal, não pode ser objeto de estudo da fisiologia ou das ciências naturais. O psiquismo subjetivo humano deve ser produto de uma análise ideológica e de uma interpretação sócio-ideológica, compreendida exclusivamente a partir de fatos sociais. Como, então, se estudar algo interior ao ser humano, sem observar seus componentes físicos? Para o autor, esse psiquismo subjetivo interior que pensa o mundo físico, exterior, só pode ser estudado através do signo. Fazendo dialogar a teoria habermaniana e volochinoviana, o ISD busca investigar o signo e a linguagem como formas de constituir, organizar e representar o mundo.

Bronckart aborda a noção de representação a partir da questão da materialidade textual de Ricoeur (1986) e dos conceitos de representação coletiva e individual de Durkheim (1898). Essa concepção difere, por exemplo, do conceito de Moscovici (2000/2010), para quem as representações são mentais e não necessariamente construídas nos e pelos textos. Segundo Jovchelovitch $(1998)^{32}$, Moscovici teria emprestado de Durkheim (1898) o conceito de "Representações Coletivas" para elaborar seu conceito de "Representações Sociais"33.

\footnotetext{
${ }^{31}$ Conhecendo as discussões de Bronckart e Bota (2012) em "Bakhtin Desmascarado" (2012) sobre a autoria dos escritos atribuídos a Bakhtin e/ou Volochinov, optamos por empregar Volochinov (1929/2006) para "Marxismo e filosofia da linguagem" e Bakhtin ([1979]/2011) para "Estética da criação verbal".

32 JOVCHELOVITCH, S. Representações Sociais: para uma fenomenologia dos saberes sociais. Psicologia e Sociedade, v. 10, n. 1, p. 54-68, 1998.

${ }^{33}$ Moscovici (2000/2010) cunhou o conceito de "representações sociais" em 1961, quando defendeu sua tese de doutorado. $O$ termo pode ser definido através de quatro postulados: a) a representação social é sempre representação de alguma coisa (objeto) ou alguém (sujeito); b) a representação social tem como seu objeto uma relação de simbolização (substituindo-o) e de interpretação (conferindo-lhe significação); c) a representação é uma nova fonte de saber, de modelização do objeto diretamente legível em diversos suportes linguísticos, comportamentais ou materiais, ela é uma forma de conhecimento; d) qualificar esse saber prático se refere à experiência, a partir da qual ele é produzido, contexto e condições, serve para agir no mundo. Para Moscovici, a finalidade de todas as representaçõe sociais (RS) é tornar familiar algo não familiar. $\mathrm{O}$ que nos é incomum, não familiar é assimilado e pode modificar nossas crenças. Esse é o processo de re-apresentar o novo. Esse processo se dá através da ancoragem: classificar o inclassificável e da objetivação, elaborar conceitos e imagens para reproduzi-los no mundo exterior
} 
O conceito de representação dentro do quadro do ISD se refere às interpretações, aos julgamentos, às avaliações que são construídos nas produções linguareiras manifestadas nos textos - sejam eles orais ou escritos - pelos falantes acerca dos fatos, dos sentimentos, das pessoas nas diferentes situações de comunicação de que participa. Essas interpretações, avaliações, julgamentos, representações expressos nos textos não nos permitem saber o que falante de fato pensa, mas o que pode ter lhe parecido adequado de expressar naquela situação (BRONCKART, 2008, p.124,148). Esse é um conceito importante em nossa pesquisa, pois integra o objetivo deste trabalho.

Poderíamos exemplificá-lo por meio de um mesmo fato, interpretado pelos diferentes participantes daquela situação. Retomando o exemplo de Feitoza (2012, p.24), imaginemos que em dada situação da sala de aula, professor e aluno discutam sobre uma brincadeira de mau gosto feita pelo aluno. A discussão pode ser interpretada de diferentes maneiras: pelo professor (que vê na atitude do aluno um desrespeito); pelo aluno (que vê na atitude do professor um exagero); pelos pais (que veem na atitude do filho falta de maturidade); pelos colegas (que veem na atitude do aluno um ato de coragem); pela direção da escola (que vê na atitude do aluno um motivo para uma sanção severa). Ainda, um mesmo indivíduo, por exemplo, o pai, poderia apresentar uma interpretação para com o filho (dando uma bronca) outra para com a direção da escola (diminuindo a gravidade do problema e defendendo seu filho). Isso ocorre justamente porque quando mudam os interlocutores, muda também a situação de comunicação. Daí decorre o fato de que as interpretações/representações expressas por um indivíduo, materializadas nos e pelos textos, não podem ser compreendidas como uma cópia ou um espelho da realidade.

Como vimos no exemplo, a materialização das representações se dá por meio da linguagem (sistema semiótico partilhado coletivamente) e têm sua origem nas interações sociais, assim, toda representação tem um caráter social, coletivo. Quando o indivíduo entra em contato com os textos, ele interioriza as representações coletivas de modo a torná-las individuais.

(MOSCOVICI, 2010). Além de um conceito, as representações sociais deram origem a uma Teoria em Sociologia, é a produção dos saberes sociais centrando-se na análise da construção e transformação do conhecimento social. Há, assim, três níveis de compreensão: o nível fenomenológico, onde as RS são objeto de investigação; nível teórico, conjunto de definições conceituais e metodológicas, construtos, generalizações sobre as RS; e nível metateórico, onde se fazem discussões sobre a teoria. 
Assim como propôs Feitoza (2012), poderíamos exemplificar a interação entre as representações coletivas e individuais observando algumas manchetes: "A missão do professor Edson” (texto de Luís Nassif, Folha - 01/03/1998) ${ }^{34}$, “'Professor não é profissão, é missão', afirma Alexandre Garcia" (O Globo, 06/08/2014) ${ }^{35}$, "Professor, a vocação para aprender e ensinar" (O povo, 15/10/2013) ${ }^{36}$. Por meio da materialidade do texto dessas manchetes, que circulam amplamente na mídia brasileira, podemos depreender a interpretação / avaliação que é feita do agir docente, no caso, como uma missão, vocação. Essas recorrências nos permite remontar a uma representação coletiva (BRONCKART, 2006) da figura do professor massivamente conhecida como aquele que nasceu para educar, cujas habilidades são inatas, que trabalha por amor e dedicação acima de tudo. Essas representações coletivas são interiorizadas e tornam-se representações individuais à medida que professores de carne e osso (como um professor universitário aposentado relatou em entrevista ${ }^{37}$ ou um professor de música se descreveu em seu perfi1 ${ }^{38}$ ) afirmam "sou professor por vocação".

Cabe também lembrar que o termo representação adotado na perspectiva interacionista discursiva se distingue do que é empregado pela psicologia cognitivista. Enquanto, para estes, a linguagem seria uma "vestimenta" das ideias, coincidindo com o pensamento, para o ISD a linguagem seria uma forma de acessar e interpretar o que aparece nos discursos, que não necessariamente representa o que, de fato, o indivíduo pensa. Retomando o exemplo anterior, quando os professores dizem "sou professor por vocação", a perspectiva cognitivista postularia que eles realmente pensam dessa forma, pois verbalizaram essa frase, ao passo que a perspectiva do ISD abordaria a materialidade do texto dentro da situação de comunicação (para quem eles dizem isso? Em que situação? Com qual objetivo?).

Dessa forma, por meio das contribuições desses e de outros teóricos, Bronckart (2005) afirma que o ISD visa a colocar em evidência que mecanismos de interação que se desdobram entre os quatro sistemas: a língua, a atividade social, o psicológico e o textual/discursivo.

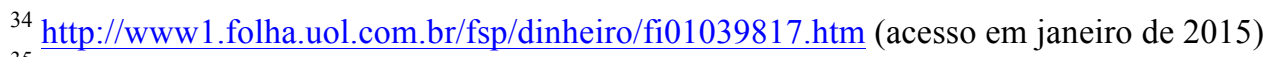

35 http://g1.globo.com/bom-dia-brasil/noticia/2014/08/professor-nao-e-profissao-e-missao-afirma-alexandregarcia.html (acesso em janeiro de 2015)

http://www.opovo.com.br/app/opovo/opiniao/2013/10/15/noticiasjornalopiniao,3146623/professor-a-vocacaopara-aprender-e-ensinar.shtml (acesso em janeiro de 2015)

${ }^{37}$ Depoimento: http://www.uel.br/portaldoaposentado/entrevista/entrevista_54.php (acesso em janeiro de 2015)

${ }^{38}$ Descrição dos professores: http://www.institutocuore.org.br/en/administracao.htm (acesso em janeiro de 2015)
} 
Apresentaremos a seguir, um esquema que resume alguns dos questionamentos acima apontados e desenvolvidos por Bronckart (2008) para fundar o ISD.

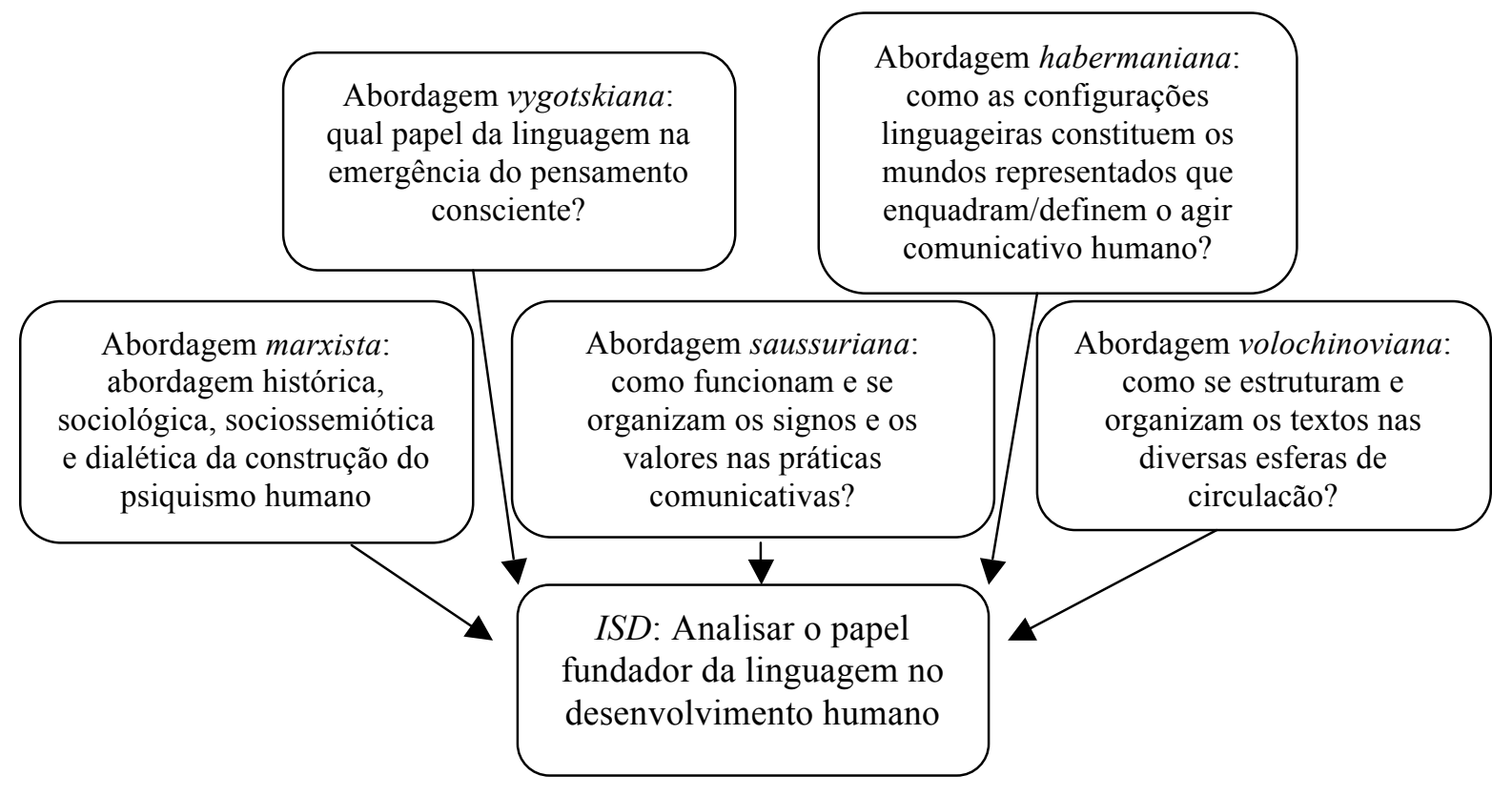

Figura 6: Esquema Síntese dos fundamentos do ISD

\subsubsection{A problemática do agir}

A partir dos conceitos de base que apresentamos, o ISD articula duas unidades centrais para compreender o desenvolvimento humano, o agir e a linguagem, bem como modelos de análise para estudá-las (que serão detalhados na seção 1.3).

Para definir ação, Bronckart (2006b) se vale de Ascombe ${ }^{39}$ e Wright $^{40}$ e separa os eventos, fenômenos naturais objetos de uma explicação causal, da ação significante, caracterizada pela intervenção humana no mundo. A ação seria uma sequência organizada de eventos atribuídos a um agente (dotado de capacidade de ação) ao qual pode ser atribuído um motivo (razão de agir) e uma intenção (representação do efeito).

Segundo Bronckart (2006b, p.68), "a ação significante, enquanto mobilizadora de representações conscientes e ativas do agente, não pode ser objeto de uma explicação causal, ela só pode ser objeto de uma interpretação compreensiva". Isso retoma o que vimos no conceito de

\footnotetext{
${ }^{39}$ ASCOMBE, E. Intention. Londres: Basil Blackwell, 1957.

${ }^{40}$ VON WRIGHT, G.H. Explanation and Understanding. Londres: Routledge\&Kegan Paul, 1971.
} 
representação, ou seja, não se pode ingenuamente identificar a ação e seu sentido, mas sim compreendê-la, o que exige, então, uma interpretação.

Ainda precisando o conceito de ação, Bronckart (2006b) afirma que as ações são sociais, não somente por serem obra de vários agentes, mas também porque têm efeitos a que não visamos. Nesse sentido toda ação é uma obra aberta, passível de interpretações dos outros, que atribuem intenções, motivos e responsabilidades, assim como o próprio agente pode interpretar sua ação, atribuindo-lhe sentidos.

Considerando os âmbitos social e individual da ação, Bronckart (2008, p.121) propõe uma distinção terminológica: "atividade designa uma leitura do agir que envolve dimensões motivacionais e intencionais mobilizadas no nível coletivo e ação designa uma leitura do agir que envolve essas mesmas dimensões mobilizadas no nível da pessoa particular" (BRONCKART, 2008, p. 121). O sujeito que o realiza é denominado actante, termo igualmente isento de valor interpretativo. Quando as configurações textuais denotam o actante como fonte de um processo, dotando-o de capacidades, motivos e intenções, utiliza-se o temo ator. Quando nenhuma dessas propriedades lhe é atribuída, utiliza-se o termo agente.

No contexto do desenvolvimento das atividades, a linguagem surge como um agir comunicacional, no sentido de permitir a intercompreensão, entendimento e acordo entre os interactantes para realizá-las. A produção linguageira que surge de proposições negociáveis, da correspondência formal entre sinais e acontecimentos, permite ao organismo humano transformar as representações idiossincráticas do mundo em representações compartilhadas controláveis e contestáveis pelos outros, ou seja, racionais. A racionalidade seria, portanto, primeiro um produto social, sendo posteriormente objeto de um processo de apropriação e interiorização que se pode constituir como racionalidade psicológica ou pensamento (BRONCKART, 2006b).

As formas de ação são, para o ISD, construídas sincronicamente na avaliação da atividade, podendo cristalizar-se, generalizar-se e tornar-se elementos constitutivos dos préconstruídos através do movimento dialético entre interações sincrônicas e a sócio-história (BRONCKART, 2006b, 2008).

É justamente essa conceituação do agir, construído nas interações e representado por meio dos textos, que empregaremos em nosso estudo. Uma das formas mais antigas e comuns de agir entre os seres humanos é o trabalho e é sobre esse agir que se volta a subseção a seguir. 


\subsubsection{O trabalho como agir}

Dentre as diversas formas de atividades coletivas organizadas, destaca-se o trabalho, destinado a assegurar a sobrevivência dos membros de um grupo ou comunidade (BRONCKART, 2008, p.126-129). Nas diferentes formações sociais, essas atividades se tornaram cada vez mais complexas e diversificadas.

Bronckart (2008, p.95) esclarece que as formas de organização do trabalho, pautadas pela relação econômica-social, produziram uma dualidade no entendimento da concepção de trabalho. De um lado, os proprietários e dirigentes das empresas definem as condições de trabalho, divisão de setores, empregos e tarefas, pensando em uma atividade econômica rentável. De outro, os trabalhadores vivem seu agir nesse quadro como um trabalho sobre o qual constroem representações e avaliações, para o qual mobilizam uma parte de seus recursos comportamentais e psíquico-mentais. A coexistência desses dois níveis e a distância entre eles é objeto das ciências do trabalho, as quais discutiremos na próxima seção.

$\mathrm{O}$ autor destaca ainda que dentre os estudos que enfocam os diversos aspectos da organização do trabalho, a abordagem ergonômica se volta para a análise da efetividade do trabalho, sustentando que "não se pode definir o trabalho real sem se considerar o conjunto de aspectos das relações entre o operador e as tarefas que ele deve realizar e visando a apreender o trabalho do ponto de vista dos operadores" (BRONCKART, 2008, p.97). Para os autores dessa perspectiva, é necessário se centrar na atividade da pessoa no trabalho.

Segundo Bronckart (2008), paralelamente à evolução da Ergonomia e das análises do trabalho, foram desenvolvidos diversos estudos sobre as produções linguageiras em situação de trabalho, inspirados sobretudo na Análise Conversacional e na Análise Crítica do Discurso. Outro viés também importante para as relações entre o agir e o trabalho foram os estudos sobre o agir formativo e a formação por meio da análise do agir, através dos métodos de entrevistas de explicitação, de autoconfrontação cruzada, de instrução ao sósia e de análise das narrativas de vida profissional. Assim,

Para a Ergonomia, a atividade dos trabalhadores é o seu fazer e o seu vivido desse fazer, que pode ser apreendida por determinados procedimentos de observação e de mensuração dos comportamentos por determinados procedimentos que visam a que os operadores verbalizam suas próprias representações das situações de trabalho e dos 
múltiplos aspectos de seu agir vivido. Portanto, essa atividade é concebida como um objeto em princípio enigmático, que as teorias buscam re-construir (ou co-construir com os trabalhadores); e também como proveniente de um compromisso entre as exigências das tarefas predefinidas e os recursos efetivos que podem ser mobilizados pelos trabalhadores (ver Teiger 1977). (BRONCKART, 2008, p.98)

Em pesquisas empíricas do ISD sobre o trabalho, buscou-se levar a problemática da morfogênese da ação, isso é lugares que dão origem às formas de agir no mundo.

Primeiramente, no plano dos pré-construídos, foram conduzidos trabalhos sobre os gêneros de texto produzidos em situação de trabalho, que contribuem para a orientação de alguns tipos de agir e que têm sido chamados de textos prescritivos, injuntivos, procedimentais, de incitação à ação etc.. Considera-se que eles propõem determinadas configurações verbais do agir e que constituem um primeiro lugar de morfogênese da ação.

No plano da realização do agir, foram realizadas análises das condutas verbais e não verbais dos actantes, evidenciando a complexidade das atividades em curso e o poder que os actantes têm de intervir e modificar os processos em curso. Para isso, buscou-se detectar índices que evidenciem a reflexividade, isso é, a consciência prática que têm das propriedades de sua situação e do agir que participam. Essa observação interpretativa do agir é um possível segundo lugar de morfogênese da ação. Além disso, foram realizadas entrevistas com os actantes antes e depois das tarefas para comentarem seu agir, assim como suas condições e restrições de realização. Essas produções verbais são um possível terceiro lugar de morfogênese da ação, sendo elas oriundas da consciência discursiva dos actantes.

No plano do desenvolvimento das pessoas e fatos sociais, buscou-se restituir às instituições o conjunto dos resultados obtidos nas pesquisas, tendo como objetivo uma posterior possível formação.

Em nosso trabalho, buscamos investigar o primeiro e o terceiro lugar de morfogênese da ação, analisando um documento prescritivo do agir dos professores e entrevistas realizadas após a situação de trabalho. 


\subsubsection{O programa de pesquisa do ISD}

Partindo das concepções teóricas e filosóficas apresentadas, o programa de pesquisa do ISD retoma os fundamentos do interacionismo social, que vimos na primeira subseção deste capítulo, e estrutura-se sobre três eixos principais em um método de análise descendente que se constrói em três etapas (BRONCKART, 2008, p.112-115): a) aquilo que já existia quando chegamos ao mundo, as produções da humanidade (os pré-construídos); b) os processos de mediação e formação pelos quais o ser humano se apropria dos pré-construídos; e c) os processos através dos quais ele se desenvolve.

O primeiro eixo, a análise dos elementos específicos do ambiente humano (chamados préconstruidos), conduz pesquisas sobre os quatro elementos principais desse ambiente: as atividades coletivas, as formações sociais, os textos e os mundos formais de conhecimento. $\mathrm{O}$ ambiente humano é constituído não só pelo meio físico, como também pelas condutas dos membros da espécie humana, que se organizam em atividades coletivas complexas, que vão além das exigências imediatas de sobrevivência, organizando e mediatizando os aspectos essenciais das relações entre os indivíduos e os meios. Quando analisamos essas atividades de maneira concreta e contextualizada, observando os aspectos físicos, econômicos e históricos, bem como as regras e valores gerados pelo grupo, falamos então de formações sociais. Às atividades coletivas, que podem ser não verbais, se articulam as atividades de linguagem, cujos correspondentes empíricos, produzidos com recursos de uma língua natural, são chamados textos. Os mundos representados ou mundos formais são, por sua vez, produtos de operações de descontextualização e de generalização que se aplicam aos textos e aos conhecimentos que eles veiculam. Isso quer dizer que determinados conhecimentos são abstraídos dos contextos socioculturais e organizados em sistemas de representações coletivas que tendem à universalidade. Esses mundos formais apresentam diferentes modalidades de organização lógica e, segundo Habermas, podem pertencer ao mundo objetivo, social e subjetivo.

O segundo eixo, a análise dos processos de mediação e de formação, envolve os processos desenvolvidos pelos grupos humanos para assegurar a transmissão e a reprodução dos préconstruídos, podendo ser agrupados em educação informal (atividades conjuntas e comentários verbais através dos quais adultos integram as crianças à sua formação social); educação formal, 
em sua dimensão didática (transmissão de conhecimentos) e pedagógica (formação das pessoas); e de transação social (interações cotidianas).

O terceiro eixo, a análise dos processos de desenvolvimento, envolve os efeitos que a transmissão dos pré-construídos produz sobre a constituição e o desenvolvimento das pessoas, subdividindo-se em três campos: a condição de emergência do pensamento consciente; análise das condições do desenvolvimento posterior das pessoas (campo com o qual nossa pesquisa dialoga) e análise dos mecanismos por meio dos quais cada pessoa contribui para a transformação contínua dos pré-construídos coletivos (seja pelos formatos de atividades coletivas, das organizações e dos valores sociais e das representações organizadas em mundos formais, seja pelas propriedades dos gêneros de textos e dos tipos de discurso).

Atualmente, o projeto de pesquisa do ISD é conduzido principalmente por dois grupos de pesquisa da Universidade de Genebra. O grupo LAF (Langage, Action et Formation) ${ }^{41}$, liderado por Jean-Paul Bronckart, realiza investigações ligadas à análise das ações e dos discursos em situação de trabalho e sua exploração dos procedimentos de formação. O grupo GRAFE (Groupe de Recherchedes Langues et Formation des Enseignants: analyse du français enseigné) ${ }^{42}$ trabalha sobre os objetos de ensino em aula de língua, (produção de texto, gramática, leitura e literatura) e pontualmente faz intervenções de formação junto a professores.

Esses dois grupos estabeleceram, ao longo dos últimos vinte anos, um diálogo com pesquisadores brasileiros, dando origem ao grupo de pesquisa ALTER, que desenvolveu parte do projeto de pesquisa do ISD no Brasil através de inúmeros colóquios, encontros, pesquisas e publicações sobre gêneros textuais, didática das línguas, trabalho docente, dentre outros ${ }^{43}$ (ABREU-TARDELLI, 2006; LOUSADA, 2006, 2011; MAZZILLO, 2006; MACHADO, 2007; GUIMARÃES, MACHADO, COUTINHO, 2007; GUIMARÃES, 2007; BUENO, 2007; BARRICELLI, 2007, 2012; MACHADO, 2009; MACHADO, LOUSADA, 2010; MACHADO, LOUSADA, FERREIRA, 2011; MUNIZ-OLIVEIRA, 2011; GUIMARÃES, KERSCH, 2012; BUENO, LOPES, CRISTOVÃO, 2013). Essas pesquisas têm em comum, além do quadro teórico, a abordagem da análise de textos do ISD, à qual nos voltaremos na seção a seguir.

\footnotetext{
${ }^{41}$ Conferir a página do grupo LAF: http://www.unige.ch/fapse/laf/

${ }^{42}$ Conferir a página do grupo GRAFE: http://www.unige.ch/fapse/recherche/groupes/SSED/didactiques/grafe.html

${ }^{43}$ Com o falecimento de Anna Rachel Machado em 2012, Eliane Lousada assumiu a liderança do Grupo ALTER, com a co-liderença de Ana Maria Guimarães. Eliane Lousada também é líder de um sub-grupo do Grupo ALTERCNPq, O Grupo ALTER-AGE-CNPq, que tem como vice-líder Luzia Bueno, ambos com sede na USP.
} 


\subsection{A abordagem do ISD para análise de textos}

Nesta seção, apresentaremos a abordagem utilizada para a análise de nossos dados. Primeiramente, apresentaremos o modelo geral de análise de textos de Bronckart, seguido das teorias de cunho enunciativo e categorias para análise das vozes que complementam o modelo. $\mathrm{Na}$ sequência, veremos o plano para análise dos textos em situação de trabalho do ISD, bem como dos textos procedimentais. Explanaremos a categoria que nos permite identificar como se configura o agir nesses textos e, por fim, terminaremos com um exemplo do modelo de análise de textos do ISD.

\subsubsection{O modelo geral de análise de textos do ISD}

Considerando os pressupostos que expusemos, Bronckart propõe originalmente em 1999 um modelo de análise de textos, reformulado e ampliado posteriormente nas publicações de 2006, 2008 e 2013.

$\mathrm{O}$ autor propõe um primeiro nível de análise, o da atividade linguageira, que tem como função primeira comentar as atividades ordinárias (ou não linguageiras), de contribuir à sua planificação, regulação e avaliação de seus efeitos. Essa atividade poderia ser qualificada como pré-linguística, pois o fenômeno pode ser analisado sem levar em conta as propriedades linguísticas da realização verbal, trata-se, portanto, de uma atividade que produz material verbal. O segundo nivel de análise é o dos textos (orais ou escritos) que materializam essa atividade através dos recursos da língua natural. Tais textos se distribuem em gêneros, cuja diversidade é potencialmente ilimitada, primeiro, porque comentam atividades ilimitadas, segundo, pois dependem de diversos tipos de mídia de interação comunicativa no curso da história e, por fim, porque suas características dependem também das escolhas das formações sociais e seus objetivos.

Há, portanto, uma primeira relação de interação que se estabelece entre atividade social e linguagem e, em decorrência desta, uma segunda relação de interação entre sistema textual discursivo e sistema da língua.

O primeiro nível de análise incide, então, sobre o contexto ou a situação de produção do texto, onde se observa os parâmetros físicos, emissor, receptor, local físico e momento, e os 
parâmetros sociossubjetivos: enunciador, destinatário, lugar social e objetivo que originaram aquela situação de comunicação. Enquanto nos parâmetros físicos se foca sobre as informações objetivas dadas no texto, nos parâmetros sociossubjetivos se observa atentamente o lugar social em que ocorre aquela situação de produção de texto, o papel de cada um dos coenunciadores, bem como a intenção por trás do texto e as demais interpretações e hipóteses que podem ser extraídas ou confirmadas a partir do próprio texto.

Para aprofundarmos a análise do contexto de produção e também considerarmos as características próprias dos textos orais das entrevistas, em nossa pesquisa valemo-nos das contribuições de Kerbrat-Orrecchioni (1996) no que tange à análise da conversação. Empregamos o conceito dos turnos de fala (KERBRAT-ORECCHIONNI, 1996, p.39), que podem ser equilibrados, encavalados, ter a predominância de um ou de outro falante; e o conceito de relação vertical ou horizontal dos falantes (KERBRAT-ORECCHIONNI, 1996, p.41-43), que explicita o grau de familiaridade e hierarquia de poder entre os falantes.

Passando para a análise da arquitetura interna do texto, o modelo de análise se divide em três extratos do folhado textual: a infraestrutura geral do texto, os mecanismos de textualização e os mecanismos enunciativos.

A infraestrutura geral do texto abarca os aspectos discursivos do texto: seu conteúdo temático, as sequências e os tipos de discurso. O plano geral dos conteúdos temáticos refere-se à organização de conjunto dos conteúdos do texto; mostra-se visível e pode ser codificado em um resumo, por exemplo. É através do plano dos conteúdos que podemos ver as temáticas que são tratadas no texto, dessa forma, essa foi a categoria que empregamos para a seleção dos dados nos dois textos que analisamos. As sequências (também usadas por outros autores sob o nome de tipos textuais) são os segmentos narrativos, argumentativos, explicativos, descritivos, injuntivos e dialogais. Já os tipos de discurso constituem uma noção menos conhecida que detalharemos na sequência.

No interior de cada texto, o ISD postula a existência de um regime de organização particular. Bronckart $(1999,2006)$ propõe a definição de tipos de discurso a partir da contribuição de outros autores: a distinção colocada por Benveniste ${ }^{44}$ (1959) entre "história" e

\footnotetext{
${ }^{44}$ BENVENISTE, E. Les relations de temps dans le verbe français. Bulletin de la société de Linguistique, n.54. Reeditado em Problèmes de linguistique générale, t. I, Paris: Gallimard, 1959/1966, p.237-250.
} 
“discurso", por Weinrich ${ }^{45}$ (1973) entre mundo comentado e mundo narrado, por SimoninGrumbach $^{46}$ (1975) entre três planos enunciativos, ou por Genette ${ }^{47}$ (1986) sobre a necessidade de distinguir as tentativas de classificação dos gêneros fundada "nos modos de enunciação", ou atitudes de locução de caráter universal, traduzidos por formas linguisticamente estáveis e identificáveis (como sujeitos, tempos verbais, etc.). Para o autor, os tipos de discurso são unidades linguísticas infraordenadas sobre dois eixos binários, como vemos no quadro a seguir.

\begin{tabular}{|c|c|c|c|}
\hline & & \multicolumn{2}{|c|}{ Coordenadas gerais dos mundos } \\
\hline & & Conjunção & Disjunção \\
\hline & & EXPOR & NARRAR \\
\hline \multirow{2}{*}{$\begin{array}{l}\text { Relação ao ato } \\
\text { de produção }\end{array}$} & Implicação & Discurso interativo & Relato interativo \\
\hline & Autonomia & Discurso teórico & Narração \\
\hline
\end{tabular}

Figura 7: Tipos de discurso (BRONCKART, 1999)

O primeiro eixo (disjunção-conjunção) organiza o conteúdo temático verbalizado situado próximo à situação de produção do agente-enunciador (ordem do EXPOR) ou distante dessa situação (ordem do NARRAR). No segundo eixo, as instâncias de agentividade são relacionadas ao agente-enunciador (implicação) ou não o são (autonomia). O cruzamento desses eixos é chamado de mundos discursivos e dá origem aos quatro tipos de discurso a seguir: o relato interativo (mundo discursivo do narrar implicado), por exemplo, um relato de alguém que fez uma viagem para um destinatário presente na enunciação; a narração (narrar autônomo), por exemplo, um conto, em que não há marcas da situação de produção do texto; o discurso interativo (expor implicado), por exemplo, um diálogo convidando alguém para ir ao cinema; e o discurso teórico (expor autônomo), por exemplo, um tratado filosófico.

$\mathrm{O}$ autor aponta ainda que esse quadro teórico permite que pesquisas empíricas sejam conduzidas, visando mostrar que, assim como a prática e a interiorização do signo estão na origem da constituição do sistema de pensamento, a prática dos tipos de discurso existentes nos textos é a ocasião de um aprendizado permanente das formas de raciocínio nas quais se desdobra

\footnotetext{
${ }^{45}$ WEINRICH, H. Le temps. Paris: Seuil, 1973.

${ }^{46}$ SIMONIN-GRUMBACH, J. Pour une typologie des discours. In: KRISTEVA, J-C., MILNER e N. RUWET (eds.) Langue, Discours et société. Pour Emile Benveniste. Paris: Seuil, 1975, p. 85-121.

${ }^{47}$ GENETTE, G et al. Théories des genres. Paris: Seuil, 1986.
} 
o pensamento: raciocínios de senso comum, que obedecem às regras das representações coletivas implicadas no tipo discurso interativo; raciocínios lógico-causais implicados no relato e na narração; raciocínios de ordem lógica ou semiológica implicados nos discursos teóricos.

O segundo nível do folhado textual é constituído dos mecanismos de textualização, caracterizado pela conexão, que se refere ao modo como é organizado um texto através de marcadores ou organizadores textuais, como, por exemplo, algumas conjunções ou advérbios; e pela coesão, esta dividida em coesão nominal, representada pelas retomadas nominais e pronominais, ou anáforas e catáforas e coesão verbal, articulação de tempos e modos verbais. Em nossa pesquisa, detemo-nos sobretudo na análise da coesão nominal, por meio da identificação de séries coesivas (BRONCKART, MACHADO, 2004; LOUSADA, 2010) e dos lexemas verbais (BRONCKART, 1999).

O terceiro nível do folhado textual compreende os mecanismos de responsabilidade enunciativa através das vozes e modalizações do texto, que lhe conferem sua característica dialógica (BRONCKART, 2008).

As modalizações são o meio através do qual os enunciadores colocam suas avaliações sobre o conteúdo temático e podem ser divididas em lógicas, do domínio da verdade (ex: é verdade, é certo, é possível, é provável); deônticas, do domínio da obrigação, da permissão, do dever (ex: é preciso); pragmáticas, do domínio da responsabilidade do actante (ex: ela quis fazer isso, mas não pôde, não conseguiu); e apreciativas, do domínio da avaliação do conteúdo (ex: é interessante, é triste).

Já as vozes explicitam as instâncias que assumem ou se responsabilizam pelo que está sendo dito, chamando para o enunciador ou distanciando dele os conteúdos veiculados no texto e seu valor. Para analisar os mecanismos enunciativos e, portanto, a questão das vozes encontradas no texto, Bronckart (1999) encoraja o apoio de outras teorias discursivas complementares, através de autores que investigam mais a fundo essa questão, os quais apresentaremos na subseção seguinte, dedicada a algumas teorias de cunho enunciativo de linha francesa. O recurso a essas teorias se justifica, pois se trata de uma categoria importante para nossas análises, como veremos mais à frente. 
Para sintetizar o modelo de análise proposto por Bronckart (1999), retomamos o quadro proposto por Feitoza (2012).

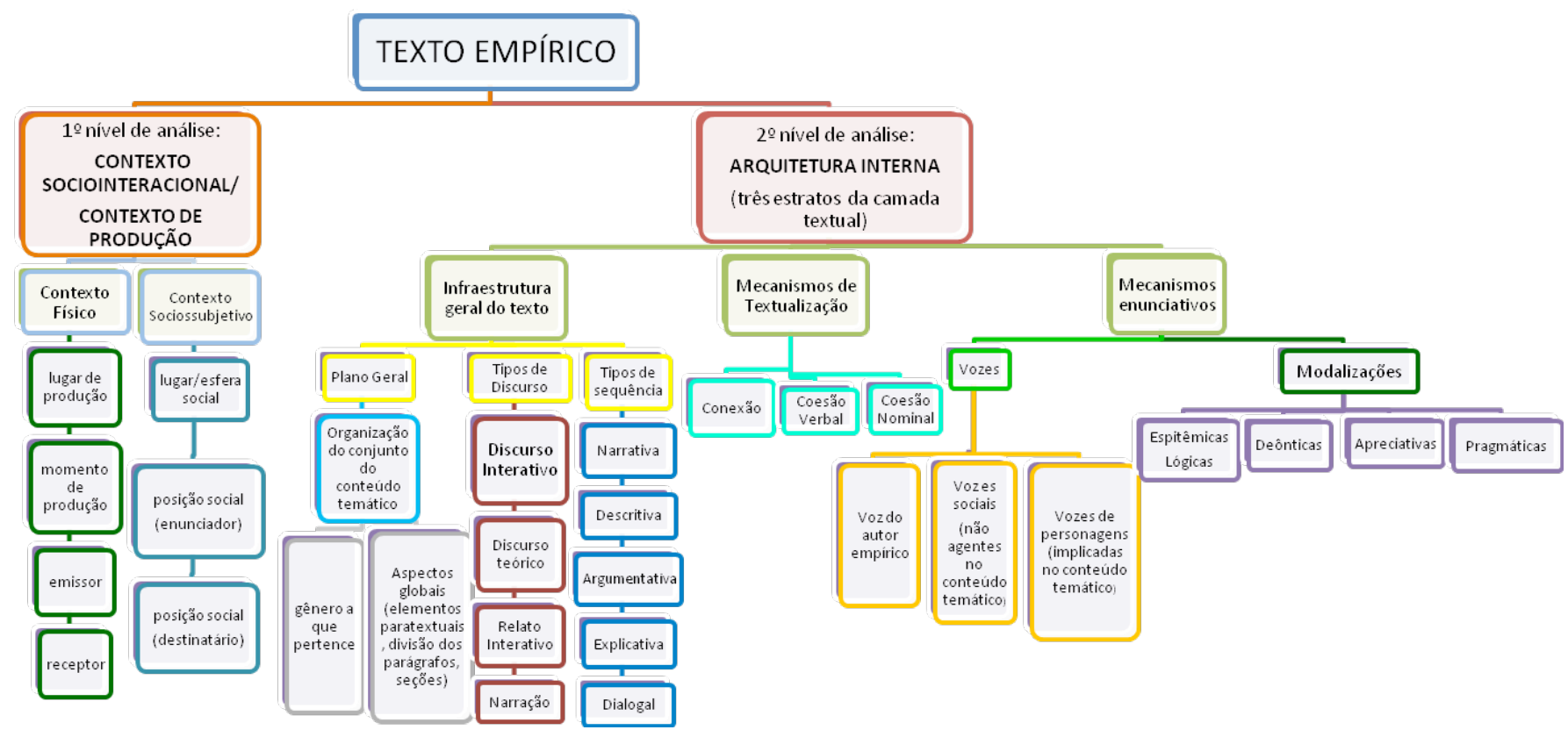

Figura 8: Modelo de planificação dos textos empíricos (FEITOZA, 2012)

\subsubsection{As teorias de cunho enunciativo: vozes e modalizações}

Para compreender a situação de comunicação, especialmente no que se refere aos enunciadores do texto, nos valemos, assim como os teóricos das ciências do trabalho (FAÏTA, 1997; CLOT, 1999), da noção de dialogismo de Bakhtin (1979/2011). Segundo este autor, o enunciado não deve ser estudado isoladamente, mas é preciso considerá-lo como um elo da cadeia de discursos que circulam desde o início da humanidade, observando a quem aquele enunciado está respondendo. Nas palavras do autor (BAKHTIN, 1979/2011, p.299):

O enunciado se verifica um fenômeno muito complexo e multiplanar se não o examinarmos isoladamente e só na relação com seu ator (falante), mas como um elo na cadeia da comunicação discursiva e da relação com outros enunciados a ele vinculados (...).

Além do caráter dialógico da linguagem, Bakhtin (1979/2011) considera que o enunciado tem um caráter polifônico, pois a responsividade do diálogo faz com que o enunciador retome a voz do outro em sua fala, diretamente ou implicitamente. Nesse sentido Bakhtin (1979/2011, p.299) nos ajuda a compreender as vozes dos textos: 
Tudo isso se verifica, antes de tudo, onde o discurso do outro (ainda que seja uma palavra que aqui ganha força de um enunciado pleno) é citado textualmente e destacado com nitidez (entre aspas): os ecos da alternância dos sujeitos do discurso e das suas mútuas relações dialógicas aqui se ouvem nitidamente. Contudo, em qualquer enunciado, quando estudado com mais profundidade em situações concretas de comunicação discursiva, descobrimos toda uma série de palavras do outro semilatentes e latentes, de diferentes graus de alteridade. Por isso o enunciado é representado por ecos como que distantes e mal percebidos das alternâncias dos sujeitos do discurso e pelas tonalidades dialógicas, enfraquecidas ao extremo pelos limites dos enunciados, totalmente permeáveis à expressão do autor. (BAKHTIN, 1979/2011, p.299)

No intuito de aprofundarmos essa questão, nos inspiramos na tese de Lousada (2006), onde encontramos algumas contribuições das teorias da enunciação de linha francesa para $o$ estudo das vozes e das modalizações para análise de textos na situação de trabalho, sobretudo quanto aos autores Maingueneau (1989, 1991, 2001) e Authier-Revuz (1998, 2001). Sendo assim, retomamos esses autores para uso em nossas análises e apresentamos, a seguir, alguns conceitos importantes para nós.

Com relação às vozes presentes nas entrevistas dos professores, baseamo-nos em Maingueneau (1989, 1991, 2001). O autor sustenta que o processo de inserção de vozes pode acontecer por meio de vários recursos, tais como: discurso direto, direto livre, indireto, indireto livre, aspas, dentre outros. A ausência de marcas explícitas, como dois pontos e travessões, por exemplo, torna mais difícil a identificação das vozes presentes em textos orais. Para tanto, a observação dos verbos discendi ou verbos introdutórios (como dizer, falar, pensar, confessar) é fundamental. Além disso, o autor sustenta que a análise dos dêiticos de pessoa (eu, você, a gente, nós, vocês e pronomes correspondentes), de tempo (ontem, hoje, agora, amanhã etc.) e espaço (aqui, aí, lá etc.) dependem da situação de enunciação e dos referentes do discurso e podem ajudar a melhor compreender as vozes que os sujeitos implicados trazem para sua fala.

Retomando a ideia de polifonia no discurso (BAKHTIN, 1979/2011), vimos que muitas vezes a inserção de vozes não é de todo evidente ou explícita. Nesse sentido, Maingueneau (2001, p.158) destaca uma categoria que permite explorar melhor o enunciado: a modalização autonímica, definida como o "conjunto de procedimentos pelos quais o enunciador desdobra seu discurso, comentando sua própria fala”.

Authier-Revuz $(1998,2001)$ faz um estudo sobre essas modalizações autonímicas e, além das formas metaenunciativas explícitas de reformulação e comentário do próprio dizer, ela 
destaca as formas puramente interpretativas (alusões, discurso indireto livre, jogo de palavras não marcado), que fazem parte da heterogeneidade constitutiva do discurso. Considerando essas formas interpretativas como "não-coincidências do dizer", Authier-Revuz (1998, 2001) mostra que essas formas podem identificar outras vozes no discurso através de alguns indicadores, como vemos no quadro abaixo.

\begin{tabular}{|c|c|c|c|}
\hline \multicolumn{4}{|c|}{$\begin{array}{l}\text { Formas puramente interpretativas da heterogeneidade constitutiva } \\
\text { (MAINGUENEAU, 2001; AUTHIER-REVUZ, 1998, 2001) }\end{array}$} \\
\hline Classificação & Definição & Exemplo & Indicadores \\
\hline $\begin{array}{l}\text { a) Não-coincidência } \\
\text { interlocutiva }\end{array}$ & $\begin{array}{l}\text { quando as modalizações } \\
\text { autonímicas indicam uma } \\
\text { distância entre os } \\
\text { coenunciadores. }\end{array}$ & $\begin{array}{l}\text { Desculpe a expressão, se } \\
\text { se pode dizer, se você } \\
\text { preferir, entende o que eu } \\
\text { quero dizer? Como você } \\
\text { mesmo diz... }\end{array}$ & \\
\hline $\begin{array}{l}\text { b) Não-coincidência do } \\
\text { discurso consigo mesmo }\end{array}$ & $\begin{array}{l}\text { quando o enunciador alude } \\
\text { a um outro discurso dentro } \\
\text { de seu próprio discurso. }\end{array}$ & $\begin{array}{l}\text { Como diz } x \text {, para usar as } \\
\text { palavras de } x \text {, para falar } \\
\text { como os esnobes, o assim } \\
\text { chamado..., o que se } \\
\text { costuma chamar... }\end{array}$ & $\begin{array}{l}\text { - palavras de outro lugar, } \\
\text { de outra época, de outra } \\
\text { teoria, de outra pessoa, } \\
\text { jargões; } \\
\text { - outra língua, região, } \\
\text { época, socioleto, posição } \\
\text { política etc. }\end{array}$ \\
\hline $\begin{array}{l}\text { c) Não-coincidência entre } \\
\text { as palavras e as coisas }\end{array}$ & $\begin{array}{l}\text { quando se trata de indicar } \\
\text { que as palavras } \\
\text { empregadas não } \\
\text { correspondem exatamente } \\
\text { à realidade que deveriam } \\
\text { designar. }\end{array}$ & $\begin{array}{l}\text { O que é preciso chamar } x \text {, } \\
\text { poderíamos dizer, como } \\
\text { dizer? ia dizer x, x ou } \\
\text { melhor y, já que é } \\
\text { necessário nomear... }\end{array}$ & $\begin{array}{l}\text { - metáforas, neologismos, } \\
\text { eufemismos, hipérboles, } \\
\text { entre outros. }\end{array}$ \\
\hline $\begin{array}{l}\text { d) Não-coincidência das } \\
\text { palavras consigo mesmas }\end{array}$ & $\begin{array}{l}\text { quando o enunciador se } \\
\text { confronta com o fato de } \\
\text { que o sentido das palavras } \\
\text { é ambíguo. }\end{array}$ & $\begin{array}{l}\text { Em todos os sentidos da } \\
\text { palavra, no sentido } \\
\text { primeiro da palavra, } \\
\text { literalmente, eis a palavra } \\
\text { adequada... }\end{array}$ & \\
\hline
\end{tabular}

Tabela 2: Formas puramente interpretativas da heterogeneidade constitutiva ${ }^{48}$

Neste trabalho, destacamos a forma b) como uma das categorias relevantes para nossas análises, especialmente no que se que refere aos jargões.

\subsubsection{Voz da fala egocêntrica e voz fala egocêntrica reconstituída}

Ainda no que diz respeito à identificação das vozes no texto, apresentamos a seguir duas categorias expostas por Lousada e Dantas-Longhi (2014, p.143-166): a voz da fala egocêntrica e voz da fala egocêntrica reconstituída. Essas duas vozes são bastante importantes para nossa pesquisa, pois elas foram identificadas em textos semelhantes aos nossos, e com o mesmo

\footnotetext{
${ }^{48}$ Baseada em MAINGUENEAU, 2001; AUTHIER-REVUZ, 1998, 2001.
} 
objetivo: analisar o agir dos professores representados nos e pelos textos produzidos em situação de trabalho. Dessa forma, optamos por apresentá-las separadamente.

Como já mencionamos, Vygotski (1934/1997) elabora uma teoria sobre o desenvolvimento do pensamento e da linguagem nas crianças. Durante o desenvolvimento da linguagem, a criança em idade pré-escolar apresenta uma linguagem egocêntrica, organizando sua ação verbalmente e que, semelhantemente à linguagem interior dos adultos, apresenta-se como uma mediação do sujeito consigo mesmo. O fato de ser verbalizada, para o autor, é um indício de que a linguagem tem um caráter primeiramente social, sendo depois interiorizada, dando origem à linguagem interior.

Com base nesses estudos e nas pesquisas de Piaget (1923/1968), as autoras (LOUSADA, DANTAS-LONGHI, 2014) sublinham o fato de que mesmo com interpretações diferentes para o mesmo fenômeno, Vygotski (1934/1997) e Piaget $(1923 / 1968)^{49}$ partilham de duas teses:

- a primeira, cuja formulação pertence a Claparède ${ }^{50}$, diz que "as dificuldades e perturbações que surgem em uma atividade conduzida automaticamente levam à uma tomada de consciência dessa atividade" (VYGOTSKI, [1934]1997, p.96, tradução das autoras)

- a segunda declara que "a aparição da linguagem sempre atesta esse processo de tomada de consciência” (VYGOTSKI, [1934]1997, p.96, tradução das autoras)

Considerando essas duas teses, as autoras (Lousada e Dantas-Longhi, 2014, p.143-166) concluem que, por um lado, as dificuldades e perturbações - ou os conflitos - podem funcionar como motores para a tomada de consciência dos sujeitos quanto a sua atividade e consequentemente para seu desenvolvimento e, por outro lado, que traços desse processo de tomada de consciência podem ser encontrados na análise da linguagem.

Para, então, identificar esses possíveis momentos de tomada de consciência, Lousada e Dantas-Longhi (2014) inspiradas em Vygotski (1934/1997), observam indícios da voz da fala egocêntrica quando, diante de um conflito, o enunciador passa a dirigir a fala a si mesmo, concentrando-se em organizar seu próprio pensamento, perdendo de vista seu interlocutor e perdendo, em algum grau, o controle de sua atividade. Marcas de hesitação, fala entrecortada, longas pausas, acompanhadas de possíveis mudanças de direção do olhar ou postura, podem ser

\footnotetext{
${ }^{49}$ PIAGET, J.; DESLEX, A. (1923). Le langage et la pensée chez l'enfant:Préface de Ed. Claparède. Neuchâtel: Delachaux\&Niestlé, 1968.

${ }^{50}$ CLAPARÈDE, E. (1923). Préface. In: PIAGET, J. Le langage et la pensée chez l'enfant. Neuchâtel: Delachaux\&Niestlé, 1968.
} 
alguns marcadores dessa fala. O momento do retorno à situação de comunicação com alguma marca linguística (bom, enfim etc.) pode ajudar também a evidenciar essas vozes. O exemplo abaixo é uma das ocorrências que encontramos em nosso dados:

Exemplo: 825S: mais en fait il y a un moment que j'ai:: il y a eu un moment de généralisation... c'était... bon laisse tomber... mais en fait on est tellement habitué dans les généralisations que... on se rend compte qu'on a généralisé les choses...

Além da voz da fala egocêntrica, as autoras encontraram também a voz da fala egocêntrica "reconstituída". Essa outra voz foi identificada, pois os métodos de verbalização sobre a situação de trabalho (como as entrevistas em autoconfrontação, que exporemos na próxima seção) permitem que sujeito possa reconstituir, além de sua ação, seu pensamento ou mesmo o diálogo consigo mesmo naquela situação. Identificada no trabalho de Dantas-Longhi (2013), Lousada e Dantas-Longhi (2014, p. 143-166) definem a voz da fala egocêntrica reconstituída, que consiste:

na recriação, sob a forma de uma voz do segundo plano enunciativo, do diálogo interior que o sujeito estabelece consigo mesmo em uma situação de conflito. Ela se assemelha à fala egocêntrica tal como interpretada por Vygotski ([1934] 1997), porque representa o momento em que o indivíduo se encontra em situação de conflito ou de esforço intelectual, servindo de apoio para que se possa resolver um problema ou tomar uma decisão. (...) Ela não é lacunária, pois sua função comunicativa não pode ser abandonada, uma vez que ela é dirigida ao mesmo tempo: i) para si mesmo, pois é uma maneira de relembrar a experiência vivida, procurando compreender como as decisões sobre a aula foram tomadas; ii) para um destinatário exterior, (a pesquisadora ou o outro professor presente na entrevista), pois o enunciador não perde de vista a situação de $\mathrm{AC}$, em que precisa explicar os motivos de sua ação a quem está compartilhando as imagens do vídeo.

Essa voz pode ser identificada através dos verbos discendi (falar, pensar, imaginar), quando estes introduzem uma conversa do sujeito consigo mesmo e não um falar efetivamente verbalizado. Além disso, esses verbos são apresentados como anterior ao tempo da voz, configurando uma instrução ou uma prefiguração da atitude que será tomada, como no exemplo abaixo.

Exemplo : 840D: \{tu vois et::/et ça c'est/c'est/ça a commencé par eux quand moi quand j'ai travaillé les/les sports et tout ça j'ai travaillé d'une manière je pen/je/je pensais plutôt à «faire du » ou « aller au » et tout ça alors je fais 


\subsubsection{A análise de textos em situação de trabalho}

O programa de pesquisa do grupo LAF e do grupo ALTER são similares, pois ambos visam, em uma de suas vertentes, à análise das condições de realização de segmentos do agir em situação de trabalho e à análise das produções verbais referentes a esses segmentos de agir.

Segundo Bronckart (2008), o programa do ISD dispõe de conjunto de dados que é constituído por quarto grupos como mostra o esquema abaixo. O primeiro conjunto contém gravações audiovisuais de sequências do trabalho real ${ }^{51}$, isso é, das condutas verbais e não verbais dos actantes durante a realização de uma tarefa. O segundo conjunto é composto dos textos que orientam esse agir, os textos prescritivos ou procedimentais. O terceiro grupo é constituído por entrevistas com os atores, antes e depois da realização de suas tarefas. Esses textos referentes ao trabalho interpretados por seus actantes mostram o que emerge em sua consciência discursiva e pode conter segmentos de construção verbal de ações sob seu ângulo interno, mostrando como são vividas pelos sujeitos. O quarto conjunto seria composto de textos produzidos pelos pesquisadores a partir de uma leitura interpretativa dos registros, entretanto, devido à amplitude dos dados, a produção desse conjunto foi deixada para uma fase posterior da pesquisa.

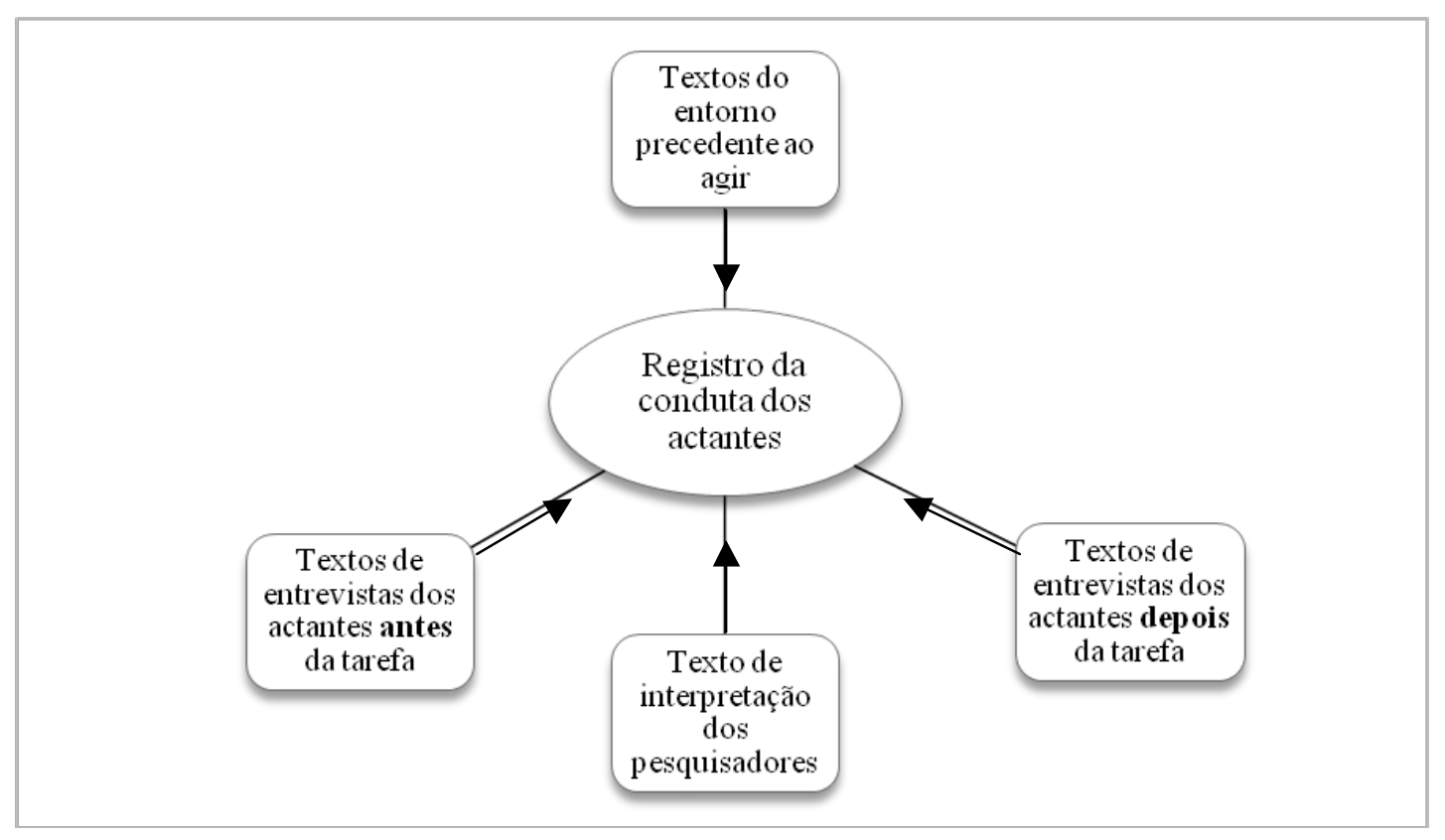

Figura 9: Plano Geral da Pesquisa do ISD (BRONCKART, 2008, p.132)

\footnotetext{
${ }^{51}$ Em nosso caso, chamamos de trabalho realizado, pois baseamo-nos em Clot (1999).
} 
Inspirados nesse modelo e no método da autoconfrontação (descrito na próxima seção), em nossa pesquisa coletamos textos do entorno precedente ao agir (o Quadro Comum Europeu de Referência para as Línguas - CECRL), fizemos o registro da conduta dos actantes (filmagem das aulas), e realizamos entrevistas após a realização da tarefa (autoconfrontação). No capítulo da Metodologia, apresentaremos um quadro com nossos dados de pesquisa.

\subsubsection{A análise de textos procedimentais}

Bronckart e Machado (2004, p.135-136) pressupõe que uma concepção ampliada da situação de trabalho se configura a partir de toda uma "rede de discursos proferidos" (ROCHA et al, 2002, p. 79-80) no entorno dessa situação. Para compreendê-lo, é preciso analisar, então, tanto o plano do agir, quanto as representações construídas socialmente sobre ele. Retomando os autores:

\footnotetext{
Segundo Bronckart, essas representações [sobre o agir educacional] se constroem em produções textuais, o que nos permite situar e julgar a contribuição de cada indivíduo para a realização de uma determinada atividade. Apropriadas e interiorizadas por esses mesmos indivíduos, tornando-se uma espécie de guias para suas ações futuras. Daí a importância de analisar os textos - orais e escritos - ou a rede discursiva que se constrói $n a$ e sobre uma determinada atividade (no nosso caso, no e sobre o trabalho educacional) para chegar a compreender a natureza e as razões das ações verbais e não verbais desenvolvidas e o papel que a linguagem aí desempenha. (BRONCKART e MACHADO, 2004, p.136)
}

Para a análise de textos prescritivos e avaliativos sobre o trabalho educacional, os autores propõem dois grupos de questões. O primeiro grupo visa a elucidar como se configura o agir prescritivo pelos e nos textos:

- Em que contexto de produção os textos são produzidos? A que outros textos se articulam ou respondem?

- Qual é o gênero mobilizado (ou os gêneros) expressa e/ou implicitamente?

- Qual é a organização interna ou global do texto? Qual sua função interacional?

- Qual é a fonte de prescrição e/ou da avaliação? Qual é o grau de sua explicitação ou ocultamento? Quais os mecanismos linguístico-discursivos utilizados para essa explicitação ou ocultamento? Que função interacional essa explicitação ou ocultamento elas desempenham? 
- Quais são os destinatários da prescrição e ou avaliação? Qual é o grau de sua explicitação ou ocultamento? Quais os mecanismos linguístico-discursivos utilizados para essa explicitação ou ocultamento? Que função interacional essa explicitação ou ocultamento elas desempenham?

- Qual é o grau de explicitação ou de ocultamento da prescrição e da avaliação? Quais os mecanismos linguístico-discursivos utilizados para essa explicitação ou ocultamento?

- Em que medida são apresentados os determinantes externos ou as motivações, as intenções ou as finalidades que orientam o agir prescritivo e o agir avaliativo?

O segundo grupo de questões visa a explicitar as diferentes dimensões do trabalho que é prescrito, das quais destacamos as duas que se referem à análise do papel que é atribuído nos e pelos textos aos protagonistas do trabalho.

- Quais são os protagonistas desse trabalho que são instaurados pelo texto como verdadeiros atores responsáveis pelo seu desenvolvimento? A instituição? O projeto de ensino? A metodologia? Os conteúdos? Os instrumentos de ensino? Os professores? Os alunos?

- Quais desses protagonistas se encontram agentivizados pelo texto, isto é, que não são apresentados como verdadeiros atores, mas apenas simples elos ou instrumentos de um processo sobre o qual não lhes é atribuída uma real responsabilidade?

Essas questões serviram para guiar nossas análises e serão retomadas indiretamente ao longo do capítulo terceiro, na apresentação dos resultados das análises.

\subsubsection{A análise do agir representado nos textos}

O modelo de análise para textos em situação de trabalho proposto por Bronckart (1999/2008) foi ampliado depois da pesquisa conduzida por Bulea e Fristalon (2004), que analisaram um conjunto de textos de enfermeiras da unidade de cirurgia digestiva do hospital universitário de Genebra, por meio de entrevistas antes da realização da tarefa. A partir das análises, as autoras elaboraram a noção de figuras de ação para conceituar formas diferentes de interpretação verbal de uma tarefa. Segundo Bulea (2010), as figuras de ação seriam segmentos 
do texto que permitiriam identificar o agir neles representados através dos tipos de discurso, dos eixos temporais e da implicação.

Apresentamos na sequência as cinco categorias de figuras de ação descritas por Bulea (2010, p.123-148), acompanhadas de um exemplo de nossos dados, seguidas de um quadro síntese de suas características principais.

a) Figura de ação ocorrência: identifica o agir sob um ângulo particular e apresenta um forte grau de contextualização (determinado actante, determinado paciente, determinada situação etc.). Essa figura se apresenta em segmentos de discurso interativo, sob o eixo temporal da situação de interação, com uma forte implicação $(e u)$ e com modalizadores pragmáticos e verbos do pensamento.

\section{Exemplo:}

832D: (ah regarde) le/le... j'ai commencé à penser un truc là maintenant donc parce que on a discuté dans/dans/dans/dans la discussion... ahn:: dans entre/entretien tout seul où::/où:: on parlait des/des activités... et on a beaucoup discuté de ça parce que:: les activités qui sont dans le livre c'est faire de la voile faire du //de l'équitation de l'escrime du ski ((risos)) //ça ne fait pas partie du tout... du tout du tout et:: peut-être je sais pas toi tu as/tu as une ahn::/tu as aperçu que là on a une discussion très française peut-être mais qui peut-être ça peut déclencher quelque chose // qui peuv/qui peut venir d'eux et:: tu as même donné un moment où on a discuté de ça... // tu vois et::/et ça c'est/c'est/ça a commencé par eux quand moi quand j'ai travaillé les/les sports et tout ça j'ai travaillé d'une manière je pen/je/je pensais plutôt à «faire du » ou «aller au » et tout ça alors je fais // à la forme j'ai pas du tout pensé au côté interculturel qui pourrait sortir je pourrais bien demander (d'eux)... « est-ce que vous/vous/vous faites ça? vous faites de l'équitation ? vous faites du ski ? vous faites... » ça pourrait déclencher d'autres choses des/des choses comme ça... c'est vrai que c'est un peu difficile différent de travailler avec le niveau quatre et le niveau un... parce qu'au niveau un la discussion ne va pas aller on ne va pas arriver à raconter une histoire// mais:: ça si/si/si je leur avais demandé déjà «vous faites ça ? " peut-être que ça pourrait déjà être une ouverture à l'interculturel... «non professeur on joue du football »... et là c'est déjà:: //« on fait du football on ne fait pas du ski on fait du football » ((risos)) et:: « je fais du football... je fais je::»

b) Figura de ação acontecimento passado: identifica o agir sob um ângulo de retrospectiva; é uma história ilustrativa e emblemática, apresentando contextualização fragmentária e seletiva. O relato interativo é predominante, o eixo temporal é anterior, marcado; há implicação (eu), modalizações da ordem do dever (deônticas) e se apresenta sob um esquema narrativo, cronológico. Bulea (2010, p. 132-133) afirma que essa figura:

propõe uma compreensão retrospectiva do agir: por um lado, esse agir sempre pode ser evocado sob o ângulo da singularidade, ainda não esteja situado na relação de contiguidade com a situação de sua textualização; por 
outro lado, esse mesmo agir pode preservar um caráter que destaca, considerando a experiência ou a prática ordinária do actante. Essa figura repousa, assim, na delimitação de uma unidade praxiológica extraída do passado, com a feição de uma "história" e cuja contextualização é manifesta, mas fragmentária e seletiva. (...) tem claramente um valor ilustrativo do agir em questão ou de uma de suas dimensões. (...) aparece em segmentos de relato interativo, os processos evocados são compreendidos em referência a um eixo temporal situado antes da entrevista, e cuja origem é marcada: "a última vez", "outro dia".

\section{Exemplo:}

758D: il y a un moment au niveau trois où on discutait des appartements/des/des annonces des appartements et dans le:: guide pédagogique on devrait met/eh:: classer les annonces donc surface on/on lisait les annonces et on devrait repérer les informations et les classer... on devrait les classer dans un tableau où c'était écrit ahn:: surface conforts particuliers et tout ça/des choses comme ça et dans le guide pédagogique on disait que... entre les conforts particuliers il y avait do/douche et wc //et j'ai trouvé ça (drôle) ((risos)) parce que pour moi ça c'est essentiel et pour eux c'est un confort particulier dans une chambre de bain par exemple // c'est un confort // et :: // oui // et on a discuté/on a commencé à classer à repérer les informations et ils n'ont pas mis douche et wc dans les conforts particuliers je leur ai dit « ah il y a une chose que manque là c'est douche et wc... dans le conforts particuliers » et il y a eu/il y en a qui ont rigolé... et:: et là on a discuté de ça j'ai dit « oui ça c'est/c'est un confort/c'est un CONFORT tu vas trouver des chambres de bain en France où il n'y a pas de douche où il n'y a pas de wc // tu/tu as QUE une chambre $» \ldots$

c) Figura de ação experiência: identifica o agir como uma cristalização pessoal de múltiplas ocorrências vividas; é um balanço da experiência do actante, configurando-se de maneira descontextualizada e recontextualizada (adaptabilidade). Essa figura apresenta o discurso interativo como predominante, sendo o eixo temporal não delimitado, apresenta o presente genérico como forma de generalizar e cristalizar a experiência; a implicação é um pouco menos marcada (eu, você, a gente - on); as modalizações podem ser deônticas, apreciativas ou outras. A cronologia é mais maleável.

\footnotetext{
Exemplos:

770D: tu/tu as QUE une chambre »... et là ça donne une discussion mais c'est/c'est un petit détail qui pourrait disparaitre/on pourrait le prendre par une blague je pense (que tout le monde) je fais aussi ah c'est une blague peut-être qu'on ne va pas discuter de ça mais... voilà c'est/on peut aller un peu loin mais normalement c'est comme ça une blague comme ça

$771 \mathrm{~S}:$

\{oui... laisser un peu:: naturel la situation

772D: ouais c'est naturel

(...)

791S: et ça c'est/c'est justement la manière naturelle parce que les gens donnent des exemples c'est pas à moi de/de comparer de donner:: j'ai/j'ai déjà donné pas mal de choses et ÇA a déclenché plusieurs::
} 
histoires... donc je pense que trois deux trois histoires... dans/dans le même contexte je pense que ça c'est/c'est bien... parce que moi je ne me sens pas capable de/d'entrer dans l'interculturel de comparer:: et:: c'est plus intéressant de/de les écouter... n'est-ce pas? c'était/c'était justement ça que je voulais expliquer

792D: uhum

d) Figura de ação canônica: caracteriza o agir como uma construção teórica prototípica, apontando para uma lógica na tarefa (normas apropriadas) de maneira a-contextualizada. Essa figura se constrói através do discurso teórico, do discurso interativo ou de um misto deles, empregando o presente genérico. O eixo de referência temporal não é marcado ou delimitado e a não há uma marca de agentividade, empregando-se o pronome neutro (on). Há a presença de modalizações externas às relações predicativas e estruturas argumentativas.

\section{Exemplo:}

924D:

925S:

\{parce qu'on est... on/on

\{la leçon/la leçon

926D: $\quad$ on a des contraintes parce qu'on a eu une contrainte et:: ahn:: on doit suivre ça et:: on ne peut pas réfléchir avec certaines contraintes de la forme c'est ça?

927S: non c'est.. par exemple si on/si on/dans ce cas c'est la fête des voisins après il y a un point langue qui parle de/de la comparaison

928D: uhum

929S: plus au moins enfin... si je les travaille ensemble ça va donner des généralisations par exemple au

Brésil on est plus généraux

930D: oui mais c'est ça on donne la contrainte de la comparaison là ils doivent utiliser la comparaison 931S: $\quad$ oui mais je ne voulais parce que::

932D: $\quad$ oui mais voilà ça/ça/ça empêche

933S: on ne peut pas tra/travailler la forme toujours ensemble

934D: uhum

935S: parce qu'elle ne tombe pas bien... dans le contenu interculturel ahn étudié... il faut voir... il faut voir bien... c'est ça.

e) Figura de ação definição: identifica o agir enquanto objeto de reflexão-definição, apreendendo o estatuto e as características desse agir como fenômeno no mundo. Há, portanto, a presença do discurso teórico, num eixo temporal não delimitado, sem marcas de agentividade. Como estrutura geral, há construções de definição como [é + grupo nominal] ou [há + grupo nominal]. 
Exemplo:

796D: (...) c'est/c'est vrai que un regard de l'interculturel c'est/c'est dans ces commentaires-là 797S:

798D: ehn:: non c'est très intéressant

799S: parce que c'est intéressant de voir des situations particulières... je ne parle en France c'est comme ça... en France au Brésil c'est comme ça 800D: uhum

801S: je pense que l'intéressant c'est entrer dans le contexte des élèves 802D: oui

803S: c'est (naturel)

O exemplo acima mostra como figura de ação definição se caracteriza por segmentos em que os actantes tematizam uma mesma unidade fonte - nesse caso, o intercultural - por meio de construções impessoais. Em nosso trabalho identificamos que a figura de ação definição são marcadas por retomadas anafóricas que definem (é + grupo nominal) e caracterizam (é + grupo ajetival) os conteúdos culturais. Essas retomadas anafóricas também serão analisdas mais detalhadamente na categoria dos mecanismos de textualização : da coesão verbal e nominal (séries coesivas).

Para encerrar essa subseção e passar ao exemplo de análise, trazemos o quadro elaborado por Dantas-Longhi (2013) que resume as características principais das figuras de ação Bulea (2010) de forma sintética e comparativa: 


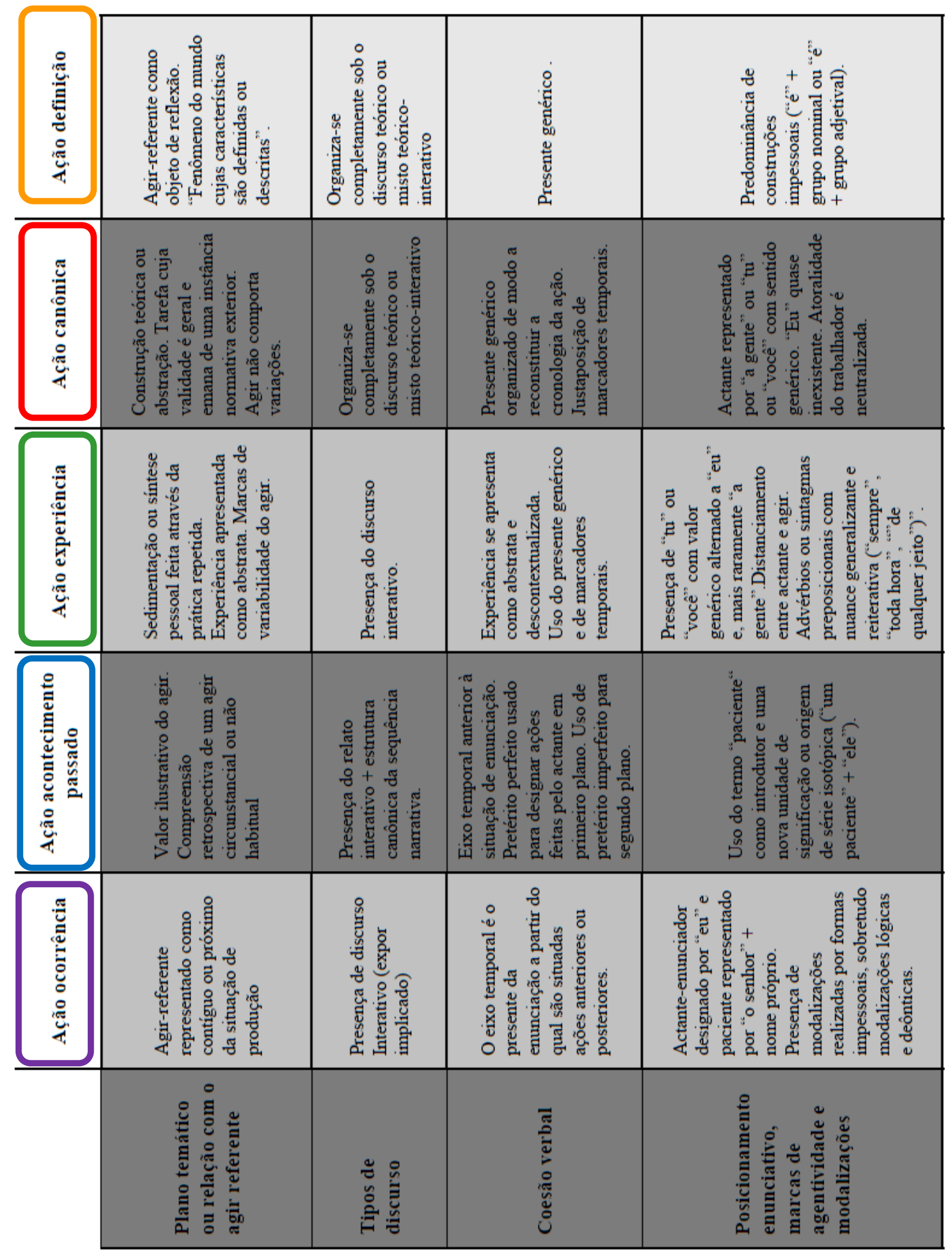

Tabela 3: Síntese das características figuras de ação (DANTAS-LONGHI, 2013, p.62) 


\subsubsection{Exemplo de análise usando o modelo do ISD para análise de textos}

A partir do modelo de análise de textos do ISD (BRONCKART, 1999, 2006) que apresentamos, mostraremos um exemplo de análise usando o texto a seguir, o qual se encontra em sua integralidade no Anexo A.

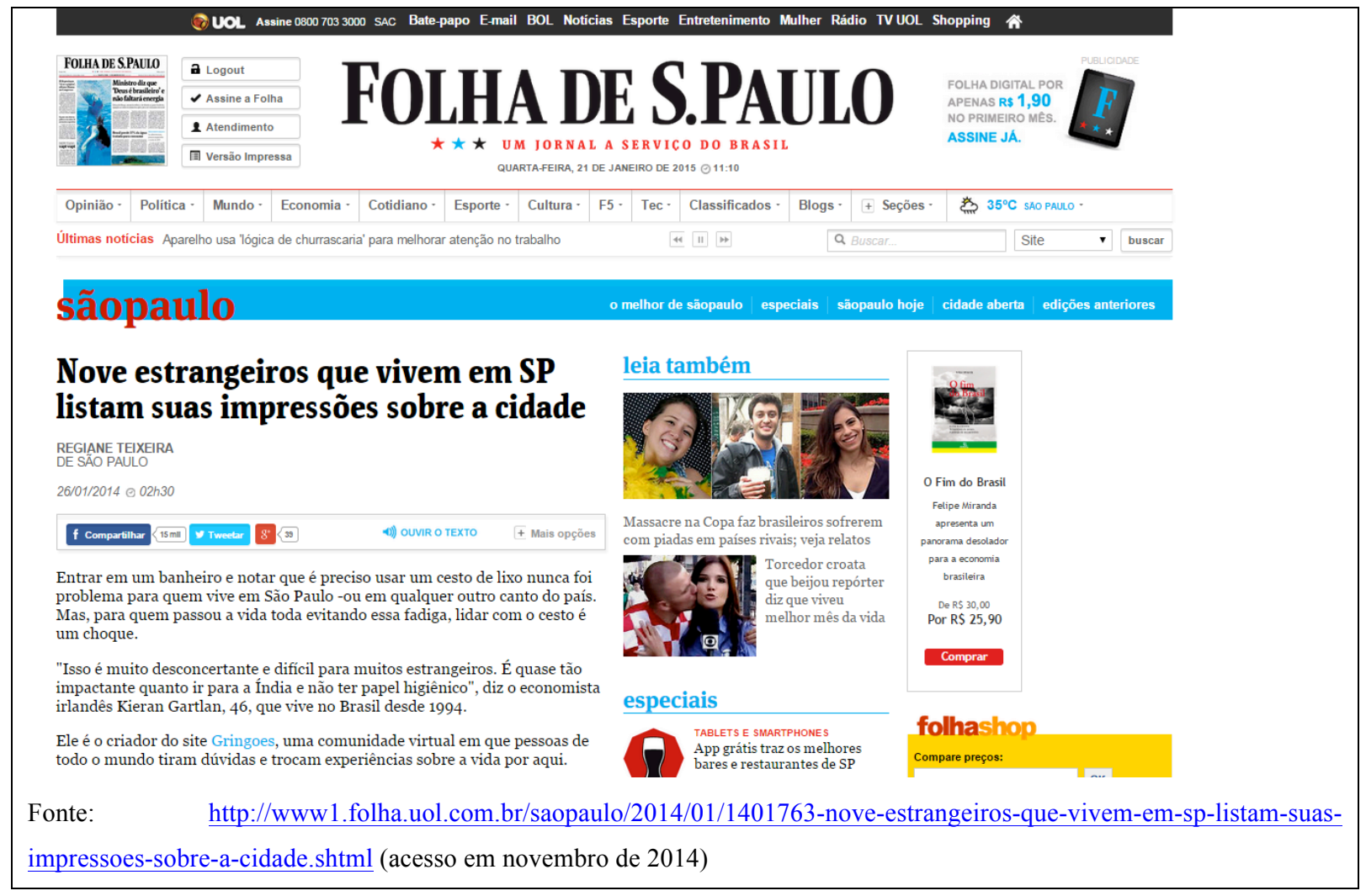

Figura 10: Captura de tela do site Folha de São Paulo

\section{A) Contexto de produção}

"Nove estrangeiros que vivem em SP listam suas impressões sobre a cidade" foi publicado na internet em 26/01/2014, no site do jornal Folha de São Paulo. Pelo seu local social e características linguístico-discusivas, que veremos a seguir, trata-se de um exemplar do gênero reportagem. Diríamos que pelo tema, está menos ligada às notícias sobre fatos próximos ao momento da enunciação (como aquelas aparecem em geral na capa, na primeira página no caso do site, ou na rubrica Cotidiano) e mais próxima às matérias jornalísticas pautadas por temas interessantes e curiosos.

A autoria, indicada logo após o título, é da jornalista Regiane Teixeira. No entanto, ela fala não de uma posição particular, em seu próprio nome, mas sim do seu lugar institucional, a 
Seção SãoPaulo do jornal Folha de São Paulo online, assim, o enunciador, no sentido amplo, seria também o próprio jornal. A matéria é composta de trechos de depoimentos, onde estrangeiros listam suas impressões sobre a cidade, dessa forma, podemos considerá-los também enunciadores.

Os destinatários do texto são, em primeira instância, os leitores da Folha online, interessados na Seção São Paulo. Vemos, porém, que através dos ícones indicadores das redes sociais (Facebook, Twitter, Google +), essa matéria foi replicada e compartilhada em torno de 15 mil vezes. Isso significa que mesmo pessoas que não tenham o hábito de ler a Folha online podem ter lido esse texto por meio de um link compartilhado pelos seus amigos. Essa parece ser uma grande tendência nos dias atuais.

O objetivo da matéria parece ser primeiramente aquele que costa no título: mostrar as impressões de estrangeiros que vivem em São Paulo sobre a cidade. Outro objetivo que estaria por trás deste seria o de fomentar a discussão sobre a experiência dos estrangeiros no Brasil justamente no ano da Copa do Mundo de Futebol da FIFA (em 2014), chamando a atenção dos leitores no sentido de conhecer e prevenir sobre possíveis mal-entendidos interculturais. Além disso, o texto promove, ainda que não de maneira proposital, um site chamado Gringões, mencionado no terceiro parágrafo, um fórum em que estrangeiros contam sua experiência e dão dica a outros visitantes. Finalmente, poderíamos dizer que o texto, ao mostrar pessoas de diferentes nacionalidades falando sobre São Paulo, satisfaz a curiosidade do leitor sobre a visão desses estrangeiros e sobre os referenciais culturais de origem deles. Sendo um texto que desperta a curiosidade, ele visa também que os leitores visitem a página do jornal, para aumentar o número de acessos ao site e para visualizar os anúncios publicitários ali colocados.

\section{B) Infraestrutura geral do texto}

Com relação ao plano geral dos conteúdos temáticos, o texto é composto de:

- cabeçalho padrão do site (UOL e Folha)

- seção do jornal (sãopaulo)

- título

- autoria, local, data e hora da publicação

- ícones das redes sociais

- corpo da matéria

* introdução e contextualização da jornalista

* fotos das pessoas que deram depoimento 
* 10 depoimentos (9 de estrangeiros e 1 de brasileiro)

- referências para outras matérias (coluna paralela ao corpo da matéria)

- anúncios publicitários (coluna paralela ao corpo da matéria e ao final dele)

- comentários

- rodapé do site com todas as seções do jornal

Aprofundando-nos nos conteúdos temáticos do corpo da matéria, analisaremos mais a fundo as duas partes: a primeira com a introdução e contextualização da jornalista e a segunda, onde se concentra o foco da matéria, os depoimentos e fotos.

A primeira parte busca introduzir o tema e preparar o leitor para os depoimentos. A jornalista começa apontando a dualidade de visões sobre as mesmas experiências. $\mathrm{O}$ primeiro exemplo é o do cesto do lixo do banheiro, necessário para os brasileiros, mas de difícil adaptação para estrangeiros. O segundo exemplo, dado por um irlandês, é o do papel higiênico, natural para os brasileiros, mas que não existe em todos os países, como na Índia, por exemplo.

Em seguida, a jornalista apresenta ao leitor o site Gringões, onde estrangeiros relatam a experiência de vida no Brasil e em São Paulo. Inspirada nesse site e nos outros textos de estrangeiros que circulavam pela internet na época, a Seção sãopaulo da Folha convidou nove estrangeiros a contarem o que havia de estranho ou peculiar na cidade e nos costumes brasileiros.

Antes de passar aos depoimentos, a autora ainda traz novamente a dualidade. Ela menciona um dado sobre o número de vistos de trabalho concedidos a estrangeiros no Estado de São Paulo (22 mil), mostrando que é, por um lado, uma "terra de oportunidades" para eles, mas que, por outro, eles sofrem com os problemas da cidade, obras, trânsito, barulho e preços altos, e do país, com a burocracia.

Na segunda parte, os dez depoimentos começam com a identificação da pessoa (nome, idade, nacionalidade, profissão e foto), seguida de uma lista de suas impressões.

Algumas impressões contidas nos depoimentos retomam tópicos frequentemente associados aos brasileiros (futebol, calor, hábitos de higiene). Algumas pessoas destacaram observações que, se comparadas a outros depoimentos, parecem contraditórias (ceder e não ceder o lugar no transporte público; sorrir muito e sorrir pouco; vestir-se com muita roupa e pouca roupa no verão; respeitar e não respeitar a filla; vestir-se bem ou mal).

Além disso, os entrevistados destacaram alguns temas que lhes chamaram a atenção, causando estranhamento, distância ou mesmo admiração. Esses temas, variados em cada 
depoimento, parecem ter sido apontadas por serem díspares da referência (sociocultural) dos entrevistados (como, por exemplo, o serviço por comanda; maneira de cozinhar o feijão; palito de dente; maneira prender o cabelo; educação das crianças; higiene bucal etc.). Dessa maneira, os entrevistaram acabaram falando das impressões sobre São Paulo, mas também de seu país ou de sua cultura de origem, como vemos nos exemplos:

Melanito Biyouha, camaronesa:

No Brasil, a mulher participa das decisões da família. Na África, ela tem de ser só bonita e calada.

Aliah Khreiis, libanesa:

A mulher aqui não nasce para ser dona de casa. É a melhor coisa do Brasil.

Marina Pipatpan, tailandesa :

Em São Paulo, sorriem pouco na comparação com a Tailândia, que é conhecida como "a terra dos sorrisos".

Com relação às sequências (narrativas, argumentativas, explicativas, descritivas, injuntivas e dialogais), observamos que os depoimentos são compostos majoritariamente de sequências descritivas das experiências das pessoas, como vemos nos exemplos a seguir:

Na Rússia anoitece por volta das 22h30. No Brasil, às 20h já está escuro.

É mais barato viajar aos EUA para comprar um computador do que comprá-lo aqui.

O transporte público português cumpre horário.

Para analisarmos os tipos de discurso, observamos o cruzamento entre a proximidade ou distância da situação de produção do enunciador (expor ou narrar) com a implicação ou autonomia do enunciador (implicado ou autônomo). A matéria contém trechos que exemplificam cada um desses tipos de discurso, exceto a narração. A seguir apresentamos os exemplos, destacando os elementos que nos permitem identificá-los:

Exemplo do tipo de discurso teórico (não há marcas de implicação do enunciador e o conteúdo é colocado como conjunto da situação de produção)

Na Rússia anoitece por volta das 22h30. No Brasil, às 20h já está escuro.

Em São Paulo, sorriem pouco na comparação com a Tailândia, que é conhecida como "a terra dos sorrisos".

Em Portugal, as pessoas são desconfiadas, não interagem.

Exemplo do tipo de discurso interativo (há marcas de implicação do enunciador e o conteúdo é colocado como conjunto à situação de produção)

Fico abismada quando vejo quantidades monumentais de comida ou de carne nos almoços de domingo.

Ainda me surpreende ver homens sem camisa nas ruas.

Aqui existem sobremesas. Na África, comemos frutas. 
Exemplo do tipo de discurso relato interativo (há marcas de implicação do enunciador e o conteúdo é colocado como disjunto da situação de produção).

Só no ano passado, até setembro, o Ministério do Trabalho concedeu 22.021 autorizações para que estrangeiros trabalhassem no Estado de São Paulo

Embalada pelas listas de estrangeiros que circulam na internet, a são paulo convidou nove pessoas de várias nacionalidades que moram em São Paulo - e um paulistano que vive há sete anos em Portugal- para contarem o que há de estranho ou peculiar na cidade e nos costumes brasileiros.

Primeira vez em que fui a um banheiro de um bar apertado, escutei do garçom: "Só tomares atenção porque o autoclismo da sanita está avariado, epa!". Entrei no banheiro e procurei algo avariado. Aparentemente, nada quebrado! Puxei a descarga e a água não parava mais de de sair. O atendente do bar não poupou "elogios"!

De uma maneira geral, vimos que os tipos de discurso predominantes são aqueles ligados ao eixo do expor: o discurso interativo e o discurso teórico. Já o relato interativo aparece apenas nas ocorrências que mencionamos acima.

$\mathrm{Na}$ segunda camada do modelo de análise, os mecanismos de textualização, podemos observar a coesão verbal e nominal e a conexão do texto. Nesse caso, vemos, na coesão verbal, a grande presença de verbos no presente do indicativo nos depoimentos, dando origem a generalizações. Isso pode ser explicado devido à forma de "lista" solicitada pelo entrevistador e não de relato, de maneira a resumir e sintetizar as impressões gerais. Na retomada nominal, observamos que São Paulo e Brasil, por exemplo, são substituídos por “aqui”, um dêitico espacial que se refere ao local de onde fala o enunciador, ao passo que o país ou cidade de origem é retomado por "ali / lá". A conexão é realizada por justaposição de conteúdos semelhantes, pela troca de sujeitos falantes, no caso dos depoimentos e por alguns conectivos, um temporal (só no ano passado) e outro concessivo (embora).

$\mathrm{Na}$ terceira camada do modelo, os mecanismos de responsabilidade enunciativa, analisamos as modalizações e inserção de vozes no texto. As modalizações nos permitem ver como os enunciadores se colocam com relação aos conteúdos. Vejamos os seguintes exemplos: 


\begin{tabular}{|l|l|}
\hline Tipos de modalização & Exemplos \\
\hline $\begin{array}{l}\text { deônticas, do domínio } \\
\text { da obrigação }\end{array}$ & $\begin{array}{l}\text { Na África, ela tem de ser só bonita e calada. } \\
\text { Você precisa ir ao "cartório" para autenticá-la. }\end{array}$ \\
\hline $\begin{array}{l}\text { lógicas, } \\
\text { do domínio da certeza, } \\
\text { verdade, possibilidade, } \\
\text { impossibilidade }\end{array}$ & $\begin{array}{l}\text { Aqui você pode ser convidado para ir a casa de alguém que não te conhece e ser bem } \\
\text { recebido. } \\
\text { Não é possível sobreviver no Brasil sem um CPF. }\end{array}$ \\
\hline $\begin{array}{l}\text { apreciativas, do } \\
\text { domínio da avaliação } \\
\text { do conteúdo }\end{array}$ & $\begin{array}{l}\text { Isso é muito desconcertante e difícil para muitos estrangeiros. É quase tão } \\
\text { impactante quanto ir para a Índia e não ter papel higiênico. } \\
\text { Comer de maneira saudável é coisa de rico aqui. }\end{array}$ \\
\hline
\end{tabular}

Tabela 4: Exemplos dos tipos de modalização

Notamos que a maioria das modalizações são de cunho apreciativo e que não houve ocorrências de modalizações pragmáticas. Isso aponta para o fato de que os sujeitos buscam apresentar suas impressões de acordo com suas experiências (normal, louco, desconcertante, perigoso). Além disso, as modalizações da ordem do dever (deônticas) apontam para os conteúdos que os estrangeiros consideram obrigatórios.

Analisando as vozes presentes nessa matéria, observamos que, além da voz da jornalista, na primeira parte, a autora traz a voz de três estrangeiros (o irlandês Kieran Gartlan, a libanesa Aliah Khreiis e o francês Baptiste Demay) em discurso direto, que identificamos por meio das aspas. Temos, em seguida, a voz de dez outras pessoas nos depoimentos, indicados explicitamente com o nome e informações pessoais de cada um. Cabe ressaltar, no entanto, que, como os depoimentos não estão entre aspas, não sabemos se se trata de uma reformulação da jornalista ou de uma lista feita pelos próprios entrevistados. Também não é possível saber se houve cortes ou edições.

A inserção de vozes também se dá através de mecanismos mais sutis. Identificamos uma voz social ou do senso comum, que possibilitaria a criação de estereótipos, por meio de jargões associados aos brasileiros, entender de futebol e torcer fervorosamente, por exemplo.

A proporção de mulheres que entendem de futebol e que torcem com fervor para um time é maior que a proporção de homens do meu país.

Observando o contexto de produção, a temática da matéria e as marcas linguísticodiscursivas, cabe levantar uma reflexão que foi também encontrada em nossos dados, como veremos mais a frente. O uso do tempo verbal presente do indicativo (presente genérico), sobretudo quando associado a esses marcadores de nacionalidade, leva a uma generalização. Se 
dizemos, "no Brasil, as pessoas são gentis", esse enunciado será entendido como uma generalização, valendo para todos os brasileiros. Em muitos casos, essa generalização se torna um estereótipo cultural.

No caso dessa matéria especificamente, não podemos afirmar se todos entrevistados realmente empregaram espontaneamente o presente genérico, se foi feita uma pergunta de maneira a direcionar as respostas, ou se a lista de impressões foi reescrita pela jornalista. Entretanto, o fato das impressões serem materializadas dessa forma no texto leva o leitor a imaginar que todos os paulistas ou todos os brasileiros agem da mesma forma. Ou ainda que as situações sempre ocorrem da mesma forma.

A sensação de unicidade e generalidade que seria gerada por esse tipo de construção é, no entanto, parcialmente desfeita através de outro mecanismo, que é, por um lado, a pluralidade de depoimentos e, por outro, a contradição presente em alguns deles. Quando lemos as impressões de diferentes sujeitos, não parece que o texto constrói um estereótipo cultural. Ao contrário, a construção de possíveis estereótipos é justamente desmontada ao vermos a experiência de viver em São Paulo retratada através de múltiplos pontos de vista. Dos exemplos que mencionamos nos conteúdos temáticos, retomamos um abaixo, o da fila:

Michelle Warmbier, 25, alemã, terapeuta de dança

Qualquer lugar no Brasil tem uma fila preferencial. As pessoas são muito atentas e educadas, sempre deixando passar na frente ou oferecendo um assento no metrô para quem está com um bebê no colo.

Kieran Gartlan, 46, irlandês, economista

Aqui as pessoas não respeitam fila. É normal ver alguém passando na frente e ninguém falar nada.

Em nossas análises, veremos também os efeitos do presente genérico na fala dos professores e dos alunos.

Com esse exemplo de análise, concluímos essa seção dedicada à abordagem do ISD para a análise de textos. Passaremos, na sequência, aos aportes teóricos e metodológicos das ciências do trabalho para nossa pesquisa. 


\subsection{Aportes das ciências do trabalho}

Nessa seção, gostaríamos de trazer os aportes teóricos de duas ciências do trabalho que se fundamentam nos escritos vygotskianos sobre desenvolvimento e que, portanto, dialogam entre si: a Clínica da Atividade e a Ergonomia da Atividade, além de serem compatíveis com nosso quadro teórico geral, do Interacionismo Sociodiscursivo.

Buscando compreender o trabalho como agir humano em toda sua complexidade, ambas as vertentes tentam escapar do impasse que se coloca hoje diante das ciências: a oposição entre a objetividade e a subjetividade (CLOT, 2011; FAÏTA, 2011). Considerar um trabalho de maneira geral, a-contextualizada, ou analisar casos pontuais e específicos parecem, para esses pesquisadores, não fazer evoluir as ciências humanas ou a compreensão do trabalho.

Partindo da corrente sócio-histórica e de um quadro epistemológico que considera o processo, a história e o coletivo, ao invés do indivíduo em seu fenômeno pontual e isolado, Clot (2011), Faïta (2011), dentre outros, propõem conceitos que, em nossa pesquisa, complementam nosso quadro teórico maior do ISD, permitindo que possamos analisar e, sobretudo, interpretar textos produzidos em situação de trabalho.

\subsubsection{O trabalho em perspectiva}

A ergonomia do trabalho de linha francesa se define, enquanto corrente teórica, pela preocupação com o ambiente e os gestos profissionais, propondo assim "adaptar o trabalho ao homem" ao invés de "adaptar o homem ao trabalho", que é o objeto de outras correntes que têm o trabalho como foco. O trabalho do professor, assim como outros tipos de atividades profissionais, se enquadra dentro das preocupações teóricas da ergonomia do trabalho, disciplina que nasce durante a segunda guerra mundial para responder aos problemas de concepção e de utilização de dispositivos militares (LAVILLE, 2001, 2007; YVON, GARON, 2006) e que se volta, então, às ações humanas no meio de trabalho.

A partir desse quadro geral da ergonomia e contando com a singularidade e diversidade dos trabalhadores e de situações nas quais ocorre a atividade produtiva, pesquisadores da 
ergonomia de linha francesa (ou ergonomia francófona) deixaram os laboratórios onde se trabalhava com níveis de tolerância a ruídos, luz, certas posturas e objetos julgados adequados para o trabalho (preocupações da ergonomia anglófona), para irem ao encontro dos trabalhadores em seu campo de atuação. Esse olhar centrado mais sobre o humano que sobre o objeto é o foco da então chamada ergonomia da atividade (LAVILLE, 2001, 2007; YVON, GARON, 2006).

Segundo Yves Clot (2001, p.7), a Clínica da Atividade busca renovar duas tradições diferentes, esforçando-se para fazê-las avançar juntas: a ergonomia francófona inspirada em Wisner $^{52}$ (1995) e Daniellou ${ }^{53}$ (1996) e a psicopatologia do trabalho, de Le Guillant ${ }^{54}$ (1984) e Billiard $^{55}$ (1998). Sua preocupação primeira é com a ação e a transformação das situações de trabalho, estendendo o poder de ação dos coletivos de trabalhadores sobre o meio de trabalho real e sobre eles mesmos.

Esse objetivo é alcançado não através da observação externa do trabalho, mas do desenvolvimento, nos trabalhadores, da observação do seu próprio trabalho (CLOT, 2001, p.10). Assim, a análise do trabalho não parte do psicólogo, do pesquisador, do formador ou do supervisor do trabalho, mas do próprio trabalhador, que observa sua prática. Segundo Clot (2001), é somente assim que se pode fazer o desenvolvimento subjetivo da experiência vivida: um desenvolvimento da consciência. Esse desenvolvimento não é somente individual e subjetivo, enquanto fonte da ação, mas um recurso para sustentar uma experiência coletiva de modificação do trabalho por aqueles que o realizam.

Compreender os conflitos, impasses, regras e impedimentos da atividade de trabalho para gerar um desenvolvimento da consciência e posteriormente uma transformação no meio constitui, em síntese, o objeto da Clínica da Atividade, que propõe alguns conceitos e métodos inovadores para lançar um novo olhar sobre essas questões.

Segundo Clot (2001, p.38), a ergonomia já havia precisado a diferença entre tarefa prescrita e atividade real: a tarefa prescrita é o que deve ser feito e a atividade real o que se efetivamente faz, ou seja, o resultado da execução da tarefa, pelos trabalhadores. Entretanto, o

\footnotetext{
${ }^{52}$ WISNER, A. Réflexions sur l'ergonomie (1962-1995). Toulouse: Octarès, 1995.

${ }^{53}$ DANIELLOU F. L'ergonomie en quête de ses principes. Toulouse : Octarès, 1996.

${ }^{54}$ LE GUILLANT, L. Quelle psychiatrie pour notre temps? Toulouse: Erès, 1984.

${ }^{55}$ BILLIARD, I. Conditions sociales historiques et scientifiques d'apparition de la psychologie du travail en France. Paris, CNAM, Thèse pour le doctorat en psychologie, 1998.
} 
autor propõe uma ampliação da compreensão da atividade real, baseando-se nos estudos vygotskianos. Justamente, para Clot (2001), atividade realizada e atividade real não são correspondentes. Evocando a célebre frase de Vygotski (1997) “O homem é cheio, a cada minuto, de possibilidades não realizadas." ${ }^{\circ 56}$, Clot (2001, p.38) considera que o comportamento nada mais é do que um "sistema de reações que venceram", sendo os outros, recusados, resíduos incontroláveis que têm mais força para exercer na atividade do sujeito uma influência contra a qual ele pode ficar indefeso.

Nesse sentido, o que a Clínica da Atividade chama de real da atividade é também aquilo que não se faz, aquilo que se tenta fazer, aquilo que se gostaria de fazer ou de poder fazer, aquilo que se pensa poder fazer em outro lugar. As atividades suspendidas, contrariadas, impedidas, retiradas ou ocultadas devem ser levadas em conta, pois não estão ausentes e têm peso sobre a atividade presente. Dessa forma, para Clot (2001), aquilo que foi de fato realizado não tem o monopólio do real dessa atividade.

Para compreender o real da atividade na situação de trabalho é preciso observar aquilo que está por trás da atividade contrariada ou impedida, isso é, o conflito ou o dilema diante do qual o trabalhador se encontra. Nesse sentido, Vygotski (1997, p. 493) afirma que o pensamento não nasceria de outro pensamento, "mas dos dilemas do real que a atividade deve afrontar" ${ }^{, 57}$.

No ponto de vista da Clínica da Atividade, o diálogo entre os trabalhadores sobre situação de trabalho é uma das maneiras de levar à identificação de conflitos e dilemas da profissão que não seriam diretamente observáveis por alguém externo. Nas palavras de Clot (2008, p.88-89):

“Quem quer compreender sua atividade, deve se confrontar com seus conflitos. (...)
Vygotski o dizia à sua maneira: 'O homem é cheio, a cada minuto, de possibilidades não
realizadas'. Assim, o comportamento nada mais é do que 'o sistema de reações que
venceram' (VYGOTSKI, 2003, p.74). Os outros, rejeitados, formam resíduos
incontroláveis, tendo mais força para exercer uma influência sobre a atividade do sujeito,
contra a qual ele pode não ter defesas. O real da atividade é também o que não se faz, o
que se busca fazer sem conseguir - o drama dos fracassos - o que se gostaria de querer

\footnotetext{
${ }^{56} \mathrm{Na}$ tradução de Carla Beliner para o português em "Teoria e Método em psicologia": "Cada minuto do homem está cheio de possibilidades não realizadas" (VYGOTSKI, 1925/2004, p.69)

${ }^{57}$ Citação original: “(...) des dilemmes du réel que l'activité doit affronter” (VYGOTSKI, 1997, p.493)
} 
ou poder fazer, o que se pensa poder fazer em outro lugar.” (CLOT, 2008, p.88-89, tradução nossa $)^{58}$.

Para a Clínica da Atividade (CLOT, 1999, 2001, 2008, 2011; ROGER, 2007) esses dilemas vividos pelos trabalhadores podem os afetar em dois polos: na eficácia e na saúde, que são as duas grandes preocupações da ergonomia como veremos mais a frente.

Clot (2011) estabelece uma forte relação entre sentido e eficácia no trabalho. Para ele, a atividade do sujeito "se vê amputada de seu poder de agir quando os objetivos da ação que está acontecendo são desligados daquilo que realmente conta para ele e que outros objetivos válidos, reduzidos ao silêncio, são deixados em repouso. Ela é então esvaziada de sentido.” (CLOT, 2011, p.29, tradução nossa) ${ }^{59}$. A perda de sentido é uma desvitalização da atividade e uma atrofia do poder de agir.

A eficácia, então, longe da concepção produtivista e mecânica, acontece quando o sujeito encontra sentido em sua atividade, quando ele contribui de alguma forma para o desenvolvimento e história dessa atividade, ao mesmo tempo em que esta faz sentido para ele. Dessa forma, sentirse ativo e exercer criatividade no trabalho, não são maneiras de viver num contexto ou sobreviver a ele, mas mais que isso, são maneiras de produzir o próprio contexto para viver e dar sentido a ele. É por isso que Clot (2011, p.35) sustenta que a eficácia não é somente ajustar os meios aos fins ou o inverso e sim renovar os próprios fins e os próprios meios.

Nesse sentido, tanto a Clínica da Atividade, quanto a Ergonomia da Atividade defendem uma noção de saúde que não corresponde à ideia de "normalidade" ou ausência de doença, mas, antes, considera-a a partir do que coloca Canguilhem, (2002, p. 68):

\footnotetext{
${ }^{58}$ Citação no original: "Qui veut comprendre lês contraintes de l'activité doit se confronter à ces conflits. (...) Vygostki le disait à sa manière : "L'homme est plein à chaque minute de possibilités non realisées . » Du coup, le comportement n'est jamais que le «système de réaction qui ont vaincu » (VYGOTSKI, 2003, p.74). Les autres, refoulées, forment des résidus incontrôles n'ayant que plus de force pour exercer dans l'activité du sujet une influence contre laquelle il peut rester sans défense. Mais c'est tout particulièrement vrai en psychologie du travail. Là aussi, le réel de l'activité c'est aussi ce qui ne se fait pas, ce qu'on cherche à faire sans y parvenir - le drame des échecs - ce qu'on aurait voulu on pu faire, ce qu'on pense pouvoir faire ailleurs." (CLOT, 2008, p.88-89)

${ }^{59}$ Citação no original: "l'activité du sujet se voit amputée de son pouvoir d'agir quand les buts de l'action en train de se faire sont déliés de ce qui compte réellement pour lui et que d'autres buts valables, réduits au silence, sont laissés en jachère. Elle est alors vidée de sons sens.” (CLOT, 2011, p.29).
} 
Eu me sinto bem na medida em que eu me sinto capaz de portar a responsabilidade dos meus atos, de trazer as coisas à existência e de criar entre as coisas relações que não teriam existido sem mim. (CANGUILHEM, 2002, p. 68, tradução nossa) ${ }^{60}$

Essa ideia amplia a ideia de saúde física e considera como fundamental a relação de atuação do homem sobre o mundo, sobre a sociedade e sobre seu trabalho, reservando ainda um lugar de destaque à criatividade humana.

A partir do que dizem Desjours (1995) ${ }^{61}$ e Canguilhem (1984) ${ }^{62}$, Clot (2001, p.44) traça um paralelo: assim como o conhecimento tem sua fonte em um fracasso na vida, a saúde tem sua fonte na experiência amadurecida do perigo. Ele afirma:

"A saúde, diferentemente da normalidade defensiva, é a transformação da doença em novo meio de existir, na metamorfose de uma experiência vivida de maneira a viver outras experiências e, finalmente, a transfiguração de um paradoxo provado em história possível, de um vivido em meio de agir”. (CLOT, 2001, p.45, tradução nossa) ${ }^{63}$

Nesse sentido, Clot (2001) salienta que o sofrimento é definido não somente pela dor física ou mental, mas "pela diminuição, ou mesmo destruição da capacidade de agir, do poderfazer" voltados a si mesmo; é uma impotência para dizer, fazer, contar e se estimar; é um impedimento. O autor (CLOT, 2001, p.47) conclui que enquanto o sofrimento é um sentimento de vida contrariado, a saúde é esse sentimento de vida encontrado.

"Buscando fazer falar o métier graças à restauração de "debates de escola", de controvérsias e de diálogos entre profissionais, conseguimos às vezes transformar a experiência mal vivida em meio de viver outras experiências." (CLOT, 2001, p.47, tradução e grifo nossos) $)^{64}$

Tomando isso por base, vemos que o conflito vivido pelo trabalhador, ao ser elaborado em meio a um coletivo de trabalho, pode adquirir sentido na história do sujeito e fazê-lo viver outras experiências, devolvendo a ele o seu "poder de agir" (CLOT, 2008).

\footnotetext{
${ }^{60}$ Citação no original: "Je me porte bien dans la mesure où je me sens capable de porter la responsabilité de mes actes, de porter des choses à l'existence et de créer entre les choses des rapports qui ne leur viendraient pas sans moi." (CANGUILHEM, 2002, p. 68)

${ }^{61}$ DESJOURS, C. Le facteur humain. Paris: PUF, 1995.

${ }^{62}$ CANGUILHEM, G. Le normal et le pathologique. Paris: PUF, 1984.

${ }^{63}$ Citação no original: "La santé, à la difficulté de la normalité defensive, c'est la transformation de la maladie en nouveau moyen d'exister, la metamorphose d'une expérience vécue en façon de vivre d'autres experiences, et finalement, la transfiguration d'un paradoxe éprouvé en histoire possible, d'un vécu en moyen d'agir." (CLOT, 2001, p.45)

${ }^{64}$ Citação no original: "En cherchant à faire parler le métier grâce à la restauration de "débats d'écoles", de controverses et de dialogues entre professionnels, nous réussisons parfois à transformer l'expérience mal vécue en moyen de vivre d'autres expériences". (CLOT, 2001, p.47)
} 
É justamente o emprego de métodos indiretos, como a entrevista de instrução ao sósia e as entrevistas em autoconfrontação, que permitem a possibilidade de perceber o desenvolvimento permanente da atividade e devolver o poder de agir aos sujeitos. Esses métodos consistem em organizar o redobramento ou o desdobramento da experiência vivida para permitir aos sujeitos transformar suas experiências de um objeto em objeto de uma nova experiência vivida. Clot (2011, p.26-27) aponta que está aí o fundamento teórico da metodologia histórica e do desenvolvimento: permitir ao sujeito transformar os funcionamentos realizados em objeto de um novo funcionamento a fim de estudar o desenvolvimento real (possível e impossível) e seus princípios. Essa metodologia busca compreender e explicar como se organiza a transformação da ação, organizando ela mesma uma transformação regrada da ação. Nesse sentido, Clot (2011, p.27) propõe que se avance da lógica da ergonomia francesa: compreender para transformar, buscando primeiramente transformar as situações, pois é o desenvolvimento possível ou impossível que se busca compreender.

\subsubsection{Focalizando o trabalho do professor}

Como apontamos na Introdução, apesar de uma grande variedade de publicações sobre o ensino-aprendizagem, a didática das línguas e culturas não traz respostas quando se trata de compreender como se passa realmente o cotidiano de ensino, pois se fixa mais nos conteúdos a ensinar e nas orientações para realizá-lo. Com efeito, a literatura existente até o momento no campo da didática não dá conta de descrever a complexidade do trabalho de ensinar (AMIGUES, 2002) e fazemos a hipótese de que isso se deva ao fato de a didática ignorar que o trabalho educacional, o trabalho de ensino, não é somente uma atividade intelectual, mas também é um "métier", um trabalho. A esse respeito, Saujat (2004, p.11) constata:

Porque estamos face a um paradoxo: o ensino é sem dúvida hoje o trabalho mais estudado, tendo em vista a grande massa de pesquisas que lhe foram consagradas, ao passo que não sabemos quase nada do ensino como trabalho. Mas o paradoxo nada mais é do que aparente: na verdade, esses estudos foram conduzidos até agora, fora dos quadros e das tradições de pesquisa e de análise do trabalho. (SAUJAT, 2004, p.11, tradução nossa) $)^{65}$

\footnotetext{
${ }^{65}$ Citação original: “Car on est face à un paradoxe : l'enseignement est sans doute aujourd'hui le travail le plus étudié, tant est importante la masse de recherches qui lui ont été consacrées, alors qu'on ne sait presque rien de
} 
Para compreender o trabalho do professor a partir não só de sua dimensão teórica ou didática, Saujat (2004) propõe que consideremos a ação de ensinar para além de uma prática intelectual ou de uma disciplina, considerando-a como um trabalho, um métier.

Paradoxalmente, devido a uma focalização nos trabalhos relacionados à produção de bens, o trabalho do professor foi, durante muitos anos, excluído das preocupações da ergonomia justamente por ser um trabalho intelectual (MACHADO, 2007). Entretanto, mais recentemente, diversas pesquisas se voltaram ao estudo do trabalho educacional. A equipe francesa ERGAPE (Ergonomia da Atividade dos Profissionais da Educação ${ }^{66}$ ), um grupo multidisciplinar inserido na tradição da ergonomia francófona, propõe um programa de estudo formação profissional voltado profissionais da educação por meio da análise do trabalho (FAÏTA, 1997, 2002, 2004, 2005, 2011; AMIGUES, 2002, 2003, 2004, 2009; SAUJAT, 2004, 2005, 2007, 2011), realizando trabalhos de intervenção na situação de trabalho (ESPINASSY, SAUJAT, 2003; FELIX, SAUJAT, 2008; ESPINASSY, MOUTON, FELIX, 2009; FAÏTA, SAUJAT, 2010).

Amigues (2002, p.243) aponta que, nas pesquisas em didática das disciplinas, o trabalho do professor é raramente levado em consideração enquanto métier. Segundo o autor, durante um bom tempo, as disciplinas privilegiaram as restrições epistemológicas ligadas aos conteúdos de saberes a serem transmitidos e às ações dos alunos. A figura do professor é, assim, mais subentendida que estudada. De acordo com a pesquisa de Goigoux (2002) sobre a didática do francês como língua materna, a atividade docente é negligenciada em detrimento do estudo dos saberes em jogo e das competências linguageiras. Amigues (2002) constata, então, dois fatos importantes: de um lado, o polo do trabalho do professor é pouco presente nas pesquisas sobre as interações didáticas e, de outro, o que o aluno faz (as estratégias que desenvolve, o que ele retém e os modos de interação), é considerado independentemente da ação do professor e das prescrições que ele coloca na atividade.

Duas pesquisadoras dessa linha, Devolvé e Poudou-Zerbato (1998, p.129), fazem uma distinção pertinente para o nosso trabalho, classificando três campos disciplinares de referência: a didática, a pedagogia e a ergonomia, e definindo seus objetos de estudo, metodologias, lugares de coleta de dados e objetivos, como vemos na tabela abaixo.

l'enseignement comme travail. Mais le paradoxe n'est qu'apparent : en effet, ces études ont été conduites, jusqu'à présent, en dehors des cadres et des traditions de recherche de l'analyse du travail." (SAUJAT, 2004, p.11)

${ }^{66}$ Sigla em francês: Ergonomie de l'Activité des Professionnels de l'Éducation. 


\begin{tabular}{|c|c|c|c|}
\hline & Didática & Pedagogia & Ergonomia \\
\hline $\begin{array}{l}\text { Campos } \\
\text { disciplinares } \\
\text { de referência } \\
\end{array}$ & Psicologia cognitiva & $\begin{array}{l}\text { Psicologia da } \\
\text { aprendizagem }\end{array}$ & Psicologia ergonômica \\
\hline $\begin{array}{l}\text { Objetos } \\
\text { estudados }\end{array}$ & $\begin{array}{l}\text { os saberes se concentram: } \\
\text { - nas metodologias para colocar em } \\
\text { prática a apropriação de conteúdos } \\
\text { específicos } \\
\text { - na elaboração de modelos de } \\
\text { inteligibilidade e de aprendizagem } \\
\text { articulando os } 4 \text { polos: psicologia, } \\
\text { axiologia, praxeologia, } \\
\text { epistemologia (as teorias da } \\
\text { aprendizagem); }\end{array}$ & $\begin{array}{l}\text { as práticas educativas se } \\
\text { concentram: } \\
\text { - na finalidade de afetar a } \\
\text { educação; } \\
\text { - na natureza dos } \\
\text { conhecimentos a serem } \\
\text { transmitidos; } \\
\text { - nos métodos utilizados } \\
\text { para transmitir esses } \\
\text { conhecimentos. }\end{array}$ & $\begin{array}{l}\text { a situação educativa se } \\
\text { concentra: } \\
\text { - nos comportamentos do } \\
\text { conjunto de atores da } \\
\text { situação; } \\
\text { - na performance do } \\
\text { sistema; } \\
\text { - nos efeitos do trabalho } \\
\text { sobre a saúde de cada um. }\end{array}$ \\
\hline Metodologias & $\begin{array}{l}\text { análise } \\
\text { - dos processos cognitivos } \\
\text { investidos para a apropriação desses } \\
\text { conteúdos a serem aprendidos; } \\
\text { - identificação das capacidades } \\
\text { requeridas; e } \\
\text { - das competências necessárias }\end{array}$ & $\begin{array}{l}\text { análise } \\
\text { - das produções escritas e } \\
\text { verbais dos alunos } \\
\text { - das avaliações }\end{array}$ & $\begin{array}{l}\text { análise } \\
\text { - dos comportamentos } \\
\text { cognitivos, sociais... } \\
\text { - das produções, dos } \\
\text { indicadores de saúde } \\
\text { produzidos pelo conjunto } \\
\text { de atores da situação }\end{array}$ \\
\hline $\begin{array}{l}\text { Locais de } \\
\text { coleta de } \\
\text { dados e } \\
\text { informações }\end{array}$ & $\begin{array}{l}\text { - uma situação experimental, } \\
\text { - a situação real de aprendizagem } \\
\text { do aluno; } \\
\text { - a situação profissional futura do } \\
\text { aprendiz }\end{array}$ & a sala de aula & $\begin{array}{l}\text { a situação de trabalho do } \\
\text { conjunto de atores da } \\
\text { situação de aprendizagem }\end{array}$ \\
\hline Objetivos & $\begin{array}{l}\text { criação de ferramentas para } \\
\text { aprender }\end{array}$ & $\begin{array}{l}\text { transmitir } \\
\text { - saberes } \\
\text { - saber-fazer } \\
\text { - saber-ser } \\
\end{array}$ & $\begin{array}{l}\text { criar uma situação onde } \\
\text { aprender seja possível em } \\
\text { uma situação de equilíbrio } \\
\text { para todos os atores. }\end{array}$ \\
\hline
\end{tabular}

Tabela 5: Didática, Pedagogia e Ergonomia (DEVOLVÉ e POUDOU-ZERBATO, 1998, p.129)

A partir dessa comparação, vemos que a ergonomia estuda a situação educativa centrada nos comportamentos do conjunto dos atores da situação; no desempenho do sistema e nos efeitos do trabalho sobre a saúde (em seu sentido amplo) de cada um, através da análise de comportamentos cognitivos, sociais e de produção, na situação de trabalho do conjunto de atores da situação de aprendizagem, com o objetivo de criar uma situação onde aprender é possível.

As autoras (DEVOLVÉ e POUDOU-ZERBATO, 1998) evidenciam que, nessa perspectiva, não convém mais manter o esquema linear tradicional saber - professor - aluno, mas sim conceber o modelo dinâmico triangular entre os três atores, em que a relação dialética entre professor e aluno articule a ação de formar, entre professor e saber, a ação de ensinar, e entre aluno e saber, a ação de aprender. 


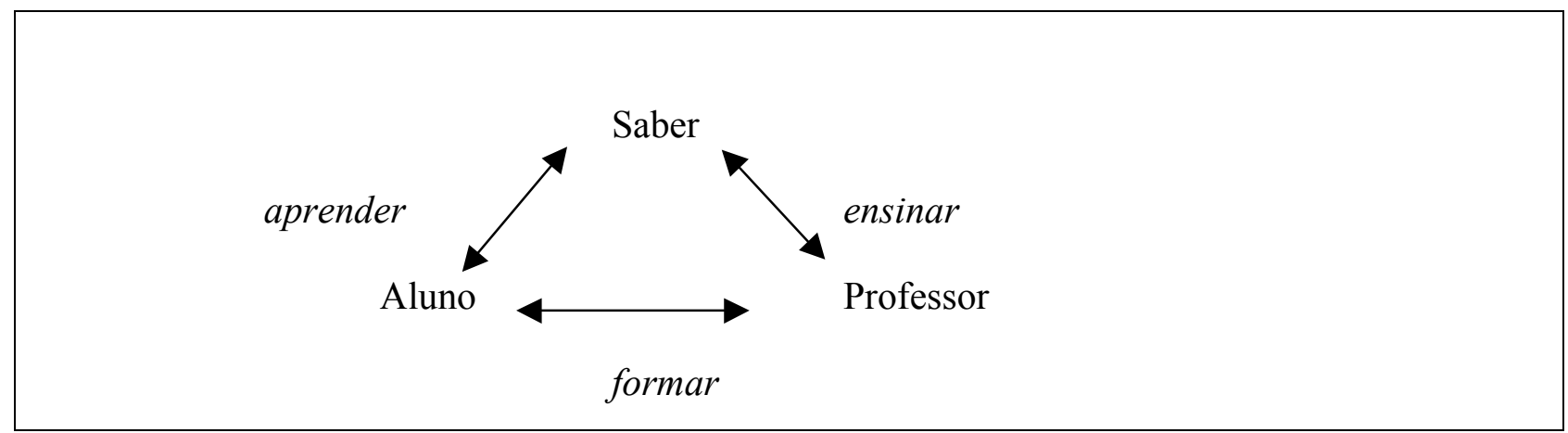

Figura 11: Relação entre saber, aluno e professor (DEVOLVÉ e POUDOU-ZERBATO, 1998, p.130)

Desenvolvendo algumas dessas constatações, Amigues (2002) discute o papel das prescrições no métier e nos meios profissionais, sendo prescrição toda orientação para a realização de uma atividade. Para a abordagem da ergonomia, as prescrições não são externas à atividade de ensino, mas consubstanciais a ela, sendo inevitavelmente reconcebidas e retrabalhadas pelos professores $^{67}$ (AMIGUES, 2002; GOIGOUX, 2001, 2005). Goigoux (2005, p.4) sustenta que:

"a análise do trabalho real implica o interesse pelas tarefas redefinidas, isso é, a maneira pela qual o professor interpreta as prescrições que lhe são dirigidas em função dos recursos que ele dispõe, assim como das coerções que ele se coloca (ou que lhe colocam)". (destaque nosso). ${ }^{68}$

As prescrições são, assim, objeto de (re)interpretação e de redefinição por parte dos professores, podendo ser chamadas de "reconcepções" e também tornar-se autoprescrições. Nesse sentido, Saujat (2002, p.41) desenvolve essa ideia destacando os três níveis do complexo objeto que é trabalho de ensino:

a organização do trabalho prescrito pela instituição escolar (desde os programas, instruções e recomendações pedagógicas até as reformulações e interpretações dos inspetores e formadores, passando pelas ferramentas, manuais e auxílios didáticos);

(ii) o trabalho de reconcepção e reorganização operado pelos coletivos de professores em seus meios de trabalho;

\footnotetext{
${ }^{67}$ O termo "reconcepção" e seu sinônimo "retrabalho" são usados por Saujat (2002) e por Clot (2001, 2008). Amigues (2002) e Goigoux (2001), na mesma linha, também emprega "redefinição". Já o termo "renormalização" é empregado por Schwartz (2003). Tais termos se assemelham por se referirem ao mesmo processo de reorganização das tarefas prescritas.

68 Citação no original: “L'analyse du travail enseignant implique donc de s'intéresser aux tâches redéfinies, c'est-àdire à la manière dont les enseignants interprètent les prescriptions en fonction des moyens et des ressources dont ils disposent et descontraintes qu'ils se fixent (ou qu'on leur fixe).” (GOIGOUX, 2005, p.4)
} 
(iii) o de retrabalho desse segundo nível por cada professor quando ele é levado a personalizar essas prescrições, a se auto-prescrever o que se deve fazer em tal situação ou com tais alunos.

Em nossas análises, vimos primeiramente como as prescrições se apresentam no documento que orienta o ensino-aprendizagem de línguas estrangeiras (Quadro Comum Europeu de Referência para as Línguas), em seguida, analisamos como os professores reconcebem essas prescrições em seu contexto. Essa comparação não visa a enxergar o professor como descumpridor das regras, ou focar em suas falhas, mas sim compreender os conflitos resultantes da distância entre "o que é pedido" e "o que a atividade em si pede" (HUBAULT, 1993) ${ }^{69}$ do ponto de vista do trabalhador, observando como o sujeito cria meios de lidar com prescrições que lhe são dadas, com aquelas que ele reconcebe e com aquelas que ele se auto-prescreve.

Amigues (2002) aponta, nesse sentido, um exemplo de retrabalho: as ferramentas fabricadas por outros que o professor utiliza (manuais escolares, atividades, avaliações). Essas ferramentas não significam que ele não possa inventar, ao contrário, ele é levado a usar esses materiais e a torcê-los ou distorcê-los para torná-los eficazes. Outro exemplo seriam as fichas de preparação de aula, que muitas vezes não são obrigatórias, mas muitos professores a fazem, pois veem nela uma ferramenta para pensar a ação na presença dos alunos.

Amigues (2002) conclui que a experiência do professor pode transformar assim as ferramentas das quais ele dispõe em instrumentos ${ }^{70}$ para sua ação, garantindo sua eficiência. É a distância entre "o que é pedido" e o sentido dado "ao que é feito", que vai modificar o sentido da atividade proposta, como instrumento da ação para o professor e como objeto da atividade significante para os alunos. Dessa forma, a distinção entre trabalho prescrito e trabalho realizado não se coloca como uma oposição pontual e imprevista, mas em um componente intrínseco à atividade de trabalho de ensino.

Por fim, cabe ressaltar que, assim como a Ergonomia da atividade conduziu trabalhos investigando a apropriação do métier por professores iniciantes (SAUJAT, 2004b, 2005, 2007,

\footnotetext{
${ }^{69}$ Hubault, F. « Le travail, ou l'interface anthropotechnologique à l'épreuve », Performances Humaines \& Techniques, $n^{\circ}$ hors série Septembre, 1993, p.2-11.

${ }^{70}$ Em francês, outil. Ressaltamos que se trata de uma tradução delicada, pois dentro dos estudos vygotskianos existem duas possibilidades: usar uma ferramenta ou se apropriar psicologicamente dela, transformando-a em instrumento para o agir. Para um maior aprofundamento sobre a gênse instrumental, conferir RABARDEL (1995) e para compreender como os professores podem criar e se apropriar dos artefatos, conferir DANTAS-LONGHI (2013).
} 
2011), o grupo ALTER-AGE também produziu trabalhos a esse respeito (MACHADO, LOUSADA, 2010; LOUSADA, 2011; BUENO, LOPES, CRISTÓVÃO, 2013), apontando elementos que nos permitem compreender essa apropriação. Nesse sentido, destacamos uma ideia de Saujat (2004) a qual retomaremos em nossos análises: a apropriação dos gestos do trabalho, do gênero profissional passa pelo métier neutro das prescrições, para o métier do outro e para o métier de si. Daí também a importância de estudarmos o trabalho prescrito reconcebido pelos professores e compreendermos essas questões dentro do diálogo do professor com seus pares, com o coletivo.

\subsubsection{Métodos de intervenção e análise da situação de trabalho}

A análise do trabalho se revela enquanto instrumento de formação dos sujeitos à medida que se torna um instrumento de transformação da experiência, possibilitando ao trabalhador mudar o estado da experiência vivida (CLOT, 2001, p.7). Embasado em Vygotski (1925/2004; 1934/1997), Clot (2001) defende que o distanciamento e a tomada de consciência que se concretizam nos métodos da autoconfrontação e da instrução ao sósia constituem oportunidades para fazer o estilo das ações encontrarem os possíveis do desenvolvimento, fazendo-os entrar em uma zona de desenvolvimento potencial.

Um dos métodos que a clínica da atividade desenvolveu para a análise do trabalho, levanto em conta todo o quadro teórico que viemos de apresentar, foi o da entrevista em autoconfrontação (CLOT, FAÏTA, 2000; CLOT, FAÏTA et al, 2001; FAÏTA, VIEIRA, 2003), que é um método de coanálise entre pesquisador ${ }^{71}$ e coletivo de trabalho. No primeiro momento desse método, há a formação de um coletivo de trabalho. A patir das demandas que emergem desse coletivo, verifica-se alguns dos dilemas e dificuldades em comum do trabalho. Em seguida, os profissionais que se sentem interpelados pelas problemáticas levantadas se voluntariam para ter uma sequência de sua atividade de trabalho gravada em vídeo e discuti-las com o pesquisador, com seu colega e com o grupo. Em nosso caso, essa parte se refere à filmagem da aula. A partir do vídeo do seu trabalho, os voluntários fazem uma entrevista autoconfrontação simples, em que: o pesquisador se reúne com um trabalhador, vê a sequência de trabalho filmada e solicita

\footnotetext{
${ }^{71}$ Apontamos a dificuldade em se traduzir o termo em francês, intervenant, cuja tradução em português, interventor, não permite guardar o mesmo sentido. Dessa forma, empregaremos pesquisador ou intervenant.
} 
explicitações a partir das imagens e dos estranhamentos que ele vislumbra. Esse procedimento é filmado. A seguir, realiza-se a autoconfrontação cruzada, em que os dois trabalhadores, em nosso caso os professores voluntários, e o pesquisador visualizam juntos trechos das sequências da atividade de trabalho filmada, buscando identificar os dilemas do trabalho e as diferentes maneiras de realizá-lo, sendo esse procedimento também filmado. Toda essa análise deve voltar para o coletivo de trabalhadores, em cujas reuniões as questões serão rediscutidas junto aos pares. Essa etapa é chamada de retorno ao coletivo. Em nossa pesquisa, como veremos na Metodologia, seguimos as etapas que acabamos de descrever.

Clot considera esses métodos indiretos como instrumentos que permitem que a atividade entre em uma zona de desenvolvimento potencial (VYGOTSKI, 1934/1997, p.335, 378), isso é, a distância entre aquilo que o sujeito já sabe fazer e aquilo que ele ainda só consegue fazer em colaboração com outra pessoa. Nesse sentido, esses método permitem, por meio da conscientização, desvendar os possíveis da aprendizagem e do desenvolvimento. Para Clot (2001, p.22,), colocar o sujeito na situação de confrontar o gênero profissional e o estilo de suas ações é potencialmente gerador de desenvolvimento:

\footnotetext{
Pensamos que é então a distância maior ou menor do sujeito com relação ao gênero profissional que é objeto de seus comentários, em outras palavras, que ele faz entrar o estilo de suas ações em uma zona de desenvolvimento potencial. (CLOT, 1999a; VYGOTSKI, 1997). ${ }^{72}$ (CLOT, 2001, p.22, tradução nossa, grifo nosso).
}

Outro método, descrito por Saujat (2005), é a entrevista de instrução ao sósia, que também se constitui enquanto trabalho de coanálise entre pesquisador e profissional, em que o trabalhador recebe a instrução de que deverá ser substituído em sua situação de trabalho e que deverá dar as instruções exatas ao seu "sósia". O objetivo é de conduzir o profissional a dialogar consigo mesmo através das questões que o sósia coloca e de tentar levá-lo a olhar sua experiência com os olhos do outro. Não detalharemos a explicação do método de instrução ao sósia, pois não utilizamos esse procedimento em nossa pesquisa, entretanto esse método de intervenção também já foi empregada para a análise do trabalho em nosso contexto de pesquisa (LOUSADA, SILVA, MENEZES, 2014).

\footnotetext{
${ }^{72}$ Citação no original: "Nous pensons que c'est donc l'écart plus ou moins grand du sujet par rapport au genre professionnel qui fait l'objet de ses commentaires, autrement dit, qu'il fait entrer le style de ses actions dans une zone de développement potenciel (Clot, 1999a; Vygotski 1997)" (CLOT, 2001, p.22).
} 
Os métodos de verbalização sobre a atividade de trabalho consideram o movimento dialógico como essencial para disparar novas formas de compreensão e, assim, potencializar o desenvolvimento. Nesse sentido, Bakhtin (1970a, p.344, apud Clot 2008, p.205) afirma:

"No diálogo, o homem não se manifesta somente do exterior, mas torna-se pela primeira
vez, o que ele é verdadeiramente e não somente aos olhos dos outros, repetimos, aos
seus próprios. Ser, é comunicar dialogicamente. Quando o diálogo se acaba, tudo se
acaba. (...) No diálogo, as réplicas de um se valem das réplicas do diálogo interior do
outro"

Tanto em um, quanto em outro método, a confrontação com a própria prática desencadeia um momento de reflexão e dá ocasião a uma possível transformação da prática. Assim, voltando à problemática que apontamos na Introdução, são essas ciências do trabalho que melhor nos convém como fundamentação teórica para nossa pesquisa, já que: i) se baseiam nos mesmos fundamentos teóricos (vygotskianos) de nosso trabalho; ii) se propõem a estudar o conjunto dos atores da situação de ensino, prestando-se mais a uma visão ascendente da compreensão do trabalho, partindo dos dilemas cotidianos; iii) os métodos que empregam são, por si só, potencialmente geradores de desenvolvimento.

A partir dos aportes de Bronckart (2004), Clot (1999, 2001), Amigues (2004) e Saujat (2002) dentre outros, Machado (2007) propõe uma concepção mais ampliada do trabalho do professor, baseada nos aportes teóricos da ergonomia da atividade e da clínica da atividade. A autora fornece alguns aspectos da atividade do professor, que consideraremos em nossa pesquisa: a atividade do professor é situada, isto é, contextualizada; é prefigurada por prescrições (como os PCNs para o Brasil e o CECRL para a Europa, com influência também em nível internacional), reelaborações e autoprescrições dos professores a partir das prescrições (como os planos de aula, por exemplo); é mediada por instrumentos e artefatos do meio de trabalho (como os livros didáticos, a lousa, o computador); é interacional, pois permite que o professor transforme o meio, ao mesmo tempo em que é por ele transformado; é interpessoal, pois interage com outros indivíduos presentes e até mesmo ausentes; é transpessoal, guiada por modelos do agir específicos do ofício, pela história do métier (por exemplo, sabe-se que o professor escreve na lousa para realizar seu trabalho, pois construímos, em nossa história, essa imagem do trabalho docente); é conflituosa, pois o trabalhador deverá permanentemente direcionar o agir mediante as diferentes situações; e, finalmente, por ser conflituosa, ela pode ser fonte para aprendizagem e para o desenvolvimento de capacidades. 
É nesse sentido que, para Machado (2007) o trabalho de ensino, assim como as formações de professores, não pode se restringir a uma série de técnicas e estratégias transversais para se atingir objetivos gerais, mas devem, antes, considerar atentamente o contexto, os trabalhadores, a interação entre eles e a história do métier, assim como os conflitos que o fazem dinâmico.

Machado (2007) traz também um esquema que resume as variáveis a serem consideradas para se estudar o trabalho do professor.

\section{Trabalho do professor}

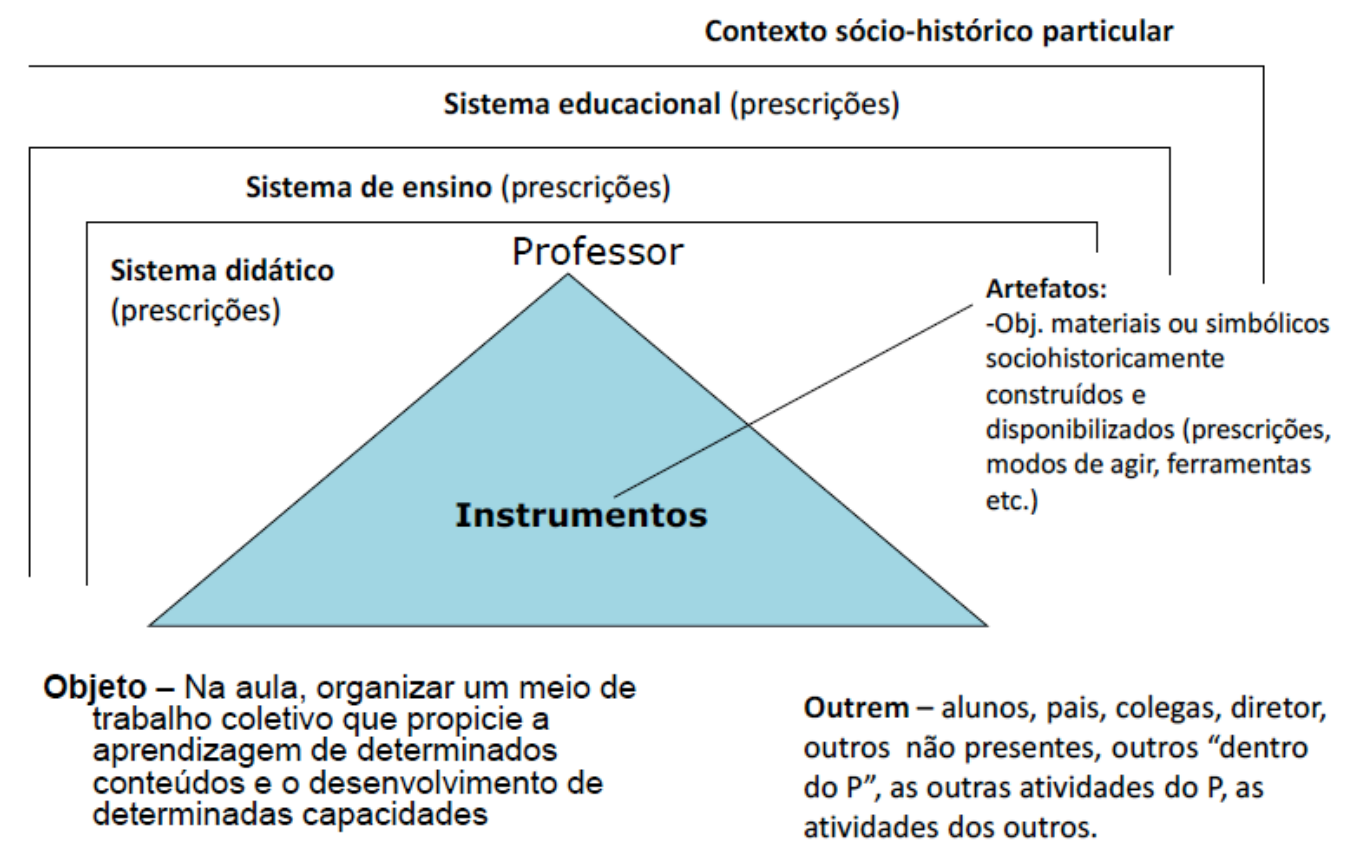

Figura 12: Esquema do trabalho do professor (MACHADO, 2007)

Assim, o trabalho dos professores com os conteúdos culturais que estudamos nesta pesquisa deve ser compreendido num contexto sócio-histórico particular (nesta pesquisa, contexto brasileiro de ensino de língua estrangeira em 2012); mais precisamente em um sistema educacional (em nosso caso, o contexto universitário da educação brasileira), dentro de um sistema de ensino (os Cursos Extracurriculares de Francês - extensão universitária) e com um sistema didático particular (metodologia empregada nos Cursos Extracurriculares e coleção Alter $E g o$ ). Dentro desse quadro, deve-se observar as relações entre o triângulo: o professor, seu objeto de ensino e aqueles a quem ele possa dirigir sua atividade, a saber, alunos, coordenadores, 
colegas etc.. Essas relações entre os polos do triângulo, por sua vez, devem ser compreendidas também através dos artefatos e instrumentos mediadores (prescrições, livro didático, documentos, lousa etc.), construídos e apropriados pelos sujeitos. É baseando-nos também nesse complexo modelo que interpretamos nossos resultados de análise.

Concluímos, portanto, essa seção com uma citação de Machado (2007) que define o trabalho docente em toda sua complexidade e que servirá de lente para a análise e interpretação de nossos dados:

Assim, o trabalho docente, resumidamente, consiste em uma mobilização, pelo professor, de seu ser integral, em diferentes situações - de planejamento, de aula, de avaliação com o objetivo de criar um meio que possibilite aos alunos a aprendizagem de um conjunto de conteúdos de sua disciplina e o desenvolvimento de capacidades específicas relacionadas a esses conteúdos, orientando-se por um projeto de ensino que lhe é prescrito por diferentes instâncias superiores e com a utilização de instrumentos obtidos do meio social e na interação com diferentes outros que, de forma direta ou indireta, então envolvidos na situação. (MACHADO, 2007, p.93)

Os aportes que expusemos até aqui nos ajudam a compreender a perspectiva que adotamos para analisar o trabalho de ensino. Na próxima seção, buscaremos refletir sobre o objeto desse ensino, os conteúdos culturais. 


\subsection{Reflexões sobre os conteúdos culturais no ensino de línguas}

Lembramos que objetivo neste trabalho é estudar a maneira como os professores de FLE trabalham os conteúdos culturais, identificando as "representações construídas nos e pelos textos" (BRONCKART, 2006) dos professores sobre a pertinência ou a necessidade que eles têm (ou não) de abordar os conteúdos culturais em aulas de FLE. Poderíamos parafrasear nosso objetivo dizendo que nosso foco é estudar o trabalho do professor por meio de um viés que é um de seus objetos de ensino: os conteúdos culturais. Esta seção foi construída, portanto, no sentido de refletir sobre esse objeto de trabalho dos professores, apresentando de maneira crítica as problemáticas ligadas a ele.

Cabe ressaltar que, ainda que nossas análises nesse estudo sejam analisadas no quadro do ISD, interpretadas pelo prisma da Clínica da Atividade e da Ergonomia da Atividade e não pelo prisma da Didática das Línguas e Culturas (doravante DLC), é importante que vejamos como esse objeto de ensino é veiculado na DLC, pois essa é justamente a disciplina de referência dos professores-monitores participantes da pesquisa. Além disso, poderia ser uma das contribuições de nossa pesquisa verificar como podemos estabelecer um diálogo entre as teorias que usamos, dentro de nosso quadro interdisciplinar, e as teorias da DLC.

Dessa forma, nesta seção apresentaremos, primeiramente, algumas das noções que subjazem aos conteúdos culturais segundo a Didática das Línguas e Culturas e o tratamento dado a esses conteúdos na história das metodologias de ensino de línguas, concluindo pela definição do que estamos chamando de conteúdos culturais. Em seguida, propomos a discussão da noção de competência, uma vez que é esse o termo que aparece no documento prescritivo associado aos conteúdos culturais. Na sequência, retomaremos alguns dos conceitos já expostos seção 1.1, abordando a perspectiva vygotskiana de desenvolvimento como "transformação por meio das obras da cultura" (BROSSARD, 2012). Por fim, faremos uma síntese do que expusemos, apresentando a perspectiva que adotamos do trabalho de ensino com os conteúdos culturais nas aulas de língua estrangeira. 


\subsubsection{A noção de “cultura” na Didática das Línguas e Culturas}

Esta subseção tem o intuito de apresentar algumas das noções que subjazem aos conteúdos culturais segundo a Didática das Línguas e Culturas e o tratamento dado a esses conteúdos em algumas das metodologias de ensino de línguas. Nesse sentido, primeiramente observaremos mais detalhadamente como as noções em torno da ideia de cultura foram tomando diferentes contornos (cultura, língua-cultura, intercultural e pluriculturalismo), relacionando-as, em seguida, com algumas das metodologias de ensino de línguas.

Segundo Chaves, Favier e Pélissier (2013), etimologicamente, o termo cultura vem do latim cultura, definido como o trabalho com a terra, com o campo, entretanto Cícero empregava o termo, no sentido figurado, para definir metaforicamente a cultura da alma, seja pela formação da mente, seja pelo ensino. Nesse sentido, de acordo com os autores, a definição de cultura se limitou frequentemente aos mundos artístico e literário, mas no século XX, as áreas sociológicas e antropológicas adicionaram à noção de cultura uma dimensão que incluía os produtos da interação do homem com seu ambiente e seus semelhantes.

O Dicionário atual da educação de Renald Legendre (1988) define a cultura como sendo

um conjunto de maneiras de ver, sentir, perceber, pensar, se expressar, reagir, os modos de vida, as crenças, os conhecimentos, as realizações, os usos e costumes, as tradições, as instituições, as normas, os valores, os costumes (moeurs), os lazeres, as aspirações que distinguem os membros de uma coletividade e que embasam sua unidade em uma dada época. (LEGENDRE, 1988, p.133 apud CHAVES et al, 2013, p.9) ${ }^{73}$.

As perspectivas sociológicas e antropológicas situam o indivíduo como ser social, ultrapassando a ideia de um simples produto de sua cultura, considerando-os como verdadeiros atores e autores dela. Nas ciências sociais, a cultura é representada pela analogia do iceberg de Gary R. Weaver (1986), tendo duas partes: a parte visível-externa, onde estão presentes as opiniões e os comportamentos conscientes, aprendidos de maneira explícita e que são da ordem do conhecimento objetivo, como as artes, a literatura, as roupas etc.; por oposição, a parte invisivel-interna, se define pelo caráter inconsciente, por uma aprendizagem implícita, pela dificuldade a ser modificada e pelos conhecimentos subjetivos, tais como os valores, modos de

\footnotetext{
${ }^{73}$ Citação no original: «Un ensemble de manières de voir, de sentir, de percevoir, de penser, de s'exprimer, de réagir, des modes de vie, des croyances, des connaissances, des réalisations, des us et coutumes, des traditions, des institutions, des normes, des valeurs, des moeurs, des loisirs, des aspirations qui distinguent les membres d'une collectivité et qui cimente son unité à une époque donnée. » (LEGENDRE, 1988, p.133).
} 
conversação, linguagem corporal, a ideia do que é correto ou não, etc. Essa cultura é mais dificilmente perceptível de maneira espontânea.

As várias ciências humanas abordam a noção de cultura pelos mais diversos vieses, sendo essa uma das razões da complexidade desse objeto. Veremos a partir de agora algumas definições discutidas por autores da Didáticas das Línguas e Culturas.

Dervin e Suomela-Salmi (2007, p.102) apresentam uma distinção clássica entre a cultura culta e a chamada cultura antropológica:

Cultura com $\mathrm{C}$ maiúsculo inclui as produções culturais de um país (arte, literatura, cinema ...), mas também o conhecimento de uma nação (geografia, história, instituições ...). Liaw (2006) refere-se à utilização deste tipo de cultura na educação através da expressão transmissão factual. Este aspecto tem sido o foco da maioria dos departamentos de línguas especializada em ensino superior. Ele é ilustrado pelo trabalho no desenvolvimento da competência cultural (ver, por exemplo, Valette, 1986).

Cultura antropológica / sociológica (estilos de vida de um povo, as comparações entre os diferentes países sociológicos, etc.) acompanhou a introdução do ensino comunicativo de línguas estrangeiras desde a abordagem intercultural (Kramsch, 1998; Byram, 1997). Vários métodos para incorporar este segundo tipo de cultura no processo de ensino e aprendizagem de línguas estrangeiras foram utilizados no ensino superior: o estudo de textos (inspirado estudos culturais), a etnografia (Roberts et al, 2001), etc. Um dos principais objetivos desses métodos é fazer linguistas, especialistas ou não, adquirirem uma competência intercultural. (DERVIN, SUOMELA-SALMI, 2007, p.102, tradução nossa $)^{74}$

Essas duas definições retomam de certa maneira as definições de Weaver (1986). A Cultura ou as produções culturais seriam a parte visível-externa de uma sociedade, enquanto a cultura antropológica e sociológica seria a parte invisível-interna.

\footnotetext{
${ }^{74}$ Citação no original: "La Culture avec un grand C englobe les productions culturelles d'un pays (art, littérature, cinéma), mais aussi des connaissances sur une nation (géographie, histoire, institutions). Liaw (2006) désigne le recours à ce type de culture dans l'enseignement par l'expression factual transmission. Cet aspect est depuis longtemps le focus de la majorité des départements de langues spécialisés dans le supérieur. Il est illustré par les travaux sur le développement d'une compétence culturelle (cf. par ex. Valette, 1986). - La culture anthropologique/sociologique (modes de vie d'un peuple, comparaisons sociologiques entre différents pays, etc.) a accompagné l'introduction de l'enseignement communicatif des langues étrangères puis l'approche interculturelle (Kramsch, 1998 ; Byram, 1997). Diverses méthodes pour intégrer ce deuxième type de culture dans l'enseignement apprentissage des langues étrangères ont été utilisées dans le supérieur: l'étude de textes (inspirée des études culturelles), l'ethnographie (Roberts et al., 2001), etc. L'un des objectifs principaux de ces méthodes est de faire acquérir à des linguistes spécialistes et non-spécialistes une compétence interculturelle." (DERVIN, SUOMELASALMI, 2007, p.102)
} 
$\mathrm{Na}$ França, a preocupação com a cultura na pesquisa em Didática das línguas-culturas foi levantada principalmente por Robert Galisson (1991), que propôs retomar essa mesma distinção. Pra ele a cultura culta é aquela que agrupa os conhecimentos adquiridos pelo ser humano, sua instrução e os saberes enciclopédicos, e cultura compartilhada, aborda os saberes e práticas transmitidos e compartilhados por um grupo social que tem uma língua em comum, tais como os sociológicos e antropológicos. Ao propor esses termos, Galisson (1991) opõe-se ao uso dos termos civilização e cultura de forma indiscriminada. Para ele, esses termos eram sinônimos, entretanto, como civilização se opunha à barbárie, e o termo cultura foi enriquecido com as atribuições antropológicas e sociológicas, assim, o primeiro passou a dar lugar ao segundo.

Galisson (1991) defende a ideia de que a cultura adquirida pelos nativos fora da escola podia ser aprendida pelos estrangeiros no interior da escola. Para ele, a aula de língua deve apresentar elementos da cultura culta e também fornecer elementos da cultura cotidiana compartilhada ativa, o que permitirá que o aprendiz adquira uma competência cultural que ele utilizará no seu encontro com a alteridade que representa o universo complexo da língua e da cultura alvo.

Já o termo "língua-cultura" fez a sua aparição na didática das línguas nos anos oitenta, provavelmente em oposição ao uso do termo " língua" pelos linguistas. Para Galisson (1998, p.110), em línguas-culturas “(...) o hífen tem valor epistemológico e simbólico, uma vez que marca a consubstancialidade da "língua" e "cultura", mas também e, sobretudo, a igualdade de importância e status dos dois componentes do objeto de estudo".

Preocupados inicialmente em desenvolver uma perspectiva lexicultural pragmática, Puren e Galisson(1999) ${ }^{75}$ sustentam uma entrada para a cultura em palavras, integrando a cultura e a língua em uma abordagem que não as separe, mas que respeite sua íntima consubstancialidade, privilegiando a cultura comum (ou seja, a cultura-compartilhada) sobre a cultura culta e atribuindo grande importância ao léxico intercultural.

Mais recentemente, a noção de "cultura" foi sendo colocada em debate a partir do contato entre os povos e a partir da compreensão de que não existiria apenas uma língua e uma cultura, mas uma série de culturas ligadas a uma língua, ou uma série de línguas associadas a uma cultura. Esse questionamento iniciou um movimento e deu origem às noções de intercultural,

\footnotetext{
${ }^{75}$ GALISSON, R. ; PUREN, C.La formation en questions.Paris, CLE International, 1999.
} 
multiculturalismo e pluriculturalismo ${ }^{76}$. De forma resumida, o intercultural se realiza no contato entre as culturas, contato que permite através do olhar do outro, voltar um olhar a si mesmo; um conceito regido, portanto, pela ideia de alteridade (ABDALLAH-PRETCEILLE E PORCHER, 2001). O multiculturalismo, na tradição anglo-saxônica, está associado ao recebimento de imigrantes, à coabitação e à coexistência paralela de diferentes grupos em uma sociedade (CONSELHO DA EUROPA, 2001, p.11). Já a noção de pluriculturalismo está associada não só à coexistência, mas à interação entre duas ou mais culturas, supondo um diálogo entre valores, crenças e práticas sociais (COSTE, MOORE e ZARATE, 1997, p.12). A seguir retomamos mais em detalhes os conceitos de intercultural e de pluriculturalismo, termos esses empregados respectivamente pelos professores na entrevista e pelo documento prescritivo.

O intercultural é uma noção recente, compreendido como um processo dinâmico de trocas entre diferentes culturas (CHAVES, FAVIER, PÉLISSIER, 2013, p.10). A interculturalidade, considerada em sua existência histórica na sociedade, é de fato antiga: os seres humanos sempre pertenceram a grupos culturais diferentes. Os encontros e as misturas se realizavam, então, pelo intermediário do comércio, das conquista e da colonização. O termo intercultural abre uma nova perspectiva: aquela de olhares cruzados. Se a diferença cultural existe, ela é não mais encarada como uma ameaça, mas como um enriquecimento cultural recíproco (VERBUNT, 2011, p.12). O intercultural só existe quando há uma troca, um encontro e um compartilhamento. Não seria um conteúdo de ensino, mas antes um procedimento que visa à construção de passarelas entre as culturas. Em consequência, essa abordagem é uma reconstrução constante da identidade na relação com a alteridade, trata-se de, por um lado, aceitar a diversidade de olhares, de encontros, de pontos de vista e de compreender os modos de vida diferentes e, por outro lado, compreender que raramente somos produtos de somente um pertencimento cultural.

Martine Abdallah-Pretceille e Louis Porcher (2001, p.8-9) postulam que a alteridade não deve ser compreendida somente no encontro com o estrangeiro, mas que é intrínseca à educação, permitindo que uma orientação em direção ao outro simbolize uma melhor consciência e si. Nesse sentido, o intercultural, para eles, se constitui no princípio de que o outro é, ao mesmo tempo, "igual a mim e diferente de mim".

\footnotetext{
${ }^{76}$ Para uma melhor compreensão da história e evolução do termo pluriculturalismo nas traduções entre inglês e francês, conferir "La compétence plurilingue et pluriculturelle: gênese et évolution d'une notion-concept" (CASTELLOTTI e MOORE, 2011), que não desenvolvemos aqui, pois foge a nosso objetivo.
} 
Abdallah-Pretceille e Porcher (2001, p.117) assumem ainda uma concepção discursiva em relação a abordagem da cultura:

O real da cultura é o uso da cultura assim como o discurso sobre ela. É por isso que a cultura não tem sentido intrínseco e só existe porque é atualizada em um discurso, necessariamente inscrito em uma situação de interlocução. Assim a única forma de compreender os elementos culturais da comunicação (sejam eles utilizados como referentes ou como sinais em uma estratégia discursiva, quer dizer,sejam eles diretamente objeto do discurso ou ao serviço dele) não é conhecer a cultura, mas analisar a situação de comunicação. Trar-se-á portanto de trabalhar essencialmente no nível dos objetivos, isso é, no nível pragmático e não somente no nível semântico (linguagem) ou semiológico (cultura). Um fato cultural não é descolado de uma prática enunciativa que torna as culturas opacas a si mesmas. Isso explica a vacuidade de toda aprendizagem, de todo ensino das culturas sobre o simples registro descritivo e denotativo. (ABDALLAHPRETCEILLE e PORCHER, 2001, p. 117, tradução nossa) ${ }^{77}$

A ética por trás da abordagem intercultural, formalizada por Louis Porcher e Martine Abdallah-Pretceille (1998, p.98) é uma ética da alteridade, caracterizada notadamente por uma atenção sustentada ao outro, assim como pela capacidade de se colocar em seu lugar. No quadro dessa abordagem, os interactantes (aprendizes e professores) são convidados a colocar em prática os princípios de abertura e curiosidade (BYRAM, 1997); de prudência (VERBUNT, 2005) ${ }^{78}$; de descentração (COHEN-EMERIQUE, 1997) ${ }^{79}$; de compreensão voluntária (BLANCHET, 2007) ${ }^{80}$ ou ainda de empatia (ZARATE, 2003) ${ }^{81}$.

Coste, Moore e Zarate (2009) se interrogam, por sua vez, sobre o ensino-aprendizagem no âmbito de uma didática do plurilinguismo e do pluriculturalismo, refletindo sobre alguns paradoxos que nos parece importante destacar.

\footnotetext{
${ }^{77}$ Citação original : «Le réel de la culture est l'usage de la culture ainsi que le discours porté sur elle. C'est pourquoi, la culture n'a pas de sens intrinsèque et n'existe que parce qu'elle est actualisée dans un acte, nécessairement inscrit dans une situation d'interlocution. Ainsi, le seule moyen de comprendre les éléments culturels de la communication (qu'ils soient utilisés comme référents ou comme signaux dans une stratégie discursive, c'est-àdire qu'ils soient directement l'objet du discours ou au service de celui-ci) n'est pas de connaître la culture mais d'analyser la situation de communication. Il s'agira donc de travailler essentiellement au niveau des objectifs, c'està-dire au niveau pragmatique et non pas seulement sémantique (pour le langage) ou (pour la culture).» (ABDALLAH-PRETCEILLE e PORCHER, 2001, p. 117)

${ }^{78}$ VERBUNT, G. Les obstacles culturels aux apprentissages, ou comment faire de l'interculturel appliqué. In : Étude Linguistique Appliquée, $n^{\circ} 140,2005$, p.409-420.

${ }^{79}$ COHEN-EMERIQUE, M. 1997.L'approche interculturelle, une prévention à l'exclusion. In : Les cahiers del'Actif, $n^{\circ} 250-251.1997$, p.19-29.

${ }^{80}$ BLANCHET, P. L'approche interculturelle comme principe didactique et pédagogique structurant dans l'enseignement/apprentissage de la pluralité linguistique. In : Revue Synergies Chili, $n^{\circ} 3$, 2007 p. 21-27.

${ }^{81}$ ZARATE, G. (dir.) Médiation culturelle et didactique des langues. Graz : Conseil de l’Europe, 2003.
} 
Segundo os autores (COSTE, MOORE, ZARATE, 2009), durante muito tempo a Didática das Línguas se desenvolveu em relação ao ensino de línguas baseado no desenvolvimento da competência de comunicação e do modelo do nativo ideal: aprender uma língua estrangeira era ter como alvo o conhecimento, a articulação, a pronúncia e o arcabouço do nativo. Todas as estratégias eram voltadas ao desenvolvimento da competência de comunicação. Nesse sentido, a aprendizagem dos conteúdos culturais viria a corroborar essa ideia, fornecendo elementos para que o aprendiz pudesse se comunicar melhor.

Partindo dessas observações, os autores fazem a defesa de uma competência plurilíngue e pluricultural, que ultrapassa a questão da dualidade (encontrada nos termos bilinguismo, interculturalismo), propondo a pluralidade; que não se foca somente na comunicação, mas na também na ação social do falante e na construção de sua própria identidade; e que rejeita a ideia ter como alvo o nativo ideal, mas assume como premissa o desenvolvimento de aspectos linguísticos e culturais em vários de graus, desenvolvendo de forma diferentes as habilidades de acordo com as necessidades de cada sujeito.

"Denotamos por competência plurilíngue e pluricultural, a competência para comunicar com a linguagem e para interagir culturalmente possuída por um falante que domina, em diferentes graus, várias línguas e, em graus variados, a experiência de muitas culturas, sendo capaz de lidar com todo o capital linguístico e cultural. A principal opção é considerar que não há a superposição ou justaposição de competências distintas, mas sim a existência de competência plural, complexa, complexa e heterogênea ou mesclada, que inclui competências singulares, por vezes parciais, mas que está disponível como um repertório para o ator social em questão."(COSTE, MOORE, ZARATE, 1997/2009, p. 12, tradução nossa, destaque dos autores) ${ }^{82}$

A mudança de perspectiva desses conceitos associados à cultura (cultura, língua-cultura, intercultural, plurilinguismo) foi evoluindo, nas metodologias de ensino de línguas, paralelamente à evolução das teorias que subjazem à visão de língua e de aprendizagem.

Para ilustrar essa evolução paralela das metodologias de ensino e aprendizagem das línguas e culturas, consideramos o estudo de Puren (2010), que elabora uma descrição das

\footnotetext{
${ }^{82}$ Citação original : « On désignera par compétence plurilingue et pluriculturelle, la compétence à communiquer langagièrement et à interagir culturellement possédée par un locuteur qui maîtrise, à des degrés divers, plusieurs langues et a, à des degrés divers, l'expérience de plusieurs cultures, tout en étant à même de gérer l'ensemble de ce capital langagier et culturel. L'option majeure est de considérer qu'il n'y a pas là superposition ou juxtaposition de compétences toujours distinctes, mais bien existence d'une compétence plurielle, complexe, voire composite et hétérogène, qui inclut des compétences singulières, voire partielles, mais qui est une en tant que répertoire disponible pour l'acteur social concerné. » (COSTE, MOORE ET ZARATE, 1997/2009, p.12, destaque dos autores)
} 
situações e competências sociais (linguageiras e culturais) de referência para cada metodologia. Segundo o autor, na metodologia tradicional, vigente no século XIX, havia um interesse em compartilhar os valores humanos universais através do estudo e tradução dos grandes textos clássicos. Nas metodologias direta e ativa, por volta de 1900 a 1960, havia uma busca por extrair e mobilizar, ainda a distância, conhecimentos sobre a cultura estrangeira por meio de documentos autênticos, o que permitia não só ler, mas falar sobre a cultura do outro. Já na abordagem comunicativa, em voga na década de 80, buscou-se desenvolver, através do domínio das representações emergentes da interação com o outro, uma competência dialogal, não mais falar sobre o outro, mas com o outro. Na didática do plurilinguismo, iniciada em 1990, objetivou-se compreender os comportamentos dos outros e adotar comportamentos aceitáveis numa sociedade multicultural com o objetivo de permitir a coabitação, o viver com o outro. Finalmente, na perspectiva acional, vigente a partir da publicação e divulgação do Quadro Europeu Comum de Referência para Línguas em 2001, a competência visada é o agir com o outro, isso é, a capacidade de elaborar coletivamente ações comuns baseadas em valores contextuais partilhados. O quadro abaixo retoma a evolução histórica das metodologias (PUREN, 2010):

\section{ÉVOLUTION HISTORIQUE DES CONFIGURATIONS DIDACTIQUES EN DIDACTIQUE DES LANGUES-CULTURES}

\begin{tabular}{|c|c|c|c|c|c|}
\hline & Situation sc & ociale de référence & \multirow{3}{*}{$\begin{array}{l}\text { Actions } \\
\text { sociales de } \\
\text { référence }\end{array}$} & \multirow{3}{*}{$\begin{array}{l}\text { Tâches } \\
\text { scolaires } \\
\text { de référence }\end{array}$} & \multirow{3}{*}{$\begin{array}{l}\text { Constructions } \\
\text { méthodoloqiques } \\
\text { correspondantes }\end{array}$} \\
\hline & \multicolumn{2}{|c|}{ Compétences sociales de référence } & & & \\
\hline & langagière & culturelle & & & \\
\hline 1. & $\begin{array}{l}\text { capacité à (re)lire les } \\
\text { grands textes classiques }\end{array}$ & $\begin{array}{l}\text { capacité à entretenir sa formation } \\
\text { d'honnête homme en se } \\
\text { replongeant dans ces grands } \\
\text { textes pour y reconnaître et } \\
\text { partager les valeurs universelles } \\
\text { qui constituent le } \alpha \text { fonds } \\
\text { commun d'humanité } »(\dot{E} \text {. } \\
\text { Durkheim): compétence } \\
\text { transculturelle }\end{array}$ & lire & traduire (= lire, en paradigme indirect) & $\begin{array}{l}\text { méthodologie traditionnelle } \\
\text { (XIX }{ }^{e} \text { siècle) }\end{array}$ \\
\hline 2. & $\begin{array}{l}\text { capacité à entretenir à } \\
\text { distance un contact avec } \\
\text { la langue-culture } \\
\text { étrangère à partir de } \\
\text { documents authentiques }\end{array}$ & $\begin{array}{l}\text { Capacité, à propos et à partir de } \\
\text { documents authentiques, à } \\
\text { mobiliser et extraire des } \\
\text { connaissances sur la culture } \\
\text { étrangère : compétence } \\
\text { métaculturelle }\end{array}$ & $\begin{array}{c}\text { lire } \\
\text { parler sur }\end{array}$ & $\begin{array}{l}\text { « explication de textes » au moyen d'une } \\
\text { série de tâches en langue cible } \\
\text { (paradigme direct): paraphraser, } \\
\text { analyser, interpréter, extrapoler, } \\
\text { comparer, réagir, transposer }\end{array}$ & $\begin{array}{l}\text { méthodologie directe pour le } \\
\text { second cycle scolaire (1900- } \\
1910) \text { et méthodologie active } \\
(1920-1960)\end{array}$ \\
\hline 3. & $\begin{array}{l}\text { capacité à échanger } \\
\text { ponctuellement des } \\
\text { informations avec des } \\
\text { étrangers de rencontre }\end{array}$ & $\begin{array}{l}\text { capacité à maîtriser les } \\
\text { représentations croisées dans } \\
\text { l'interaction avec les autres: } \\
\text { compétence interculturelle } \\
\end{array}$ & $\begin{array}{l}\text { parler avec } \\
\text { agir sur }\end{array}$ & $\begin{array}{l}\text {-simulations et jeux de rôles } \\
\text {-actes de parole }\end{array}$ & $\begin{array}{l}\text { approche communicative } \\
(1980-1990)\end{array}$ \\
\hline 4. & $\begin{array}{l}\text { compétence plurilingue : } \\
\text { capacité à gérer } \\
\text { langagièrement la } \\
\text { cohabitation avec des } \\
\text { gens de langue-culture } \\
\text { entièrement ou } \\
\text { partiellement différente }\end{array}$ & $\begin{array}{l}\text { capacité à comprendre les } \\
\text { comportements des autres et } \\
\text { adopter des comportements } \\
\text { communs acceptables dans une } \\
\text { société multiculturelle: } \\
\text { compétence pluriculturelle }\end{array}$ & vivre avec & $\begin{array}{l}\text { activités de médiation entre des langues } \\
\text { et des cultures différentes : } \\
\text { interprétation, reformulation, résumés, } \\
\text { périphrases, équivalences,... }\end{array}$ & $\begin{array}{l}\text { didactiques du plurilinguisme } \\
\text { (1990-?) }\end{array}$ \\
\hline 5. & $\begin{array}{l}\text { capacité à travailler dans } \\
\text { la durée en langue } \\
\text { étrangère avec des } \\
\text { locuteurs natifs ou non } \\
\text { natifs de cette langue, ou } \\
\text { avec des natifs de sa } \\
\text { propre langue maternelle }\end{array}$ & $\begin{array}{l}\text { capacité à élaborer avec les } \\
\text { autres des conceptions } \\
\text { communes de l'action collective } \\
\text { sur la base de valeurs } \\
\text { contextuelles partagées: } \\
\text { compétence co-culturelle }\end{array}$ & agir avec & $\begin{array}{l}\text { «co-actions », actions collectives à } \\
\text { dimension collective (type « pédagogie } \\
\text { du projet) }\end{array}$ & $\begin{array}{l}\text { ébauche d'une "perspective } \\
\text { actionnelle » } \text { dans le CECRL } \\
(2000-?)\end{array}$ \\
\hline
\end{tabular}

Tabela 6: Evolução histórica das configurações didáticas (PUREN, 2010) 
Essas mudanças de orientações no ensino de línguas refletiam uma mudança de perspectiva social e política, ao encontrar no contexto do início do século XXI demandas diferentes das que se tinha no século XX, ou mesmo nas décadas de 80 e 90 . A mobilidade na Europa atingiu, no final dos anos 90 e no início do século XXI, um nível bem mais amplo, como consequência das mudanças suscitadas pelas demandas progressivas da União Europeia. Reconhecendo tais impasses e buscando adequar o paradigma do ensino de línguas às demandas do contexto do velho continente, o Conselho da Europa publicou em 2001 o CECRL, cujos princípios básicos foram:

- que o rico patrimônio que representa a diversidade linguística e cultural na Europa constitui uma valiosa fonte comum que convém proteger e desenvolver, sendo necessários esforços consideráveis no domínio da educação, de modo a que essa diversidade, em vez de ser um obstáculo à comunicação, se torne numa fonte de enriquecimento e de compreensão recíprocos;

- que apenas através de um melhor conhecimento das línguas vivas europeias conseguirá facilitar a comunicação e a interação entre Europeus de línguas maternas diferentes, de forma a promover a mobilidade, o conhecimento e a cooperação recíprocas na Europa e a eliminar os preconceitos e a discriminação;

- que os Estados-membros, ao adotarem ou desenvolverem uma política nacional no domínio do ensino e da aprendizagem das línguas vivas, poderiam atingir um maior entendimento a nível europeu, graças a acordos adequados que visem uma cooperação e uma coordenação constantes das suas políticas.

(CONSELHO DA EUROPA, 2001, p.20)

Cooperação, diversidade, interação, mobilidade, entendimento, compreensão e reciprocidade adquirem, assim, grande importância nesse contexto. Segundo esses princípios, a aprendizagem de línguas não se restringiria mais às estruturas linguísticas, mas, como mostra detalhadamente o CECRL, contemplaria o indivíduo como ator social, com características próprias, inserido numa comunidade cada vez mais plurilíngue, pluricultural, buscando realizar e completar tarefas em língua estrangeira, buscando agir coletivamente. Assim, podemos afirmar que o CECRL focaliza dois aspectos centrais: o aprendiz de língua estrangeira como ator social, entendendo por ator aquele que realiza ações linguageiras, que age no mundo por meio da linguagem, e por social a qualidade desse aprendiz que possui valores, história, que está inserido num contexto social e cuja cultura, não só nacional, mas também particular, estará em constante 
diálogo durante o aprendizado. Lidar, portanto, com essa perspectiva de ensino da língua-cultura supõe reflexão e estudo, complexificando de maneira determinante o trabalho do professor.

Paralelamente a essas questões sobre o objeto de ensino "conteúdos culturais", parece-nos essencial lembrar que, na maioria das metodologias de ensino-aprendizagem de línguas, foi necessário formar os professores para empregá-las. É assim que temos, por exemplo, durante a metodologia áudio-visual ${ }^{83}$, na França (não contemplada no quadro de PUREN, 2010), uma intensa formação do professor para dominar aspectos técnicos, já que era necessário manipular equipamentos como o projetor de imagens e os gravadores em áudio, com instruções específicas e explícitas sobre o tipo e ocasião de repetição, para citar um exemplo (GERMAIN, 1993). Essa constatação nos leva a pensar sobre como formar os professores para esse trabalho, uma vez que no contexto atual ele é orientado a trabalhar as "competências gerais e linguageiras" dos alunos. É justamente para a questão da competência que se volta a subseção a seguir, observando que concepções subjazem esse conceito e que impasses isso traz para o trabalho do professor.

Tendo observado as definições, implicações e sentidos atrelado a cada um desses termos, gostaríamos de definir o que estamos chamando em nossa pesquisa de "conteúdos culturais" antes de passar à próxima subseção. A princípio, não estamos fazendo nenhuma distinção sobre cultura visível-externa (culta, produções culturais, transmissão factual) e cultura invisível-externa (popular, sociológica, etnográfica, implícita), inter, multi ou pluriculturalismo. Ao objetivarmos estudar a maneira como os professores trabalham os conteúdos culturais, buscamos tratar qualquer tipo de indício relacionado à cultura ou às culturas, de origem ou alvo, que aparecesse na aula de língua estrangeira como objeto da ação do professor, seja ele uma transmissão factual (como, por exemplo, a Festa dos Vizinhos que ocorre na França), seja ele um aspecto de um grupo social (por exemplo, os esportes mais comuns praticados no Brasil), uma distinção mais ligada à língua-cultura (por exemplo, duas palavras e dois locais - douche e wc no quarto de hotel- que corresponderia a um só em português, no Brasil - banheiro), ou mesmo um olhar sobre traços e características de um outro povo (por exemplo, um povo mais honesto ou um povo menos honesto) ${ }^{84}$.

\footnotetext{
${ }^{83}$ Em francês, Structuro-Globale-Audio-Visuelle (SGAV).

${ }^{84}$ Neste parágrafo, os exemplos são oriundos dos conteúdos que aparecem nas entrevistas com os professores e que veremos mais a frente no Resultado das Análises.
} 
Optamos por utilizar o termo "conteúdos culturais", encontrado em Byram (2011), ao invés de cultura, intercultural, competência intercultural etc., por dois motivos. Primeiramente, porque trata-se de um termo mais neutro e menos carregado das conotações que vimos anteriormente, dessa forma, ele vai ao encontro do nosso intuito que é, inicialmente, observar como os professores representam seu trabalho com esses conteúdos, buscando elementos de definição desse conteúdos pela ótica dos professores a posteriori. Em segundo lugar, porque remete à ideia de objeto de ensino, objeto de trabalho do professor, um conteúdo a ser trabalho ${ }^{85}$, uma prescrição a ser levada em conta. Nesse sentido, restituímos ao professor seu local de atuação, que parece ter sido apagado quando se fala da aquisição de competências pelos alunos (como no CECRL), pois, em nossa perspectiva, o desenvolvimento não se dá apenas como uma evolução natural dos alunos, mas é motivado pela interferência do professor na situação de ensino. Assim, a ideia de se "trabalhar conteúdos culturais" devolve ao professor, a nosso ver, seu papel de mediar a aprendizagem.

\subsubsection{A problemática da noção de "competência"}

Como vimos no quadro de Puren (2010), a ideia de competência perpassa a evolução da Didática das Línguas e Culturas é fortemente presente no Quadro Comum Europeu de Referência para as Línguas (CONSELHO DA EUROPA, 2001), o qual apresenta as noções de cultura sob a ideia de competência: competências gerais, competências linguísticas, competência cultural, competência intercultural, portanto, achamos conveniente colocá-las em discussão.

Logo na introdução do capítulo 5 do CECRL, alguns elementos que indicam uma definição do que se considera competência. Vejamos o excerto a seguir:

Afin de mener à bien les tâches et activités exigées pour traiter les situations communicatives dans lesquelles ils se trouvent, les utilisateurs et les apprenants utilisent un certain nombre de compétences acquises au cours de leur expérience antérieure. En retour, la participation à des événements de communication (y compris, bien sûr, ceux qui visent l'apprentissage de la langue) a pour conséquence l'accroissement des compétences de l'apprenant à moyen et à long terme. Toutes les compétences humaines contribuent, d'une façon ou d'une autre, à la capacité de communiquer de l'apprenant et peuvent être considérées comme des facettes de la compétence à communiquer. Toutefois, il peut être

\footnotetext{
${ }^{85}$ Estamos cientes de que palavra "conteúdo" pode, por outro lado, remeter a uma ação de transmissão. No entanto, como explicamos na sequência, estamos dentro de uma perspectiva em que o desenvolvimento não se dá apenas como uma evolução natural dos alunos, mas é motivado pela interferência do professor na situação de ensino, diferindo, portanto, da ideia de uma transmissão direta de conteúdos.
} 
utile de distinguer celles qui ne sont pas directement en relation avec la langue des compétences linguistiques proprement dites. (CECRL 2001, p. 82, grifo nosso)

Vemos, nesse excerto, a ideia competência como algo adquirido ao longo da experiência de vida. Apesar de associado às características humanas em geral, o termo competência não é precisamente definido no Quadro. Podemos, no entanto, refletir sobre a ideia de se adquirir uma competência, que traz em si um sentido de possuir, absorver de maneira passiva, diferindo da ideia de desenvolvê-la, de maneira ativa.

Buscando nos aprofundar nesses termos, encontramos em Bronckart, Bulea e Pouliot (2005) algumas considerações importantes. Segundo os autores, a expressão "competência linguística" foi introduzida por Chomsky em um artigo de 1955, um dos textos fundadores da revolução cognitiva nas ciências humanas. Chomsky $(1995)^{86}$ considerou que a extrema rapidez da aquisição da língua e de suas unidades pelas crianças não podia ser explicada em termos de aprendizagem, justificando assim que esse fenômeno só poderia estar ligado à uma disposição linguageira inata e universal que chamou de competência. Bronckart et al (2005, p.29) explicam que, segundo a corrente do cognitivismo radical, todas as funções psicológicas superiores estariam sustentadas por um dispositivo inato, posição essa divergente da vygotskiana, que defende o desenvolvimento dessas funções nas interações.

Paralelamente, esse termo foi retomado pela abordagem funcionalista (HYMES, 1973/1991) ${ }^{87}$ do ensino de língua estrangeira que sustentava que, se existisse uma competência linguística, ela não seria suficiente para se desenvolver o domínio prático de uma língua, já que esta implicava a capacidade de adaptação das produções linguageiras aos contextos de comunicação (BRONCKART et al, 2005, p.29). Nesse sentido, Hymes (1973/1991) distorceu o conceito colocado por Chomsky, que não era mais inato, mas adaptado e contextualizado, dependente de uma aprendizagem formal ou informal.

Ainda segundo Bronckart et al (2005), desde os anos 90, o termo competência ganhou um novo significado, perdendo a característica que adquiriu na abordagem anterior. No campo do trabalho e da formação profissional, houve uma recusa das qualificações exigidas como

\footnotetext{
${ }^{86}$ CHOMSKY, N. The Minimalist Program. Current studies in linguistics 28. Cambridge, MA: MIT Press, 1995.

${ }^{87}$ HYMES, D.H. Vers la compétence de la communication. [Primeira edição 1973] Paris: Créditif-Hatier, 1991, 219 p.
} 
conhecimentos estáticos. Com as novas tecnologias, surgiu a necessidade de um trabalhador que se adapte velozmente às transformações no ambiente de trabalho; dessa forma, os conhecimentos atestados (pelo Estado) não eram mais suficientes, fazendo-se necessária uma capacidade de adaptação e flexibilidade aos novos objetivos e instrumentos. A noção de competência, que antes era vista como os conhecimentos estáveis no indivíduo, passou então a ser definida como as capacidades mais gerais e mais flexíveis permitindo encarar a variedade de tarefas e de tomar decisões em tempo real, sendo mais próxima do saber-fazer do que do saber e das capacidades metacognitivas que do domínio dos saberes estabilizados (BRONCKART et al, 2005, p.30).

Essas duas acepções contrárias, por um lado, a das propriedades do sujeito à adaptação ao meio, como proposta por Chomsky (1995) e, por outro lado, a das exigências do meio às capacidades exigidas do sujeito, fundamentada tanto na ideia de Hymes (1973/1991), quanto na de produtividade do trabalho, podem contribuir com uma redefinição dos conteúdos de formação, para que sejam melhor adaptados às situações efetivas de atividade. Entretanto, elas colocam dois problemas gerais.

O primeiro é justamente ligado ao caráter instável da noção de competência que flutua entre "repertório de comportamentos", "sistema de conhecimentos declarativos", "esquemas operatórios", "saber-agir", "federação de habilidades e atitudes" (BRONCKART et al, 2005, p.31). Sem insistir por um purismo conceitual, os autores apontam que um termo que designa ao mesmo tempo todas as funções superiores não contribuiria de maneira eficaz a programas de formação. O segundo problema que o autor aponta está relacionado à "lógica das competências" imposta por poderes econômicos e políticos, que buscam a inserção de uma série de formações na lógica do mercado.

Em nosso caso, apesar de essa noção ser muito utilizada no âmbito da Didática das Línguas-Culturas, entendemos que: i) no CECRL, a noção de competência é associada às experiências de vida do aluno, seu contexto sócio-histórico-cultural; no entanto, essa competência seria adquirida, e não trabalhada, o que lhe confere um caráter mais estático, excluindo o papel do professor; ii) como postulam Bronckart et al (2005), a noção de competência é bastante instável, tornando difícil sua determinação e seu estudo e, por outro lado, demasiadamente ligada à lógica de mercado, esta bastante distante das vertentes das Ciências do Trabalho que adotamos. Portanto, embora no campo da Didática das Línguas-Culturas seja esperado que uma pesquisa 
sobre conteúdos culturais aborde essa noção, optamos justamente por não adotá-la, centrando nosso estudo no trabalho que pode ser desenvolvido pelo professor para possibilitar a aprendizagem desses conteúdos culturais.

\subsubsection{Desenvolvimento como transformação pela apropriação das obras da cultura}

Tendo visto as concepções da Didática sobre cultura e conhecendo a problemática da ideia de aquisição de competências, apresentamos a seguir uma perspectiva vygotskiana sobre os conteúdos culturais, observando o desenvolvimento como transformação pela apropriação das obras da cultura.

Vimos, na primeira seção do capítulo, que, na perspectiva vygotskiana, o desenvolvimento humano está atrelado ao desenvolvimento do pensamento e da linguagem, aos instrumentos e às atividades mediadoras.

Brossard (2012) propõe uma reflexão sobre o desenvolvimento comparando esse conceito em textos de dois momentos diferentes da obra de Vygotski: Psicologia da arte (1925) e o capítulo sexto de Pensamento e Linguagem (1934), tomando como fio condutor o conceito de cultura, que dialoga diretamente com as questões que buscamos investigar neste trabalho .

O autor (BROSSARD, 2012) ressalta a importância que Vygotski (1934/1997) confere à história elemento constituinte do próprio conceito de humano. Segundo este, a história é composta de atividades mediadas (médiatisées), da criação e reemprego de meios artificiais e da transmissão de produtos da atividade, acumulados, o que marca o futuro das sociedades. Assim, as sociedades criaram não somente produtos da cultura - como o conhecimento, as instituições -, mas também os instrumentos necessários à sua produção- a linguagem oral, escrita, o sistema de contagem. Esse mundo, produzido pelas atividades humanas, transformado e perpetuamente retrabalhado, constitui o mundo da cultura na perspectiva vygotskiana.

Retomando Vygotski (1934/1997), Brossard (2012) aponta que o desenvolvimento humano é o objeto de um duplo trabalho: a transmissão por parte de um adulto e a apropriação por parte da criança. Ele define que o processo de apropriação: 
"consiste em realizar, com a ajuda de outro, todo um conjunto de atividades pelas quais o sujeito torna seu, no curso de sua história pessoal, o mundo de diferentes produções culturais inicialmente exteriores a ele" (BROSSARD, 2012, p.98, tradução nossa) ${ }^{88}$.

Segundo Vygotski (1934/2004), ao se apropriar das produções culturais, o psiquismo do indivíduo é transformado. O desenvolvimento consiste, assim, em novas formas de atividades decorrentes do uso que esse indivíduo faz das produções culturais (a linguagem, por exemplo). Dessa forma, o binômio apropriação-transformação traz uma ruptura com o desenvolvimento natural e faz emergir uma nova forma de desenvolvimento original característico do meio humano. Esse meio é permeado de signos bi-orientados: dirigidos a outrem, mas também a si mesmos (VYGOTSKI, 1934/2004; BROSSARD, 2012).

Para compreender a relação que se estabelece entre apropriação, transformação e desenvolvimento, Brossard (2012) propõe uma reflexão sobre os conceitos cotidianos e científicos (VYGOTSKI, 1934/1997), que foram apresentados na primeira seção do capítulo, e sobre a reação estética, baseado em Psicologia da Arte (VYGOTSKI, 1925, 1932).

Como vimos anteriormente, Vygotski (1934/1997) postula que há um único sistema de conceitos com dois grupos. Fora da escola, a criança estabelece múltiplas redes de significações (complexo, preconceitos, conceitos potenciais), construindo para si cosmogonias: maneiras de ver o mundo, que são os conceitos cotidianos. Os produtos desse trabalho (conceitos cotidianos) constituem a matéria primeira a ser transformada em conceitos científicos, por meio de um trabalho didático que vise a transformar e não a inculcar (BROSSARD, 2012).

Inspirando-nos nesses pressupostos de Vygotski (1934/1997), podemos dizer que há desenvolvimento quando o aluno consegue fazer uso dos conceitos científicos, provocando uma transformação em seu psiquismo decorrente da apropriação do conceito. Nesse sentido, entendemos que o ensino e a aprendizagem baseados nessa abordagem devem se voltar para ações que propiciem ocasiões favoráveis a essa apropriação.

Com relação ao exemplo da reação estética, Brossard (2012) afirma que Vygotski (1925 ${ }^{89}$, $1932^{90}$ ) dá um lugar central às emoções em nossa vida psíquica. As emoções são definidas por

\footnotetext{
${ }^{88}$ Citação original: “Le processus d'appropriation consiste à mettre en œuvre avec l'aide d'autrui tout un ensemble d'activités par lesquelles le sujet fait sien, au cours de son histoire personnelle, le monde de différentes productions culturelles initialement extérieures à lui”. (BROSSARD, 2012, p.98)

${ }^{89}$ VYGOTSKI, L.S. Psychologie de l'art. Traduction Françoise Sève, Paris: La Dispute, [1925]/2005.

${ }^{90}$ VYGOTSKI, L.S. Les émotions et leur développement chez l'enfant. In: Lev Vygotski, Conscience, Inconscient, Émotions. Paris: La Dispute, [1932]/2003, p.123-164.
} 
Vygotski (1932) como “os vividos mais significativos e importantes, os mais próximos do núcleo da personalidade" e compreendidas de duas maneiras pelo autor.

Primeiramente, Vygotski (1925) aponta que nossa capacidade de receber estímulos e experienciar emoções é muito maior que nossa capacidade de agir. As emoções dão conta de experimentar e viver no plano psicológico uma série de ações impedidas, recusadas, energias não empregadas, ao passo que no plano da ação real, apenas uma dessas possibilidades será concretizada.

Em segundo lugar, ao elaborar sobre a reação estética, Vygotski (1926) ${ }^{91}$ recoloca a vida emocional integralmente nas situações sociais. Opondo-se aos que consideram as emoções como resquícios rudimentares de uma vida animal, o autor postula que a diversidade e a riqueza das emoções se constroem e se diversificam nos contextos sociais significantes. Para explicar essa diversidade e riqueza, Vygotski (1926) propõe o conceito de perezivanije, que, em russo, significa experiência, experiência emocional, experiência vivida. A partir desse conceito Brossard (2012, p.111) sustenta que as emoções são portadoras de significações essenciais no e para o desenvolvimento da personalidade.

Em síntese, as emoções provocadas na reação estética recuperam a experiência vivida do sujeito e as transforma, permitindo o acesso a uma nova maneira de ver o mundo, dotada uma energia nova para enfrentar situações no porvir. Vemos, assim, uma forte ligação da questão das emoções provocadas na reação estética com o próprio método da autoconfrontação, que apresentamos na primeira seção do capítulo.

Brossard (2012) conclui, ressaltando que, para Vygotski (1925; 1934), tanto nos conceitos cotidianos, quanto nas emoções da experiência vivida, há um processo de transformação, seja ele mediado pelo ensino-aprendizagem ou pela obra estética, sendo essa transformação interior ao sujeito que debate consigo mesmo e transforma seu psiquismo. Essa transformação é, portanto, interior e psicológica, mediada pelas obras da cultura.

A perspectiva vygotskiana que viemos de apresentar difere das noções de cultura que vimos na primeira subseção, bem como da ideia de competência que vimos na segunda subseção. Nessa abordagem, a cultura é constituída tanto dos produtos (obras que possam provocar a reação estética, por exemplo), quanto dos meios para produzi-la (a linguagem). Do ponto de vista do trabalho com a cultura, também encontramos considerações interessantes em Vygotski (1925,

\footnotetext{
${ }^{91}$ VYGOTSKI, L. V. Educational Psychology. St. Lucie Press, Boca Raton, [1926]/1997.
} 
1934): o desenvolvimento é provocado a partir de uma apropriação do sujeito pelo uso das obras da cultura, de forma mediada. Por outro lado, ele é também é mediado pelas emoções das experiências vividas do sujeito, ligando-se à sua história e seu contexto social.

\subsubsection{O trabalho de ensino com os conteúdos culturais na perspectiva do ISD}

À luz das discussões teóricas mencionadas nesse capítulo, faremos uma síntese do que expusemos, destacando as implicações para o trabalho do professor de línguas estrangeiras e apresentando a perspectiva que adotamos para a análise do trabalho de ensino com os conteúdos culturais nas aulas de língua estrangeira.

Em síntese, vimos que as noções de cultura e termos referentes a ela foram assumindo diferentes significados ao longo de alguns momentos da história das metodologias de ensino. Tanto a complexidade, quanto os múltiplos termos associado à cultura, acabam por tornar os conteúdos culturais um objeto difuso e difícil de apreender, portanto, ainda mais complexo de se trabalhar.

Observamos que, no CECRL, a ideia dos conteúdos culturais aparece dentro da noção de competência, entretanto essa noção também é problemática do ponto de vista do trabalho do professor, uma vez que ela é colocada no âmbito da aquisição e não como algo sobre o qual o professor possa atuar.

Finalmente, vimos a perspectiva vygotskiana, que considera tanto os produtos da cultura, quanto os instrumentos para produzi-la como objetos de apropriação geradores de desenvolvimento, os quais consideraremos a seguir.

Retomando alguns elementos de nosso quadro teórico, podemos dizer que, em nossa perspectiva, pautamo-nos na ideia de cultura trazida por Brossard (2012), que é constituída tanto por produtos da cultura (uma obra, uma pintura ou livro, por exemplo), quanto por instrumentos para a criação dessas obras (a linguagem, por exemplo). Essa cultura não é somente concreta, mas está dissipada nas representações coletivas e individuais dos sujeitos. Assim, ela só existe dentro dos quadros de interação do homem nas atividades humanas, sendo perpetuamente transformada e retrabalhada.

Retomando o quadro do Interacionismo Social, podemos afirmar que a cultura faz parte dos pré-construídos, pois já existia antes que existíssemos. Entretanto, vemos que ela também é 
instrumento de mediação e atuação no mundo. Isso permite que a cultura seja modificada por nós através das interações sócio-históricas e de nossas intervenções no mundo.

Assim sendo, quando falamos de conteúdos culturais em aula de língua estrangeira podese entender, erroneamente, que estamos nos referindo tão somente aos produtos da cultura (cultura culta, Cultura, produções de um grupo social), o que poderia ser amplamente criticado. Porém, vale a pena lembrar que, se nos baseamos na perspectiva vygotskiana, é preciso considerar a linguagem e outros instrumentos mediadores como cultura também. Nesse sentido, a cultura não será somente o que a DLC considera como tal, ou o quadro "Point Culture" no final da lição do livro didático que mencionaremos nas análises, mas estará presente no léxico, nas fórmulas de cumprimento, nos gestos, nas relações sociais etc., enfim, em tudo o que o professor constroi e traz para a sala de aula para instaurar (novas) relações dos alunos com os objetos estudados.

Como vimos, a opção de utilizar o termo “conteúdos culturais" também se justifica porque estamos dentro de um quadro de situação de trabalho educacional, no qual consideramos esse complexo objeto como uma das prescrições para o trabalho do professor, assim, "conteúdo" ajuda-nos a termos em mente que estamos falando de um objeto de ensino presente no trabalho de professor de línguas estrangeiras, seja ele um produto da cultura, ou um aspecto cultural da linguagem.

Nesse sentido, a ideia de se trabalhar conteúdos culturais, na abordagem que adotamos, também não pode ser restringida a estratégias de ensino-aprendizagem universais ou acontextualizadas. Nosso pressuposto é que o desenvolvimento dos alunos através das obras da cultura (linguagem e produções) se dê pela uso e pela apropriação dessas produções pelos sujeitos. Além disso, como destaca Brossard (2012), há de se enfatizar a importância da experiência vivida nesse processo: a emoção, os afetos, a história pessoal e a linguagem interior interferem na transformação dos indivíduos.

Isso posto, acreditamos que o trabalho de pesquisa exposto a seguir poderá explorar essas questões, fornecendo-nos elementos concretos para um aprofundamento da discussão. 


\section{Capítulo 2 - Metodologia}

Em nossa época, o cientista precisa tomar consciência da utilidade social e do destino prático reservado a suas descobertas.

Florestan Fernandes 


\subsection{Orientação metodológica: os instrumentos de pesquisa}

Ao adotar o quadro teórico-metodológico do ISD, da Clínica da Atividade e Ergonomia da Atividade, todos de base vygotskiana, buscamos proceder de maneira coerente com seus pressupostos e, portanto, optamos por considerar os fenômenos estudados como processo e não como estado, levando em conta a história dos indivíduos implicados. Considerar o processo significa também ponderar sobre as interaçães dos sujeitos, com o outro, consigo mesmo, com sua história e com o coletivo.

Dentro desse quadro teórico-metodológico e tendo em vista nosso objetivo nesta pesquisa, identificar as "representações construídas nos e pelos textos" (BRONCKART, 2006) dos professores sobre a pertinência ou a necessidade que eles têm (ou não) de abordar os conteúdos culturais em aulas de FLE, não seria pertinente empregarmos métodos chamados "diretos" (VYGOTSKI, 2004; FRIEDRICH, 2012) como, por exemplo, um questionário sobre a importância dos conteúdos culturais em aula, pois tal procedimento apontaria mais elementos da ordem das orientações para trabalho, do que elementos do "trabalho real" dos professores. Paralelamente, não seria suficiente realizar uma filmagem da aula e uma análise posterior pelo pesquisador, pois tal procedimento seria uma projeção externa do pesquisador sobre a questão e deixaria de propiciar a coanálise do trabalho, que pode levar à transformação, bem como não permitiria levar em conta, por exemplo, o coletivo. De forma análoga, somente realizar uma entrevista com o professor não seria suficiente para observar a contraposição entre o trabalho realizado e o real do trabalho, desconsiderando também as dimensões coletivas do métier.

Nossa perspectiva, tal como apontamos na Fundamentação Teórica, é de investigar o trabalho por meio de um método indireto (VYGOTSKI, [1930b]/2004), que, tal como a perspectiva vygotskiana, se baseia na atividade mediada e que, portanto, busque ir além das concepções que se filiam ao objetivismo ou ao subjetivismo (FAÏTA, 2011; CLOT, 2011).

O método que optamos por utilizar, as entrevistas em autoconfrontação, que apresentamos na subseção Aportes das ciências do trabalho, é um método de intervenção clínica nas situações de trabalho, que busca identificar dilemas do métier e fazer com que os próprios sujeitos encontrem soluções em meio a um coletivo, colocando em diálogo e em confronto a atividade e as diferentes maneiras de fazer dos sujeitos. 
Esse método, de caráter indireto, embasado em pressupostos teóricos vygotskianos, permite que o professor reviva suas experiências, para compreender o real do seu trabalho, suas escolhas, imprevistos ou omissões ao longo do processo, buscando discutir sobre elas junto ao coletivo e, potencialmente, gerando transformações no indivíduo. As entrevistas com base nas imagens filmadas instauram uma atividade mediada que permite que outros elementos não visíveis sejam retomados em um momento posterior ao do trabalho e contribuam para criar zonas de desenvolvimento potencial (ZPD). Nossa pesquisa se pauta, portanto, por um duplo objetivo: o de transformar a realidade e o de produzir conhecimentos relativos a essas transformações (CLOT, 2001). Diferentemente das pesquisas clássicas, que passam pela formulação dos problemas, negociação de acesso ao campo, coleta de dados, avaliação, análise e a apresentação dos resultados, em nossa pesquisa não formulamos hipóteses a priori, mas reconhecemos uma problemática que nasce num contexto real e de um grupo em conflito. O problema não é provocado, mas constatado, e o papel do pesquisador não é de analisar de um ponto de vista externo, mas está ligado à provocação da tomada de consciência dos atores numa ação coletiva.

Nesse paradigma, a produção de dados não busca constituir uma amostra representativa, mas procura trabalhar com a evolução de uma questão pelos diversos atores envolvidos com dados longitudinais, que ultrapassam a dicotomia de subjetividade e objetividade. Além disso, o método que empregamos permite um movimento de externalização, distanciamento e observação da situação que foi internamente vivida e experienciada, tornando possível sua transformação.

Com relação à avaliação e à qualidade dos dados, enquanto na pesquisa tradicional os dados devem ser confiáveis e isolados de fatores externos, sendo objeto da única interpretação do pesquisador, em nossa perspectiva os dados são retransmitidos ao coletivo, a fim de conhecer sua percepção da realidade e de orientá-la de modo a permitir uma avaliação mais apropriada dos problemas detectados e o exame dos dados visa a mostrar como os sujeitos redefiniriam o problema e apontariam soluções para ele.

Com relação à análise e interpretação dos dados, a pesquisa clássica utiliza a estatística para verificar a correlação entre as variáveis, enquanto neste estudo buscamos compreender uma questão a partir das representações dos sujeitos nos e pelos textos, solicitando que os próprios participantes interpretem a questão, assim como a expandam dentro de seu grupo. O papel do 
pesquisador é conduzir esse trabalho e, posteriormente, propor análises e reflexões à luz das teorias.

Sendo assim, os métodos de intervenção da Clínica da Atividade e da Ergonomia da Atividade baseiam-se em um movimento de implicação do sujeito no mundo, do sujeito que realiza seu trabalho, seguido de um distanciamento através da observação de sua atividade, expandindo posteriomente a problemática para o âmbito da discussão coletiva entre os pares. Segundo Clot (2001), esse procedimento pode incorrer em uma transformação do sujeito e de seu agir. Esses métodos indiretos são, portanto, os mais coerentes com nossos pressupostos teóricos e os mais adequados às nossas perguntas de pesquisa.

A seguir, detalharemos as fases de realização da pesquisa, abordando o contexto em que se realizará o estudo e os participantes (2.2); em seguida, apresentaremos os procedimentos de coleta e produção (2.3), de seleção (2.4) e de análise (2.5) dos dados; terminaremos apontando os aspectos éticos e a credibilidade do estudo (2.6).

\subsection{Contexto da pesquisa}

$\mathrm{Na}$ sequência apresentaremos o contexto onde foi realizada a pesquisa, bem como seus participantes.

\subsubsection{Os Cursos Extracurriculares de Francês}

Nossa pesquisa concretizou-se no contexto dos Cursos Extracurriculares de Francês ${ }^{92}$, um curso livre de francês língua estrangeira oferecido pelo Serviço de Cultura e Extensão ${ }^{93}$ da Faculdade de Filosofia, Letras e Ciências Humanas (FFLCH) da Universidade de São Paulo (USP), coordenado pela Área de Estudos Linguísticos, Literários e Tradutológicos em Francês da faculdade, que atende tanto à comunidade interna da universidade, estudantes, funcionários e docentes, quanto à comunidade externa, professores da rede pública e privada, moradores e trabalhadores nas proximidades do campus Armando Salles de Oliveira (Butantã, São Paulo). O curso tem um custo moderado, sendo seus dois principais objetivos proporcionar a difusão de conhecimentos gerados na universidade, nesse caso através da oferta de cursos de francês de

\footnotetext{
${ }^{92}$ Conferir LOUSADA, 2011, $2011 \mathrm{~b}$.

${ }^{93}$ O Serviço de Cultura e Extensão situa-se à Rua do Lago, 717 - sala 126 - Cidade Universitária - 05508-080 - São Paulo - SP Tel.: 3091-4583 e 3091-4645 - E-mail: agenda@usp.br - Site oficial: http://sce.fflch.usp.br/
} 
referência acessíveis à comunidade, assim como um espaço de pesquisa e formação prática para os alunos-pesquisadores da universidade.

A estrutura geral dos Cursos Extracurriculares de Francês contou em 2013 com 12 "níveis" semestrais de 45 horas, (3 horas por semana nos cursos regulares e 12 horas por semana nos cursos intensivos), cujos objetivos gerais são desenvolver habilidades orais e escritas em francês em situações cotidianas, assim como desenvolver habilidades comunicativas através do ensino-aprendizagem de elementos gramaticais, lexicais, culturais e fonológicos. As ementas detalhadas de cada nível podem ser consultadas no site oficial do Serviço de Cultura e Extensão da FFLCH, sendo que, de maneira geral, os níveis correspondem aos seguintes níveis do CECRL e utilizam os seguintes materiais didáticos:

\begin{tabular}{|l|l|l|}
\hline $\begin{array}{l}\text { Nível - Cursos } \\
\text { Extracurriculares de } \\
\text { Francês }\end{array}$ & $\begin{array}{l}\text { Nível correspondente ao } \\
\text { CECRL }\end{array}$ & Material didático adotado em 2012 \\
\hline Nível 1 & A1.1 & Alter Ego 1, Hachette, 2011 \\
\hline Nível 2 & A1.2 & Alter Ego 1, Hachette, 2006 \\
\hline Nível 3 & A1 > A2 & Alter Ego 1, Hachette, 2006 \\
\hline Nível 4 & A2.1 & Alter Ego 2, Hachette, 2011 \\
\hline Nível 5 & A2.2 & Alter Ego 2, Hachette, 2006 \\
\hline Nível 6 & A2 > B1 & Alter Ego 2, Hachette, 2006 \\
\hline Nível 7 & B1.1 & Alter Ego 3, Hachette, 2006 \\
\hline Nível 8 & B1.2 & Alter Ego 3, Hachette, 2006 \\
\hline Nível 9 & B1 > B2 & Alter Ego 3, Hachette, 2006 \\
\hline Nível 10 & B2.1 & Nouvel Édito B2, 2010 \\
\hline Nível 11 & B2.2 & Nouvel Édito B2, 2010 \\
\hline Nível 12 & B2 $>$ C1 & Nouvel Édito B2, 2010 \\
\hline
\end{tabular}

Tabela 7: Níveis dos Cursos Extracurriculares de Francês

As aulas do curso acontecem nos prédios da FFLCH na Cidade Universitária em São Paulo, majoritariamente no prédio de Letras. É interessante ressaltar que, para a universidade, a prioridade é a graduação, seguida da pós-graduação e, finalmente, a extensão universitária; dessa forma, os cursos integram a estrutura universitária, entretanto não pelo viés da formação em nível de graduação, como acontece com os Centros de Línguas Universitários das universidades federais, por exemplo, ou de algumas estaduais (como a UNICAMP), mas pelo viés da extensão 
universitária, o que confere aos cursos um caráter muito mais comunitário e um público mais diversificado.

Retomando o quadro proposto por Luiza Guimarães-Santos (2012), evidenciamos o crescente número da procura de alunos e de professores pelos cursos, como vemos abaixo.

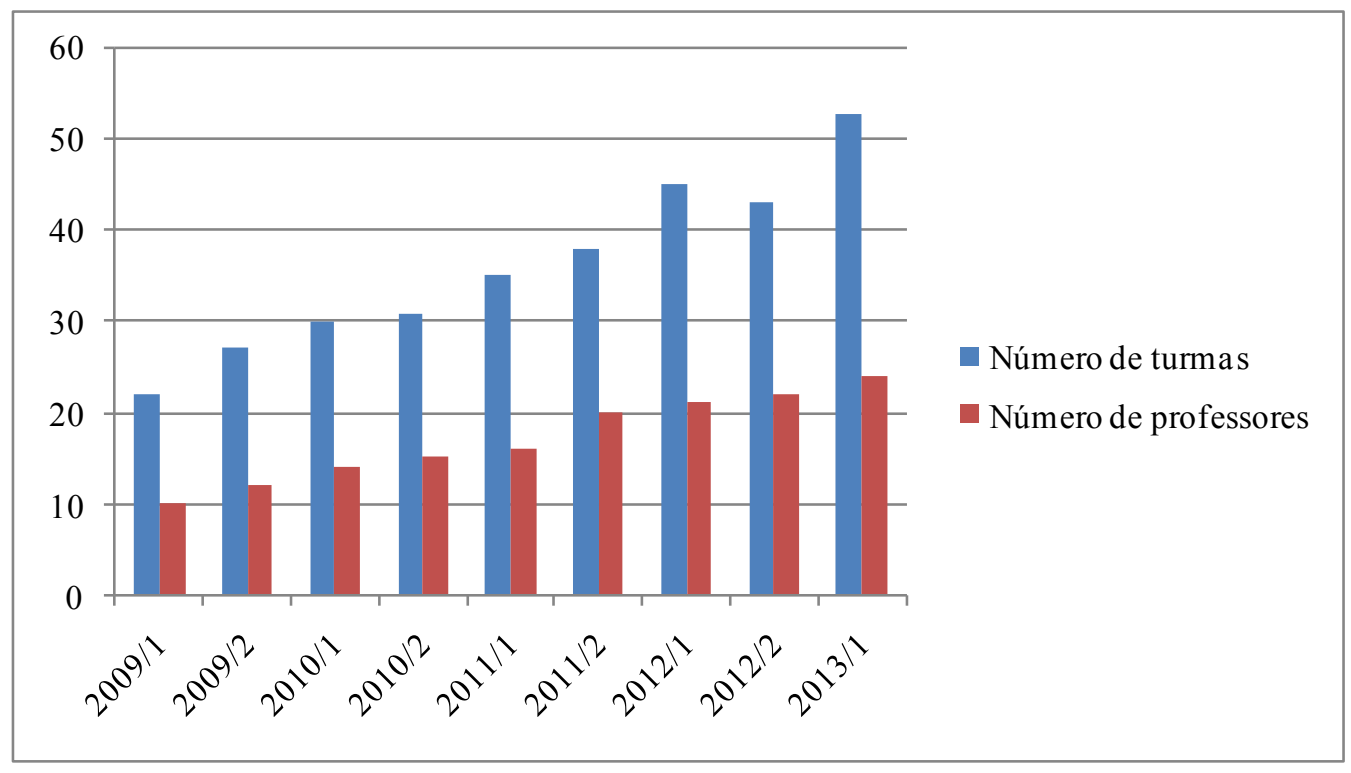

Figura 13: Gráfico do número de turmas por semestre: de 2009 a $2013^{94}$

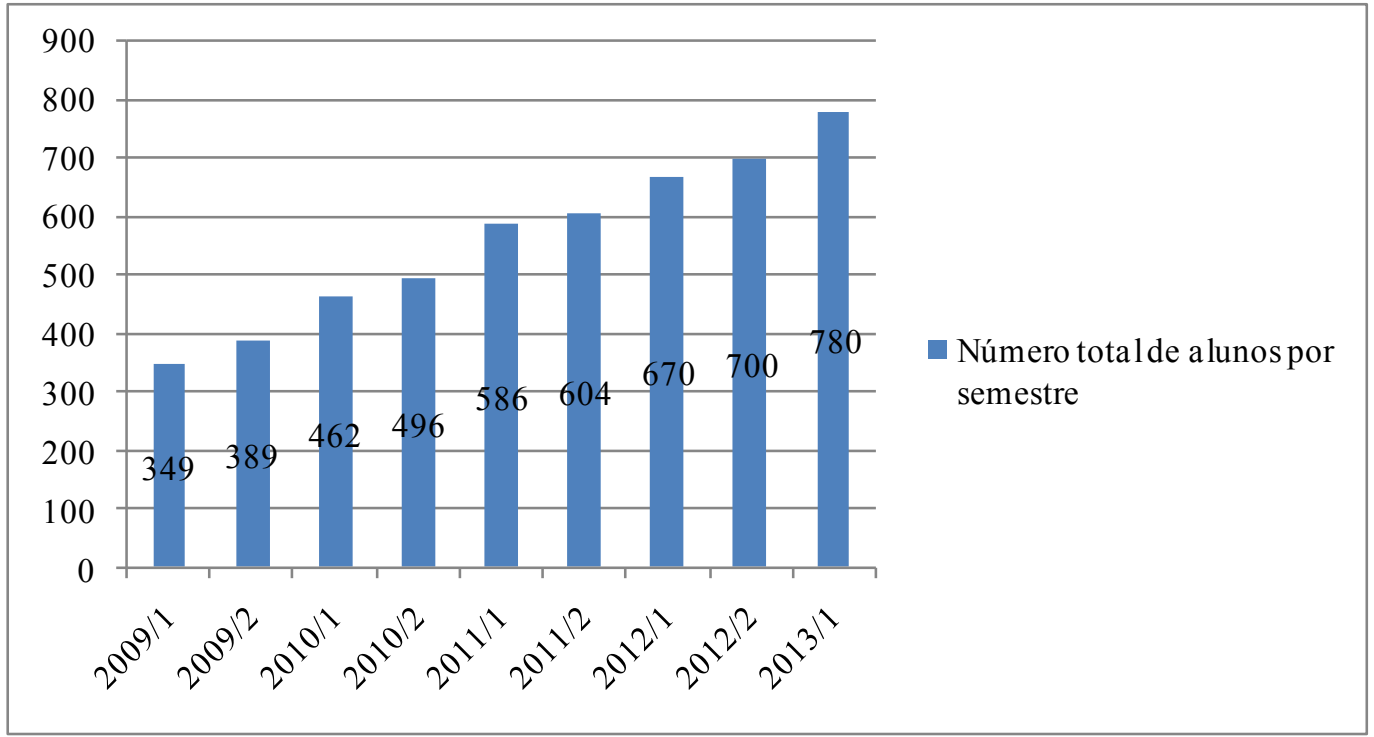

Figura 14: Gráfico do número de alunos por semestre 2009 a 2013

\footnotetext{
${ }^{94}$ Dado até 2011 foram obtidos em GUIMARÂES-SANTOS (2012), dados de 2012 e 2013 foram obtidos de acordo com a tabela interna de distribuição de turmas e professores.
} 
Os professores desses cursos são alunos da universidade já diplomados que continuam seus estudos no curso de licenciatura, mestrado ou doutorado. Para a universidade, tais professores têm o estatuto de monitores-bolsistas, sem vínculo empregatício, sendo remunerados mediante uma bolsa. Assim, os professores podem ter e renovar seu estatuto de monitor enquanto mantiverem o vínculo de aluno, porém, uma vez cessado o vínculo, eles serão automaticamente desligados dos Cursos Extracurriculares de Francês. Essa realidade determina um grupo de monitores-professores com alta rotatividade, composto majoritariamente de recém-formados com pouca (entenda-se menos de três anos) ou nenhuma experiência de ensino; dessa forma, os professores que façam parte do grupo há um ou dois anos são considerados experientes por aqueles que integram o contexto em seu primeiro ou segundo semestre de trabalho.

Para integrar o corpo de monitores-professores é preciso passar por um processo seletivo que tem as seguintes exigências: análise de currículo e histórico escolar, uma avaliação escrita e uma entrevista realizadas por uma comissão de professores universitários. Durante o período em que lecionam, os monitores-professores fazem parte de um dispositivo de formação com reuniões pedagógicas mensais, jornadas de formação, acompanhamento da preparação de aulas por um tutor, dentre outros.

Foi desse grupo de monitores-professores, que contava com catorze professores no ano de 2012, que emergiu a demanda de formação sobre o tratamento de conteúdos culturais como tema para uma das reuniões mensais. O tema era de tal relevância para o grupo que foi votado e escolhido para a jornada semestral de formação ${ }^{95}$. Foi, então, junto a esse grupo que realizamos a pesquisa.

Vale ressaltar que outras pesquisas relacionadas ao ensino-aprendizagem do francês língua estrangeira já foram realizadas nesse mesmo contexto (GUIMARÃES-SANTOS, 2012; DANTAS-LONGHI, 2013; ROCHA, 2014; MELÃO, 2014; ANEZ-OLIVEIRA, 2014).

\footnotetext{
${ }^{95}$ V Jornada de Formação dos Cursos Extracurriculares de Francês: "O Intercultural em questão" (L'interculturel en question). Blog: www.journeecursoextra.blogspot.com.br
} 


\subsubsection{Os professores monitores}

Dentre os participantes da pesquisa, temos dois professores-monitores dos Cursos Extracurriculares de Francês que se voluntariaram para participar da pesquisa, ambos com experiência de mais de um ano de ensino nos Cursos Extracurriculares de Francês. Eles sabiam que o procedimento implicaria em terem uma de suas aulas gravada em vídeo, seguida de duas entrevistas em autoconfrontação com a pesquisadora, a primeira individual, discutindo sua própria aula, e a segunda com o outro colega filmado, discutindo ambas as aulas. Gostaríamos de explicar que os alunos que participaram das aulas gravadas não são considerados participantes diretos da pesquisa, pois não foram enquadrados na filmagem, nem serão objetos da nossa análise, que porta sobre a atividade de ensino; entretanto, estamos conscientes de que a presença dos alunos e suas reações são relevantes para a atividade do professor e, por isso, serão registradas na transcrição do vídeo e comentadas na análise, quando pertinente.

\section{Danilo}

Em julho de 2012, no período da produção e coleta de dados, Danilo, um dos professores participantes da pesquisa, integrava o corpo docente dos Cursos Extracurriculares de Francês havia um ano e meio. Durante sua graduação em Letras, Danilo havia feito intercâmbio e, quando voltou, começou a dar aulas particulares, sendo, nessa época, selecionado para dar aulas nos Cursos Extracurriculares de Francês. Em seu primeiro ano, foi acompanhado de reuniões semanais com uma tutora mais experiente. Considerado pelos professores mais "novos" como um professor dinâmico, Danilo tinha, além da experiência, uma boa reputação entre os alunos por suas aulas descontraídas e atividades lúdicas e criativas. Durante a filmagem das aulas, Danilo ministrava o curso intensivo de férias de nível 1, tendo aulas de 3 horas quatro vezes por semana durante o mês de julho.

É interessante notar que Danilo havia sido voluntário para o mesmo procedimento de gravação de aulas e entrevista em autoconfrontação no ano anterior, quando houve um convite para a participação em uma pesquisa que abordava o uso de jogos em aulas de FLE (conferir a pesquisa de DANTAS-LONGHI, 2013). Em 2012, fizemos um novo convite para gravação de aula e participação em pesquisa e Danilo se voluntariou prontamente, mais uma vez. 


\section{Suélen}

Suélen integra os Cursos Extracurriculares desde agosto de 2009, tendo ministrado cursos dos níveis 1, 2, 3 e 4. Fez sua graduação, Bacharelado em Letras - Português e Francês - na FFLCH. Em 2008, havia passado um ano na França, onde trabalhou como Au pair e cursou um semestre na faculdade Paris VIII Saint-Denis. Teve experiência também como professora de francês em uma instituição privada (2011 e 2012). Ingressou no mestrado em fevereiro de 2011, no Programa Pós Graduação em Estudos Linguísticos, Literários e Tradutológicos em Francês, para estudar o desenvolvimento da escrita de alunos dos Cursos Extracurriculares de Francês.

Como Danilo, Suélen sempre se mostrou interessada em participar de atividades formativas, estando presente nas reuniões pedagógicas e nas jornadas de formação. Participava igualmente do grupo de pesquisa ALTER-AGE (frequentado igualmente pela professorapesquisadora) e, por isso, percebia a formação, o desenvolvimento e a aprendizagem a partir do embasamento teórico do interacionismo sociodiscursivo. No segundo semestre de 2012, durante a produção e coleta de dados, Suélen ministrava aulas de três horas para um grupo de nível 4 às quartas-feiras.

É importante salientar também que Suélen e Danilo trabalharam juntos propondo uma oficina de formação na Jornada de Formação dos Cursos Extracurriculares de Francês realizada no primeiro semestre de 2012, cujo tema foi o "Intercultural em questão". Na oficina intitulada “Os estereótipos na sala de aula: o que fazer da baguete, da boina e do perfume?"96, eles propuseram jogos e atividades para desconstruir os estereótipos em aulas de FLE. Esse talvez tenha sido um dos fatores mais significantes que os tenha motivado a participar da pesquisa e de uma discussão sobre os conteúdos culturais.

\subsubsection{A professora-pesquisadora}

A professora-pesquisadora que realizou a filmagem e as entrevistas de autoconfrontação é a autora da presente pesquisa. Formei-me em Letras, Bacharelado e Licenciatura em Português e Francês na FFLCH-USP. Como dito na Introdução, iniciei minha carreira profissional nos Cursos Extracurriculares de Francês, em 2010, seguida de duas experiências como professora de língua

\footnotetext{
${ }^{96}$ Título original em francês: "Les stéréotypes en salle de classe: que faire de la baguette, du béret et du parfum?"
} 
estrangeira no exterior, uma na França e outra no Canadá. Os professores monitores voluntários para participar da pesquisa eram, portanto, colegas de trabalho da pesquisadora, Danilo tinha um pouco menos de experiência de ensino que a pesquisadora e Suélen aproximadamente o mesmo tempo.

Muito interessada na questão da formação, tive a oportunidade de colaborar com a coordenação dos cursos, atuando como tutora na formação de professores iniciantes, assim como na elaboração de materiais e avaliações. Ao longo de minha formação acadêmica e início da formação profissional, pude participar de oficinas de formação da Associação de Professores de Francês do Estado de São Paulo, de Congressos Brasileiro de Professores de Francês, além de outras conferências e formações oferecidas na universidade. Instigada pelo trabalho de ensino e pelas questões culturais que emergem na sala de aula, ingressei no mestrado com o intuito de compreender e articular melhor ambas as problemáticas e de contribuir com uma pesquisa para tentar suprir parte dessa lacuna de trabalhos experimentais nessa área da didática, assim como para colaborar com o avanço dos estudos do Grupo ALTER-AGE, no Brasil, e até mesmo do ISD e da Ergonomia da atividade e da Clínica da Atividade, no que diz respeito ao trabalho educacional.

\subsection{Coleta e produção de dados}

A seguir, apresentaremos cada fase da coleta e produção de dados com a descrição das etapas seguidas.

\subsubsection{Coleta dos documentos prescritivos e análise}

Preliminarmente, fizemos um levantamento e análise bibliográfica, buscando identificar o que é prescrito nos documentos oficiais para o trabalho dos professores de francês acerca dos conteúdos culturais. Verificamos que existem, no contexto dos Cursos Extracurriculares de Francês, dois documentos que orientam o trabalho dos professores com conteúdos culturais: a) o Quadro Comum Europeu de Referências para as Línguas (CONSELHO DA EUROPA, 2001), que é um documento destinado a todos os professores de francês (e de línguas estrangeiras, em 
geral); e b) o livro didático e o guia pedagógico utilizados em cada instituição de ensino. Em nosso caso, trata-se do livro Alter Ego 1 (BERTHET, HUGOT, CATHERINE et al, 2006).

Tais documentos foram considerados em nossa pesquisa. O Quadro foi objeto de análise, tendo dois capítulos selecionados para compor os dados, buscando-se identificar como ele orienta o trabalho com conteúdos culturais, de maneira que pudéssemos melhor compreender as aulas e entrevistas em autoconfrontação com os professores. Já o livro didático foi considerado apenas para melhor compreender as referências nas autoconfrontações, como veremos mais a frente.

\subsubsection{Produção de dados: etapas de realização da autoconfrontação}

\section{Etapa 1: Realização das filmagens de aula}

O primeiro passo para realizar nossa pesquisa foi o de encontrar voluntários engajados em participar de um processo formativo. Nesse sentido, a coordenadora do curso enviou um emailconvite ao coletivo de professores dos cursos de francês perguntando se haveria alguém interessado em participar de um processo formativo que integrava uma pesquisa de uma colega professora. Foi informado que os voluntários seriam submetidos à filmagem de suas aulas e a duas entrevistas também filmadas posteriormente. Dois professores se voluntariaram, Danilo e Suélen. Combinamos, então, um dia da escolha de cada um deles para registrar uma de suas aulas, como podemos ver na tabela abaixo:

\begin{tabular}{|l|l|l|}
\hline Filmagem das aulas & Danilo & Suélen \\
\hline Data & $24 / 07 / 2012$ & $22 / 08 / 2012$ \\
\hline Horário & $9 \mathrm{~h}$ & $14 \mathrm{~h}$ \\
\hline Duração da filmagem & $1 \mathrm{~h} 30$ aproximadamente & $1 \mathrm{~h} 30$ aproximadamente \\
\hline Nível da turma & nível 1 & nível 4 \\
\hline
\end{tabular}

Tabela 8: Informações sobre as fïlmagens das aulas

Utilizamos câmeras de vídeo posicionadas no fundo da sala de aula, focando o professor próximo à lousa e acompanhando seus movimentos na sala de aula, durante uma aula de uma hora e meia de aula. Antes de a aula começar, os alunos foram informados de que a aula seria gravada com o intuito de realizar uma atividade de formação para os professores em questão e posteriormente e que seria objeto de uma pesquisa de mestrado. Foi-lhes explicado que o foco da gravação estaria no professor e que as vozes dos alunos ficariam registradas nos vídeos e nas 
transcrições. Uma vez conscientes do processo, os alunos concordaram em ceder o direito de sua voz e imagem ao Grupo de pesquisa ALTER-AGE através de um termo de consentimento (conferir Anexo D). Ambas as aulas foram gravadas, não havendo interferência da pesquisadora nesse momento.

A aula de Danilo correspondia à lição de número 1 do dossiê 3 do livro Alter Ego 1, cujos conteúdos previstos eram: falar do que gosta e de suas atividades; falar de sua profissão. $\mathrm{O}$ sumário com a progressão do livro, assim, como a lição, composta de quatro páginas, podem ser consultados no Anexo B.

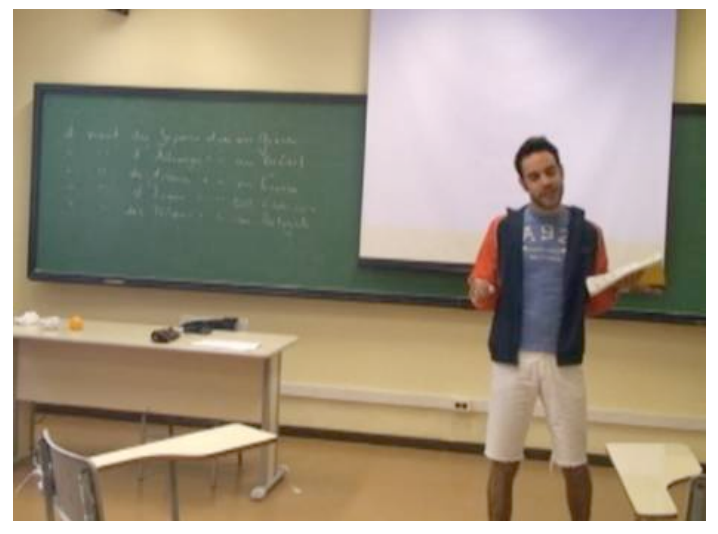

Figura 15: Foto da aula de Danilo

A aula de Suélen correspondia à lição 2 do dossiê 1 do livro Alter Ego 2, cujo objetivo era: falar de suas relações de vizinhança; reportar a fala de alguém; evocar e comparar mudanças. Também composta de quatro páginas, a lição e o sumário do livro podem ser consultados no Anexo C.

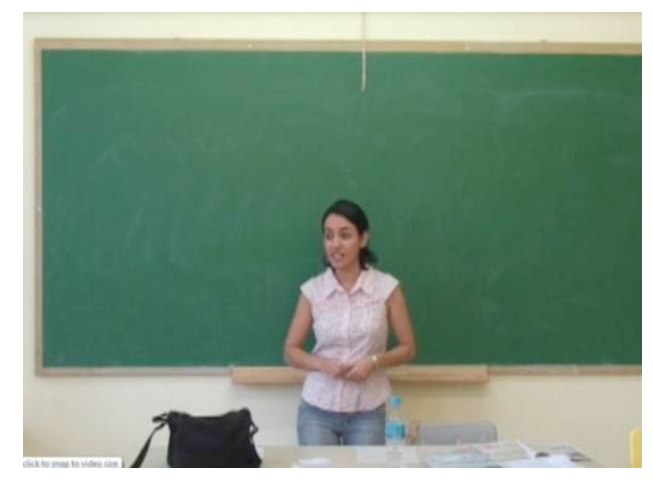

Figura 16: Foto da aula de Suélen 
Ambos fizeram aulas de 3 horas (divididas por um intervalo em duas partes de 1h30), trabalhando o início de uma lição e seu desenvolvimento.

\section{Etapa 2: Realização das entrevistas em autoconfrontação simples}

Para a entrevista em autoconfrontação simples, cada professor participante recebeu individualmente sua aula gravada em DVD para assistir a ela com antecedência. No dia da realização da entrevista, posicionamos uma tela de computador voltada ao professor e à pesquisadora, onde seria projetada a filmagem da aula, e uma segunda tela voltada para a câmera que registrava a entrevista, enquadrando os participantes de frente (Figura 17 e 18). Esse posicionamento nos permitiu observar, ao mesmo tempo, as reações dos participantes e a cena à qual eles estavam assistindo no momento da reação.

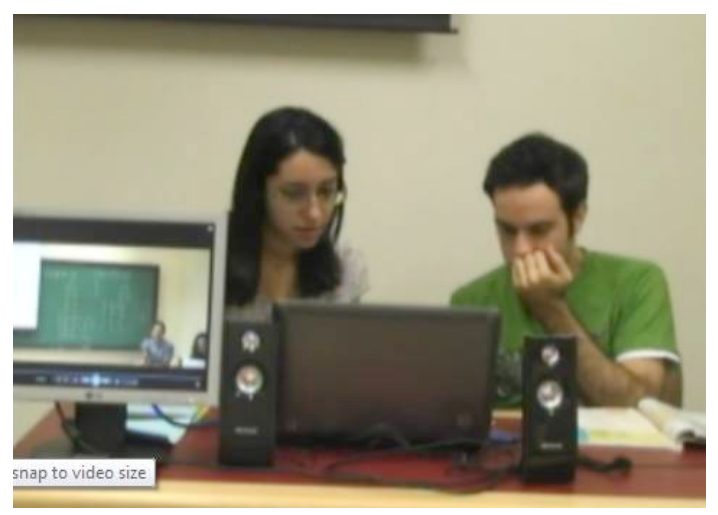

Figura 17: Entrevista em autoconfrontação simples com Danilo

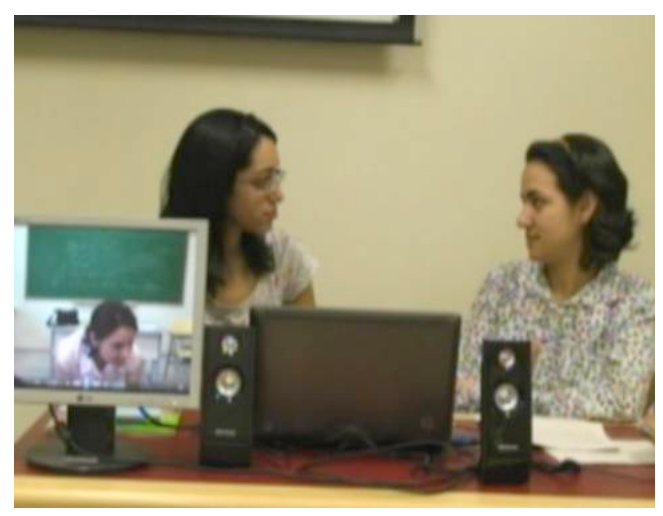

Figura 18: Entrevista em autoconfrontação simples com Suélen 
A pesquisadora deu as instruções antes do início da entrevista dizendo que iriam assistir e comentar os excertos da aula gravada em vídeo livremente e que, tanto o professor, quanto a pesquisadora, poderiam parar a reprodução do vídeo para comentá-lo. No momento da entrevista, o professor poderia optar por assistir ao vídeo inteiro na sequência ou ver somente os fragmentos pré-selecionados, caso o professor já tivesse o feito. A entrevista foi realizada em francês, uma vez que essa é a língua de comunicação entre os professores dos Cursos Extracurriculares de Francês, mesmo quando estão fora da sala de aula. No entanto, os participantes foram informados de que poderiam falar em português se assim o desejassem.

A entrevista com Danilo gerou um vídeo de uma hora e vinte minutos e com Suélen, um vídeo de uma hora e três minutos. No capítulo de Resultado das Análises, veremos os quadros com os conteúdos veiculados nas entrevistas.

\begin{tabular}{|l|l|l|}
\hline Autoconfrontação simples & Danilo & Suélen \\
\hline Data: & $27 / 08 / 2012$ & $27 / 08 / 2012$ \\
\hline Duração: & $1 \mathrm{~h} 20$ & $1 \mathrm{~h} 03$ \\
\hline
\end{tabular}

Tabela 9: Informações sobre a filmagem da ACS

\section{Etapa 3: Realização da entrevista em autoconfrontação cruzada}

A entrevista em autoconfrontação cruzada foi realizada na quinta-feira, dia 30 de agosto de 2012, às $8 \mathrm{~h}$, com a presença dos dois professores participantes e da pesquisadora, que se reuniram juntos para assistir às cenas, de ambas as aulas, algumas previamente selecionadas, outras que foram escolhidas no momento da entrevista. A disposição dos participantes e das telas na sala foi semelhante ao da autoconfrontação simples (Figura 19). A instrução da pesquisadora (originalmente em francês, como se pode conferir no Apêndice) foi a seguinte: "Vamos falar dos excertos das aulas e vocês decidem quem quer começar. Vamos assistir aos excertos, se vocês virem alguma coisa que surpreende e que vocês gostariam de comentar na aula da outra pessoa, vocês podem parar [o vídeo], ok?”.

Após essa instrução inicial, os participantes começaram a assistir à aula de Danilo, passando, posteriormente, à aula de Suélen. A ordem das cenas e os excertos escolhidos ficaram a critério dos participantes e a entrevista foi de caráter livre, não havendo questões previamente preparadas. Ambos os professores selecionaram segmentos dos vídeos de sua própria aula, 
muitos deles discutidos na ACS, entretanto, a discussão aconteceu como uma "repetição sem repetição", já que se havia um novo interlocutor presente e sujeito enunciador que já não era o mesmo, do ponto de vista psicológico, que aquele da ACS.

Em vários momentos da entrevista, um professor solicitava a opinião do outro sobre prática, o que mostrou uma relação bastante horizontal (KERBRAT-ORECCHIONI, 1996) entre eles. A pesquisadora conduziu a entrevista de maneira discreta, fazendo perguntas em alguns momentos específicos no sentido de solicitar explicitações das ações e das escolhas dos professores na sala de aula. A gravação dessa entrevista durou uma hora e dezessete minutos (76 minutos), tendo sido integralmente transcrita (disponível no Apêndice deste trabalho).

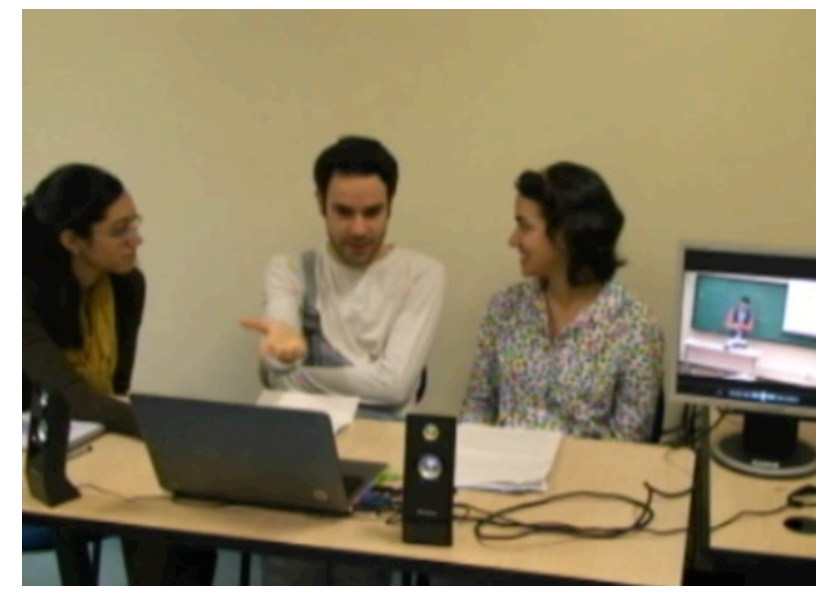

Figura 19: Entrevista em autoconfrontação cruzada com Danilo e Suélen

Ressaltamos que trabalhar com filmagens nem sempre é tão simples quanto se pode pensar. Do ponto de vista técnico, apesar de termos gravado os vídeos em qualidade aceitável, tivemos alguns problemas técnicos quanto à qualidade e formato dos vídeos das aulas e das autoconfrontações (gravados ainda em fita). Entretanto, conseguimos transformá-los em formato digital, assim, os vídeos se encontram com a pesquisadora e estão disponíveis para consulta. Além desse impedimento, não foi possível legendar os vídeos com o texto da transcrição.

\section{Etapa 4: Retornos ao coletivo}

A última etapa foi o retorno ao coletivo de professores, etapa em que os professores selecionaram pequenos excertos da entrevista em autoconfrontação cruzada que traziam questões do métier para discussão junto ao coletivo de professores. $\mathrm{O}$ primeiro, segundo e quarto encontros foram realizados nas reuniões pedagógicas mensais em 2013, com todo o conjunto de 
professores dos Cursos Extracurriculares; a terceira sessão foi realizada com um grupo menor, fora da reunião ${ }^{97}$.

O primeiro retorno ao coletivo aconteceu tardiamente com relação à realização da entrevista em ACC, devido ao fato de que a pesquisadora ausentou-se no segundo semestre de 2012, enquanto ocupava o cargo de professor-assistente de língua francesa e portuguesa no Canadá, dentro de um acordo interuniversidades. No semestre seguinte, a professora participante Suélen participou do mesmo programa, retornando apenas no mês de maio de 2013. Em 2013, o professor Danilo teve de deixar os Cursos Extracurriculares, pois ingressou em um curso de áster em literatura na França. Dessa forma, o retorno foi realizado em junho de 2013, contando apenas com a participação de Suélen, da pesquisadora e do grupo de professores, como mostra a figura abaixo.

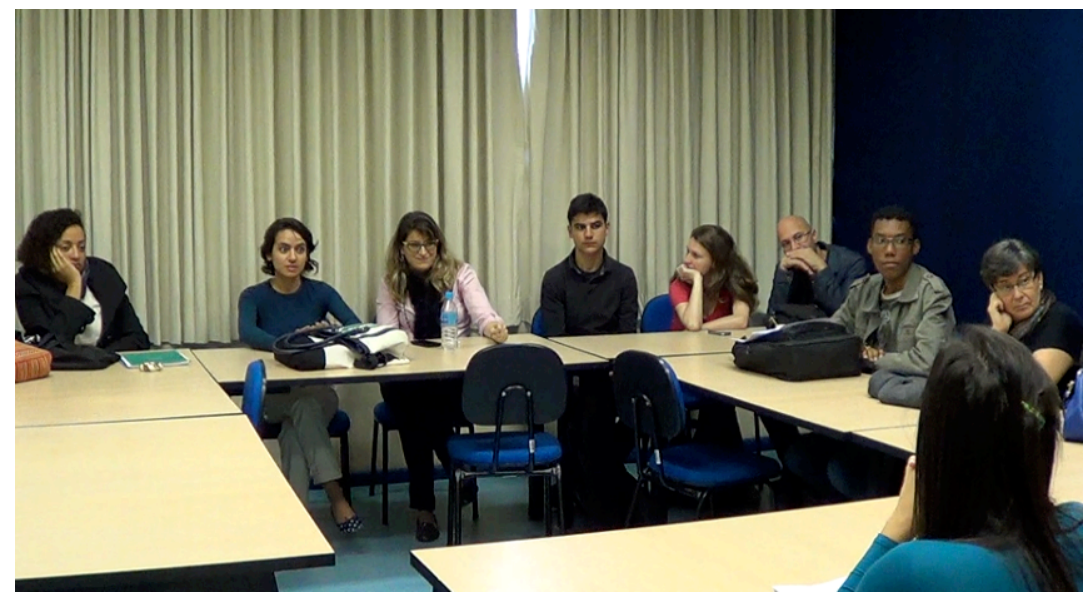

Figura 20: Retorno ao coletivo 1 (junho de 2013)

Como o propósito dos métodos indiretos não é a produção de dados para pesquisa, mas, sim, de fazer uma intervenção em uma situação de trabalho, ao se discutir com todo o grupo sobre duas questões trazidas por Suélen para a reunião (um trecho sobre sua maneira de utilizar

\footnotetext{
${ }^{97}$ No Colóquio Internacional Analisar o Trabalho Educacional, realizado em novembro de 2013 em São Paulo, junto com a equipe ERGAPE e pesquisadores brasileiros, tive a honra de ter os excertos dos dados dessa pesquisa selecionados para discutir o trabalho de ensino em seminário. Uma das discussões foi sobre o caráter dos filmes de "retorno ao coletivo", que encarnaram a questão intervention x formação. Nesse sentido, para chamar as reuniões de "retorno ao coletivo" tal como no método de ACC, como definem CLOT e FAITA (2001), não poderíamos ter realizado as discussões em uma situação institucional de formação (no nosso caso foram durante as reuniões pedagógicas dos Cursos Extracurriculares de Francês), pois o método trata primeiramente da análise do trabalho e a formação seria uma apropriação posterior dessa análise. Entretanto, cabe ressaltar que essa experimentação foi extremamente importante para nos apropriarmos desse método. Mesmo não correspondendo à ideia original de retorno ao coletivo, pudemos ver que a análise do trabalho também dialoga de maneira produtiva com a formação.
} 
documentos para falar de conteúdos culturais e outro excerto sobre sua correção de exercícios), o tema da correção fez eco às preocupações dos monitores-professores, muitos iniciantes, engendrando outros três retornos ao coletivo (Figuras 21 a 23), que tiveram como tema essa questão.

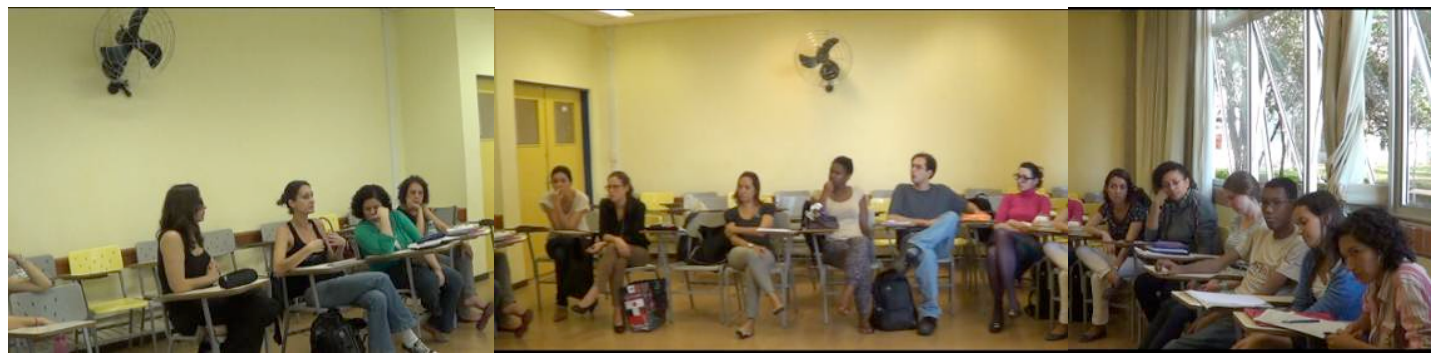

Figura 21: Retorno ao coletivo 2 (agosto de 2013)

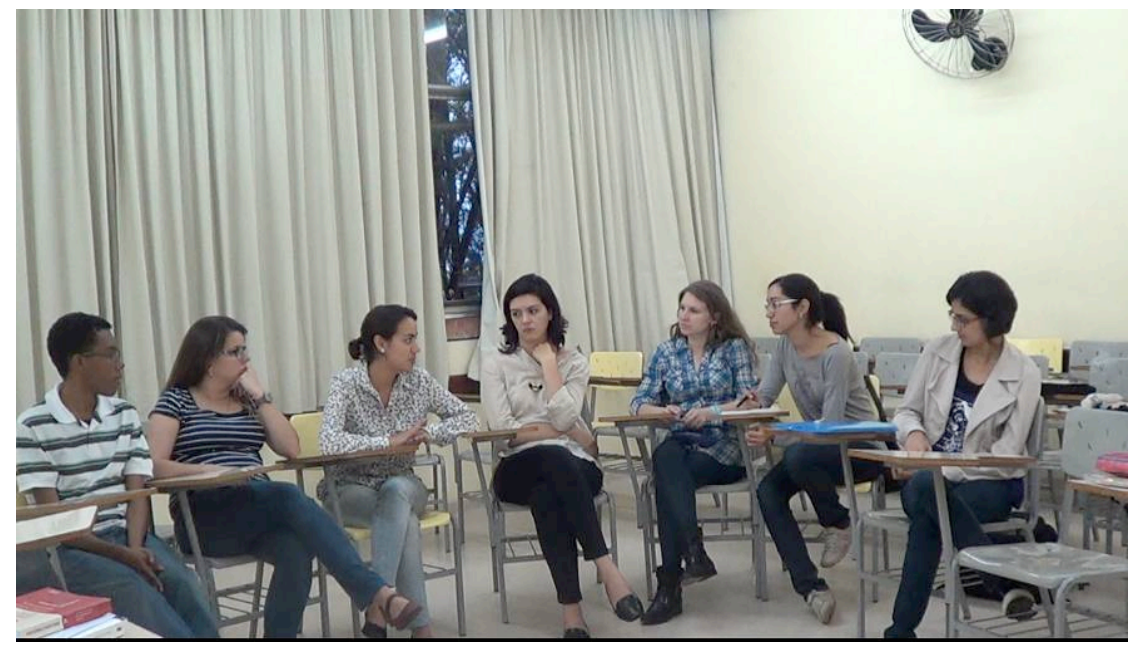

Figura 22: Retorno ao coletivo 3 (setembro de 2013)

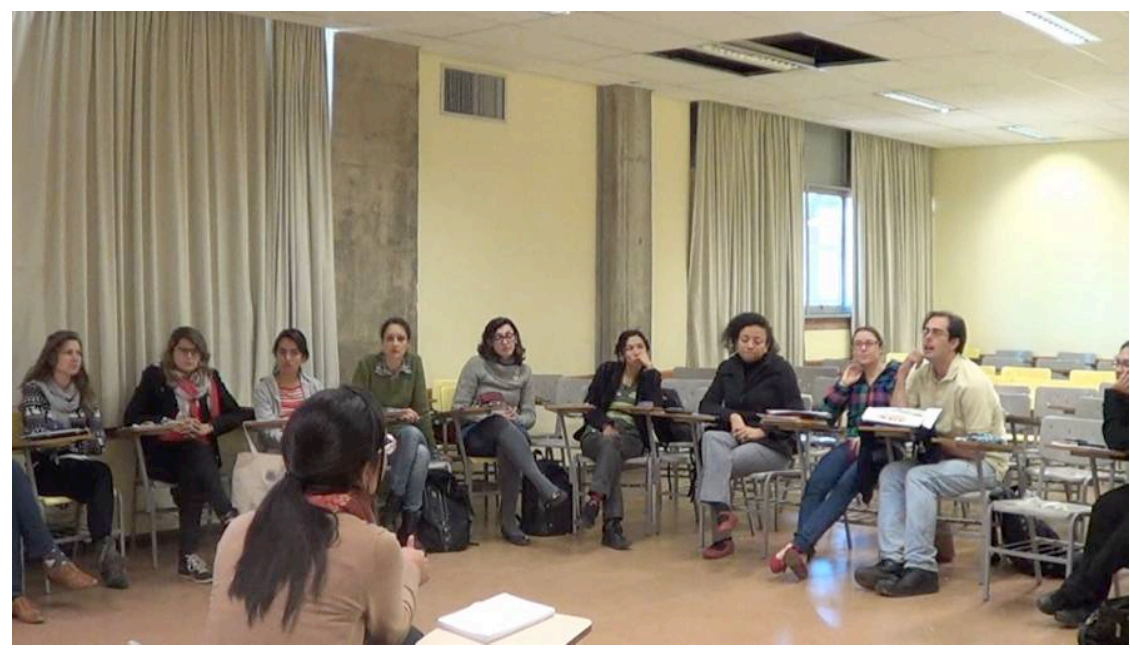

Figura 23: Retorno ao coletivo 4 (setembro de 2013) 
Apesar do interesse desses dados, como nossa pesquisa focaliza o tratamento dos conteúdos culturais, não traremos o tema da correção pontualmente, mas este tema será tratado em outras publicações de nosso grupo de pesquisa ${ }^{98}$. Portanto, os retornos ao coletivo não serão analisados nesta pesquisa.

Tendo apresentado a forma como produzimos nossos dados, sintetizamos no quadro abaixo a data e a duração de todas as filmagens realizadas no âmbito desta pesquisa.

\begin{tabular}{|l|l|l|}
\hline Data & Filmagem & $\begin{array}{l}\text { Horas de gravação } \\
\text { (aproximadamente) }\end{array}$ \\
\hline $\mathbf{2 4 / 0 7 / 2 0 1 2}$ & aula do Danilo & $1 \mathrm{~h} 30$ \\
\hline $\mathbf{2 2 / 0 8 / 2 0 1 2}$ & aula da Suélen & $1 \mathrm{~h} 30$ \\
\hline $\mathbf{2 7 / 0 8 / 2 0 1 2}$ & entrevista com Danilo & $1 \mathrm{~h} 20$ \\
\hline $\mathbf{2 7 / 0 8 / 2 0 1 2}$ & entrevista com Suélen & $1 \mathrm{~h}$ \\
\hline $\mathbf{3 0 / 0 8 / 2 0 1 2}$ & entrevista com Danilo e Suélen & $1 \mathrm{~h} 20$ \\
\hline $\mathbf{2 1 / 0 6 / 2 0 1 3}$ & retorno ao coletivo 1 & $35 \mathrm{mn}$ \\
\hline $\mathbf{2 3 / 0 8 / 2 0 1 3}$ & retorno ao coletivo 2 & $1 \mathrm{~h} 15$ \\
\hline $\mathbf{2 3 / 0 9 / 2 0 1 3}$ & retorno ao coletivo 3 & $55 \mathrm{mn}$ \\
\hline $\mathbf{2 7 / 0 9 / 2 0 1 3}$ & retorno ao coletivo 4 & $40 \mathrm{mn}$ \\
\hline
\end{tabular}

Tabela 10: Quadro síntese - data e duração das filmagens realizadas

\section{Etapa 5: Transcrição da autoconfrontação cruzada}

Como o intuito de analisar linguístico-discursivamente as "representações construídas nos e pelos textos" (BRONCKART, 2006) dos professores sobre a pertinência ou a necessidade que eles têm (ou não) de abordar os conteúdos culturais em aulas de FLE, realizamos a transcrição do áudio da gravação da autoconfrontação cruzada segundo as regras de transcrição do projeto NURC/SP. Optamos por essa norma de transcrição, que podem ser encontradas no Anexo E, pois ela permite manter os traços da oralidade (hesitações, ênfase, fala entrecortada etc.), indícios importantes para a análise das vozes. A partir do texto da transcrição é que realizamos as análises segundo o modelo de análise de textos do ISD (BRONCKART, 1999, 2006, 2008).

\footnotetext{
${ }^{98} \mathrm{Em}$ meu artigo "L'analyse du travail enseignant pour la formation: enjeux et possibilités d'une expérience d'appropriation du cadre méthodologie de l'auto-confrontation" (SILVA, no prelo) aceito na Revista Non Plus, n.5, propus uma discussão sobre a evolução de outros dilemas do métier que apareceram nas interações produzidas na ACS, ACC e retorno ao coletivo.
} 


\subsection{Procedimentos de seleção dos dados}

Nesta seção, apresentamos os procedimentos de seleção de dados dos documentos de orientação e das autoconfrontações. Cabe lembrar que tanto o CECRL, quanto a entrevista estão em língua francesa, pois é a língua empregada nesse contexto. Tanto as aulas, quanto as reuniões de formação ou comunicações entre professores e coordenadora (informais ou formais, orais ou escritas) são realizadas em francês. Assim, os dados serão apresentados na língua original e faremos uma paráfrase em português para que a compreensão do leitor não seja prejudicada.

Quanto aos documentos que orientam o agir, optamos por analisar um recorte do CECRL que porta sobre a cultura e sobre as competências relacionadas a ela. Os capítulos 5 e 6 do Quadro, que se referem às competências dos aprendizes e as operações de ensino-aprendizagem, são os trechos em que há mais referências e desdobramentos sobre a cultura, dessa forma, buscamos focar a análise naqueles que nos interessavam. Além disso, o Quadro se constitui, como veremos nas análises, como o primeiro local de morfogênese do agir dos professores de nosso contexto (BRONCKART, 2008).

Apesar de ser também um elemento de prescrição para o trabalho de ensino, optamos por não analisar o livro didático por três razões. Primeiramente, porque incorreríamos na análise do discurso e das representações dos autores de livro didático, elemento que, apesar de interessante, não consta em nossos objetivos, que se centra em observar o trabalho de ensino. Além disso, sabemos que há uma vasta produção científica que se concentra em analisar currículos e materiais didáticos, tendo um amplo quadro teórico para isso. Em segundo lugar, porque, para realizar uma análise completa, teríamos que investigar todo o material, as lições do livro do aluno, do guia pedagógico, os áudios, bem como verificar se os outros livros da série também reproduziriam a mesma ideia, o que necessitaria de um tempo do qual não dispúnhamos para esta pesquisa e fugiria novamente ao nosso objetivo. Finalmente, porque esse seria um segundo local de morfogênese do agir, já que ele reconcebe as prescrições do Quadro e dá origem a novas orientações para o agir do professor. Optamos assim, por deixar essa análise para futuras pesquisas. No entanto, reproduzimos algumas partes dos livros didáticos nos anexos, para que seja possível compreender as aulas filmadas.

Com relação às entrevistas em autoconfrontação, por se tratar de entrevistas livres, foram muitos os temas de discussão suscitados pelos vídeos e comentados pelos participantes. 
Entretanto, a fim de responder nossas perguntas de pesquisa, selecionamos, do total de mais de sete horas de filmagens, um recorte para compor os dados da nossa pesquisa. Optamos por trabalhar apenas com os segmentos em que os conteúdos culturais foram objetos de discussão; assim, selecionamos um fragmento de 23 minutos da autoconfrontação cruzada, o qual foi dividido e analisado em oito excertos menores. Através, então da análise linguístico-discursiva desse excerto, empregando nossas categorias de análise e interpretando-as à luz de nosso quadro teórico, levantamos elementos para discutir nossas perguntas de pesquisa. Os materiais de transcrição e vídeo que não foram empregados nas análises desta dissertação poderão possivelmente integrar o conjunto de dados de futuras pesquisas e publicações do grupo ALTERAGE.

Assim, tanto no caso do CECRL, quanto na entrevista, a categoria dos conteúdos temáticos do modelo de análise de textos de Bronckart $(1999,2006)$ nos permitiu realizar o recorte pertinente ao nosso objetivo e perguntas de pesquisa.

Ainda no que se refere às entrevistas, apesar de nossos dados serem compostos de imagem e som e de conhecermos pesquisas cujas análises contemplam materiais visuais e multimodais, optamos aqui por analisar somente o material verbal por algumas razões. Primeiro, porque nosso recorte de análise nesta dissertação é composto de um excerto da entrevista, onde os professores e pesquisadora comentam a aula em vídeo. Dessa forma, em uma pré-análise do material visual, observamos que os dados que poderiam ser levantados a partir da entrevista eram pouco ricos em detalhes como gestos, movimentos, feições, se comparados, por exemplo, à análises de um professor efetivamente em aula. Em segundo lugar, porque, buscamos, neste trabalho, aprofundar a questão dos conteúdos culturais, pouco explorada na Didática do ponto de vista do trabalho real do professor e, através de um referencial teórico já conhecido e empregado em outras pesquisas, pudemos identificar as representações construídas no e pelo discurso dos professores que são bastante reveladoras para nossos propósitos. Sendo assim, pareceu-nos mais interessante aprofundarmo-nos nessa questão. E finalmente, porque, com o intuito de identificar as representações dos professores sobre seu agir com os conteúdos culturais, seriam as categorias de análise linguístico-discursivas, sobretudo a das figuras de ação, que mais contribuiriam com dados que respondessem a nossas perguntas de pesquisa. 


\subsection{Procedimentos de análise dos dados}

Uma vez que os dados foram coletados e produzidos, realizamos sua análise por meio do modelo proposto por Bronckart $(1999,2006,2008)$, dentro do quadro do ISD, já apresentado na Fundamentação Teórica e também exemplificado, acrescido de outras categorias de análise.

Primeiramente, observamos o nivel dos contextos, isso é, em que condições (físicas e sociossubjetivas) os textos foram produzidos. Buscamos responder às seguintes questões: onde e quando os textos foram produzidos? Que lugares sociais foram ocupados pela professorapesquisadora e pelos professores-monitores? Como cada um deles percebe seus destinatários? Como os enunciadores são representados e se representam no texto? Quais são os protagonistas do agir?

Em seguida, no nivel da infraestrutura geral dos textos, o plano global dos conteúdos temáticos nos permitiu selecionar os excertos de análise sobre os conteúdos culturais tanto no Quadro como na entrevista em ACC. Os tipos de discurso nos permitiram, no Quadro, observar a implicação dos enunciadores no texto e, na entrevista, identificar as figuras de ação. No nível dos mecanismos de textualização identificamos as séries coesivas nominais e os lexemas verbais que retomavam os conteúdos culturais e as ações ligadas a eles, bem como aos protagonistas do agir.

No nivel enunciativo, observamos, por meio das modalizações como, tanto o Quadro como os professores, se posicionaram com relação ao que estavam dizendo, isso é, se aquele conteúdo era considerado como bom, ruim, possível, impossível, verdadeiro ou um dever. A categoria de inserção de vozes, nos ajudou a observar que outros discursos eram trazidos para aquele momento. Para tanto, empregamos os mecanismos de inserção de vozes (MAINGUENEAU, 1991, 2001), a categoria da heterogneidade discursiva (AUTHIER-REVUZ, 1998, 2001) e da voz da fala egocêntrica e voz da fala egocêntrica reconstituída (LOUSADA; DANTAS-LONGHI, 2014). Para o Quadro, buscamos indicar, através das vozes, o grau de explicitação ou ocultamento da orientação (BRONCKART; MACHADO, 2004).

Empregamos também as categorias produzidas por Bulea e Fristalon (2004), retomadas em Bulea (2010), buscando compreender como o agir em relação à situação de trabalho foi configurado na entrevista. Para tanto, identificamos as figuras de ação ocorrência, acontecimento passado, canônica, definição e experiência. 
Para as entrevistas, compostas naturalmente de sequências dialogais, empregamos também duas categorias da análise da conversação, a dos turnos de fala e da hierarquia (vertical ou horizontal) dos falantes (KERBRAT-ORECCHIONI, 1996). Baseamo-nos nas normas de transcrição do projeto NURC/SP para manter os traços da oralidade (hesitações, ênfase, fala entrecortada etc.), traços que foram fundamentais para a análise das vozes.

Ao analisar a contraposição entre o CECRL e a entrevista, empregamos o conceito de rede discursiva (ROCHA et al, 2002).

Toda essa análise sociointeracional e linguístico-discursiva foi interpretada e discutida:

(i) no que tange ao métier, à luz dos conceitos já apresentados da Clínica da Atividade (CLOT, 1999, 2001, 2008, 2011) e da Ergonomia da atividade (FAÏTA, 1997; AMIGUES, 2002, 2009; SAUJAT, 2004, 2011);

(ii) no que tange à análise da configuração e da morfongênse do agir, à luz do Interacionismo Sociodiscursivo (BRONCKART, 2008; BULEA, 2010);

(iii) no que tange às hipóteses de desenvolvimento (VYGOTSKI, [1934]/2004; BROSSARD, 2012), à luz dos conceitos vygotskianos de consciência (VYGOTSKI, [1925]/2004), instrumento (VYGOTSKI, [1930b]/2004), de atividade mediadora (VYGOTSKI, [1930b]/2004) e de conceito cotidiano e conceito científico (VYGOTSKI, [1934]/1997).

Dessa forma, podemos sintetizar os procedimentos de análise de dados retomando nossas perguntas de pesquisa no quadro abaixo.

\begin{tabular}{|c|c|c|}
\hline Perguntas de pesquisa & Dados & Categorias de análise \\
\hline $\begin{array}{l}\text { (i) Quais são as orientações nos documentos } \\
\text { oficiais acerca da cultura e do tratamento } \\
\text { dos conteúdos culturais? }\end{array}$ & $\begin{array}{l}\text { Documento } \\
\text { prescritivo } \\
(\mathrm{CECRL})\end{array}$ & $\begin{array}{l}\text { - contexto de produção; } \\
\text { - infraestrutura geral: plano global dos } \\
\text { conteúdos temáticos; } \\
\text { - nível textual: séries coesivas nominais e } \\
\text { lexemas verbais } \\
\text { - nível enunciativo: vozes e modalizações; }\end{array}$ \\
\hline
\end{tabular}




\begin{tabular}{|c|c|c|}
\hline $\begin{array}{l}\text { (ii) Quais são as representações construídas } \\
\text { nos e pelos textos dos professores sobre a } \\
\text { relevância ou a pertinência de se trabalhar } \\
\text { conteúdos culturais? }\end{array}$ & $\begin{array}{l}\text { Autoconfrontação } \\
\text { cruzada }\end{array}$ & $\begin{array}{l}\text { - contexto de produção; } \\
\text { - infraestrutura geral: plano global dos } \\
\text { conteúdos temáticos, tipos de discurso; } \\
\text { sequência dialogal (turnos de fala e } \\
\text { hierarquia) } \\
\text { - mecanismos de textualização: séries } \\
\text { coesivas nominais e lexemas verbais } \\
\text { - mecanismos enunciativos: vozes e } \\
\text { modalizações; } \\
\text { - figuras de ação }\end{array}$ \\
\hline $\begin{array}{l}\text { (iii) Quais são as representações construídas } \\
\text { nos e pelos textos dos professores sobre seu } \\
\text { trabalho com conteúdos culturais? Há } \\
\text { diferenças nas maneiras que os professores } \\
\text { encontram para trabalhar os conteúdos } \\
\text { culturais? }\end{array}$ & $\begin{array}{l}\text { Autoconfrontação } \\
\text { cruzada }\end{array}$ & $\begin{array}{l}\text { - contexto de produção; } \\
\text { - infraestrutura geral: plano global dos } \\
\text { conteúdos temáticos, tipos de discurso; } \\
\text { sequência dialogal (turnos de fala e } \\
\text { hierarquia) } \\
\text { - mecanismos de textualização: séries } \\
\text { coesivas nominais e lexemas verbais } \\
\text { - mecanismos enunciativos: vozes e } \\
\text { modalizações; } \\
\text { - figuras de ação }\end{array}$ \\
\hline $\begin{array}{l}\text { (iv) A partir de uma } \\
\text { comparação/contraposição entre o trabalho } \\
\text { prescrito, o trabalho realizado e o real da } \\
\text { atividade de trabalho, como podemos } \\
\text { apontar elementos para uma melhor } \\
\text { compreensão sobre o trabalho do professor } \\
\text { com conteúdos culturais? }\end{array}$ & $\begin{array}{l}\text { CECRL e } \\
\text { Autoconfrontação } \\
\text { cruzada }\end{array}$ & $\begin{array}{l}\text { - contexto de produção - mecanismos de } \\
\text { textualização: séries coesivas nominais e } \\
\text { lexemas verbais } \\
\text { - mecanismos enunciativos: vozes e } \\
\text { modalizações; } \\
\text { - figuras de ação }\end{array}$ \\
\hline $\begin{array}{l}\text { (v) A partir de uma } \\
\text { comparação/contraposição entre o trabalho } \\
\text { prescrito, o trabalho realizado e o real da } \\
\text { atividade de trabalho, como a análise da } \\
\text { situação de trabalho pode ser considerada } \\
\text { como potencialmente geradora de } \\
\text { desenvolvimento? Que elementos podem } \\
\text { ajudar a identificar e interpretar esse } \\
\text { potencial? }\end{array}$ & $\begin{array}{l}\text { Resultados das } \\
\text { análise dos dados }\end{array}$ & $\begin{array}{l}\text { - nível do contexto sociointeracional; } \\
\text { - dinâmica das figuras de ação } \\
\text { - voz da fala egocêntrica }\end{array}$ \\
\hline
\end{tabular}

Tabela 11: Síntese dos procedimentos de análise dos dados

Passemos, na sequência, aos aspectos éticos e credibilidade da pesquisa. 


\subsection{Credibilidade e aspectos éticos}

A ética e confiabilidade da pesquisa são importantes para garantir que o estudo proceda dentro dos parâmetros da legalidade e traga contribuições relevantes para meio científico da área.

Com reação aos aspectos éticos ${ }^{99}$, é importante lembrar que estamos realizando uma pesquisa que envolve seres humanos. Assim, todos os participantes foram informados das implicações de sua participação na pesquisa e puderam manifestar seu eventual interesse ou desinteresse. Um termo de consentimento foi elaborado (conferir Anexo D) e devidamente assinado por todos os participantes (professores-monitores e inclusive os alunos que participaram das aulas filmadas), no qual cediam sua voz e imagem para o banco de dados do grupo ALTERAGE para fins de pesquisa. Toda a documentação encontra-se arquivada com a pesquisadora e disponível para consulta. Ao fim desta pesquisa, todos os participantes terão acesso aos resultados obtidos se assim o desejarem.

Os dois monitores-professores voluntários, protagonistas deste trabalho, concordaram com o aparecimento de seus nomes reais na pesquisa, considerando que as pesquisas que se realizam nesse contexto servem também como meio de se documentar a história das pessoas que ali atuaram.

Um dos meios de garantir a credibilidade da pesquisa é justificar a pertinência para a área, apresentando uma pesquisa que formule de maneira clara seus objetivos, apresente um estado da arte das pesquisas sobre o tema e se proponha a contribuir de alguma forma para o avanço das problemáticas existentes. Além disso, a fundamentação teórica precisa ser atualizada, coerente entre si, fazendo autores dialogarem e apresentando uma reflexão que mostre sua apropriação pelo pesquisador. Essa fundamentação deve ser coerente com a metodologia empregada e servir para melhor compreender os resultados das análises, na discussão desses resultados. Em nosso caso, acreditamos ter atendido a essas exigências.

Outro meio de assegurar a credibilidade é o contato constante com outros pesquisadores, da mesma ou de outras linhas teóricas, para validar o projeto, verificar seu grau de aprofundamento e levantar articulações interessantes e inovadoras. Em nosso caso, tivemos a

\footnotetext{
${ }^{99}$ A FFLCH não conta ainda com um comitê de ética para pesquisas em que são envolvidos seres humanos, entretanto, tomamos o cuidado de nos preocupar com essa questão e explicitá-la neste trabalho.
} 
ocasião de apresentar a pesquisa em inúmeros encontros e congressos, em nível nacional e internacional e, dessa forma, asseguramos a credibilidade da pesquisa.

Em terceiro lugar, é importante que os levantamentos e conclusões que decorrem do trabalho de pesquisa possam voltar ao contexto em que foi realizada, à comunidade acadêmica e à comunidade em geral, através de publicações, formações ou cursos de divulgação e difusão. Isso não necessariamente indica que os resultados das análises devam ser generalizáveis e aplicáveis a qualquer contexto, pois isso entraria em conflito com nossa fundamentação teóricometodológica. Mas a divulgação e o retorno aos participantes, assim como à comunidade científica e geral, é uma forma de fazer eco aos dilemas do métier, despertando novas formas de compreender o trabalho de ensino, propondo novas modalidades de formação, observadas as particularidades de cada contexto. Além disso, é essencial que os resultados de pesquisa possam ser autoavaliados pelos pesquisadores, expondo com ética e responsabilidade os impedimentos e as limitações encontrados. Isso foi realizado em nossa pesquisa, pois o método de intervenção que empregamos continuou sendo utilizado como método de análise do trabalho no contexto dos Cursos Extracurriculares de Francês, para que os professores, iniciantes ou não, pudessem compreender os dilemas do trabalho a partir de sua prática e da de seus pares. Além disso, os vídeos das aulas e das entrevistas foram usados, com a devida autorização prévia dos participantes, em trabalhos de formação de professores, o que mostra que nossa pesquisa dialoga também com a esfera da formação.

Uma pesquisa que contenha indícios de coerência interna, que tenha dialogado com grupos de pesquisa e outros pesquisadores em congressos e que aponte ou contemple meios de retorno dos conhecimentos ali elaborados à comunidade, conferirá credibilidade e confiabilidade ao trabalho. É o que acreditamos ter conseguido realizar neste estudo. 


\section{Capítulo 3 - Resultados das Análises}

Diálogo com o ser amado

o semelhante

$o$ diferente

$o$ indiferente

o oposto

o adversário

o surdo-mudo

o possesso

o irracional

o vegetal

o mineral

o inominado

Diálogo consigo mesmo

com a noite

os astros

os mortos

as ideias

o sonho

o passado

o mais que futuro

Escolhe teu diálogo

$e$

tua melhor palavra

ou

teu melhor silêncio.

Mesmo no silêncio e com o silêncio

dialogamos.

Carlos Drummond de Andrade

Discurso da Primavera 
Como apresentado no capítulo de Fundamentação Teórica, consideramos que a situação de trabalho educacional se configura a partir de uma rede discursiva e a análise dessa rede constitui o instrumento para uma melhor compreensão das relações entre linguagem e trabalho, do agir profissional e das representações que socialmente se constroem sobre ele (MACHADO, BRONCKART, 2004).

Em nossas análises, estudamos dois textos sobre o trabalho de ensinar: um que orienta e prescreve o trabalho, de maneira abrangente e não destinada a um contexto específico, mas que tem influência sobre o trabalho com línguas estrangeiras, a saber, o Quadro Comum Europeu de Referência para o Ensino de Línguas e o outro, que foi produzido pelos próprios professores depois da realização de sua aula, a entrevista em autoconfrontação cruzada. Apresentaremos os resultados das análises do Quadro na primeira seção deste capítulo (3.1), da entrevista em ACC na segunda seção (3.2) e, por fim, a discussão dos resultados (3.3) à luz dos conceitos apresentados em nossa Fundamentação Teórica.

Para adiantarmos um panorama geral do que será apresentado nas subseções a seguir, elaboramos um quadro que introduz o contexto de produção desses dois textos:

\begin{tabular}{|l|l|l|}
\hline & CECRL & Entrevista em autoconfrontação \\
\hline Produtor & $\begin{array}{l}\text { Conselho da Europa, em primeira } \\
\text { instância; em segunda instância, } \\
\text { professores, pesquisadores, linguistas, } \\
\text { especialistas e teóricos em línguas. }\end{array}$ & $\begin{array}{l}\text { Dois professores de um curso de francês; } \\
\text { pesquisadora }\end{array}$ \\
\hline Destinatário & $\begin{array}{l}\text { Contextos educacionais relacionados à } \\
\text { língua estrangeira, Professores de línguas } \\
\text { estrangeiras, Formadores de professores } \\
\text { de línguas estrangeiras, Editores de livros } \\
\text { didáticos de línguas estrangeiras }\end{array}$ & $\begin{array}{l}\text { Destinatários diretos: Dois professores de } \\
\text { um curso de francês; pesquisadora (por ser } \\
\text { um diálogo, os destinatários e produtores } \\
\text { se alternam). } \\
\text { Destinatários indiretos: coordenadora, } \\
\text { colegas; orientadora etc. }\end{array}$ \\
\hline Contexto & $\begin{array}{l}\text { Europeu num primeiro momento, } \\
\text { estendendo-se o uso de referência mundial }\end{array}$ & $\begin{array}{l}\text { Cursos de extensão universitária; esfera } \\
\text { acadêmica }\end{array}$ \\
\hline Circulação & Mundial, âmbito do ensino de línguas & $\begin{array}{l}\text { Local, pessoas relacionadas ao Curso; } \\
\text { mais abrangente, enquanto texto analisado } \\
\text { em uma pesquisa de mestrado }\end{array}$ \\
\hline $\begin{array}{l}\text { Momento em } \\
\text { relação à aula } \\
\text { registrada em } \\
\text { vídeo }\end{array}$ & Anterior & Posterior \\
\hline Modalidade & Escrito & Oral, transcrito \\
\hline
\end{tabular}

Tabela 12: Quadro geral do contexto de produção dos dados 
Ressaltamos que nosso intuito não foi realizar uma análise exaustiva de todos os dados dos dois documentos, mas sim identificar, através do modelo de análise de textos do ISD e das categorias que mencionamos, elementos que contribuam para responder nossas perguntas de pesquisa, trazendo os resultados para uma discussão mais interpretativa na última seção deste capítulo. 


\subsection{Quadro Comum Europeu de Referência para as Línguas}

Esta seção é composta de cinco partes. Iniciaremos com a análise do contexto de produção do CECRL, onde discutiremos a complexidade dos seus enunciadores e destinatários; em seguida, passaremos à infraestrutura geral do texto, observando o que e como o Quadro define o trabalho dos professores com os conteúdos culturais, através dos conteúdos temáticos e os tipos de discurso nele presentes. Seguiremos com os mecanismos de textualização, mecanismos enunciativos e terminaremos com uma síntese intermediária dos resultados dessas análises.

\subsubsection{Contexto de produção}

Como já apresentado na Fundamentação Teórica deste estudo, o Quadro Comum Europeu de Referência para o Ensino de Línguas (CECRL) surgiu da necessidade de se criar uma ferramenta comum para aprendizagem e avaliação das línguas estrangeiras numa Europa que passava a ser integrada e unificada em termos políticos e econômicos. Elaborado ao longo de cerca de vinte anos por um grupo de pesquisadores em didática reunidos sob a demanda do Conselho da Europa, esse Quadro expressa não somente orientações para a prática de ensino, mas também orientações sobre a política linguística a ser adotada na região. Nesse contexto, o CECRL tornou-se uma referência não somente para toda a Europa, mas para o mundo todo, notadamente pela proposta de abordagem do plurilinguismo e pela definição de descritores disponíveis de competências dos utilizadores da língua, com base nos estudos desenvolvidos até então, inclusive das escalas propostas pelos grupos DIALANG ${ }^{100}$ e ALTE $^{101}$ (CONSELHO DA EUROPA, 2001): usuário elementar (A1 e A2), usuário independente (B1 e B2) e usuário experimentado $(\mathrm{C} 1$ e $\mathrm{C} 2)$, que passaram a ser um parâmetro de referência na publicação de materiais didáticos, em programas de cursos, dentre outros (CONSELHO DA EUROPA, 2001).

Enquanto documento de referência, a publicação do CECRL foi amplamente discutida por professores e pesquisadores da Didática das Línguas e Culturas, gerando um grande volume de publicações e tornando-se parte dos cursos de formação de professores, que passaram a considerar as práticas e reflexões nele propostas. Em consonância com uma série de publicações

\footnotetext{
${ }^{100}$ DIA-LANG (Language Assessment System / Sistema de avaliação das línguas)

${ }^{101}$ ALTE (Association of Language Testers in Europe / Associação dos centros de avaliação de línguas na Europa)
} 
que o precederam, o CECRL propõe um olhar mais complexo sobre a aprendizagem e sobre as línguas, trazendo a noção de "perspectiva acional", a visão do aprendiz como "ator social”, que utilizará suas "competências gerais e comunicativas" para "agir e interagir no mundo". Apesar de essas noções serem compreendidas como inovadoras, elas dialogam com uma gama de discussões filosóficas, discursivas e epistemológicas sobre o "agir", notadamente as da segunda metade do século XX, como Baudoin e Friedrich $(2001)^{102}$. Construiu-se a partir desses diálogos e, sobretudo, a partir do uso que se fez do CECRL na Didática das LE, uma grande rede discursiva citando e fazendo referência ao Quadro nos mais diversos contextos de ensino de línguas.

Aprofundando-nos na análise dos enunciadores do texto, vemos que Quadro faz referência aos autores empíricos na nota preliminar da edição:

\section{Excerto $1^{103}$}

\section{Note préliminaire}

Cette version restructurée d'un Cadre européen commun de référence pour l'apprentissage/enseignement des langues et l'évaluation représente le dernier stade d'un processus activement mené depuis 1991 et qui doit beaucoup à la collaboration de nombreux membres de la profession enseignante à travers l'Europe et au-delà.

Le Conseil de l'Europe tient à reconnaître avec gratitude les contributions faites par

- le Groupe de Projet Apprentissage des langues et citoyenneté européenne représentant tous les États membres du Conseil de la coopération culturelle, ainsi que le Canada en qualité d'observateur, pour avoir suivi son développement avec attention

- le Groupe de travail mis en place par le Groupe de Projet, comprenant vingt ressortissants des États membres et représentant les divers intérêts professionnels concernés, ainsi que des représentants de la Commission européenne et de son programme LINGUA, pour leurs inestimables conseils et la supervision du projet

- le Groupe d'auteurs mis en place par le Groupe de travail, et qui comprenait Monsieur le Professeur J.L.M. Trim(Directeur de Projet), le Professeur D. Coste (École Normale Supérieure de Fontenay/Saint-Cloud, CREDIF, France), M. B. North (Eurocentres, Suisse), ainsi que M. J. Sheils (Secrétariat). Le Conseil de l'Europe exprime ses remerciements aux institutions qui ont permis aux personnes concernées de contribuer à cette importante entreprise

- la Commission permanente des directeurs cantonaux de l'éducation et le Fonds national suisse de recherche scientifique pour son soutien au travail de M. B. North et du Professeur G. Schneider (Université de Fribourg) concernant l'élaboration et l'étalonnage de descripteurs de compétences langagières pour les Niveaux communs de référence

- la Fondation Eurocentres pour avoir fourni l'expertise nécessaire à la définition et à l'étalonnage des niveaux de competences langagières

- le US National Foreign Language Center, qui a accordé à MM. Trim et North des Bourses Mellon, ce qui a facilité leur participation à ce projet

- les nombreux collègues et institutions à travers l'Europe qui ont répondu, souvent avec beaucoup de soins et des details concrets, à la demande de commentaires et de réactions concernant les projets précédents.

Les réactions sur la mise en pratique du Cadre de référence ont été recueillies auprès d'un échantillon représentatif

${ }^{102}$ BAUDOIN, J.-M.; FRIEDRICH, J. Théories de l'action et éducation.Bruxelles: De Boeck, 2001, p.8.

${ }^{103}$ Todos os excertos analisados nesta seção são extraídos do CECRL (CONSELHO DA EUROPA, 2001), dessa forma, indicaremos apenas a página de referência ao final do excerto selecionado. 
d'utilisateurs différents. D'autres, en outre, ont été invités à communiquer au Conseil de l'Europe les résultats de leur utilisation du Cadre à des fins spécifiques. Les informations reçues ont été prises en compte pour la révision du Cadre et des Guides à l'usage des utilisateurs avant leur adoption dans toute l'Europe. Cette révision a été réalisée par MM. Trim et North.

(p.3)

A partir dessa nota, o Conselho da Europa explicita a autoria desse documento no lugar de dezenas de autores e quem sabe até centenas de colaboradores. Primeiramente, há uma referência ao Grupo de Aprendizagem das línguas e cidadania europeia, formado pelos estados membros da União Europeia (UE). Essa divisão, permanente, formou um grupo de trabalho especialmente para a elaboração do projeto de um quadro comum para a Europa, grupo esse formado por vinte representantes dos países da EU, cuja direção foi realizada por: John .L.M. Trim (diretor do projeto), Daniel Coste (da França), Brian North (da Suíça) e Joseph Sheils (secretário). Essa direção, por sua vez, formou e orientou um grupo de autores que não são referidos nominalmente e também contou com a colaboração de centros, grupos e fundações (políticos e de pesquisa), alguns deles citados no texto. Assim, poderíamos sintetizar a cadeia de enunciadores do Quadro no seguinte esquema:

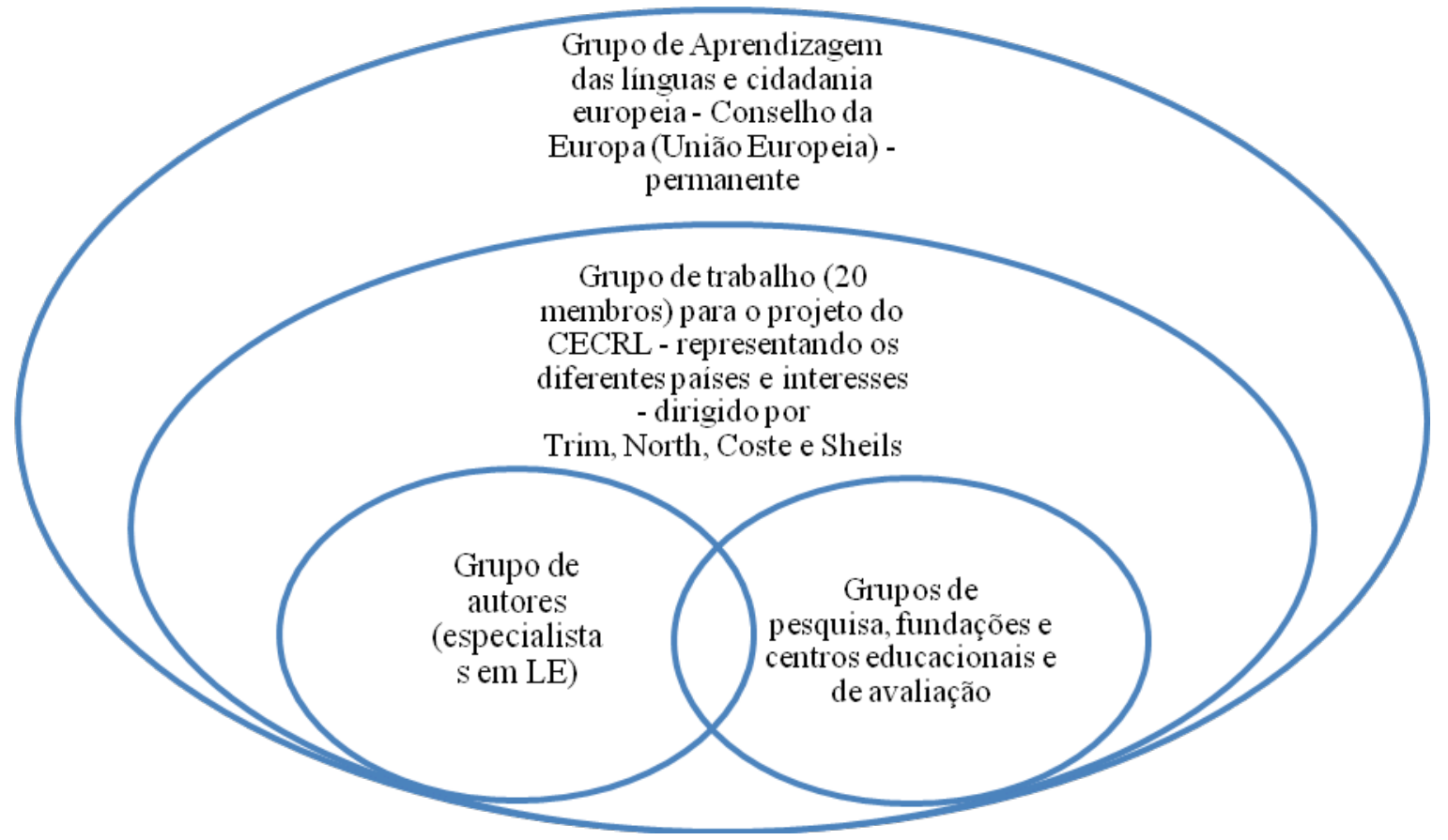

Figura 24: Cadeia de enunciadores do CECRL 
Um dos motivos pelos quais o Quadro foi amplamente difundido e apreciado por especialistas da DLC foi o fato de não pretender ser um conjunto de imposições, mas sim de indicadores a serem considerados, deixando claro para os leitores de que se tratava de um documento passível de reformulações, adaptações e contextualizações.

Por outro lado, uma crítica que se fez nos anos que se seguiram, foi justamente a rápida incorporação de conceitos do Quadro em todo o mundo e em muitos livros didáticos, sem, entretanto, se fazer uma reflexão sobre a necessidade de contextualização em cada país e região: se aquele Quadro se referia a um contexto plurilíngue e pluricultural europeu, como ele deveria ser recebido nas Américas ou na Ásia, com populações muitos maiores, com menos contato com diferentes línguas?

Outra crítica diz respeito à ideia ingênua de que seria possível que um documento publicado pelo Conselho da Europa, com o selo da Comunidade Europeia, não tivesse um valor impositivo. Dessa forma, apesar de o Quadro dizer não pretender ser impositivo, ele acaba, pela força do local social em que é produzido, sendo determinante em relação às políticas de ensino de línguas e influenciando, portanto, materiais didáticos, escolas de línguas etc..

Os destinatários desse documento seriam, em primeira instância, as instituições educativas e de ensino de línguas das comunidades europeias, na figura de seus dirigentes, integrantes e professores. Além desses destinatários que poderíamos chamar de "diretos", o Quadro acabou por dialogar também com (i) instâncias de formação de professores, pois estes deveriam já ter, em sua formação, conhecimento das políticas de ensino de línguas; (ii) o meio editorial de produção de material didático; (iii) avaliações internacionais de línguas estrangeiras e; (iv) finalmente, sendo um documento que se destacou por seu lugar social e pela repercussão com todos esses destinatários, o Quadro acabou sendo lido e discutido, ou ao menos conhecido, em instituições educativas e de formação de línguas estrangeiras em diversos lugares do $\operatorname{mundo}^{104}$.

O motivo pelo qual o Quadro é considerado um documento que prescreve e orienta trabalho dos professores (também chamado de documento prescritivo) do contexto que analisamos é, primeiramente, o fato de ser trazido para discussão e conhecimento como parte da

\footnotetext{
${ }^{104}$ No caso da USP, o CECRL é mencionado nas disciplinas de metodologia de ensino de línguas estrangeiras, além de ser discutido nas reuniões de formação do Cursos Extracurriculares de Francês, à luz de outros teóricos e das informações do contexto.
} 
formação desses professores na universidade, nas reuniões pedagógicas e formações oferecidas, mas, principalmente, por ser o enquadramento de base do livro didático utilizado, livro esse que estabelece a progressão do curso e orienta as avaliações propostas. Ressaltamos, no entanto, que apesar de ser trazido para discussão no ambiente universitário, especialmente nas disciplinas relacionadas à formação de professores de línguas estrangeiras, esse é um documento político e não um estudo teórico.

Como já mencionado na Metodologia, a partir de uma primeira leitura completa do Quadro, optamos por selecionar os excertos em que se tratava mais específica e profundamente do nosso objeto de investigação, os conteúdos culturais, encontrados nos capítulos 5 e 6 do CECRL.

\subsubsection{Infraestrutura geral: conteúdos temáticos e tipos de discurso}

Observaremos nesta subseção como os conteúdos culturais são referidos e definidos no CECRL, buscando identificar e discutir que ideias e valores são integrados a eles. Em seguida, passaremos à análise dos tipos de discurso que figuram nesses excertos.

Os excertos selecionados para a análise foram os seguintes:

\begin{tabular}{|c|c|c|}
\hline Capítulo & Excertos selecionados e analisados & $\begin{array}{l}\text { Perguntas que } \\
\text { orientam a } \\
\text { análise dos } \\
\text { conteúdos }\end{array}$ \\
\hline $\begin{array}{l}\text { Chapitre 5: } \\
\text { Les compétencesde } \\
\text { l'utilisateur/appre } \\
\text { nant }\end{array}$ & $\begin{array}{l}\text { 5.1 Compétences générales } \\
\text { 5.1.1 Savoir } \\
\text { 5.1.2 Aptitudes et savoir-faire } \\
\text { 5.1.3 Savoir-être } \\
\text { 5.2 Compétences communicatives langagières } \\
\text { 5.2.2 Compétence sociolinguistique }\end{array}$ & $\begin{array}{l}\text { Como são } \\
\text { definidos os } \\
\text { conteúdos } \\
\text { culturais? }\end{array}$ \\
\hline $\begin{array}{l}\text { Chapitre 6: } \\
\text { Les opérations } \\
\text { d'apprentissage et } \\
\text { d'enseignement } \\
\text { des langues }\end{array}$ & $\begin{array}{l}\text { 6.1 Qu'est-ce que les apprenants doivent apprendre ou } \\
\text { acquérir? } \\
\text { 6.1.3 Compétence plurilingue et pluriculturelle } \\
\text { 6.4 Quelques options méthodologiques pour l'enseignement et } \\
\text { l'apprentissage des langues } \\
\text { 6.4.6 Formes variées du développement des } \\
\text { compétences générales } \\
\text { 6.4.8. Transferir a competência sociolinguística? }\end{array}$ & $\begin{array}{c}\text { Como é definido } \\
\text { o trabalho de } \\
\text { ensino desses } \\
\text { conteúdos? }\end{array}$ \\
\hline
\end{tabular}

Tabela 13: Excertos do CECRL selecionados e analisados 
O Quadro busca definir as competências do aprendiz no capítulo 5 e trata das operações realizadas para se aprender e desenvolver essas competências no capítulo 6. A seguir, veremos quais são as ideias explicitamente veiculadas através da análise dos conteúdos temáticos desses excertos.

Dividido em competências gerais e competências comunicativas linguageiras, o quinto capítulo do CECRL coloca os conteúdos culturais primeiramente nas competências gerais, subdivididas em saber, aptidões e saber-fazer, saber-ser e saber-aprender (savoir, aptitudes et savoir-faire, savoir-être et savoir-apprendre) ${ }^{105}$.

Para explicar o saber (p.82), o Quadro traz primeiramente a ideia de "cultura geral", compreendida como "conhecimento do mundo", isso é, todos os objetos, os fenômenos, relações que nomeamos com nossa língua. Esse conhecimento de mundo engloba aquilo que se aprende por experiência, pela educação ou pela informação. Junta-se a essa primeira acepção o "saber sociocultural", compreendido como o conhecimento da vida cotidiana, das condições de vida, das relações interpessoais, dos valores e crenças, da linguagem corporal, do saber-viver e dos comportamentos rituais da sociedade e da cultura da comunidade em questão. Soma-se a isso, finalmente, a tomada de consciência intercultural. "O conhecimento, a consciência e a compreensão das relações (semelhanças e diferenças distintivas) entre "o mundo de onde viemos" e "o mundo da comunidade alvo" estão na origem de uma tomada de consciência intercultural" (p.83). Além do conhecimento objetivo, a consciência intercultural englobaria "a consciência da maneira como cada comunidade aparece na ótica do outro, sob a forma de estereótipos nacionais" (p.83). Podemos dizer que, nessa categoria, os conteúdos culturais, sejam eles da ordem da cultura culta, sejam da ordem da cultura antropológica, aparecem como elementos do conhecimento e da consciência ou, em outras palavras, da ordem da compreensão e da recepção.

O Quadro ainda aponta duas listas de "aptidões e saber-fazer", sem, entretanto, definir com precisão esses termos. A primeira engloba as "aptidões práticas": sociais, da vida cotidiana, técnicas, profissionais e próprias ao lazer. A segunda, apresenta as "aptidões e saber-fazer interculturais" que compreendem :

\footnotetext{
${ }^{105}$ Optamos por tratar somente das três primeiras, saber, saber-fazer, saber-ser, pois apresentavam uma ligação explícita com os conteúdos culturais, enquanto saber-aprender se refere a atitudes positivas e de interesse diante da aprendizagem.
} 


\section{Excerto 2}

\subsubsection{Aptitudes et savoir-faire interculturels}

Les aptitudes et les savoir-faire interculturels comprennent

- la capacité d'établir une relation entre la culture d'origine et la culture étrangère

- la sensibilisation à la notion de culture et la capacité de reconnaître et d'utiliser des stratégies variées pour établir le contact avec des gens d'une autre culture

- la capacité de jouer le rôle d'intermédiaire culturel entre sa propre culture et la culture étrangère et de gérer efficacement des situations de malentendus et de conflits culturels

- la capacité à aller au-delà de relations superficielles stéréotypées.

(p.84)

Diferentemente do primeiro tópico (saber), da ordem da recepção, do conhecimento, e da consciência, essa seção do Quadro (saber-fazer) se coloca na ordem do fazer, da expressão, da comunicação, referindo-se a um aspecto antropológico e relacional da cultura. As atitudes evocadas nesse excerto compreendem a capacidade de estabelecer uma relação entre a cultura de origem e a cultura estrangeira, a sensibilização à noção de cultura, a capacidade de assumir um papel de intermediário cultural entre sua própria cultura e a cultura estrangeira e a capacidade de ir além das relações superficiais estereotipadas.

Quanto ao "saber-ser", o CECRL (p.85) sustenta que a atividade de comunicação é afetada por seus conhecimentos, compreensão e aptidões, mas também por fatores pessoais, ligados à personalidade, como motivações, valores, crenças, estilos cognitivos e tipos de personalidade.

\section{Excerto 3}

Les facteurs personnels et comportementaux n'affectent pas seulement le rôle des utilisateurs/apprenants d'une langue dans des actes de communication mais aussi leur capacité d'apprendre. Beaucoup considèrent que le développement d'une " personnalité interculturelle " formée à la fois par les attitudes et la conscience des choses constitue en soi un but éducatif important.

Des questions se posent, de type éthique et pédagogique, telles que

- Dans quelle mesure le développement de la personnalité peut-il être un objectif éducatif explicite?

- Comment réconcilier le relativisme culturel avec l'intégrité morale et éthique?

- Quels traits de la personnalité a. facilitent, b. entravent l'apprentissage et l'acquisition d'une langue étrangère ou seconde?

- Comment aider les apprenants à exploiter leurs forces et à surmonter leurs faiblesses ?

- Comment réconcilier la diversité des personnalités avec les contraintes que subissent et qu'imposent les systèmes éducatifs?

(p.85, destaque nosso) 
Vemos aqui uma preocupação não só da ordem do conhecimento da cultura antropológica do outro, mas também do aspecto relacional e da tolerância: o "desenvolvimento de uma personalidade intercultural". Ao mesmo tempo, o Quadro não hesita em questionar um tema mais espinhoso que são as implicações de um relativismo em detrimento de uma integridade moral e ética dos aprendizes.

Ao finalizar esse excerto, o Quadro propõe, em síntese, que seus usuários explicitem quais experiências e conhecimentos anteriores o aluno deve ter, quais experiências e conhecimentos novos da vida em sociedade o aluno deve adquirir e qual consciência da relação entre sua cultura de origem e a cultura alvo o aprendiz terá necessidade a fim de desenvolver uma "competência intercultural". Registramos que essa é a única ocorrência desse termo no capítulo.

Caberia comentar que essa interessante categorização do Quadro (saber, saber-fazer e saber-ser) retoma a essência dos três mundos de Habermas: físico, social e subjetivo.

Até aqui analisamos os conteúdos que o CECRL classificou como competências gerais. Na sequência, focalizamos as competências comunicativas linguageiras, dentre as quais figura a "competência sociolinguística".

\section{Excerto 4}

\subsubsection{Compétence sociolinguistique}

La compétence sociolinguistique porte sur la connaissance et les habiletés exigées pour faire fonctionner la langue dans sa dimension sociale. Comme on l'a déjà souligné avec la compétence socioculturelle, et puisque la langue est un phénomène social, l'essentiel de ce qui est présenté dans le Cadre de référence, notamment en ce qui concerne le socioculturel, pourrait être pris en considération. Seront traitées ici spécifiquement les questions relatives à l'usage de la langue et non abordées ailleurs:

- marqueurs des relations sociales (5.2.2.1)

- règles de politesse (5.2.2.2)

- expressions de la sagesse populaire (5.2.2.3)

- différences de registre (5.2.2.4)

- dialecte et accent (5.2.2.5).

(p.93)

Apresenta-se, então, alguns exemplos de elementos linguísticos intrinsecamente relacionados aos aspectos culturais, usados em determinadas situações, tais como as de saudação, agradecimento etc. Muito semelhante à competência sociocultural apresentada anteriormente, a competência sociolinguística compreende praticamente os mesmos savoir-faire, porém do ponto 
de vista da linguagem, uma vez que para realizar ações no mundo, na maioria das vezes, fazemos uso da linguagem.

Se no capítulo 5, o CECRL buscou localizar e delimitar as competências dos aprendizes, no capítulo 6 aparecem "As operações de aprendizagem e de ensino das línguas", isso é, o que deve fazer o professor para trabalhar aquelas competências. Selecionamos três dessas subseções para nosso estudo: “6.1.3 Competência plurilíngue e pluricultural” (p.105-106),“6.4.6 Formas variadas do desenvolvimento das competências gerais" (p.113-114) e "6.4.8. Transferir a competência sociolinguística?” (p.117).

O Quadro sustenta que a competência plurilíngue e pluricultural se apresenta geralmente como desequilibrada, devido ao domínio naturalmente desigual das competências gerais ou linguísticas nas interações que o indivíduo tem ao longo de sua experiência de vida. $\mathrm{O}$ desenvolvimento dessa competência plurilíngue e pluricultural tornaria o aprendiz mais consciente para controlar suas próprias maneiras de aprender, aproveitando de suas habilidades sociolinguística e pragmática, bem como suas capacidades para entrar em relação com o outro e com o novo, como evidencia o excerto a seguir.

\section{Excerto 5}

Une compétence plurilingue et pluriculturelle se présente généralement comme déséquilibrée. Et ce de différentes manières :

- maîtrise générale plus grande dans une langue que dans d'autres

- profil de compétences différent dans une langue de ce qu'il peut être dans telle ou telle autre (par exemple : excellente maîtrise orale de deux langues, mais efficacité à l'écrit pour l'une d'entre elles seulement)

- profil multiculturel de configuration autre que le profil multilingue (par exemple : bonne connaissance de la culture d'une communauté dont on connait mal la langue, ou faible connaissance de la culture d'une communauté dont on maîtrise pourtant bien la langue dominante).

(p.105)

O conhecimento de diversas línguas e culturas colabora também para outra função: a de ultrapassar a visão etnocêntrica da língua e cultura materna em relação às línguas e culturas estrangeiras. Segundo o Quadro, o trabalho com apenas uma língua poderia reforçar estereótipos e preconceitos, ao passo que o trabalho com várias línguas e culturas tenderia a enriquecer o potencial de aprendizagem e a ultrapassar essa barreira (p.106). 


\section{Excerto 6}

Il est possible de dire, en outre, que, si la connaissance d'une langue et d'une culture étrangères ne conduit pas toujours à dépasser ce que peut avoir d'ethnocentrique la relation à la langue et à la culture « maternelles » et peut même avoir l'effet inverse (il n'est pas rare que l'apprentissage d'une langue et le contact avec une culture étrangères renforcent plus qu'ils ne les réduisent les stéréotypes et les préjugés), la connaissance de plusieurs mène, elle, plus sûrement à un tel dépassement, tout en enrichissant le potentiel d'apprentissage.

(p.106)

Nessa perspectiva, o respeito pela diversidade de línguas é colocado como algo que vai além da decisão política de ensinar várias línguas e culturas, seria uma garantia de um futuro melhor aos jovens em escolarização. Trata-se, sobretudo, de construir sua identidade linguageira e cultural, integrando nela uma experiência diversificada de alteridade e de desenvolver as capacidades dos aprendizes através dessa mesma experiência diversificada de relação a outras diversas línguas e culturas.

\section{Excerto 7}

Il s'agit bien surtout d'aider les apprenants

- à construire leur identité langagière et culturelle en y intégrant une expérience diversifiée de l'altérité;

- à développer leurs capacités d'apprenants à travers cette même expérience diversifiée de la relation à plusieurs langues et cultures autres.

(p.106)

No excerto sobre as "Formas variadas do desenvolvimento das competências gerais", o Quadro se interroga sobre o conhecimento de mundo a ser requerido do aluno de língua estrangeira, chamando a atenção para os casos em que o conhecimento de mundo exigido do aluno, sobretudo aqueles ainda em fase de escolarização, ultrapassa seu nível de maturidade.

Com relação ao "saber sociocultural" e às "habilidades interculturais", o Quadro retoma sua contextualização europeia, mostrando que existe, para alguns, uma cultura comum e, para outros, uma diferença considerável não só entre os países, mas entre as regiões, classes, comunidades étnicas, gêneros etc. Nesse sentido, haveria algum espaço para os estereótipos pitorescos e folclóricos? Segundo o CECRL, isso caberia somente para os estereótipos que correspondem à ideia que o país faz de si mesmo, em festivais, por exemplo, desde que se guarde 
esse viés e se deixe claro que aquela imagem não teria nenhuma relação com a vida cotidiana da maioria da população.

Chamamos também a atenção para o fato de que vários termos utilizados no CECRL para falar desta questão não estão estabilizados e flutuam bastante. Por exemplo, o que se chamou no capítulo 5 de "saber-fazer intercultural", passou a ser, no capítulo 6, "habilidades interculturais", sem que houvesse alguma precisão sobre o termo.

Partindo para um olhar sobre a sala de aula e sobre o trabalho do professor para se trabalhar essas competências/habilidades, o Quadro responde como se deve tratar as competências não especificamente linguageiras:

\section{Excerto 8}

6.4.6.3 En conséquence, comment doit-on traiter les compétences non spécifiquement langagières dans un cours de langue?

a. en considérant qu'elles existent déjà ou qu'elles ont été mises en place ailleurs (par exemple dans d'autres disciplines enseignées en L1) de manière suffisante pour qu'on les considère comme acquises en L2

b. en les traitant au coup par coup quand la question surgit

c. en sélectionnant ou en produisant des textes qui illustrent de nouveaux points et de nouveaux domaines de connaissance

d. par des cours ou des manuels qui traitent des domaines particuliers (Landeskunde, civilisation, etc.) en L1 et en L2

e. par une composante interculturelle conçue pour provoquer la prise de conscience de la partie pertinente du background respectif de l'apprenant et du locuteur natif en termes socioculturels, d'expérience et de processus cognitifs

f. par des jeux de rôle et des simulations

g. par l'utilisation de la L2 comme langue d'enseignement d'autres disciplines

h. par le contact direct avec des locuteurs natifs et des textes authentiques.

6.4.6.4 Les traits de la personnalité, les motivations, les attitudes, les croyances, etc., de l'apprenant (voir 5.1.3) peuvent être

a. laissés de côté comme ne regardant que l'apprenant

b. pris en considération dans la planification et le suivi du processus d'apprentissage

c. traités comme un objectif du programme d'apprentissage.

(p.114)

Vemos, nesse excerto, orientações sobre as possíveis maneiras de fazer emergir ou tratar as competências gerais, dentre elas, aquelas relacionadas a cultura. Nos excertos "tratando passo a passo", "por um componente intercultural concebido para provocar uma tomada de consciência”, observa-se que essas sugestões se mostram tão abertas que se tornam indefinidas e nebulosas, deixando o professor-leitor sem uma orientação sobre o que efetivamente precisa 
fazer. Já no excerto "pelo contato direto com falantes nativos e textos autênticos" aparece uma sugestão mais concreta. De uma maneira geral, para um objeto com complexas acepções (considerado como uma competência geral da ordem do saber, saber-fazer e saber-ser, como uma habilidade prática, como um desenvolvimento da personalidade, como uma consciência plural de línguas e culturas), as orientações para o trabalho prático em sala de aula careceriam de ser mais concretamente detalhadas ou mesmo exemplificadas.

O segundo trecho do capítulo 6, "transferir a competência sociolinguística?" também se propõe a apontar estratégias para realizar a passagem das experiências da vida social para essa competência: exposição à língua, textos que explicitem os contrastes, tratamento de erros etc.:

\section{Excerto 9}

6.4.8 Transférer la compétence sociolinguistique?

Peut-on considérer que le développement de la compétence sociolinguistique de l'apprenant (voir 5.2.2) est transférable de l'expérience qu'a l'apprenant de la vie sociale ou facilité

a. par l'exposition à une langue authentique utilisée de manière appropriée dans son cadre social ?

b. par la sélection ou la production de textes qui exemplifient les contrastes sociolinguistiques entre la société d'origine et celle de la langue cible?

c. en attirant l'attention sur les contrastes sociolinguistiques lorsqu'ils apparaissent, en les expliquant et en les discutant?

d. en attendant que des erreurs soient commises et en les faisant alors remarquer pour les analyser, les expliquer et indiquer l'usage correct?

e. comme une partie de l'enseignement explicite d'une composante socioculturelle dans l'étude d'une langue vivante?

(p.117)

Ao abordar a "transferência" da competência sociolinguística vinda da experiência que o aprendiz tem em sua vida social, o CECRL o faz por meio de questões acerca do contato e da vivência que os aprendizes têm em situações da vida, por meio de textos e na sala de aula. Ao colocar tal transferência não como uma orientação direta, mas como uma possibilidade a ser verificada, essa indicação corrobora com falta de contornos precisos do objeto e das maneiras de fazer, abrindo possibilidades de caminhos nebulosos a serem explorados pelo professor.

Tendo analisado como aparecem as referência aos conteúdos culturais nos conteúdos temáticos, observamos (i) uma abrangência de diferentes concepções de cultura (produtos da cultura, conhecimento de mundo, o próprio léxico da língua, hábitos e costumes, consciência de si e do outro; aspectos socioculturais realizados linguisticamente; perfil multicultural, isso é, o domínio em diferentes graus das culturas e das línguas); (ii) uma variação e flutuação 
terminológica. Com relação às orientações para o trabalho com os conteúdos culturais, vemos (iii) uma gama de possibilidades de agir, desde indicações a) para um trabalho intencional e planejado com estratégias comuns ao ensino de LE (documentos autênticos, jogos,); b) indicações vagas de trabalho (tratar a questão quando ela surge em classe; elaborar um componente de tomada de consciência intercultural); ou mesmo c) a ausência de indicações (deixar de lado os conteúdos culturais - não tratar essas questões como objetivo do ensinoaprendizagem de LE).

Com relação à análise dos tipos de discurso (BRONCKART, 1999/2008) encontrados nesses trechos do CECRL, o mais frequente é o discurso teórico: da ordem do expor, conjunto ao momento da produção e autônomo em relação aos parâmetros da situação de enunciação. Há marcas do presente genérico e ausência de dêiticos. Vejamos os exemplos:

\section{Excerto 10}

Les aptitudes et les savoir-faire interculturels comprennent la capacité d'établir une relation entre la culture d'origine et la culture étrangère (...) (p.84)

\section{Excerto 11}

Les facteurs personnels et comportementaux n'affectent pas seulement le rôle des utilisateurs/apprenants d'une langue dans des actes de communication mais aussi leur capacité d'apprendre.

(p.85)

\section{Excerto 12}

La compétence sociolinguistique porte sur la connaissance et les habiletés exigées pour faire fonctionner la langue dans sa dimension sociale.

(p.93)

Esse tipo de discurso produz um efeito de distanciamento e de objetividade, tendo as asserções como verdades e definições. Os atores da situação de ensino-aprendizagem são representados em terceira pessoa, como professor e aprendiz (enseignant et apprenant), reforçando a ideia de objetividade e descrição exterior do fenômeno. Quando o pronome on aparece, não se trata de um on inclusivo, com valor de "a gente" ou "nós", mas um on impessoal e indeterminado (excertos 10 e 11, "pode-se", “deve-se") ou um on que se refere ao enunciador 
geral do texto (excerto 12). Há, assim, um apagamento dos enunciadores, como vemos nos excertos abaixo:

\section{Excerto 13}

Peut-on considérer que le développement de la compétence sociolinguistique de l'apprenant (voir 5.2.2) est transférable de l'expérience qu'a l'apprenant de la vie sociale ou facilité a. par l'exposition à une langue authentique utilisée de manière appropriée dans son cadre social ? (...)

(p.117, destaque nosso)

\section{Excerto 14}

En conséquence, comment doit-on traiter les compétences non spécifiquement langagières dans un cours de langue ?

(p.114, destaque nosso)

\section{Excerto 15}

(...) Comme on l'a déjà souligné avec la compétence socioculturelle, et puisque la langue est un phénomène social, l'essentiel de ce qui est présenté dans le Cadre de référence, notamment en ce qui concerne le socioculturel, pourrait être pris en considération.

(p.93, destaque nosso)

Observamos, no entanto, que apesar da objetividade e assertividade das definições e postulados trazidos pelo discurso teórico, o Quadro também traz ao longo dos capítulos inúmeras sentenças interrogativas, como visto nos excertos 9, 13 e 14. Essas perguntas que o sujeitoenunciador coloca para o leitor, caracterizam, segundo Bronckart (1999, p.168) ${ }^{106}$ uma interação discursiva com o leitor/interlocutor, pois “a interação marca-se (...), tanto nos diálogos quanto nos monólogos, pela presença de numerosas frases não declarativas: - frases interrogativas, frases imperativas", por exemplo.

Esse efeito dialógico faz com que as orientações colocadas no CECRL sejam percebidas pelos leitores de forma amenizada, como se devessem a ser verificadas e contextualizadas. Podemos inferir que se trata, então, de um tipo de discurso misto teórico-interativo (BRONCKART, 1999): teórico com o intuito de criar o efeito de objetividade e o interativo com o propósito de aproximar o leitor, criando um efeito interativo e participativo

Tendo examinado os conteúdos e tipos de discurso, vejamos a seguir os elementos que as categorias da coesão nominal e verbal acrescentam.

\footnotetext{
${ }^{106}$ Ver também Bronckart (1999, p.184, 190, 192).
} 


\subsubsection{Mecanismos de textualização: coesão nominal e coesão verbal}

Nesta subseção apresentaremos a análise das séries coesivas nominais e verbais, observando como os conteúdos culturais são retomados lexicalmente no texto.

Dentre as séries apontadas, vimos que, nos capítulos quarto e quinto do Quadro, os actantes associados ao ensino-aprendizagem de língua estrangeira aparecem sob o nome de aprendiz, utilizador (da língua), usuário (da língua) e ator (social), totalizando 79 ocorrências, como ilustra o quadro abaixo. Os termos "usuário" e "utilizador" podem se referirem aos alunos, mas também aos professores e conceptores de cursos de LE, aos autores e editores de materiais didáticos de LE. A ideia de ator social é, entretanto, mais abrangente e contempla o falante genérico daquela língua: pode se referir ao aprendiz, ao aluno proficiente, ao nativo ou falante que esteja em condições de agir socialmente em algum contexto.Já a palavra "professor" aparece apenas uma vez, ligada à atividade de ensino. O conjunto de dados da Tabela 14, abaixo, nos mostra que o foco desses capítulos que tratam dos conteúdos culturais está explicitamente mais associado ao aluno e no desenvolvimento de suas capacidades no processo de aprendizagem que ao trabalho do professor.

\begin{tabular}{|c|c|}
\hline Série coesiva nominal : Actantes & N. de ocorrências \\
\hline Apprenant & 48 \\
\hline Utilisateur & 15 \\
\hline (inter)locuteur & 7 \\
\hline Natif & 4 \\
\hline Acteur & 4 \\
\hline Usager & 1 \\
\hline Enseignant & 1 \\
\hline Total & 80 \\
\hline
\end{tabular}

Tabela 14: Série coesiva nominal dos protagonistas do agir do CECRL

O campo lexical da cultura vem a ser um dos elementos mais evocados nesses capítulos, com 73 ocorrências dentre suas variações, como mostra a tabela a seguir:

\begin{tabular}{|l|l|}
\hline Série coesiva nominal : cultura & N. de ocorrências \\
\hline Culture/s & 31 \\
\hline Pluriculturel/le & 13 \\
\hline Interculturel/le & 11 \\
\hline Culturel/le rater & 11 \\
\hline Socioculturel/le & 7 \\
\hline \multicolumn{1}{r}{ Total } & \\
\hline
\end{tabular}

Tabela 15: Série coesiva nominal da cultura no CECRL 
A cultura aparece atrelada ao que é da ordem da "sociedade", da "comunidade", do "social", havendo, portanto, menos ocorrências dos termos "sujeito" e "indivíduo", como na Tabela 16:

\begin{tabular}{|c|c|}
\hline $\begin{array}{l}\text { Série coesiva nominal : social } \\
x \text { individual }\end{array}$ & N. de ocorrências \\
\hline Culture & 73 \\
\hline Social & 21 \\
\hline Communauté & 13 \\
\hline Personnel & 6 \\
\hline Société & 5 \\
\hline Sujet (=personne) & 1 \\
\hline Individu & 1 \\
\hline Total & 120 \\
\hline
\end{tabular}

Tabela 16: Série coesiva nominal dos termos associados a social e individual no CECRL

A língua, objeto central do Quadro, mantém um número de ocorrências próximo ao da cultura, sendo muitas vezes colocados lado a lado ${ }^{107}$. Além disso, registramos a ocorrência dos termos plurilinguismo e multilinguismo em menor proporção:

\begin{tabular}{|c|c|}
\hline Série coesiva nominal : língua & N. de ocorrências \\
\hline Langue & 67 \\
\hline Plurilingue/isme & 14 \\
\hline Langage & 2 \\
\hline Multilingue/isme & 1 \\
\hline Total & 84 \\
\hline
\end{tabular}

Tabela 17: Série coesiva nominal de língua e linguagem no CECRL

A perspectiva que vimos na análise dos conteúdos temáticos mostra uma tentativa de delimitar e definir o objeto das competências relacionadas à aprendizagem dos conteúdos culturais, pois seria através do desenvolvimento delas que ocorreria a aprendizagem da língua e cultura alvo. Dentre todos os excertos analisados, a ideia de competência ligada aos conteúdos culturais foi associada a uma série de nomes, que elencamos a seguir por ordem de maior ocorrência: 


\begin{tabular}{|l|l|}
\hline $\begin{array}{l}\text { Série coesiva nominal : } \\
\text { competência }\end{array}$ & $\begin{array}{l}\text { N. de } \\
\text { ocorrências }\end{array}$ \\
\hline Compétence & 46 \\
\hline Connaissance & 27 \\
\hline Relation & 27 \\
\hline Apprentissage & 21 \\
\hline Capacité & 19 \\
\hline Conscience & 17 \\
\hline Savoir & 16 \\
\hline Expérience & 16 \\
\hline Aptitudes & 14 \\
\hline Enseignement & 12 \\
\hline Développement & 11 \\
\hline Attitudes & 7 \\
\hline Communication & 6 \\
\hline Activité & 6 \\
\hline Prise de conscience & 6 \\
\hline Identité & 3 \\
\hline Habiletés & 2 \\
\hline Métier & 0 \\
\hline & \\
\hline
\end{tabular}

Tabela 18: Série coesiva nominal de competência no CECRL

Dentre eles, observamos a alta frequência de um léxico da ordem do abstrato, do campo semântico das competências, capacidades, habilidades intelectuais, o que se mostra coerente com a proposta do documento de fornecer orientações para reconceber e repensar o ensinoaprendizagem no contexto europeu, mas que deixa a desejar do ponto de vista do professor de LE que busca encontrar ali orientações para sua prática.

De maneira análoga, a partir do levantamento das séries coesivas, elencamos os lexemas verbais referentes aos três grupos de actantes: os utilizadores do quadro (escolas, instituições, editoras) na Tabela 19; os aprendizes na Tabela 20; e os professores na Tabela 21. Além disso destacamos os verbos relacionados diretamente com as competências e seus desenvolvimento, como aponta a Tabela 22.

\begin{tabular}{|c|c|}
\hline $\begin{array}{l}\text { Lexemas verbais } \\
\text { competências }\end{array}$ & N. de ocorrências \\
\hline Développer & 7 \\
\hline Enrichir & 4 \\
\hline Permettre & 3 \\
\hline Transférer & 2 \\
\hline Total & 16 \\
\hline
\end{tabular}

Tabela 19: Lexemas verbais referentes às competências no CECRL 


\begin{tabular}{|c|c|}
\hline $\begin{array}{l}\text { Lexemas verbais referentes aos } \\
\text { utilizadores do quadro }\end{array}$ & N. de ocorrências \\
\hline Expliciter & 15 \\
\hline Envisager & 10 \\
\hline Utiliser & 6 \\
\hline Total & 31 \\
\hline
\end{tabular}

Tabela 20: Lexemas verbais referentes aos utilizadores do CECRL

As tabelas acima fazem ressaltar o grande número de ocorrências que tratam dos utilizadores do Quadro (31 no total), que vão explicitar, objetivar ou utilizar os conteúdos culturais possivelmente dentro de seus programas e livros didáticas. Paralelamente, vemos que as competências estão correlacionadas a ações (16 ocorrências) que possibilitam e facilitam o desenvolvimento dos aprendizes, enquanto enriquecem seus conhecimentos e capacidades. A seguir, vemos os verbos que indicam ações ligadas aos professores e aos alunos:

\begin{tabular}{|c|c|}
\hline $\begin{array}{l}\text { Lexemas verbais referentes aos } \\
\text { professores/ ensino }\end{array}$ & N. de ocorrências \\
\hline Aider & 2 \\
\hline Traiter & 2 \\
\hline Encourager & 2 \\
\hline Expliquer & 2 \\
\hline Discuter & 1 \\
\hline Enseigner & 1 \\
\hline Travailler $^{108}$ & 0 \\
\hline Agir $^{9}$ & 0 \\
\hline Total & 10 \\
\hline
\end{tabular}

Tabela 21: Lexemas verbais referentes à ação de ensino / dos professores no CECRL

\begin{tabular}{|l|l|}
\hline $\begin{array}{l}\text { Lexemas verbais referentes aos } \\
\text { aprendizes }\end{array}$ & N. de ocorrências \\
\hline Avoir Besoin & 15 \\
\hline Reconnaître & 9 \\
\hline Développer & 7 \\
\hline Disposer & 6 \\
\hline Acquérir & 6 \\
\hline Communiquer & 6 \\
\hline Apprendre & 5 \\
\hline Jouer & 3 \\
\hline Remplir & 3 \\
\hline Comprendre & 3 \\
\hline Etablir & 2 \\
\hline Posséder & 2 \\
\hline \multicolumn{2}{|c|}{ Total } \\
\hline
\end{tabular}

Tabela 22: Lexemas verbais referentes à ação dos aprendizes no CECRL

\footnotetext{
${ }^{108}$ Acrescentamos os termos "trabalhar" e "agir" no levantamento dos lexemas verbais, pois são os verbos que se ligam a nossa perspectiva das ciências do trabalho. Nossa intenção foi observar se haveria no Quadro alguma referência ao trabalho do ponto de vista prático dos professor.
} 
Notamos um grande número de ocorrências de verbos que tratam de ações referentes aos alunos, dentre os quais a maioria aponta para uma postura mais passiva e receptiva (ter necessidade, compreender, dispor, possuir, reconhecer, adquirir). No que se refere aos professores, há um registro baixo de ocorrências no total (10) para desenvolver as competências apontadas, dentre os quais figuram elementos de tratamento relacional: ajudar, encorajar; e elementos discursivos: tratar, explicar, discutir, ensinar.

A fim de verificar se a série coesiva nominal referente aos conteúdos culturais se mantinha em todo o documento do CECRL, realizamos uma busca por todas as expressões que comportavam o adjetivo "intercultural” e suas variações de gênero e número. O resultado obtido se mostra nesta tabela a seguir:

\begin{tabular}{|l|c|c|}
\hline Expressão & no. de ocorrências & Página do CECRL \\
\hline prise de conscience interculturelle & 5 & $40,81,83$ \\
\hline aptitudes et savoir-faire interculturels & 3 & 81,84 \\
\hline compétence interculturelle & 2 & 25,83 \\
\hline conscience interculturelle & 2 & 44,83 \\
\hline relation interculturelle & 2 & 131,132 \\
\hline aptitudes interculturelles & 2 & 95,110 \\
\hline expérience interculturelle & 1 & 11 \\
\hline approche interculturelle & 1 & 9 \\
\hline communication interculturelle & 1 & 16 \\
\hline personnalité interculturelle & 1 & 85 \\
\hline interrogation culturelle et interculturelle & 1 & 131 \\
\hline attitudes interculturelles & 1 & 110 \\
\hline capacités interculturelles & 1 & 122,123 \\
\hline habiletés interculturelles & 1 & 114 \\
\hline composante interculturelle & 1 & 114 \\
\hline malentendus interculturels & 1 & 123 \\
\hline & $\mathbf{2 6}$ & \\
\hline
\end{tabular}

Tabela 23: Expressões contendo o termo "intercultural” no CECRL

Vemos uma pulverização da forma adjetival "intercultural” para as mais diversas expressões. Identificamos nesse levantamento um campo semântico ligado às competências (aptidão, capacidade, habilidade), outro campo semântico relacionado à experiência pessoal (relação, personalidade, mal entendido) e o campo das abordagens educacionais (abordagem, interrogação, componente). De uma maneira geral, o que as expressões têm em comum é que se situam no âmbito da abstração e da definição. 


\subsubsection{Mecanismos enunciativos: vozes e modalizações}

Se, por um lado, vimos que há uma série de afirmações, descrições e asserções no discurso teórico, asserções essas que indicam o grau máximo de verdade da modalização (MAINGUENEAU, 1991, p.116), por outro lado, as interrogações que se colocam em vários excertos produzem um efeito amenizador ou compensatório quase que contrário ao das asserções e definições, relativizando-as, com o objetivo de levar o leitor à reflexão, sem dar a ele uma resposta final, como mostra o excerto abaixo.

\section{Excerto 16}

Peut-on considérer que le développement de la compétence sociolinguistique de l'apprenant (voir 5.2.2) est transférable de l'expérience qu'a l'apprenant de la vie sociale ou facilité a. par l'exposition à une langue authentique utilisée de manière appropriée dans son cadre social ? (...)

(p.117)

Além do uso da interrogação, o efeito assertivo do quadro é também minimizado pelo uso de lista de perguntas, construindo o sentido de abertura, de várias possibilidades (como ilustra o excerto 17), opções ao invés um caminho unidirecional, abertura essa que discutiremos a seguir.

\section{Excerto 17}

Des questions se posent, de type éthique et pédagogique, telles que

- Dans quelle mesure le développement de la personnalité peut-il être un objectif éducatif explicite?

- Comment réconcilier le relativisme culturel avec l'intégrité morale et éthique?

- Quels traits de la personnalité a. facilitent, b. entravent l'apprentissage et l'acquisition d'une langue étrangère ou seconde?

- Comment aider les apprenants à exploiter leurs forces et à surmonter leurs faiblesses ?

- Comment réconcilier la diversité des personnalités avec les contraintes que subissent et qu'imposent les systèmes éducatifs?

(CECRL, 2001:85)

As questões parecem predominar no capítulo 6 justamente depois do momento em que os enunciadores do Quadro afirmar que não há única metodologia para ensinar e aprender línguas (p.109). A partir daí surgem listas de perguntas que levam o leitor a se questionar sobre os vários aspectos a serem considerados antes de abordar uma questão.

A posição do CECRL é de justamente não tomar posição sobre a metodologia de ensino, por isso as diversas questões sobre as maneiras de conceber o trabalho com esses conteúdos são colocadas (excertos 8, 9, 13, 14 e 17). Assim, o que poderia ser entendido também como uma 
abertura da parte dos autores, é na verdade uma consequência devido à ausência de tomada de posição, ainda mais, em uma época em que se impera o ecletismo nas políticas e nas ciências. Talvez, por esse motivo os professores tenham ainda mais dificuldade em compreender o que fazer com os conteúdos culturais, mencionados no Quadro tantas vezes, através de tantas abordagens, mas cujas metodologias de trabalho não sejam claramente explicitadas.

Através da categoria de análise das modalizações, encontramos, nos excertos analisados, modalizações lógicas, da ordem da possibilidade (pode-se, poderia), e deônticas (deve-se) amenizadas pela interrogação:

\section{Excerto 18}

Peut-on considérer que le développement de la compétence sociolinguistique de l'apprenant (voir 5.2.2) est transférable de l'expérience qu'a l'apprenant de la vie sociale ou facilité a. par l'exposition à une langue authentique utilisée de manière appropriée dans son cadre social ? (...)

(p.117, destaque nosso)

\section{Excerto 19}

En conséquence, comment doit-on traiter les compétences non spécifiquement langagières dans un cours de langue?

Les traits de la personnalité, les motivations, les attitudes, les croyances, etc., de l'apprenant (voir 5.1.3) peuvent être a. laissés de côté comme ne regardant que l'apprenant (...)

(p.114, destaque nosso)

\section{Excerto 20}

Comme on l'a déjà souligné avec la compétence socioculturelle, et puisque la langue est un phénomène social, l'essentiel de ce qui est présenté dans le Cadre de référence, notamment en ce qui concerne le socioculturel, pourrait être pris en considération.

(p.93, destaque nosso)

Quanto à categoria das vozes, encontramos alguns exemplos onde há a inserção de vozes por verbos discendi (excerto 21) e por expressões introdutórias (excerto 22). As vozes inseridas através dessas categorias se referem aos diversos autores e teóricos que fundamentaram o Quadro através de referentes vagos e indefinidos (beaucoup, certains, d'autres - muitos, certos, alguns). Essa indefinição não é por acaso, mas corrobora a ideia de diluir a autoria dos conceitos, já que o Quadro opta por não adotar nenhuma especificamente. 


\section{Excerto 21}

Beaucoup considèrent que le développement d'une "personnalité interculturelle » formée à la fois par les attitudes et la conscience des choses constitue en soi un but éducatif important.

(p.85, destaque nosso)

\section{Excerto 22}

À certains égards, les peuples d'Europe semblent partager une culture commune. À d'autres, il y a une diversité considérable, non seulement d'un pays à un autre mais également entre les régions, les classes, les communautés ethniques, les genres, etc. Il faut examiner avec précaution la représentation de la culture cible et le choix du ou des groupes sociaux sur les- quels on se focalise.

(p.114, destaque nosso)

No decorrer do documento, há efetivamente poucas ocorrências como as dos exemplos anteriores, já que a intenção do documento é produzir uma orientação única, do Conselho da Europa e não propor uma revisão da literatura existente, mesmo que ela seja oriunda de centenas de outras vozes, como vimos no contexto de produção.

Dessa forma, não há referências teóricas explícitas no decorrer do texto. No entanto, sabemos que as ideias ali contidas retomam ideias da produção acadêmica e científica da linguística e da didática, o que se justifica também pela bibliografia ao final do documento. Concebido e publicado em nome do Conselho da Europa, compreendemos, pelo contexto de produção, que as vozes ali presentes são tanto de autores da didática e dos especialistas das subáreas específicas, quanto de representantes políticos dessa área na União Europeia, mas que se encontram apagados pela instância enunciadora primeira.

Outra categoria que ilustra a polifonia do documento, encontrada tanto as asserções e definições, quanto nas possibilidades de trabalho, é a da heterogeneidade constitutiva (AUTHIER-REVUZ, 2001), especialmente no que se refere aos jargões e termos específicos de algumas linhas teóricas. Um exemplo seria o excerto abaixo, em que uma série de termos "competência", "compreensão oral e escrita", "recepção" revelam-se jargões da didática da línguas.

\section{Excerto 23}

La compétence partielle dans une langue donnée peut concerner des activités langagières de réception (mettre l'accent par exemple sur le développement d'une capacité de compréhension orale ou écrite) ; elle peut concerner un domaine particulier et des tâches spécifiques (permettre par exemple à un employé de la poste de donner des renseignements à des clients étrangers d'une langue donnée sur les opérations postales les plus courantes). (p.106, destaque nosso) 
Retomando o contexto de produção, há uma outra voz que permeia todo o documento, que é uma voz política. Enquanto publicação oficial, o CECRL expressa, em última instância, um posicionamento político oficial da Europa com relação às línguas e às culturas. Essa voz pode ser identificada pela autoria do texto, do Conselho da Europa, cujo logotipo está estampado na capa do Quadro, como vemos nas imagens abaixo:

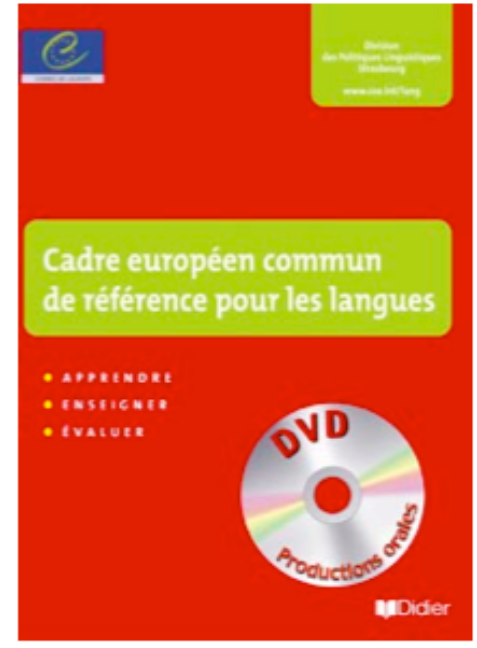

Figura 25: Capa da publicação do CECRL

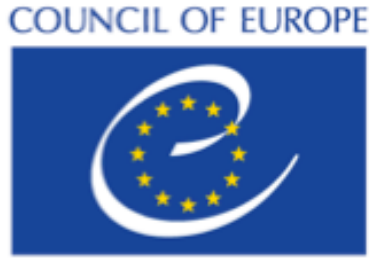

CONSEIL DE L'EUROPE

Figura 26: Logo do Conselho da Europa

\subsubsection{Síntese intermediária dos resultados das análises do CECRL}

Se retomarmos nossa primeira pergunta de pesquisa - quais são as orientações nos documentos oficiais acerca da cultura e do tratamento dos conteúdos culturais? -, podemos indicar alguns elementos de resposta a partir das análises, porém ressaltamos que os apontamentos desta síntese serão discutidos à luz de nosso quadro teórico na última seção deste capítulo.

No nível dos conteúdos, observamos nos excertos do capítulo 5 uma extensa tentativa de definir e delinear os conteúdos culturais através de esferas diferentes: primeiramente a do saber declarativo, do conhecimento, da informação sobre a cultura; em seguida, a das práticas culturais e das maneiras de fazer de uma determinada cultura; e, finalmente, a esfera do individual, da atitude e da personalidade em relação ao outro. Além disso, os conteúdos culturais não são representados como o objeto de ensino do trabalho docente, mas como elementos de uma competência a ser desenvolvida. 
No capítulo 6, o CECRL busca elencar como tratar as competências gerais, apontando para relações com a língua e a cultura de origem. Isso seria feito por meio do desenvolvimento de competências plurilíngue e pluricultural, para a intencionalidade do professor ao trazer essas questões para a sala, através de textos com outros pontos de vista ou de documentos autênticos, ou simplesmente tratando as questões quando elas surgem na sala de aula. Quanto aos traços de personalidade, atitude e crenças, o Quadro descreve três situações possíveis (não entrar no mérito, levá-los em consideração no percurso de aprendizagem, considerá-los um dos objetivos do curso), não orientando explicitamente o leitor a optar por nenhuma delas.

Quanto aos tipos de discurso, vimos que através do discurso teórico e do misto teóricointerativo, o Quadro busca definir, classificar e elencar temas e modos de trabalho, se colocando como um documento orientador do trabalho com o ensino de línguas, objetivo e descritivo, mas não pretendendo ser uma imposição. Para tanto, as asserções, que teriam conotação categórica, são suavizadas pelas interrogações reflexivas e pelas enumerações de possibilidades que se apresentam, mostrando momentos de diálogo com o leitor. Vimos que essa abertura se deve, no entanto, ao fato do Quadro não se posicionar sobre uma teoria ou metodologia.

Nos mecanismos de textualização, observamos que o foco dos dois capítulos está no desenvolvimento de uma competência relacionada à cultura. Com relação aos actantes, constatamos que a figura do aprendiz que desenvolve suas habilidades é preponderante, ao passo que há um apagamento da figura do professor e seu agir. A competência relacionada à cultura é retomada por uma série coesivas da ordem do abstrato, do campo semântico das competências, capacidades e habilidades intelectuais. Os conteúdos culturais são retomados tanto pelos elementos do saber declarativo (savoir, connaissance), do saber prático (habilidades), quanto por elementos de reflexão (prise de conscience).

Quanto à análise dos lexemas verbais, verificamos que aqueles ligados às competências traziam uma ideia de desenvolvimento em progressão (développer, enrichir); aqueles ligados aos utilizados do quadro propunham uma ideia de intenção, de explicitação (envisager, expliciter); aqueles relacionados aos aprendizes, se referiam a uma ideia passiva de aprendizagem (disposer, acquérir etc.); e, finalmente, as ações desenvolvidas pelos professores, com uma quantidade de ocorrências marcadamente menor do que a dos anteriores, eram também imprecisas (aider, traiter, encourager, expliquer, discuter, enseigner), não mostrando o que faria efetiva e 
praticamente um professor para desenvolver essas competências. Observamos, por fim, que ao longo de todo CECRL, o adjetivo interculturel possui 26 ocorrências, das quais 16 se referem a substantivos diferentes, o que indica uma imprecisão e diversidade terminológica. Através dessa categoria, podemos observar que o quadro representa as competências e, depois, o aprendiz como os protagonistas do agir (BRONCKART, MACHADO, 2004) relacionado aos conteúdos culturais.

No nível enunciativo, as modalizações lógicas da ordem da possibilidade corroboram a ideia de opções e de variação da maneira de fazer, assim como as modalizações deônticas corroboram com o status prescritivo do documento. Observamos também que há uma pluralidade de vozes identificadas pelos verbos discendi e pelos pronomes indefinidos que diluem as teorias e os conceitos empregados.

Identificamos uma forte presença da voz da didática através dos jargões empregados nas definições e questionamentos. A bibliografia que consta ao final do documento confere autenticidade e embasamento teórico para o Quadro. No corpo do texto, o que confere autenticidade é o fato de estar chancelado pelo Conselho da Europa, já que muitos usuário do Quadro não chegam a consultar a bibliografia final. Essa voz, especificamente, confere autenticidade, autoridade e validade científica de referência. Dessa forma, apontamos que há uma voz política que permeia todo o documento, assumindo e trazendo para si a autoria dele, em nome do Conselho da Europa.

Com relação ao grau de explicitação ou ocultamento das prescrições (BRONCKART, MACHADO, 2004), observamos que, pelo local social em que é produzido, contendo o logo do Conselho da Europa e falando em seu nome (como vimos na nota preliminar), o Quadro acaba por tornar-se um documento com uma autoridade que certamente influencia o contexto do ensino de línguas, em particular de LE, repercutindo em livros didáticos, formação de professores, institutos de ensino etc. É, portanto um documento que se coloca, desde o princípio, como uma prescrição explícita. No entanto, como vimos, as orientações nele contidas são modalizadas.

Por fim, ao dizer que não adota metodologia nenhuma, o CECRL tem o intuito de ser adotado por todos, pois não cria controvérsia entre as diferentes linhas teóricas e não desagrada seus usuários e leitores. Esse é outro elemento que contribui para que ele se torne "prescritivo", no sentido de que todos se baseiam nele independente dos pressupostos teóricos. Mas o fato de 
não adotar nenhuma metodologia acaba por ter um contraponto: deixar sem orientação precisa aqueles que se baseiam somente nele (sobretudo os professores). Essa seria uma das razões pelas quais há tantas outras obras que se prestam a explicar o Quadro.

Tendo apresentado o resultado das análises desse documento prescritivo, passaremos aos resultados das análises da entrevista. 


\subsection{Análise da entrevistas em ACC}

Nesta segunda seção do capítulo, apresentaremos os resultados encontrados nas análises da entrevista em autoconfrontação cruzada com Danilo e Suélen. Como dissemos anteriormente, nossas análises seguiram o modelo teórico-metodológico do ISD, proposto por Bronckart (1999/2009) e completado por outros autores, tais como: Bulea (2010), que pertence ao mesmo quadro teórico, propondo a categoria de análise das figuras de ação; Authier-Revuz (2001) e Maingueneau (1991, 2001) e Lousada e Dantas-Longhi (2014) para a análise das vozes no texto.

Os resultados das análises serão apresentados da seguinte forma: primeiramente, explanaremos o contexto produção da autoconfrontação cruzada, em seus aspectos físicos e sociossubjetivos. Em seguida, mostraremos a infraestrutura geral da entrevista em ACC, evocando também o plano global dos conteúdos temático das duas entrevistas em autoconfrontação simples, para contextualizar o recorte realizado para compor o corpus de nossa pesquisa.

Depois, passaremos à apresentação dos resultados desse recorte, que será apresentada em 8 (oito) excertos ${ }^{109}$. Apresentaremos, em cada excerto, os resultados obtidos em cada categoria de análise: desde o plano geral dos conteúdos temáticos, passando pelos mecanismos de textualização, mecanismos enunciativos até as figuras de ação, novamente não de maneira exaustiva, mas apontando elementos que possam contribuir para responder nossas perguntas de pesquisa. Finalmente, proporemos uma síntese desta seção, destacando os pontos que serão trazidos para discussão no próximo capítulo.

\subsubsection{Contexto de produção}

A entrevista em autoconfrontação cruzada de Suélen e Danilo foi realizada às $8 \mathrm{~h}$ do dia 27 de agosto de 2012 em uma das salas do Laboratório de Apoio à Pesquisa e ao Ensino em Letras (LAPEL) da Universidade de São Paulo, tendo duração total de 76 minutos. Essa entrevista aconteceu um mês após a filmagem da aula de Danilo e uma semana após a filmagem da aula de Suélen.

\footnotetext{
${ }^{109}$ Agradeço à prof. Dra. Luzia Bueno, pela sugestão de apresentação dos resultados das análise seguindo o viés temático da entrevista e mostrando sua evolução.
} 
Com relação aos aspectos sociossubjetivos, isso é, aos papeis e ao lugar social de cada participante, reiteramos o que apresentamos em nosso capítulo de metodologia: ambos os professores participantes, assim como a pesquisadora integravam o mesmo contexto de trabalho, os Cursos Extracurriculares de Francês. Suélen tinha um semestre a mais de experiência nesse contexto que a pesquisadora, também realizava uma pesquisa de mestrado na mesma instituição, tinha a mesma orientadora e participava do mesmo grupo de pesquisa, tendo, portanto, uma relação muito próxima à pesquisadora e talvez hierarquicamente superior. Já Danilo iniciou seu trabalho um ano depois da pesquisadora e, na época, cursava ainda a licenciatura. Um fato interessante a apontar é que Danilo já havia sido voluntário para uma pesquisa sobre o trabalho do professor, tendo já participado de filmagens e entrevistas em autoconfrontação ${ }^{110}$. Dessa forma, ambos professores, tinham, em algum grau, uma posição próxima à da pesquisadora.

É importante ressaltar que durante a V Jornada de Formação dos Cursos Extracurriculares de Francês, cujo tema era o "Intercultural em questão", Danilo e Suélen propuseram, juntos, uma oficina de formação para professores de FLE, realizando atividades didáticas e jogos para apontar e desconstruir estereótipos sobre outros povos e nações, o que já mostrava uma sensibilidade e um interesse particular dos dois monitores-professores no tratamentos dos conteúdos culturais, assim como uma afinidade para discutir e trabalhar juntos. Nesse sentido, havia uma relação de hierarquia bastante horizontal entre os dois (KERBRAT-ORECCHIONNI, 1996).

Com relação ao destinatário do texto, ou no caso das entrevistas em vídeos, os professores estavam cientes de que as gravações seriam mostradas ao coletivo de professores e também de que teriam suas entrevistas analisadas para fins de pesquisa; dessa forma, o destinatário primeiro da entrevista era a pesquisadora, mas, em segunda instância, os professores sabiam que o que dissessem poderia também ser lido ou ouvido pelo grupo de professores, pela coordenadora dos Cursos Extracurriculares que é também a professora orientadora da pesquisa e por outros destinatários que se interessassem pela leitura da dissertação.

Se por um lado, o fato de os participantes estarem interrelacionados em um âmbito particular de formação e pesquisa possa causar um estranhamento em relação à validade, credibilidade e transferência das reflexões e conclusões para os outros contextos, por outro lado, somente a análise da situação pelos próprios atores da situação pode fornecer elementos mais

\footnotetext{
${ }^{110}$ Conferir a dissertação de DANTAS-LONGHI (2013) disponível no banco de teses e dissertações da USP.
} 
afinados e detalhados para compreender o contexto. Além disso, como apontam Clot (2011) e Faïta (2011) o método da ACC, ao transformar o dilema e o conflito individual em objeto de observação e trazê-lo para a discussão no coletivo, se constitui em uma terceira via, escapando à dualidade da subjetividade $\mathrm{x}$ objetividade dos estudos científicos que costumam restringir a possibilidade de compreensão das questões do métier.

\subsubsection{Infraestrutura geral}

Tendo analisado o contexto sociointeracional, passaremos à análise do material verbal das entrevistas $^{111}$. Apresentaremos primeiramente a infraestrutura geral das três entrevistas, observando o plano geral dos conteúdos temáticos, que nos permitiu fazer o recorte do excerto que optamos analisar nesta dissertação.

Observando os conteúdos temáticos das três entrevistas podemos dizer que, sendo de caráter livre e não diretivo, a autoconfrontação pode suscitar praticamente qualquer tema, seja ele imediatamente ligado à cena observada, seja uma memória ou comentário a partir da observação do vídeo.

Na autoconfrontação simples de Danilo, encontramos os seguintes temas:

\begin{tabular}{|l|l|}
\hline \multicolumn{1}{|c|}{ Conteúdos temáticos } & Quem introduz \\
\hline 1. ordem e progressão no livro didático & Emily \\
\hline 2. conteúdos culturais no livro didático & Emily \\
\hline 3. documentos autênticos como alternativa ao livro & Emily \\
\hline 4. confiança no professor para esperar a explicação & Danilo \\
\hline 5. tempo das atividades & Danilo \\
\hline 6. dificuldades dos alunos & Danilo \\
\hline 7. subjetividade nas atividades & Emily \\
\hline 8. oposição entre focar na forma linguística ou no conteúdo do que é dito & Danilo \\
\hline 9. correção da atividade & Danilo \\
\hline 10. dinâmica, movimento e diversão & Danilo \\
\hline 11. trabalho com o documento autêntico & Emily \\
\hline
\end{tabular}

Tabela 24: Plano global dos conteúdos temáticos da ACS de Danilo

$\mathrm{Na}$ autoconfrontação simples de Suélen, encontramos os seguintes temas:

\footnotetext{
${ }^{111}$ Conferir na Metodologia, os procedimentos de seleção dos dados.
} 


\begin{tabular}{|l|l|}
\hline \multicolumn{1}{|c|}{ Conteúdos temáticos } & Quem introduz \\
\hline 1.postura do professor diante do aluno & Suélen \\
\hline 2. revisão no início da aula & Emily \\
\hline 3. dificuldades dos alunos & Emily \\
\hline 4. comparação entre culturas diferentes & Suélen \\
\hline 5. documentos disparadores de discussão & Suélen \\
\hline 6. particularidades dos alunos & Suélen \\
\hline 7. generalização de culturas, nacionalidades e povos & Suélen \\
\hline
\end{tabular}

Tabela 25: Plano global dos conteúdos temáticos da ACS de Suélen

No quadro abaixo, sintetizamos os principais conteúdos que apareceram na autoconfrontação cruzada, quem os introduziu e a partir de qual elemento.

\begin{tabular}{|l|l|l|}
\hline \multicolumn{1}{|c|}{ Conteúdo temático } & Quem introduz & Vídeo disparador \\
\hline 1. início da aula & Danilo & aula do Danilo \\
\hline 2. correção de exercícios & Suélen & aula da Suélen \\
\hline 3. explicação da atividade, do comando da atividade & Suélen/ Danilo & aula do Danilo \\
\hline 4. dificuldades dos alunos & Danilo/Suélen & aula do Danilo \\
\hline 5. tratamento dos conteúdos culturais & Suélen & aula da Suélen \\
\hline
\end{tabular}

Tabela 26: Plano Global dos conteúdos temáticos da ACC

Vemos que alguns temas da autoconfrontação cruzada retomam temas das autoconfrontações simples. Como dissemos na Metodologia, para este trabalho recortamos somente o excerto da autoconfrontação cruzada referente ao nosso objeto de estudo, o tratamento dos conteúdos culturais (do minuto 9 ao minuto 45 da segunda fita), do qual analisamos as falas dos professores-monitores (e não da pesquisadora). Toda a análise que será explanada a seguir tem como foco o trabalho com os conteúdos culturais, assim, buscaremos investigar a maneira como esses conteúdos são introduzidos e tratados, se foram ou não expandidos na aula, tornandose tema de discussão em classe. 


\subsubsection{Apresentação dos resultados das análises por excerto da entrevista}

\section{A) Plano global dos conteúdos temáticos}

No quadro abaixo podemos visualizar o plano de desenvolvimento da entrevista, na parte referente ao tratamento dos conteúdos culturais, dividido pela evolução dos tópicos em oito segmentos.

\begin{tabular}{|c|c|c|}
\hline Excerto & $\begin{array}{l}\text { Identificação } \\
\text { dos turnos }\end{array}$ & Conteúdos temáticos: \\
\hline \multicolumn{3}{|r|}{ Tratamento dos conteúdos culturais... } \\
\hline 1 & $719-737$ & $\begin{array}{l}\text { através da exposição aos documentos e comentários dos } \\
\text { alunos, sem desenvolver a discussão }\end{array}$ \\
\hline $\begin{array}{l}2 \mathrm{~A} \\
\mathbf{2 B}\end{array}$ & $\begin{array}{l}738-757 \\
758-772\end{array}$ & $\begin{array}{l}\text { através de uma atividade do livro, sem desenvolver a } \\
\text { discussão } \\
\text { A) Formulação da questão } \\
\text { B) Resposta de Danilo }\end{array}$ \\
\hline 3 & $779-792$ & $\begin{array}{l}\text { através da exposição aos documentos e histórias dos alunos, } \\
\text { sem desenvolver a discussão }\end{array}$ \\
\hline $\begin{array}{l}4 \mathrm{~A} \\
4 \mathrm{~B}\end{array}$ & $\begin{array}{l}793-803 \\
804-831\end{array}$ & $\begin{array}{l}\text { através da opinião sobre quem introduziu esses temas } \\
\text { A) aluno } \\
\text { B) professor }\end{array}$ \\
\hline 5 & $832-846$ & $\begin{array}{l}\text { através das diferenças e da comparação entre a aula de Danilo } \\
\text { e de Suélen }\end{array}$ \\
\hline 6 & $847-876$ & através de uma sugestão de atividade \\
\hline 7 & $877-920$ & $\begin{array}{l}\text { através dos documentos do livro didático e documentos } \\
\text { autênticos }\end{array}$ \\
\hline 8 & $921-936$ & através da possibilidade de trabalhar forma e conteúdo juntos \\
\hline
\end{tabular}

Tabela 27: Conteúdos temáticos relacionados ao tratamento dos conteúdos culturais

Como dissemos, observando como os temas da entrevista foram evoluindo, optamos por guardar a evolução dessa progressão temática, expondo nossos resultados em oito excertos.

\section{B) Tipos de discurso}

Enquanto entrevista, o texto que analisamos se configura como um grande diálogo através da predominância do tipo de discurso interativo, intercalada com relatos interativos para situar um acontecimento, uma memória no passado. Encontramos também algumas ocorrências de 
discurso teórico. Os tipos de discurso, articulados com as modalizações e outras categorias nos permitiram configurar o agir através das figuras de ação.

\section{C) Configuração do agir}

A fim de analisar como se configura o agir dos professores através das figuras de ação (BULEA, 2010), optamos por identificá-las através de cores. Assim, como já mencionamos, nos excertos apresentados a seguir, identificamos a figura de ação ocorrência com a cor roxa. Essa figura é usada para relatar e explicitar o agir dos professores gravado em vídeo, com características linguístico-discursivas que permitiram identificar um forte grau de contextualização, próximo à situação de enunciação, com uso do passado e do futuro imediato. A figura de ação acontecimento passado (cor azul) foi identificada com uma feição de história, também contextualizada, mas com um valor ilustrativo do agir, normalmente introduzida por um marcador temporal "uma vez", "um dia". A figura de ação experiência (cor verde) caracteriza a cristalização das experiências vividas, podendo ser descontextualizada e recontextualizada. Ela se apresenta com marcadores de frequência "sempre", "nunca", "normalmente" e através de um presente genérico. A figura de ação definição (cor laranja) configura, normalmente através do discurso teórico, uma abstração ou uma definição, usando um presente genérico, sem marcas dos enunciadores, introduzida muitas vezes por “c'est". Por fim, a figura de ação canônica (cor vermelha), configura o agir a partir da ótica das prescrições, orientações e obrigações, empregando modalizações deônticas.

Nesse trabalho, procuramos não somente identificar e classificar os excertos relativos a cada figura de ação, mas buscamos avançar nesse tipo de análise, fazendo um levantamento da dinâmica dessas figuras no discurso. Dessa forma, retomaremos na síntese deste capítulo os movimentos das figuras de ação no discurso dos professores sobre seu trabalho.

\section{Excerto 1: Quando damos voz aos alunos...}

O excerto que analisamos a seguir se refere ao vídeo da aula de Suélen em que ela realiza uma atividade de introdução à temática da lição: La Fête des Voisins (conferir anexos), para seu grupo de nível 4 (correspondente ao A2 do CECRL). Suélen trouxe documentos autênticos 
encontrados na internet, em que pessoas relatavam fatos e problemas de vizinhança. Eram pequenos bilhetes (mots, affiches), que vizinhos de um mesmo edifício colocavam nas áreas em comuns para avisar, prevenir, reclamar ou convidar os outros moradores. Os bilhetes, trazidos por Suélen, foram colados nas paredes das salas. A atividade consistia em circular na sala, observando rapidamente do que se tratava, escolher um desses bilhetes para lê-lo por inteiro e discutir com um colega. No momento de compartilhar com o restante da sala sobre o que tratava o bilhete, os alunos perceberiam algo em comum nessas histórias: as relações de vizinhança, que introduziriam a temática da lição.

Vejamos a seguir a transcrição do excerto da aula de Suélen em que os alunos compartilham as histórias lidas com toda a sala, visto por Suélen e Danilo na autoconfrontação:

\section{Excerto da aula da Suélen - 41'00 - 42'15}

Élève $1:$ je pense que notre problème c'est le plus léger... de nos collègues

$\mathrm{S}:$ peut-être ce n'est pas un problème non

Élève 1 : c'est pas un problème/ c'est un problème de honnêteté ((risos))... notre personnage a trouvé un billet de dix euros au parking... d'un immeuble... dans/ dans un bâtiment et il cherche le propriétaire alors il a décidé de laisser un petit billet

$\mathrm{S}$ : oui... bien comment/ comment c'est la définition... le mot le plus indiqué dans cette situation... c'est une personne...

$\mathrm{S}$ : honnête

Plusieurs élèves : honnête

$\mathrm{S}$ : oui

Élève 2 : comment se parle la « nota de dix euros »... que ela falou

$\mathrm{S}$ : un billet/ un billet... un billet de dix euros/ c'est un billet

Élève 3 : TRÈS TRÈS TRÈS honête... dix euros ((risos))

Plusieurs élèves : ((risos))

Nesse momento da aula, uma dupla de alunas (alunas 1 e 3) apresentam para a sala a situação contextual do bilhete escolhido por elas: uma pessoa encontrou uma nota de dez euros no estacionamento do prédio e colocou um aviso, perguntando se alguém havia perdido aquela nota. Suélen aproveita a situação para retomar o conteúdo da aula anterior que foi objeto de correção nesta mesma aula, perguntando qual o caráter daquela pessoa, ao que os alunos responderam "honesta". A aluna da dupla enfatiza aquela qualidade, comentando: "muito, muito muito, muito honesta, dez euros", o que desperta imediatamente o riso dos colegas. O conteúdo cultural implícito aqui, as diferentes atitudes e diferentes traços de personalidade - de uma pessoa ou de um povo -, entram na aula através do comentário dessa aluna, que evoca risos da sala, mas não se torna objeto de discussão. 
Ao observar esse excerto junto com Danilo, Suélen faz alguns apontamentos:

Excerto em análise 1 - Autoconfrontação Cruzada - Tratamento dos conteúdos culturais através da exposição aos documentos e comentários dos alunos, sem desenvolver a discussão

*início vídeo*

((Aluna no vídeo : TRÈS TRÈS TRÈS honnête... dix euros))

719S: là dans ce moment-là ça apparaît ahn:: l'interculturel... c'est ça que je voulais::

720D: uhum

721S: $\quad$ vous montrer parce que... je/je les expose à des situations de/de l'interculturel...

et:: ahn:: ça arrive des/des rigolades:: et je/je pense que c'est plus naturel

722D: mais qu'est-ce que tu discutais avec eux?

723S: c'était le billet de dix euros

724D:

oui le/le billet de dix euros

725S: la personne a dit « ah la personne est très très TRÈS honnête » et tout le monde a rigolé

726D: uhum

727S: ça montre déjà... ahn:: l'aspect... ahn:: de notre culture... on n'aurait jamais par exemple mis un mot comme ça... ((risos))

$728 \mathrm{D}:$

729E:

730S:

731D: $\quad$ ouais... probablement non

732E: dans ce cas ce qu'elle a dit c'est ((tosse))/ elle a dit que «c'est très très TRÈS honnête dix euros $\gg . .$. parce que si c'était cinq millions peut-être mais dix euros

733D: $\{$ dix euros... ouais

734E: c'est ça

735S: oui c'est le commentaire de Margarete qui/qui donne la/ l'aspect interculturel donc $\mathrm{j}$ 'attendais ça en fait quand j'ai apporté ahn:: ce mot-là

736E: et après... personne n'a fait un commentaire ça veut dire ça est sorti comme ahn:: comme une blague presque

$737 \mathrm{~S}$ :

\{tout le monde a compris le billet... c'était ça c'est bien... tout le monde a compris le billet et a comparé ahn:: avec notre culture

Suélen parece escolher assistir a esse excerto com Danilo para mostrar como os conteúdos culturais surgem na aula, quem os introduz, a partir do quê e como eles são tratados em sala.

Com relação aos turnos de fala, esse excerto é predominantemente desenvolvido por Suélen (8 turnos), havendo breves interações de validação e acompanhamento de seus turnos pela pesquisadora (4 turnos) e por seu colega (7 turnos).

Ainda nesse excerto, no nível dos mecanismos de textualização, observamos que a série coesiva nominal construída para se falar dos conteúdos culturais é "l'interculturel”, "situations de l'interculturel”, “rigolades”, “culture”, “commentaire (de l'élève)”, "l'aspect interculturel”. Vemos, nesse exemplo, que os substantivos utilizados nessa série coesiva que ampliam o sentido de "interculturel" são as risadas ("rigolades") e os comentários ("commentaires"). Dessa forma, 
vemos o posicionamento enunciativo da professora-monitora em relação aos conteúdos culturais: ela os associa a algo "que faz rir" e algo que é acessório (“commentaires”), não sendo a essência da aula.

Já os lexemas empregados para dar a progressão temática na coesão verbal podem ser divididos entre o que o professor faz para se trabalhar os conteúdos culturais, isso é, expô-los a situações interculturais ("exposer à des situations de l'interculturel”); o que os alunos fazem é comentar, rir, entender e comparar ("commenter", "rigoler”, “comprendre”, “comparer"); e o que o comentário pode evocar provocar risos ("arriver des rigolades").

No que diz respeito aos mecanismos enunciativos, lembramos que um dos índices de inserção de vozes é a presença de discurso direto, indireto, direto livre e indireto (MAINGUENEAU, 1991, 2001). Nesse segmento, Danilo solicita uma reconstituição da passagem vista no vídeo “o que você estava conversando com eles?” (qu'est-ce que tu discutais avec eux) e Suélen retoma a voz da aluna de através do verbo discendi “dizer" (dire):

725S: la personne [l'élève Margarete] a dit " ah la personne est très très TRÈS honnête 》 et tout le monde a rigolé

Com esse exemplo, constatamos que uma das vozes que aparecem na autoconfrontação é a dos alunos, reconstituída pelos professores participantes da autoconfrontação, como já demonstraram Lousada (2006) e Dantas-Longhi (2013).

Outras vozes também podem ser distinguidas através da análise dos dêiticos empregados: “on" e "notre”. Nesse segmento, evidenciamos a utilização do "on" que, por ter uma plasticidade grande com relação a seu referente, pode trazer diferentes significados ao texto. Em um primeiro momento, o "on" refere-se aos brasileiros ou à cultura brasileira (em "a gente nunca teria colocado um bilhete como esse"). Entretanto, por sua plasticidade, esse mesmo "on" pode se referir ao grupo que estava na aula, ou mesmo a Suélen, Danilo e a pesquisadora, pois, em qualquer uma das situações, a sentença manteria seu sentido, guardando a ideia de que os brasileiros não fariam tal coisa. Já no segundo momento o "on" se reporta aos professores em geral ou à atitude que Suélen defende de não generalizar (no trecho "a gente não diz nunca"). $\mathrm{O}$ uso de "nossa" antes de cultura traz também uma voz que a reconhece como pertencente à cultura brasileira - dela, dos colegas e dos alunos.

Além das vozes inseridas através dos verbos discendi e dos dêiticos, podemos observar vozes através da categoria da heterogeneidade discursiva (AUTHIER-REVUZ, 1998). Nesse 
excerto, podemos assinalar o uso dos jargões profissionais para evidenciar uma voz da didática. Quando Suélen descreve a situação ocorrida na sala, ela emprega a frase "nesse momento aparece o intercultural" e depois "é o comentário de Margarete que dá o aspecto intercultural". Nomear a situação com "interculturel", uma palavra que aparece nos documentos prescritivos, nos manuais didáticos e nas práticas de formação, aponta para o fato de que ela e seu colega estão a par das concepções por detrás do termo e que é algo comum a seus universos profissionais. É possível, portanto, compreender então que há uma voz da didática nesse discurso, através desse jargão.

Quanto à análise das modalizações, pudemos identificar que o modo como o conteúdo cultural foi introduzido na situação da sala de aula foi apreciado positivamente por Suélen como bom e natural ("c'est plus naturel”, “c'est bien, tout le monde a compris”). A modalização pragmática, que remete à responsabilidade e intencionalidade da ação do enunciador, indica o grau de responsabilidade que Suélen teve sobre a concepção e realização daquela atividade e consequentemente sobre a introdução dos conteúdos culturais em aula. Ela diz "na verdade eu esperava isso quando trouxe esse bilhete" ( "j'attendais ça”).

Empregando a categoria de análise das figuras de ação propostas por Bulea (2010), podemos ver como Suélen caracteriza seu agir profissional de maneira contextualizada, por meio da figura de ação ocorrência, destacada abaixo na cor roxa, caracterizada pelo tipo de discurso interativo (expor implicado e conjunto - imbricado na situação de enunciação), pelo agir próximo à situação de comunição. Nesse caso, a figura de ação ocorrência é usada para relatar e contextualizar o acontecimento visto no vídeo, trazendo o relato para o momento da enunciação.

\section{Análise das figuras de ação de Suélen no Excerto em análise $1^{112}$}

719S: là dans ce moment-là ça apparaît ahn:: l'interculturel... c'est ça que je voulais::/vous montrer parce que... je/je les expose à des situations de/de l'interculturel... et:: ahn:: ça arrive des/des rigolades:: et je/je pense que c'est plus naturel // c'était le billet de dix euros // la personne a dit « ah la personne est très très TRËS honnête » et tout le monde a rigolé//ça montre déjà... ahn:: l'aspect... ahn:: de notre culture... on n'aurait jamais par exemple mis un mot comme ça... ((risos)) // on ne dit pas jamais mais // oui c'est le commentaire de Margarete qui/qui donne la/ l'aspect interculturel donc j'attendais ça en fait quand j'ai apporté ahn:: ce mot-là// tout le monde a compris le billet... c'était ça c'est bien... tout le monde a compris le billet et a comparé ahn:: avec notre culture

Legenda: Roxo - ocorrência / Azul - acontecimento passado / Laranja - definição / Verde - experiência / Vermelho - canônica

${ }^{112}$ Para facilitar a visualização da análise de como os professores configuram seu agir através das figuras de ação, compilamos em um bloco único as falas de cada professor no excerto da entrevista em análise. Guardamos porém a separação dos turnos de fala com a indicação de uma barra dupla. 
Contextualizando seu trabalho, Suélen busca caracterizar sua maneira de tratar os conteúdos culturais com os alunos, dizendo que é natural quando ela os expõe a situações e acontecem risadas (“c'est plus naturel”). Em seguida, há uma retomada da situação vista nos vídeos. No excerto "je/je les expose à des situations de/de l'interculturel... et:: ahn:: ça arrive des/des rigolades", Suélen retoma aquilo que ela acaba de ver em vídeo empregando o presente, trazendo a situação próxima de seus interlocutores. Essa retomada do episódio em sua aula lhe permite elaborar um comentário sobre a cultura. Como vimos nos mecanismos enunciativos, na frase "on n'aurait jamais mis un mot comme ça", o on pode fazer referência aos brasileiros em geral, mas pode também se referir aos professores e alunos no momento da aula, como também ao grupo que estava assistindo ao vídeo, Suélen, Danilo e a pesquisadora. Após isso, Suélen faz uma reflexão sobre o que disparou o trabalho com os conteúdos culturais, afirmando que foi o comentário da aluna que "deu o aspecto intercultural" e que todos os alunos haviam entendido o texto e comparado com a cultura brasileira.

\section{Excerto 2: Quando trabalhamos o livro didático...}

Na sequência desse episódio, a pesquisadora evoca um momento da gravação da aula de Danilo e faz uma observação comparando as aulas dos dois professores. Tanto na aula de um, quanto na do outro, ocorreu uma compreensão implícita dos conteúdos culturais da parte dos alunos. Na aula de Suélen, uma aluna fez um comentário sobre a devolução de dez euros, dizendo que a pessoa do texto era excessivamente honesta. Esse comentário provocou o riso da classe. $\mathrm{Na}$ aula de Danilo, ao explicar o que era a palavra "vela", de barco a vela, (voile) em francês, o professor usa uma definição, faz gestos e termina fazendo o comentário que se pode praticar esse esporte, se o esportista tiver bastante dinheiro. Nos dois casos, houve uma compreensão implícita dos comentários, seguida de risos, sem que se desenvolvesse uma discussão na sequência. Danilo evoca a partir da pergunta da pesquisadora uma outra experiência vivida em classe. Vejamos o excerto abaixo: 
Excerto em análise 2 - Autoconfrontação Cruzada: Tratamento dos conteúdos culturais através de uma atividade do livro, sem desenvolver a discussão

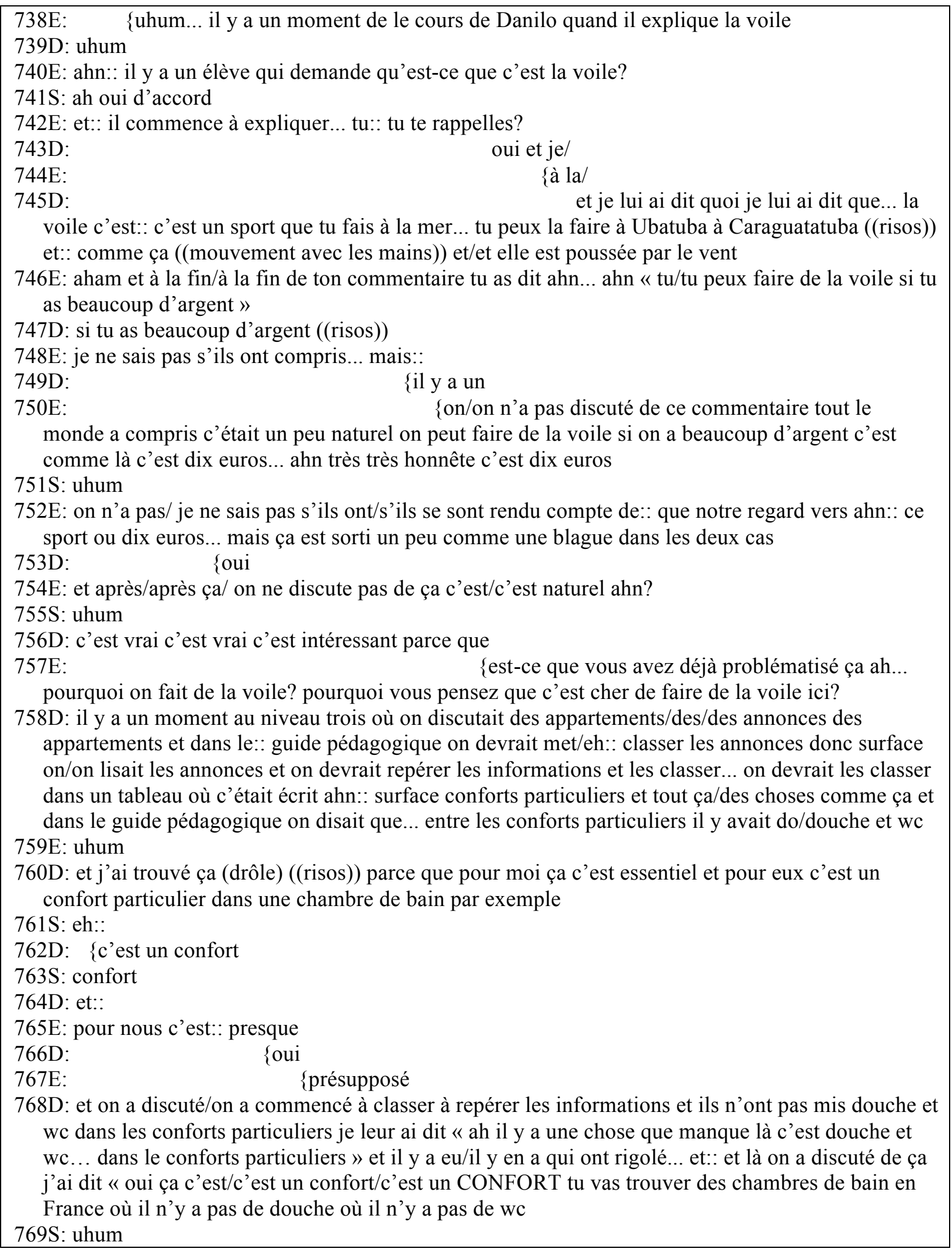


770D: tu/tu as QUE une chambre »... et là ça donne une discussion mais c'est/c'est un petit détail qui pourrait disparaître/on pourrait le prendre par une blague je pense (que tout le monde) je fais aussi ah c'est une blague peut-être qu'on ne va pas discuter de ça mais... voilà c'est/on peut aller un peu loin mais normalement c'est comme ça une blague comme ça

$771 \mathrm{~S}:$

\{oui... laisser un peu:: naturel la situation

772D: ouais c'est naturel

A pesquisadora relembra o momento da aula de Danilo em que, após explicar a expressão "velejar" ("faire de la voile”), ele faz um breve comentário que também desperta risos: "você pode velejar, se tiver bastante dinheiro" (“tu peux faire de la voile si tu as beaucoup d'argent”). A pesquisadora chama a atenção para o fato de que, nos dois casos, houve um momento breve de comparação entre culturas e que, tanto na aula de um, quanto na de outro, o comentário não foi desenvolvido ou discutido. Danilo imediatamente conta uma outra experiência em que, realizando uma atividade do livro didático, os alunos deveriam classificar as partes de um apartamento segundo um quadro em que havia a categoria "confortos particulares". Ele teve de explicar então que a ducha e o banheiro faziam parte dessa categoria, pois havia apartamentos que não dispunham dessas partes e alguns alunos acharam tal fato engraçado. Danilo ressalta que esse é um detalhe pequeno que poderia desaparecer na aula ou poderia gerar uma discussão mais aprofundada, mas que, normalmente em sua experiência, é tratado como um momento engraçado, descontraído, quase como uma piada.

Podemos notar o contraponto entre esse excerto e o anterior. Na aula da Suélen, o que introduziu o conteúdo cultural foi o comentário da aluna, através de um documento selecionado pela professora, que já esperava esse comentário. Já nesse relato de Danilo, o conteúdo cultural foi introduzido pelo próprio professor ao corrigir um exercício, motivado portanto por uma atividade do livro didático. Vemos, assim, duas maneiras de provocar o surgimento desses conteúdos, documentos trazidos pelo professor ou documentos do livro, e duas maneiras de ele ser verbalizado na aula, pela voz do aluno ou pela voz do professor.

Com relação aos turnos de fala, aparece primeiramente a pesquisadora formulando a questão (10 turnos na parte A), com interações curtas de validação dos co-enunciadores ( 7 turnos de Danilo e 3 de Suélen); em seguida, Danilo aparece predominantemente com 8 turnos, contando com curtas interações de Suélen (4 turnos) e da pesquisadora (3 turnos).

$\mathrm{Na}$ categoria dos mecanismos de textualização, chamamos atenção para a série coesiva nominal que se constrói para se falar dos conteúdos culturais. Vemos o uso de "drôle", 
"discussion", "petit détail", "blague", reforçando o campo do riso, evocado inicialmente por Suélen no excerto anterior. Quanto aos lexemas verbais "rigoler", "trouver drôle", "prendre par [sic] une blague", "être une blague", verificamos que eles ratificam essa insistência no campo do riso e da descontração. Os lexemas ligados à ação do professor, "discuter", "ne pas discuter" e "pouvoir aller plus loin", indicam que, para Danilo, essas são as ações que o professor pode ou não fazer para trabalhar os conteúdos culturais.

Analisando os mecanismos enunciativos, observamos a inserção da vozes dos alunos através do discurso direto (MAINGUENEAU, 1991, 2001). Além disso, vimos outras vozes através do índice de inserção de vozes "on": um on inclusivo referindo-se a Danilo e seus alunos durante o relato da atividade; um "on" referente aos professores ("on pourrait le prendre par une blague"; "on peut aller un peu loin"); e um "on" referente ao livro didático ("dans le guide pédagogique on disait que"). A voz da cultura aparece novamente através da oposição entre a cultura dele, do professor, e do outro ("pour moi ça c'est essentiel, pour eux c'est un confort"). A voz da didática também aparece no jargão da área , quando Danilo evoca as orientações do guia pedagógico ou do livro do professor ("dans le guide pédagogique”).

Ainda nos mecanismos enunciativos, pode-se observar como Danilo se posiciona em relação aos elementos que são introduzidos no discurso através das modalizações. Encontramos, por exemplo, modalizações deônticas - da ordem do dever, da obrigação - relacionadas ao livro didático ("on devrait classer", "on devrait repérer"). Há uma grande presença de modalizações lógicas ligadas à possibilidade ("c'est um petit détail qui pourrait disparaître", "peut-être on ne va pas discuter de ça"; "on peut aller un peu loin", "on pourrait le prendre par une blague”), assim podemos inferir que Danilo associa o trabalho com os conteúdos culturais no campo da obrigação imposta pelo livro, da possibilidade e não da realização.

Diferente do primeiro excerto, em que Suélen comentou a ação vista em vídeo através da figura de ação ocorrência, neste excerto, Danilo evoca uma situação contextualizada no passado, através da figura de ação acontecimento passado. Essa distinção pode ser feita baseada no que sustenta Bulea (2010, p.132-133). A figura de ação acontecimento passado propõe uma compreensão retrospectiva do agir, sob o ângulo da singularidade, com a feição de uma "história", em referência a um eixo temporal situado antes da entrevista, e cuja origem é marcada: "a última vez", "outro dia". 


\section{Análise das figuras de ação de Danilo no Excerto em análise 2}

758D: il y a un moment au niveau trois où on discutait des appartements/des/des annonces des appartements et dans le:: guide pédagogique on devrait met/eh:: classer les annonces donc surface on/on lisait les annonces et on devrait repérer les informations et les classer... on devrait les classer dans un tableau où c'était écrit ahn:: surface conforts particuliers et tout ça/des choses comme ça et dans le guide pédagogique on disait que... entre les conforts particuliers il y avait do/douche et wc //et j'ai trouvé ça (drôle) ((risos)) parce que pour moi ça c'est essentiel et pour eux c'est un confort particulier dans une chambre de bain par exemple // c'est un confort // et :: // oui // et on a discuté/on a commencé à classer à repérer les informations et ils n'ont pas mis douche et wc dans les conforts particuliers je leur ai dit « ah il y a une chose que manque là c'est douche et wc... dans le conforts particuliers » et il y a eu/il y en a qui ont rigolé... et:: et là on a discuté de ça j'ai dit « oui ça c'est/c'est un confort/c'est un CONFORT tu vas trouver des chambres de bain en France où il n'y a pas de douche où il n'y a pas de wc // tu/tu as QUE une chambre »...et là ça donne une discussion mais c'est/c'est un petit détail qui pourrait disparaître/on pourrait le prendre par une blague je pense (que tout le monde) je fais aussi ah c'est une blague peut-être qu'on ne va pas discuter de ça mais... voilà c'est/on peut aller un peu loin mais normalement c'est comme ça une blague comme ça//ouais c'est naturel

Roxo - ocorrência / Azul - acontecimento passado / Laranja - definição / Verde - experiência / Vermelho canônica

Por meio de um relato simbólico, exemplar e "ilustrativo" (BULEA, 2010) do que seria a compreensão implícita das diferenças culturais por parte dos alunos, Danilo formula seu agir através da figura de ação acontecimento passado. Esse caso serve para que Danilo conclua, formulando seu agir cristalizado em experiência: o trabalho com os conteúdos culturais para ele é um "pequeno detalhe" que pode desaparecer na aula e pode ser compreendido como uma brincadeira, uma piada. Ele desenvolve, dizendo que poder-se-ia ir mais longe, mais a fundo na discussão, mas esses conteúdos culturais observados por meio das diferenças entre a cultura de origem e a cultura alvo são normalmente uma brincadeira, uma piada ("normalement c'est comme ça une blague comme ça”). Ele conclui, fazendo um paralelo com o que disse sua colega, dizendo que o tratamento dos conteúdos culturais dessa maneira implícita é natural nas aulas de FLE.

\section{Excerto 3: Quando os alunos nos contam histórias...}

Após esse relato de Danilo, Suélen coloca outra cena de sua aula, a qual ela havia escolhido para comentar. Após a atividade de escolher o bilhete e compartilhar com a sala a situação de vizinhança retratada, Suélen propõe que os alunos conversem com as mesmas duplas se já haviam vivido situações como aquelas com seus vizinhos. Depois de um momento em 
duplas, Suélen pergunta se alguém gostaria de compartilhar a história com a classe toda. Vejamos a transcrição da aula:

\section{Excerto da aula da Suélen 48'35 - 51'55}

S: oui... qui peut/ ça va ?... oui... vous avez déjà vécu... hein... qui peut/ qui pourrait/ hein... partager dans le groupe ce que vous avez discuté ? qui veut partager ? d'accord... nous avons une histoire... on peut... attention tout le monde...

Élève 1: \{quand j'habitais en Espagne... \{quand j'habitais en Espagne il y a avait un voisine qui a perdu:: son chat et elle a:: écrit un billet:: parce qu'elle... cherchait son chat... et il a écrit ah:: j'au perdu mon chat s'il vous plait ah:: je cherche mon chat et un autre voisin ou une voisine a écrit... un autre billet un autre billet... il est mort ((risos))

Plusieurs élèves : ((risos))

$\mathrm{S}$ : il est mort... ah... il a écrit dans le même... ah oui... il a toujours une réponse dans ces billets n'est-ce pas... le billet/ le billet non les mots/ les mots... les mots échangés dans les parties en commun l'ascenseur la cour... il y a toujours des réponses... écrit en... en stylo... c'était écrit ça... il est mort... quelle histoire... il y ah d'autres personnes d'autres groupes qui veut... partager

Élève 1 : mais... ah pardon il y a un petit (détail) dans le réponse... eh... ce personne qui a écrit il est mort... en espagnol... ah quand... ah on fait un exclamation... on doit ah.: écrire l'exclamation après...

$\mathrm{S}:$ au contraire

Élève 1 : au contraire et normalement mais... cette personne a écrit il est mort seulement avec l'exclamation normale... et cette voisin a dit IL EST ESTRANGER !

Plusieurs élèves : ((risos))

Élève $1:$ il n'écrit pas avec l'exclamation

$\mathrm{S}$ : il est Étranger... parce qu'il écrit comme ça... il ne connaît pas bien la langue donc ça dénonce

Élève 1 : oui $\quad$ \{exactement $\quad$ \{oui... $\quad$ \{parce qu'il est mort avec deux exclamation

$\mathrm{S}:$ et en langue espagnole ce n'est pas admis...

Élève 1 : obligataire

$\mathrm{S}$ :ça c'est obligatoire... voyez c'est intéressant

Élève $1:\{$ obligataire [sic]

Uma aluna compartilha uma situação que viveu na Espanha: um de seus vizinhos havia perdido um gato e colocou um aviso no prédio, informando que estava procurando seu bixano perdido. Um dos moradores do prédio escreveu uma resposta no mesmo aviso "Ele morreu!". Entretanto, em espanhol, as sentenças exclamativas contém uma exclamação inversa (i) antes da frase e uma exclamação normal (!) no fim. Ao ver que a pessoa que respondeu colocara somente uma exclamação final, o vizinho que perdera seu gato concluiu que aquele comentário era de um estrangeiro.

Após assistir a essa cena com Danilo, Suélen comenta: 
Excerto em análise 3 - Autoconfrontação cruzada: Tratamento dos conteúdos culturais através da exposição aos documentos e histórias dos alunos, sem desenvolver a discussão

778S: ah c'est autre chose... cinquante cinquante cinq...

*pause vidéo*

779S: elle parle d'une situation qui s'est passée ahn:: en Espagne... où elle a habité ahn:: elle parle d'un mot comme ça $(($ montre le mot) $)$... une personne qui réclamait son chat

*vidéo*

*pause vidéo*

780E: peut-être tu peux expliquer un peu l'histoire avant?

781S: oui c'est/c'est le/le mot qu/qu'elle a vu dans un immeuble c'était écrit ahn:: que la personne cherchait son chat et il y a eu une réponse... « il est mort »... à stylo

782D: uhum

783S: normalement il y a ce type de réponse (en espagnol) ((risos)) dans les mots échangés dans/dans des immeubles

784D: $\quad$ ouais ouais (on) répond comme ça

785S: oui et elle a expliqué que la/la personne a écrit «il est mort» avec exclamation... comme ça ((montre le point d'exclamation écrit au tableau dans la vidéo $i)$ )

786D: uhum uhum

787S: et en espagnol...

788D: on met un avant et un après

789S: et ça c'est c'est

790D: c'est un étranger... et on a dit ça aussi

791S: et ça c'est/c'est justement la manière naturelle parce que les gens donnent des exemples c'est pas à moi de/de comparer de donner:: j'ai/j'ai déjà donné pas mal de choses et ÇA a déclenché plusieurs:: histoires... donc je pense que trois deux trois histoires... dans/dans le même contexte je pense que ça c'est/c'est bien... parce que moi je ne me sens pas capable de/d'entrer dans l'interculturel de comparer:: et:: c'est plus intéressant de/de les écouter... n'est-ce pas? c'était/c'était justement ça que je voulais expliquer

792D: uhum

Suélen reconstitui a história no vídeo, respondendo ao pedido da pesquisadora e, em seguida, pondera sobre a maneira natural como os comentários dos alunos surgem depois das atividades e documentos trazidos pelo professor. Para ela, duas ou três histórias bastam para disparar falas dos alunos e o interessante é escutar os alunos, pois ela não se sente à vontade para comparar as culturas ou entrar "no intercultural".

Esse excerto mostra novamente a predominância de Suélen nos turnos de fala, revelando momentos de alternância do domínio das falas, o que pode ser ratificado pelo fato de que ambos se sentem à vontade para falar de sua prática e que estão fazendo parte de uma conversa onde não há hierarquia de posições, são ambos professores no mesmo contexto.

Nos mecanismos de textualização, encontramos a continuidade da série coesiva nominal referente aos conteúdos culturais: exemplos, história, intercultural ("exemples", "histoires, 
“interculturel”). Com relação aos lexemas da coesão verbal, vemos que Suélen aponta as ações referentes ao professor: dar várias coisas [textos, atividades], não comparar, não se sentir capaz de entrar no intercultural, escutar os alunos ("j'ai déjà donné pas mal des choses”, "je ne me sens pas capable d'entrer dans l'interculturel, de comparer”, “c'est plus intéressant de les écouter"), caracterizando, ao nosso ver, uma postura ao mesmo tempo ativa e resguardada. Ela aponta também as ações referentes aos alunos: dar exemplos ("les gens donnent des exemples”). E aos materiais, textos e atividades concebidas pelo professor: disparar várias histórias ( "et ça a déclenché plusieurs histoires").

Os mecanismos enunciativos desse excerto trazem novamente a voz da aluna, introduzida por verbos discendi ("elle parle”, “elle explique”), voz essa que será posteriormente retomada por Suélen. Ao mesmo tempo, o estudo das vozes através dos dêiticos também mostra que Suélen se vê no vídeo também como protagonista da situação, distinguindo bem sua prática da dos alunos. Podemos notar esse fenômeno a partir do uso do "je" em oposição ao excerto anterior de Danilo, que representou majoritariamente sua ação por meio do "on" ("j’ai déjà donné pas mal de choses", “c'est pas à moi de comparer", "je ne me sens pas capable”). No excerto 1, vimos que ela estava consciente da atividade e esperava comentários dos alunos sobre os conteúdos culturais ("j'attendais ça”) .

Através das modalizações, vemos que ela atribui apreciações positivas a essa prática que desperta comentários e que leva em conta a voz do aluno: é natural, é bom, é mais interessante de escutá-los ("c'est justement la manière naturelle”, “c'est bien”, “c'est plus intéressant”).

Analisando a sequência de figuras de ação, Suélen recupera e explica a situação do vídeo, através da figura de ação ocorrência ("elle parle d'une situation”). Essa história que a aluna conta e ela reproduz na ACC dá elementos para que Suélen possa formular seu agir cristalizado em experiência, primeiramente fazendo uma reflexão mais abstrata e depois pensando no agir prático do professor. Daquela cena, ela depreende que tratar os conteúdos culturais através de contribuições espontâneas dos alunos é uma maneira natural de fazê-lo ( "c'est justement la manière naturelle") e é mais interessante escutá-los [que explicar esses conteúdos] ("c'est plus intéressant de/de les écouter"). Essa reflexão engendra uma descrição das ações dos alunos e dos professores, mostrando que cabe aos alunos dar exemplos, comparar e não ao professor; para que isso ocorra, seu papel enquanto professora é fornecer elementos para suscitar a discussão (no caso, textos autênticos sobre as relações de vizinhança). É também a partir de sua experiência que ela 
diz que não se sente capaz de "entrar no intercultural, de comparar" sozinha, sendo mais interessante ouvir os alunos.

\section{Análise das figuras de ação de Suélen no Excerto em análise 3}

778S: ah c'est autre chose... cinquante cinquante cinq... // elle parle d'une situation qui s'est passée ahn:: en Espagne... où elle a habité ahn:: elle parle d'un mot comme ça ((montre le mot))... une personne qui réclamait son chat // oui c'est/c'est le/le mot qu/qu'elle a vu dans un immeuble c'était écrit ahn:: que la personne cherchait son chat et il y a eu une réponse... « il est mort »... à stylo // normalement il y a ce type de réponse (en espagnol) ((risos)) dans les mots échangés dans/dans des immeubles // oui et elle a expliqué que la/la personne a écrit «il est mort 》 avec exclamation... comme ça ((montre le point d'exclamation écrit au tableau dans la vidéo ¡)) // et en espagnol... // et ça c'est c'est // et ça c'est/c'est justement la manière naturelle parce que les gens donnent des exemples c'est pas à moi de/de comparer de donner:: j'ai/j'ai déjà donné pas mal de choses et ÇA a déclenché plusieurs:: histoires...donc je pense que trois deux trois histoires... dans/dans le même contexte je pense que ça c'est/c'est bien... parce que moi je ne me sens pas capable de/d'entrer dans l'interculturel de comparer:: et::c'est plus intéressant de/de les écouter... n'est-ce pas? c'était/c'était justement ça que je voulais expliquer

Legenda: Roxo - ocorrência / Azul - acontecimento passado / Laranja - definição / Verde - experiência / Vermelho - canônica

\section{Excerto 4: Quando temos a "voz da razão"...}

Referindo-se ao excerto anterior, Suélen solicita as impressões e avaliações de Danilo, buscando uma validação ou outras sugestões de trabalho, prática essa comum entre os professores. Vejamos:

Excerto em análise 4: Autoconfrontação cruzada - Tratamento dos conteúdos culturais através da opinião sobre quem introdução esses temas

793S: comment tu penses que c'est/j'aurais/ahn je devrais faire une autre activité plus intéressante ou:: la discussion 794D: 795S: $\{$ non... je pense que c'est génial... c'est c'est

\{laisser... laisser naturel comme ça? sans...

796D: j'ai beaucoup aimé j'avais pas pensé à ça... c'est/c'est vrai que un regard de l'interculturel c'est/c'est dans ces commentaires-là 797S:

798D: ehn:: non c'est très intéressant

799S: parce que c'est intéressant de voir des situations particulières... je ne parle en France c'est comme ça... en France au Brésil c'est comme ça

800D: uhum

801S: je pense que l'intéressant c'est entrer dans le contexte des élèves 802D: oui

803S: c'est (naturel) 


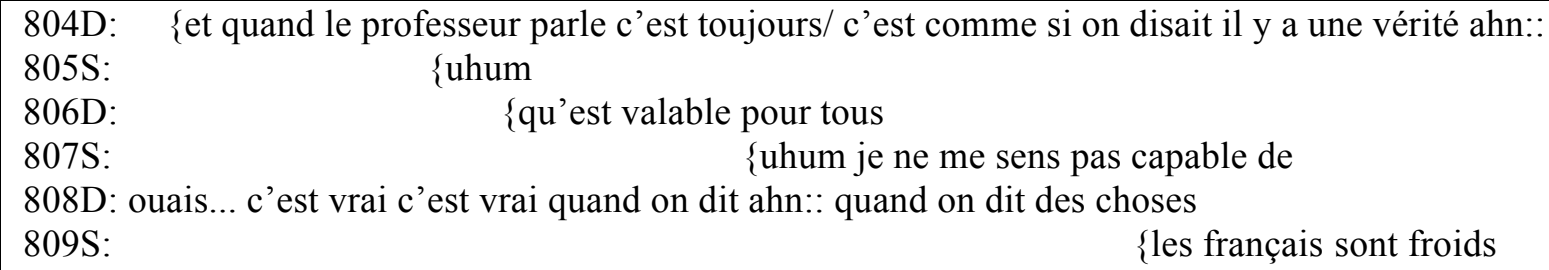

Ao questionar Danilo, Suélen obtém uma validação de seu colega, que reconhece ser interessante ver os conteúdos culturais a partir das experiências e histórias dos alunos. Essa 
discussão gera uma conscientização sobre o peso que tem a fala do professor na sala de aula. Nesse sentido, Danilo dá outro exemplo de uma experiência sua: uma vez, pelo fato de escrever o pingo da letra i com uma bolinha, os alunos acharam que todos os franceses escreviam o i dessa mesma maneira. Com esse exemplo, Danilo enfatiza a importância da particularização e da necessidade de não generalizar. Suélen concorda, retoma o tema, falando novamente de sua aula e da importância de se despertar o interesse dos alunos e de não generalizar. Ao mesmo tempo, ela se dá conta de que houve um momento de generalização em sua aula, tema que ela retomará mais tarde.

Esse excerto se mostra equilibrado quanto aos turnos de fala: conta com 5 turnos de Danilo e 6 de Suélen enquanto se referiam à importância da introdução do tema pelos alunos e, depois, com 14 turnos de Danilo e 14 de Suélen enquanto se referiam ao valor imbricado no papel ou na voz do professor em sala de aula. Alguns turnos se completam (por exemplo, os turnos 796, 808, 816 a 823), pois, por várias vezes, Danilo e Suélen estão em pleno acordo sobre não generalizar, sobre a importância da participação do aluno - elementos que já haviam sido trabalhados quando elaboraram uma oficina de formação em conjunto sobre estereótipos.

Com relação os mecanismos de textualização, observamos que a série coesiva nominal ganha novos contornos entre a generalização e a particularização (verité, réalité, commentaireslà, particularité, choses ponctuelles, situations particulières, découverte, intérêt de savoir). Os lexemas verbais desse excerto trazem informações que podem ser interpretadas à luz das modalizações apreciativas. Através dessas categorias pudemos identificar ações com valor positivo e com valor negativo dos professores e dos alunos, bem como ações ligadas aos documentos e atividades, como vemos nos exemplos a seguir. As modalizações apreciativas (positivas e negativas) e as modalizações deônticas (on ne peut pas), marcadas a seguir com negrito mostram como os professores avaliam suas ações (sublinhadas), como vemos no quadro a seguir.

\section{Exemplos das modalizações do Excerto em análise 4}

793S: comment tu penses que c'est/j'aurais/ahn je devrais faire une autre activité plus intéressante ou:: la discussion

794D:

795S:

796D: j'ai beaucoup aimé j'avais pas pensé à ça... c'est/c'est vrai que un regard de l'interculturel c'est/c'est dans ces commentaires-là 
799S: parce que c'est intéressant de voir des situations particulières... je ne parle en France c'est comme ça... en France au Brésil c'est comme ça

801S: je pense que l'intéressant c'est entrer dans le contexte des élèves

\section{S: c'est (naturel)}

820D: la particularité ce sont des choses qui se passent qu'on pas/ on peut pas hyper généraliser

822D: $\quad$ on ne peut pas simplifier les choses et/c'est de/de/normalement des:: choses ponctuelles

823S: \{oui bon je préfère aller vers la découverte... EUX ils posent des questions... c'est pas intéressant de lire un document la date de la fête des voisins... comment ça a commencé... donc:: c'est pour ça que c'est intéressant de déclencher l'intérêt de savoir

825S: parce que il y a des moments que la personne demande « ah mais il y a une date spécifique » et je dis « oui c'est le vingt neuf/dix-neuvième... » et et::c'est plus intéressant que lire un document qu'ils vont rien remplir ça fait pas partie de/de/du contexte brésilien:: mais en fait il y a un moment que j'ai:: il y a eu un moment de généralisation... c'était... bon laisse tomber... mais en fait on est tellement habitué dans les généralisations que... on se rend compte qu'on a généralisé les choses... on dit « ahn mais en France ahn:: il y a beaucoup d'indifférence... il y a un repli sur soi » il y avait un sondage c'est un sondage... ça ((montre le sondage))

Sintetizando o que vimos nos exemplos acima, por meio das modalizações e dos lexemas verbais dos exemplos, elaboramos o quadro abaixo com as ações consideradas como positivas e negativas referente ao trabalho com os conteúdos culturais, segundo Danilo e Suélen:

\begin{tabular}{|c|c|c|}
\hline & Ações com valor positivo & Ações com valor negativo \\
\hline Professores & $\begin{array}{l}\text { faire une activité } \\
\text { (fazer uma atividade [que dê voz aos alunos } \\
\text { para comentarem, como a da Suélen]) } \\
\text { voir situations particulières } \\
\text { (ver situações particulares) } \\
\text { entrer dans le contexte des élèves } \\
\text { (entrar no contexto dos alunos) } \\
\text { déclencher l'intérêt du savoir } \\
\text { (despertar o interesse do saber) } \\
\text { aller vers la découverte } \\
\text { (ir pela descoberta/ fazer descobrir) }\end{array}$ & $\begin{array}{l}\text { parler } \\
\quad \text { (falar [com valor de verdade válida para } \\
\text { todos]) } \\
\text { hyper-généraliser } \\
\quad \text { (hipergeneralizar ) } \\
\text { simplifier } \\
\quad \text { (simplificar) } \\
\text { être habitué dans les généralisations } \\
\quad \text { (estar acostumado com as generalizações ) }\end{array}$ \\
\hline Alunos & $\begin{array}{l}\text { faire des commentaires } \\
\text { (fazer comentários) } \\
\text { poser des questions } \\
\text { (perguntar) }\end{array}$ & $\begin{array}{l}\text { prendre pour des vérités } \\
\text { (tomar como verdade) }\end{array}$ \\
\hline
\end{tabular}




\begin{tabular}{|c|c|c|}
\hline $\begin{array}{l}\text { Conteúdos } \\
\text { culturais } \\
\text { (textos, } \\
\text { atividade, } \\
\text { comentários } \\
\text { dos alunos) }\end{array}$ & $\begin{array}{l}\text { venir d'eux } \\
\text { (vir deles [dos alunos] (comentários)) } \\
\text { exprimer ce qui est l'interculturel } \\
\text { (expressar o intercultural (comentários dos } \\
\text { alunos)) }\end{array}$ & $\begin{array}{l}\text { lire un document } \\
\text { (ler um documento) } \\
\text { rien remplir [les questions/les activités] } \\
\quad \text { (não preencher nada [as perguntas/ as } \\
\text { atividades) } \\
\text { ne pas faire partie du contexte brésilien } \\
\quad \text { (não fazer parte do contexto) }\end{array}$ \\
\hline
\end{tabular}

Tabela 28: Ações relacionadas aos conteúdos culturais no excerto 4 da ACC

As vozes que aparecem indicadas por verbos discendi "perguntar", “dizer", "exprimir" remetem aos alunos ("la personne demande”) e à autoridade presente na voz dos professores ("comme si on disait il y a une verité", "si on dit des choses qu'on fait eles sont prises par des vérités normalment”, “quand ça vient d'eux, ça exprime exactement ça ce qui est l'interculturel la particularité”). Através do dêitico “on”, Danilo e Suélen definem e caracterizam ações que se referem aos professores em geral ("on peut pas hyper généraliser", "notre position a un impact dans la salle de classe”). Esse “on”, assim como o "notre”, identifica uma voz do métier, pois se refere não somente aos dois, mas aos professores em geral, especialmente aos de língua estrangeira.

Como vimos na Tabela 28, as modalizações apreciativas positivas estão ligadas às ações que ambos consideram como positivas: “é interessante ver situações particulares”; “é genial”; “é natural”. Danilo emprega uma série de modalizações lógicas com valor de certeza/verdade ( “c'est vrai”), porém, nesse excerto, elas não exercem uma função de verdade, mas são usadas para concordar com a colega. Além disso, Danilo usa modalização deôntica ( “on ne peut pas”), sendo assertivo com o fato de não generalizar. Poderíamos assim inferir que as prescrições quanto à não generalização são bastante fortes e já foram interiorizadas pelos professores.

Para falar do tratamento dos conteúdos culturais até o turno 825, Suélen sempre se coloca através do dêitico " $j e$ ", definindo suas ações separadamente das ações dos alunos, enquanto Danilo usa mais o "on" e em geral o verbo "discuter", o que aponta para uma definição não muito delineada de sua prática com esses assuntos. No turno 825, Suélen, que até então usava o "je”, passa a usar o "on" quando ela se dá conta e fala de um momento que vai de encontro ao que ela afirmava até então: apesar de valorizar o particular, houve um momento de generalização em sua aula ("en fait on est tellement habitué dans les généralisations que... on se rend compte qu'on a généralisé les choses... on dit "ahn mais en France ahn:: il y a beaucoup d'indifférence... il y a un repli sur soi »"). Esse "on" que aparece, na verdade engloba o "je”, pois é inclusivo, ou seja 
ela está se reportando ao momento de sua aula. Por outro lado, podemos refletir sobre a mudança de "je" para "on" ao longo da autoconfrontação.

Aprofundando a análise dessa sentença, levantamos a hipótese de que houve um momento de tomada de consciência, através de indícios da voz da fala egocêntrica.

825S: mais en fait il y a un moment que j'ai:: il y a eu un moment de généralisation... c'était... bon laisse tomber... mais en fait on est tellement habitué dans les généralisations que... on se rend compte qu’on a généralisé les choses...

Esse excerto parece ecoar de um diálogo interior de Suélen consigo mesma. Embora nem tudo tenha sido verbalizado, vemos que nesse pequeno excerto é como se ela pensasse introspectivamente, tendo a si mesma como destinatário principal, como se a figura de seu colega e da figura da pesquisadora quase desaparecem. Além disso, algumas marcas da fala egocêntrica caracterizam esse momento: as pausas (“j'ai::”, “c'était...”) e hesitações ("un moment que j'ai" "un moment de généralisation”), indicam que ela estava refletindo naquele momento sobre aquela situação, foi ali que ela pode perceber que também havia momentos de generalização em suas aulas. Os marcadores "en fait" e "bon"constituem marcas de um momento de reflexão. O primeiro ("en fait") possivelmente aponta para um pensamento interior, levando em conta ela mesma como destinatária, enquanto o segundo, acompanhado da expressão equivalente a "deixa pra lá" (“bon laisse tomber”), evidencia o pensamento para o outro, a retomada dos destinatários presentes. A tomada de consciência nesse excerto fica ainda mais evidente diante da mudança de "je" para "il y a" et depois para "on".

O fato de deixar de lado o tratamento dessa questão foi uma opção de Suélen, que já havia até ali, levantado muitos indícios do seu trabalho com os conteúdos culturais. A tomada de consciência nesse pequeno excerto permitirá que ela desenvolva, mais a frente, o contexto de seu trabalho, especialmente no que tange às prescrições.

Observamos a seguir como se configuram o agir do professor de Danilo e de Suélen:

\section{Análise das figuras de ação de Danilo do Excerto em análise 4}

794D: \{non... je pense que c'est génial... c'est c'est //j'ai beaucoup aimé j’avais
pas pensé à ça... c'est/c'est vrai que un regard de l'interculturel c'est/c'est dans ces commentaires-
là // ehn:: non c'est très intéressant // uhum // oui // et quand le professeur parle c'est toujours/
c’est comme si on disait il y a une vérité ahn:: // qu'est valable pour tous // ouais... c'est vrai c'est
vrai quand on dit ahn:: quand on dit des choses // ouais quand on dit des choses comme ça ils
prennent pour des vérités // même si/je me rappelle // notre position ... ouais exactement... le


premier jour/au niveau un ils ont dit j'écrivais le i je ne fais pas un point sur le... je fais une petite boule et ils m'ont demandé « ah les français font comme ça? » ((risos)) une chose hyper particulière [moi j'écris des i avec/ je fais pas comme ça non je fais jamais ça je/je fais pas un point je fais une boule] ${ }^{113}$ ahn « les français font comme ça pour les français c'est ça/c'est comme ça ?» « non ça c'est moi » ((risos)) //si on dit des choses qu'on fait elles sont prises pour des vérités normalement //c'est vrai que:: quand ça vient d'eux ((risos)) c'est ça/ exprime exactement ça ce qui est l'interculturel:: la particularité // la particularité ce sont des choses qui se passent qu'on pas/ on peut pas hyper généraliser//on ne peut pas simplifier les choses et/c'est de/de/ normalement des:: choses ponctuelles // uhum //uhum // uhum // ouais

Legenda: Roxo - ocorrência / Azul - acontecimento passado / Laranja - definição / Verde - experiência / Vermelho - canônica

Nessa sequência de Danilo, o foco central parece ser a formulação de sua experiência, mas no decorrer do diálogo há a inserção de um caso ilustrativo e duas sequências com frases mais impessoais em que os actantes não são tematizados.

A partir do que havia ouvido de Suélen no excerto anterior, Danilo concorda e afirma que "o intercultural" estaria nos comentários espontâneos dos alunos, pois a voz e a figura do professor na sala de aula pode ter uma carga de autoridade mais forte do que talvez deveria. Ele ilustra essa ideia através de uma ação acontecimento passado, em que os alunos generalizaram sua forma de escrever a letra " $\mathrm{i}$ " manuscrita na lousa, imaginando que todos os franceses escrevessem assim. Ele retoma a elaboração de sua experiência, ilustrada pelo caso contado, que as coisas que os professores dizem e fazem são compreendidas pelos alunos como verdades absolutas.

Ele prossegue, retomando o que havia dito e ampliando sua definição do que seria esse trabalho: "quando [os comentários] vêm dos alunos, eles exprimem exatamente o que é o intercultural", assim, "as particularidades são coisas que acontecem que não se pode hipergeneralizar", "são normalmente coisas pontuais". Lembramos que só consideramos figura de ação definição quando as construções impessoais tematizam os conteúdos culturais, criando uma série coesiva a partir da mesma unidade-fonte.

Ele representa por meio das modalizações deônticas uma prescrição que já interiorizou: "não se pode hiper-generalizar", "não se pode simplificar", mostrando-se de acordo com as prescrições didáticas que se colocam contra os estereótipos.

\footnotetext{
${ }^{113} \mathrm{O}$ trecho entre colchetes é uma figura de ação experiencia, mas se refere à escrita, assim, não cabe para a análise. Dessa forma, estamos considerando comodentro do acontecimento passado, porque se refere à escrita e não ao trabalho de ensino com conteúdos culturais.
} 
Vejamos as figuras de ação nas falas de Suélen. No caso, a figura de ação experiência que encontramos não se configura com os advérbios de frequência (normalement, toujours), mas com o presente genérico apenas. Imaginamos que isso se deva também ao fato de que, diferente dos conteúdos linguísticos, a inserção dos conteúdos culturais ocorra com menos frequência, dispensando a marcação explícita desses advérbios.

\section{Análise das figuras de ação de Suélen do Excerto em análise 4}

793S: comment tu penses que c'est/j’aurais/ahn je devrais faire une autre activité plus intéressante ou:: la discussion // laisser... laisser naturel comme ça? sans...//uhum//parce que c'est intéressant de voir des situations particulières...je ne parle en France c'est comme ça... en France au Brésil c'est comme ça // je pense que l'intéressant c'est entrer dans le contexte des élèves //c'est (naturel) //uhum //uhum je ne me sens pas capable de //les français sont froids // oui // oui parce que notre position:: a un impact dans une salle de classe // ((risos)) //uhum // la particularité //oui// oui bon je préfère aller vers la découverte... EUX ils posent des questions... c'est pas intéressant de lire un document la date de la fête des voisins... comment ça a commencé... donc:: c'est pour ça que c'est intéressant de déclencher l'intérêt de savoir //parce que il y a des moments que la personne demande « ah mais il y a une date spécifique » et je dis « oui c'est le vingt neuf/dix-neuvième... » et et::c'est plus intéressant que lire un document qu'ils vont rien remplir ça fait pas partie de/de/du contexte brésilien:: mais en fait il y a un moment que j'ai:: il y a eu un moment de généralisation... c'était... bon laisse tomber... mais en fait on est tellement habitué dans les généralisations que... on se rend compte qu’on a généralisé les choses... on dit « ahn mais en France ahn:: il y a beaucoup d'indifférence... il y a un repli sur soi » il y avait un sondage c'est un sondage... ça ((montre le sondage)) //et:: ça/ça généralise... mais j’ai voulu [quand]-même apporter ce document //pour montrer que ça existe //ce type d'activité sociale tu fais des sondages tu réponds à des questions

Valendo-se da situação do vídeo trazida no excerto anterior, Suélen prossegue elaborando sua experiência ao longo das interações com Danilo. No curto trecho inicial, ela tematiza através de frases impessoais que o interessante é "olhar situações particulares", "entrar no contexto dos alunos" e "despertar o interesse do saber", identificados como figura de ação definição por indicarem uma abstração, sem focalizar os actantes, tampouco o eixo temporal. Em seguida, de maneira mais contextualizada, ela fala da cristalização de suas experiências sobre as formas de lidar com os conteúdos culturais: ela prefere "fazer descobrir", que os alunos "façam perguntas". Ao mesmo tempo ela consegue fazer uma autocrítica dizendo o que não se sente capaz de fazer [comparações entre as culturas] e que, apesar de valorizar a particularidade, ela tomou consciência de que generaliza algumas situações. 


\section{Excerto 5: Quando confrontamos nossas práticas...}

No excerto que vemos a seguir, toda a conversa entre os dois professores parece despertar em Danilo uma reflexão sobre sua aula. Vejamos:

Excerto em análise 5: Autoconfrontação Cruzada - Tratamento dos conteúdos culturais através das diferenças e da comparação entre a aula do Danilo e Suélen

832D: (ah regarde) le/le... j'ai commencé à penser un truc là maintenant donc parce que on a discuté dans/dans/dans/dans la discussion... ahn:: dans entre/entretien tout seul où::/où:: on parlait des/des activités... et on a beaucoup discuté de ça parce que:: les activités qui sont dans le livre c'est faire de la voile faire du

833E: $\quad$ Shum d'équitation, du ski

834D: $\quad$ d'équitation de l'escrime du ski ((risos))

835S: ça ne fait pas partie de la/de leur réalité

836D: $\quad$ ç̧a ne fait pas partie du tout... du tout du tout et:: peut-être je sais pas toi tu as/tu as une ahn::/tu as aperçu que là on a une discussion très française peut-être mais qui peutêtre ça peut déclencher quelque chose

837S:

\{uhum

838D: qui peuv/qui peut venir d'eux et:: tu as même donné un moment où on a discuté de ça... 839S: uhum

840D: \{tu vois et::/et ça c'est/c'est/ça a commencé par eux quand moi quand j'ai travaillé les/les sports et tout ça j'ai travaillé d'une manière je pen/je/je pensais plutôt à « faire du » ou « aller au » et tout ça alors je fais

841S:

\{pensé/tu as pensé plutôt à la forme?

842D: \{à la forme j'ai pas du tout pensé au côté interculturel qui pourrait sortir je pourrais bien demander (d'eux)... « est-ce que vous/vous/vous faites ça ? vous faites de l'équitation ? vous faites du ski ? vous faites... » ça pourrait déclencher d'autres choses des/des choses comme ça... c'est vrai que c'est un peu difficile différent de travailler avec le niveau quatre et le niveau un... parce qu'au niveau un la discussion ne vais pas aller on ne va pas arriver à raconter une histoire 843S:

844D: \{uhum \{mais:: ça si/si/si je leur avais demandé déjà « vous faites ça ?» peut-être que ça pourrait déjà être une ouverture à l'interculturel... « non professeur on joue du football »... et là c'est déjà:: 845S: 846D: \{uhum... uhum $\{\ll$ on fait du football on ne fait pas du ski on fait du football » ((risos) $)$ et:: « je fais du football... je fais je:: »

Danilo apresenta indícios de que estava refletindo sobre sua aula, ele diz "ah, eu comecei a pensar numa coisa agora" e se remete à entrevista em autoconfrontação simples ("porque na discussão, na entrevista sozinho, a gente falava das atividades e a gente discutiu bastante"). Trazemos a seguir o excerto da ACS de Danilo, onde esse tema foi evocado. 


\section{Excerto da autoconfrontação simples de Danilo -}

E: je sais que tu suis les exemples du livre, mais ce sont quand-même des phrases, donc «vous faites du théâtre, du vélo, vous faites de la voile, vous faites de la photo, vous faites de l'équitation, vous faites de l'escrime $» .$. ahn... de toute façon ce sont des affirmationsoui... je sais pas...

$\mathrm{D}$ : oui

$\mathrm{E}: \mathrm{tu} / \mathrm{tu} / \mathrm{tu}$ n'aime/ ahn... je sais pas... est-ce qu'ils connaissent ces sports ? tu penses...

$\mathrm{D}$ : ces sports qui sont là... l'escrime, la voile... c'est vrai qu'ils sont peu... ahn... excentriques... de l'équitation de l'escrime... oui

$\mathrm{E}$ : enfin...et et au moment où tu faisais ça tu posais même pas la question... je veux dire « est-ce que vous faite de l'escrime ? est-ce que vous faite du... de... je sais pas... de l'équitation?»

$\mathrm{D}:$ non... je leur pose pas cette question

E : parce que... bon... je sais que tu es concentré sur les prépositions

$\mathrm{D}$ : oui je suis concentré sur ça / peut-être que c'est intéressant [de demander ça]

$\mathrm{E}$ : oui parce que...la question que j'ai eu à ce moment-là c'était... on travaille/ on peut [travailler]... surla forme et sur les structures et:: je sais pas... tu faisais pas le rapport avec le....

$\mathrm{D}$ : non... c'est vrai que c'est intéressant... j'ai jamais pensé à ça... normalement... quand...je pense que... ouais/ je pense que quand on entre dans un point langue...je... «vous aimez»... oui c'est vrai... non je/ je/ je pense que... là un autre point langue avec des...les conjugaison du verbe aller je pense que je ne leur ai pas demandé ce/ où ils font ce qu'il font...ahn... là non plus... oui «aller à préposition » je ne leur demande pas « vous allez au cinéma ? vous allez au théâtre ? » et là quand on parle d'« aimer » probablement je leur demande pas... on/ ils le font après... ((risos)) normalement je prévois ça pour/ pour/ pour la partie où... pour la production orale... pour la partie où...avec cherchez quelqu'un qui... les sondages... le moment où on interroge l'élève à côté...

(...)

D : c'est exactement ça... là je me concentre tout à fait sur la forme et... je ne profite pas de ce moment pour parler à eux sur leur vie... pour leur demander de leur vie.

Nesse excerto da ACS, ao assistir à aula de Danilo, a pesquisadora pergunta se os alunos conheciam os esportes que estavam sendo apresentados na parte gramatical como exemplos de verbo e preposição (faire de la voile, faire de l'escrime) e pergunta se ele não havia perguntado aos alunos se eles praticavam aqueles esportes. Danilo, com expressões de surpresa ("c'est vrai", “j'avais pas pensé à ça”), parece tomar consciência e observar aquela situação a partir do ponto de vista da pesquisadora. Ele olha para o livro e consulta os "point langue" anteriores, verificando que em nenhum deles ele havia perguntado aos alunos se faziam aquelas atividades. Ao pensar sobre isso, ele se dá conta que guarda esse momento ligado a compreensão do sentido para o momento de produção oral, para atividades de falar com o colega e perguntar-lhe algo. Ele conclui dizendo que estava concentrado na forma, na estrutura gramatical e que não aproveita [normalmente] esse espaço para perguntar aos alunos sobre suas vidas.

Retomando a análise da ACC, vemos que no excerto há uma predominância de turnos de Danilo (8 turnos), ele aponta para o fato de que os conteúdos do livro eram ligados às atividades 
de velejar, fazer equitação, esquiar e Suélen ressalta o fato de que são atividades que não fazem parte da realidade dos alunos. Danilo concorda e faz uma comparação entre sua prática e a de sua colega: enquanto ela percebeu uma "discussão francesa" (Fête des Voisins), que poderia disparar alguns comentários dos alunos, Danilo conta que estava concentrado mais nas preposições ("faire $d u$, faire de la”), isso é, mais na forma que no conteúdo. Ele diz que não pensou no lado intercultural que poderia ser evocado se tivesse perguntado aos alunos se eles praticavam aqueles esportes.

Nos mecanismos de textualização, podemos observar a continuação da série coesiva nominal que retoma "intercultural" como adjetivo "lado intercultural" e como nome "abertura ao intercultural" ("coté interculturel”, “ouverture à l'interculturel”). Nos lexemas verbais identificamos novamente as ações atribuídas aos professores e aos alunos:

\begin{tabular}{|l|l|l|}
\hline & Suélen & Danilo \\
\hline $\begin{array}{l}\text { Ações } \\
\text { realizadas }\end{array}$ & $\begin{array}{l}\text { percevoir une discussion très française qui } \\
\text { pourrait déclencher quelque chose } \\
\text { (perceber uma discussão que poderia } \\
\text { disparar algo dos alunos) } \\
\text { donner un moment [pour la discussion] } \\
\text { (dar um momento [para a discussão]) } \\
\text { commencer par eux } \\
\text { (começar pelos alunos) }\end{array}$ & $\begin{array}{l}\text { ne pas penser au cóterculturel } \\
\text { (não pensar no lado intercultural) } \\
\text { penser plutôt à la forme } \\
\text { (pensar mais na forma) }\end{array}$ \\
\hline $\begin{array}{l}\text { Ações } \\
\text { possíveis }\end{array}$ & -- & $\begin{array}{l}\text { demander[une question personelle/ réelle/de } \\
\text { leur contexte] } \\
\text { (perguntar uma questão pessoal/ real/ do } \\
\text { contexto deles) }\end{array}$ \\
\hline $\begin{array}{l}\text { Resultados } \\
\text { prováveis }\end{array}$ & -- & $\begin{array}{l}\text { être une ouverture à l'interculturel } \\
\text { (se tivesse perguntado, isso poderia ser } \\
\text { uma abertura ao intercultural) }\end{array}$ \\
\hline
\end{tabular}

Tabela 29: Ações realizadas, ações possíveis e resultados prováveis no excerto 5 da ACC

Nesse excerto, Danilo traz as vozes dos alunos na sala de aula através de discurso direto e também sua voz na sala de aula ("je pourrais bien demander”). Mas não só isso, ele traz também traços de sua fala interior, por meio de uma fala egocêntrica reconstituída identificada através do verbo "pensar", da fala entrecortada, das hesitações. Não houve mudança de destinatário, mas essa fala o permitirá, mais tarde (excerto 7), reorganizar seu pensamento. Vejamos: 
840D: \{tu vois et::/et ça c'est/c'est/ça a commencé par eux quand moi quand j'ai travaillé les/les sports et tout ça j'ai travaillé d'une manière je pen/je/je pensais plutôt à « faire du » ou « aller au » et tout ça alors je fais

842D: \{à la forme j'ai pas du tout pensé au côté interculturel qui pourrait sortir (...)

Podemos dizer que há uma comparação ou uma contraposição das práticas de aula de Danilo e Suélen porque os dêiticos de pessoa que aparecem no excerto são "tu", "toi" em oposição a "moi", "je". Nesse excerto, nenhum dos dois professores usa o "on" para falar dos professores em geral; em um primeiro momento, Danilo o empra para referir-se à ele e à pesquisadora ("on a discuté dans l'entretien tout seul") e depois para remete-se somente aos alunos ("on ne va pas arriver à raconter une histoire", "on fait du football").

Com relação às modalizações, vemos que Danilo emprega uma lógica com valor de certeza seguida de uma modalização apreciativa negativa para enfatizar a diferença de se trabalhar em níveis iniciais e intermediários ("C'est vrai que c'est difficille / différent"). Há também uma série de modalizações lógicas de possibilidade através do verbo "poder", que mostram a reflexão de Danilo sobre o que seria possível de se fazer em sua aula ("ça [poser des questions aux éléves] peut déclencher quelque chose qui peut venir d'eux", "ça pourrait déjà être une ouverture à l'interculturel, "ça pourrait ouvrir à une discussion interculturelle").Nesse sentido, podemos retomar Clot (2001), quando o autor diz que as escolhas impedidas, contrariadas e não realizadas constituem o real da atividade. Retomando ainda Vygotki (1997), podemos lembrar que o homem está cheio a cada minuto de possibilidades. Essas, de Danilo, foram as atividades que poderiam ter sido realizadas.

Danilo configura seu agir através das figuras de ação ocorrência, reconstituindo o que vira tanto em seu vídeo, quanto no de Suélen. A restituição do vídeo permite-lhe imaginar o que poderia ter sido feito por ele: poderia ter perguntado se os alunos praticam aqueles esportes e, dependendo do que resultasse, haveria uma abertura ao intercultural, o que dispararia outras contribuições. Danilo pondera sobre isso, afirmando que há uma diferença entre trabalhar em nível iniciante e nível intermediário numa classe de língua estrangeira, pois os debutantes não conseguiriam contar uma história usando a língua estrangeira. 


\section{Análise das figuras de ação de Danilo do Excerto em análise 5}

832D: (ah regarde) le/le... j'ai commencé à penser un truc là maintenant donc parce que on a discuté dans/dans/dans/dans la discussion... ahn:: dans entre/entretien tout seul où::/où:: on parlait des/des activités... et on a beaucoup discuté de ça parce que:: les activités qui sont dans le livre c'est faire de la voile faire du //de l'équitation de l'escrime du ski ((risos)) //ça ne fait pas partie du tout... du tout du tout et:: peut-être je sais pas toi tu as/tu as une ahn::/tu as aperçu que là on a une discussion très française peut-être mais qui peut-être ça peut déclencher quelque chose // qui peuv/qui peut venir d'eux et:: tu as même donné un moment où on a discuté de ça... // tu vois et::/et ça c'est/c'est/ça a commencé par eux quand moi quand j'ai travaillé les/les sports et tout ça j'ai travaillé d'une manière je pen/je/je pensais plutôt à « faire du » ou «aller au » et tout ça alors je fais // à la forme j'ai pas du tout pensé au côté interculturel qui pourrait sortir je pourrais bien demander (d'eux)... « est-ce que vous/vous/vous faites ça ? vous faites de l'équitation ? vous faites du ski ? vous faites... » ça pourrait déclencher d'autres choses des/des choses comme ça... c'est vrai que c'est un peu difficile différent de travailler avec le niveau quatre et le niveau un... parce qu'au niveau un la discussion ne va pas aller on ne va pas arriver à raconter une histoire// mais:: ça si/si/si je leur avais demandé déjà « vous faites ça ? » peut-être que ça pourrait déjà être une ouverture à l'interculturel... «non professeur on joue du football »... et là c'est déjà:: //« on fait du football on ne fait pas du ski on fait du football » ((risos)) et:: « je fais du football... je fais je::»

Legenda: Roxo - ocorrência / Azul - acontecimento passado / Laranja - definição / Verde - experiência / Vermelho - canônica

Uma vez que estavam no campo das possibilidades, Suélen se sente à vontade para dar sugestões de atividades ao seu colega. É sobre isso que trata o excerto a seguir.

\section{Excerto 6: Quando sugerimos atividades...}

No fragmento que leremos a seguir predominam os turnos de Suélen. Leiamos a continuação da transcrição:

Excerto em análise 6 : Autoconfrontação cruzada - Tratamento dos conteúdos culturais através de uma sugestão de atividade

847S: oui ou peut-être prendre comme c'était dans le moment des olympiades je ne sais pas si c'était à cette époque

848D:

\{uhum

849S:

\{c'était ce moment non? c'était::

850E: oui... peut-être

851D: \{ouais

852S: $\quad$ c'était proche des Jeux Olympiques

853E: c'était cette année

854S: $\quad$ \{peut-être... on a:: ((risos))... [je vais] donner des suggestions...

855D: $\quad$ oui comme ça a été cette année peut-être oui ((risos))

856S: prendre des athlètes brésiliens quels sont les sports qu'ils/qu'ils font

857D: uhum 
858S: ça/ça fait partie de notre réalité et peut-être qu'ils les connaissent pas... on ne sait pas qu'il y a des... un brésilien qui c'est très bon dans l'équitation... (tu savais?) 859D:

860E:

faisait de la voile

861S: oui c'était le...

862D: $\{$ Amyr Klynk ((risos))

863E: $\quad$ ((risos))

864S: $\quad$ Lle brésilien qui a gagné trois médailles

865D: oui... oui

866S: c'est intéressant d'apporter ces données

867D: uhum... oui c'est vrai

868S: $\quad \quad$ il y a aucun brésilien qui fait de l'escrime hein? ((risos))

869D: ((risos)) c'est vrai

870E: ((risos))

871S: il y a... comment s'appelle la:: la lutte grec romana grega-romana ((risos))

872E et D: ((risos))

873S: c'est/c'est intéressant qu'il y a plein des choses de l'interculturel mais on ne voit pas... on ne voit pas

874D: \{ on ne voit pas... non moi ça c'est assez/ (comme) je parle maintenant je commence à réfléchir à mon cours et j'ai vu ah mais c'est vrai j'aurais pu demander à eux s'ils le font et ça pourrait ouvrir à une discussion in/interculturelle (je l'ai pas fait) 875S:

876D: \{oui... à la forme

$\{()$ là je suis préoccupé de « faire du » « aller au»

Uma prática recorrente entre os professores que partilham o mesmo contexto de trabalho, algo que seguramente ocorre no contexto dos Cursos Extracurriculares, é pedir e dar sugestões de atividades ao colega. Nesse excerto, Suélen pensa em uma sugestão de atividade para aquele momento da aula de Danilo, em que trabalhava o conteúdo das atividades com o verbo faire e as preposições, seguida de esportes e atividades. Já que a aula do colega pautava-se em atividades e esportes, Suélen relaciona com o momento contextual dos alunos, que estavam na época dos Jogos Olímpicos, mostrando que poderia ser feita uma atividade dentro desse tema. Ela sugere levantar os atletas brasileiros de destaque e relacioná-los com os esportes que praticam, mesmo os não tão usuais, como equitação, luta greco-romana ou esgrima, e trazer esses dados para os alunos com o número de medalhas, por exemplo. Suélen conclui que há muitas coisas relacionadas aos conteúdos culturais que os professores não veem. Em seguida, Danilo retoma o que dizia antes, explicitando que naquele momento da entrevista está pensando em sua aula e que se tivesse perguntado, poderia ter gerado uma discussão em torno dos conteúdos culturais. 
Como esse excerto se configura quase como uma digressão em que Suélen dá uma sugestão de atividade, destacaremos as categorias de análise que permitam responder a nossas perguntas de pesquisa.

Na série coesiva nominal, aparecem novos elementos de retomada dos conteúdos culturais: "coisas do intercultural" e "discussão intercultural” ("choses de l'interculturel”, "discussion interculturelle”), expressões que reiteram a ideia de indefinição e imprecisão do trabalho com os conteúdos culturais em classe.

Nos lexemas verbais, podemos identificar os que se associam às modalizações apreciativas positivas. Para Suélen, são "pegar os atletas e os esportes", "trazer dados [dos atletas e esportes]", "fazer parte da nossa realidade", "não conhecer [esses dados]" ("prendre les athlètes et les sports", “apporter des données", "faire partie de notre réalité", "ne pas connaître ces données"). Vemos que ela mostra uma preocupação em trazer informações novas para a sala, sobretudo aquelas que façam parte da realidade dos alunos. Os verbos que aparecem na voz Danilo são "perguntar", essas perguntas podem "abrir uma discussão intercultural"("demander”, “ouvir à une discussion interculturelle”). Eles parecem se surpreender com o fato de que, assim como os professores em geral, "não veem coisas do intercultural" ( "qu'il y a plein des choses de l'interculturel mais on ne voit pas"). Não "ver" ou não perceber os momentos em que se possa trabalhar os conteúdos culturais poderia ser interpretado de duas formas: por um lado, uma carência ou deficiência por parte da formação do professores com esse objeto e, por outro lado, a própria amplitude do objeto, que ultrapassa uma concepção única, mas perpassa a língua, as produções culturais, os costumes, as relações e a personalidade.

Com relação às modalizações, vemos que Suélen aprecia positivamente a ideia de trazer informações do contexto dos alunos ("c'est intéressant"). Danilo emprega uma modalização pragmática, apontando que poderia ter feito uma pergunta em sua aula ("j'aurais pu demander") e essa pergunta poderia ter gerado uma discussão interessante. Com esse exemplo, vemos, como em Lousada (2006), que as modalizações pragmáticas podem ser uma maneira de revelar o real da atividade, ou seja, as ações que não foram realizadas.

Através de figura de ação ocorrência (marcada pelo discurso interativo, agir contextualizado), Suélen sugere ao colega que ele poderia ter trabalhado com conteúdos das olimpíadas, pois para ela é importante trazer esses dados da realidade do contexto dos alunos. Ela 
conclui sua sugestão observando que "há muitas coisas do intercultural que a gente não vê", para isso Suélen emprega o "on/ a gente” para se referir aos professores de língua estrangeira em geral, grupo no qual ela e Danilo se incluem.

\section{Análise das figuras de ação de Suélen do Excerto em análise 6}

847S: oui ou peut-être prendre comme c'était dans le moment des olympiades je ne sais pas si c'était à cette époque // c'était ce moment non? c'était:: //c'était proche des Jeux Olympiques //peut-être... on a:: ((risos))... [je vais] donner des suggestions... // prendre des athlètes brésiliens quels sont les sports qu'ils/qu'ils font//ça/ça fait partie de notre réalité et peut-être qu'ils les connaissent pas... on ne sait pas qu'il y a des... un brésilien qui c'est très bon dans l'équitation... (tu savais?)//oui c'était le... // le brésilien qui a gagné trois médailles // c'est intéressant d'apporter ces données //il y a aucun brésilien qui fait de l'escrime hein? ((risos)) // il y a... comment s'appelle la:: la lutte grec romana grega-romana ((risos)) //c'est/c'est intéressant qu'il y a plein des choses de l'interculturel mais on ne voit pas... on ne voit pas// oui... à la forme

Legenda: Roxo - ocorrência / Azul - acontecimento passado / Laranja - definição / Verde - experiência / Vermelho - canônica

A ação ocorrência de Danilo no excerto anterior, onde comparou sua aula com a da colega, seguida das contribuições acima de Suélen, permitiu a ele reformular sua fala, observando o que poderia ter sido feito para "dar abertura a uma discussão intercultural". Esse trecho, também calcado no discurso interativo, contextualizado, configura o agir como uma ocorrência. Ao final da reformulação, Danilo parece tomar consciência e verbalizar seu objetivo no momento de sua aula: ele estava, na verdade, preocupado com o conteúdo gramatical (verbo faire acompanhado das preposições contraídas, $d u$, de la).

\section{Análise das figuras de ação de Danilo do Excerto em análise 6}

874D: \{ on ne voit pas... non moi ça c'est assez/ (comme) je parle maintenant je commence à réfléchir à mon cours et j'ai vu ah mais c'est vrai j'aurais pu demander à eux s'ils le font et ça pourrait ouvrir à une discussion in/interculturelle (je l'ai pas fait)// () là je suis préoccupé de « faire du » « aller au»

No fragmento a seguir, Danilo continua a reflexão sobre o que poderia ter ocorrido em sua aula e enfatiza um novo elemento que influencia a organização de seu trabalho e consequentemente do trabalho com os conteúdos culturais: o livro didático. 


\section{Excerto 7: Quando trazemos nossos textos e criamos nossas atividades...}

No segmento a seguir, Danilo e Suélen ponderam sobre os textos e materiais usados em sala de aula, dando atenção especial ao livro que utilizam em seu contexto. Vejamos:

\section{Excerto em análise 7 -Autoconfrontação cruzada: Tratamento dos conteúdos culturais através dos documentos do livro didático e documentos autênticos}

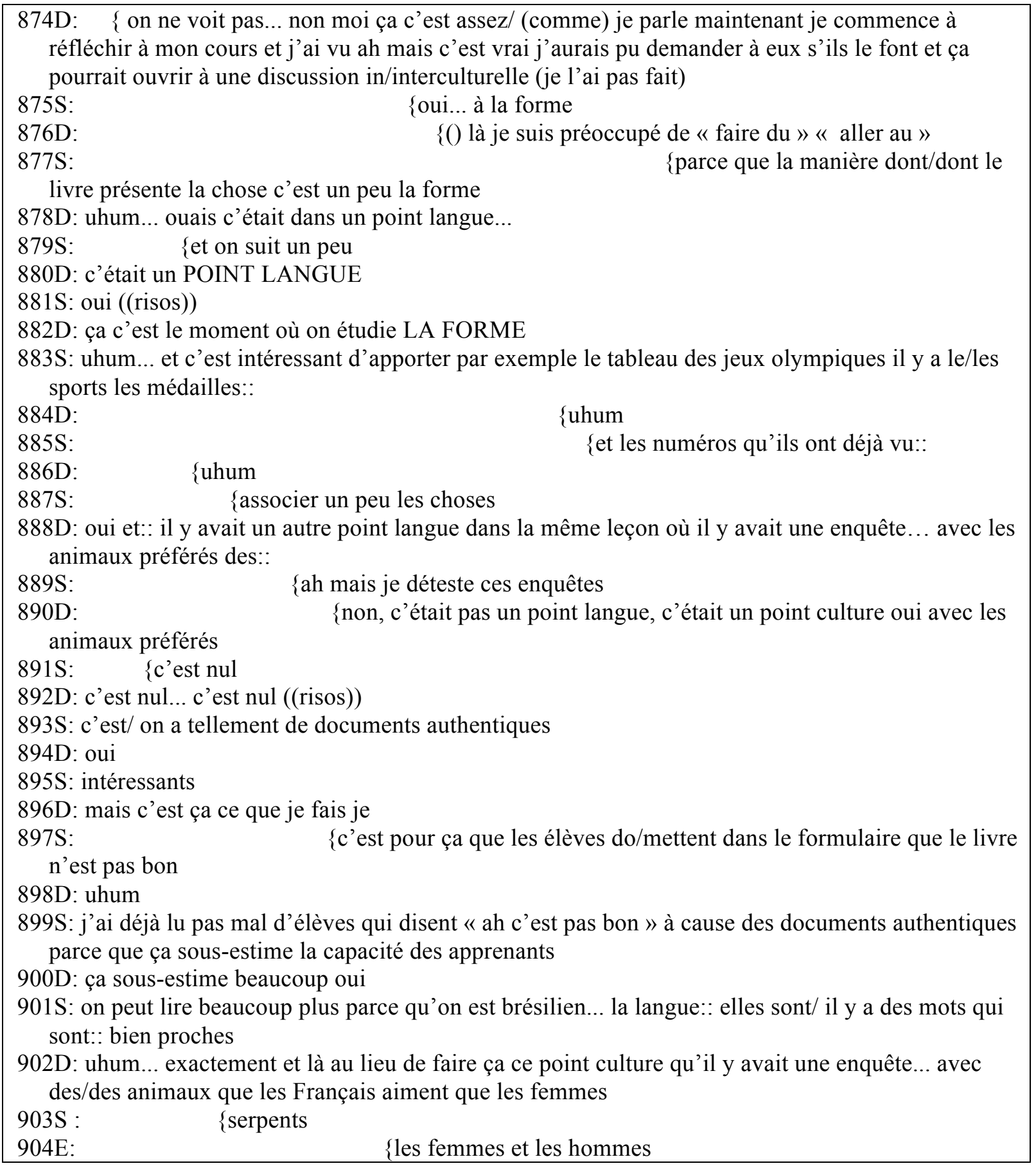


905D: qui les femmes oui

906S: les femmes

907D: \{que les femmes aiment et que les hommes aiment je me suis dit non je vais apporter un

document authentique j'ai apporté le/le filme Prince et Princesse où il y a plusieurs animaux

908S: ah:: oui

909D: et ça/ bon... ça c'est quelque chose d'authentique

910S: ah non oui c'est beaucoup plus:: motivant

911D: motivant... c'était/c'était (cool)

912S:

$\{c$ 'est clair

913D:

\{voilà voilà on a travaillé un vocabulaire qui n'était pas là tout ça

mais::... et:: on essaie de mettre ça pour travailler un peu l'interculturelde toute façon mais:....

914E: on va oui

915D: $\quad$ oui mais il y des choses

916E: $\quad \quad$ il y a quelques minutes

917D: $\quad$ ahn: qui passent et on peut on/on ne voit pas c'est vrai

918S: c'est une discussion qui commence en fait à:: venir l'interculturel comment le traiter n'est-ce pas

919D: $\quad$ \{ouais parce qu'on va aller chercher/je suis allé chercher un film pour les montrer mais voilà juste un peu avant dans un point culture j'aurai pu travailler juste les exemples qui/qui étaient là

920S: uhum

Nesse excerto, vemos uma alternância equilibrada de turnos de fala. Os turnos entrecortados pela voz de um e de outro, e o fato de completarem o turno do colega mostram como os enunciadores estão de acordo. Esse indício é corroborado pelo conteúdo das falas, onde um concorda e completa o que o outro diz. Observa-se que o assunto já havia sido objeto de reflexão e discussão anterior dos professores, pelo grau de assertividade e certeza que empregam, como detalharemos a seguir.

Danilo, ao retomar o excerto anterior (que classificamos de fala egocêntrica reconstituída “je n'ai pas du tout pensé au coté interculturel qui pourrait sortir”), o reformula após a sugestão de atividade de Suélen sobre as olimpíadas. Danilo continua nesse fragmento observando o que teria impedido sua possibilidade de se trabalhar com os conteúdos culturais, ou o que fez efetivamente em vez daquilo. Enquanto trabalhava os verbos com preposições "esquiar, "fazer equitação" etc., Danilo pensava mais na forma do que no conteúdo, pois estava concentrado em trabalhar essa parte gramatical do livro, chamada "point langue" no livro Alter Ego, utilizado nos Cursos Extracurriculares de Francês. Ele enfatiza que estava trabalhando a forma, pois era justamente aquele o momento da aula e do livro em que se trabalharia a parte gramatical. 
Suélen continua sua sugestão de aula e atividade, propondo que se trabalhe com o número de medalhas, sendo os números um conteúdo daquele grupo em nível inicial de francês. Danilo assinala que havia outro momento do livro, chamado "point culture" em que se mostrava os animais preferidos dos homens e das mulheres. Ambos criticam esse documento, afirmando que documentos autênticos são mais interessantes e que, devido à escolha dos textos, muitos alunos reclamam do livro. Danilo diz ainda que ao invés de trabalhar esse "point culture" ele trouxe outro documento: um filme curta-metragem chamado "Prince et Princesse", em que pôde trabalhar um vocabulário que não estava no livro. Ele afirma que tentou trabalhar esse documento para trabalhar o intercultural e conclui que apesar de ter ido buscar um documento autêntico para mostrar aos alunos, ele poderia ter simplesmente trabalhado os exemplos do "point langue" em interação com os alunos.

Os mecanismos de textualização desse excerto apontam novos elementos da série coesiva nominal ligada aos conteúdos culturais: "point culture”, "document authentique”, "des choses qui passent et qu'on ne voit pas”, “exemples [du livre]”, “un film”. Esses elementos passam agora para o campo do livro didático, dos textos e dos documentos trazidos e trabalhados em sala.

Nos lexemas verbais, encontramos uma série de ações contrapostas ligadas ao professor. A primeira oposição é entre "fazer o point culture do livro" ou "trazer um documento autêntico"; a segunda é entre "tentar trabalhar o intercultural" versus "não ver as coisas do intercultural que acontecem"; a terceira é "ir buscar um filme" versus "trabalhar os exemplos que estavam no livro".

Analisando os mecanismos enunciativos, notamos a inserção das vozes dos alunos, que não gostam do livro, porque os documentos subestimam suas capacidades de leitura, enquanto falantes de língua latinas ("ils disent que c'est pas bon”, “ils mettent dans le formulaire”). $\mathrm{O}$ dêitico "on" nesse excerto assume diferentes acepções: os professores dos Cursos Extracurriculares de Francês ("on suit un peu [le livre]”); os professores de língua estrangeira ("on a tellement de documents authentiques", "on essaie de mettre ça pour travailler l'interculturel”, “on ne voit pas”); os brasileiros ("on peut lire beaucoup plus parce qu'on est brésilien”); os professores e alunos (“on étudie la forme”, "on a travaillé un vocabulaire”, “on suit un peu”).

O verbo discendi também nos permite identificar outro momento em que Danilo reconstitui sua fala interior («je me suis dit non je vais apporter un document authentique j'ai 
apporté le/le filme Prince et Princesse »), mostrando que diante dos documentos do livro didático, a seu ver, ruins, ele optou por trazer uma alternativa.

Há também (desde o excerto 6) uma série de jargões profissionais. Danilo emprega jargões ligados ao livro didático (point langue, point culture, guide pédagogique), ao passo que Suélen emprega jargões ligados à teoria que utiliza em sua pesquisa, o Interacionismo Sociodiscursivo (activité sociale, capacité des apprenants) e à didática (documents authentiques, interculturel), sendo que esses ligados à didática são reempregados por Danilo. Ambos empregam jargões referentes aos Cursos Extracurriculares (niveau un, niveau quatre, formulaire). Esses jargões nos permitem identificar, segundo Authier-Revuz (2001) e a exemplo do que foi mostrado por Lousada (2006), uma série de vozes: voz do livro didático, voz da teoria do ISD, voz da didática e, também, voz do métier, nesse caso os Cursos Extracurriculares de Francês.

Com relação às modalizações, há uma divisão clara entre as modalizações apreciativas positivas, que se referem aos documentos autênticos, vistos como mais "autênticos", "motivadores", "legais", "interessantes”, em oposição às modalizações apreciativas negativas que se reportam à enquete presente no "point culture" do livro didático, vista como "ruim", "nula" ( “c'est nul”).

Danilo configura seu agir através da ação ocorrência, referindo-se à sua aula em vídeo, onde estava preocupado com o conteúdo gramatical, na parte chamada "point langue" do livro, o qual ele caracteriza como o momento onde se estuda a "forma" (em oposição ao conteúdo). Ele cita ainda, com eixo temporal não marcado, outro episódio em que havia no livro uma pesquisa sobre os animais preferidos das mulheres e dos homens, que ele e Suélen concordam ser desinteressante. Nesse excerto, ele usa a fala egocêntrica reconstituída para dizer o que pensou no momento ("eu disse a mim mesmo, não, vou trazer um documento autêntico"). Ao invés de trabalhar esse documento, Danilo conta que trabalhou um filme (curta-metragem) chamado "Prince et Princesse", em que apareciam vários animais. Se o documento do livro foi definido como "nulo", ruim e que subestima os alunos, o filme é definido como algo autêntico, motivador e legal. A partir disso, Danilo elabora uma reflexão dizendo: "a gente tenta colocar isso [o filme, documento autêntico] para trabalhar um pouco o intercultural, mas tem coisas que acontecem e a gente não vê”. Essa percepção de Danilo de seu agir - o de não perceber a ocasião de trabalhar os conteúdos culturais -, corrobora o sentido da definição, dada por ele antes: os conteúdos culturais 
seriam um pequeno detalhe, quase uma piada, portanto, passariam despercebidos pelos professores.

\section{Análise das figuras de ação de Danilo do Excerto em análise 7}

874D: \{ on ne voit pas... non moi ça c'est assez/ (comme) je parle maintenant je commence à réfléchir à mon cours et j'ai vu ah mais c'est vrai j'aurais pu demander à eux s'ils le font et ça pourrait ouvrir à une discussion in/interculturelle (je l'ai pas fait) // là je suis préoccupé de « faire du » « aller au » // uhum... ouais c'était dans un point langue... // c'était un POINT LANGUE //ça c'est le moment où on étudie LA FORME// uhum // uhum // oui et:: il y avait un autre point langue dans la même leçon où il y avait une enquête... avec les animaux préférés des::// non, c'était pas un point langue, c'était un point culture oui avec les animaux préférés//c'est nul... c'est nul ((risos)) // oui// mais c'est ça ce que je fais je // uhum // ça sous-estime beaucoup oui // uhum... exactement et là au lieu de faire ça ce point culture qu'il y avait une enquête... avec des/des animaux que les Français aiment que les femmes // qui les femmes oui // que les femmes aiment et que les hommes aiment je me suis dit non je vais apporter un document authentique j'ai apporté le/le filme Prince et Princesse où il y a plusieurs animaux// et ça/ bon... ça c'est quelque chose d'authentique // motivant... c'était/c'était (cool) //voilà voilà on a travaillé un vocabulaire qui n'était pas là tout ça mais:.... et:: on essaie de mettre ça pour travailler un peu l'interculturelde toute façon mais::... //oui mais il y des choses //ahn: qui passent et on peut on/on ne voit pas c'est vrai //ouais parce qu'on va aller chercher/je suis allé chercher un film pour les montrer mais voilà juste un peu avant dans un point culture j'aurai pu travailler juste les exemples qui/qui étaient là //

Legenda: Roxo - ocorrência / Azul - acontecimento passado / Laranja - definição / Verde - experiência / Vermelho - canônica

Nesse trecho, Suélen caracteriza seu agir e o de seu colega de maneira contextualizada, através da figura de ação ocorrência - alternando momentos de pequenos relatos do que acontece na sala de aula e momentos de reflexão com o colega. Em interação e completando as falas de Danilo, pergunta ao colega se em sua aula ele havia pensado mais na forma, ao que ele concorda. Ela então atribui ao livro didático essa preocupação com a forma, dizendo que é essa a maneira como o livro apresenta as coisas [os conteúdos] ("parce que la manière dont/dont le livre présente la chose c'est un peu la forme"). Em uma sentença curta, mas extremamente significativa, ela conclui que eles seguem um pouco essa forma do livro (“et on suit un peu”). Vemos assim que as prescrições do livro didático influenciam de fato o trabalho dos professores e são reconhecidas como tal. Vale apontar que a modalização "un peu”, mostra que, apesar das prescrições, eles ainda inserem nas aulas, à sua maneira, elementos como os documentos autênticos "Prince et Princesse" e "mots échangés dans les immeubles". 
Suélen retoma sua sugestão de trabalhar com os jogos olímpicos e, quando Danilo fala da pesquisa apresentada no livro, ela diz que detesta essas pesquisas, que são "nulas" frente aos documentos autênticos. Na sequência, a professora faz uma reflexão, concluindo que, porque os documentos do livro subestimam a capacidade dos alunos, os alunos colocam no formulário de avaliação de curso ao final do semestre que o livro não é bom pois os tipos de documento ali disponíveis subestimam a capacidade dos alunos brasileiros. Ela aponta que os alunos podem ler facilmente porque são brasileiros e o francês, sendo língua latina, tem palavras próximas do português, assim, o trabalho com documentos autênticos é mais motivador. Suélen termina com uma meta-reflexão: que o tratamento do intercultural é uma discussão que está começando emergir.

\section{Análise das figuras de ação de Suélen do Excerto em análise 7}

875S: $\quad$ \{oui... à la forme //parce que la manière dont/dont le livre présente la chose c'est un peu la forme //et on suit un peu //oui ((risos)) //uhum... et c'est intéressant d'apporter par exemple le tableau des jeux olympiques il y a le/les sports les médailles:: //et les numéros qu'ils ont déjà vu:: //associer un peu les choses //ah mais je déteste ces enquêtes //c'est nul //c'est/on a tellement de documents authentiques //intéressants //c'est pour ça que les élèves do/mettent dans le formulaire que le livre n'est pas bon //j'ai déjà lu pas mal d'élèves qui disent «ah c'est pas bon » à cause des documents authentiques parce que ça sousestime la capacité des apprenants //on peut lire beaucoup plus parce qu'on est brésilien...la langue:: elles sont/ il y a des mots qui sont:: bien proches //serpents // les femmes// ah:: oui //ah non oui c'est beaucoup plus:: motivant //c'est clair // c'est une discussion qui commence en fait à:: venir l'interculturel comment le traiter n'est-ce pas //uhum

Legenda: Roxo - ocorrência / Azul - acontecimento passado / Laranja - definição / Verde - experiência / Vermelho - canônica

\section{Excerto 8: Quando nos encontramos entre a forma e o sentido...}

Após esse momento, a pesquisadora, para concluir, coloca a seguinte pergunta para os participantes: "vocês acham possível trabalhar os dois ao mesmo tempo? A forma, a estrutura e os conteúdos e tentar fazer relações culturais ou vocês acham que um momento deve ser separado do outro?". Vejamos a resposta: 


\section{Excerto em análise 8 - Autoconfrontação cruzada: Tratamento dos conteúdos culturais através da}

possibilidade de trabalhar forma e conteúdo juntos

921E: et juste une question/(une question) enfin est-ce que vous pensez que c'est possible de travailler les deux en même temps? la form/ c'est-à-dire la structure la forme et aussi ahn les contenus essayer de faire les rapports culturels ou vous pensez qu'un moment:: doit être séparé l'un de l'autre?

922D: je pense que:: moi je suis une personne... je suis pas très bien organisé... alors dans ma tête il faut que je sois vraiment très::... très strict avec ce que je vais faire parce que sinon je n'arrive/je n'arrive pas ça déraille...alors si c'est le moment de:: là si c'est le moment de la forme c'est (là) qu'on va travailler la forme et:: peut-être qu'il y a des gens qui/ on dit que les filles arrivent à faire plusieurs choses au [sic] même temps ((risos)) mais:: peut-être c'est/(voilà) probablement mais moi je suis une personne qui doit être vraiment méthodique parce que sinon/ peut-être oui... mais pour moi je pense que ça va pas marcher... là on va penser la forme d'accord on va penser la forme on va regarder (et faire tout ce qu'il faut faire) des/des tableaux et utiliser de la craie colorée pour voir les terminaisons et les prépositions ((risos)) et après peut-être on peut discuter de ça mais en même temps comme ça on va et on revient pour moi c'est difficile

923S: uhum... bon pour moi l'interculturel c'est plutôt travailler la réflexion... ahn:: s'ils ont des outils pour ça... pour la réflexion c'est bien parce que moi j'ai commencé le cours et::/et la réflexion elle est venue avec les outils qu'ils avaient... et ça a donné pas mal des choses... après on a vu en fait on a vu:: la comparaison et:: si je travaille ensemble la fête des voisins avec la comparaison/avec l'interculturel je vais comparer les cultures donc la forme je pense que la grammaire dans ce moment là elle ne tombe pas bien parce que ça va donner des généralisations... des comparaisons par exemple plus moins:.... et il y a des moments que la forme elle peut aider... donner ahn:: des généralisation... par exemple

924D:

925S:

926D: \{on a des contraintes parce qu'on a eu une contrainte et:: ahn:: on doit suivre ça et:: on ne peut pas réfléchir avec certaines contraintes de la forme c'est ça?

927S: non c'est.. par exemple si on/si on/dans ce cas c'est la fête des voisins après il y a un point langue qui parle de/de la comparaison

928D: uhum

929S: plus au moins enfin... si je les travaille ensemble ça va donner des généralisations par exemple au Brésil on est plus généraux

930D: oui mais c'est ça on donne la contrainte de la comparaison là ils doivent utiliser la comparaison

931S:

932D: \{oui mais je ne voulais parce que::

\{oui mais voilà ça/ça/ça empêche

933S: on ne peut pas tra/travailler la forme toujours ensemble

934D: uhum

935S: parce qu'elle ne tombe pas bien... dans le contenu interculturel ahn étudié... il faut voir... il faut voir bien... c'est ça.

936E : c'est bon... je pense... merci.

(fim da entrevista)

De maneira equilibrada, os dois professores dividem os turnos e respondem à questão da pesquisadora. Danilo responde de maneira pessoal, dizendo que ele, particularmente, não consegue fazer os dois ao mesmo tempo. Prefere trabalhar a forma e depois, eventualmente, 
conversar sobre o conteúdo. Já Suélen, através de um ponto de vista mais distanciado, tenta responder definindo o que é o intercultural para ela e fazendo ressalvas sobre quais estruturas gramaticais trabalhar com quais conteúdos, pois, em sua aula, a estrutura gramatical da comparação foi trabalhada justamente com características dos povos, dando margem à generalizações. Isso para ela foi negativo.

Com relação aos mecanismos de textualização, vemos, na série coesiva nominal relativa aos conteúdos culturais, os termos: reflexão, instrumentos, generalizações, comparações, evocados por Suélen ("réflexion”, “outils”, "généralisations”, “comparaisons”); e forma, conteúdo intercultural e discussão intercultural, evocados por Danilo ("forme, "contenu”, “interculturel”). Os lexemas verbais que se remetem às ações dos professores, alunos e dos conteúdos culturais foram os seguintes :

\begin{tabular}{|c|c|c|}
\hline & Ações evocadas por Suélen & Ações evocadas por Danilo \\
\hline Professores & $\begin{array}{l}\text { commencer le cours (le prof) } \\
\text { começar a aula (o professor) }\end{array}$ & $\begin{array}{l}\text { ne pas pouvoir travailler la forme toujours } \\
\text { ensemble } \\
\text { não poder trabalhar a forma sempre junto }\end{array}$ \\
\hline Alunos & $\begin{array}{l}\text { avoir des outils pour la réflexion } \\
\text { ter ferramentas para a reflexão }\end{array}$ & \\
\hline $\begin{array}{l}\text { Conteúdos } \\
\text { culturais } \\
\text { (textos, } \\
\text { atividade, } \\
\text { comentários } \\
\text { dos alunos) }\end{array}$ & $\begin{array}{l}\text { travailler la réflexion } \\
\text { trabalhar a reflexão } \\
\text { la réflexion est venue avec les outils } \\
\text { qu'ils avaient } \\
\text { a reflexão veio com as ferramentas que } \\
\text { eles tinham }\end{array}$ & $\begin{array}{l}\text { ne pas pouvoir réfléchir avec certaines contraintes } \\
\text { de la forme } \\
\text { não poder refletir com algumas coerções da forma } \\
\text { empêcher (la forme empêche la réflexion) } \\
\text { impedir (a forma impede a reflexão) } \\
\text { ne pas tomber bien dans le contenu interculturel (la } \\
\text { forme) } \\
\text { não cair bem com o conteúdo intercultural (a forma) }\end{array}$ \\
\hline
\end{tabular}

Tabela 30: Ações ligadas aos conteúdos culturais no excerto 8 da ACC

Analisando os mecanismos enunciativos, notamos que o "on" assume novamente diferentes funções: há o "on” inclusivo de professores e alunos ("là on va penser à la forme, on va regarder, après on peut discuter de ça”); há o “on” que representa uma voz social ("on dit que les filles arrivent à faire plusieurs choses au [sic] même temps"); o "on" que se refere aos professores ("on peut pas travailler la forme toujours ensemble”, “on a des contraintes", “on doit suivre ça”), indicando a voz do métier de professor de línguas estrangeiras; e o "on" que se reporta aos brasileiros ("au Brésil, on est plus généreux”). Identificar os referentes dos dêiticos permite-nos atribuir o sentido que vem a seguir. 
Com relação às modalizações, temos, pela segunda vez, o aparecimento das modalizações deônticas. Vejamos:

\begin{tabular}{|c|c|c|}
\hline $\begin{array}{l}\text { Modalizações } \\
\text { deônticas }\end{array}$ & Danilo & Suélen \\
\hline $\begin{array}{l}\text { ligadas às } \\
\text { auto- } \\
\text { prescrições }\end{array}$ & $\begin{array}{l}\text { Il faut que je sois vraiment très strict avec ce } \\
\text { que je vais faire } \\
\text { É preciso que eu seja estrito com o que vou } \\
\text { fazer } \\
\text { Je suis une personne qui doit être vraiment } \\
\text { méthodique } \\
\text { Sou uma pessoa que tem que ser realmente } \\
\text { metódica }\end{array}$ & \\
\hline $\begin{array}{l}\text { ligadas às } \\
\text { prescrições }\end{array}$ & $\begin{array}{l}\text { On va faire tout ce qu'ilfaut faire [pour } \\
\text { travailler la forme] } \\
\text { A gente vai fazer tudo que tiver que ser feito } \\
\text { [para trabalhar a forma] } \\
\text { On a des contraintes, on doit suivre ça } \\
\text { Temos restrições, temos que ser segui-las }\end{array}$ & \\
\hline $\begin{array}{l}\text { ligadas às } \\
\text { experiências }\end{array}$ & $\begin{array}{l}\text { On ne peut pas réfléchir avec certaines } \\
\text { contraintes de la forme } \\
\text { Não podemos pensar com certas restrições da } \\
\text { forma }\end{array}$ & $\begin{array}{l}\text { On ne peut pas travailler la forme toujours } \\
\text { ensemble } \\
\text { Não podemos trabalhar a forma sempre junto } \\
\text { Il faut voir, il faut voir bien } \\
\text { Tem que ver, temque ver bem }\end{array}$ \\
\hline
\end{tabular}

Tabela 31: Modalizações deônticas no excerto 8 da ACC

Nesse caso, as modalizações da ordem da obrigação (deônticas) aparecem tanto como uma prescrição externa, imposta por razões alheias aos professores (Danilo: “on a des contraintes, on doit suivre ça”, “on va faire tout ce qu'il faut faire”, Suélen: “on suit un peu”), quanto como uma auto-prescrição, que emerge dos próprios professores (Danilo: "Il faut que je sois vraiment très strict avec ce que je vais faire", "Je suis une personne qui doit être vraiment méthodique”).

Há ainda dois exemplos em que os professores reformulam a prescrição, fazendo assim uma auto-prescrição ( "On ne peut pas réfléchir avec certaines contraintes de la forme”; "On ne peut pas travailler la forme toujours ensemble”, “Il faut voir, il faut voir bien”). Analisando esses excertos, vemos que a orientação da didática é no sentido de que se deve trabalhar forma e sentido junto, entretanto, ambos se colocam contra essa orientação em alguns casos: Danilo por razões pessoais e Suélen por uma questão de conteúdo. Isso nos leva a entender que a voz do métier vai, de certa maneira, contra a voz da didática, justamente porque considera os atores na real situação de trabalho, com as limitações pessoais e contextuais. 
As modalizações deônticas permitem ainda identificar a figura de ação canônica e, consequentemente, aquilo que os professores veem como obrigação. Vejamos a seguir o excerto de Danilo, seguido do de Suélen:

\section{Análise das figuras de ação de Danilo do Excerto em análise 8}

922D: je pense que:: moi je suis une personne... je suis pas très bien organisé... alors dans ma tête il faut que je sois vraiment très:.... très strict avec ce que je vais faire parce que sinon je n'arrive/je n'arrive pas ça déraille....alors si c'est le moment de:: là si c'est le moment de la forme c'est (là) qu'on va travailler la forme et:: peut-être qu'il y a des gens qui/ on dit que les filles arrivent à faire plusieurs choses au [sic] même temps ((risos)) mais:: peut-être c'est/(voilà) probablement mais moi je suis une personne qui doit être vraiment méthodique parce que sinon/ peut-être oui... mais pour moi je pense que ça va pas marcher... là on va penser la forme d'accord on va penser la forme on va regarder (et faire tout ce qu'il faut faire) des/des tableaux et utiliser de la craie colorée pour voir les terminaisons et les prépositions ((risos)) et après peut-être on peut discuter de ça mais en même temps comme ça on va et on revient pour moi c'est difficile // parce qu'on est... on/on//on a des contraintes parce qu'on a eu une contrainte et:: ahn:: on doit suivre ça et:: on ne peut pas réfléchir avec certaines contraintes de la forme c'est ça?// uhum // oui mais c'est ça on donne la contrainte de la comparaison là ils doivent utiliser la comparaison // oui mais voilà ça/ça/ça empêche //uhum //

Legenda: Roxo - ocorrência / Azul - acontecimento passado / Laranja - definição / Verde - experiência / Vermelho - canônica

$\mathrm{Na}$ continuação do que foi discutido anteriormente sobre se preocupar com a forma ao trabalhar um conteúdo gramatical, a pesquisadora pergunta: "Vocês acham que é possível trabalhar os dois ao mesmo tempo? A estrutura da forma e os conteúdos, tentar fazer uma relação entre as relações culturais, ou vocês acham um momento deve ser separado do outro?". Ambos os professores respondem trazendo elementos de sua experiência e suas características pessoais, empregando para isso o presente genérico. Danilo começa dizendo que não se considera muito bem organizado, por isso faz uma prescrição para si mesmo (auto-prescrição), marcada pela modalização deôntica, em ser bastante estrito com o que vai fazer em sua aula. Quando trabalha a forma, a gramática, ele utiliza o giz colorido, quadros e o que mais for preciso e só depois se concentra em trabalhar o sentido daquelas expressões. Para ele, agir sobre os dois objetos ao mesmo tempo, para ele é difícil.

Suélen elabora sua experiênciaa começando por uma reflexão "para mim, o intercultural é trabalhar mais a reflexão; se os alunos têm ferramentas para isso, está bom". Ela ilustra essa reflexão relembrando o exemplo de sua aula discutido anteriormente: "porque eu comecei o curso 
e a discussão veio com as ferramentas que os alunos tinham e isso resultou em muitas coisas". Após isso, pondera sobre o conteúdo gramatical dessa mesma aula da Fête des Voisins, a comparação: se ela se propõe a trabalhar os dois conteúdos juntos, isso vai desencadear uma comparação entre as culturas e vai dar margem a generalizações ("em alguns momentos a forma pode ajudar a fazer generalizações”). A partir dessa constatação, ela continua, faz uma autoprescrição (reconcebendo uma prescrição da didática) para seu trabalho através da figura de ação canônica, afirmando que não se pode sempre trabalhar a forma junto do sentido. Como em uma mise en abyme, ela relativiza uma generalização da didática.

\section{Análise das figuras de ação de Suélen do Excerto em análise 8}

923S: uhum... bon pour moi l'interculturel c'est plutôt travailler la réflexion... ahn:: s'ils ont des outils pour ça... pour la réflexion c'est bien parce que moi j'ai commencé le cours et::/et la réflexion elle est venue avec les outils qu'ils avaient... et ça a donné pas mal des choses... après on a vu en fait on a vu:: la comparaison et:: si je travaille ensemble la fête des voisins avec la comparaison/avec l'interculturel je vais comparer les cultures donc la forme je pense que la grammaire dans ce moment là elle ne tombe pas bien parce que ça va donner des généralisations... des comparaisons par exemple plus moins::... et il y a des moments que la forme elle peut aider... donner ahn:: des généralisation... par exemple//la leçon/la leçon //non c'est... par exemple si on/si on/dans ce cas c'est la fête des voisins après il y a un point langue qui parle de/de la comparaison// plus au moins enfin... si je les travaille ensemble ça va donner des généralisations par exemple au Brésil on est plus généraux // oui mais je ne voulais parce que:: //on ne peut pas tra/travailler la forme toujours ensemble //parce qu'elle ne tombe pas bien... dans le contenu interculturel ahn étudié... il faut voir... il faut voir bien... c'est ça.

Legenda: Roxo - ocorrência / Azul - acontecimento passado /Laranja - definição /Verde - experiência / Vermelho canônica

Danilo retoma o que disse Suélen através da figura de ação canônica (on a des contraintes parce qu'on a eu une contrainte et:: ahn:: on doit suivre ça), apontando que existem algumas coerções da forma e do conteúdo gramatical que têm de ser seguidas e que impedem a reflexão. Essa obrigação de seguir as prescrições da progressão do livro didático e do programa do curso vem ao encontro de como aconteceu a aula de Danilo comentada na autoconfrontação. Devido à sua relação de obrigação de trabalhar o conteúdo gramatical (faire du, faire de la), ele se preocupou justamente com isso e não em perguntar para os alunos que esportes e atividades eles realmente praticavam. Para ele, as estruturas linguísticas, ou a "forma", impede a reflexão (on ne peut pas réfléchir avec certaines contraintes de la forme).

Suélen corrige o que dizia Danilo, precisando o que havia dito antes: para ela, o problema não estava nas coerções de seguir a progressão do curso ou do livro, mas sim na obrigação de se 
trabalhar determinadas formas linguísticas associadas a certos conteúdos. Por exemplo, o conteúdo das comparações, no seu caso, deu margem à criação de generalizações culturais: "no Brasil, a gente é mais generoso", por exemplo. Ela relata que não queria trabalhar esses conteúdos na mesma lição dessa forma justamente "porque a forma não caia bem com o conteúdo intercultural estudado". Assim, ela termina, através de uma ação canônica, apontando que têm que se ver e analisar mais profundamente essas questões (il faut voir, il faut voir bien). 


\subsubsection{Síntese intermediária dos resultados das análises da entrevista em ACC}

Tendo apresentado o resultado das análises por excerto da entrevista, apresentamos a seguir uma síntese apontando os aspectos mais relevantes de cada categoria.

\subsubsection{Infraestrutura Geral}

Com relação aos turnos de fala, vimos que houve um equilíbrio por parte dos professores, pois ambos tiveram momentos de predominância e momentos mais silenciados, alternados, o que revelou um balanço consideravelmente igualitário no excerto analisado e a ausência de uma hierarquia, mesmo sabendo que Suélen tinha um ano a mais de experiência. Os risos, vocativos e elementos não verbais, como o tom e postura, não foram objetos de nossa análise, mas se observados no vídeo, também corroboram nossa hipótese de equilíbrio hierárquico (KERBRATORECCHIONI, 1996).

Vimos também que os conteúdos temáticos que apareceram na entrevista nos oito fragmentos trazem diferentes ângulos de tratamento dos conteúdos culturais.

\begin{tabular}{|c|c|c|}
\hline Excerto & $\begin{array}{l}\text { Identificação dos } \\
\text { turnos }\end{array}$ & $\begin{array}{l}\text { Conteúdos temáticos } \\
\text { Tratamento dos conteúdos culturais }\end{array}$ \\
\hline 1 & $719-737$ & $\begin{array}{l}\text { através da exposição aos documentos e comentários dos alunos, sem } \\
\text { desenvolver a discussão }\end{array}$ \\
\hline $\begin{array}{l}2 \mathrm{~A} \\
\mathbf{2 B}\end{array}$ & $\begin{array}{l}738-757 \\
758-772 \\
\end{array}$ & $\begin{array}{l}\text { através de uma atividade do livro, sem desenvolver a discussão } \\
\text { A) Formulação da questão } \\
\text { B) Resposta de Danilo }\end{array}$ \\
\hline 3 & $779-792$ & $\begin{array}{l}\text { através da exposição aos documentos e histórias dos alunos, sem } \\
\text { desenvolver a discussão }\end{array}$ \\
\hline $\begin{array}{l}4 \mathrm{~A} \\
\mathbf{4 B}\end{array}$ & $\begin{array}{l}793-803 \\
804-831 \\
\end{array}$ & $\begin{array}{l}\text { através da opinião sobre quem introduziu esses temas } \\
\text { A) aluno } \\
\text { B) professor }\end{array}$ \\
\hline 5 & $832-846$ & $\begin{array}{l}\text { através das diferenças e da comparação entre a aula de Danilo e de } \\
\text { Suélen }\end{array}$ \\
\hline 6 & $847-876$ & através de uma sugestão de atividade \\
\hline 7 & $877-920$ & através dos documentos do livro didático e documentos autênticos \\
\hline 8 & $921-936$ & através da possibilidade de trabalhar forma e conteúdo juntos \\
\hline
\end{tabular}

Tabela 32: Conteúdos temáticos relacionados ao tratamento dos conteúdos culturais 
No plano dos conteúdos, vimos que ambos os professores falam explicitamente dos conteúdos culturais, contando que os trabalham em suas aulas. Foram temas: como surgem os conteúdos culturais, como são tratados e que documentos são usados para esse tratamento.

Suélen ressalta o fato de que já esperava os comentários feitos por sua aluna tendo trazido aquela atividade com os recados deixados nas partes em comum dos imóveis, o que demonstra uma preocupação com a seleção dos documentos e com a atividade proposta. Em outras palavras, aqueles comentários dos alunos não viriam sem o input do documento ou sem uma proposta de atividade que favorecesse a tomada de fala por parte dos alunos.

Através da pergunta feita pela pesquisadora, ambos professores refletiram sobre o tratamento que deram aos conteúdos culturais que apareceram em suas aulas, apontando para o fato de que preferem que sejam tratados de maneira natural, muitas vezes através do riso. É possível que essa seja uma maneira de contrabalancear as diferenças entrepostas entre as culturas dos países, como se, ao falar de diferenças, a melhor maneira de fazê-lo seria abordá-las da forma mais natural e descontraída possível.

Entretanto, apesar dessa maneira natural voltada mais ao entender do que ao explicar, portanto, centrada mais ao aluno que ao professor, Suélen ainda ressalta que, para ela, trabalhar os conteúdos culturais é trabalhar a reflexão, de acordo com as competências, habilidades e ferramentas de que os alunos dispõem. Nesse sentido, a contextualização é fortemente presente: não seria proveitoso trabalhar da mesma maneira em níveis diferentes, ou mesmo em turmas diferentes. Para tanto, a subjetividade do professor, ao perceber quais assuntos desenvolver ou não, é essencial, já que para ambos não há referência a prescrições para o trabalho ou avaliação dos conteúdos culturais.

Para eles, há uma distinção sobre o ensino da gramática (chamado por Suélen de "forma") e o ensino das práticas de linguagem, de interpretação, de letramento e produção textual (chamado por Danilo de "conteúdo"). Danilo descreve e explicita conscientemente suas práticas relacionadas às rotinas de curso - à disciplina de horário, correção de exercício, no início da autoconfrontação cruzada - e de ensino da gramática (quadros e giz colorido), contudo, ao comentar sobre os conteúdos culturais, coloca-se no campo do "falar sobre" (discuter), sem elaborar muito a descrição dos gestos e atividades que emprega. Suélen, por ter uma formação voltada ao estudo do desenvolvimento das capacidades de linguagem através dos gêneros 
textuais, buscou ponderar sobre suas ações como professora e sobre as práticas de aprendizagem do aluno, sejam elas de leitura ou de produção oral, bem como o uso de textos autênticos. ${ }^{114}$

Essa discussão toca num ponto chave do ensino da língua estrangeira e revela uma inquietação inerente ao trabalho desses professores, pois um de seus grandes desafios é justamente fazer equilibrar o ensino da gramática de maneira a veicular "conteúdos" de interesse dos alunos, evitando ficar entre os extremos: um ensino puramente repetitivo de formas e estruturas, ou um ensino de língua estrangeira, mas realizando as discussões em língua materna.

Um dos destaques dados pelos professores é o papel do documento que é trazido e trabalho na sala de aula. O livro didático é criticado explicitamente, pois, na opinião deles, não traz documentos interessantes, o que acaba sendo positivamente convertido em espaço de escolha e criatividade dos professores: Suélen traz a atividade dos recados para substituir a explicação do livro sobre a Fête des Voisins e Danilo traz o curta Prince et Princesse para substituir a enquete desinteressante sobre os animais preferidos dos homens e das mulheres. Essa dimensão pessoal, do exercício da criatividade e do poder de escolha do professor, é avaliada de maneira extremamente positiva por eles, pois confere sentido e realização ao trabalho.

Apontamos aqui para a possível ambigüidade do verbo "discuter" empregado pelos dois professores, pois embora caiba o sentido de "falar sobre", "conversar sobre", esse verbo também pode ter sido empregado como um falso cognato de "discutir", "colocar em discussão" ("mettre en question”).

Com relação aos tipos de discurso presentes na entrevista, como mencionamos no início da subseção, encontramos uma predominância do relato interativo, ancorado no eixo da disjunção e da implicação, normalmente usado para restituir e contar a situação do vídeo ou alguma história relacionada ao tema.O discurso interativo também aparece como recorrente, quando as interações entre os participantes referem-se ao momento da entrevista e não à reconstituição do que ocorre na aula em vídeo. Vimos uma alternância entre o relato interativo e o discurso interativo pela presentificação da cena da sala no momento da entrevista. Identificamos alguns excertos pontuais de discurso teórico, quando os participantes tentam definir e teorizar sobre seu trabalho com os conteúdos (“o intercultural é trabalhar a reflexão...”) e também quando revelam opiniões colocadas de forma genérica ("não é interessante ler um

\footnotetext{
${ }^{114}$ Lembramos que, evitando fazer qualquer um julgamento de valor, nossa perspectiva aqui é de observar como os próprios sujeitos professores compreendem e analisam suas experiências de ensino, apontanto as arbitragens que fazem à luz das prescrições que seguem, das reconcepções ou auto-prescrições que fazem delas.
} 
documento...") sobre aspectos trabalhados em aula pelo professor. Vale lembrar que a categoria dos tipos de discurso não foi empregada isoladamente para a análise, mas como uma das características que nos permitiu identificar e analisar as figuras de ação.

Dessa forma, vemos que os tipos de discurso encontrados e suas proporções estão em consonância com as primeiras análises de entrevistas em autoconfrontação a partir do quadro teórico-metodológico do ISD, realizadas por Lousada (2006), sobre o trabalho do professor de FLE. Elas também revelam o que foi encontrado por Dantas-Longhi (2013), realizado com a mesma metodologia e no mesmo contexto, com participantes diferentes.

\subsubsection{Mecanismos de textualização}

A análise dos mecanismos de coesão nominal, especialmente, a série coesiva que retoma os conteúdos culturais nos permite compreender como os professores constroem no discurso o significado dos conteúdos culturais e do seu trabalho com esses temas. De uma maneira geral, identificamos seis campos lexicais: o da reflexão, o do humor e riso, o da descoberta, experiência pessoal e participação dos alunos, o da cultura e interculturalidade, o das generalizações e o da particularidade, como vemos no quadro abaixo.

\begin{tabular}{|c|c|c|}
\hline \multicolumn{3}{|c|}{$\begin{array}{l}\text { Série coesiva nominal associada aos « conteúdos culturais » } \\
6 \text { campos lexicais }\end{array}$} \\
\hline Reflexão & Humor e riso & $\begin{array}{l}\text { Descoberta, experiência pessoal e } \\
\text { participação dos alunos }\end{array}$ \\
\hline $\begin{array}{l}\text { Réflexion }(S) \\
\text { Discussion }(D / S)\end{array}$ & $\begin{array}{l}\text { Drôle }(D) \\
\text { Blague }(D) \\
\text { Rigolades }(S)\end{array}$ & $\begin{array}{l}\text { Découverte }(S) \\
\text { Intérêt de savoir }(S) \\
\text { Ouverture à l'interculturel }(D) \\
\text { Commentaires (de l'élève) }(D / S) \\
\text { Exemples }(S) \\
\text { Histoires }(S)\end{array}$ \\
\hline Cultura e Interculturalidade & Generalizações & Particularidade \\
\hline $\begin{array}{l}\text { Interculturel }(D / S) \\
\text { Culture }(S) \\
\text { Regard de l'interculturel }(D) \\
\text { Ouverture à l'interculturel }(D) \\
\text { Coté interculturel }(D) \\
\text { Discussion interculturelle }(D) \\
\text { Contenu interculturel }(S) \\
\text { Situations de l'interculturel }(S) \\
\text { L'aspect interculturel }(S)\end{array}$ & $\begin{array}{l}\text { Généralisations }(S) \\
\text { Vérité }(D) \\
\text { Réalité }(S)\end{array}$ & $\begin{array}{l}\text { Petit détail }(D) \\
\text { Particularité }(D) \\
\text { Choses ponctuelles }(D) \\
\text { Situations particulières }(S) \\
\text { Des choses qui passent et qu'on ne } \\
\text { voit pas }(D / S)\end{array}$ \\
\hline
\end{tabular}

Tabela 33: Os campos lexicais identificados a partir das séries coesivas nominais da ACC 
Paralelamente, analisamos os lexemas da coesão verbal, que permitem a progressão temática do discurso, elencando as ações ligadas aos professores, aos alunos e aos conteúdos culturais. Os verbos que descrevem ações dos professores ligados aos conteúdos culturais podem ser enunciadas por meio de asserções, na afirmativa, mas também podem aparecer na negativa. As ações em relação aos conteúdos culturais que os professores representam na forma afirmativa são: expor, falar sobre, perceber uma discussão, antecipar, trazer dados da realidade, trazer documentos autênticos, entrar no contexto dos alunos, trabalhar os exemplos que estão na aula, dar um momento para conversar sobre, despertar o interesse pelo saber, compreender como uma piada. Já os verbos que descrevem as ações e aparecem na forma negativa são: não comparar, não generalizar, não ver coisas do intercultural, estar acostumado com as generalizações. As ações ligadas aos alunos são: rir, dar exemplos, comentar, perguntar, assumir como verdades, ter ferramentas para a reflexão; aquelas relacionadas aos conteúdos culturais são: despertar/disparar risadas, despertar/disparar história, gerar uma discussão, desaparecer, abrir em direção a uma discussão intercultural; a preocupação com a gramática: impedir a reflexão. Todas essas ações estão sintetizadas no quadro a seguir e buscaremos discutir esse levantamento na próxima seção. 


\begin{tabular}{|c|c|c|}
\hline \multicolumn{3}{|c|}{ Lexemas verbais associados aos conteúdos culturais } \\
\hline & Ações consideradas como positivas & Ações consideradas como negativas \\
\hline $\begin{array}{l}\text { Conteúdos } \\
\text { culturais } \\
\text { competências } \\
\text { relacionadas }\end{array}$ & $\begin{array}{l}\text { Arriver des rigolades } \\
\text { Etre une blague } \\
\text { Déclencher plusieurs histoires [les exemples, } \\
\text { les documents authentiques] } \\
\text { Venir d'eux } \\
\text { Exprimer ce qui est l'interculturel } \\
\text { Déclencher d'autres choses } \\
\text { Faire partie de la réalité des élèves } \\
\text { Venir [la discussion] avec les outils qu'ils } \\
\text { avaient }\end{array}$ & $\begin{array}{l}\text { Lire un document } \\
\text { Rien remplir [les questions/les activités] } \\
\text { Ne pas faire partie du contexte brésilien } \\
\text { Ne pas tomber bien [la combinaison entre } \\
\text { grammaire et les contenus interculturels] } \\
\text { Empêcher [la forme empêche la } \\
\text { réflexion] }\end{array}$ \\
\hline Aprendizes & $\begin{array}{l}\text { Commenter } \\
\text { Rigoler } \\
\text { Comprendre } \\
\text { Comparer } \\
\text { Prendre par une blague } \\
\text { Discuter } \\
\text { Donner des exemples } \\
\text { Faire des commentaires } \\
\text { Poser des questions } \\
\text { Commencer la discussion } \\
\text { Avoir des outils [pour la réflexion] }\end{array}$ & Prendre pour des vérités \\
\hline Professores & $\begin{array}{l}\text { Exposer [les élèves à des situations de } \\
\text { l'interculturel] } \\
\text { Trouver drôle } \\
\text { Prendre par une blague } \\
\text { Discuter } \\
\text { Peut-être ne pas discuter } \\
\text { Aller plus loin } \\
\text { Donner pas mal de choses } \\
\text { Écouter [les élèves] } \\
\text { Faire une activité } \\
\text { Voir situations particulières } \\
\text { Entrer dans le contexte des élèves } \\
\text { Déclencher l'intérêt du savoir } \\
\text { Aller vers la découverte } \\
\text { Percevoir [une discussion interculturelle] } \\
\text { Donner un moment pour la discussion } \\
\text { Demander } \\
\text { Prendre des données [du contexte des élèves] } \\
\text { Apporter des données [du contexte des élèves] } \\
\text { Ouvrir à une discussion interculturelle } \\
\text { Apporter un document authentique } \\
\text { Essayer de mettre [un document authentique] } \\
\text { pour travailler l'interculturel } \\
\text { Aller chercher un film } \\
\text { Travailler les exemples qui étaient là [dans le } \\
\text { livre] } \\
\text { Travailler la réflexion } \\
\text { Commencer le cours }\end{array}$ & $\begin{array}{l}\text { Comparer [les cultures] } \\
\text { Entrer dans l'interculturel } \\
\text { Parler [valeur d'autorité] } \\
\text { Hyper-généraliser } \\
\text { Simplifier } \\
\text { Etre habitué dans les généralisations } \\
\text { Ne pas penser au côté interculturel } \\
\text { Penser plutôt à la forme } \\
\text { Ne pas voir des choses de l'interculturel } \\
\text { Préoccuper de faire le point langue } \\
\text { Travailler la forme } \\
\text { Aller et revenir [entre la forme et le sens] } \\
\text { Ne pas pouvoir réfléchir avec certaines } \\
\text { contraintes de la forme } \\
\text { Ne pas pouvoir travailler la forme toujour } \\
\text { ensemble [avec le sens] }\end{array}$ \\
\hline
\end{tabular}

Tabela 34: Lexemas verbais associados aos conteúdos culturais ACC 


\subsubsection{Mecanismos enunciativos}

Uma das características linguísticas das autoconfrontações é a superposição de dois planos enunciativos distintos (LOUSADA, 2006; DANTAS-LONGHI, 2013). O primeiro plano é o da interação em curso entre os participantes das entrevistas: professores e pesquisadora, em que o "eu" representa o enunciador e o "você/vocês" os interlocutores ali presentes. O segundo plano enunciativo é o da aula registrada em vídeo à qual os participantes da entrevista assistem. Nesse plano, a reconstituição das vozes dos alunos e do professor é constante dando outros referentes ao dêiticos de pessoa.

Um dos mecanismos enunciativos que investigamos são as vozes que os enunciadores trouxeram em suas falas, as quais foram identificadas através de marcadores linguísticodiscursivos como os verbos discendi, a reprodução dos discursos diretos e indiretos, (identificadas com aspas nas transcrições quando ditas em uma entonação diferente), os dêiticos de pessoa, especialmente do on/nous, e da heterogeneidade constituída, através dos jargões da área.

Através da categoria dos dêiticos de pessoa (MAINGUENEAU, 1991, 2001), vimos como os professores se colocam em relação à sua prática docente. Suélen, por exemplo, verbaliza suas ações com mais frequência através do "je”, buscando ao mesmo tempo delinear e analisar detalhadamente sua prática, enquanto Danilo descreve mais através do "on" inclusivo, falando das atividades ligadas a si e aos alunos. O uso do "on" nos permite identificar também que vozes esses professores trazem em suas falas. Vimos que, ao falar da cultura, ambos usaram o "on" inclusivo como uma voz da cultura brasileira. Ao falar de suas ações para ensinar, identificamos um "on" referente ao conjunto dos alunos e professores, aos professores em geral, e também ao métier dos professores de línguas estrangeiras.

Identificamos através da categoria da heterogeneidade discursiva outras vozes trazidas pelos professores. Ao empregar jargões ligados ao contexto dos cursos extracurriculares, ambos os professores trazem uma voz do seu meio de trabalho (milieu de travail). Ao trazer jargões ligados ao livro didático, ambos trouxeram a voz da didática para seu discurso. Suélen ainda empregou termos da teoria do ISD, trazendo uma voz de seu referencial teórico para a discussão.

Se, por um lado, em grande parte das vezes as vozes da sala de aula consistem em discursos diretos e indiretos correspondentes a diálogos entre os professores e alunos, por outro, identificamos vozes que ilustram um diálogo do sujeito consigo mesmo. Nesse sentido, nós 
encontramos momentos de tomada de consciência através de duas ocorrências da voz da fala egocêntrica, umade Danilo no excerto de sua ACS, retomada explicitamente em sua reflexão na ACC, e uma de Suélen na ACC. Além disso, encontramos duas ocorrências da voz da fala egocêntrica reconstituída (DANTAS-LONGHI e LOUSADA, 2014).

A voz da fala egocêntrica de Suélen na ACC foi identificada através de algumas mudanças lingüísticas que evidenciam um momento de tomada de consciência de que apesar de se posicionar contra a generalizações, ela observa que em sua aula houve um momento de generalização. Embora nem tudo tenha sido verbalizado, vemos que nesse pequeno excerto é como se ela pensasse consigo mesma, perdendo os outros destinatários de vista. Além disso, algumas marcas da fala egocêntrica caracterizam esse momento: as pausas e hesitações; os marcadores "en fait" e "bon" que indicam reflexão; a alternância do je para o on; e a expressão “deixa pra lá" (“bon laisse tomber”) que retoma o direcionamento da fala aos destinatários.

\section{Voz da fala egocêntrica de Suélen (ACC)}

825S: mais en fait il y a un moment que j'ai:: il y a eu un moment de généralisation... c'était... bon laisse tomber... en fait on est tellement habitué dans les généralisations que... on se rend compte qu'on a généralisé les choses... on dit « ahn mais en France ahn:: il y a beaucoup d'indifférence... il y a un repli sur soi.

No caso de Danilo, é justamente a interação com pesquisadora através de sua pergunta que lhe permite verbalizar sobre sua atividade, encadeando um momento de tomada de consciência. Danilo tem hesitações para responder, afirma que não tinha nunca pensado sobre isso e vai checar no livro para formular uma resposta. As marcas linguísticas que evidenciam esse momento são as hesitações, a fala entrecortada, a mudança de destinatário, a digressão que é feita para elaborar a resposta, verificando os outros várias páginas do livro até o momento queretoma sua resposta à pesquisadora ("on / ils le font après (risos) normalement je prévios ça pour la partie de production orale”).

\section{Voz da fala egocêntrica de Danilo (ACS)}

E : oui parce que...la question que j'ai eu à ce moment-là c'était... on travaille/ on peut [travailler]... surla forme et sur les structures et:: je sais pas... tu faisais pas le rapport avec le....

$\mathrm{D}:$ non... c'est vrai que c'est intéressant... j'ai jamais pensé à ça... normalement... quand...je pense que... ouais/ je pense que quand on entre dans un point langue...je... « vous aimez »... oui c'est vrai... non je/ je/ je pense que... là un autre point langue avec des...les conjugaison du verbe aller je pense que je ne leur ai pas demandé ce/ où ils font ce qu'il font... ahn... là non plus... oui «aller à préposition » je ne leur demande pas « vous allez au cinéma ? vous allez au théâtre ? » et là quand on parle d' " aimer» probablement je leur demande pas... on/ ils le font après... ((risos)) 
normalement je prévois ça pour/ pour/ pour la partie où... pour la production orale... pour la partie où... avec cherchez quelqu'un qui... les sondages... le moment où on interroge l'élève à côté...

Em dois excertos da ACC vimos que Danilo reconstitui seu diálogo interior na situação registrada em vídeo, que pudemos identificar através dos verbos discendi "pensar" e "dizer" ocorrências de voz da fala egocêntrica reconstituída:

\section{Voz da fala egocêntrica reconstituída de Danilo (1)}

840D: \{tu vois et::/et ça c'est/c'est/ça a commencé par eux quand moi quand j'ai travaillé les/les sports et tout ça j'ai travaillé d'une manière je pen/je/je pensais plutôt à « faire du » ou «aller au » et tout ça alors je fais

841S:

\{pensé/tu as pensé plutôt à la forme?

842D: \{à la forme j'ai pas du tout pensé au côté interculturel qui pourrait sortir je pourrais bien demander (d'eux)... « est-ce que vous/vous/vous faites ça ? vous faites de l'équitation ? vous faites du ski ? vous faites... » ça pourrait déclencher d'autres choses des/des choses comme ça... c'est vrai que c'est un peu difficile différent de travailler avec le niveau quatre et le niveau un... parce qu' au niveau un la discussion ne vais pas aller on ne va pas arriver à raconter une histoire

Voz da fala egocêntrica reconstituída de Danilo (2)

902D: uhum... exactement et là au lieu de faire ça ce point culture qu'il y avait une enquête... avec des/des animaux que les Français aiment que les femmes 903S :

905D: qui les femmes oui

$\{$ les femmes et les hommes

906S: les femmes

907D: \{que les femmes aiment et que les hommes aiment je me suis dit non je vais apporter un document authentique j'ai apporté le/le filme Prince et Princesse où il y a plusieurs animaux

Através dessa formulação, Danilo consegue identificar o conflito vivido e a arbitragem sobre suas opções, como colocamos no quadro abaixo:

\begin{tabular}{|c|c|c|}
\hline Opção rejeitada & Opção escolhida & Justificativa \\
\hline $\begin{array}{l}\text { Trabalhar conjuntamente } \\
\text { forma e sentido }\end{array}$ & $\begin{array}{l}\text { Trabalhar somente a forma, } \\
\text { separadamente do sentido }\end{array}$ & $\begin{array}{l}\text { - É diferente trabalhar no nível um, iniciante } \\
\text { - Por uma questão de personalidade e } \\
\text { organização, Danilo prefere fazer as coisas } \\
\text { separadamente }\end{array}$ \\
\hline $\begin{array}{c}\text { Trabalhar o documento do } \\
\text { livro didático }\end{array}$ & $\begin{array}{l}\text { Trazer e trabalhar documentos } \\
\text { autênticos escolhidos pelo } \\
\text { professor }\end{array}$ & $\begin{array}{c}\text { - É mais motivador, divertido, legal, } \\
\text { interessante } \\
\text { - O documento do livro é desinteressante e } \\
\text { subestima a capacidade dos alunos }\end{array}$ \\
\hline
\end{tabular}

Tabela 35: Conflito de Danilo relacionado ao tratamento dos conteúdos culturais 
Segundo os clínicos do trabalho (CLOT, 1999) são esses momentos de tomada de consciência, em que o sujeito verbaliza para si mesmo a atividade, que ele entra em sua zona de desenvolvimento proximal, o que pode, segundo Vygotski ([1934] 1997), desencadear o desenvolvimento. A continuação da tomada de consciência de Danilo na ACC se dá na ACC, quando ele, que já havia se confrontado à pergunta da pesquisadora, se depara com a prática de sua colega registrada em vídeo.

Com relação às modalizações, observamos um emprego freqüente de modalizações apreciativas positivas, referindo-se às praticas ligadas aos conteúdos culturais, algumas negativas, reportando-se ao livro didático. As modalizações deônticas aparecem ligadas ao livro didático e as auto-prescrições sobre a maneira de trabalhar.

Atentamos para uma distinção no uso das modalizações pelos professores: Danilo empregou um grande número de modalizações lógicas de possibilidade, se comparado à Suélen, apontando para o que se poderia ter feito. Já Suélen emprega algumas modalizações lógicas de possibilidade não para falar de si, mas dos brasileiros em geral ou dos conteúdos gramaticais; e emprega mais modalizações pragmáticas, marcando um protagonismo e consciência de como havia planejado e executado suas ações. Já as modalizações pragmáticas afirmativas revelam o que Suélen realizou em aula (j'attendais, j'ai voulu), e as negativas, ao que Danilo não fez (on essaie, je n'arrive [pas], ça dérraille). Dessa forma, os elementos que indicam a tentativa e a falha nas falas de Danilo nos aproximam do que Dantas-Longhi (2013) encontrou em suas análises como figura de ação experiência negativa ${ }^{115}$.

\footnotetext{
${ }^{115}$ No nosso caso analisamos somente enquanto modalização. A figura de ação experiência negativa ainda conta com advérbios de frequência ligado à experiência (eu nunca consigo, eu sempre erro). No nosso caso, as modalizações pragmáticas foram pontuais, mas ainda sim representam um professor em desenvolvimento, lidando com questões que lhe causam dificuldade na aprendizagem do métier.
} 


\begin{tabular}{|c|c|c|}
\hline & Danilo & Suélen \\
\hline $\begin{array}{l}\begin{array}{l}\text { Modalizações } \\
\text { lógicas } \\
\text { possibilidade }\end{array} \\
\text { Danilo } 8+10 \\
\text { Suélen } 1+2\end{array}$ & $\begin{array}{l}\text { Peut-être (x8) } \\
\text { On peut aller un peu loin } \\
\text { Petit détail qui pourrait disparaître } \\
\text { On pourrait le prendre par une blague } \\
\text { Ça peut déclencher quelque chose qui peut } \\
\text { venir d'eux (la discussion que la prof a } \\
\text { aperçu, a prévu) } \\
\text { Ça pourrait déjà être une ouverture à } \\
\text { l'interculturel (si je leur avais demandé } \\
\text { « vous faites ça? ») } \\
\text { ça pourrait ouvrir à une discussion } \\
\text { interculturelle } \\
\text { On va faire tout ce qu'il faut faire (pour } \\
\text { travailler la forme) et après peut-être on peut } \\
\text { discuter de ça } \\
\text { J'ai pas du tout pensé au côté interculturel } \\
\text { qui pourrait sortir } \\
\text { Je pourrais bien demander « vous faites ça » } \\
\text { J'aurais pu demander à eux s'ils le font et } \\
\text { J'aurais pu travailler juste les exemples qui } \\
\text { étaient là }\end{array}$ & $\begin{array}{l}\text { Peut-être comme c'était dans le moment des } \\
\text { olympiades... peut-être }(4 \mathrm{x}) \mathrm{p} 4 / 5 \\
\text { On peut lire beaucoup plus parce qu'on est } \\
\text { brésilien } \\
\text { Il y a des moments que la forme elle peut } \\
\text { aider donner des généralisations }\end{array}$ \\
\hline $\begin{array}{l}\text { Modalizações } \\
\text { pragmáticas } \\
\text { Danilo } 5 \\
\text { Suélen } 5\end{array}$ & $\begin{array}{l}\text { On essaie de mettre ça pour travailler un peu } \\
\text { l'interculturel } \\
\text { Parce que sinon je n'arrive/ ça déraille (Il } \\
\text { faut que je sois vraiment très strict avec ce } \\
\text { que je vais faire) }\end{array}$ & $\begin{array}{l}\text { Je voulais vous montrer } \\
\text { J'attendais (ce commentaire avec cette } \\
\text { activité) } \\
\text { Je voulais (vous) expliquer } \\
\text { J'ai voulu apporter ce document } \\
\text { Je ne voulais pas (travailler forme et contenu } \\
\text { ensemble parce que ça donne des } \\
\text { généralisations) }\end{array}$ \\
\hline
\end{tabular}

Tabela 36: Modalizações lógicas de possibilidade e pragmáticas com relação aos conteúdos culturais

Levantamos a hipótese de que o fato de Danilo empregar muitas modalizações ligadas à possibilidade pode ser compreendido como uma consequência após a tomada de consciência que vimos em sua fala egocêntrica da ACS. Uma vez que ele se deu conta de como atua em sua prática e confrontou-a com o espaço que Suélen deu para que seus alunos falassem, ele abriu um grande leque de possibilidades para aquela situação. É justamente esse fenômeno que permite a compreensão do real da atividade (CLOT, 2001). Nesse sentido compreendemos o que diz Vygotski: "cada minuto do homem está cheio de possibilidades não realizadas" (VYGOTKSI, [1925]/2004, P.69). No trecho abaixo vemos mais alguns exemplos das modalizações lógicas de possibilidade de Danilo, após se confrontar com a aula da colega: 
832D - 882D: (ah regarde) le/le... j'ai commencé à penser un truc là maintenant donc parce que on a discuté dans/dans/dans/dans la discussion... ahn:: dans entre/entretien tout seul où::/où:: on parlait des/des activités... et on a beaucoup discuté de ça parce que:: les activités qui sont dans le livre c'est faire de la voile faire du //de l'équitation de l'escrime du ski ((risos)) //ça ne fait pas partie du tout... du tout du tout et:: peut-être je sais pas toi tu as/tu as une ahn::/tu as aperçu que là on a une discussion très française peut-être mais qui peut-être ça peut déclencher quelque chose // qui peuv/qui peut venir d'eux et:: tu as même donné un moment où on a discuté de ça... // tu vois et::/et ça c'est/c'est/ça a commencé par eux quand moi quand j'ai travaillé les/les sports et tout ça j'ai travaillé d'une manière je pen/je/je pensais plutôt à « faire du » ou « aller au » et tout ça alors je fais // à la forme j'ai pas du tout pensé au côté interculturel qui pourrait sortir je pourrais bien demander (d'eux)... « est-ce que vous/vous/vous faites ça ? vous faites de l'équitation? vous faites du ski ? vous faites... » ça pourrait déclencher d'autres choses des/des choses comme ça...c'est vrai que c'est un peu difficile différent de travailler avec le niveau quatre et le niveau un... parce qu'au niveau un la discussion ne va pas aller on ne va pas arriver à raconter une histoire// mais:: ça si/si/si je leur avais demandé déjà « vous faites ça ? " peut-être que ça pourrait déjà être une ouverture à l'interculturel... « non professeur on joue du football »... et là c'est déjà:: //« on fait du football on ne fait pas du ski on fait du football » ((risos)) et:: « je fais du football... je fais je:: »// \{ on ne voit pas... non moi ça c'est assez/ (comme) je parle maintenant je commence à réfléchir à mon cours et j'ai vu ah mais c'est vrai j'aurais pu demander à eux s'ils le font et ça pourrait ouvrir à une discussion in/interculturelle (je l'ai pas fait) // là je suis préoccupé de « faire du » « aller au »// uhum... ouais c'était dans un point langue... // c'était un POINT LANGUE // ça c'est le moment où on étudie LA FORME //

Essas marcas linguístico-discursivas das modalizações lógicas de possibilidade nos permitem identificar linguisticamente indícios de uma reconstituição do poder de agir, pois observando sua atividade, o próprio sujeito vislumbra e elabora outras modos de agir que caberiam em situações como aquela.

\subsubsection{Figuras de ação}

Com relação às figuras de ação, há uma predominância da figura de ação ocorrência à medida que os professores estão interagindo na entrevista, configurando seu agir de maneira contextualizada, no eixo temporal presente, evocando vez ou outra o agir no vídeo ou algum momento de suas aulas.

Obsevamos que, enquanto Suélen se baseia nos registros dos vídeo em que apareceram comentários sobre os conteúdos culturais em suas aulas, Danilo, por sua vez, evoca, nos excertos 2, e 4, figuras de ação de acontecimento passado, trazendo relatos que exemplifiquem e ilustrem seu ponto de vista na interação com Suélen e com a pesquisadora. Como o material em vídeo que suscitou a discussão eram excertos da aula de Suélen, Danilo tenta trazer elementos de sua prática 
através desses relatos para equilibrar os pontos de discussão e comparação, baseando-se mais em um ou outro exemplo vivido para calibrar sua ação.

Nos excertos 2 e 4, vimos que em meio a elaboração da experiência cristalizada, há pequenos trechos com frases impessoais, nas quais não são tematizados os actantes, mas sim o objeto de ensino ou a ação do professor. Essas frases são também objetos da avaliação dos professores, que usam modalizações apreciativas para definir e caracterizar seu trabalho. Esses segmentos foram identificados como figuras de ação definição dentro de trechos em que os professores elaboravam sua experiência.

Vimos que os relatos trazidos nas figuras de ação ocorrência e acontecimento passado engendravam a elaboração da cristalização da experiência dos professores através da figura de ação experiência. Esse movimento ocorreu repetidas vezes ao longo da entrevista (excertos 2, 3, 4, $7,8)$, observação que discutiremos na subção de Discussão dos Resultados.

No início da entrevista, as figuras de ação experiência de Danilo se relacionam aos acontecimentos passados, apontando para o pequeno detalhe dos conteúdos culturais (excerto 2), para a voz de autoridade do professor em sala ou que os conteúdos culturais são geralmente coisas pontuais (excerto 4). Se compararmos com trechos da figura de ação ocorrência em que ele também se vale do presente genérico para caracterizar seu agir, observamos que a experiência nos excertos 2 e 4 são afirmativas, enquanto as ocorrências dos excertos 5, 7 e 8 são negativas (a discussão não vai andar; coisas que não se veem; ir e voltar na forma e conteúdo é difícil). Em todas elas, Danilo se coloca como "on" e não como "je”, mostrando que a experiência se liga mais ao objeto (a discussão, o conteúdo) do que ao sujeito professor. Essas observações apontam para sua menor experiência com os conteúdos culturais e para o fato de ele colocar isso como uma dificuldade coletiva, própria da complexidade do objeto e não particularmente individual (exceto pelo último excerto - "para mim é difícil”). 


\begin{tabular}{|c|c|}
\hline Referente & Excerto das figuras de ação experiência e ocorrência (no presente genérico) \\
\hline $\begin{array}{l}\text { professores - } \\
\text { frases afirmativas }\end{array}$ & $\begin{array}{l}\text { on pourrait le prendre par une blague je pense (que tout le monde) je fais aussi ah } \\
\text { c'est/on peut aller un peu loin } \\
\text { ouais /et quand le professeur parle c'est toujours/ c'est comme si on disait il y a } \\
\text { une vérité ahn:: // qu'est valable pour tous // ouais... c'est vrai c'est vrai } \\
\text { quand on dit ahn:: quand on dit des choses // ouais quand on dit des } \\
\text { choses comme ça ils prennent pour des vérités //si on dit des choses } \\
\text { qu'on fait elles sont prises pour des vérités normalement //et/c'est } \\
\text { de/de/normalement des:: choses ponctuelles }\end{array}$ \\
\hline $\begin{array}{l}\text { professores - } \\
\text { frases negativas }\end{array}$ & $\begin{array}{l}\text { oui mais il y des choses //ahn: qui passent et on peut on/on ne voit pas c'est vrai } \\
/ / \text { mais en même temps comme ça }\end{array}$ \\
\hline Danilo & $\begin{array}{l}\text { /on essaie de mettre ça pour travailler un peu l'interculturel de toute façon mais:..... } \\
\text { on va et on revient pour moi c'est difficile }\end{array}$ \\
\hline Danilo + alunos & peut-être qu'on ne va pas discuter de ça mais... voilà \\
\hline Alunos & $\begin{array}{l}\text { // parce qu'au niveau un la discussion ne va pas aller on ne va pas arriver à } \\
\text { raconter une histoire// mais }\end{array}$ \\
\hline Objeto de ensino & mais normalement c'est comme ça une blague comme ça// \\
\hline
\end{tabular}

Tabela 37: Referentes da figura de ação experiência de Danilo

Diferentemente de seu colega, Suélen representa sua experiência considerando os vários aspectos da situação de ensino: ela separa o papel do aluno (fazer perguntas, comentar), do papel do professor (dar histórias, não entrar nas comparações), das suas escolhas e características pessoais (ir pela descoberta), do objeto de ensino (algumas formas não vão cair bem com alguns conteúdos). Há a alternância de je para on, quando ela passa das ações conscientes para a tomada de consciência naquele momento e quando ela se refere ao coletivo do métier. Há a ocorrência de elementos negativos tanto ligados à professora (eu não me sinto capaz de entrar no intercultural); como ao coletivo (não vemos coisas do intercultural). De uma maneira geral, na configuração da experiência de Suélen não constam com muitos elementos de frequência (sempre, nunca) - até porque talvez porque ela esteja conscientemente os evitando, já que evita generalizações. 


\begin{tabular}{|c|c|}
\hline Referente & Excerto das figuras de ação experiência e ocorrência (no presente genérico) \\
\hline $\begin{array}{l}\text { Suélen - (experiência } \\
\text { negativa) }\end{array}$ & $\begin{array}{l}\text { parce que moi je ne me sens pas capable de/d'entrer dans l'interculturel de comparer:: } \\
\text { et:: /uhum //uhum } \\
\text { je ne me sens pas capable de / parce que } \\
\text { c'est pas à moi de/de comparer de donner::/ }\end{array}$ \\
\hline $\begin{array}{l}\text { Suélen - (experiência } \\
\text { positiva) }\end{array}$ & $\begin{array}{l}\text { donc je pense que trois deux trois histoires... dans/dans le même contexte je pense que } \\
\text { ça c'est/c'est bien... } \\
\text { oui bon je préfère aller vers la découverte... / }\end{array}$ \\
\hline $\begin{array}{l}\text { professores em geral - } \\
\text { experiência positiva) }\end{array}$ & $\begin{array}{l}\text { mais en fait on est tellement habitué dans les généralisations que... on se rend compte } \\
\text { qu'on a généralisé les choses... } \\
\text { notre position:: a un impact dans une salle de classe // } \\
\text { et on suit un peu / }\end{array}$ \\
\hline $\begin{array}{l}\text { professores em geral - } \\
\text { (experiência negativa) }\end{array}$ & mais on ne voit pas... on ne voit pas / \\
\hline objeto de ensino & $\begin{array}{l}\text { c'est/c'est intéressant qu'il y a plein des choses de l'interculturel } \\
\text { et il y a des moments que la forme elle peut aider... donner ahn:: des généralisation... } \\
\text { par exemple }\end{array}$ \\
\hline brasileiros & $\begin{array}{l}\text { ça montre déjà... ahn:: l'aspect... ahn:: de notre culture... on n'aurait jamais par } \\
\text { exemple mis un mot comme ça... ((risos)) // on ne dit pas jamais mais } \\
\text { on peut lire beaucoup plus parce qu'on est brésilien / }\end{array}$ \\
\hline alunos & $\begin{array}{l}\text { parce que les gens donnent des exemples } \\
\text { EUX ils posent des questions... } \\
\text { c'est pour ça que les élèves do/mettent dans le formulaire que le livre n'est pas bon / }\end{array}$ \\
\hline
\end{tabular}

Tabela 38: Referentes da figura de ação experiência de Suélen

Comparando as duas experiências, vemos que Suélen parece ter mais experiência no tratamento dos conteúdos culturais, uma vez que ela consegue refletir sobre elementos de sua aula e formular sua experiência passando por uma análise do que conseguiu realizar e do que ainda não está habilitada a fazer. Danilo formula sua experiência a partir de casos pontuais e exemplares (acontecimento passado) e reflete sobre eles configurando sua experiência ainda como social e coletiva (on), com mais elementos de negativos.

A partir dos dêiticos empregados nas figuras de ação experiência, podemos inferir que desenvolvimento de um conflito do métier também pode se aproximar do modelo vygotskiano de desenvolvimento. Danilo, ainda com menos experiência que Suélen, evoca casos ilustrativos e pontuais de trabalho com os conteúdos culturais de outras aulas e quando formula sua própria experiência, usa o pronome on, em nome da coletividade dos professores. Trata-se, portanto, de partir do coletivo para discutir uma questão que também o inquieta, mas que ele ainda parece não possuir meios de avaliar sua prática individualizada. Suélen já parte de exemplos que aparecem em sua aula em vídeo, formulando em sua experiência momentos de dificuldades pessoais, 
particulares (je ne me sens pas capable, je préfère aller vers la découverte) e dificuldades comuns ao coletivo (on généralise, on ne voit pas).

Poderíamos dizer que ao realizar o métier de ensino de FLE, os professores estão permanentemente em interação e em desenvolvimento. No momento da ACC, Suélen estava em outro momento do desenvolvimento, pois o dilema dos conteúdos culturais comum aos professores já havia sido interiorizado e experimentado, dilema esse que lhe permitiu elaborar sobre sua experiência individual e sobre a dificuldade do coletivo. Já Danilo ainda precisou se basear em exemplos ilustrativos, colocando o dilema na voz do coletivo, talvez por não ter ainda interiorizado e pensando qual seria sua dificuldade pessoal com esse tema.

Levantamos a hipótese de que não houve muitas figuras de ação canônica (da ordem do dever e da obrigação) ao longo da parte analisada da entrevista, justamente porque os professores não configuram seu agir com os conteúdos culturais a partir das prescrições que lhes são impostas. Ao contrário, a quantidade de figuras de experiência e de definição mostram que a todo momento os professores buscam definir esse trabalho a partir do seu vivido, do ponto de vista prático e concreto.

A prescrição de se trabalhar os conteúdos culturais é colocada por Danilo como algo secundário diante do trabalho com os conteúdos gramaticais (estava preocupado com a forma, com as estruturas na aula filmada). Para Suélen é algo da ordem do despertar, co-construído com os alunos em sala, podendo ou não ser relacionado ao conteúdo linguístico. A prescrição de trabalhar forma e conteúdo juntos é questionada por Danilo, que, levando em conta suas características pessoais de organização, faz uma autoprescrição de trabalhar ambos separadamente. Já Suélen faz uma autoprescrição justamente para relativizar a prescrição de trabalhar os dois juntos. Ela vai definir se ambos podem ser ensinados em conjunto não de acordo com suas características pessoais, mas de acordo com o objeto: o tipo de conteúdo linguístico ou cultural. A partir desses elementos, podemos interpretar que os professores tem perfis diferentes e que Suélen, até por ter mais experiência no contexto e ter uma formação teórica diferenciada, é mais experiente como professora.

Retomaremos a interpretação dos dados apontados através dessas figuras e através das categorias analisadas na seção a seguir: Discussão dos Resultados. 


\subsection{Discussão dos Resultados}

Lembramos que nosso foco nesta pesquisa é identificar as "representações construídas nos e pelos textos" (BRONCKART, 2006) dos professores sobre a pertinência ou a necessidade que eles têm (ou não) de abordar os conteúdos culturais em aulas de FLE. Com base nos resultados das análises, neste capítulo propomos uma discussão deles à luz de nosso quadro teórico. Para tanto, nesta seção retomaremos nossas cinco perguntas de pesquisas, buscando discutir os resultados encontrados e articular a interpretação dos dados de acordo com nossa fundamentação teórica.

\subsubsection{Quais são as orientações nos documentos oficiais acerca da cultura e do tratamento dos conteúdos culturais?}

A partir das duas análises que propusemos, a do CECRL e a da entrevista em autoconfrontação cruzada, gostaríamos de discutir primeiramente como os discursos presentes nesses dois textos se encontram. O CECRL, inicialmente proposto como diretrizes de orientação e reflexão sobre o ensino de línguas para a Europa, foi amplamente discutido e apropriado pela didática do francês na década seguinte a sua divulgação. A compilação de propostas e conceitos ali sumarizados vem de uma longa tradição de estudos lingüísticos, filosóficos e em educação. Por essa razão e pelo fato de ser um documento produzido por um órgão oficial, suas ideias tiveram um extenso alcance, através da publicação de diversos livros didáticos e artigos de especialistas que fazem referência a ele. Sendo assim, formou-se uma ampla rede discursiva (ROCHA et al, 2002) no ensino de línguas estrangeiras que contém referências ao quadro quer implícita ou explicitamente. Os livros didáticos, por exemplo, citam-no em sua introdução (avant-propos), usando os níveis descritivos de proficiência (A1, A2, B1, B2, C1, C2), empregando certo léxico no sumário, como "competências comunicativas linguageiras", "competências intercultural, plurilíngüe" etc. Dessa forma, o fato de os professores em nosso contexto utilizarem um livro didático baseado no CECRL para organizar o curso e sua progressão faz com que as orientações apresentadas nesse documento apareçam de alguma forma no curso e no dizer dos professores.

Pelo local social em que é produzido, contendo o logo do Conselho da Europa e falando em seu nome (como vimos na nota preliminar), pelo respaldo científico conferido através da 
bibliografia ao final, o Quadro se constitui como um documento cuja autoridade influencia o contexto do ensino de línguas, livros didáticos e formações de professores, portanto, vimos que ele se configura como um documento prescritivo do agir dos professores de nosso contexto.

A partir dos elementos de análise do CECRL, vimos que as orientações são apresentadas com viés reflexivo e questionador. Essa característica se deve ao fato de o Quadro não adotar nenhuma linha metodológica precisa para o ensino-aprendizagem, elemento que contribui para que ele se torne "prescritivo", no sentido de que todos se baseiam nele independente dos pressupostos teóricos. O fato de não adotar nenhuma metodologia também acaba por ter um contraponto: deixar sem orientação precisa aqueles que se baseiam somente nele (sobretudo os professores), apresentando indicações para se trabalhar as LE de maneira vaga e indefinida.

Nossa análise evidenciou que os conteúdos culturais são mencionados e detalhados explicitamente no CECRL como algo que deve ser trabalhado no ensino-aprendizagem de uma LE para desenvolver as competências gerais e linguageiras do aluno. Através de diversos vieses, vimos que esses conteúdos são apresentados como complexos, permeando o conhecimento objetivo e declarativo (saberes e conhecimentos), as práticas sociais (hábitos, costumes, rituais, práticas e saber-fazer), bem como a consciência subjetiva e individual (tomada de consciência, personalidade aberta à descoberta). Além da complexidade dos conteúdos culturais, o que é colocado como objetivo do ensino é algo que vai mais além: o desenvolvimento de competências gerais, linguageiras, plurilíngues e pluriculturais nos indivíduos, através do trabalho com esses conteúdos culturais.

Notamos, nesse sentido, um grande esforço do Quadro em definir o complexo desenvolvimento de competências, entretanto, há uma ausência do ponto de vista da implementação do trabalho do professor. Para dar conta de um objeto tão complexo, pode-se imaginar que a tarefa do professor terá um grau tão ou mais dificultoso e multifatorial que o próprio objetivo a ser atingido, já que é ele que o executará.

O fato de o Quadro não representar o professor como um protagonista da organização do trabalho que leva à aprendizagem dos alunos causa um apagamento de sua figura e de seu trabalho. Cria-se a impressão de que as competências mencionadas serão desenvolvidas naturalmente, sem seja necessária uma ação consciente e anteriormente elaborada pelo professor.

Vimos que, no capítulo seis, o CECRL fornece algumas orientações do ponto de vista prático, das ações em sala de aula. Entretanto, tais prescrições se concretizam através de 
modalizações da ordem da possibilidade e verbos com uma conotação por demais abstrata (tratar, ajudar), não deixando claro ao professor como proceder. Ora, se há uma prescrição com o objetivo, mas sem seu modus operandi, podemos dizer que essa prescrição é fluida e deixa um grande espaço a ser preenchido pelo professor no curso de seu agir.

Nesse sentido, Amigues (2002, p.204) lembra que as prescrições podem chegar ao professor por diversos canais e de maneira difusa, afirmando que "quando as tarefas prescritas aos professores são fluidas, elas convocam sistematicamente uma atividade de redefinição, de elaboração permanente que engaja o sujeito ele mesmo".

Se, por um lado, as orientações do CECRL são incompletas, na análise da ACC, vimos que os professores se expressam também negativamente com relação ao livro didático, criticando os documentos trazidos por ele para trabalhar os conteúdos culturais. Como apontamos na Fundamentação Teórica, o livro didático é outro elemento de prescrição para o trabalho de ensino, pois, como vimos, a progressão que devem seguir em seus cursos é baseada nele.

Diante das complexas e incompletas prescrições do CECRL, e também dos documentos e das atividades propostos pelo livro didático, os professores iniciam um processo dialético de reconcepção das tarefas prescritas por ambos. Nas palavras de Clot (2008):

"Existe, entre a organização do trabalho e o sujeito ele mesmo, um trabalho de reorganização da tarefa pelos coletivos profissionais, uma recriação da organização do trabalho pelo trabalho de organização do coletivo" (Clot, 2008, p.103, tradução nossa).

Vimos que ambos professores fazem uso de sua criatividade no trabalho, quando retrabalham o livro didático, trazendo outras atividades didáticas para sala de aula. Essa forma de reconceber as prescrições lhes permite realizar seu trabalho de uma maneira saudável (CANGUILHEM, 2002).

Com essa análise, aproximamo-nos da compreensão da morfogênese do agir do professor, já que, como coloca Bronckart (2008), a instância que primeiro orienta o trabalho é o primeiro lugar de morfogênese do agir. Em outras palavras, a ação que ocorre de fato na sala de aula começa a tomar forma a partir do que é prescrito.

Passemos, agora, para a resposta à segunda pergunta de pesquisa. 


\subsubsection{Quais são as representações construídas nos e pelos textos dos professores sobre a relevância ou a pertinência de se trabalhar conteúdos culturais?}

As representações construídas pelos professores nos e pelos textos sobre esse tema tornam-se acessíveis através das entrevistas em autoconfrontação, ao analisarmos a materialidade do discurso expressa nos textos, isso é, através de marcadores linguísticos empregados nas categorias de análise. A própria proposta da autoconfrontação de criar um espaço para verbalizações sobre o trabalho não significa apenas transpor o pensamento para a as palavras, mas sim realizá-lo através das palavras (VYGOTSKI, 1997). Isso só se torna possível por meio de um movimento dialógico (BAKHTIN, 1984), em que o sujeito reflita sobre sua própria atividade através das réplicas do diálogo aparente ecoando réplicas do diálogo interior. Em outras palavras:

\footnotetext{
"No diálogo, o homem não se manifesta somente do exterior, mas torna-se pela primeira vez, o que ele é verdadeiramente e não somente aos olhos dos outros, repetimos, aos seus próprios. Ser, é comunicar dialogicamente. Quando o diálogo se acaba, tudo se acaba. (...) No diálogo, as réplicas de um se valem das réplicas do diálogo interior do outro (Bakhtin, 1970 ${ }^{116}$, p.344).”(CLOT, 2008 p.205, tradução nossa).
}

Através das modalizações apreciativas (é interessante $\mathrm{X}$, é motivador $\mathrm{X}$ ), pudemos distinguir como os professores reconceberam o trabalho com os conteúdos culturais, caracterizando-o e definindo-o. Suélen começa enfatizando o caráter natural com que as diferenças culturais são trazidas, afirmando que é mais interessante escutar os alunos e observar situações particulares, do contexto dos alunos. Para ela, é interessante despertar o interesse do saber. Ao mesmo tempo, ela aconselha Danilo a trazer dados, documentos autênticos da realidade dos alunos, mais interessantes e motivadores que os do livro didático, que subestimam a capacidade dos alunos, pois, enquanto brasileiros, conseguem ler mais facilmente. Ela ainda aponta que a discussão sobre como tratar o "intercultural” é algo recente. Para ela, trabalhar esses conteúdos seria trabalhar a reflexão de acordo com as capacidades das quais os alunos dispõem.

Danilo, por sua vez, aponta que os conteúdos culturais são pequenos detalhes que poderiam desaparecer, são muitas vezes uma piada, algo naturalmente compreendido pelos alunos. Ele aprecia a atividade proposta por sua colega e reconhece que quando esses conteúdos culturais emergem dos comentários dos alunos, eles expressam mais concretamente o que seria o "intercultural". Os casos particulares, as histórias dos alunos são muitas vezes coisas que

\footnotetext{
${ }^{116}$ BAKHTINE, M. La poétique de Dostö̈eviski. Paris: Le seuil, "Points”, 1970.
} 
acontecem na aula, mas que não são discutidas posteriormente. Ele afirma que, em sua aula, estava trabalhando um conteúdo gramatical, ou seja, a forma e, por isso, não trabalhou o sentido. Sendo assim, vemos que, na aula de Danilo, o trabalho com os conteúdos culturais é colocado em segundo plano. Além disso, ele critica os documentos do livro didático e concorda que eles subestimam os alunos, assim, para ele, é necessário substitui-los por algo mais interessante.

Vimos que a recorrência de frases impessoais com modalizações apreciativas ligada ao tratamento dos conteúdos culturais mostram um esforço dos professores em defini-los, corroborando duas ideias principais: a de que o objeto do trabalho é complexo e tem múltiplos fatores a serem considerados pelos os professores; e a de que o próprio trabalho com esse objeto é também dificultoso, exigindo que o professor veja sua posição de autoridade, não generalize etc..

Se por um lado, Suélen e Danilo parecem praticar a compreensão implícita e natural desses conteúdos em suas aulas, por outro lado, eles também dizem valorizar a discussão e um momento de reflexão das diferenças culturais. Através dos mecanismos enunciativos, vimos que a valorização da reflexão comentada pelos professores é permeada por outras vozes, como a da Didática das Línguas e a dos professores de línguas estrangeiras. Assim, notamos que, apesar de não ter registros de momentos de reflexão nas aulas gravadas em vídeo, eles são representados como importantes para os professores, reforçados por modalizações apreciativas positivas.

Isso se explica porque a maneira como ambos representam o trabalho com os conteúdos culturais é justamente uma redefinição (AMIGUES, 2002) ou reconcepção (SAUJAT, 2002) das prescrições. A partir do que eles compreendem e depreendem dos diversos graus de prescrições, Suélen e Danilo reformulam com suas próprias palavras aquilo que é, para eles, sua atividade de ensino e em seu meio de trabalho.

Sendo assim, podemos perceber que há uma divergência entre o que é observado no vídeo, ou seja, uma compreensão implícita e natural das diferenças culturais, e o que os professores dizem ser importante fazer com os conteúdos culturais em sala de aula, ou seja, refletir, discutir, perguntar. Nas turmas dos níveis um e quatro dos Cursos onde ambos trabalham, a compreensão dos comentários na aula de Suélen ("muito honesto") e de Danilo ("você pode praticar barco a vela, se você tiver muito dinheiro") foram entendidas sem que houvesse explicitação e verbalização pelos professores. Em outras palavras, em vez de uma discussão explícita e uma reflexão sobre as diferençais culturais, observamos uma compreensão implícita e natural, sendo o elemento que denotou que os alunos compreenderam as diferenças foi o riso. 
Ampliando a interpretação desse dado à luz do contexto de produção, podemos inferir que o que os professores dizem ser importante fazer em uma aula (refletir e discutir sobre os conteúdos culturais) seria uma resposta esperada no contexto da pesquisa, tendo em vista que "o autor de um enunciado, de maneira mais ou menos consciente, pressupõe um super-destinatário" (BAKHTIN, 1984, p.336, tradução nossa). Os participantes sabiam que as entrevistas circulariam dentro do contexto institucional de ensino e aprendizagem e seriam vistos pela coordenadora do curso também. Dessa forma, a consciência de um super-destinatário, ainda que ausente e implícito na entrevista, pode ter orientado o discurso de maneira a se dizer o que esses destinatários esperariam ouvir ("não se pode hiper-generalizar", "o intercultural é trabalhar a reflexão"). Cientes de que esses conteúdos culturais deveriam ser trabalhos por serem prescritos no livro, que contemplam a orientação do CECRL e da didática das línguas em geral, os professores sabem que eles são relevantes e pertinentes do ponto de vista da prescrição.

Aqui cabe também uma discussão sobre como o próprio trabalho com os conteúdos culturais é também algo sujeito aos matizes da cultura no qual está inserido. Sabemos que, no contexto dos Cursos Extracurriculares de Francês, os professores e os alunos são, em sua maioria, brasileiros. Há, portanto, um entendimento "natural”, já que ambos, professores e alunos, dispõem mais ou menos dos mesmos pressupostos culturais. Além disso, a maneira como essa mútua compreensão foi notificada e percebida pelos interlocutores foi, nos dois casos, por intermédio do riso, que é também uma das características que são associadas, de forma consciente e pertinente ou não, ao senso comum da brasilidade e do brasileiro, o que é, inclusive, comentado por alguns estudiosos da cultura brasileira, como, por exemplo, Holanda (1936) em sua obra em que aborda a cordialidade do brasileiro ${ }^{117}$.

Assim, podemos dizer que a forma como se trabalha elementos culturais na aula de língua estrangeira demonstra a percepção que os professores têm de sua própria cultura. Além disso, ela se constrói dentro de um contexto onde circulam de antemão as prescrições e se realiza na interação com os outros actantes, no nosso caso, especialmente entre professor e o conjunto de alunos, portanto deve também ser compreendida dentro do contexto sócio-histórico-cultural em que se realiza.

\footnotetext{
${ }^{117}$ Conferir a ideia e a crítica da cordialidade do povo brasileiro na obra de Sérgio Buarque de Holanda: HOLANDA, S. B. Raízes do Brasil. Rio de Janeiro, José Olympio, 1936.
} 
Nesse sentido, retomamos o quadro do trabalho do professor proposto por Machado (2007):

\section{Trabalho do professor}

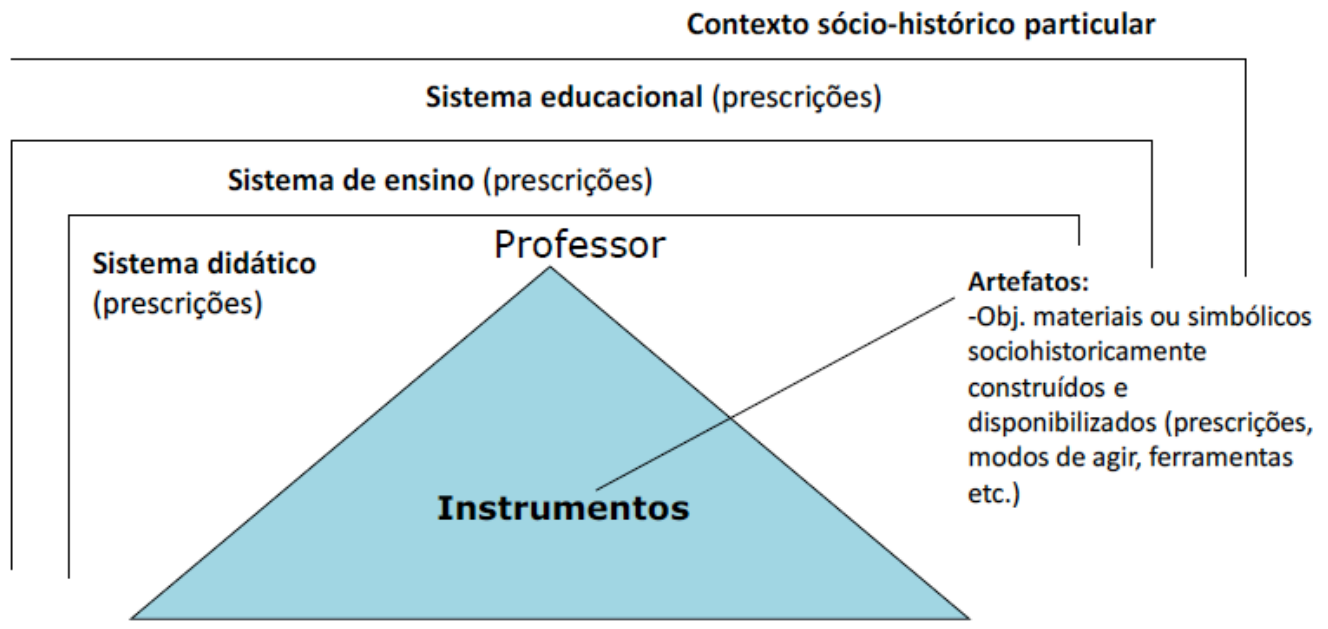

\begin{abstract}
Objeto - Na aula, organizar um meio de trabalho coletivo que propicie a aprendizagem de determinados conteúdos e o desenvolvimento de determinadas capacidades
\end{abstract}

Outrem - alunos, pais, colegas, diretor, outros não presentes, outros "dentro do P", as outras atividades do P, as atividades dos outros.

Figura 27: Esquema do trabalho do professor (MACHADO, 2007)

Além de toda a rede discursiva e das camadas de prescrições que mencionamos anteriormente, o trabalho com os conteúdos culturais depende ainda de outras variáveis, como mostra o esquema. Tanto o entendimento implícito dos conteúdos, quanto o desenvolvimento de uma discussão dos conteúdos culturais dependem do objeto de ensino (tipo de conteúdo), dos instrumentos utilizados (livro, textos autênticos), da ação do professor (dar espaço ou não para discussão) e ação dos alunos (compreender implicitamente, possuir as capacidades necessárias para discutir, contar relatos, participar etc.). Vimos que os conteúdos culturais podem se traduzir em informações sobre outra cultura, podem ser estereótipos, podem ser também uma comparação entre a cultura dos alunos e cultura-alvo. O professor pode tratar essas questões ou não em classe, dependendo do nível linguístico dos alunos para a compreensão e para desenvolver a discussão.

Em síntese, respondendo à pergunta, observamos que os professores afirmam, na ACC, que é relevante e pertinente trabalhar com os conteúdos culturais. No entanto, ao observarmos as 
aulas sobre as quais comentam na ACS e na ACC, percebemos que a maneira de trabalhar esses conteúdos não é a mesma que eles afirmam ser importante, ou seja, através de reflexão e discussões. Influenciados pelo contexto de pesquisa ou não, vemos que há, aqui, uma distância entre a prescrição e sua atividade.

Por fim, concluímos essa resposta retomando Amigues (2002), para compreendermos que a questão da distância entre o "prescrito" e o "realizado" é considerada diferentemente segundo as abordagens. De uma maneira geral, as pesquisas que tratam de eficácia de ensino, consideram essa distância como um defeito (de concepção, de planificação, de antecipação, de decisão etc.) que deveria ser reduzido pela formação (déficit de teoria nos professores, que a formação deveria poder resolver) ou por formas normativas (posição administrativa e inspeção). Já os ergonomistas da atividade de ensino, por sua vez, consideram essa distância irredutível como um sintoma dos conflitos e das tensões que "trabalham" constantemente o professor e podem estar na origem do compromisso que ele deverá fazer consigo mesmo ou com os outros (professores, alunos etc.). Assim, na análise do trabalho, essa distância é considerada como sendo a regra e não a exceção. "Ela não é considerada de maneira pejorativa, ao contrário, já que a hipótese de trabalho considera que essa distância irredutível está na origem do desenvolvimento da experiência profissional" (AMIGUES, 2002, p. 204, grifo do autor). Nesse sentido, podemos compreender que se, por um lado, Suélen e Danilo verbalizam como trabalhar com os conteúdos culturais tendo como apoio as prescrições da Didática, por outro lado, eles não fazem exatamente assim em suas aulas, mostrando uma adaptação "saudável", no nosso entender, do que é prescrito ao seu contexto particular de ensino.

\subsubsection{Quais são as representações construídas nos e pelos textos dos professores sobre seu trabalho com conteúdos culturais? Há diferenças nas maneiras que os professores encontram para trabalhar os conteúdos culturais?}

Para responder a essa pergunta, lembramos da citação de Vygotski (1934/1997 p.493): “O pensamento não nasce de um outro pensamento, mas dos dilemas do real que a atividade deve afrontar". Se vimos que, no nível declarativo, ambos os professores reconheceram e reforçaram a pertinência de se trabalhar os conteúdos culturais, ao falar sobre seu trabalho especificamente, cada um dos professores entrevistados representou seu agir de forma diferente. 
A fim de compartilhar exemplos de sua prática, ambos trouxeram elementos da sala de aula para a entrevista, momentos que identificamos através das figuras de ação ocorrência e acontecimento passado. Suélen evocou dois momentos de sua aula registrada em vídeo (comentário da aluna sobre ser "muito honesto" e a história de um conflito entre vizinhos estrangeiros devido a uma exclamação), enquanto Danilo, por não ter elementos na aula gravada, optou por recuperar três histórias para que houvesse alguma forma possível de confrontação (atividade sobre os confortos do quarto de hotel com ducha e banheiro; sua maneira de colocar o pingo no "i”; e o documentário "Prince et Princesse”).

Ao confrontar-se com sua prática, vemos que Suélen primeiramente colocou em evidência o que apareceu no vídeo de sua aula. Escolher bons documentos sobre os conteúdos culturais, dar espaço para os alunos se expressarem e gerenciar a atividade deles parecem ser o que de fato potencializa as discussões interculturais e, portanto, isso permite-lhe considerar sua atividade como eficaz: houve compreensão implícita, houve participação ativa dos alunos.

Se boa parte da atividade de Suélen foi apontada por ela e pelo colega como bemsucedida, por outro lado, a maneira como ela viveu essa experiência teve também um outro lado. Suélen frisa, em um segundo momento, um conflito interno vivido: apesar de todo seu investimento em valorizar a particularidade, o contexto dos alunos, houve momentos de generalização, o qual identificamos através da voz da fala egocêntrica e da mudança do parâmetro enunciativo empregado por Suélen, que passa do dêitico "je" a uma expressão de impessoalidade: "il y a eu" e "on". Dessa forma, identificamos um conflito vivido por Suélen em relação à maneira como acredita que os conteúdos culturais devem ser trabalhados e a maneira como os trabalhou. Ou, nas palavras de Clot (2008):

"Quem quer compreender sua atividade, deve se confrontar com seus conflitos. (...) Vygotski o dizia à sua maneira: 'O homem é cheio, a cada minuto, de possibilidades não realizadas'. Assim, o comportamento nada mais é do que 'o sistema de reações que venceram’ (Vygotski, 2003, p.74). Os outros, rejeitados, formam resíduos incontroláveis, tendo mais força para exercer uma influência sobre a atividade do sujeito, contra a qual ele pode não ter defesas. O real da atividade é também o que não se faz, o que se busca fazer sem conseguir - o drama dos fracassos - o que se gostaria de querer ou poder fazer, o que se pensa poder fazer em outro lugar." (CLOT, 2008, p.88-89, tradução nossa). 
No dizer de Clot (2008), poderíamos considerar que o momento em que ela se viu generalizando foi vivido, ao mesmo tempo, como uma espécie de "drama do fracasso" e como uma tomada de consciência, momento que lhe permitiu abrir novas possibilidades futuras, novas maneiras de agir. Ao analisarmos a fonte desse conflito, vemos que, segundo ela, o conteúdo gramatical da lição que ela trabalhava (a comparação) não poderia ser trabalhado juntamente com a proposta de falar sobre as diferentes relações de vizinhança nos países, pois esses dois vieses juntos resultariam em generalizações sobre países e culturas. Portanto, podemos concluir que o conflito se deu entre a prescrição do livro didático, a necessidade de continuar a seguir a progressão do livro didático daquela lição, e sua auto-prescrição, a construção de sua sequência de aula, composta de atividades didáticas elaboradas por ela mesma.

Porém, longe de ser visto de maneira negativa, consideramos o conflito vivido por ela como algo que pode contribuir para que Suélen reviva aquele momento criando novas possibilidades de lidar com essas situações no futuro. A ACC permite que o sujeito dê importância tanto ao "que se diz daquilo que se vê" quanto "àquilo que se faz do que se diz" (CLOT, FAITA et al, 2001).

Já Danilo traz exemplos de como trabalha os conteúdos culturais, primeiramente no nível dos hábitos e costumes de uma sociedade (a separação entre quarto, lavabo e banheiro), através dos quais, a partir de uma proposta de atividade do livro, ele pode explicar aos alunos essa diferença. Ele também traz a questão da autoridade da figura do professor, quando os alunos projetam toda a identidade cultural de um povo na figura de um falante daquela língua, no caso, o professor (se o professor de francês faz um pingo no i com uma bolinha, deve ser porque os franceses fazem assim). Finalmente, ele traz uma proposta de substituição a uma atividade do livro, trazendo um filme de animação, documento autêntico, para falar dos animais.

Ao se observar trabalhando os conteúdos gramaticais, sua forma, sua estrutura, sua pronúncia, Danilo afirma que separa esse momento da exploração dos possíveis sentidos de usar aquelas estruturas. Na ACS, observamos que Danilo não havia se dado conta desse aspecto e toma consciência disso naquele momento, através da pergunta da pesquisadora, momento esse identificado através dos traços da voz da fala egocêntrica. Na ACC, quando esse elemento é trazido pela colega, Danilo confirma que não havia pensado em trabalhar o sentido naquela ocasião, reconstituindo o diálogo interior daquele momento (voz da fala egocêntrica 
reconstituída). Ele evoca não somente o que não foi feito (trabalhar o sentido), mas consegue projetar formar do que poderia ter sido feito (possibilidades de perguntas, interação com os alunos), compreendendo assim o real de sua atividade.

Tanto no primeiro caso, como no segundo, o conflito colocado em perspectiva desencadeou uma tomada de consciência. Segundo Vygotski ([1925]/2004, p.71), a consciência é "vivência das vivências" ou, na reformulação de Clot (2008) a "experiência vivida de uma experiência vivida". Assim, Clot (2008, p.199) explica que a tomada de consciência não é uma descoberta de um objeto mental inacessível, mas a redescoberta, a recriação de uma experiência em um novo contexto, que o 'faz ver de outra maneira'. Ela repousa sobre uma transformação da experiência psíquica.

Tanto Danilo ou Suélen, revivem suas experiências na ACC, tomando consciência do conflito de sua atividade. Esse conflito pode ser interpretado como uma tensão entre os resultados do trabalho acerca de seu objeto de ensino, a eficácia de sua atividade e os efeitos do trabalho sobre si-mesmos em termos amplos de saúde (FAÏTA, SAUJAT, 2010, p.5).

Danilo conclui dizendo que aquele momento era um momento de se trabalhar a gramática, uma das prescrições para seu trabalho da qual tinha que dar conta e que ele colocou na frente de outras prescrições, como a do trabalho com os conteúdos culturais, por exemplo. Vale lembrar que, no caso da Didática das Línguas, as prescrições com relação à gramática são muito mais antigas, bem exploradas e estão muito mais solidificadas do que as com relação à cultura. Ele, ao focar nas estruturas linguísticas, "na forma", priorizando essa prescrição sobre a dos conteúdos culturais, encontrou sentido e considerou sua atividade como eficaz, por contemplar o que havia necessidade de ser trabalhado. Poderíamos dizer que houve compromisso entre a eficácia e os efeitos do trabalho sobre sua saúde, entretanto, o conflito se deu em termos de resultados sobre os conteúdos culturais.

Suélen, por sua vez, realizou sua proposta com sucesso, mas o fato de alguns conteúdos temáticos do livro colocados com certos conteúdos culturais encadearem generalizações foi, para ela, um momento de insucesso. Ela atingiu os resultados acerca do objeto de ensino, sua atividade foi eficaz no ponto de vista de Danilo, porém, o momento de generalizações teve efeito sobre sua saúde em termos amplos. Dessa forma, percebemos que a discordância entre "o que se 
pede" e "o que a atividade em si pede" (HUBAULT, 1993) ${ }^{118}$ desencadeia uma tensão entre esses elementos, gerando um conflito interno. Nos dizeres de Clot (2001), vemos que:

"Eles sentem que seu poder de agir sobre o meio e sobre eles mesmos, ligando saúde e eficácia, tem uma dupla origem: o desenvolvimento do sentido de sua experiência e de sua eficiência." (CLOT, 2001, p.15, tradução nossa).

Poder observar seus conflitos, longe de ser uma constatação de fracasso, é um meio de compreendê-los e aumentar seu poder de agir sobre a situação vivida. "O que é formador para os trabalhadores, isso é, o que aumenta seu raio de ação e seu poder de agir é encontrar a possibilidade de mudar de status seu vivido: de objeto de análise, o vivido deve tornar-se meio de viver outras vidas" (CLOT, 2001, p. 15, tradução nossa). Nesse sentido, levantamos a hipótese de que as experiências vividas e revividas com as ACS e ACC possam ter servido, para Suélen e Danilo, como uma forma de viver outras experiências, embora a verificação dessa hipótese fuja ao escopo de nossa dissertação.

Ainda, através dos mecanismos enunciativos (vozes e modalizações), podemos ampliar a compreensão desse panorama. Suélen falou de seu trabalho empregando modalizações pragmáticas, que mostraram que ela teve a intenção e orientou seu agir de maneira a realizar atividades que envolvessem os conteúdos culturais. Ela ainda trouxe a voz da didática e da teoria do ISD para embasar sua prática, mostrando-se consciente e protagonizando o processo que orientaria a atividade dos alunos. Já Danilo, valendo-se de uma grande quantidade de modalizações lógicas de possibilidade, caracterizou seu agir não do ponto de vista do realizado, mas do possível - desencadeado pela tomada de consciência. Ele traz em seu discurso a voz do livro didático e dos professores de línguas estrangeiras, externando sua prioridade em dar conta das prescrições: o conteúdo gramatical que garantiria a progressão dos alunos nas avaliações e no próximo nível do curso.

\subsubsection{A partir de uma comparação/confrontação entre o trabalho prescrito, o trabalho realizado e o real da atividade de trabalho, como podemos apontar elementos para uma melhor compreensão sobre o trabalho do professor com conteúdos culturais?}

\footnotetext{
${ }^{118}$ Hubault, F. " Le travail, ou l'interface anthropotechnologique à l'épreuve », Performances Humaines \& Techniques, $n^{\circ}$ hors série Septembre, 1993, p.2-11.
} 
Diante das prescrições do CECRL e das mais diversas contribuições da Didática e de outras disciplinas, o professor de línguas estrangeiras é consciente de que deve trabalhar elementos culturais em suas aulas. Entretanto, vimos que essas prescrições apresentam uma perspectiva complexa e múltipla sobre seu objeto (conteúdos culturais) e sobre a competência a se desenvolver através dele. O quadro que se forma é de uma carência de orientações do ponto de vista prático, do ponto de vista do trabalho do professor, de seu métier. Nosso intuito, ao analisar e comparar o trabalho prescrito, o trabalho realizado e o real da atividade de trabalho,é de levantar elementos de explicitação do trabalho em sala de aula, sur le terrain, que possam contribuir para sua melhor compreensão. Nesse sentido, nosso trabalho buscou responder também a uma demanda da Didática das Línguas, no sentido de realizar uma pesquisa empírica a fim de levantar elementos para possivelmente "fazer evoluir a formação de professores e as metodologias de ensino" (BYRAM, 2011, p.254, 255).

Uma das categorias de análise mais esclarecedoras nesse sentido foram os mecanismos de textualização (nas séries coesivas nominais e lexemas verbais de retomada), por meio dos quais verificamos como são expressos e retomados os conteúdos culturais e quais ações eram ligadas a eles. Vimos que as séries coesivas nominais se distribuíram em seis campos lexicais diferentes, como mostra a Tabela 33: o da reflexão, o do humor e do riso, o da descoberta, da experiência pessoal e da participação dos alunos, o da cultura e interculturalidade, o da generalização e o da particularidade. A partir desses campos semânticos, vemos que a experiência dos professores e sua relação com os conteúdos culturais amplia, ultrapassa e contextualiza as denotações que esses conteúdos têm nas prescrições, seja no CECRL, seja no livro didático.

Nossa análise dos lexemas verbais, divididas ações consideradas como positivas e ações consideradas como negativas, como vimos na Tabela 34, mostrou que os professores focaram de maneira mais expressiva sua atividade enquanto professores, do que a dos alunos ou a dos conteúdos culturais (essas duas contempladas mais no CECRL). Os professores representaram sua ação de maneira contextualizada, levando em conta que o riso e o humor são uma característica dos alunos, enquanto brasileiros. Ambos falam sobre a necessidade de familiarizar e de aproximar o conteúdo da visão de mundo, dos centros de interesse do aluno. Há também, na fala dos professores, mostras do exercício da criatividade, ao desejarem trazer textos autênticos e elementos não previsíveis. Os professores apontam o despertar da curiosidade e do interesse pela 
descoberta, assim como a discussão sobre a cultura alvo, e o intuito de evitar a comparação e a generalização.

Dessa forma, concluímos que a maneira possível de trabalhar os conteúdos culturais, diante das prescrições que são determinadas na conjuntura atual do ensino de línguas e dentro de uma sala de aula de francês, para alunos brasileiros, em nosso contexto de ensino-aprendizagem se caracterizou, sobretudo, pelas seguintes ações dos professores: perceber potenciais diferenças culturais, expor os alunos a situações de outra cultura através de documentos autênticos, introduzir ou levantar as diferenças através do riso, da descontração, entrar no contexto dos alunos, abrir um espaço para suas experiências pessoais, para escutá-los e para discussão. Essas ações são completadas pelas ações dos alunos: comparar, falar sobre, refletir, perguntar, dar exemplos e fazer comentários.

Ressaltamos, entretanto, que esses elementos extraídos de nossos dados têm a limitação de se referirem ao trabalho com conteúdos culturais a partir de um contexto específico. Caberia explorá-los mais a fundo em outros contextos, propondo eventualmente estudos comparativos.

\subsubsection{A partir de uma confrontação entre o trabalho prescrito, o trabalho realizado e o real da atividade de trabalho, como a análise da situação de trabalho pode ser considerada como potencialmente geradora de desenvolvimento? Que elementos podem ajudar a interpretar esse potencial?}

Nossa última pergunta de pesquisa se baseia em uma interpretação dos resultados, buscando uma aproximação entre o que observamos nas análises e alguns conceitos teóricos. Enquanto interpretações, as ideias que seguem não podem ser entendidas como afirmações, mas como aproximações teóricas a serem melhor investigadas, como hipóteses a serem comprovadas a partir de novas pesquisas e mais dados.

Para responder essa questão, retornaremos aos conceitos vygotskianos apresentados na Fundamentação Teórica. Além dos exemplos em que encontramos traços de tomada de consciência (por meio da voz da fala egocêntrica), outros apontamentos nos permitem indicar traços de desenvolvimento. Na sequência, interpretaremos, primeiramente, a aula de Suélen e ACC à luz do conceito de atividade mediadora; em seguida, veremos a representação da experiência e do conflito através da alternância de dêiticos como um movimento inter e 
intrapsicológico; e finalmente, a dinâmica das figuras de ação à luz dos conceitos científicos e cotidianos.

Em primeiro lugar, gostaríamos de desdobrar uma interpretação de traços do desenvolvimento no plano da análise do trabalho na ACC (com relação ao desenvolvimento dos professores). Embora o foco principal do trabalho seja as representações dos professores a partir das entrevistas, faremos aqui uma pequena digressão para observar um momento o que se passou na aula de Suélen, tal como retomada na ACS e na ACC, pois ali encontramos uma forma de paralelismo com a entrevista.

Retomando os conceitos de instrumento psicológico e de atividade mediadora (VYGTOSKI [1930]/2004, p.93-101; FRIEDRICH, 2012) vistos em nossa Fundamentação Teórica, podemos inferir que a pesquisadora se vale de instrumentos para seu trabalho (vídeo das aulas), que ela almeja que se torne um instrumento psicológico (que lhes permitam confrontar-se a sua própria atividade) no intuito de desenvolver uma nova percepção e uma nova compreensão sobre a atividade, sobre o métier.

Vejamos o esquema da atividade mediadora, originalmente proposto por Friedrich (2012), adaptado aos nossos dados:

Texto (a aula registrada em vídeo como texto disparador)
Percepção dos professores sobre sua atividade. Traços de tomada de consciência. Traços de expansão do poder de agir.

$=$ análise do trabalho através da $\mathrm{ACC}$
A pesquisadora, baseada no quadro metodológico da ACC, organiza a atividade de maneira a deixar que o texto (a aula em vídeo) aja sobre os professores e que eles a comentem livremente.

Pesquisadora e professores atuam sobre a escolha dos excertos. A pesquisadora faz perguntas, direcionamento de alguma maneira a atividade para alavancar verbalizações e possibilitar a vivência de uma experiência vivida.

Figura 28: ACC como atividade mediada 
Para que o registro da aula em vídeo seja apropriado como instrumentos psicológicos, a pesquisadora realiza uma atividade mediadora: a partir dos trechos do vídeo que interpelam os professores, ela organiza e conduz a entrevista em autoconfrontação estimulando-os a perceber sua atividade ou a do outro com distanciamento. Seguindo o quadro da ACC tal como proposto por seus conceptores (CLOT, FAITA et al, 2001), os professores assistem às aulas registradas e comentam livremente, havendo intervenção da pesquisadora ou do colega para ressaltar, questionar e solicitar verbalizações sobre alguns pontos conflituosos ou simplesmente que lhe causem estranhamento.

A pesquisadora organiza a atividade de maneira a provocar uma nova percepção ou compreensão da atividade. Entretanto, não é, e nem poderia ser, ela quem realiza essa mudança no outro. Com efeito, não é possível prever ou afirmar de antemão o que ocorrerá através de uma atividade mediadora como esta, pois pode haver apropriação ou não. No nosso caso, vimos traços de tomada de consciência (por exemplo, a voz da fala egocêntrica) e marcas que indiquem a expansão do poder de agir (modalizações lógicas de possibilidade após a tomada de consciência) daqueles professores a partir das situações vividas e revividas.

Encontramos, assim, um paralelo entre a proposta da autoconfrontação e os conceitos ligados ao desenvolvimento da consciência proposto por Vygtoski (1934/1997; 1925/2004) e retomado por Bronckart (2006, p.59-89). Para Vygotski (1997), esse desenvolvimento se dá (i) pela exposição e interação com as representações, com as construções mentais do mundo vivido; (ii) pela racionalidade social e individual, que tem como base a língua natural e são portanto contextualizadas e de ordem sociocultural; (iii) pela racionalidade lógica universal, que constrói processos de generalização e descontextualização dessas significações particulares - abstração reflexiva, conceitos. O desenvolvimento da consciência seria, assim, mediado por duas instâncias: pela linguagem e pela atividade mediadora.

Apontamos ainda dois dos fatores preponderantes na ACC: a socialização e a experiência. O elemento da socialização se mostra quando o sujeito se dirige ao colega e pesquisador presentes, mas também aos super-destinatários daquela gravação ou mesmo quando ele se dirige a si mesmo, fazendo um diálogo interior. Sem a proposta de compartilhar, de socializar, talvez não haveria espaço para o confronto da atividade. A experiência (perezivanije, segundo Vygotski, que, em russo, significa experiência, experiência emocional, experiência vivida) permitiu aos professores integrar um dado subjetivo da situação vivida e revivida, criando uma 
relação marcada e significante em seu desenvolvimento. Nesse sentido, retomamos o que aponta Vygotski (1925, 1932) e retoma Brossard (2012, p.111), "nós nos desenvolvemos dentro de situações sociais significantes e nossas emoções são a maneira pela qual nós experienciamos a diversidade e a riqueza dessas situações". Pensar a atividade de ensino não somente como um objeto, mas como uma experiência que fez e faz parte de sua história pessoal confere outra dimensão de significado ao desenvolvimento, pois, como vimos, "as emoções são portadoras de significações essenciais na e para o desenvolvimento da personalidade" (BROSSARD, 2012, p. 111).

De acordo com a perspectiva que apresentamos na Fundamentação Teórica, podemos apontar que o desenvolvimento parece ter sido provocado a partir de uma apropriação dos instrumentos (vídeo da aula), por meio de uma atividade mediada pela linguagem e pela atividade de pesquisadora. Esse desenvolvimento é também é mediado pelas emoções das experiências vividas do sujeito, ligando-se à sua história e seu contexto social. Nesse sentido, conseguimos observar uma aproximação da ACC com a ideia de desenvolvimento formulada nas teses de Vygotski (1925, 1932, 1934).

Finalmente, outro elemento que potencializa o desenvolvimento é o que Clot (2008) chama de "repetição sem repetição". O autor postula: "há desenvolvimento graças a uma repetição sem repetição", pois o destinatário e o objetivo mudam a cada nova atividade mediadora dirigida (CLOT, 2008, p.169). De fato, os professores viveram a situação da aula em diversos momentos: na planificação antes da atividade, na atividade realizada, na ACS, na ACC e nos retornos ao coletivo. A vivência de cada uma dessas fases será fatalmente diferente, pois o sujeito estará interagindo com diferentes interlocutores, com diferentes objetivos, estando em um novo momento do desenvolvimento. No caso dos momentos de análise do trabalho, ACS e ACC parecem ter sido meio adequado de proporcionar, retomar e desenvolver algumas questões do métier.

Em segundo lugar, a partir da observação da figura de ação experiência, vimos que os dois professores se representam de maneira diferente na categoria dos dêiticos. Danilo, ainda com menos experiência que Suélen, evoca casos ilustrativos e pontuais de trabalho com os conteúdos culturais de outras aulas e quando formula sua própria experiência, usa o pronome on, em nome da coletividade dos professores. Suélen comenta as situações de sua aula em vídeo, formulando sua experiência com elementos positivos e negativos, empregando je (je ne me sens pas capable, 
je préfère aller vers la découverte) e também dificuldades comuns ao coletivo (on généralise, on ne voit pas).

Ora, Vygotski ([1930]/2004, p.112,114) lembra que toda forma superior de comportamento aparece em cena duas vezes: no nível interpsicológico (social) e no nível intrapsicológico (individual). Dessa forma, poderíamos inferir que a configuração da experiência de Danilo aponta para uma fase de apropriação, em que ele ainda partilha com coletivo (on) as dificuldades presentes. Essa configuração seria a aprendizagem do métier ainda no nível da socialização, a atividade ainda interpsicológica, entre os sujeitos. Sua experiência, no caso, ainda é fortemente ligada ao coletivo, não estando ainda completamente interiorizada. A configuração da experiência de Suélen, por sua vez, indica que ela consegue falar sobre si (je) e sobre o métier (on), separando as duas instâncias. Isso mostra que sua atividade passa de inter a intrapsicológica e que ela já teria interiorizado traços dessa atividade, constituída coletiva e psicologicamente. Essa análise faz eco ao que Saujat (2004b) observou nos professores iniciantes quando se apropriam do métier, fazendo do métier dos outros um métier de si. Ao verbalizar elementos positivos e negativos de sua experiência, Suélen se mostra em um estágio mais seguro de desenvolvimento com relação às questões de seu trabalho.

Em terceiro e último lugar, outra interpretação que fizemos com relação ao potencial desenvolvimento foi através da dinâmica das figuras de ação. Como vimos, foi possível identificar através do conjunto das figuras de ação um movimento bastante peculiar no que diz respeito a como Suélen e Danilo representam, mas também (re)configuram seu agir com os conteúdos culturais nos e pelos textos das ACS e ACC. É o que mostramos abaixo ao apontar a dinâmica de emprego das figuras de ação da ACC:

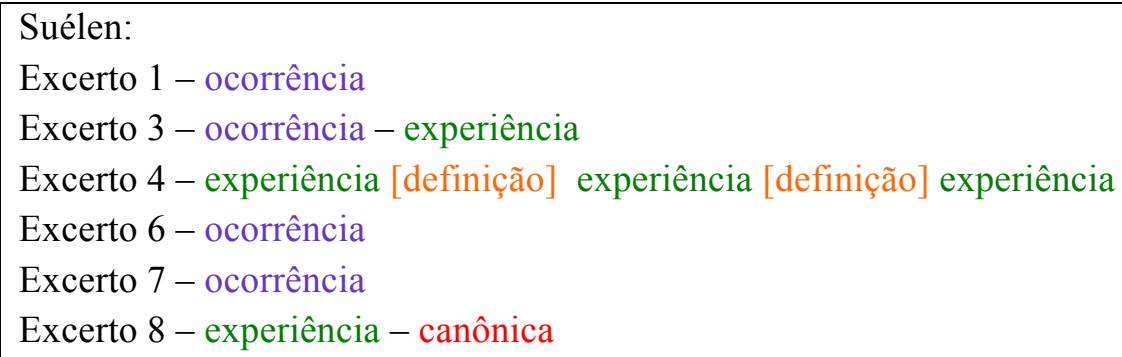

Figura 29: Dinâmica das figuras de ação de Suélen na ACC 
Danilo:

Excerto 2 - ocorrência [definição] - acontecimento passado - experiência

Excerto 4 - experiência [definição] experiência [acontecimento passado] experiência [definição] experiência

Excerto 5 - ocorrência

Excerto 6 - ocorrência

Excerto 7 - ocorrência

Excerto 8 - experiência - canônica

Figura 30: Dinâmica das figuras de ação de Danilo na ACC

A partir dos quadros acima, notamos um movimento dinâmico das figuras de ação. As figuras ocorrência ou acontecimento passado (que relatam casos vivenciados próximos ao presente ou já no passado, ou seja, experiências únicas, não ainda cristalizadas) engendram um movimento de abstração, de reflexão, que lhes permite, então, elaborar a cristalização de suas experiências (figura de ação experiência). Essas figuras se alternam ao longo da entrevista, contudo, observamos que esse movimento se repete por mais de quatro vezes.

Em alguns turnos, a experiência é relacionada à prescrição e ao dever, representado pela modalização deôntica (descontextualizada) e pelo presente genérico com valor de regra, que aparece por quatro vezes nas falas de Danilo e apenas uma na de Suélen. Dessa forma, compreendemos que a maneira como Danilo configura seu agir, apesar de contar muito com sua experiência, se relaciona ainda fortemente com as prescrições, ao passo que Suélen configura seu agir a partir do que ela mesma avalia ser pertinente em aula. Interpretando o que observamos nas análises à luz dos conceitos das ciências do trabalho, vemos que a figura de ação canônica presente no final da entrevista nos indica que os professores elaboram regras para si, autoprescrições, em função de sua experiência. Essas auto-prescrições são, portanto, o resultado da reconcepção do trabalho: ao reconceber o trabalho, o professor recria novas maneiras de agir, novas orientações, novas prescrições para si, modificando aquelas que existiam anteriormente.

Levantamos a hipótese interpretativa de que esse movimento esteja intrinsecamente ligado ao modelo vygotskiano de formação de conceitos (FRIEDRICH, 2012, p.95). Vygotski (1997) postula que os conceitos cotidianos se formam com as experiências de mundo, ou seja, as experiências únicas (em nosso caso, figura de ação ocorrência e acontecimento passado), isso é, no contato direto com o mundo, enquanto os conceitos científicos são generalizações de segunda ordem, pois não operam de maneira imediata e direta, mas se apóiam nos conceitos cotidianos e 
existem dentro de um sistema de conceitos. "É o processo de generalização/ particularização que Vygotski consideraria como sinal da 'tomada de consciência'"(CLOT, 2008, p.176).

Poderíamos levantar a hipótese de que os relatos dos acontecimentos na aula, possibilitados pelas entrevistas em ACS e ACC (figuras de ação ocorrência e acontecimento passado), se aproximariam à ideia dos "conceitos cotidianos", no sentido de possibilitar uma abstração da prática em forma de figura de ação experiência, além de reflexões teóricas sobre seu objeto com nas figuras de ação definição. Estas duas figuras, por sua vez, teriam uma função próxima à do "conceito científico", permitindo a realização do pensamento dos professores de outra forma, através da tomada de consciência de suas ações de um ponto de vista geral. A figura de ação experiência permite, então, a formulação das experiências dos professores também em forma de generalização.

Partindo dessa interpretação, é possível inferir que os movimentos de particularização e de generalização que engendrariam uma potencial tomada de consciência estariam ligados respectivamente, na análise do trabalho, às figuras de ação ocorrência e acontecimento passado, de um lado, e às figuras de ação definição e experiência, de outro. Sendo assim, levantamos a hipótese de que uma dinâmica que se passe das figuras de ação de particularização ("cotidianas") às figuras de ação de generalização ("abstratas"/ "científicas") indique também indícios de desenvolvimento, pois evidencia-se uma compreensão mais madura por parte do sujeito.

Em síntese, as três hipóteses interpretativas que expusemos nos permitem repensar a análise do trabalho dos professores de FLE com os conteúdos culturais a partir de um quadro teórico-metodológico que busca investigar o desenvolvimento por meio da análise do agir, portanto, do trabalho, e da linguagem. Reiteramos, no entanto, que essas hipóteses se fundamentam em aproximações teóricas e, portanto, não têm a pretensão de afirmar que houve, de fato, desenvolvimento.

Tendo, finalmente, apresentado nossos resultados e discutido-os à luz de nosso quadro teórico, passemos às considerações finais. 


\section{Considerações Finais}

Mire veja: o mais importante e bonito, do mundo, é isto: que as pessoas não estão sempre iguais, ainda não foram terminadas - mas que elas vão sempre mudando. Afinam ou desafinam.

João Guimarães Rosa Grande Sertão: Veredas 
Para apresentar nossas considerações finais, gostaríamos de lembrar que um trabalho de pesquisa não acaba de fato: ao contrário, ele geralmente suscita novas pesquisas, a partir das reflexões que ele permite entre os possíveis e não possíveis do estudo. Tendo isso em mente, apresentaremos, primeiramente, uma retomada geral de nossas motivações iniciais e das inquietações que suscitaram a pesquisa; em seguida, apontaremos algumas limitações de nosso estudo que fornecerão material para novas pesquisas; dando continuidade, retomaremos nossos resultados e apontaremos as conclusões a que chegamos para, finalmente, apontar nossas contribuições para a questão estudada, para os participantes da pesquisa, para o grupo de pesquisa ao qual está ligado e para novas pesquisas que podem ser feitas a partir da nossa.

Em nossa introdução, esclarecemos que o primeiro aspecto que motivou a presente pesquisa foram as experiências de ensino da pesquisadora em contextos internacionais e sua aprendizagem do métier professor de línguas estrangeiras, experiências que tinham como inquietação principal o trabalho com os conteúdos culturais. A preocupação com esses conteúdos culturais encontrava-se também no coletivo de professores-monitores dos Cursos Extracurriculares de Francês da Universidade de São Paulo, que relatavam dificuldades em trabalhar esse assunto a tal ponto que escolheram como tema de sua jornada de formação do ano de 2012 o "intercultural".

$\mathrm{Na}$ verificação do estado da arte na produção científica brasileira, identificamos apenas um pouco mais de uma dezena de trabalhos sobre a formação de professores e os conteúdos culturais no ensino de língua estrangeira. Na revisão da literatura, pudemos constatar que o tema da cultura intrigava não somente a Didática das Línguas, mas outras disciplinas das humanidades, como a Filosofia, a Sociologia, a Psicologia, a Pedagogia etc. Segundo Byram (2011), apesar de haver inúmeras publicações sobre o tema, o sentido dado a expressões como "cultura", "competência intercultural", "conteúdos culturais" e noções vizinhas é objeto de debate em si mesmo, assim, os modelos que se referem a elas são numerosos e influenciam a formulação das problemáticas de pesquisa. Especificamente na Didática das Línguas, Byram (2011, p.253) apontou que "essas expressões servem mais para nomear as finalidades educativas que para definir ou descrever práticas pedagógicas atuais, enunciando mais "o que deveria ser feito" do que "o que se faz"”.

Tendo como pano de fundo, por um lado, uma carência de pesquisas empíricas sobre "o que se faz para se trabalhar os conteúdos culturais em sala" e, por outro lado, um contexto de 
ensino, pesquisa e extensão, que motivou a pesquisa e onde havia um coletivo de professores iniciantes em formação, elaboramos nosso objetivo e perguntas de pesquisa, pensando em investigar justamente o que se diz que "deve ser feito" e o que os professores dizem fazer em sala de aula, em busca de uma melhor compreensão do trabalho educacional com conteúdos culturais.

Nosso intuito foi retomar a discussão teórica existente na Didática de Línguas e Culturas em torno de orientações e objetivos de ensino para o trabalho com os conteúdos culturais, buscando compreendê-la para além dessas noções dadas a priori, a partir do ponto do vista um dos atores da situação de ensino-aprendizagem, o professor. As perguntas que nos orientaram foram:

a) Quais são as orientações nos documentos oficiais acerca da cultura e do tratamento dos conteúdos culturais?

b) Quais são as representações construídas nos e pelos textos dos professores sobre a relevância ou a pertinência de se trabalhar conteúdos culturais?

c) Quais são as representações construídas nos e pelos textos dos professores sobre seu trabalho com conteúdos culturais? Há diferenças nas maneiras que os professores encontram para trabalhar os conteúdos culturais?

d) A partir de uma comparação/contraposição entre o trabalho prescrito, o trabalho realizado e o real da atividade de trabalho, como podemos apontar elementos para uma melhor compreensão sobre o trabalho do professor com conteúdos culturais?

e) A partir de uma comparação/contraposição entre o trabalho prescrito, o trabalho realizado e o real da atividade de trabalho, como a análise da situação de trabalho pode ser considerada como potencialmente geradora de desenvolvimento? Que elementos podem ajudar a identificar e interpretar esse potencial?

O diferencial desta pesquisa, de base vygotskiana, foi partir de uma visão sócio-histórica da metodologia, produzindo dados de forma longitudinal (de filmagem de aulas aos retornos dessas filmagens e discussão nos coletivos de professores) e considerando o diálogo sobre o trabalho e os possíveis conflitos que emergem quando se revive o vivido (CLOT, 2008) como motores potenciais do desenvolvimento. Assim, para respondermos às perguntas de pesquisa, nos valemos de um método indireto de análise do trabalho, a autoconfrontação cruzada, que não se presta somente à produção e coleta de dados, mas que é, por definição, formativo e que extrapola a dualidade das pesquisas científicas nos eixos da subjetividade e da objetividade. 
Realizamos a pesquisa no contexto que motivou as inquietações para a pesquisa: um curso de extensão universitária de francês língua estrangeira na Universidade de São Paulo, os Cursos Extracurriculares de Francês. Do grupo de professores-monitores que ali iniciavam a aprendizagem do trabalho de ensino, dois se voluntariaram para participar das filmagens de aula e entrevistas que compuseram os dados deste trabalho. Quase um ano após as entrevistas em autoconfrontação simples e cruzada, excertos dessas filmagens foram trazidos para reuniões de retorno ao coletivo e reuniões pedagógicas.

Como em todo trabalho de pesquisa (que é também um trabalho, portanto, com suas orientações, prescrições, ações realizadas, impedidas, suspendidas etc.), tivemos algumas limitações e impedimentos.

Do ponto de vista da metodologia, foi minha primeira experiência como pesquisadora (intervenante) no que tange à análise das situações de trabalho. Foi também a segunda experiência com autoconfrontações no contexto dos Cursos Extracurriculares de Francês (sendo a primeira de Dantas-Longhi, 2013). Apesar de termos realizado quatro sessões de retorno ao coletivo nesse contexto, três delas não foram feitas da maneira como os clínicos da atividade e ergonomistas as conceberam - exclusivamente para a análise do trabalho -, mas, sim, em situação de formação de professores. Essa foi uma das limitações de nossa pesquisa.

Se, por um lado, realizar esses retornos foi essencial para que nos apropriássemos, enquanto grupo, do método da autoconfrontação e pudéssemos compreender melhor sobre a distinção entre os momentos de análise do trabalho, de pesquisa e de formação; por outro lado, essa experiência nos levou a observar que a análise do trabalho por meio da autoconfrontação é um recurso que dialoga com a formação, que permite que os novos professores partilhem e verbalizem sobre os dilemas do métier, fazendo eco às preocupações dos que já exerciam a docência naquele meio ${ }^{119}$. Essa seria, portanto, uma das possíveis maneiras de se estudar o aspecto transpessoal do trabalho.

Uma segunda restrição foi não termos conseguido realizar os retornos ao coletivo logo após as autoconfrontações simples e cruzada, mas, sim, dez meses depois, quando um dos professores voluntários já não integrava mais o contexto. Nesse lapso de tempo, o grupo de professores-monitores se modificou, perdendo e ganhando integrantes, fato que estimulou novos

\footnotetext{
${ }^{119}$ Conferir SILVA (no prelo), Non Plus, n.5.
} 
questionamentos no grupo. Isso inviabilizou que os retornos ao coletivo ecoassem sobre a questão dos conteúdos culturais, levantando novas questões mais prioritárias para aquele grupo. Essa mudança de conformação do grupo e do surgimento de novos interesses deve ser considerada, no entanto, como natural e constitutiva deste contexto, que é, por definição, rotativo, como vimos na Metodologia.

Outro aspecto que poderia ser considerado uma limitação foi o recorte dos dados. Apesar de termos produzidos os dados de forma longitudinal, optamos por fazer um recorte somente da autoconfrontação cruzada para análise, uma vez que foi nele que encontramos mais elementos que responderiam a nossas perguntas de pesquisa. Elementos da aula e da autoconfrontação simples foram trazidos em alguns momentos específicos para uma melhor compreensão da ACC em análise. Da mesma forma, a análise do material verbal em detrimento do material visual foi também uma opção que pode ter limitando o escopo trabalho. Apesar dessas aparentes limitações, o recorte não foi algo que invalidou a pesquisa, pois pudemos chegar a conclusões pertinentes com nossos dados. Além disso, os materiais não explorados nessa dissertação serão (e já o são) objetos de outras produções científicas como apresentações e artigos.

Finalmente, outra limitação com relação aos resultados encontrados é que eles foram baseados nas entrevistas com apenas dois professores, o que, para certos tipos de pesquisa, pode ser considerado pouco. No entanto, em um paradigma qualitativo como o nosso, não buscamos a generalização, pois sabemos que as pessoas e situações são únicas e os resultados seriam dificilmente generalizáveis. De qualquer forma, mais pesquisas podem ser feitas para validar ou estabelecer parâmetros de comparação para nossas conclusões.

Contudo, apesar dessa aparente restrição com relação aos dois participantes, o método da autoconfrontação visa justamente a não restringir a questão a um sujeito apenas, mas permitir que aquele dilema seja ampliado e discutido em meio aos seus pares e ao conjunto de professores do contexto, passando do conflito específico à discussão e ao saber-fazer coletivo do métier.

Apesar das limitações que mencionamos, acreditamos ter atingido nossos objetivos. Como demonstramos na seção de Discussão dos Resultados, nossas perguntas de pesquisa puderam ser respondidas a partir dos dados e das categorias de análise e pudemos chegar a uma série de interpretações pertinentes sobre nosso objeto de estudo. 
Os resultados de nossa pesquisa retomam nossas duas inquietações iniciais: por um lado, o trabalho dos professores de FLE com os conteúdos culturais e, por outro lado, o desenvolvimento e a aprendizagem do trabalho de ensino.

Primeiramente, no que tange ao trabalho dos professores de FLE com os conteúdos culturais, poderíamos apontar uma contribuição para o campo da Didática das Línguas e Culturas. Lembramos que não era nosso objetivo elaborar uma nova definição dos conteúdos culturais, mas, sim, ver como esses conteúdos são representados pelos professores que os trabalham na sala de aula. Vimos que os conteúdos culturais constituem um desafio para os professores. Ao apontarem os impedimentos, a priorização da gramática em detrimento dos conteúdos culturais, ou a organização do livro didático, que se colocam como obstáculo ao trabalho, ambos os professores deixam claro que os conteúdos culturais são algo com o que ainda estão aprendendo a lidar. Por outro lado, ambos mostram prova de eficácia ao mencionarem que trabalham esses conteúdos cada um à sua maneira. Ao mesmo tempo em que reiteram sua importância, eles introduzem esses conteúdos por um viés comum (o humor e o riso - possivelmente uma maneira cultural brasileira de lidar com alguns assuntos e, possivelmente, com os conteúdos culturais em sala de aula de LE), mostrando que não é exatamente pela maneira apresentada pelo livro didático que eles os trabalham. É, portanto, no exercício de sua criatividade que organizam e realizam seu trabalho de modos diferentes (trazendo documentos autênticos ou solicitando experiências pessoais dos alunos).

Nesse sentido, cremos que nossos resultados vão no sentido de fornecer elementos de definição do trabalho dos professores de FLE com os conteúdos culturais, obtidos através dados empíricos de professores em plena atuação. Nossa aspiração é a de que, futuramente, a Didática das Línguas e Culturas possa elaborar repensar os conteúdos culturais no ensino de LE, levando em conta pesquisas empíricas, como a nossa, que apresentam a visão dos professores desse objeto de seu trabalho, a partir do seu uso no campo de trabalho. Nesse sentido, cremos eventualmente ter levantado indícios para "fazer evoluir a formação de professores e as metodologias de ensino" (BYRAM, 2011, p.254, 255), entretanto, uma formação dentro de novos moldes como defendem Bulea et al (2013):

\footnotetext{
"Não há mais espaço para uma formação de professor que dita modelos, é preciso ter acesso às representações reconstruídas do agir do professor e dele próprio por ele mesmo oralizada. É com base nesta materialização que temos dados que nos permitem entender
} 
o espaço e o papel da linguagem nas interações sociais". (BRONCKART-BULEA, LEURQUIN, CARNEIRO, 2013, p.129)

Dessa forma, nosso estudo suscita novas pesquisas, que poderiam ser realizadas com outros professores de FLE ou de outras LE, no intuito de verificar se para esses professores o trabalho com os conteúdos culturais é representado de maneira semelhante ou divergente e que fatores influenciariam essas representações.

Em segundo lugar, nossa pesquisa apresenta contribuições no que tange ao próprio trabalho de ensino e à aprendizagem dos professores sobre esse métier.

Do ponto de visto da análise do trabalho, concluímos que o CECRL se configura enquanto documento prescritivo do agir dos professores com os conteúdos culturais, definindo o objeto de trabalho dos professores de maneira múltipla, imprecisa e complexa. Essa prescrição é retomada pelos professores como uma obrigação apenas em um aspecto, o de não generalizar. $\mathrm{Na}$ tentativa de definir seu trabalho com esses conteúdos, os professores se valeram muito mais de suas experiências e definições próprias, construídas pela experiência, do que das orientações do Quadro, o que mostra, portanto, que o CECRL é, como outras, uma prescrição fluida.

Por outro lado, vimos que os professores representam o trabalho com os conteúdos culturais como algo multifatorial, onde entram em jogo a ação dos alunos, dos professores, o objeto de ensino e os instrumentos. Eles representam os conteúdos culturais como pertinentes, como algo ligado à reflexão; entretanto, em sua prática, outros fatores interferem e influenciam seu trabalho, sendo, para eles, mais importantes no momento da ação, como, por exemplo, o objetivo de se trabalhar o conteúdo gramatical ou mesmo a relação do conteúdo gramatical com o conteúdo cultural.

Observamos também que ao se confrontarem com sua prática, ambos colocaram seu trabalho em perspectiva e perceberam o conflito entre aquilo que estava prescrito ou autoprescrito e o que a própria situação da aula exigia. Danilo se focou no trabalho com a gramática, priorizando essa prescrição sobre a dos conteúdos culturais, encontrou sentido e considerou sua atividade como eficaz, por contemplar o que havia necessidade de ser trabalhado. Houve compromisso entre a eficácia da atividade de ensino e os efeitos do trabalho sobre sua saúde, entretanto, o conflito se deu em termos de resultados sobre os conteúdos culturais - segundo ele, a aula poderia ter sido dada de outra forma. Já Suélen realizou sua proposta com sucesso, mas o 
fato de alguns conteúdos gramaticais associados aos conteúdos culturais encadearem generalizações foi, para ela, um momento de insucesso. Ela atingiu os resultados acerca do objeto de ensino, sua atividade foi eficaz no ponto de vista de Danilo, porém, o momento de generalizações teve efeito sobre sua saúde em termos amplos, pois ela sentiu estar fazendo algo justamente contra as prescrições nas quais acreditava.

Nossas conclusões nos aproximam assim dos de Faïta e Saujat (2010, p.6), permitindonos sustentar a hipótese de que a criatividade, a saúde e a eficácia do trabalho teriam resultados em comum, resultados que desenvolvem o dinamismo do poder de agir do sujeito.

Além disso, como vimos, a possibilidade de desenvolver o poder de agir (CLOT, 2001) está atrelada à tomada de consciência dos sujeitos durante a coanálise do trabalho. Em nossas análises, levantamos indícios linguístico-discursivos de tomada de consciência sobre o próprio trabalho em excertos da entrevista dos dois professores, fato que corrobora a proposta da autoconfrontação como método de transformação e, portanto, de nova compreensão da atividade de trabalho. Se, por um lado, faltam-nos dados gerados posteriormente para confirmar os resultados dessa tomada de consciência com vistas a uma transformação da ação, por outro lado, com os indícios que levantamos, podemos inferir que houve desenvolvimento no plano da consciência e que, eventualmente, pode ter havido desenvolvimento do plano da ação (LOUSADA, DANTAS-LONGHI, 2014). Acreditamos que foi o confronto das atividades dos dois professores por meio da ACC que levou Danilo e Suélen a encontrarem outros possíveis para sua atividade e que, pelos indícios que vimos, isso parece contribuir para aumentar seu poder de agir (CLOT, 2001, 2008).

Nesse sentido, nosso estudo suscita futuras pesquisas que possam acompanhar os professores ao longo dos anos para observar seu desenvolvimento em relação ao trabalho e outras que possam verificar a questão do desenvolvimento da tomada de consciência também no plano da ação.

A partir dessa segunda contribuição, podemos destacar outras de cunho teóricometodológico para o grupo ALTER-AGE. A primeira seria o enfoque que demos à análise, evidenciando a dinâmica das figuras de ação associada à questão do desenvolvimento. Cremos que nossa análise da dinâmica das figuras de ação e do paralelo entre essa dinâmica e a construção do pensamento abstrato, segundo Vygotski (1934/1997), possa ser uma contribuição 
para uma análise interacionista sociodiscursiva dos textos produzidos nas situações de trabalho. Com essa forma de interpretação, nós tentamos dar conta do dinamismo do discurso e do processo de desenvolvimento por meio das diferentes configurações do agir representado nos textos.

Outra contribuição de cunho teórico-metodológico foi o modo como interpretamos dados à luz de nosso quadro teórico, empregando os conceitos de instrumento e atividade mediadora no processo de desenvolvimento. Tanto no caso da autoconfrontação, quanto no caso dos trabalhos com gênero textuais, a intenção é de empregá-los como instrumentos no intuito de transformar e provocar o desenvolvimento dos sujeitos. Em nossa pesquisa, nós buscamos aprofundar essa questão, destacando que a mediação não se dá somente por meio da linguagem, mas vai além, se dando através do instrumento e da atividade mediadora. Nossas hipóteses finais conseguiram assim exemplificar, através de indícios linguísticos de tomada de consciência, como os possíveis do desenvolvimento podem ser encontrados e interpretados.

Nosso estudo suscita, portanto, outras pesquisas usando as figuras de ação para ver o desenvolvimento de um ponto de vista dinâmico. Além disso, outros estudos podem ser feitos para verificar se a dinâmica das figuras de ação encontra parâmetros de comparação com professores iniciantes ou com os mesmos professores em outro momento, confirmando ou não essa maneira de interpretar o desenvolvimento.

Apesar de não haver meios para mensurar o legado que esta pesquisa deixou para o contexto em que foi realizada, os cursos extracurriculares, é plausível que os sujeitos envolvidos tenham atentado para a questão dos conteúdos culturais e outras discutidas nos retornos ao coletivo, já que os trabalhos de intervenção e pesquisa desenvolvidos nesse contexto têm se mostrado produtivos e gerado frutos no âmbito da formação de professores ${ }^{120}$. Um indício concreto que poderia confirmar essa hipótese é o fato de que Suélen se tornou, em 2014, tutoraformadora dos novos professores-monitores dos Cursos Extracurriculares de Francês, contribuindo hoje para as atividades formação docente.

Refeito o percurso dessa caminhada, é possível afirmar que levantamos indícios sobre o trabalho do professor de FLE com os conteúdos culturais, a partir de um contexto específico.

\footnotetext{
${ }^{120}$ Como dissemos, os dados da pesquisa (filmagens e transcrições) foram objetos de análise do Colóquio Internacional Analisar o Trabalho Educacional em 2013. Além disso foram empregados em minicursos de formação de professores em congressos e em Reuniões Pedagógicas dos Cursos Extracurriculares no mesmo ano.
} 
Esses indícios nos permitiram compreender um pouco mais desse métier complexo, bem como desse objeto que desperta interesse e desafio, que são os conteúdos culturais. Nossas análises responderam nossas perguntas de pesquisa, apontaram para apropriações teóricas e nossos dados geraram também recursos para a formação de professores, contribuindo, assim, não só acadêmica e cientificamente, mas também profissionalmente para possíveis projetos de formação docente. Ao final desse percurso, vemos que, longe de terminar a caminhada sobre o trabalho do professor, conseguimos agora ver que ainda há muito mais a se percorrer e a descobrir. 


\section{Referências Bibliográficas}

ABDALLAH-PRETCEILLE, M. L'éducation interculturelle. Paris : PUG, 1999.

.; PORCHER, L. Éducation et communication interculturelle. Paris : PUG, 2001.

. ; PORCHER, L'Éthique de la diversité et éducation. Paris : Presses Universitaires de France, 1998.

ABREU-TARDELLI, L. S. trabalhodoprofessor@chateducacional.com.br- Aportes para compreender o trabalho do professor iniciante em EAD. Tese de Doutorado - Pontifícia Universidade Católica de São Paulo, São Paulo, 2006.

ANEZ-OLIVEIRA, R. O fait divers no ensino: influências da sequência didática nas produções escritas de alunos de FLE. Dissertação (Mestrado em Estudos Linguísticos, Literários e Tradutológicos em Francês). Universidade de São Paulo, 2014.

AMIGUES, R. Le travail enseignant : prescriptions et dimensions collectives de l'activité. In : Les Sciences de l'éducation - Pour l'Ère nouvelle,Vol. 42, 2009-2, p.11-26.

. Trabalho do professor e trabalho de ensino. In: MACHADO, A.R. (org.) 2004. O ensino como trabalho. Uma abordagem discursiva. Londrina: Eduel, 2004.

. Pour une approche ergonomique de l'activité enseignante. Skholê, hors-série 1, p.5-16, 2003. Disponível em: http://sites.univprovence.fr/ergolog/Bibliotheque/Divers/Amigues_approche_ergonomique.pdf (acesso em novembro de 2013).

. L'enseignement comme travail. In: BRESSOUX, P. (Ed.) Les stratégies d'enseignement en situation d'interaction. Note de synthèse pour Cognitique. Paris: Programme Ecole et Sciences Cognitives, 2002, p. 243-262.

AUTHIER-REVUZ, J. Palavras Incertas : as não-coincidências do dizer. Campinas : Editora da UNICAMP, 2001.

BAKHTIN, M. Os gêneros do discurso. In : Estética da criação verbal. Tradução feita a partir do russo por Paulo Bezerra. [Original em russo publicado em 1979] $6^{a}$ ed. São Paulo : Martins Fontes, 2011.

BARRICELLI, E. A reconfiguração pelos professores da proposta curricular de educação infantil. Dissertação (Mestrado em Lingüística Aplicada e Estudos da Linguagem) - Pontifícia Universidade Católica de São Paulo, 2007. 
- Transformações e conflitos no processo de elaboração, de difusão e de utilização de instruções oficiais de educação infantil: um estudo genealógico. Tese (Doutorado em Lingüística Aplicada e Estudos da Linguagem) - Pontifícia Universidade Católica de São Paulo, 2012.

BRONCKART, J.P. O agir nos discursos : das concepções teóricas às concepções dos trabalhadores. $1^{\mathrm{a}}$ ed. Trad. Anna Rachel Machado; Maria Lucia Meirelles Matêncio. Campinas : Mercado de letras, 2008.

. Atividade de linguagem, discurso e desenvolvimento humano. $1^{\mathrm{a}}$ ed. Trad. Anna Rachel Machado. Campinas : Mercado de Letras, 2006.

. Ação, discurso e racionalização : a hipótese de desenvolvimento de Vygotsky revisitada. In : Atividade de linguagem, discurso e desenvolvimento humano. $1^{\mathrm{a}}$ ed. Trad. Anna Rachel Machado. Campinas : Mercado de Letras, 2006b, p.59-91.

. Les différentes facettes de l'interactionnisme socio-discursif. In : Calidoscópio, Vol. 3, n.3, set/dez 2005, p. 149-159.

. Atividade de linguagem, textos e discursos : por um interacionismo sociodiscursivo. $1^{\mathrm{a}}$ ed. Trad. Anna Rachel Machado. São Paulo : Educ, 1999.

.; Groupe LAF (org.). Agir et discours en situations de travail. Genebra : Cahiers de la section des Sciences de l'Education, n. 103, jun/2004, p. 9-144.

; MACHADO, A. R. Procedimentos de análise de textos sobre o trabalho educacional. In: MACHADO, A.R. (org.) 2004. O ensino como trabalho. Uma abordagem discursiva. Londrina: Eduel, 2004.

.; DOLZ, J. A noção de competência: qual é a sua pertinência para o estudo da aprendizagem das ações de linguagem ? In : DOLZ, J. ; OLLAGNIER, E. (orgs.) O Enigma da Competência em Educação. Trad. Claudia Schilling. Porto Alegre : Artmed, 2004, p.29-46.

BRONCKART, J.P.; BULEA, E.; POULIOT, M. Introduction: pourquoi repenser l'enseignement des langues ? In : BRONCKART, J.P.; BULEA, E. ; POULIOT, M. (éd.) Repenser l'enseignement des langues: comment identifier et exploiter les compétences? Lille : Presses du Septentrion, 2005, p.7-40.

BRONCKART-BULEA, E. ; LEURQUIN, E. V. L. F.; CARNEIRO, F. D. V. O agir do professor e as figuras de ação. In: BUENO, L. ; LOPES, M. A. P. T. ; CRISTOVÃO, V. L. L. (orgs.) Gêneros Textuais e Formação Inicial. Uma Homenagem à Malu Matencio. São Paulo : Mercado de Letras, 2013.

BULEA, E. ; BRONCKART, J.-P. Pour une approche dynamique des compétences langagières. In : BRONCKART, J.P.; BULEA, E. ; POULIOT, M. (éd.) Repenser l'enseignement des 
langues: comment identifier et exploiter les compétences? Lille : Presses du Septentrion, 2005, p.193-227.

BUENO, L. ; LOPES, M. A. P. T. ; CRISTOVÃO, V. L. L. (orgs.) Gêneros Textuais e Formação Inicial. Uma Homenagem à Malu Matencio. São Paulo : Mercado de Letras, 2013.

BUENO, L. A construção de representações sobre o trabalho docente: o papel do estágio. Tese de Doutorado LAEL/ PUC SP, 2007.

BULEA, E. Linguagem e efeitos desenvolvimentais da interpretação da atividade. Trad. Eulália V. L. F. Leurquin, Lena L. E. R. Figueirêdo. Campinas: Mercado de Letras, 2010.

BULEA, E.; FRISTALON, I. Agir, agentivité et temporalité dans des entretiens sur le travail infirmier. In: BRONCKART, J. P. (org.). Agir et discours en situation de travail: Université de Genève, Faculté de psychologie et des sciences de l'éducation, 2004.

BYRAM, M. Culture et éducation en langue étrangère. Collection Langues et Apprentissage des Langues. Paris : Les Éditions Didier, 1992.

. La compétence interculturelle. In : CHARDENET; BLANCHET (dir.) Guide pour la recherche en didactique des langues et des cultures. Approches contextualisées. Paris: Éditions des Archives Contemporaines (EAC) Didier, 2011.

CANGUILHEM, G. Ecrits sur la médecine. Paris : Editions du Seuil, 2002.

CHAVES, R.-M., FAVIER, L., PÉLISSIER, S. L'interculturel en classe. Paris : PUG, 2012.

CLOT, Y. Théorie en Clinique de l'Activité. In : MAGGI, B. (dir.) Interpréter l'agir : un défi théorique. Paris : PUF, 2011.

. Travail et pouvoir d'agir. Paris : PUF, 2008.

. A função psicológica do trabalho. Petrópolis, RJ: Vozes, 2007.

. Editorial. In : Éducation Permanente, n. 146 - Clinique de l'activité et pouvoir d'agir, Paris, 2001, p. 7-16.

. La fonction psychologique du travail. Paris, Presses Universitaires de France, 1999.

.; FAÏTA, D.; FERNANDEZ, G ; SCHELLER, L. Entretiens en autoconfrontation croisée: une méthode en clinique de l'activité. In : Éducation Permanente, n. 146 - Clinique de l'activité et pouvoir d'agir. Paris, 2001, p. 17-25.

.; FAÏTA, D. Genre et style en analyse du travail, concepts et méthodes. In : Travailler, Revue internationale de Psychopathologie et Psychodynamique du Travail, n.4, 2000. 
CONSEIL DE L'EUROPE. Cadre Européen Commun de Référence pour les Langues. Paris : Les Éditions Didier, 2001.

COSTE, D.; MOORE, D.; ZARATE, G. Compétence plurilingue et pluriculturelle. Vers un Cadre Européen Commun de référence pour l'enseignement et l'apprentissage des langues vivantes: études préparatoires. Conseil de l'Europe, Strasbourg, 1997. Version révisée 2009.

DANTAS-LONGHI, S. M. Como os jogos podem revelar outras dimensões do trabalho do professor de língua estrangeira? Dissertação (Mestrado em Estudos Linguísticos, Literários e Tradutológicos em Francês). Universidade de São Paulo, 2013.

DERVIN, F. ; SUOMELA-SALMI, E. Évaluer les compétences langagières et interculturelles dans l'enseignement supérieur. Départementd'étudesfrançaises, Université de Turku, Finlande, 2007.

DEVOLVÉ, N.; POUDOU-ZERBATO, M.-T. Didactique, pédagogie, ergonomie, quelle complémentarité. In : Société d'ergonomie de langue française. Recherche et ergonomie, Toulouse, février 1998, p. 128-131.

DURVEEN, G. Introdução: O poder das ideias. In : Representações Sociais : investigações em psicologia social. $7^{\mathrm{a}}$ ed. Editado em inglês por Gerard Duveen [2000]; traduzido do inglês por Pedrinho A. Guareschi. Petrópolis, RJ : Editora Vozes, 2010.

ESPINASSY, L.; MOUTON, J-C.; FELIX, C. La " fiche de préparation » : un outil organisateur

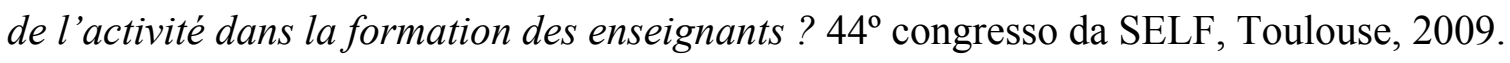

ESPINASSY, L.; SAUJAT, F. Enseigner les arts plastiques em ZEP: les dessous du métier. Recherche et Formation, INRP, n. 44, 2003.

FAÏTA, D. Théorie de l'activité langagière. In : MAGGI, B. (dir.) Interpréter l'agir : un défi théorique. Paris : PUF, 2011.

. Análise dialógica da atividade profissional. Rio de janeiro: Imprinta Express Editora, 2005.

Gêneros de discurso, gêneros de atividade, análise da atividade do professor, In: MACHADO, A.R. (org.) O ensino como trabalho: uma abordagem discursiva. Londrina: Eduel, 2004.

Análise das práticas linguageiras e situações de trabalho: uma renovação metodológica imposta pelo objeto. In: SOUZA-E-SILVA, M.C.P. e FAITA, D. (orgs). Linguagem e trabalho: construção de objetos de análise no Brasil e na França. São Paulo: Cortez, 2002.

. La conduite du TGV : exercices de styles. Champs visuels, n.6, 1997, p. 75-86. 
FAÏTA, D. ; SAUJAT, F. Développer l'activité des enseignants pour comprendre et transformer leur travail : un cadre théorique et méthodologique. In: SAUSSEZ, F. ; YVON, F. (org.) Analyser l'activité enseignante: des outils méthodologiques et théoriques pour l'intervention et la formation. Québec, Presses de l’Université de Laval, 2010, p.41-69.

. ; VIEIRA, M. Réflexions méthodologiques sur l'autoconfrontation croisée. DELTA, 2003, vol.19, no.1, p.123-154.

FELIX, C., SAUJAT, F. L'aide au travail personnel des élèves entre déficit de prescriptions et « savoirs méthodologiques » : un double regard didactique et ergonomique. In: Les Dossiers de Sciences de l'Education, n²0, 2008, p. 125-138.

FEITOZA, C. J. A. Trabalho docente em EAD: representações construídas em uma entrevista de instrução ao sósia. Dissertação (Mestrado) - Universidade São Francisco, Itatiba, 2012.

FILLIETTAZ, L. Une réflexion de l'agir au service de l'analyse des textes procéduraux. In: BRONCKART, J.P. et al. (org.) Agir et discours en situation de travail. Cahier $n^{o} 103$. Genebra, jun/2004, p.147-183.

FRIEDRICH, J. Lev Vigotski - Mediação, Aprendizagem e Desenvolvimento. Uma leitura filosófica e epistemológica. Campinas: Mercado de Letras, 2012.

. Lev Vigotski : médiation, apprentissage et développement. Une lecture philosophique et épistémologique. Genebra: Université de Genève - Carnets des sciences de l'éducation, 2010.

GALISSON, R. De la langue à la culture par les mots. Paris : CLE international, 1991.

GERMAIN, C. Evolution de l'enseignement des langues: 5000 ans d'histoire. Paris: CLE International, 1993.

GIGER, I. P. Prescrire l'agir enseignant? Le cas de l'allemand à l'école primaire genevoise. In : BRONCKART, J.P. et al. (org.) Agir et discours en situation de travail. Cahier $n^{o} 103$. Genebra, jun/2004, p.147-183.

GOIGOUX, R. Un modèle d'analyse de l'activité enseignante. Conférence donnée le 27 mai 2005 au séminaire inter-IUFM (pôle sud-est) de formation de formateurs à Carry-le-Rouet, 2005. http://espe.univ-lyon1.fr/pse/files/2011/12/Carry_27mai05_Goigoux_Modele-analyseactivite.pdf (acesso em dezembro de 2014)

. Recherche en didactique du français: contribution aux débats d'orientation. In: MARQUILLO LARRUY, M. (org.) Questions d'épistémologie en didactiques du Français. Poitiers: Forell, 2001, p.125-132. 
GUIMARÃES, A.M.M.; MACHADO, A.R.; COUTINHO, A. (orgs.) O Interacionismo Sociodiscursivo. Questões epistemológicas e metodologógicas. Campinas : Mercado de Letras, 2007.

GUIMARÃES-SANTOS, L. O ensino-aprendizagem do FLE: pensando o agir social a partir do gênero itinéraire de Voyage. Dissertação (Mestrado em Estudos Linguísticos, Literários e Tradutológicos em Francês) - Universidade de São Paulo, São Paulo, 2012.

KERBRAT-ORECCHIONI, C. La conversation. Paris : Éditions du Seuil, 1996.

LAVILLE, A. Repères pour une histoire de l'ergonomie francophone. In : Comptes Rendus du XXXVIème Congrès de la Société d'Ergonomie de Langue Française - Les transformations du travail, enjeux pour l'ergonomie, Montréal : ACE, v.1, p.1-6, 2001.

- Referências para uma história da ergonomia francófona. In: FALZON, P. (ed.). Ergonomia. São Paulo: Editora Blucher, 2007.

LEGENDRE, R. Dictionnaire Actuel de l'Éducation. Paris, Montreal: Larousse, 1988.

LOUSADA, E. G. Gêneros textuais e trabalho educacional: a linguagem revelando práticas de ensino. Apresentação oral no Colóquio Linguagem e Trabalho Docente, realizado em junho de 2012 na Faculdade de Educação da USP. 2012.

. Aprendendo o "métier" de professor: uma análise de textos produzidos em situação de formação inicial de professores de francês. In: SZUNDY, P. T. C. et al (orgs.). Linguística Aplicada e Sociedade: Ensino e Aprendizagem de Linguas no Contexto Brasileiro. Campinas: Pontes Editora, 2011, v. 1, p. 111-134.

. A emergência da voz do métier em textos sobre o trabalho do professor. In: MACHADO, A. R.; LOUSADA, E. G.; FERREIRA, A. D. O professor e seu trabalho: a linguagem revelando práticas docentes. Campinas: Mercado de Letras, 2011b, p. 61-96.

. Entre o trabalho prescrito e o realizado: um espaço para a emergência do trabalho real do professor. Tese (Doutorado em Linguística Aplicada e Estudos da Linguagem) - Pontifícia Universidade Católica de São Paulo, São Paulo, 2006.

- Os pequenos grandes impedimentos do trabalho do professor: entre tentativas e decepções. In: MACHADO, A. R. (org.) O ensino como trabalho: uma abordagem discursiva. Londrina: Eduel, 2004

. ; DANTAS-LONGHI, S. M. Vozes em confronto: o papel das entrevistas de confrontação no desenvolvimento do professor e de sua atividade de trabalho. In: NASCIMENTO, E. L. ; ROJO, R. H. R. (org.) Gêneros de texto/discurso e os desafios da contemporaneidade. Campinas: Pontes Editora, 2014, p. 143-166. 
. ; SILVA, E. C. ; MENEZES, M. C. Méthodes d'intervention, co-analyse et formation au travail enseignant à l'Université de São Paulo. In : Sous la loupe - Le français à l'université. $n$. 19-02. Montréal, 2014. Disponível em http://www.bulletin.auf.org/index.php?id=1802 (acesso em dezembro de 2014).

MACHADO, A. R. Por uma concepção ampliada do trabalho do professor. O trabalho do professor: revelações possíveis pela análise do agir apresentado nos textos. In: GUIMARÃES, A. M. M.; MACHADO, A. R.; COUTINHO, A. (orgs). O interacionismo sociodiscursivo: questões epistemológicas e metodológicas. Campinas: Mercado de Letras, 2007, p.77-97.

. (org.) O ensino como trabalho: uma abordagem discursiva. Londrina: Eduel, 2004.

;) LOUSADA, E.G. A apropriação de gêneros textuais pelo professor: em direção ao desenvolvimento pessoal e evolução do "métier". In : Linguagem em (Dis)curso. Palhoça, SC, v. 10, n. 3, set/dez, 2010, p. 619-633.

MAINGUENEAU, D. Análise de textos de comunicação. Tradução de Ceclícia P. de Souza-eSilva e Décio Rocha. São Paulo : Cortez Editora, 2001.

. L'analyse du discours : introduction aux lectures de l'archive. Paris : Hachette, 1991.

. Novas tendências em análise do discurso. Tradução de Freda Indursky. Campinas : Pontes Editora, 1989.

. Nouvelles tendances en analyse du discours. Paris : Hachette, 1987.

MAZZILLO, T. M.da F. O trabalho do professor de língua estrangeira representado e avaliado em diários de aprendizagem. Tese de Doutorado defendida no LAEL - PUC/SP, 2006.

MELÃO, P. A. O gênero textual anúncio publicitário no ensino do FLE: o desenvolvimento da capacidade discursiva 'argumentar' por meio de recursos verbais e visuais. Dissertação (Mestrado em Estudos Linguísticos, Literários e Tradutológicos em Francês). Universidade de São Paulo, 2014.

MOSCOVICI, S. O fenômeno das representações sociais. In: Representações Sociais: investigações em psicologia social. $7^{\mathrm{a}}$ ed. Editado em inglês por Gerard Duveen [2000]; traduzido do inglês por Pedrinho A. Guareschi. Petrópolis, RJ : Editora Vozes, 2010.

MUNIZ-OLIVEIRA, S. O trabalho representado do professor de pós-graduação de uma universidade pública. Tese de Doutorado, LAEL/PUC-SP, 2007.

OLIVEIRA, M. K. Vygotsky: aprendizado e desenvolvimento: um processo sócio-histórico. São Paulo: Scipione, 1997 ( $4^{\mathrm{a}}$ ed. 2003). 
PUREN, C. La problématique culturelle dans l'enseignement-apprentissage des langues en LANSAD [LANgues pour Spécialistes d'Autres Disciplines à l'université]. Conférence faite à la Journée d'études du laboratoire LIDILE EA 3874, Axe DiLeM (Didactique des Langues et Multimédia, Rennes 1) le jeudi 9 décembre 2010. Disponible sur: http://www.christianpuren.com/mes-travaux-liste-et-liens/2010j/ (acesso em novembro de 2013).

ROGER, J.L. Refaire son métier. Essais de la clinique de l'actvité. Editions Ères, 2007.

ROCHA, S. M. Coerções e liberdades textuais em francês como língua estrangeira: por um desenvolvimento do estilo na produção escrita por meio do gênero textual relato de viagem. Dissertação (Mestrado em Estudos Linguísticos, Literários e Tradutológicos em Francês) Universidade de São Paulo, São Paulo, 2014.

SAUJAT, F. L'activité enseignante. In : MAGGI, B. (dir.) Interpréter l'agir : un défi théorique. Paris : PUF, 2011.

. Enseigner : un travail. In : DUPRIEZ, V.; CHAPELLE, G. (orgs.). Enseigner Paris : PUF, 2007, p.179-188.

. Fonction et usage de l'instruction au sosie en formation initiale, 2005. (texte d'une conférence) Disponible sur : http://probo.free.fr/textes_amis/instruction_au_sosie_f_saujat.pdf (Acesso em 26/09/2011)

. O trabalho do professor nas pesquisas em educação: um panorama. In: MACHADO, Anna Rachel. (org.) O ensino como trabalho: uma abordagem discursiva. Londrina: Eduel, 2004, p.3-34.

. Comment les enseignants débutants entrent dans le métier. Formation et pratiques d'enseignement en questions. Revue des HEP de Suisse Romande et du Tessin, 1, 2004b, p. 97-106.

. Systèmes d'apprentissage: systèmes d'évaluation. 2002. Thèse (Doctorat) soutenue à l'Université de Provence, Provence, 2002.

SILVA, E. C. L'analyse du travail enseignant pour la formation: enjeux et possibilités d'une expérience d'appropriation du cadre méthodologie de l'auto-confrontation. In : Non Plus, n. 5, (no prelo).

VYGOTSKI, L. S. [1934]. Pensée et Langage. Trad. Françoise Sève. Paris: La Dispute, [1934]/1997.

A consciência como problema da psicologia do comportamento [escrito e publicado originalmente em 1925]. In : Teoria e Método em psicologia. Trad. Claudia Berliner. $3^{\mathrm{a}}$ ed. São Paulo : Martins Fontes, [1925]/2004, p.55-85. 
. O significado histórico da crise em psicologia [obra escrita em 1927]. In : Teoria e Método em psicologia. Trad. Claudia Berliner. $3^{\text {a }}$ ed. São Paulo : Martins Fontes, [1927]/2004, p.203-417.

. Sobre os sistemas psicológicos [transcrição estenográfica de comunicação lida em 1930]. In : Teoria e Método em psicologia. Trad. Claudia Berliner. $3^{\mathrm{a}}$ ed. São Paulo : Martins Fontes, [1930]/2004, p.103-135.

. O método instrumental em psicologia [conferência proferida em 1930]. In : Teoria e Método em psicologia. Trad. Claudia Berliner. $3^{\mathrm{a}}$ ed. São Paulo: Martins Fontes, [1930b]/2004, p.93-101.

. A psicologia e a teoria da localização das funções psíquicas. [comunicação em congresso e publicação em anais em 1934]. In : Teoria e Método em psicologia. Trad. Claudia Berliner. $3^{\mathrm{a}}$ ed. São Paulo : Martins Fontes, [1934]/2004, p.191-201.

. Teoria e Método em psicologia. Trad. Claudia Berliner. $3^{\mathrm{a}}$ ed. São Paulo: Martins Fontes, 2004.

VERBUNT, G. Penser et vivre l'interculturel. Chronique Sociale, 2011.

VOLOCHINOV, V.N. Marxismo e filosofia da linguagem. 12 $12^{\mathrm{a}}$ ed. São Paulo: HUCITEC, $[1929] / 2006$.

YVON, F., GARON, R. Une forme d'analyse du travail pour développer et connaître le travail enseignant : l'autoconfrontation croisée. In : Recherches Qualitatives - Vol. 26(1), 2006, p. 5180. 


\section{Apêndice - Transcrição completa da Autoconfrontação Cruzada}

- Referência: Autoconfrontação cruzada: 30 de agosto de 2012 (1h17)

- Normas de transcrição : Projeto NURC-USP

- Legendas dos participantes:

$$
\begin{aligned}
& \text { E : Emily - pesquisadora } \\
& \text { D : Danilo - professor-monitor } \\
& \text { S : Suélen - professora-monitora }
\end{aligned}
$$

- Contagem dos turnos de fala contínua (936 turnos)

- Tempo total da entrevista : 1 h17 (77’30'”), sendo Fita 4 (45') e Fita 5 (32’30)

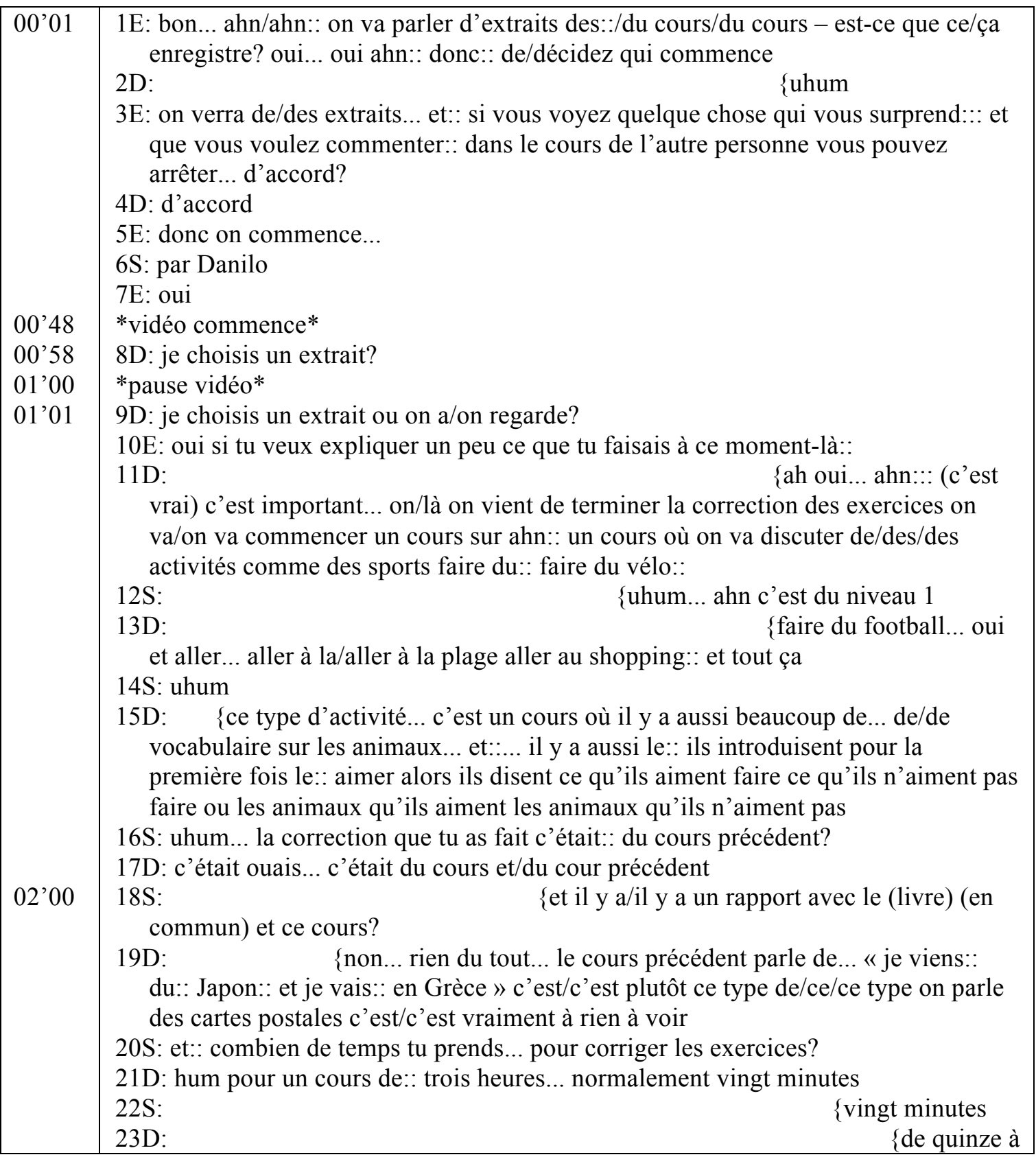




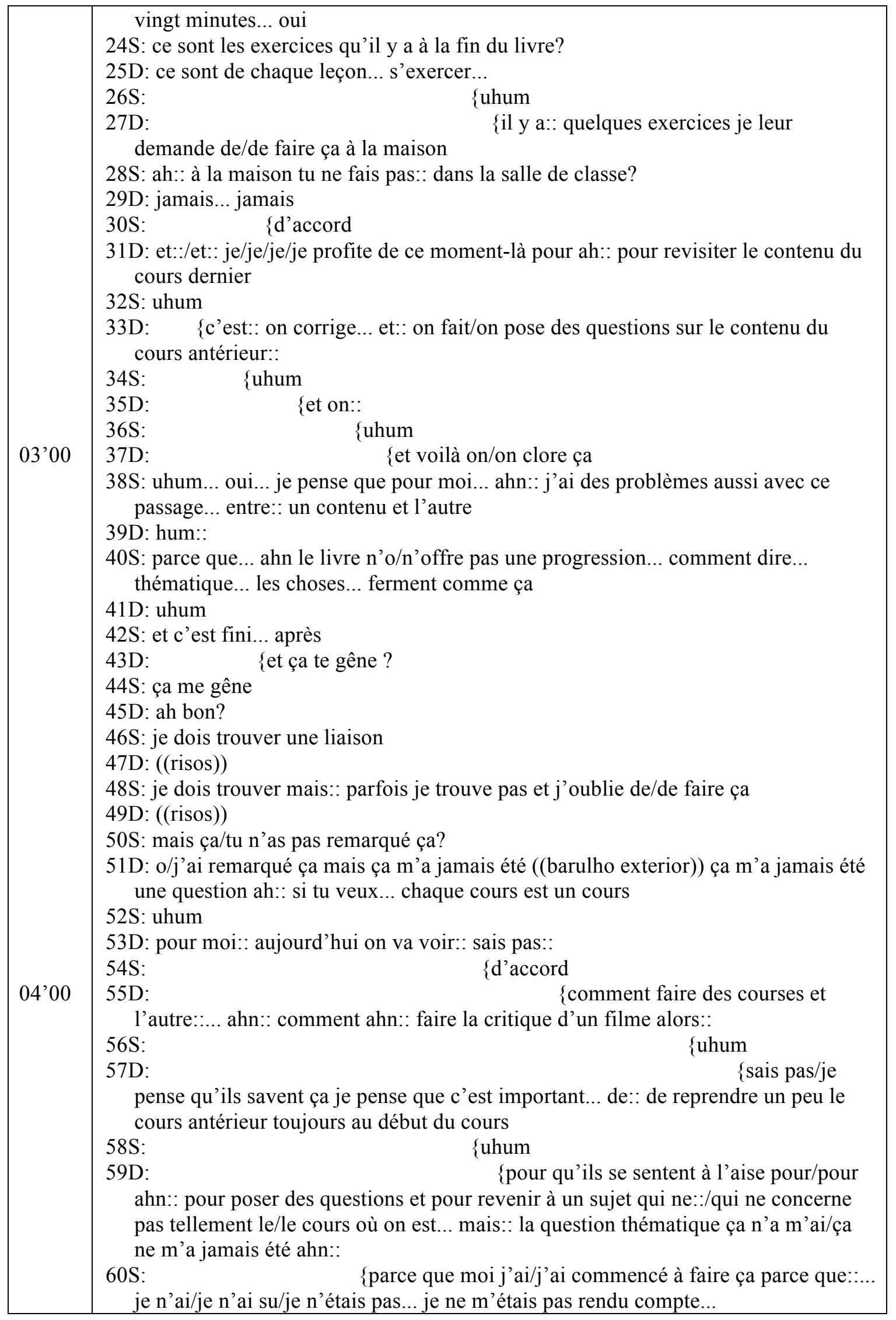




\begin{tabular}{|c|c|}
\hline $07^{\prime} 00$ & 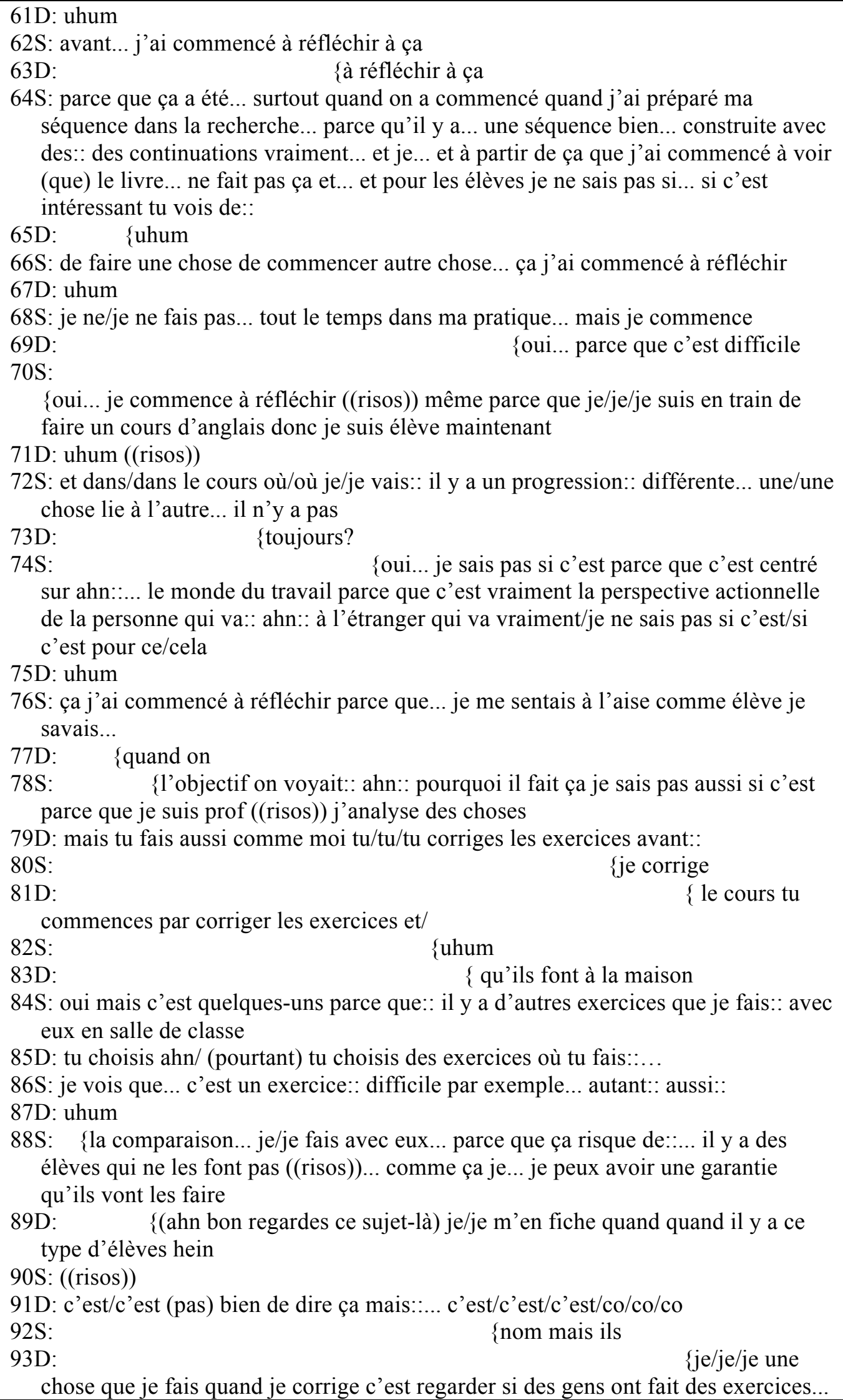 \\
\hline
\end{tabular}




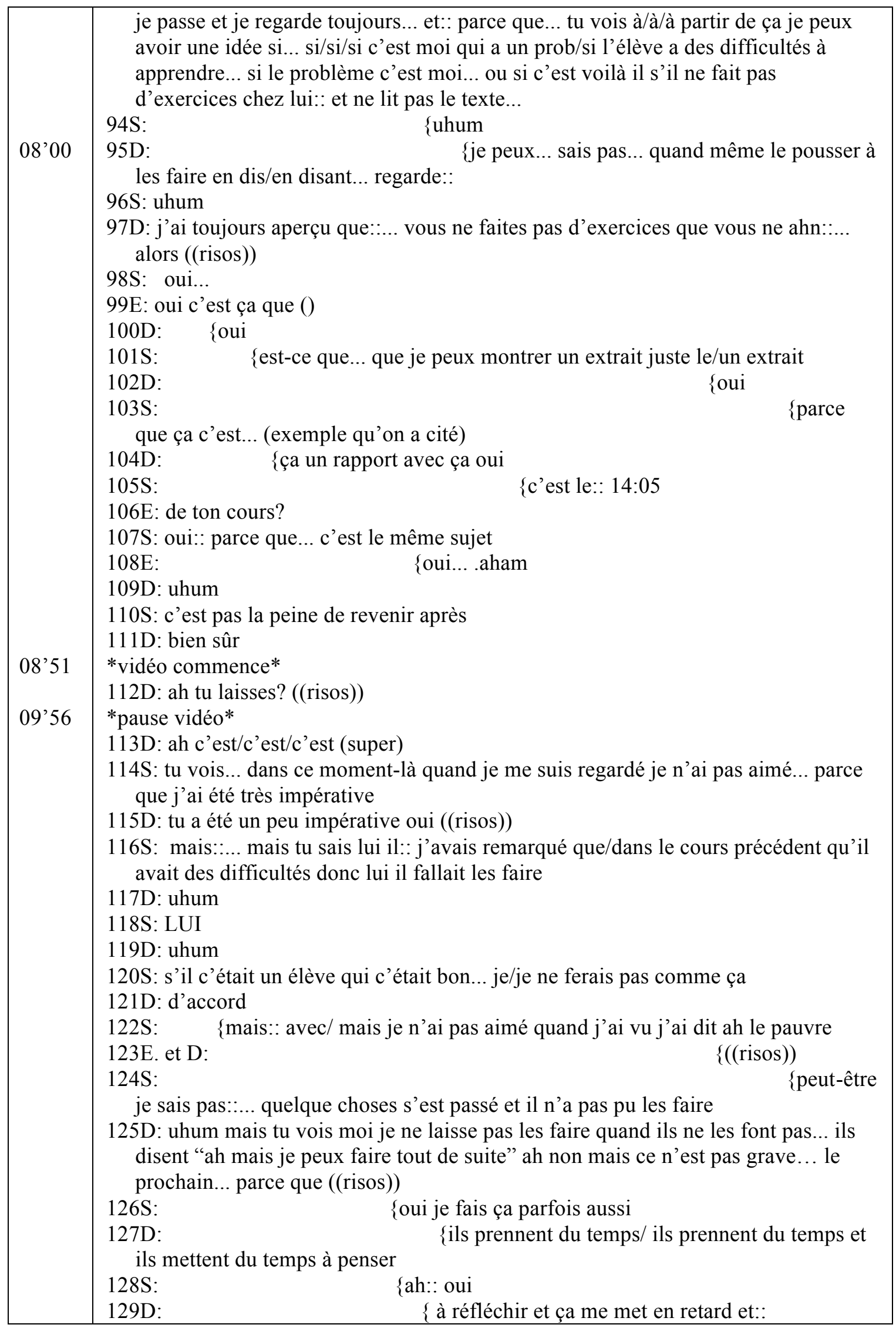




\begin{tabular}{|c|c|}
\hline $12^{\prime} 00$ & 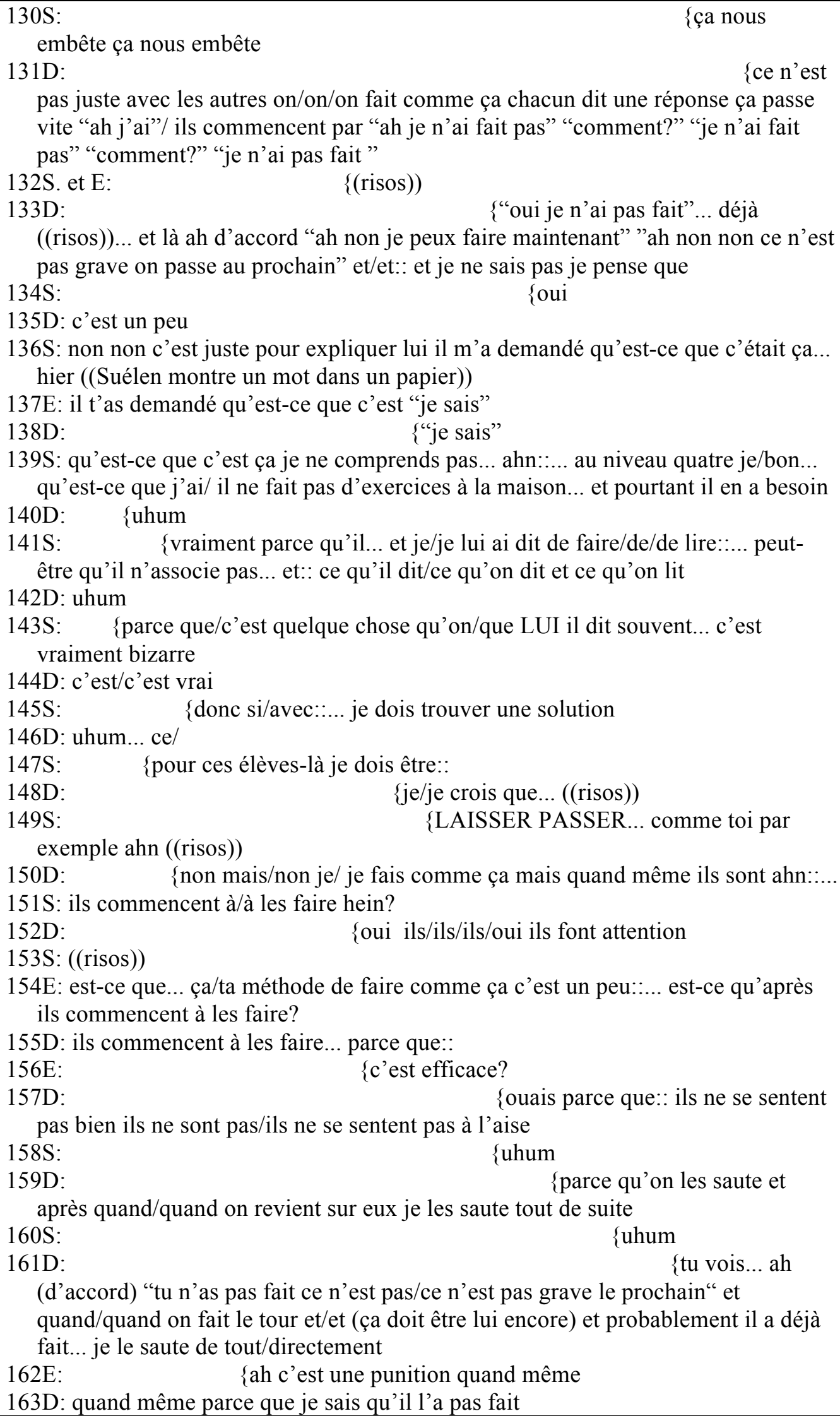 \\
\hline
\end{tabular}




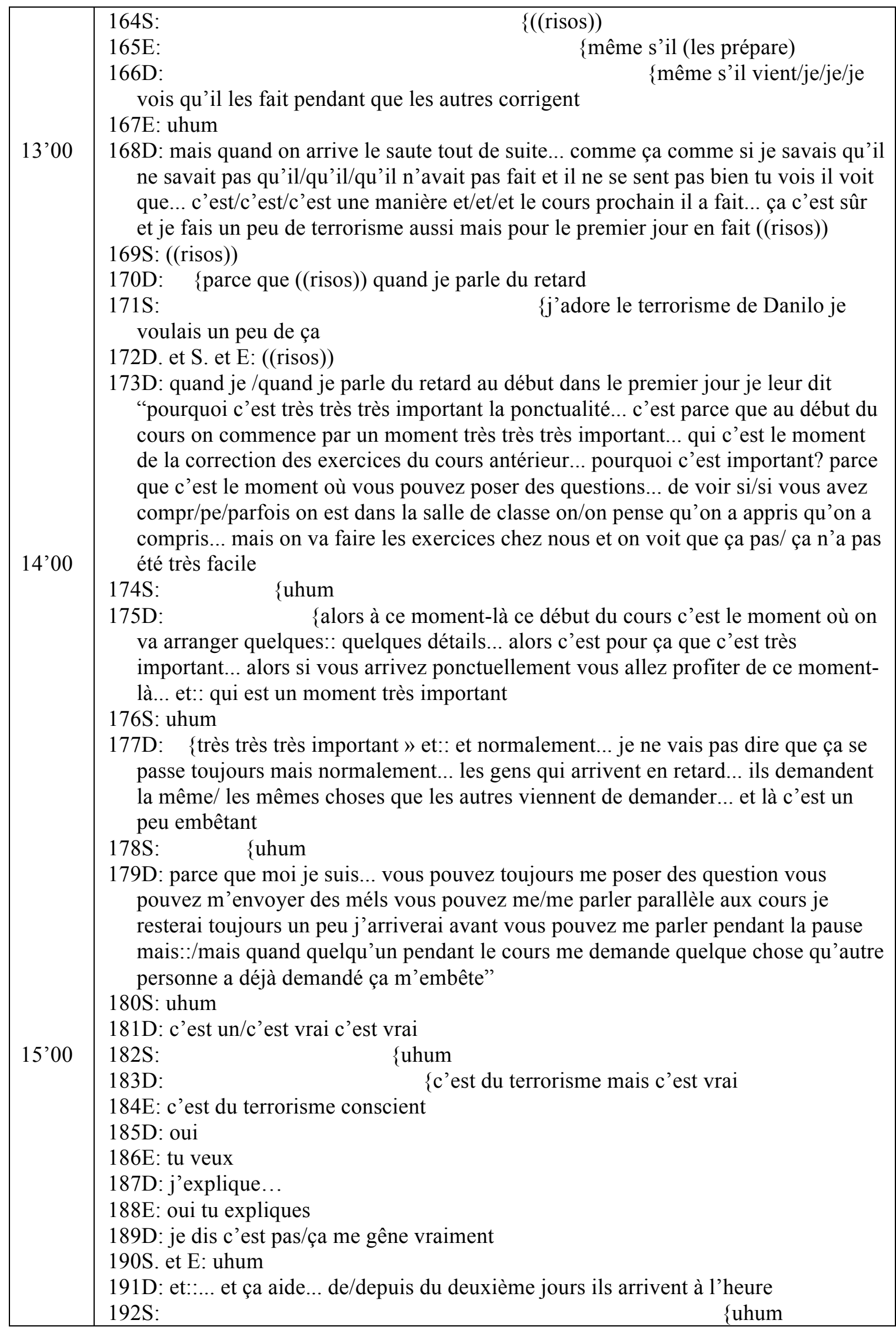




\begin{tabular}{|c|c|}
\hline $17^{\prime} 00$ & 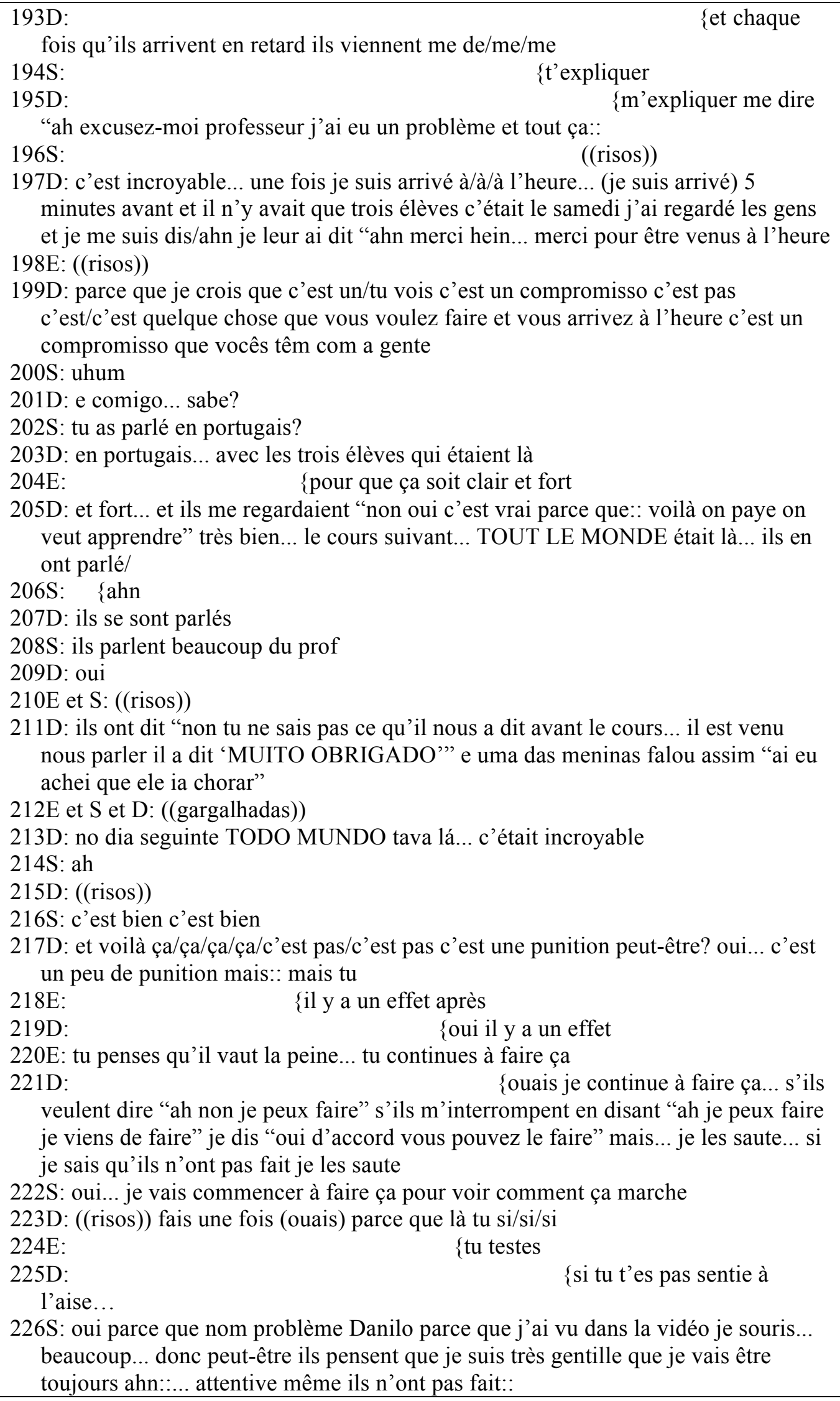 \\
\hline
\end{tabular}




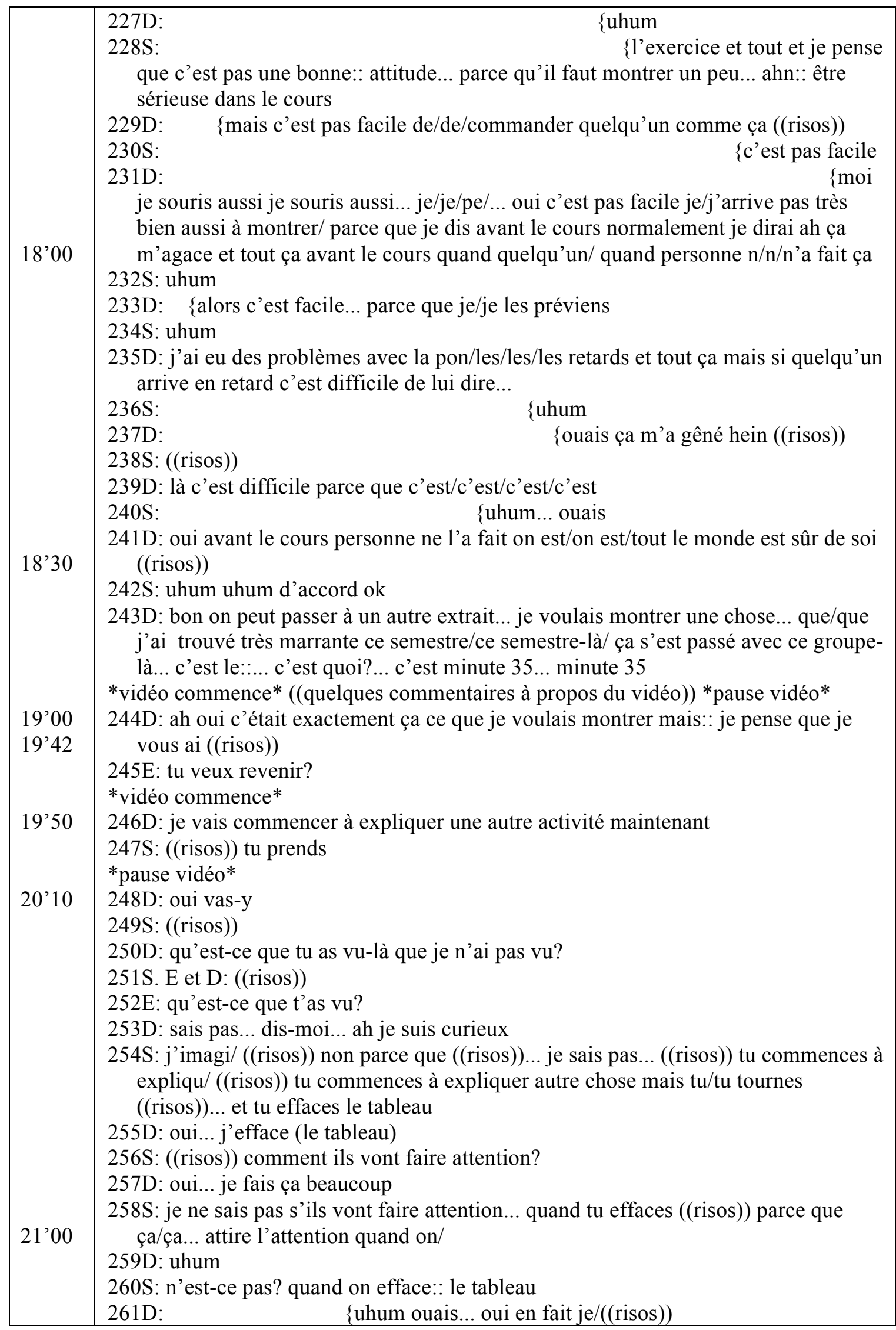




\begin{tabular}{|c|c|}
\hline $22 ’ 17$ & 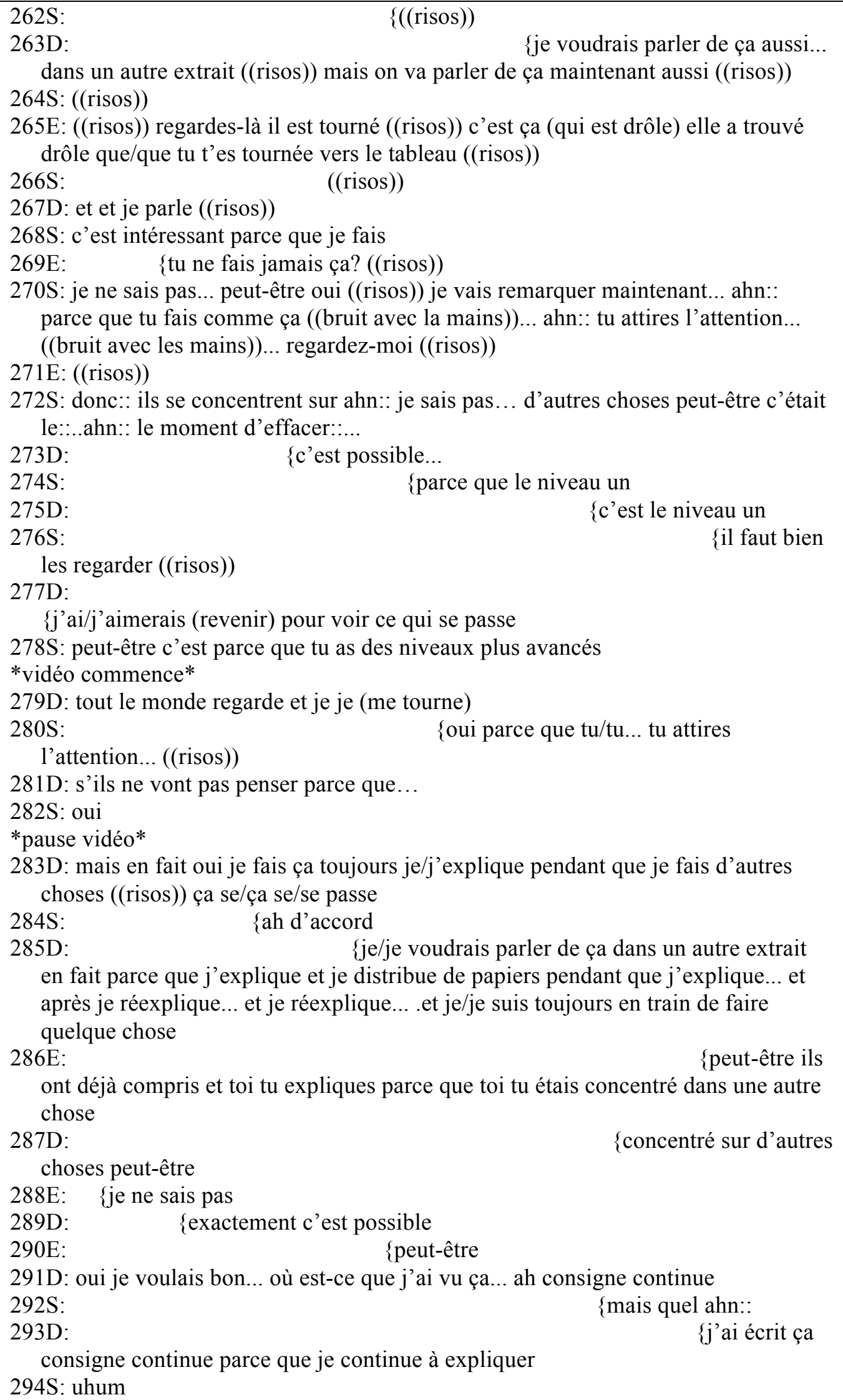 \\
\hline
\end{tabular}




\begin{tabular}{|c|c|}
\hline $25^{\prime} 00$ & 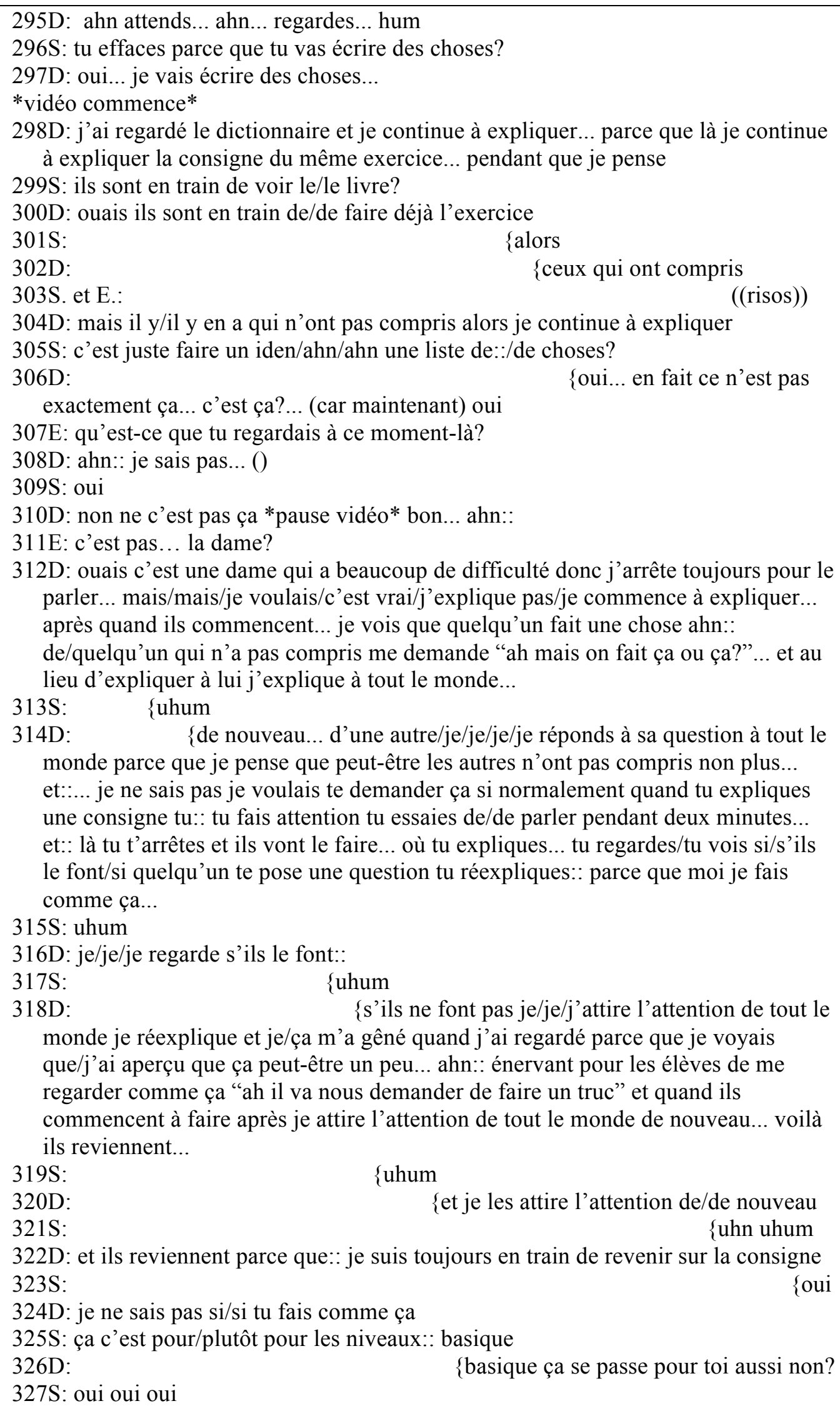 \\
\hline
\end{tabular}




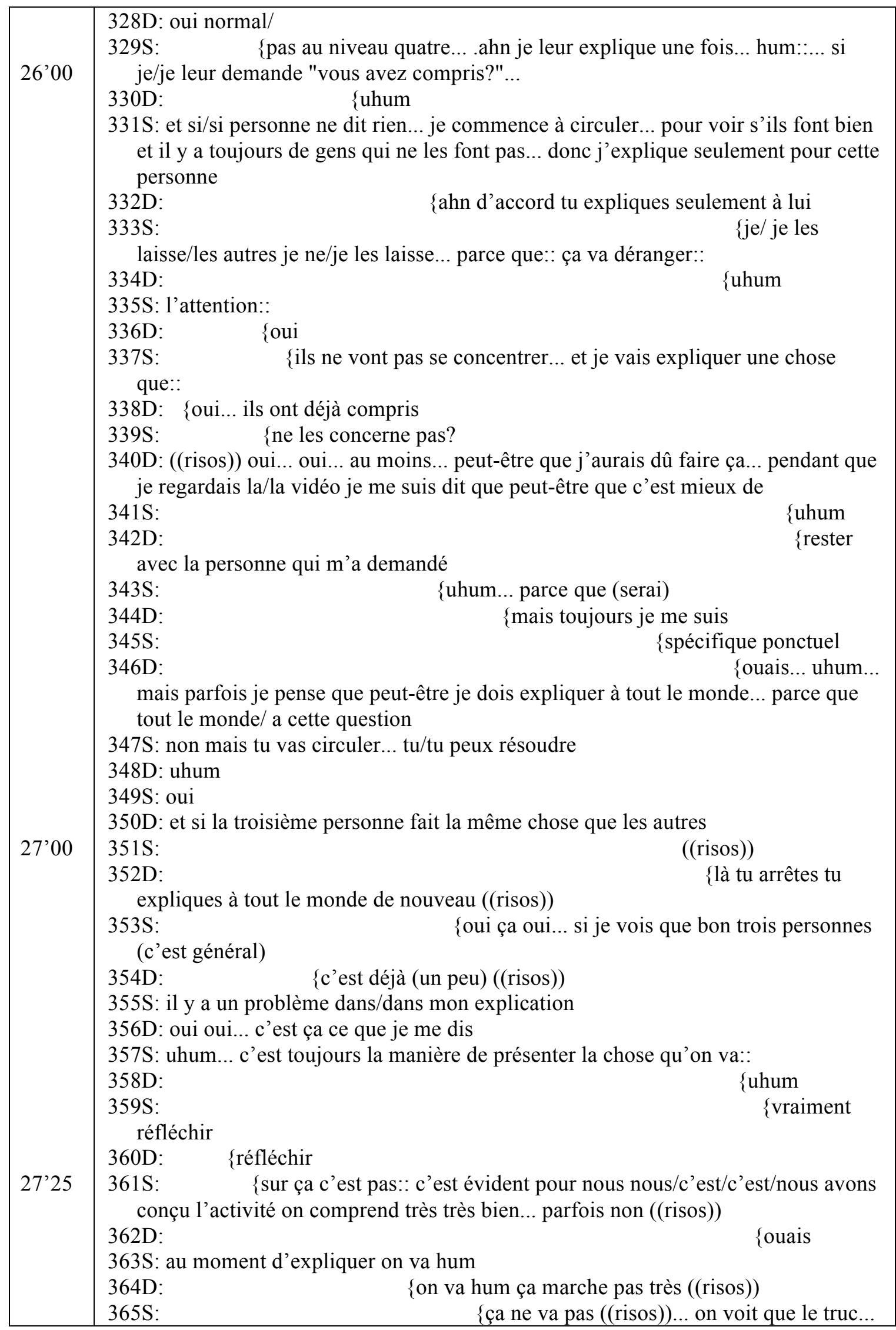




\begin{tabular}{|c|c|}
\hline 29’00 & 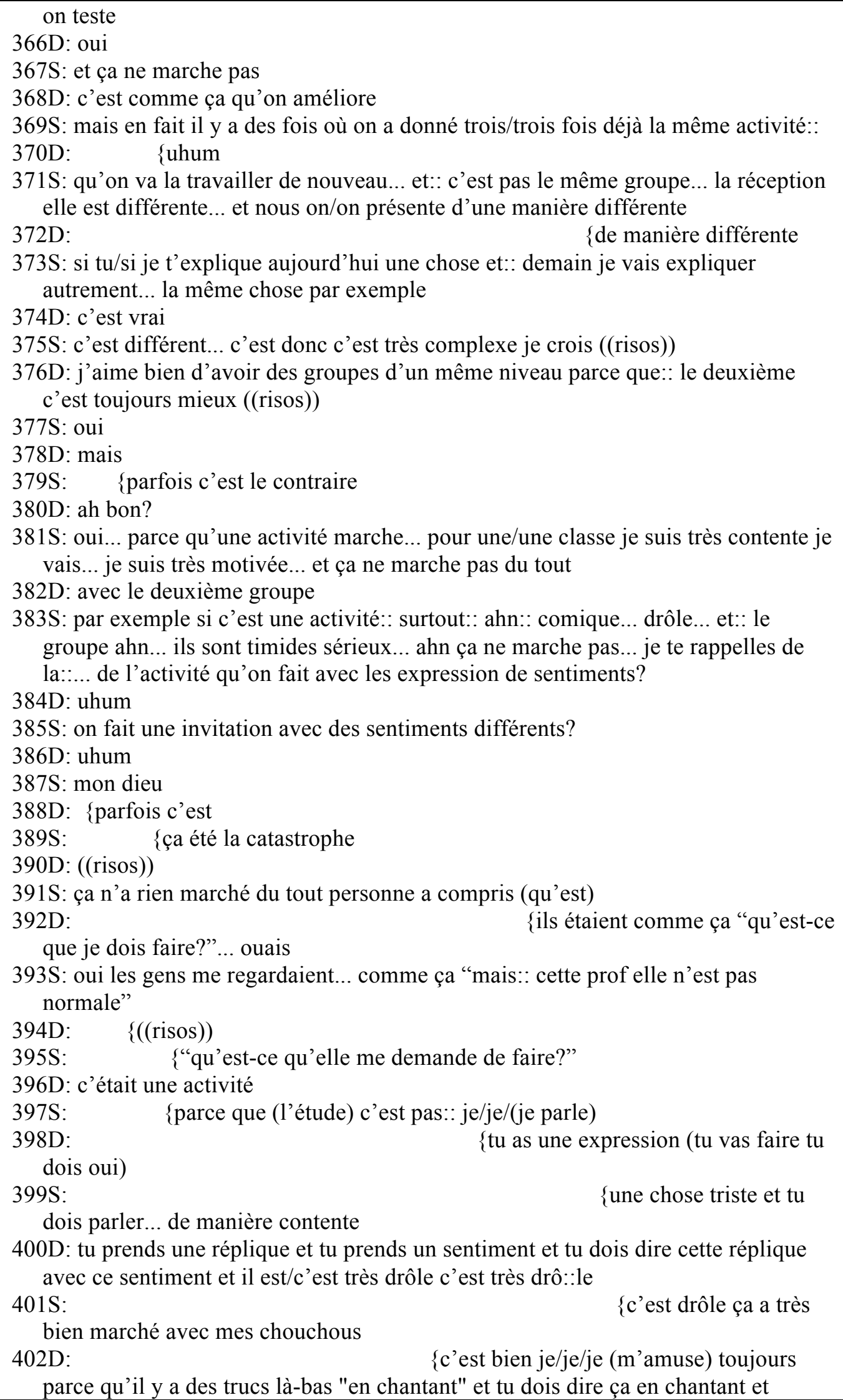 \\
\hline
\end{tabular}




\begin{tabular}{|c|c|}
\hline $300^{\prime} 00$ & 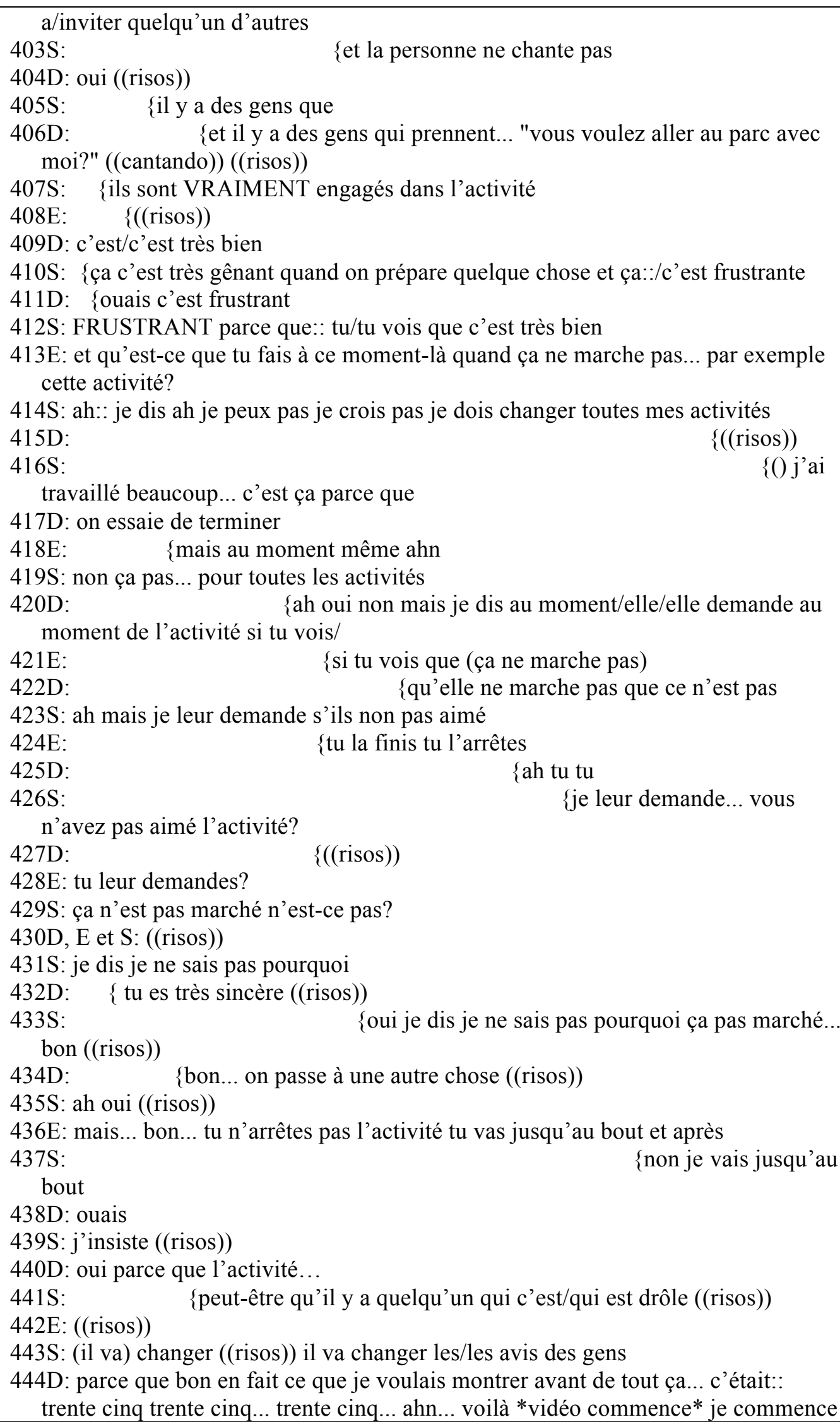 \\
\hline
\end{tabular}




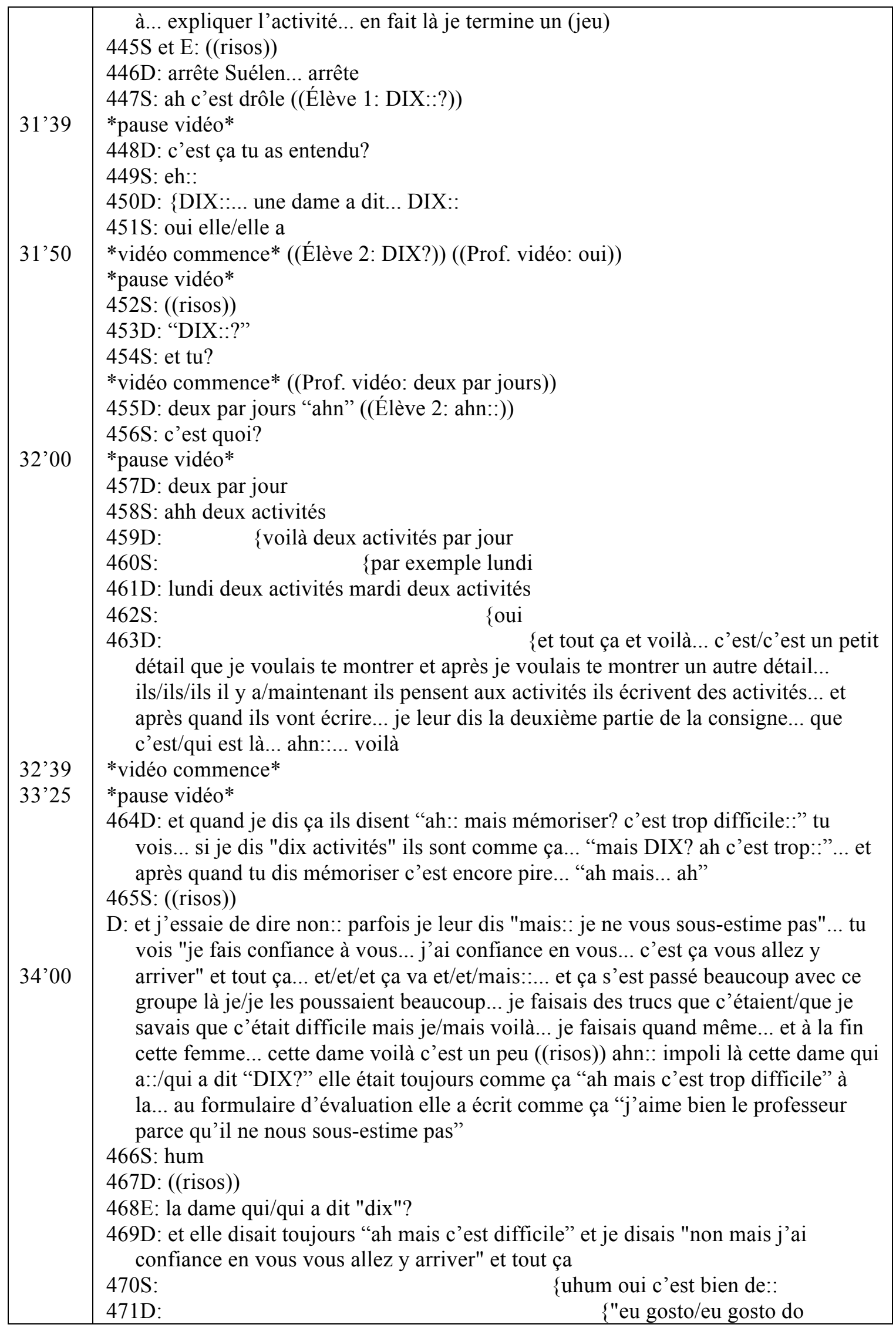




\begin{tabular}{|c|c|}
\hline $36^{\prime} 00$ & 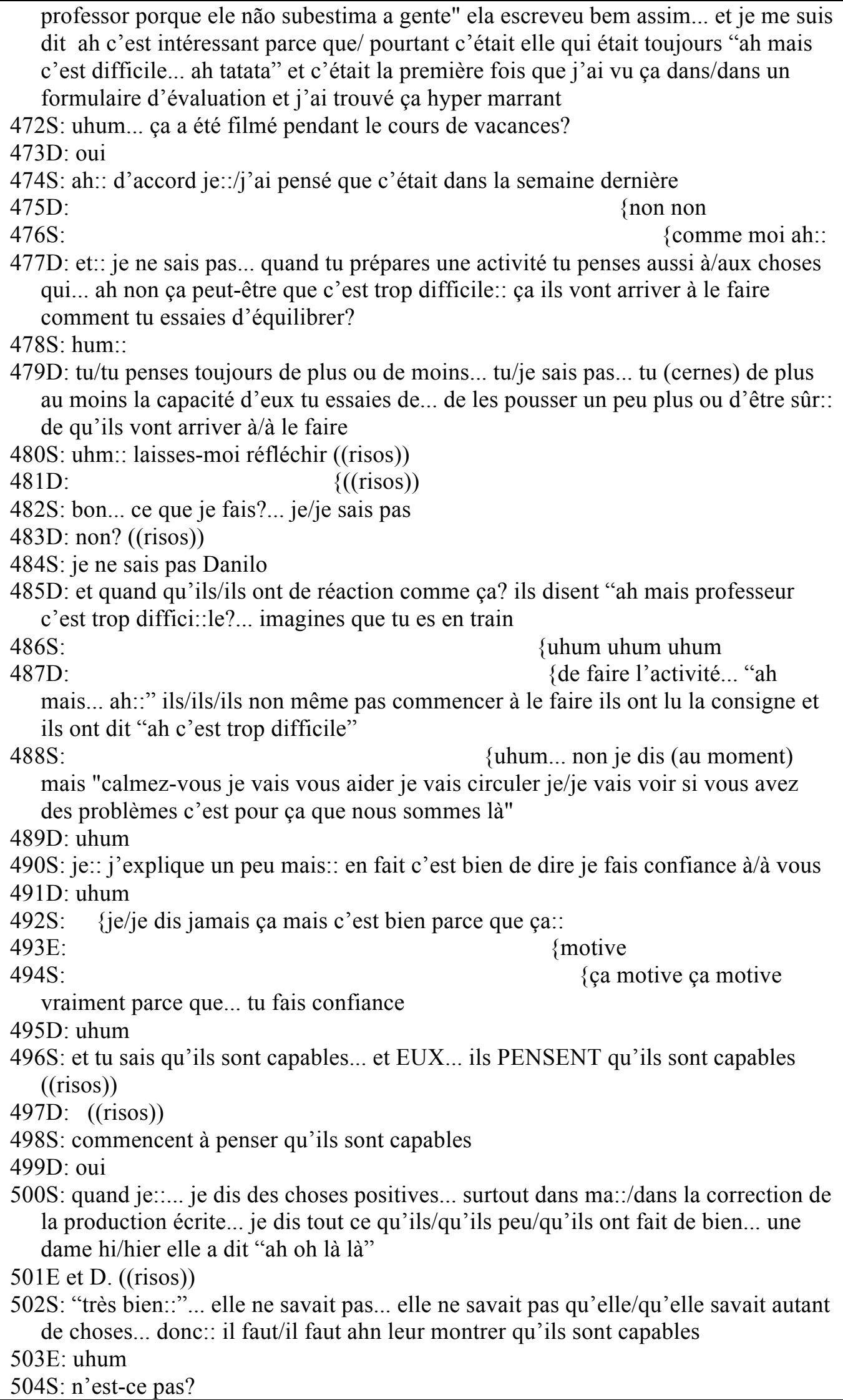 \\
\hline
\end{tabular}




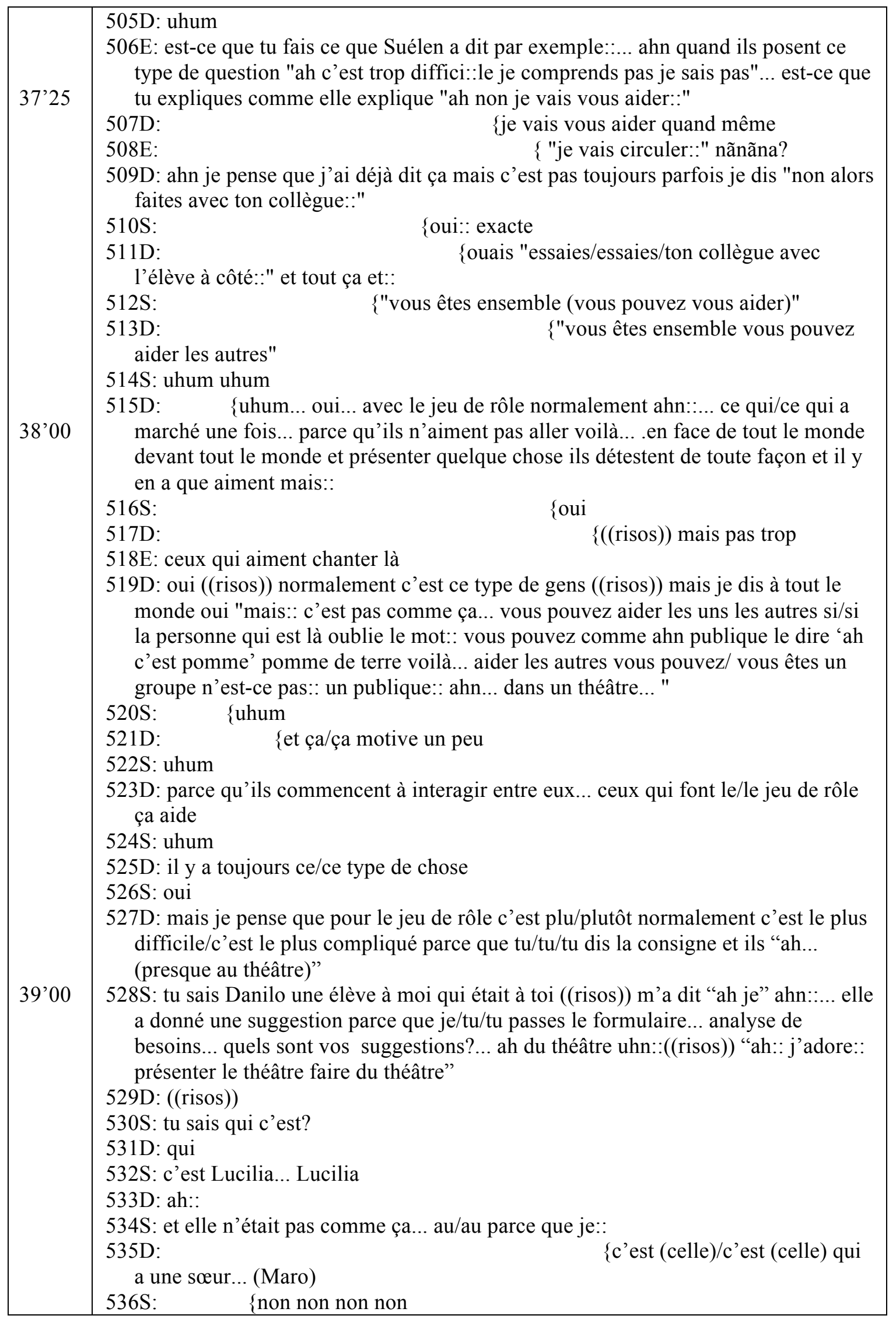




\begin{tabular}{|c|c|}
\hline $40 ’ 00$ & 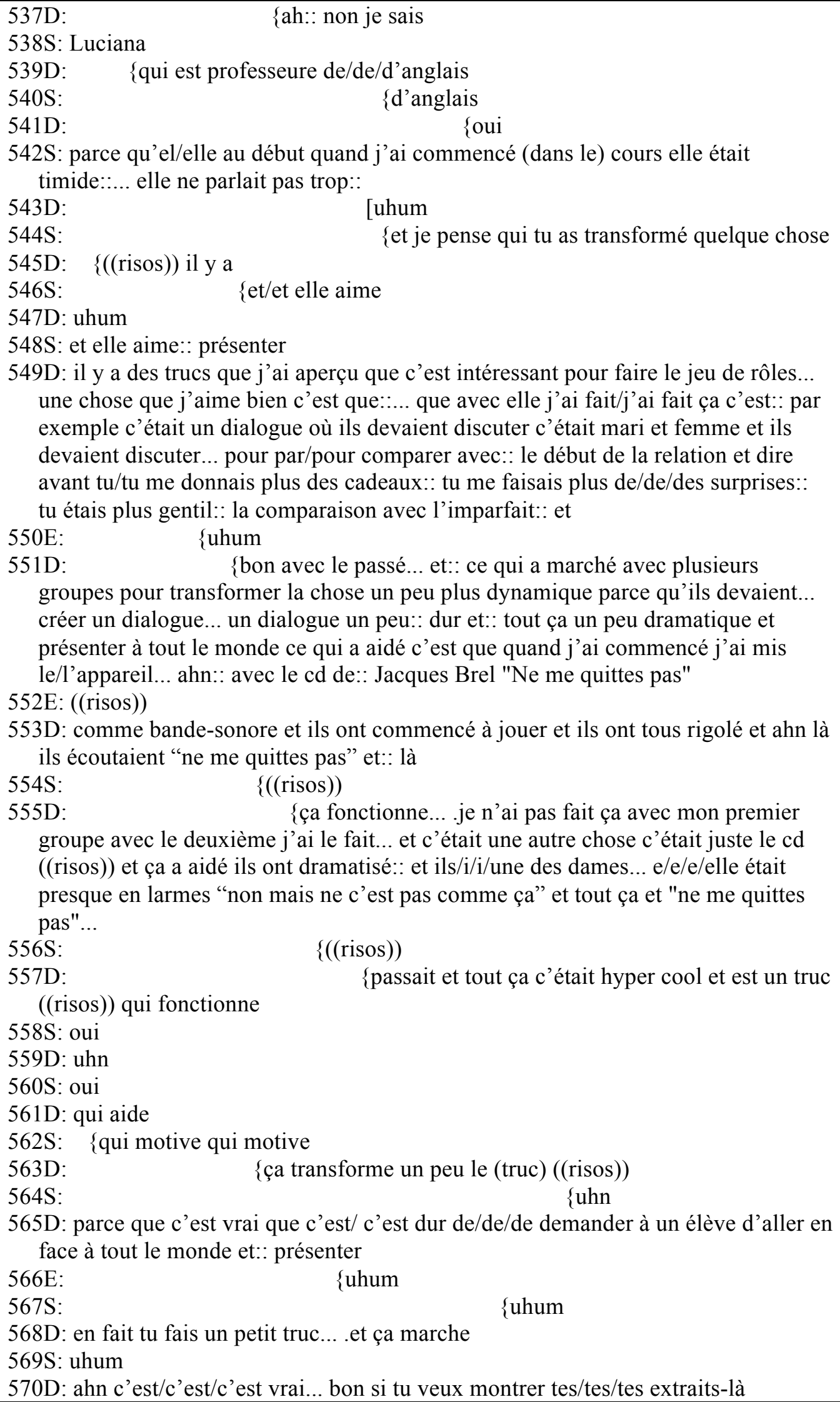 \\
\hline
\end{tabular}




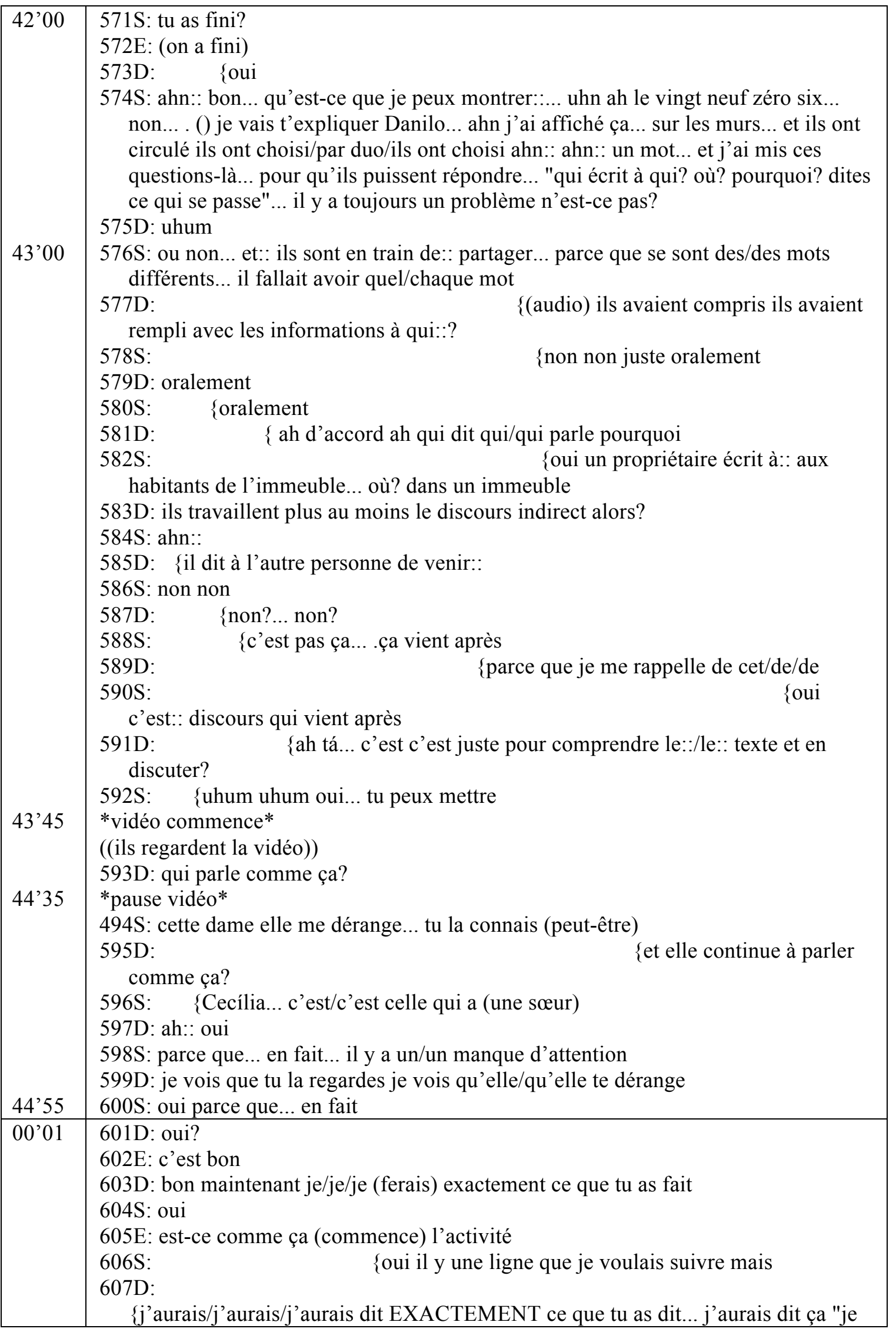




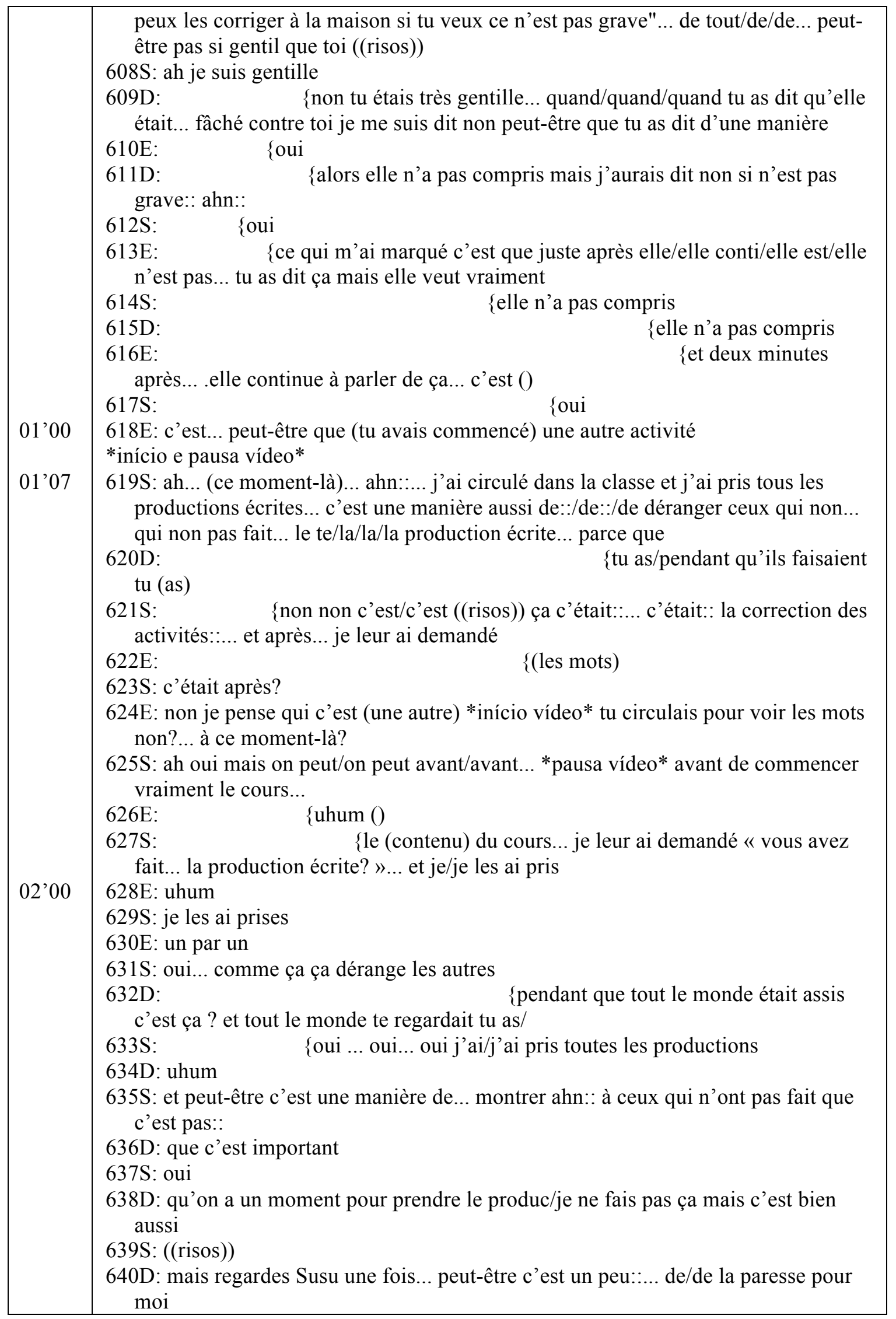




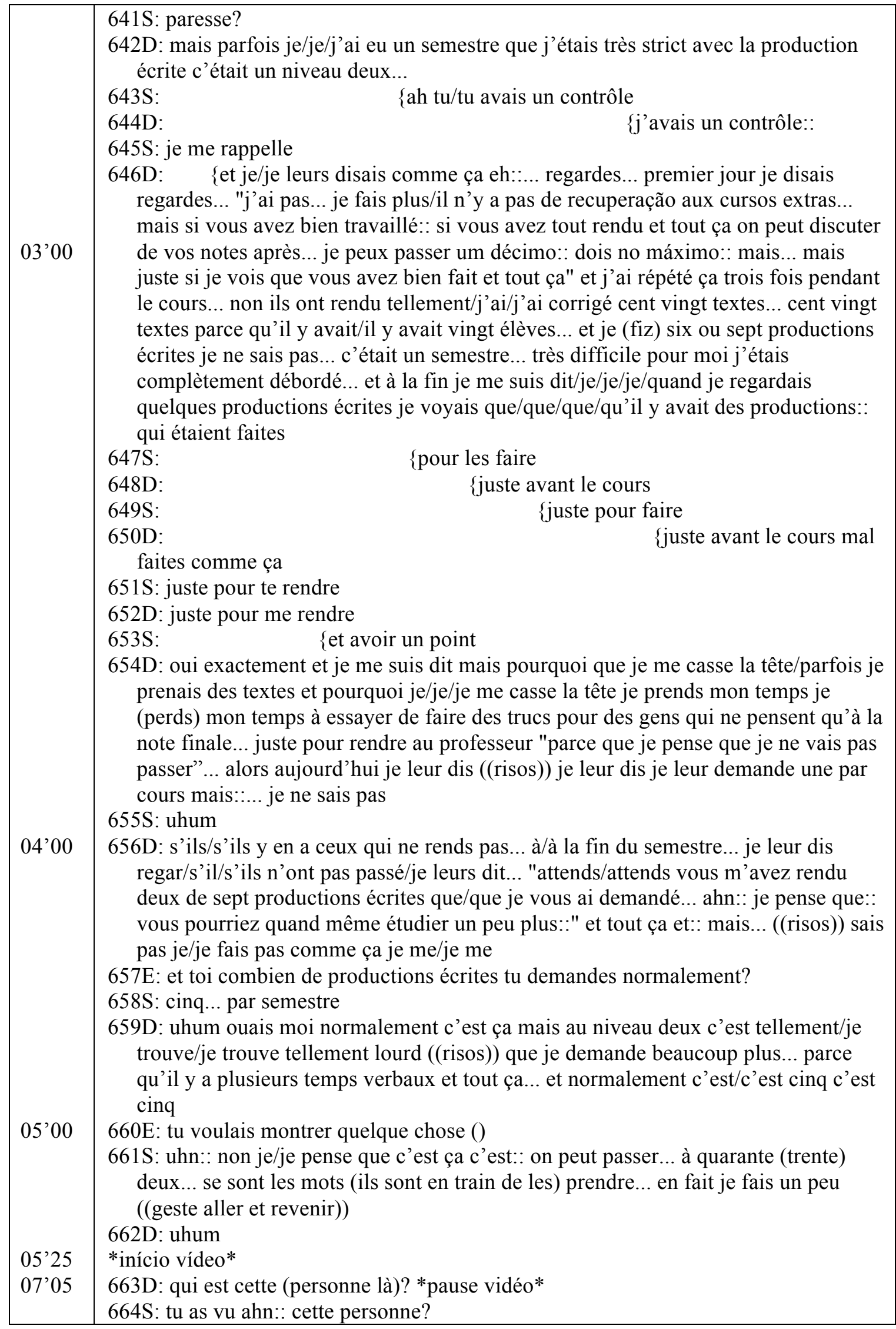




\begin{tabular}{|c|c|}
\hline $08^{\prime} 00$ & 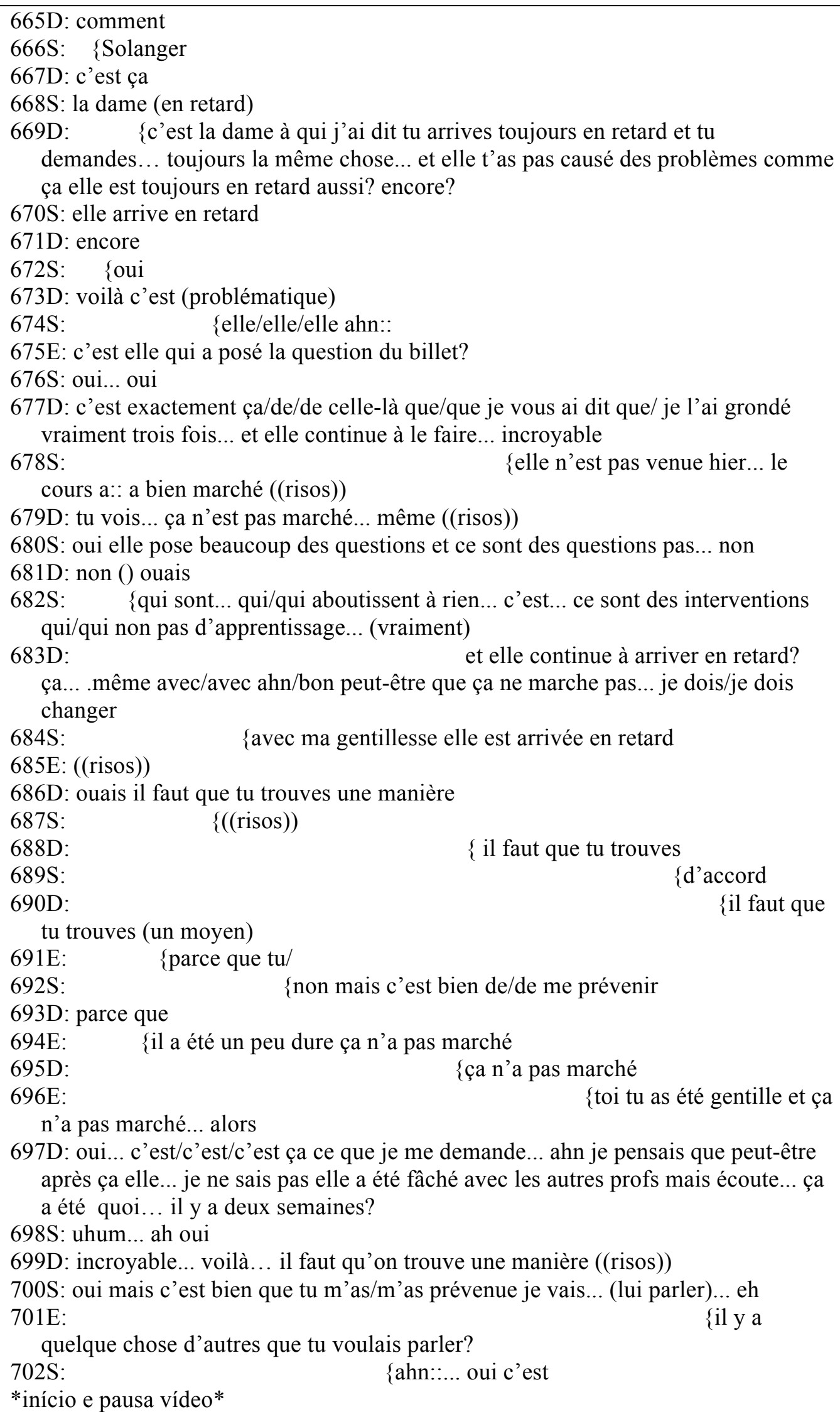 \\
\hline
\end{tabular}




\begin{tabular}{|c|c|}
\hline $09^{\prime} 03$ & $\begin{array}{l}\text { 703S: là je voulais juste ahn::... revenir au cours précédent parce qu'on avait vu des } \\
\text { définitions des adjectifs... d'accord? donc c'était }\end{array}$ \\
\hline \multirow[t]{2}{*}{$09^{\prime} 14$} & *início vídeo* \\
\hline & 704S: elle parle en portugais:: \\
\hline \multirow[t]{15}{*}{$09^{\prime} 23$} & *pausa vídeo* \\
\hline & 705E: t'as dit qu'elle parle en portugais? \\
\hline & 706S: elle parle:: en portugais parfois \\
\hline & 707E: et tu laisses? \\
\hline & 708S: en fait je::.... \\
\hline & 709E: parfois tu réponds:: tu? \\
\hline & 710D: $\quad$ non mais là elle a dit \\
\hline & \{ça te gênes pas? \\
\hline & $\{c ̧ a$ fait pas/ça fait \\
\hline & $\begin{array}{l}\text { 713D: } \\
\text { en francais alors elle a dit comment }\end{array}$ \\
\hline & \{ela falou nota... nota \\
\hline & $\begin{array}{l}\text { 715D: } \\
\text { traduction elle a dit "comment on parle une nota?" } \quad \text { oui mais elle voulait la }\end{array}$ \\
\hline & \{ah d'accord... j'ai pas écouté \\
\hline & 717D: mais elle parle c'est vrai elle parle en portugais \\
\hline & 718S: \\
\hline \multirow[t]{2}{*}{09,50} & *início vídeo* \\
\hline & ((Aluna no vídeo : TRÈS TRÈS TRÈS honête... dix euros)) \\
\hline \multirow[t]{16}{*}{$09 ’ 55$} & $\begin{array}{l}\text { 719S: là dans ce moment-là ça apparaît ahn:: l'interculturel... c'est ça que je voulais:: } \\
\text { 720D: } \quad \text { uhum }\end{array}$ \\
\hline & \{vous montrer parce que... je/je les expose à des situations de/de \\
\hline & $\begin{array}{l}\text { l'interculturel... et:: ahn:: ça arrive des/des rigolades:: et je/je pense que c'est plus } \\
\text { naturel }\end{array}$ \\
\hline & 722D: mais qu'est-ce que tu discutais avec eux? \\
\hline & 723S: c'était le billet de dix euros \\
\hline & oui le/le billet de dix euros \\
\hline & $\begin{array}{l}\text { 725S: la personne a dit « ah la personne est très très TRÈS honnête » et tout le monde } \\
\text { a rigolé }\end{array}$ \\
\hline & 726D: uhum \\
\hline & $\begin{array}{l}\text { 727S: ça montre déjà... ahn:: l'aspect... ahn:: de notre culture... on n'aurait jamais par } \\
\text { exemple mis un mot comme ça... ((risos)) }\end{array}$ \\
\hline & \{comme ça probablement non \\
\hline & ahn puis \\
\hline & \{on ne dit pas jamais \\
\hline & ouais... probablement non \\
\hline & 732E: dans ce cas ce qu'elle a dit c'est ((tosse))/ elle a dit que « c'est très très TRÈS \\
\hline & $\begin{array}{l}\text { honnête dix euros } \gg . . . \text { parce que si c'était cinq millions peut-être mais dix euros } \\
\text { 733D: }\{\text { dix euros... ouais }\end{array}$ \\
\hline & 734E: c'est ça \\
\hline \multirow[t]{3}{*}{$11^{\prime} 00$} & $\begin{array}{l}\text { 735S: oui c'est le commentaire de Margarete qui/qui donne la/ l'aspect interculturel } \\
\text { donc j'attendais ca en fait quand j'ai apporté ahn:: ce mot-là }\end{array}$ \\
\hline & $\begin{array}{l}\text { 736E: et après... personne n'a fait un commentaire ça veut dire ça est sorti comme } \\
\text { ahn } . \text { comme une blague presque }\end{array}$ \\
\hline & $\begin{array}{l}\text { 737S: } \quad \text { tout le monde a compris le billet... c'était ça c'est } \\
\text { bien... tout le monde a compris le billet et a comparé ahn:: avec notre culture }\end{array}$ \\
\hline
\end{tabular}




\begin{tabular}{|c|c|}
\hline $12^{\prime} 00$ & 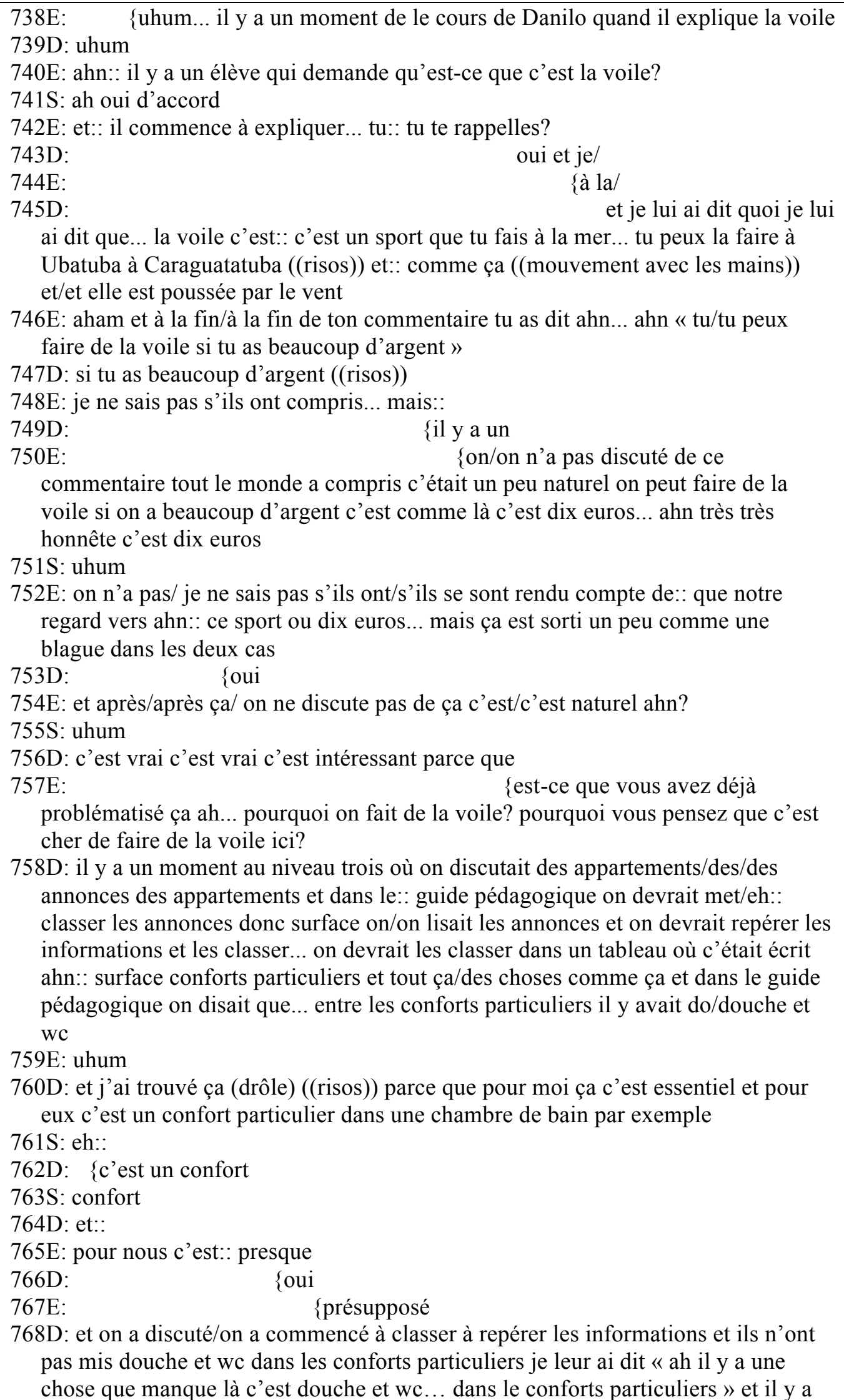 \\
\hline
\end{tabular}




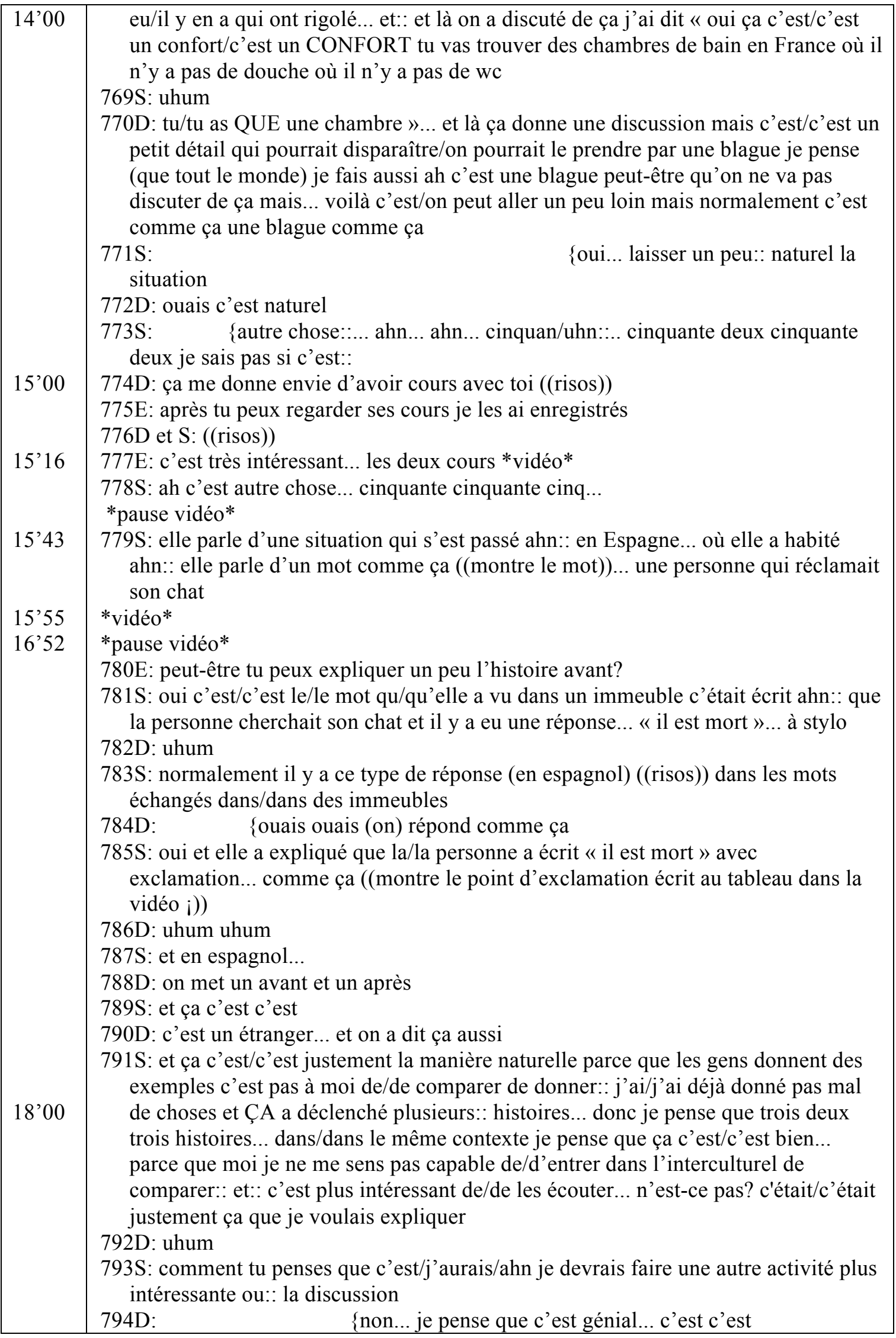




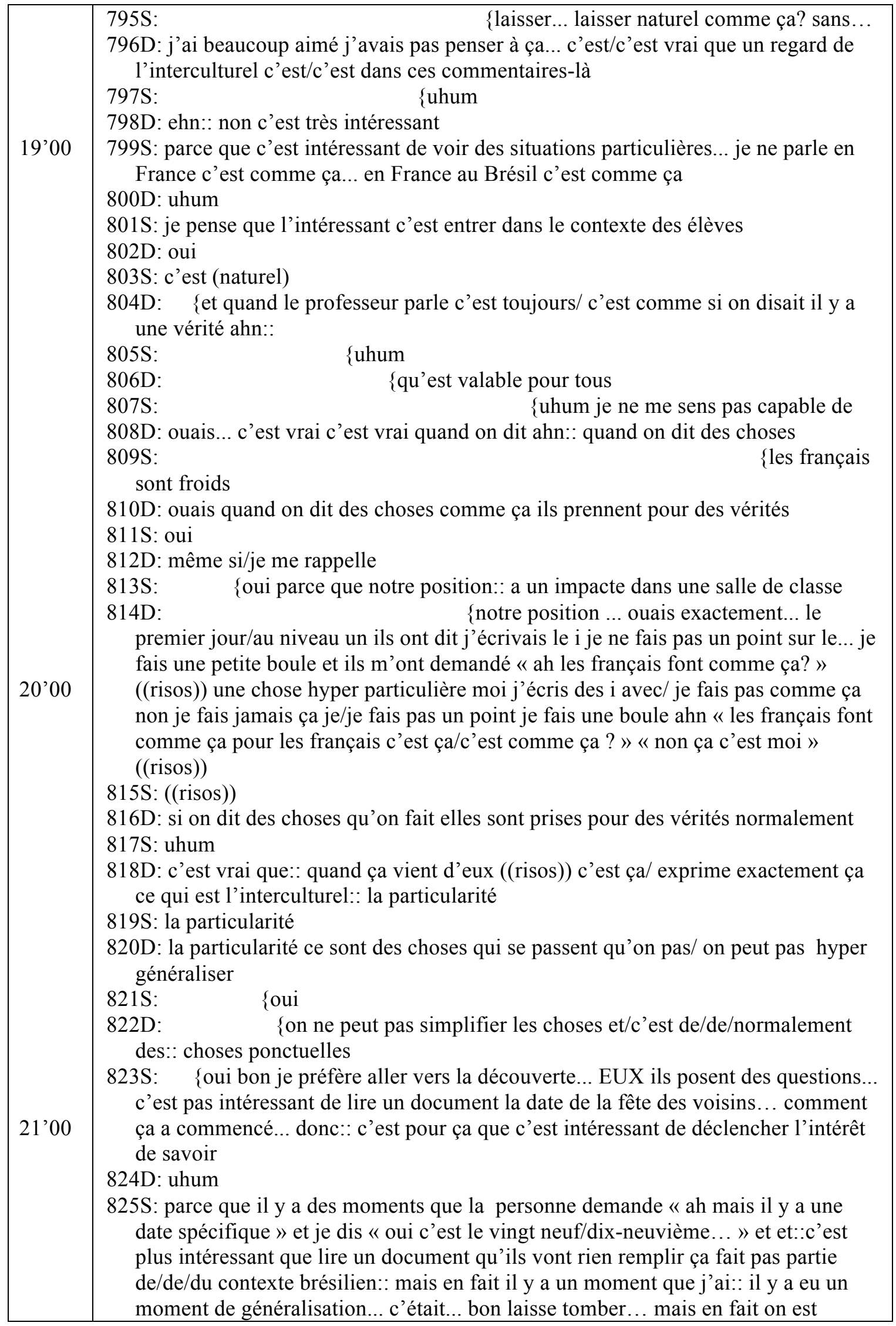




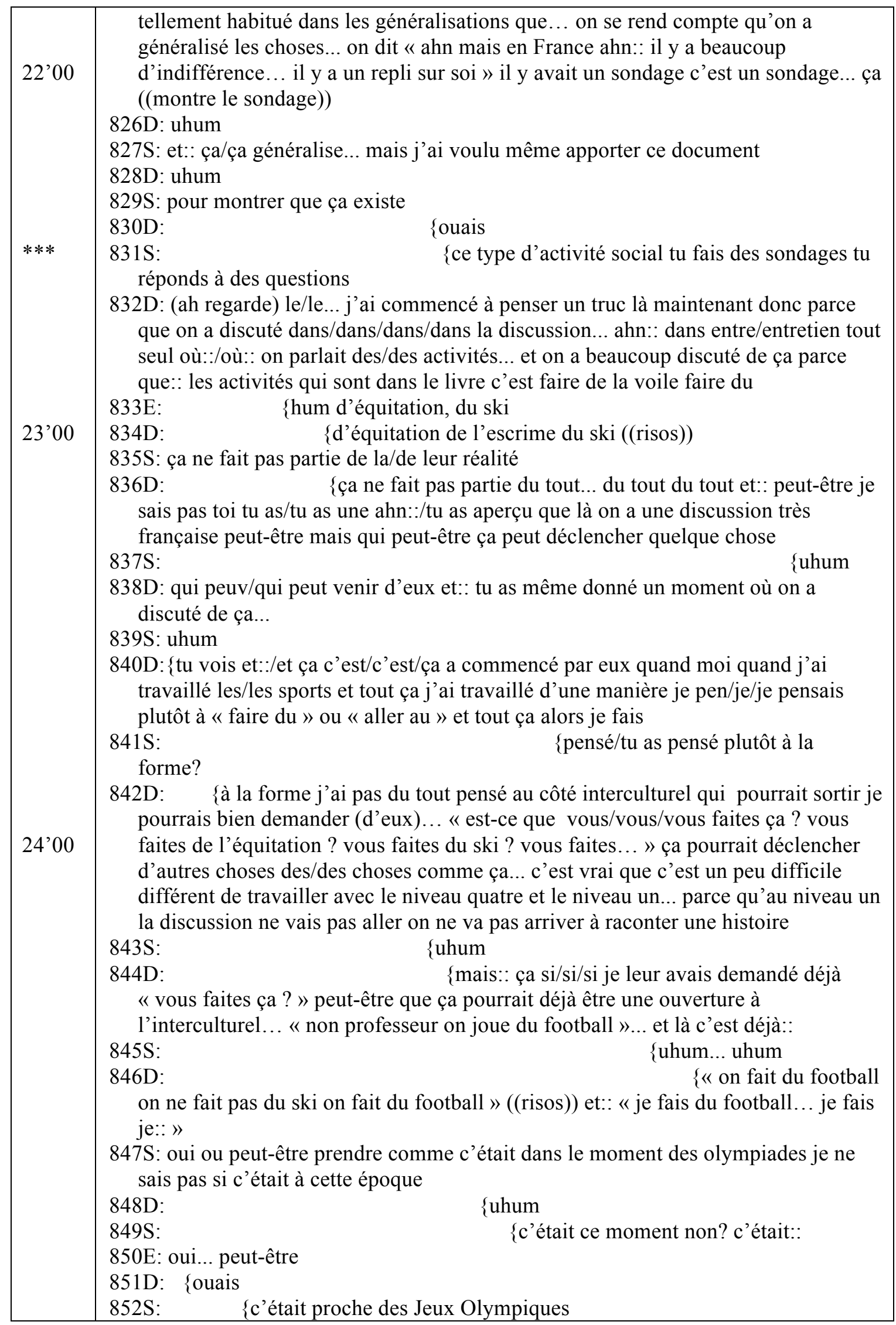




\begin{tabular}{|c|c|}
\hline $26^{\prime} 00$ & 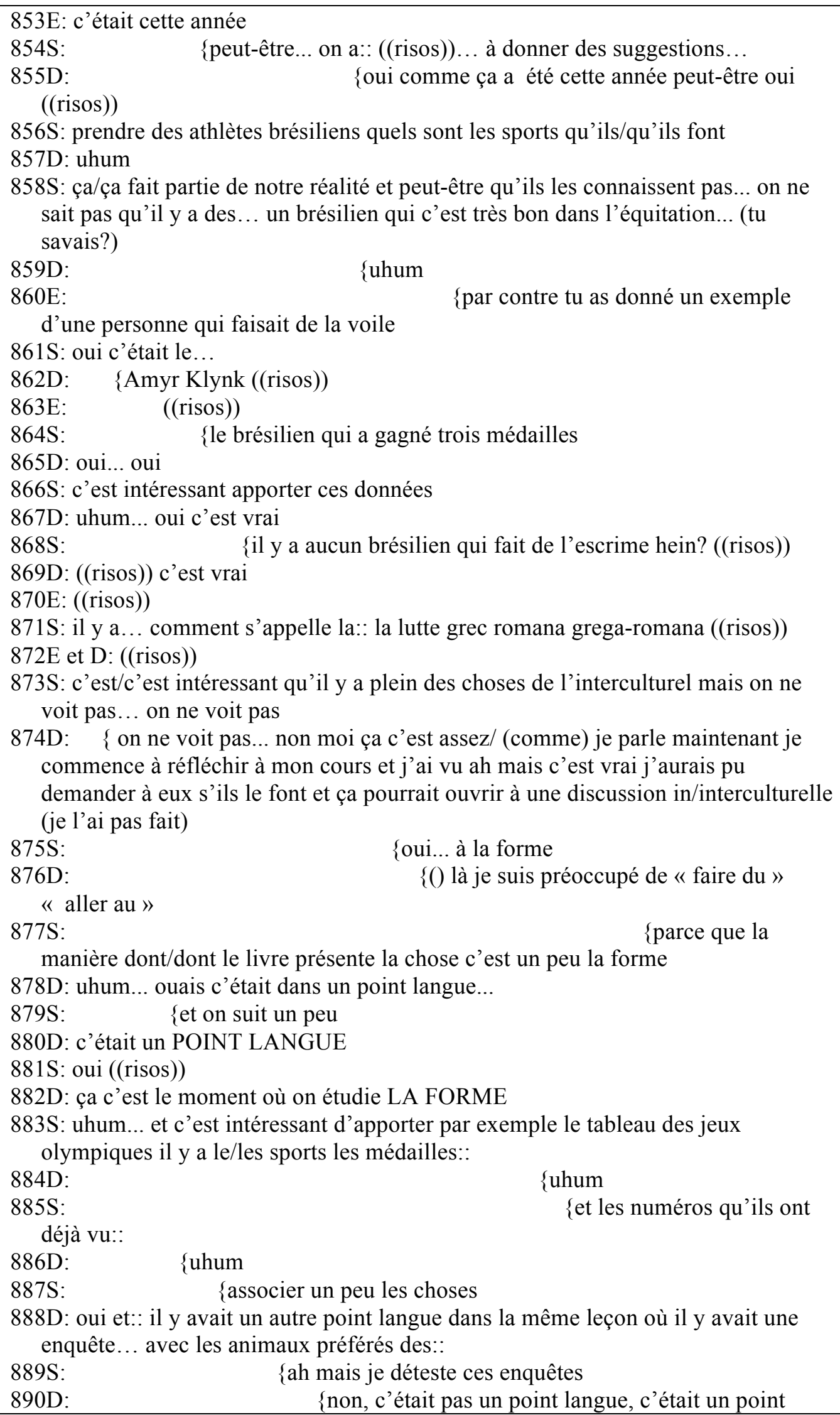 \\
\hline
\end{tabular}




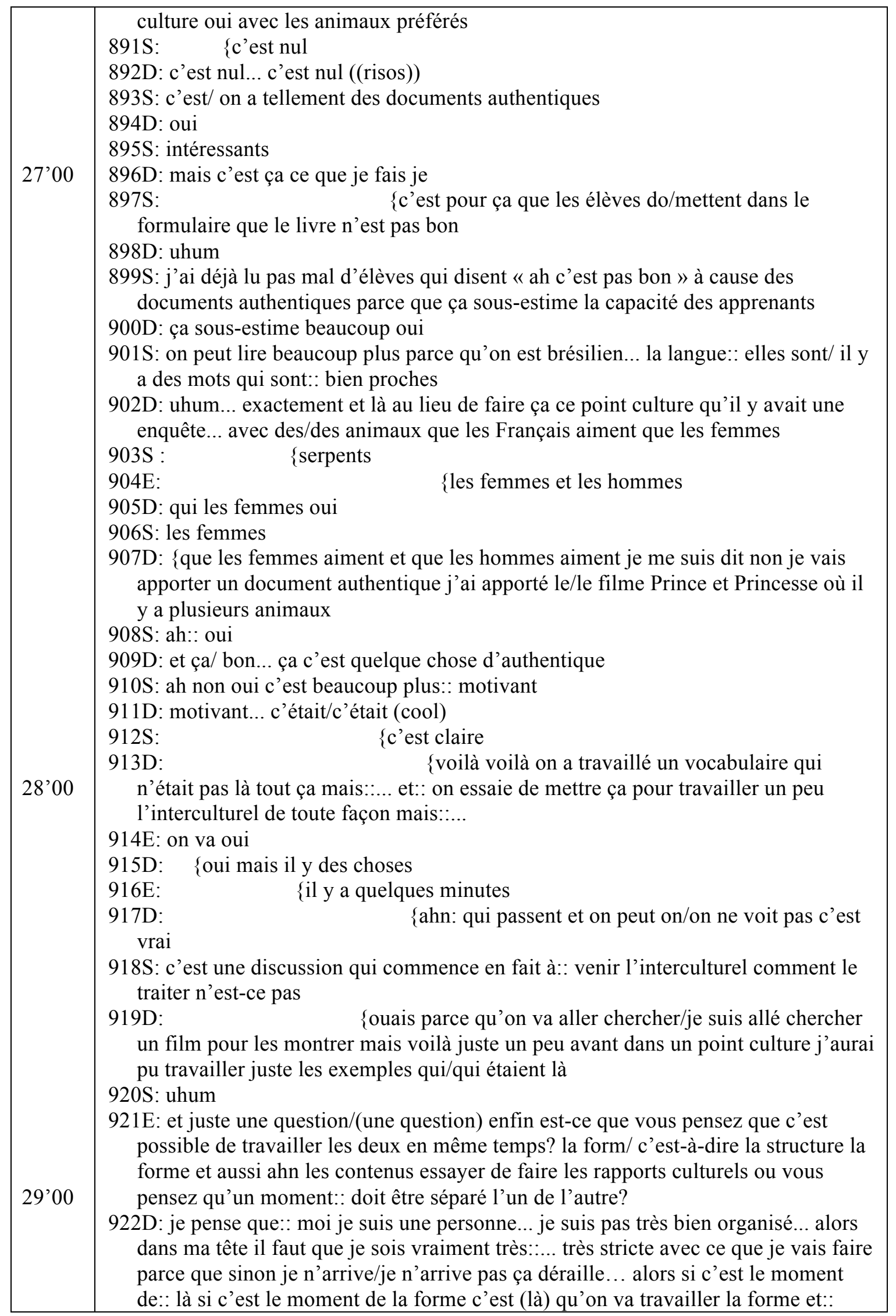




\begin{tabular}{|c|c|}
\hline $32 ’ 30$ & 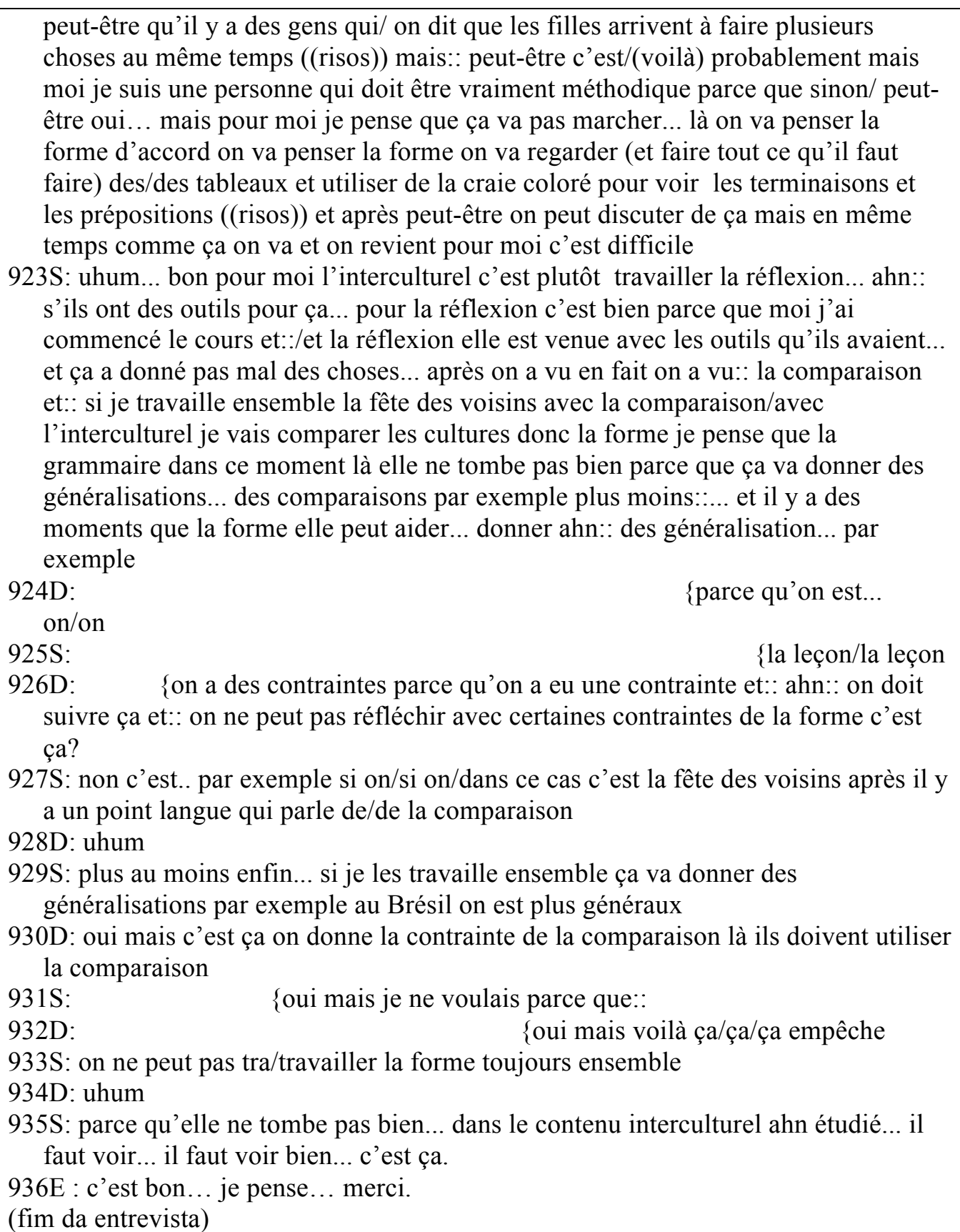 \\
\hline
\end{tabular}


Anexo A - Texto "Nove brasileiros que vivem em SP listam suas impressões sobre a cidade" (1) UOL Assine 08007033000 SAC Bate-papo E-mail BOL Notícias Esporte Entretenimento Mulher Rádio TV

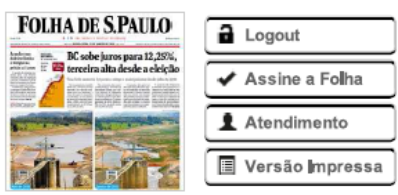

\begin{tabular}{|c|c|c|c|c|c|c|c|c|c|c|c|}
\hline Opinião - & Politica - & Mundo - & Economia - & Cotidiano - & Esporte - & Cultura - & F5 . & Tec . & Classificados - & Blogs - & $+\leqslant$ \\
\hline
\end{tabular}

\section{Nove estrangeiros que vivem em SP listam suas impressões sobre a cidade}

REGIANE TEIXEIRA

DE SÄO PAULO

$26 / 01 / 2014 \bigcirc 02 h 30$

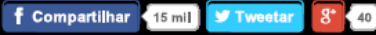

41)) OUVIR O TEXTO

Entrar em um banheiro e notar que é preciso usar um cesto de lixo nunca foi problema para quem vive em São Paulo -ou em qualquer outro canto do país. Mas, para quem passou a vida toda evitando essa fadiga, lidar com o cesto é um choque.

"Isso é muito desconcertante e difícil para muitos estrangeiros. É quase tão impactante quanto ir para a Índia e não ter papel higiênico", diz o economista irlandês Kieran Gartlan, 46, que vive no Brasil desde 1994.

Ele é o criador do site Gringoes, uma comunidade virtual em que pessoas de todo o mundo tiram dúvidas e trocam experiências sobre a vida por aqui.

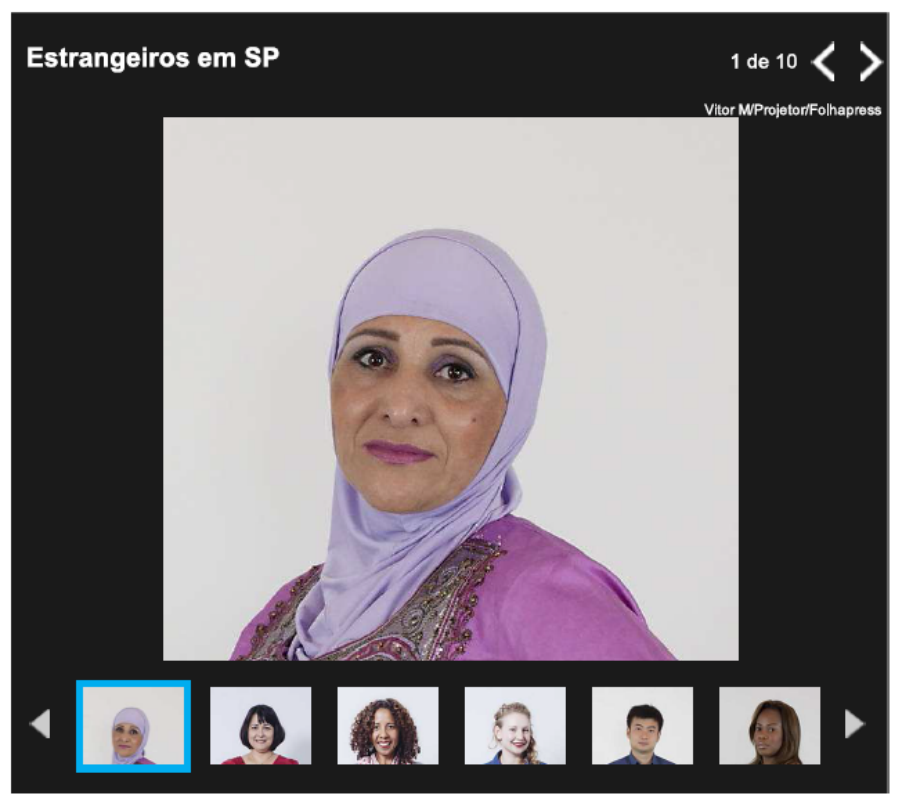

Embalada pelas listas de estrangeiros que circulam na internet, a sãopaulo leia também

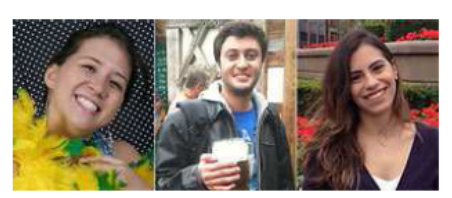

Massacre na Copa faz brasileiros sofrerem com piadas em países rivais; veja relatos

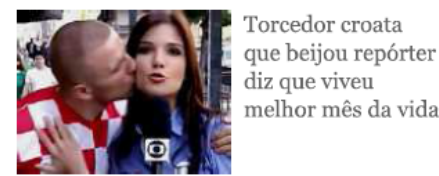

especiais

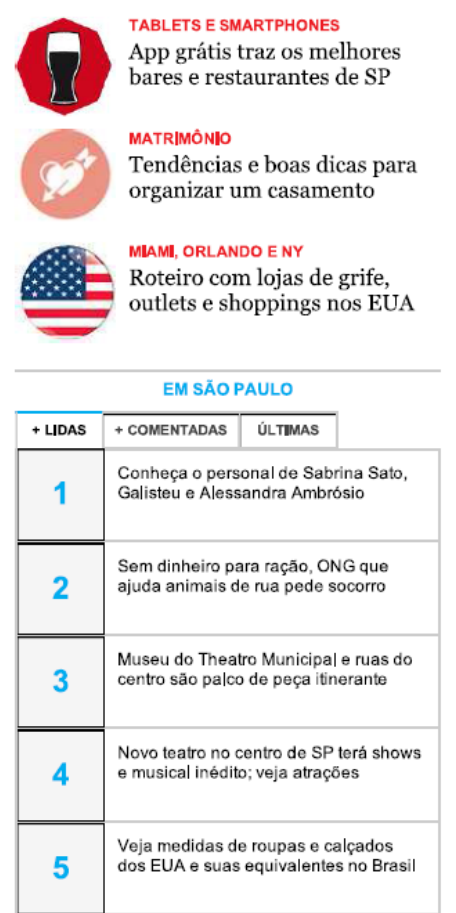


convidou nove pessoas de várias nacionalidades que moram em São Paulo -e um paulistano que vive há sete anos em Portugal- para contarem o que há de estranho ou peculiar na cidade e nos costumes brasileiros.

Só no ano passado, até setembro, o Ministério do Trabalho concedeu 22.021 autorizações para que estrangeiros trabalhassem no Estado de São Paulo. "Só que os brasileiros não sabem que aqui é uma terra de oportunidades", diz a libanesa Aliah Khreiis, 37, sócia de um restaurante na região central.

Embora sejam bem recebidos, os que vêm tentar a vida por aqui sofrem com o barulho, com a burocracia e com os preços altos. "Obra e trânsito formam o casal mais paulistano de todos", brinca o modelo francês Baptiste Demay, 26. "Por outro lado, São Paulo é onde mais sinto boas vibrações e troca de energia entre o morador e a cidade."

Veja abaixo o que os estrangeiros dizem sobre a cidade:

\section{Sasha Yaklovena, 25, russa, jornalista}

- Em São Paulo, no verão, poucas pessoas usam roupa curta e aberta. Em Moscou, homens e mulheres andam quase pelados!

- Na Rússia anoitece por volta das 22h3o. No Brasil, às 2oh já está escuro.

- Você tem que estar muito arrumado para entrar na balada em Moscou, senão pode ser barrado. Em São Paulo, mesmo nas baladas mais chiques, tem gente de jeans, tênis e camiseta

- Aqui as pessoas se ajudam. Dão informações na rua ou no metrô, seguram sua bolsa no vagão e ajudam a carregar a mala.

- A capital paulista tem ruas muito íngremes e cheias de buracos. Vejo mulheres de São Paulo usando salto só nos escritórios.

- O serviço nos restaurantes de São Paulo é excelente. Nunca vi tantos garçons gentis e sorridentes.

- Parques em São Paulo são feitos só para praticar esportes.

\section{Kieran Gartlan, 46, irlandês, economista}

- Os brasileiros adoram tomar banho.

- As pessoas falam muito alto, ouvem música alta e buzinam em túneis.

- As crianças fazem o que querem aqui. Parece que os pais brasileiros têm problema em dizer "não" aos seus filhos.

- Os brasileiros escovam os dentes a cada refeição. A higiene dental não é tão importante na Irlanda.

- Aqui as pessoas não respeitam fila. É normal ver alguém passando na frente e ninguém falar nada.

- Em São Paulo, você pode sair à noite qualquer dia da semana e achar o que fazer.

- No Brasil existe o sistema de comandas nos bares. Na Irlanda, sai muito mais caro, as pessoas pagam rodadas para todos os amigos.

\section{Michelle Warmbier, 25, alemã, terapeuta de} dança

- Tem muita gente com olhos da cor verde ou mel e com a pele meio escura. É uma combinação bonita que você não vê muito na Alemanha.

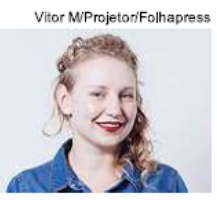

\section{siga a folha}

Q RECEBA NOSSA NEWSLETTER

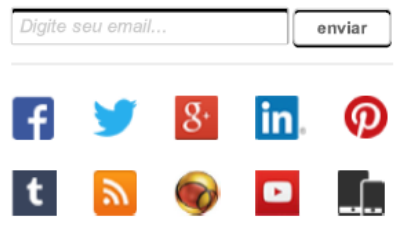

\section{envie sua notícia}

a Fotos Videos / Relatos
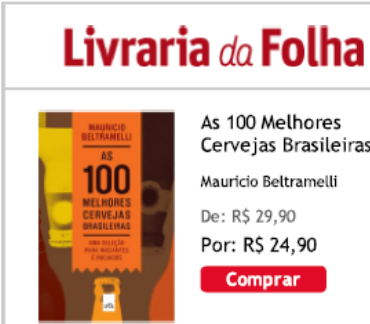

As 100 Melhores Cervejas Brasileiras

Mauricio Bettramelli

De: $R \$ 29,90$

Por: R\$ 24,90

Comprar

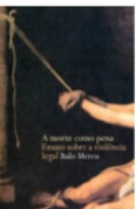

A Morte Como Pena

Italo Mereu

De: $\operatorname{RS} 53,00$

Por: $\mathrm{R} \$ 44,90$

Comprar

= Os Trapalhões (DVD)

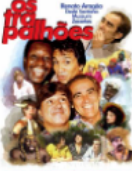

Vúrios

De: $R \$ 54,90$

Por: $\mathrm{R} \$ \mathbf{4 7 , 9 0}$

Comprar
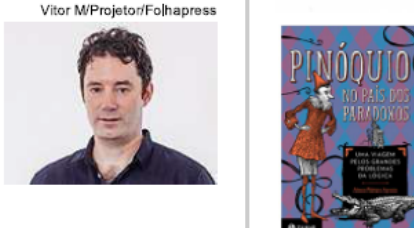

Pinóquio no País dos Paradoxos

Alessio Paimero Aprosio

De: $R \$ 34,90$

Por: R\$29,50

Comprar

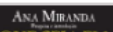

Que Seja em Segredo

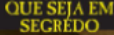

Ana Miranda (Org.)

De: $R \$ 14,90$

Por: R\$ 12,90

Comprar 
- As mulheres prendem o cabelo com o próprio cabelo fazendo um nó.

- Na Alemanha, jogamos o papel higiênico no vaso, não no lixo.

- Em São Paulo, você dá um beijo na pessoa quando a encontra.

- Sempre tem suco de laranja natural nos restaurantes e nas lanchonetes. É a melhor bebida do mundo!

- Aqui é muito comum que os filhos morem na casa dos pais até casar.

- Aqui a família tem prioridade muito alta. Lá, nem sempre.

- Os biquínis são muito pequenos. Particularmente a parte de baixo.

- Grafite aqui é arte e não só vandalismo. Que bom!

- Qualquer lugar no Brasil tem uma fila preferencial. As pessoas são muito atentas e educadas, sempre deixando passar na frente ou oferecendo um assento no metrô para quem está com um bebê no colo.

\section{Marina Pipatpan, 54, tailandesa, empresária}

- Em São Paulo, sorriem pouco na comparação com a Tailândia, que é conhecida como "a terra dos sorrisos".

- Na Tailândia, cumprimentamos o outro colocando as mãos juntas em forma da flor de Lótus. Nada de beijinhos.

- Em São Paulo tem poucas frutas e comida sendo vendidas na rua.

- Aqui nem sempre se tira sapato quando se entra na casa de alguém. $\mathrm{Na}$ Tailândia, chegamos ao ponto de funcionários usarem chinelos fofinhos no local de trabalho.

- Os paulistanos falam muito alto. Os tailandeses, que sussurram delicadamente, não entendem por que tudo mundo berra.

- Quando recebo tailandeses, aviso que eles têm de tirar suas joias. Eles não entendem como é realmente perigoso.

\section{Baptiste Demay, 26, francês, modelo}

- Aqui você pode ser convidado para ir a casa de alguém que não te conhece e ser bem recebido.

- A proporção de mulheres que entendem de futebol e que torcem com fervor para um time é maior que a proporção de homens do meu país.

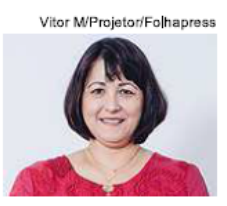

Vestir-se bem não é coisa de macho.

- A burocracia do meu país é bem louca, mas o Brasil fica em primeiro lugar. Tenho a impressão de ser o Asterix realizando um dos seus 12 trabalhos quando tenho que fazer qualquer serviço administrativo.

- Ver as babás (geralmente negras) vestidas de branco é chocante -é algo que remete à escravidão ou, ao menos, a uma regressão social.

- Comer de maneira saudável é coisa de rico aqui.

- As pessoas expressam muito mais os seus sentimentos, deixam saber o que elas sentem de bom sobre a outra pessoa. Às vezes, até demais. Acho legal. Os franceses e os europeus são mais frios e têm bastante a aprender com isso.

- Fazer tatuagem no Brasil é como trocar de cueca. 
ônibus, é comum ver as mães em pé e as crianças sentadas nos lugares preferenciais.

- Fico abismada quando vejo quantidades monumentais de comida ou de carne nos almoços de domingo. Por que tanta comida? "Não pode nunca faltar. Pode sobrar,

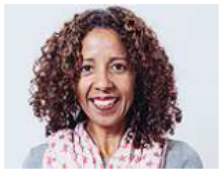
mas faltar jamais!"

- Brasileiras têm mania de limpar tudo com água sanitária: calçadas, casas, carros e, desconfio eu, até cachorros!

- "Está servido?" Sempre que alguém come algo, oferece para outra pessoa, mesmo que seja um completo estranho.

- Ainda me surpreende ver homens sem camisa nas ruas. Quando faz calor, os brasileiros não pensam duas vezes e tiram a camisa onde quer que estejam.

- Esse tal de palitinho após as refeições. Fico intrigada cada vez que vejo alguém com uma mão sobre a boca e a outra fazendo alguma coisa com o palitinho nos dentes.

\section{Zhen Zhang, 27, chinês, gerente de marketing}

- No futebol, as pessoas não se importam só com o seu time. Se há um jogo, elas sentam e assistem à partida inteira.

- Não é possível sobreviver no Brasil sem um CPF. Não dá

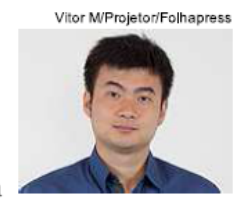
para ter nem um número de celular sem isso.

- Em muitos documentos, não basta a sua assinatura. Você precisa ir ao "cartório" para autenticá-la.

- Muita gente aqui é religiosa e é estranho para eles saberem que tem gente que não tem religião.

- Nunca vi tanta gente se beijando como no carnaval.

- É mais barato viajar aos EUA para comprar um computador do que comprálo aqui.

- Dá para pagar com crédito ou débito até em uma ilha.

\section{Melanito Biyouha, 43, camaronesa, dona de restaurante}

- Aqui existem sobremesas. Na África, comemos frutas.

- O modo de cozinhar feijão aqui é diferente. Na África, ele tem muitos temperos, vai tomate e é bem seco.

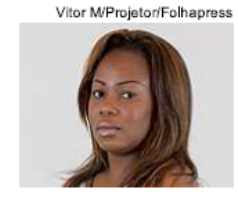

- O Brasil é mais bonito do que nos documentários, que só mostram a parte ruim do país.

- No Brasil, a mulher participa das decisões da família. Na África, ela tem de ser só bonita e calada.

- Em São Paulo existem muitas invasões de prédios. Nunca tinha visto isso.

\section{Aliah Khreiis, 37, libanesa, sócia de restaurante}

- A educação nas escolas é ruim e os brasileiros não sabem dos direitos que têm.

- A mulher aqui não nasce para ser dona de casa. É a melhor coisa do Brasil.

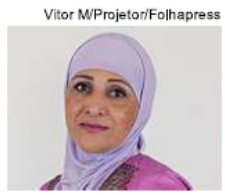

- Aqui você aprende a respeitar as diferenças.

- Aqui há muitas oportunidades de trabalho e de se crescer na vida.

- No meu país, há uma guerra declarada. Aqui ela parece que acontece 
escondida (se referindo às pessoas que vivem na cracolândia).

Eduardo Cavellucci, 31, paulistano que mora em Lisboa, tatuador

- Em Portugal, as pessoas são desconfiadas, não interagem. A gente sempre será estrangeiro.

- Primeira vez em que fui a um banheiro de um bar apertado, escutei do garçom: "Só tomares atenção porque o autoclismo da sanita está avariado, epa!". Entrei no banheiro e procurei algo avariado. Aparentemente, nada quebrado! Puxei a descarga e a água não parava mais de de sair. $\mathrm{O}$ atendente do bar não poupou "elogios"!

- Os portugueses se arrumam mais, se vestem melhor.

-Vinte quilômetros km pro português é longe. $100 \mathrm{~km}$ é uma viagem.

- O transporte público português cumpre horário.

- Meu breve glossário do português de Portugal:

Autoclismo $=$ descarga

Rotunda $=$ rotatória

Comboio $=$ trem

Nadador salvador $=$ salva-vidas

Comando da TV $=$ controle remoto

Fixe = legal

Faixa de travessia de peões $=$ faixa de pedestre

Palinha $=$ canudinho

Bué da fixe $=$ muito louco

Os putos $=$ as crianças

Casa de banho $=$ banheiro

Bicha $=$ fila

$\mathbf{C u}=$ bunda

Rola $=$ vagina, ha ha ha $\star \star \star$

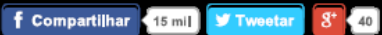

4)) OUVIR O TEXTO $\bigoplus$ Mals op̧̧ōe:

\section{Livraria da Folha}

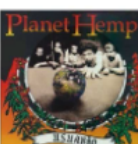

Planet Hemp - Usuário

(CD)

Planet Hemp

De: $R \$ 13,90$

Por: R\$ 12,90

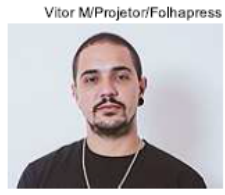

Comprar

- Cervejaria tem rótulos divertidos como Gordelícia, Loira do Banheiro e Cabra Macho - Animação adapta a crítica de George Orwell ao stalinismo

- Espiritismo aceita a diversidade por ter visão modema do mundo, diz autor

- Seremos lembrados como mimados e covardes, diz Pondé

- Conheça a página de conteúdo da Livraria da Folha

\section{comentários}

Ver todos os comentários (10)

\section{Comentar esta reportagem}

Ed (6) 26/01/2014 10h40 B 2 B $0 \triangle \Delta$ Denunciar

Boa reportagem. Legal que escolheram pessoas dos mais diversos paises, não só norte americanos ou europeus. Parabens.

O comentário năo representa a opiniáo do jormal; a responsabilidade e do autor da mensagen

$\rightarrow$ Responder 
Artigo muito bom, espero que seja lido principalmente pelos inúmeros brasileiros que ainda sofrem do complexo de vira-latas...

O comentário nâo representa a opiniâo do jornal, a responsabilidade é do autor da mensagem

$\rightarrow$ Responder

Marisa Coan (1180) 26/01/2014 11h43 B1 0 B Denunciar

+ COMPARTILHAR

Kieran-Que bom q o pessoal aqui gosta de uma água e sabonete,não é? Imagine com o nosso calor se não fosse assim.E escovar os dentes também.É muito bom...

o comentário nấo representa a opiniáo do jornal; a responsabilidade é do autor da mensagem

$\rightarrow$ Responder

\begin{tabular}{|l|l|}
\multicolumn{1}{c|}{ Termos e condições } \\
\hline $\begin{array}{l}\text { Reinvente a Cidade! } \\
\text { Aptos. sob medida para a familia moderna. Duplex 1 ou 2 suites. Veja } \\
\text { Vitacon_com.br }\end{array}$ \\
$\begin{array}{l}\text { A GVT chegou em São Paulo } \\
\text { Banda Larga GVT Saiba mais } \\
\text { www.gvt.com.br }\end{array}$ \\
$\begin{array}{l}\text { Imóveis em São Paulo } \\
\text { Conquiste sua casa própria na MRV. Subsídio de até RS 25,000,00, Veja } \\
\text { wnww.MRV.com_br }\end{array}$
\end{tabular}

FOLHA

$\star \star \star$

FOLHA DE S.PAULO

Sobre a Folha

Expediente

Fale com a Folha

Folha en Español

Folha in English

Folhaleaks

Folha Integra

Folha Transparência

Folha 10

E-mail Folha

Ombudsman

Atendimento ao Assinante

ClubeFolha

Publifolh

Banco de Dados

Datafolha

Folhapress

Treinamento

Trabalhe na Folha

Publicidade

Regras de acesso ao site

Polltica de Privacidade

OPINIÃO

Editoriais

Blogs

Colunistas

Ex-colunistas

Tendências/Debates

\begin{tabular}{|l|}
\hline a Logout \\
\hline $\mathbf{A s s i n e}$ a Follha \\
\hline $\mathbf{1}$ Atendimento \\
\hline 目 Versão Impressa \\
\hline
\end{tabular}

国 Versão Impressa

POLITICA

Poder

Eleições 2014

Poder e Politica

Mensalăo

Tudo Sobre

MUNDO

Mundo

BBC Brasil

Deutsche Welle

Financial Times

Los Hermanos

Radio France

Internationale

The Guardian

The New York Times

ECONOMIA

Mercado

Folhainvest

Indicadores

MPME

PAINEL DO LEITOR

Painel do Leitor

A Cidade é Sua

Envie sua Noticia

Semana do Leito

Agenda Folha

\begin{tabular}{|c|c|c|}
\hline COTIDIANO & CULTURA & + SEÇÕES \\
\hline Cotidiano & Ilustrada & As Mais \\
\hline Folha Verăo & Grade de TV & Acervo Follha \\
\hline Especial Crise da Água & Melhor de sãopaulo & Calendário 2014 \\
\hline Educaçẫo & Moda & Em Cima da Hora \\
\hline Escolha a Escola & Cartuns & Empreendedor Social \\
\hline Simulados & Comida & Erramos \\
\hline Ranking Universitário & Banco de receitas & Especiais \\
\hline Ribeirăo Preto & Guia & Feeds da Folha \\
\hline Rio de Janeiro & Ilustrissima & Folha apps \\
\hline Revista sãopaulo & Serafina & Folhinha \\
\hline sãopaulo hoje & & Fotografia \\
\hline Loterias & TEC & Horóscopo \\
\hline Aeroportos & $\mathrm{Tec}$ & Infográficos \\
\hline Praias & Games & Turismo \\
\hline \multirow[t]{2}{*}{ Trânsito } & Smartphones & Minha História \\
\hline & TVs & \\
\hline ESPORTE & Quadrinhos & TV FOLHA \\
\hline Esporte & & TV Folha \\
\hline Folha na Copa & F5 & \\
\hline Paulista 2014 & F5 & CLASSIFICADOS \\
\hline Calendário esportivo & Bichos & Empregos \\
\hline Rio 2016 & Celebridades & Imóveis \\
\hline Seleçâo brasileira & Colunistas & Negócios e Carreiras \\
\hline Tênis & Estranho! & Veiculos \\
\hline Turfe & Eu Amo & \\
\hline \multirow[t]{2}{*}{ Velocidade } & Factoides & REDES SOCIAIS \\
\hline & \#fofices & Facebook \\
\hline ClÊNCIA & Fotos & Twitter \\
\hline Ciência & Humanos & Google + \\
\hline \multirow[t]{2}{*}{ Ambiente } & Nascimentos & Instagram \\
\hline & Saiu no NP & Linkedh \\
\hline SAÚDE & Televisão & Pinterest \\
\hline Equilibrio e Saúde & Videos & Tumblr \\
\hline
\end{tabular}

\section{ACESSE O APLICATIVO PARA TABLETS E SMARTPHONES}

Copyright Foha de S.Paub. Todos os direitos reservados. É proibida a reprodução do conteúdo desta página em qualquer meio de comunicaçăo elatrônico ou impresso, sem autorizaçăo escrita da Fohapress (pesquisa@iolhapress,com,br).

Fonte: http://www1.folha.uol.com.br/saopaulo/2014/01/1401763-nove-estrangeiros-que-vivem-em-sp-listamsuas-impressoes-sobre-a-cidade.shtml (acesso em novembro de 2014) 
Anexo B - Material didático referente à aula de Danilo (Alter Ego A1, 2006)

\section{(i) Alter Ego A1 - Sumário (Tableau de Contenus)}

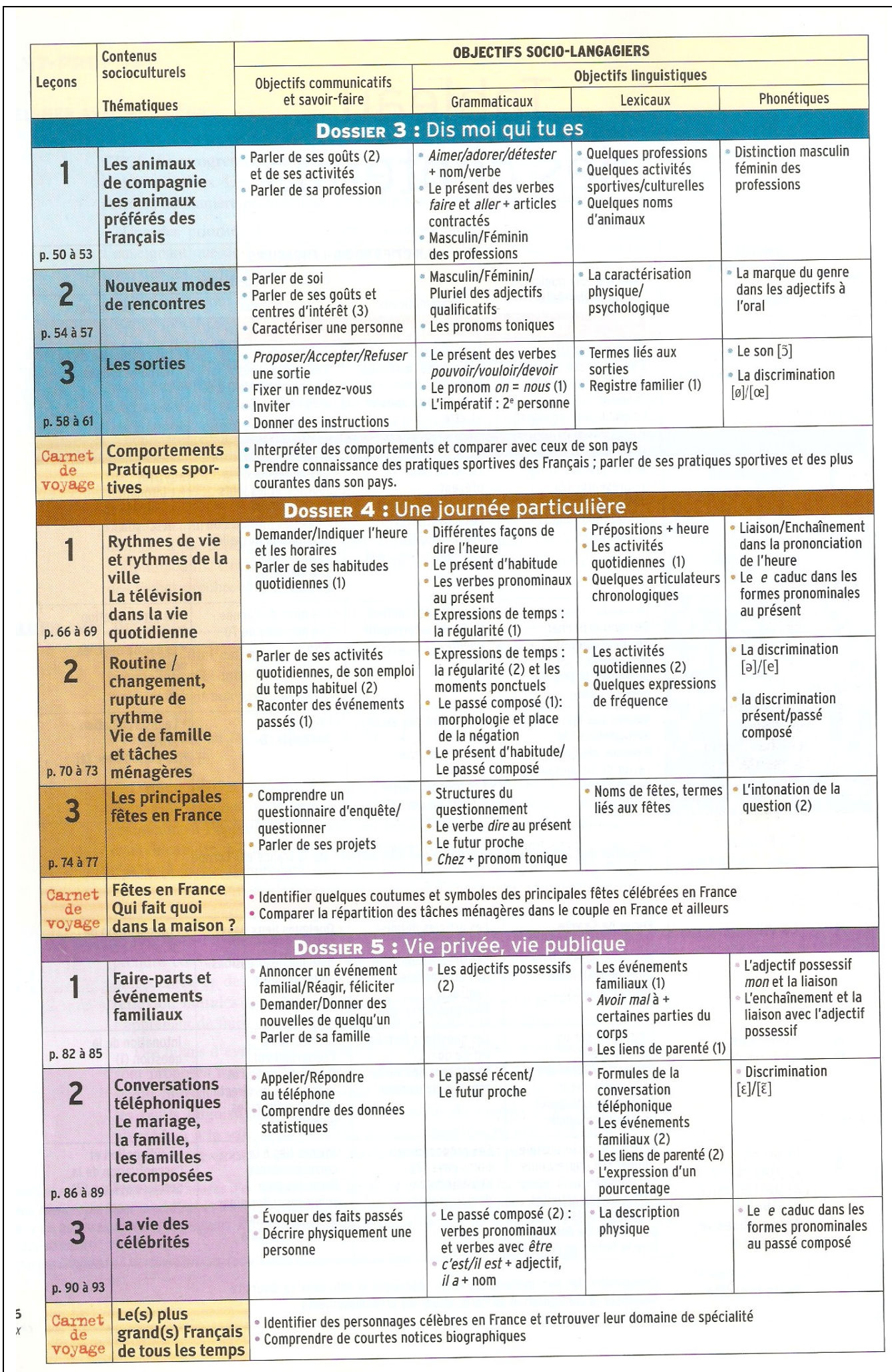


(ii) Alter Ego A1 - Dossiê 3, Lição 1 “Dis-moi qui tu es" (p.50)

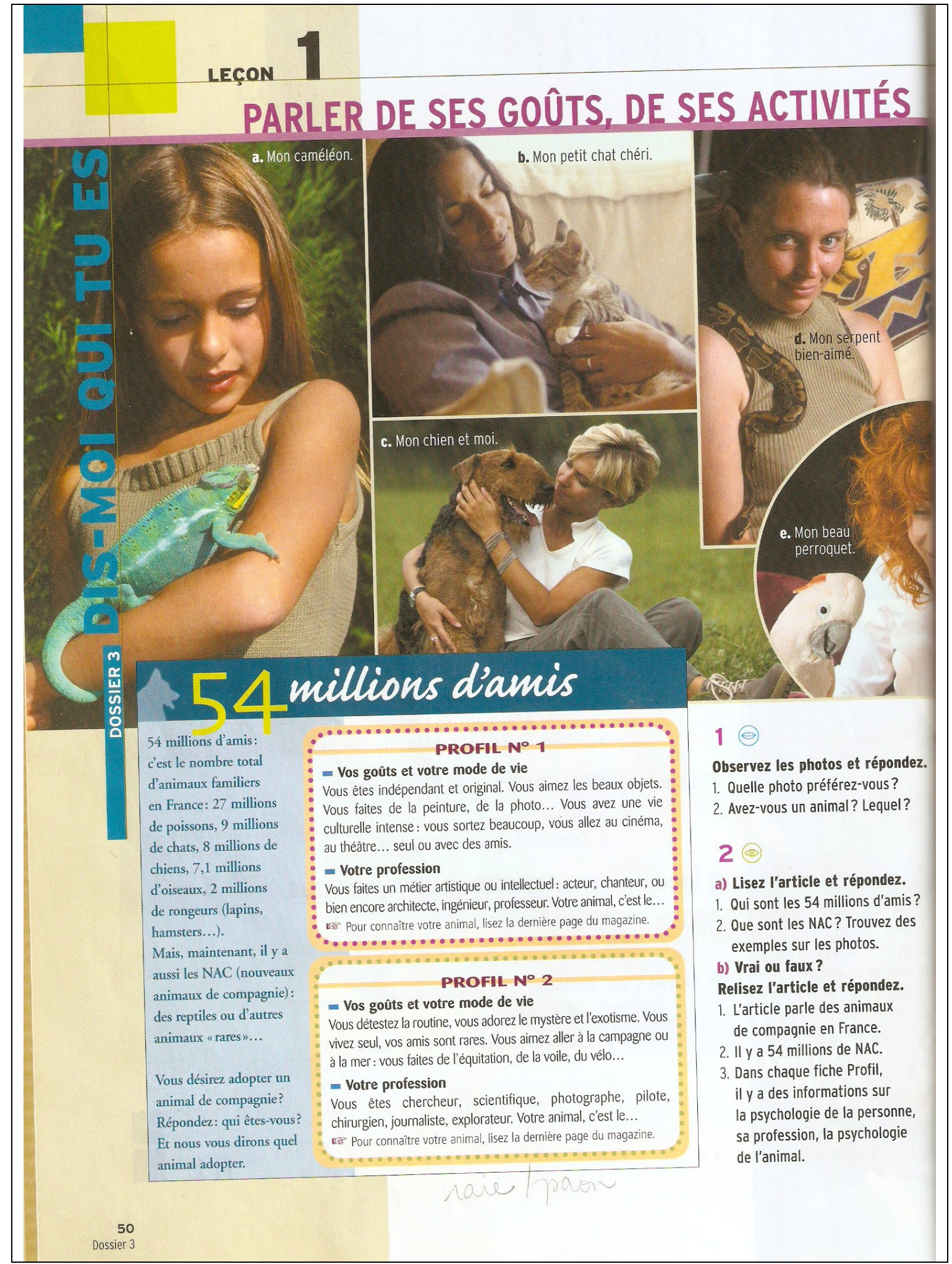


(ii) Alter Ego A1 - Dossiê 3, Lição 1 “Dis-moi qui tu es” (p.51)

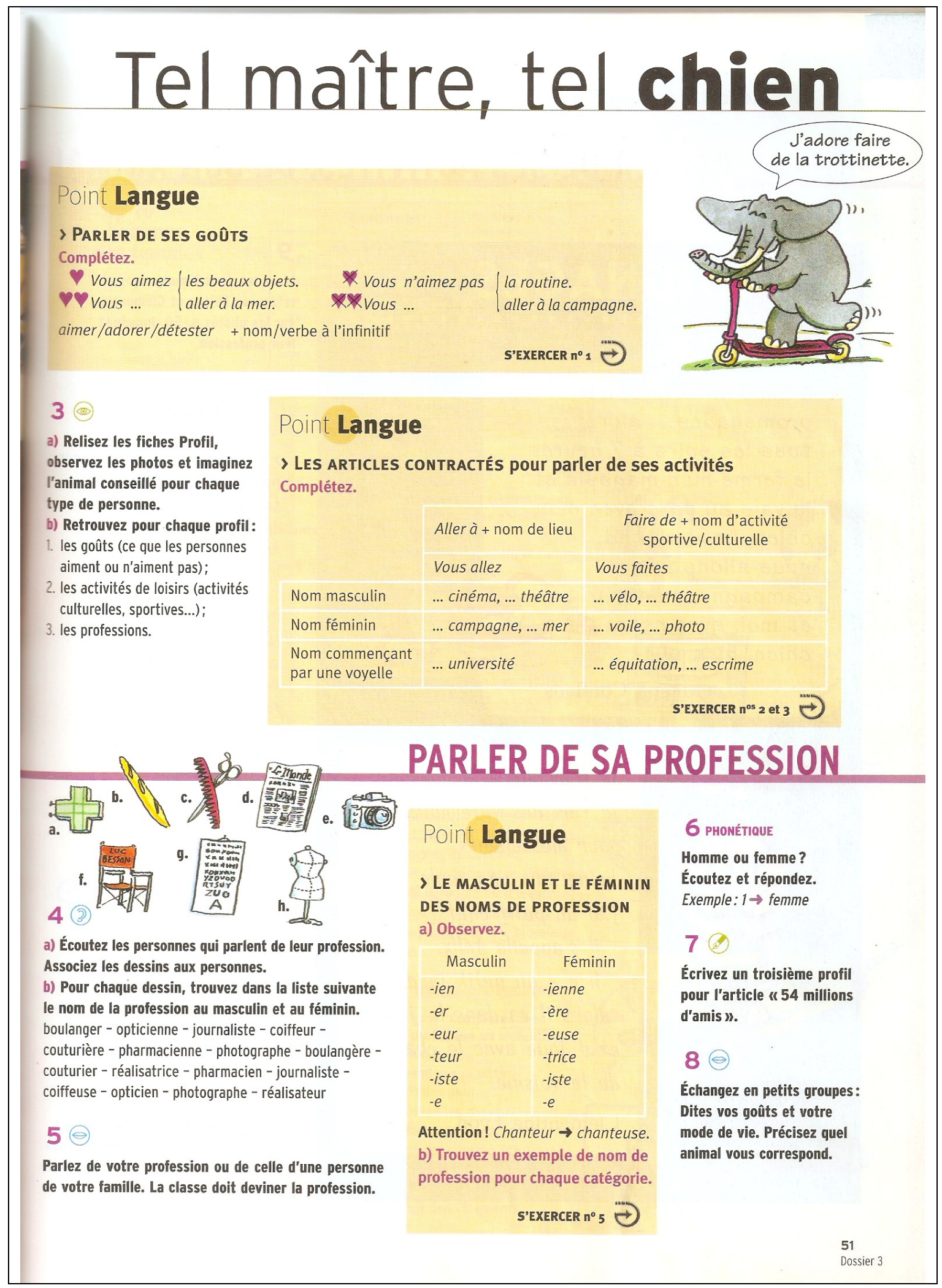


(ii) Alter Ego A1 - Dossiê 3, Lição 1 “Dis-moi qui tu es” (p.52)

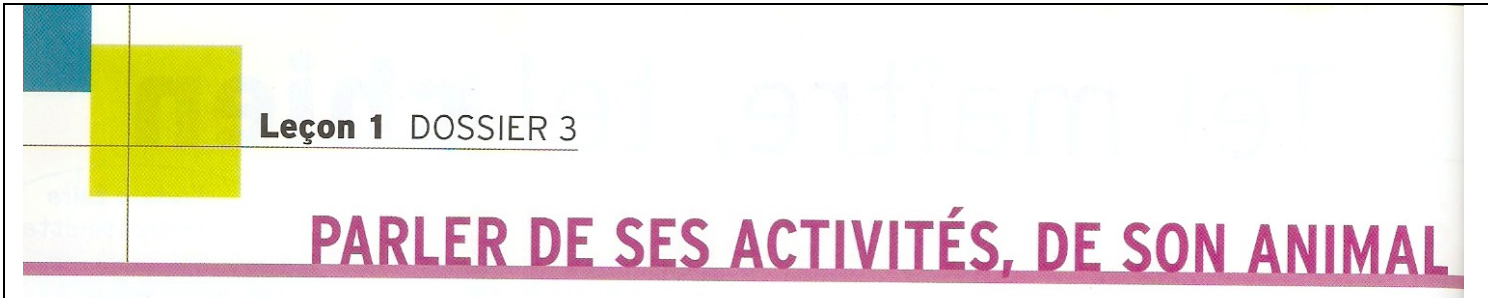

\section{TÉMOIGNAGES

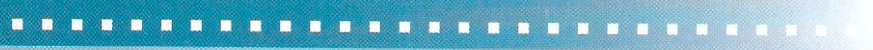

J'aime la nature, les

promenades... alors

tous les soirs à 7 heures

je ferme mon magasin et

je vais au parc avec mon

chien. Le week-end, nous allons à la campagne, mon mari et moi, avec notre chien, bien sûr!

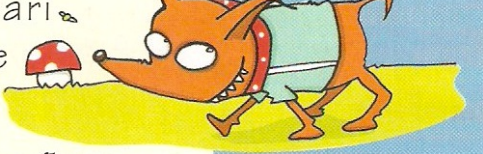

Miléna, Conflans

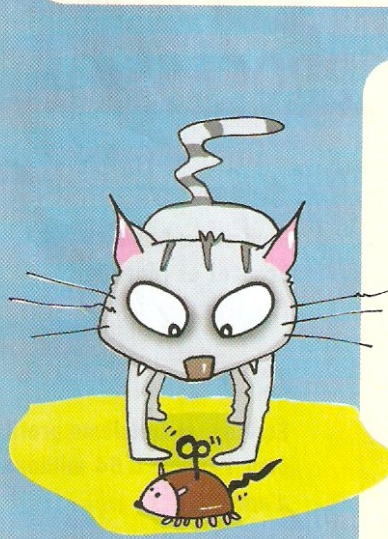

Se travaille à la maison:

je fais des vêtements

pour mes clients.

Se ne suis pas seule,

j'ai un petit chat:

il s'appelle félix.

II y a un petit jardin ici, alors il va dans le jardin et il joue avec le chat de la voisine.

Clémentine, Lyon
9 웅

Lisez les deux témoignages et retrouvez Miléna et Clémentine sur les photos p. 50. Imaginez leur profession.

\section{Point Langue}

> ALLER ET FAIRE À L'INDICATIF PRÉSENT pour parler de ses activités

Complétez. Aller

Je ... au parc.

Tu vas à la mer.

IlElle ... dans le jardin.

Nous ... à la campagne.

Vous allez au cinéma.

Ils/Elles vont au restaurant.

Faire

Je ... de la natation.

Tu fais du basket.

IIElle fait du sport.

Nous ... du roller.

Vous ... du ski.

Ils/Elles font de l'équitation.

$$
S^{\top} \text { EXERCER } n^{\circ}{ }_{4} \circlearrowright
$$

10

Échangez avec votre voisin(e): Dites quelles sont vos activités et où vous allez le week-end, en semaine (le Iundi, le mardi, etc.), en vacances.

\section{1}

Imaginez! Une des personnes sur les photos p. 50 témoigne et parle de ses goûts, de son travail et de sa vie avec son animal. Écrivez l'article. 
(ii) Alter Ego A1 - Dossiê 3, Lição 1 “Dis-moi qui tu es” (p.53)

\section{Les animaux préférés des Français}

A. Faites deux groupes dans la classe: femmes et hommes. Dites vos trois animaux préférés. Comparez les résultats des deux groupes: quels points communs et quelles différences?
B. Comparez avec les réponses des Français: lisez ce sondage sur les animaux préférés des Français. Observez les différences entre les hommes et les femmes.
Le top 10

des hommes

et des femmes

D'après sondage Ipsos pour la fondation

30 millions d'amis, février 2005.

\begin{tabular}{|c|l|l|}
\cline { 2 - 3 } \multicolumn{1}{c|}{} & \multicolumn{1}{|c|}{ Hommes } & \multicolumn{1}{c|}{ Femmes } \\
\hline $1^{\mathrm{er}}$ & le chien & le chien \\
$2^{\mathrm{e}}$ & le chat & le chat \\
$3^{\mathrm{e}}$ & le cheval & le cheval \\
$4^{\mathrm{e}}$ & le dauphin & le dauphin \\
$5^{\mathrm{e}}$ & le tigre & l'écureuil \\
$6^{\mathrm{e}}$ & le lion & le lapin \\
$7^{\mathrm{e}}$ & l'écureuil & la biche \\
$8^{\mathrm{e}}$ & le lapin & le poisson rouge \\
$9^{\mathrm{e}}$ & la biche & le panda \\
$10^{\mathrm{e}}$ & le loup & le perroquet \\
\hline
\end{tabular}

\section{$>$ Parler de ses goûts}

1. Exprimez vos goûts avec les éléments suivants.

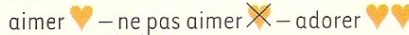
- détester XX

\section{a. Activités}

Exemple: aller au cinéma

$\rightarrow$ J'adore aller au cinéma.

aller au théâtre - regarder la

télévision - faire la cuisine - aller au supermarché - écouter de la musique lire le journal - dormir - faire une promenade - visiter des musées

b. Animaux

Exemple: J'aime les oiseaux mais je déteste les araignées.

les chiens - les oiseaux - les tortues les rats - les chats - les souris -

les araignées - les serpents -

les chevaux - les poissons

\section{$>$ Parler de ses activités}

\section{Répondez par des phrases.}

Où allez-vous:

a. le week-end?

b. pendant la semaine?

c. pendant les vacances?

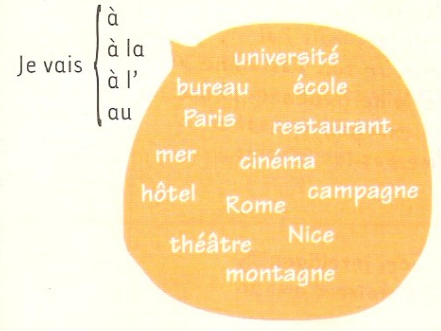

3. Associez les dessins ci-contre aux activités puis faites des phrases, comme dans l'exemple.

Exemple: J'aime le football, je fais du football tous les dimanches.

le tennis - le piano - la peinture - le judo - le football - l'escrime - le basket l'équitation - le roller - la guitare

4. Complétez avec faire de ou aller à. Faites les changements nécessaires.

a. - Le dimanche, vous ... le cinéma?

- Oui, avec des amis. Et après nous ... le restaurant.

b. - Vous ... le jogging?

- Non, je déteste ça. Mais je ... la natation tous les mercredis.

c. - Les Français ... la mer, en été?

- Oui, et, en hiver, ils ... la montagne; ils ... le ski.

d. - Moi, je ... la bicyclette, j'adore ça

- Tu ... le bureau à bicyclette?

- Non, mais, le dimanche, je ... la campagne, j'ai une bicyclette là-bas.

\section{$>$ Parler de sa profession}

5. Qui fait quoi? Complétez avec un nom de profession au masculin ou au féminin.

a. Une ... vend des lunettes.

b. Un ... fait des photos.

c. Une ... coupe les cheveux.

d. Un ... vend des médicaments.

e. Un ... fait des gâteaux.

f. Une ... joue dans un film.

g. Un ... fait des reportages.

h. Une ... fait des vêtements.
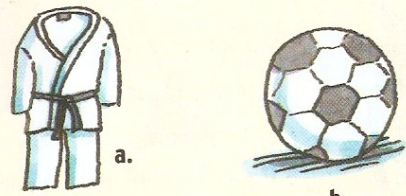

b.

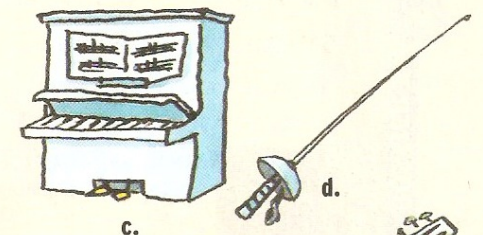

c.
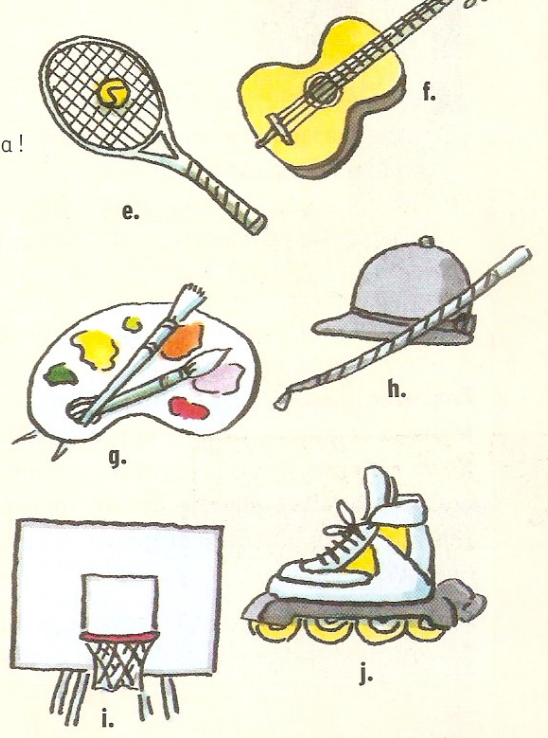

53 
Anexo C - Material didático referente à aula de Suélen (Alter Ego A2, 2006)

(i) Alter Ego A2, Sumário (Tableau de Contenus)

\section{Tableau des contenus}

\begin{tabular}{|c|c|c|c|c|c|}
\hline \multirow{3}{*}{ Leçons } & \multirow{3}{*}{$\begin{array}{l}\text { Contenus } \\
\text { socioculturels } \\
\text { Thématiques }\end{array}$} & \multicolumn{4}{|c|}{ OBJECTIFS SOCIOLANGAGIERS } \\
\hline & & \multirow{2}{*}{$\begin{array}{l}\text { Objectifs communicatifs } \\
\text { et savoir-faire }\end{array}$} & \multicolumn{3}{|c|}{ Objectifs linguistiques } \\
\hline & & & Grammaticaux & Lexicaux & Phonétiques \\
\hline \multicolumn{6}{|c|}{ DossiaR 1 : J'ai des relations! } \\
\hline p. 12 à 15 & $\begin{array}{l}\text { Relations } \\
\text { amicales }\end{array}$ & $\begin{array}{l}\text { - Parler d'une relation } \\
\text { amicale } \\
\text { - Décrire une personne } \\
\text { (caractère, défauts, } \\
\text { qualités) }\end{array}$ & \begin{tabular}{|l|} 
- Les pronoms relatifs : \\
qui, que, à qui \\
- Les structures pour \\
donner une définition : \\
c'est + infinitif, c'est \\
quand, c'est + nom \\
+ proposition relative \\
- L'accord du participe \\
passé (révision)
\end{tabular} & $\begin{array}{l}\text { - Noms et adjectifs } \\
\text { de la caractérisation } \\
\text { psychologique, } \\
\text { la personnalité }\end{array}$ & 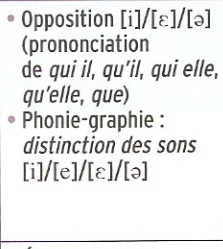 \\
\hline p. 16 à 19 & $\begin{array}{l}\text { Relations } \\
\text { de voisinage }\end{array}$ & $\begin{array}{l}\text { - Parler de ses relations } \\
\text { de voisinage } \\
\text { - Rapporter des paroles } \\
\text { - Comparer, évoquer } \\
\text { des changements }\end{array}$ & $\begin{array}{l}\text { - Le discours indirect } \\
\text { au présent } \\
\text { - Imparfait/présent } \\
\text { (révision) } \\
\text { - Structures } \\
\text { de la comparaison }\end{array}$ & $\begin{array}{l}\text { - Lieux et habitants, } \\
\text { vie en copropriété, } \\
\text { voisinage } \\
\text { - Expressions pour } \\
\text { réagir positivement } \\
\text { à un événement }\end{array}$ & $\begin{array}{l}\text { - Élision de « i » } \\
\text { dans « s'il » } \\
\text { et prononciation } \\
\text { de « si elle » } \\
\text { - Rythme et mélodie } \\
\text { dans le discours } \\
\text { indirect au présent } \\
\text { (groupes rythmiques) }\end{array}$ \\
\hline p. 20 à 23 & $\begin{array}{l}\text { Rencontres } \\
\text { amoureuses }\end{array}$ & $\begin{array}{l}\text { - Raconter une rencontre } \\
\text { - Raconter les suites } \\
\text { d'une rencontre }\end{array}$ & $\begin{array}{l}\text { - Imparfait/passé } \\
\text { composé } \\
\text { - Les marqueurs } \\
\text { temporels }(1): \text { il y } a_{,} \\
\text {dans, pendant }\end{array}$ & $\begin{array}{l}\text { - Termes liés } \\
\text { à la rencontre } \\
\text { amoureuse } \\
\text { et au coup de foudre }\end{array}$ & $\begin{array}{l}\text { Opposition }[e] /[\varepsilon]: \\
\text { distinction imparfait/ } \\
\text { passé composé } \\
\text { - Phonie-graphie :- } \\
\text { les sons }[\mathrm{e}] /[\varepsilon]\end{array}$ \\
\hline $\begin{array}{l}\text { Carmet } \\
\text { de } \\
\text { voyage }\end{array}$ & Relations & \multicolumn{4}{|c|}{$\begin{array}{l}\text { - Découvrir/échanger sur les grands noms de la culture française ou francophone à partir de documents } \\
\text { (littérature, cinéma, bande dessinée, peinture) liés aux thématiques du dossier. }\end{array}$} \\
\hline \multicolumn{6}{|c|}{ Dossian 2 : Tout travail mérite salaire } \\
\hline p. 28 à 31 & $\begin{array}{l}\text { Recherche } \\
\text { d'emploi } \\
\text { et présentation } \\
\text { en situation } \\
\text { professionnelle }\end{array}$ & $\begin{array}{l}\text { Comprendre } \\
\text { une annonce d'emploi } \\
\text { et se présenter } \\
\text { en contexte profession- } \\
\text { nel } \\
\text { Comprendre et rédiger } \\
\text { un CV et une lettre } \\
\text { formelle simples }\end{array}$ & $\begin{array}{l}\text { - Les marqueurs tem- } \\
\text { porels (2): pendant, } \\
\text { depuis, de... à, en }\end{array}$ & \begin{tabular}{|l|} 
- Termes pour parler \\
des études \\
- Termes pour parler \\
du salaire \\
- Formules de la lettre \\
formelle, de motivation
\end{tabular} & - Opposition [u] [w] \\
\hline p. 32 à 35 & $\begin{array}{l}\text { Conseils pour } \\
\text { les entretiens } \\
\text { d'embauche }\end{array}$ & $\begin{array}{l}\text { - Donner des conseils, } \\
\text { mettre en garde } \\
\text { - Indiquer } \\
\text { des changements } \\
\text { nécessaires }\end{array}$ & $\begin{array}{l}\text { - Structures pour } \\
\text { exprimer le conseil : } \\
\text { impératif, devoir } \\
\text { + infinitif, si+ présent/ } \\
\text { futur, il faut que } \\
\text { + subjonctif } \\
\text { - Le subjonctif pour expri- } \\
\text { mer la nécessité (1) } \\
\end{array}$ & $\begin{array}{l}\text { - Formules impersonnel- } \\
\text { les pour exprimer la } \\
\text { nécessité : il est impor- } \\
\text { tant/essentiel de... } \\
\text { - Le registre standard } \\
\text { et le registre familier (1) }\end{array}$ & $\begin{array}{l}\text { - Registres de langue } \\
\text { à l'oral } \\
\text { - Intonation: } \\
\text { conseil/obligation } \\
\text { - Prononciation } \\
\text { du subjonctif }\end{array}$ \\
\hline p. 36 à 39 & $\begin{array}{l}\text { Expériences } \\
\text { de stages } \\
\text { en entreprise }\end{array}$ & $\begin{array}{l}\text { - Raconter une expérience } \\
\text { professionnelle } \\
\text { - Parler de ses activités } \\
\text { professionnelles }\end{array}$ & $\begin{array}{l}\text { - Le plus-que-parfait } \\
\text { Les pronoms et } \\
\text { adverbes indéfinis: } \\
\text { quelqu'un, } \\
\text { rien, personne, } \\
\text { nulle part, etc. } \\
\text { Les adverbes }\end{array}$ & $\begin{array}{l}\text { - Termes liés à la } \\
\text { recherche d'emploi } \\
\text { et à l'entreprise }\end{array}$ & 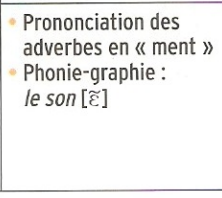 \\
\hline $\begin{array}{l}\text { Camnet } \\
\text { de } \\
\text { voyage }\end{array}$ & $\begin{array}{l}\text { Les Français } \\
\text { et le travail }\end{array}$ & \multicolumn{4}{|c|}{ - Découvrir deux visions du monde du travail : vision ludique (le jeu de l'oi(e)siveté) et vision sociologique } \\
\hline
\end{tabular}


(ii) Alter Ego A2, Dossiê 1, Lição 2 “J'ai des relations” (p.16)

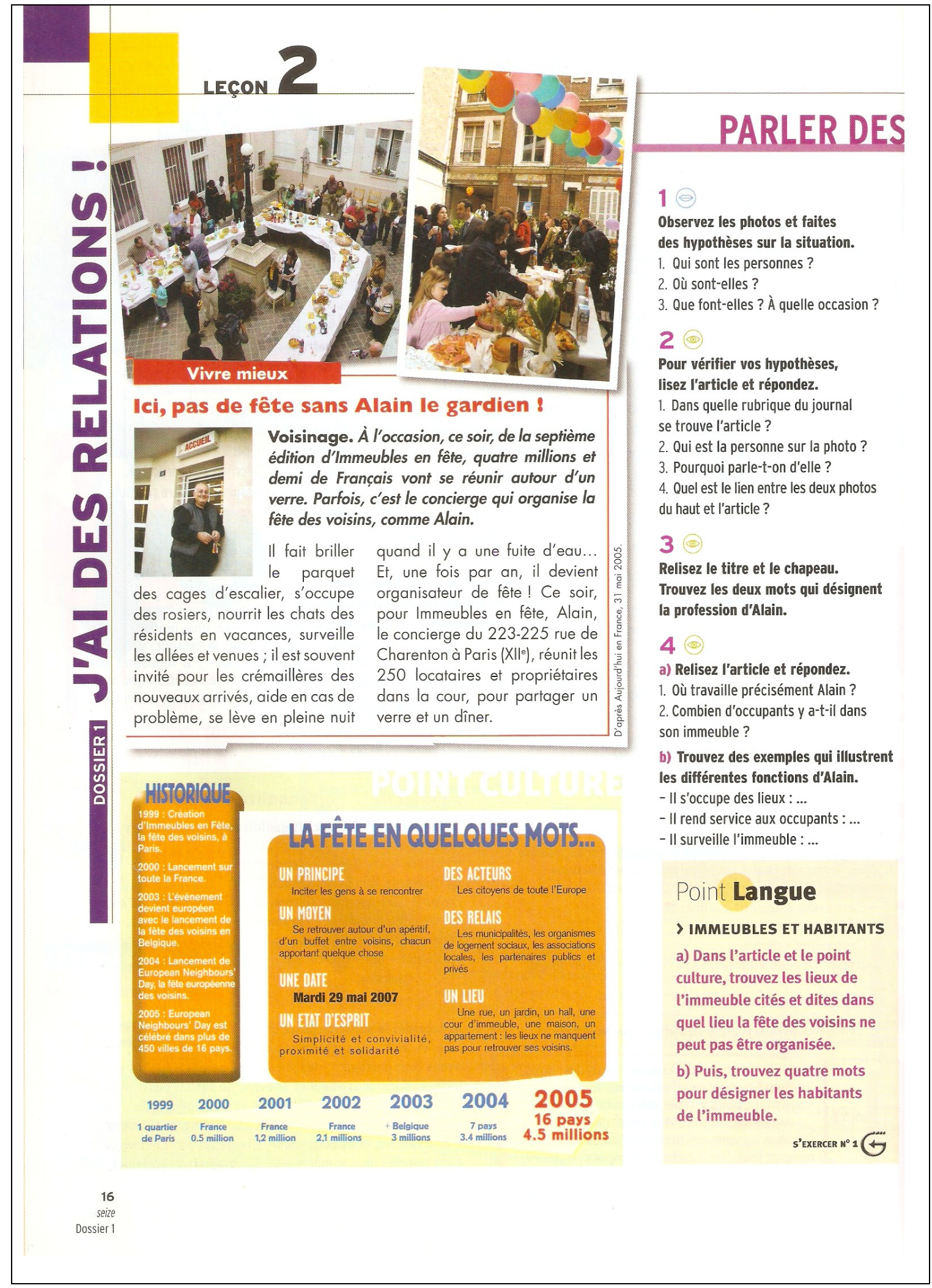


(ii) Alter Ego A2, Dossiê 1, Lição 2 “J'ai des relations” (p.17)

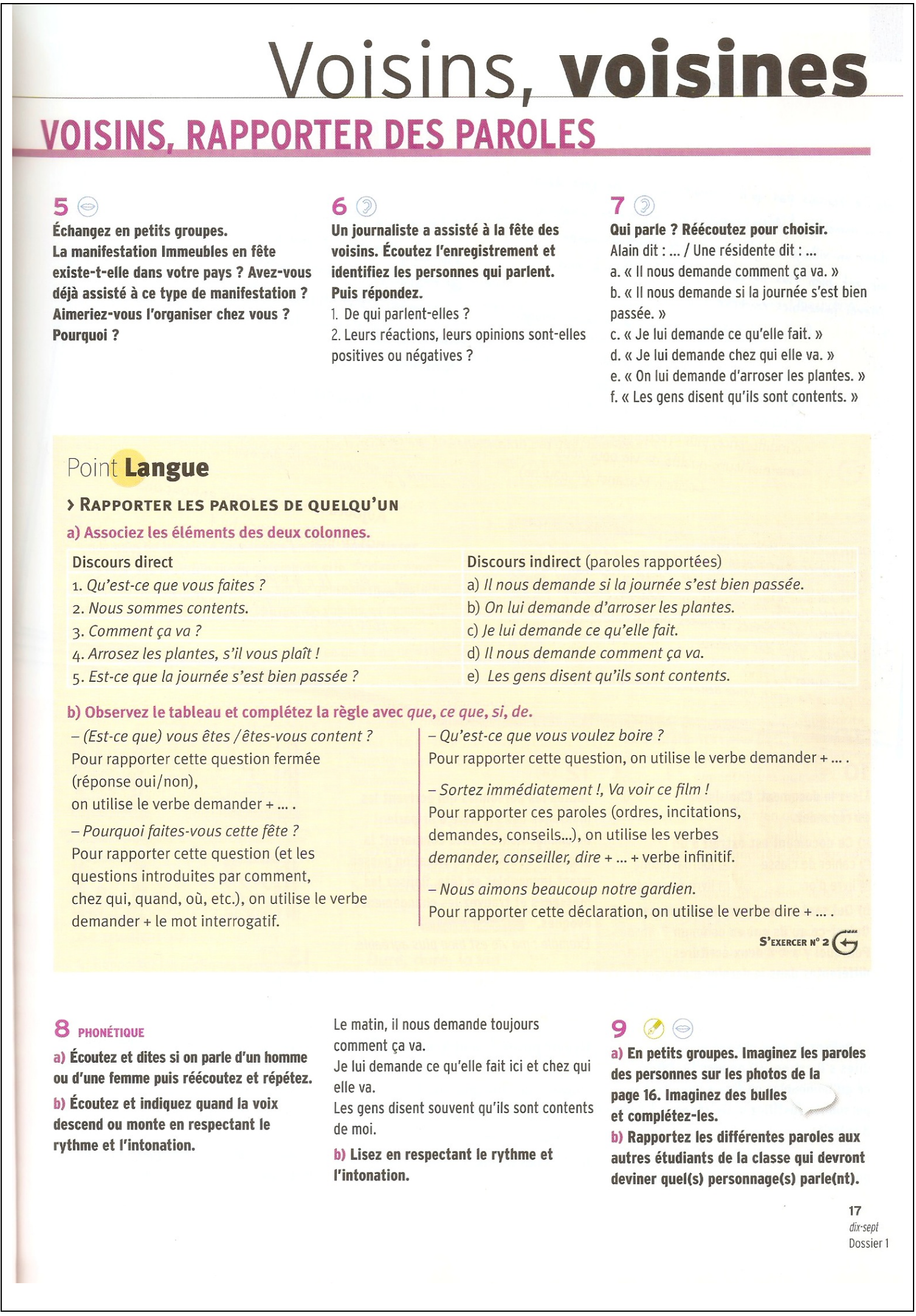


(ii) Alter Ego A2, Dossiê 1, Lição 2 “J'ai des relations” (p.18)

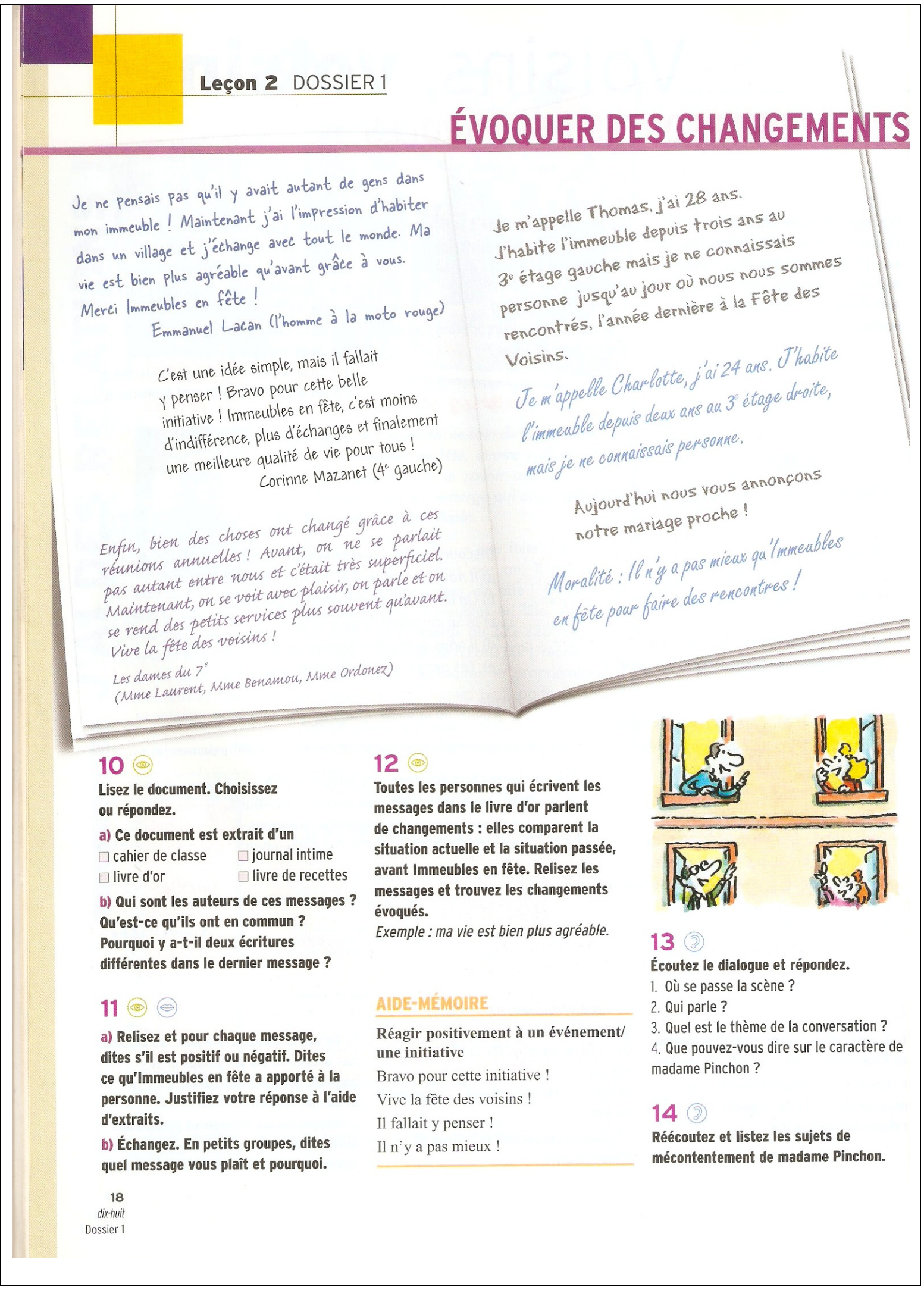


(ii) Alter Ego A2, Dossiê 1, Lição 2 “J'ai des relations” (p.19)

\section{Point Langue}

\section{> FAIRE UNE COMPARAISON}

Complétez le tableau avec les éléments de comparaison suivants : plus $\left(d e / d^{\prime}\right)-$ moins $\left(d e / d^{\prime}\right)$ - meilleur $(e)-$ mieux

\begin{tabular}{|c|c|c|c|}
\hline \multicolumn{4}{|c|}{ La comparaison porte sur } \\
\hline \multicolumn{2}{|c|}{ la quantité } & \multicolumn{2}{|c|}{ la qualité } \\
\hline Nom & Verbe & Adjectif & Adverbe \\
\hline ... échanges & On se parle plus & $\begin{array}{l}\text { Une ... qualité de vie } \\
\text { Une vie ... agréable }\end{array}$ & $\begin{array}{l}\text { II n'y a pas... } \\
\text { On se rend des services ... souvent }\end{array}$ \\
\hline $\begin{array}{l}\text { Autant d" } \\
\text { échanges }\end{array}$ & On ne se parlait pas... & $\begin{array}{l}\text { Une aussi bonne qualité de vie } \\
\text { Une vie aussi agréable }\end{array}$ & $\begin{array}{l}\text { II n'y a pas aussi bien } \\
\text { Aussi souvent }\end{array}$ \\
\hline ... indifférence & On se parlait moins & $\begin{array}{l}\text { Une moins bonne qualité de vie } \\
\text { Une vie moins agréable }\end{array}$ & C'était moins bien / Moins souvent \\
\hline
\end{tabular}

NB : Quand le $2^{\mathrm{e} e ́ l e ́ m e n t ~ d e ~ l a ~ c o m p a r a i s o n ~ e s t ~ e x p r i m e ́, ~ i l ~ e s t ~ i n t r o d u i t ~ p a r ~ q u e . ~ E x e m p l e s ~: ~ . . . ~}$

S'EXERCER N $3 \circlearrowleft$

15

Le lendemain de la soirrée Immeubles en fête, vous laissez un message sur le forum de discussion du site. Écrivez pour : - donner vos impressions, votre avis sur ce genre de manifestation; - dire si cela a changé vos rapports avec vos voisins, et comment. Vous pouvez aussi :

- parler de vos relations avec vos voisins, de ce qui va ou ne va pas là où vous habitez.

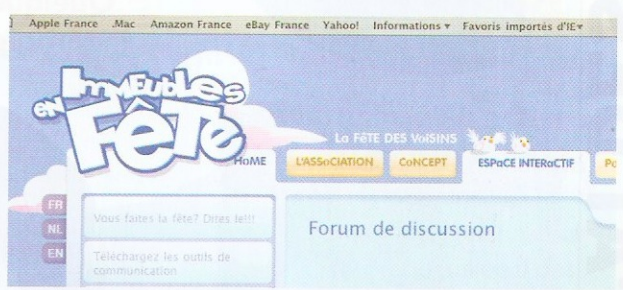

$>$ Pour parler des immeubles et des habitants

\section{Trouvez l'intrus.}

a. un locataire - un gardien -

un propriétaire - un agent immobilier

- un voisin - un copropriétaire.

b. la cage d'escalier - le jardin - la loge

- la cour - la chambre-le hall d'entrée.

\section{> Rapporter les paroles} de quelqu'un

\section{Rapportez les répliques suivantes.} Complétez.

1. « Est-ce que vous pouvez me prêter quatre chaises? Je les rapporterai dimanche soir. »

Mme Habib vient de me téléphoner elle me demande ... et elle me dit... 2. "Qu'est-ce que vos enfants font dans le parking? II est interdit de jouer dans le sous-sol de l'immeuble. » Je viens de rencontrer le gardien. II me demande ... et il me rappelle ...
3. « J'ai un problème de fuite d'eau. Venez vite m'aider, s'il vous plaît! » Mme Ramirez me dit ... et elle me demande....

\section{$>$ Faire une comparaison}

3. a) Faites des comparaisons pour exprimer l'égalité. Complétez avec la forme qui convient : aussi/autant (de)

\begin{tabular}{|l|}
\multicolumn{1}{|c|}{ Témoignages } \\
Dure, dure, la vie \\
dans un immeuble ! \\
« C'est comme l'année dernière, \\
et comme l'année d'avant ! Les \\
réunions de copropriétaires durent \\
toujours ... longtemps, on parle ... \\
mais rien ne change : les poubelles \\
sont toujours ... pleines, les escaliers \\
sont toujours ... sales, les enfants \\
font ... bruit et les frais d'entretien \\
sont ... élevés qu'avant. » \\
\multicolumn{1}{c}{. }
\end{tabular}

b) Utilisez un comparatif de supériorité ou d'infériorité : plus (de), moins (de). a. On a ... échanges avec nos voisins qui sont ... sympathiques que les précédents, et puis on a ... problèmes avec les enfants : ils n'en ont pas! Donc, on se parle ... souvent, et on met... messages de réclamation dans leur boîte aux lettres!

b. Grâce au nouveau gardien, la cage d'escalier est ... propre qu'avant et le jardin est ... fleuri aussi. Et puis, il y a ... incidents, il y a ... surveillance.

c) Complétez en utilisant mieux ou meilleur(e)(s).

a. Avec mes précédents voisins, j'avais de ... relations et puis leurs enfants étaient ... élevés !

b. Depuis qu'on s'est rencontrés à la fête des voisins, il y a une ... entente entre nous et on vit ... ensemble.

c. Fini les voisins bruyants! On a une ... qualité de vie, maintenant: on respire ..., on dort.... 
Anexo D - Termo de consentimento de participação na pesquisa

\section{TERMO DE CONSENTIMENTO LIVRE E ESCLARECIDO}

Nome do participante:

Data:

Endereço: CEP:

Telefone:

RG:

CPF:

Nome do pesquisador principal: Eliane Gouvêa Lousada

Instituição: Grupo de pesquisa ALTER-AGE (CNPq)

Você está sendo convidada (o) a participar desta pesquisa. Ao integrar este estudo estará permitindo a utilização dos dados aqui fornecidos. Você tem liberdade de se recusar a participar e ainda se recusar a continuar participando em qualquer fase da pesquisa, sem qualquer prejuízo pessoal.

1. Propósito do estudo: estudar e compreender o trabalho educacional.

2. Procedimentos: gravações de áudio e vídeo; coleta de textos escritos pelos participantes (relatórios, diários, etc).

3. Riscos e desconfortos: nenhum.

Benefícios: a participação é voluntária e não trará nenhum benefício direto, mas proporcionará um melhor conhecimento do trabalho - métier - de professor.

4. Direitos dos participantes: o participante pode se retirar deste estudo sem nenhum prejuízo.

5. Compensação financeira: não existem despesas e nem compensação.

6. Incorporação ao banco de dados do grupo ALTER-AGE. Os dados obtidos com esta participação serão incorporados ao bando de dados do grupo ALTER-AGE (núcleo USP), cuja responsável zelará pelo uso e aplicabilidade das amostras unicamente para fins científicos, apenas consentindo o seu uso futuro em projetos que atestem pelo cumprimento dos preceitos éticos em pesquisas envolvendo seres humanos. Algumas amostras poderão ser usadas em publicação, sem que haja identificação do falante e sem que seus direitos sejam atingidos.

7. Confidencialidade: os resultados deste estudo poderão ser publicados em jornais profissionais ou apresentados em congressos profissionais, sem que a identidade dos participantes seja revelada.

Eu compreendo meus direitos como um sujeito de pesquisa e voluntariamente consinto em participar deste estudo e em ceder meus dados para o banco de dados do ALTERAGE. Compreendo sobre o que, como e porque este estudo está sendo feito. Receberei uma cópia assinada deste formulário de consentimento.

Assinatura do sujeito participante

Assinatura do pesquisador 


\section{Anexo E - Normas de transcrição do projeto NURC/SP}

\begin{tabular}{|c|c|c|}
\hline \multicolumn{3}{|c|}{ Normas para transcrição de entrevistas gravadas } \\
\hline Ocorrências & Sinais & Exemplificação \\
\hline $\begin{array}{l}\text { Incompreensão de palavras ou } \\
\text { segmentos }\end{array}$ & () & $\begin{array}{l}\text { Do nives de rensa ( ) nível de renda } \\
\text { nominal }\end{array}$ \\
\hline Hipótese do que se ouviu & (hipótese) & $\begin{array}{l}\text { (estou) meio preocupado (com o } \\
\text { gravador) }\end{array}$ \\
\hline $\begin{array}{l}\text { Truncamento (havendo } \\
\text { homografia, usa-se acento } \\
\text { indicativo da tônica e/ou timbre) }\end{array}$ & I & E comé/e reinicia \\
\hline Entonação enfática & Maiúscula & Porque as pessoas reTÊM moeda \\
\hline $\begin{array}{l}\text { Prolongamento de voga e } \\
\text { consoante (como s, r) }\end{array}$ & $\begin{array}{c}:: \text { podendo } \\
\text { aumentar para ::.:: } \\
\text { ou mais }\end{array}$ & Ao emprestarmos éh::: .... dinheiro \\
\hline Silabação & - & Por motivo tran-sa-ção \\
\hline Interrogação & ? & E o Banco... Central... certo? \\
\hline Qualquer pausa & $\ldots$ & $\begin{array}{l}\text { São três motivos... ou três razoes ... } \\
\text { que fazem com que se retenha moeda } \\
\text {... existe uma ... retenção }\end{array}$ \\
\hline $\begin{array}{l}\text { Comentários descritivos do } \\
\text { trancritor }\end{array}$ & ((minúscula)) & $(($ tossiu $))$ \\
\hline $\begin{array}{l}\text { Comentários que quebram a } \\
\text { seqüência temática da } \\
\text { exposição: desvio temático }\end{array}$ & $\cdots$ & $\begin{array}{l}\text {... a demanda de moeda - - vamos dar } \\
\text { casa essa notação - - demanda de } \\
\text { moeda por motivo ... }\end{array}$ \\
\hline $\begin{array}{l}\text { Superposição, simultaneidade de } \\
\text { vozes }\end{array}$ & Ligando as linhas & $\begin{array}{ll}\text { a. } & \text { na casa de sua irmã } \\
\text { b. } & \text { [sexta-feira? } \\
\text { a. fazem LÁ } \\
\text { b. } & \text { [cozinham lá }\end{array}$ \\
\hline $\begin{array}{l}\text { Indicação de que a fala foi } \\
\text { tomada ou interrompida em } \\
\text { determinado ponto. Não no seu } \\
\text { início, por exemplo. }\end{array}$ & $(\ldots)$ & (...) nós vimos que existem... \\
\hline $\begin{array}{l}\text { Citações literais de textos, } \\
\text { durante a gravação }\end{array}$ & "entre aspas" & $\begin{array}{l}\text { Pedro Lima ... ah escreve na ocasião.. } \\
\text { "O cinema falado em língua } \\
\text { estrangeira não precisa de nenhuma } \\
\text { baRREIra entre nós"... }\end{array}$ \\
\hline \multicolumn{3}{|c|}{ 1. Iniciais maiúsculas : só para nomes próprios ou para siglas (USP etc) } \\
\hline \multicolumn{3}{|c|}{ 2. Fáticos: ah, éh, ahn, ehn, uhn, tá (não por está: tá? Você está brava?) } \\
\hline \multicolumn{3}{|c|}{ 3. Nomes de obras ou nomes comuns estrangeiros são grifados. } \\
\hline \multicolumn{3}{|l|}{ 4. Números por extenso. } \\
\hline \multicolumn{3}{|c|}{ 5. Não se indica o ponto de exclamação (frase exclamativa) } \\
\hline \multicolumn{3}{|c|}{ 6. Não se anota o cadenciamento da frase. } \\
\hline \multicolumn{3}{|c|}{ 7. Podem-se combinar sinais. Por exemplo: oh:...... (alongamento e pausa) } \\
\hline \multicolumn{3}{|c|}{$\begin{array}{l}\text { 8. Não se utilizam sinais de pausa, típicas da língua escrita, como ponto e vírgula, ponto } \\
\text { final, dois pontos, vírgula. As reticências marcam qualquer tipo de pausa. }\end{array}$} \\
\hline
\end{tabular}

Exemplos retirados dos inquéritos NURC/SP no. 338 EF e 331 D2.

PRETI D. (org) O discurso oral culto $2^{a}$. ed. São Paulo: Humanitas Publicações - FFLCH/USP, 1999 - (Projetos Paralelos. V.2) 224p. 